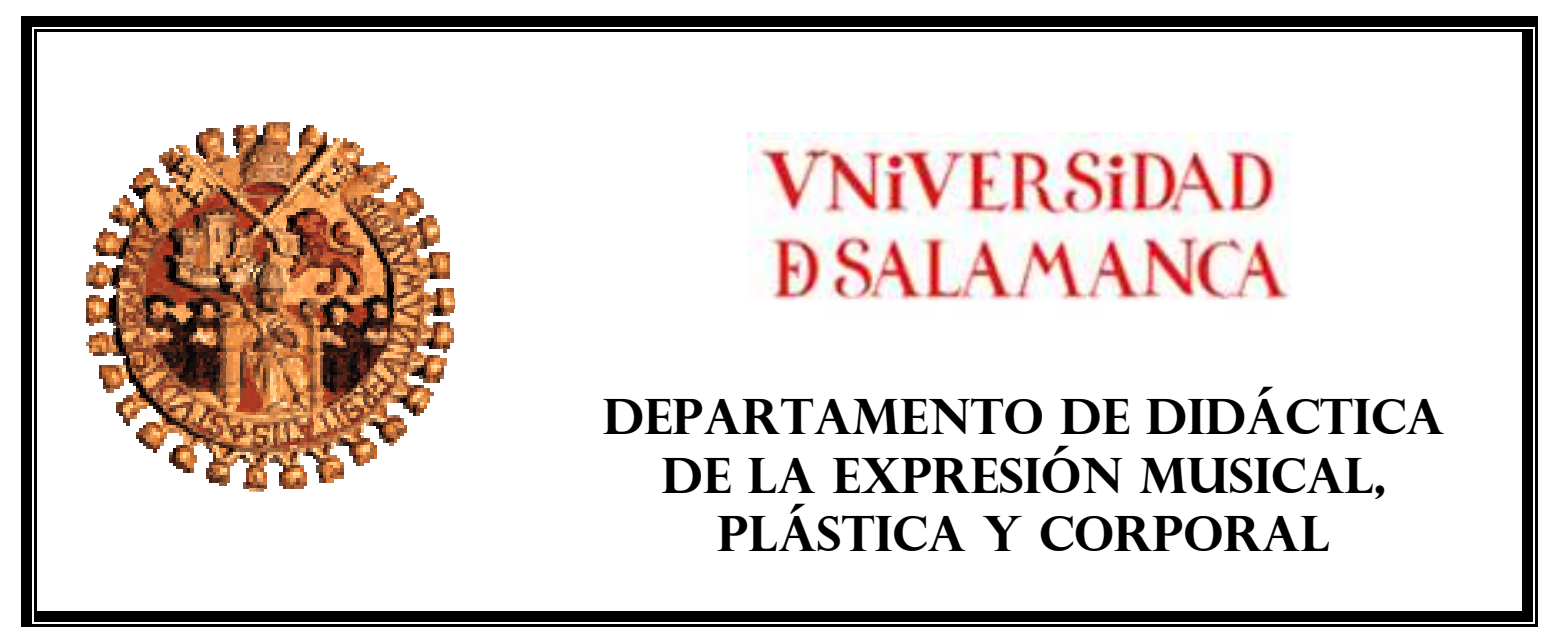

TESIS DOCTORAL

\title{
MÚSICA Y MEDIOS AUDIOVISUALES. PLANTEAMIENTOS DIDÁCTICOS EN EL MARCO DE LA EDUCACIÓN MUSICAL
}

\author{
JUAN CARLOS MONTOYA RUBIO \\ DIRECTORA: DR ${ }^{\mathrm{a}}$. MATILDE OLARTE MARTÍNEZ
}

$\mathrm{V}^{\circ} \mathrm{B}^{\mathrm{o}}$ DE LA DIRECTORA

DE LA TESIS DE DOCTORADO

$D^{a}{ }^{a} D^{a}$. MATILDE OLARTE MARTÍNEZ 
MÚSICA Y MEDIOS AUDIOVISUALES.

PLANTEAMIENTOS DIDÁCTICOS EN EL MARCO DE LA EDUCACIÓN MUSICAL. Juan Carlos Montoya Rubio 
A la memoria de mis abuelos, Juan Rubio Montoya y Rosario Cano Martínez, y a mi madre, Rosario Rubio Cano, el mejor ejemplo de tesón que jamás pudiera tener. 
MÚSICA Y MEDIOS AUDIOVISUALES.

PLANTEAMIENTOS DIDÁCTICOS EN EL MARCO DE LA EDUCACIÓN MUSICAL. Juan Carlos Montoya Rubio 


\section{AGRADECIMIENTOS}

No quisiera extenderme en un apartado de estas características el cual, en todo caso, siempre quedaría inacabado. Muy brevemente quiero dejar constancia de mi gratitud de manera expresa:

A Matilde Olarte Martínez, rara vez convergen en una misma persona la capacidad y el conocimiento de la materia con el trato entrañable y la comprensión en los momentos de dificultad. No imagino este texto de tesis doctoral bajo otra tutoría. No es retórico afirmar que sin su cuidada supervisión y atenciones este proyecto no hubiera visto la luz nunca.

A Víctor Manuel Montoya Rubio, siempre dispuesto, amigo en las dificultades, consejero en las dudas, paciente asesor en cuestiones informáticas y audiovisuales. Otra aportación definitiva y sin paliativos.

A mi familia, muy especialmente a Celia y Tono, quienes se han acostumbrado a verme tomando notas ante sus dibujos animados.

A todos los alumnos a los que he impartido docencia desde que la investigación estaba en sus etapas embrionarias. Tanto en las aulas de primaria como en las de secundaria y universitarias, a través de la experimentación directa y puesta en práctica de procedimientos, ellos han sido protagonistas del ajuste de actividades $y$ planteamientos teóricos.

A la Consejería de Educación, Formación y Empleo de la Región de Murcia, bajo cuyo auspicio se desarrolló una parte decisiva de esta investigación, merced a la concesión de una licencia por estudios que me liberó en gran medida de determinadas obligaciones laborarles y me permitió centrarme en el desarrollo de la tesis doctoral. Asimismo, es de justicia reseñar que en todo momento desde este organismo se facilitaron los permisos y trámites necesarios para llevar a cabo el trabajo de muestreo y se permitió compatibilizar la licencia concedida con la docencia universitaria, lo cual redundó en un mejor acceso a fondos bibliográficos. 
MÚSICA Y MEDIOS AUDIOVISUALES.

PLANTEAMIENTOS DIDÁCTICOS EN EL MARCO DE LA EDUCACIÓN MUSICAL. Juan Carlos Montoya Rubio 
ÍNDICE DE CONTENIDOS

1 INTRODUCCIÓN.

FUNDAMENTOS PARA UNA INVESTIGACIÓN

INTERDISCIPLINAR

\begin{tabular}{|c|c|c|}
\hline 1.1 & $\begin{array}{l}\text { Características, potencialidades y límites de la } \\
\text { investigación }\end{array}$ & 23 \\
\hline Ace & ca de la elección del tema & 23 \\
\hline Obj & tivos & 27 \\
\hline Crite & rios metodológicos & 31 \\
\hline Esta & do de la cuestión & 34 \\
\hline
\end{tabular}

\begin{tabular}{|c|c|c|}
\hline 1.2 & $\begin{array}{l}\text { La investigación educativa musical en la vertiente } \\
\text { audiovisual de las TICs }\end{array}$ & 40 \\
\hline \multirow{2}{*}{\multicolumn{2}{|c|}{$\begin{array}{l}\text { Breve aproximación a una queja fundada } \\
\text { Derivaciones para un estudio musical desde el audiovisual }\end{array}$}} & 40 \\
\hline & & 47 \\
\hline
\end{tabular}

2 MARCO TEÓRICO - REFERENCIAL.

LA MÚSICA Y LOS MEDIOS AUDIOVISUALES. ELEMENTOS

PARA UNA APROXIMACIÓN EN CLAVE PEDAGÓGICA

\begin{tabular}{|l|c|}
\hline 2.1 $\begin{array}{l}\text { La educación musical actual y su canalización hacia los } \\
\text { medios audiovisuales }\end{array}$ & $\mathbf{5 7}$ \\
\hline De dónde venimos y, sobre todo, hacia dónde vamos & 57 \\
\hline ¿A quién no le gusta la música? & 59 \\
\hline
\end{tabular}

\begin{tabular}{|l|l|}
\hline 2.2 Profesorado: Contingencias para un cambio & $\mathbf{6 6}$ \\
\hline El reto de no permanecer impasibles & 66 \\
\hline Enseñar música hoy. De la disposición a la predisposición & 70 \\
\hline Una nueva mirada a Willems, metáfora de cambio & 75 \\
\hline
\end{tabular}

\begin{tabular}{|l|l|}
\hline 2.3 Virajes metodológicos en educación musical & $\mathbf{8 0}$ \\
\hline La Escuela Nueva y sus consecuencias & 80 \\
\hline Reflexión, reactivación y reinvención metodológica & 85 \\
\hline La redimensión de los materiales pedagógicos & 87 \\
\hline De Kodály a la "Sinfonía del Mundo Nuevo" & 91 \\
\hline
\end{tabular}

\begin{tabular}{|c|c|c|}
\hline 2.4 & $\begin{array}{l}\text { La problemática de la educación musical actual y el uso } \\
\text { de las TICs }\end{array}$ & 97 \\
\hline Mot & vaciones para un cambio & 97 \\
\hline Mús & ica y TICs: Vertiente informática & 105 \\
\hline Mús & ica y TICs: Vertiente audiovisual & 109 \\
\hline
\end{tabular}




\begin{tabular}{|c|c|c|}
\hline 2.5 & $\begin{array}{l}\text { Aplicaciones prácticas desde el paradigma del } \\
\text { aprendizaje significativo }\end{array}$ & 114 \\
\hline \multicolumn{2}{|r|}{ La significatividad desde el audiovisual } & 114 \\
\hline \multicolumn{2}{|r|}{ Propuesta de actuación didáctica en educación musical } & 121 \\
\hline 2.6 & $\begin{array}{l}\text { El uso del audiovisual como recurso pedagógico. } \\
\text { Clasificaciones y posibilidades }\end{array}$ & 125 \\
\hline \multicolumn{2}{|r|}{ Intentos de acotación } & 125 \\
\hline \multicolumn{2}{|r|}{ En la busca de una clasificación funcional } & 128 \\
\hline \multicolumn{2}{|r|}{ La plasmación en secuencias didácticas } & 137 \\
\hline \multicolumn{2}{|r|}{ Aportaciones y beneficios } & 144 \\
\hline
\end{tabular}

3 MÉTODOS Y TÉCNICAS EN TORNO A LA INSERCIÓN DEL AUDIOVISUAL EN LAS AULAS DE EDUCACIÓN MUSICAL

\begin{tabular}{|c|c|c|}
\hline 3.1 & $\begin{array}{l}\text { Ideas preliminares. Transitando entre inquietudes y } \\
\text { oquedades }\end{array}$ & 153 \\
\hline & apertura de nuevas vías de actuación & 153 \\
\hline El et & tiquetado de las prácticas audiovisuales en el aula de & 158 \\
\hline
\end{tabular}

\begin{tabular}{|c|c|c|}
\hline 3.2 & $\begin{array}{l}\text { Conocimiento y comprensión musical a través del } \\
\text { audiovisual }\end{array}$ & 160 \\
\hline \multicolumn{2}{|r|}{ Tipología de casos } & 160 \\
\hline A & $\begin{array}{l}\text { Producciones audiovisuales dirigidas específicamente al } \\
\text { aprendizaje musical }\end{array}$ & 163 \\
\hline B & $\begin{array}{l}\text { Producciones audiovisuales que combinan la faceta lúdica } \\
\text { con la instrucción musical }\end{array}$ & 164 \\
\hline \multirow[t]{3}{*}{ C } & $\begin{array}{l}\text { Producciones audiovisuales centradas en personajes } \\
\text { directamente involucrados en el arte musical. Biopics } \\
\text { musicales }\end{array}$ & 165 \\
\hline & \begin{tabular}{l|l} 
El tratamiento didáctico del biopic. La dupla \\
significatividad / falacias
\end{tabular} & 165 \\
\hline & $\begin{array}{l}\text { Ejemplo procedimental: las figuras de Mozart y } \\
\text { Beethoven }\end{array}$ & 169 \\
\hline D & $\begin{array}{l}\text { Producciones audiovisuales que tienen en lo musical un } \\
\text { anclaje argumental decisivo }\end{array}$ & 179 \\
\hline$E$ & $\begin{array}{l}\text { Producciones audiovisuales que desarrollan tópicos } \\
\text { musicales }\end{array}$ & 182 \\
\hline $\mathbf{F}$ & $\begin{array}{l}\text { Producciones audiovisuales dirigidas al público infantil - } \\
\text { juvenil que aportan elementos musicales significativos }\end{array}$ & 190 \\
\hline G & $\begin{array}{l}\text { Producciones audiovisuales dirigidas al gran público con } \\
\text { aspectos musicales destacables }\end{array}$ & 193 \\
\hline
\end{tabular}




\begin{tabular}{|c|c|c|}
\hline 3.3 & $\begin{array}{l}\text { Extrapolación de elementos sonoros extraídos del } \\
\text { audiovisual }\end{array}$ & 202 \\
\hline \multicolumn{2}{|r|}{ La diatriba de la música preexistente } & 202 \\
\hline \multicolumn{2}{|c|}{ Una praxis relativamente extendida } & 204 \\
\hline \multicolumn{2}{|r|}{$\begin{array}{l}\text { Extrapolación de un fragmento musical paradigmático: el "tema } \\
\text { insignia" }\end{array}$} & 208 \\
\hline \multirow{2}{*}{\multicolumn{2}{|c|}{$\begin{array}{l}\text { Extrapolación de un fragmento musical seleccionado ad hoc } \\
\text { Extrapolación de varios fragmentos musicales que conforman el } \\
\text { audiovisual }\end{array}$}} & 218 \\
\hline & & 230 \\
\hline A & Aplicaciones pedagógicas derivadas de la banda sonora & 236 \\
\hline B & Aplicaciones pedagógicas derivadas de la música de cine & 244 \\
\hline $\mathrm{C}$ & Aplicaciones pedagógicas derivadas de la música original & 247 \\
\hline D & $\begin{array}{l}\text { Aplicaciones pedagógicas derivadas de otras apariciones } \\
\text { de la música }\end{array}$ & 256 \\
\hline
\end{tabular}

\begin{tabular}{|l|l|}
\hline 3.4 La sonorización desde un prisma pedagógico & $\mathbf{2 6 0}$ \\
\hline $\begin{array}{l}\text { Criterios básicos para la sonorización dentro del aula de } \\
\text { educación musical }\end{array}$ & 260 \\
\hline Inserción de música y sonidos pregrabados & 272 \\
\hline Sonorización "en vivo" & 280 \\
\hline
\end{tabular}

\begin{tabular}{|c|c|}
\hline 3.5 Filmación y representación visual de la música & 313 \\
\hline Delimitación metodológica & 313 \\
\hline Registro de las prácticas de aula & 315 \\
\hline $\begin{array}{l}\text { Uso de prácticas registradas dedicadas al aprendizaje o al } \\
\text { perfeccionamiento }\end{array}$ & 320 \\
\hline $\begin{array}{l}\text { Representación visual de la música: Musicogramas en } \\
\text { movimiento }\end{array}$ & 321 \\
\hline
\end{tabular}

\section{LA APREHENSIÓN DE CONTENIDOS INTERCULTURALES A TRAVÉS DE LOS SONIDOS DEL AUDIOVISUAL}

\begin{tabular}{|l|l|l|}
\hline 4.1 & $\begin{array}{l}\text { Introduciendo conceptos básicos: interculturalidad e } \\
\text { inclusión como marco educativo para los medios } \\
\text { audiovisuales }\end{array}$ & $\mathbf{3 3 5}$ \\
\hline Escuela inclusiva: hacia la vivencia de la interculturalidad & 335 \\
\hline ¿Qué interculturalidad?: Visualizando la alteridad & 338 \\
\hline Prácticas musicales e interculturales: querer y poder & 342 \\
\hline
\end{tabular}

\begin{tabular}{|c|c|c|}
\hline 4.2 & $\begin{array}{l}\text { La música del audiovisual como elemento de análisis } \\
\text { discursivo en las aulas }\end{array}$ & 349 \\
\hline \multicolumn{2}{|r|}{ Consideraciones previas } & 349 \\
\hline \multicolumn{2}{|r|}{$\begin{array}{l}\text { Definición de otras culturas a través de la música. Función } \\
\text { expresiva de los sonidos del audiovisual }\end{array}$} & 353 \\
\hline \multicolumn{2}{|r|}{$\begin{array}{l}\text { Música no occidental en el audiovisual: de la emoción a la } \\
\text { evocación sesgada }\end{array}$} & 361 \\
\hline \multicolumn{2}{|r|}{$\begin{array}{l}\text { Traslación didáctica de los planteamientos teóricos. Ejemplos } \\
\text { prácticos }\end{array}$} & 367 \\
\hline
\end{tabular}




\begin{tabular}{|c|c|}
\hline 4.3 Música, inclusión y compensación educativa & 384 \\
\hline El marco de la acción compensatoria & 384 \\
\hline $\begin{array}{l}\text { Los parámetros inclusivos por medio del audiovisual y la } \\
\text { educación musical. Propuesta metodológica globalizadora. }\end{array}$ & 387 \\
\hline Diseño práctico 1 & 390 \\
\hline Diseño práctico 2 & 400 \\
\hline
\end{tabular}

\section{ESTUDIO EMPÍRICO. USO Y POSIBILIDADES DE LOS RECURSOS AUDIOVISUALES EN LAS AULAS DE EDUCACIÓN MUSICAL}

\begin{tabular}{|c|c|}
\hline Enfoque, objetivos y diseño metodológico & 409 \\
\hline Enfoque de la investigación: otra vez la "mirada pedagógica" & 409 \\
\hline Elementos a investigar: objetivos & 412 \\
\hline Diseño metodológico & 414 \\
\hline
\end{tabular}

\begin{tabular}{|l|c|}
\hline $\mathbf{5 . 2}$ Resultados obtenidos & $\mathbf{4 3 1}$ \\
\hline Aspectos introductorios & 431 \\
\hline $\begin{array}{l}\text { Ámbito 1. } \\
\text { Los procedimientos de sonorización. Usos y posibilidades }\end{array}$ & 432 \\
\hline $\begin{array}{l}\text { Ámbito } 2 . \\
\text { Los procedimientos de conocimiento musical a través del } \\
\text { audiovisual. Usos y posibilidades }\end{array}$ & 435 \\
\hline $\begin{array}{l}\text { Ámbito 3. } \\
\text { Los procedimientos de musicogramas y movimiento. Usos y } \\
\text { posibilidades }\end{array}$ & 439 \\
\hline $\begin{array}{l}\text { Ámbito } 4 . \\
\text { Los procedimientos de extrapolación. Usos y posibilidades }\end{array}$ & 442 \\
\hline $\begin{array}{l}\text { Ámbito 5. } \\
\text { Vinculación entre el uso declarado y las potencialidades } \\
\text { observadas en los distintos procedimientos }\end{array}$ & 446 \\
\hline $\begin{array}{l}\text { Ámbito } 6 . \\
\text { Nivel de aplicación que se estima de los diversos tipos de } \\
\text { procedimientos audiovisuales }\end{array}$ & 448 \\
\hline $\begin{array}{l}\text { Ámbito 7. } \\
\text { Grado de significatividad observada en los diversos tipos de } \\
\text { procedimientos audiovisuales }\end{array}$ & 449 \\
\hline $\begin{array}{l}\text { Ámbito } 8 . \\
\text { Validez de los tipos de procedimientos audiovisuales como parte } \\
\text { integral de una unidad didáctica }\end{array}$ & 450 \\
\hline $\begin{array}{l}\text { Ámbito 9. } \\
\text { Posibilidades de globalización de los procedimientos } \\
\text { audiovisuales con otras áreas diferentes a la educación musical }\end{array}$ & 451 \\
\hline $\begin{array}{l}\text { Ámbito 10. } \\
\text { Nivel de utilización real de los procedimientos audiovisuales }\end{array}$ & 453 \\
\hline
\end{tabular}


ANEXO I. Guía didáctica

ANEXO II. Fichas didácticas

\begin{tabular}{|c|c|c|}
\hline \multicolumn{2}{|c|}{ BIBLIOGRAFÍA } & 481 \\
\hline I & Introducción & 483 \\
\hline II & $\begin{array}{l}\text { Referencias en el marco de la musicología y la música } \\
\text { del audiovisual }\end{array}$ & 485 \\
\hline III & $\begin{array}{l}\text { Referencias en el ámbito de la investigación y prácticas } \\
\text { educativas musicales }\end{array}$ & 496 \\
\hline IV & $\begin{array}{l}\text { Referencias sobre aspectos educativos, sociales y } \\
\text { medios audiovisuales }\end{array}$ & 512 \\
\hline
\end{tabular}


MÚSICA Y MEDIOS AUDIOVISUALES.

PLANTEAMIENTOS DIDÁCTICOS EN EL MARCO DE LA EDUCACIÓN MUSICAL. Juan Carlos Montoya Rubio 


\section{ÍNDICE DE FIGURAS}

Figura 1 Investigación en educación musical a partir de la

interacción maestro - alumno

Sebastián Díaz Iglesias y Rosario Díaz Guerra

Figura 2 Tabla de competencias musicales y dimensiones asociadas

Concha Carbajo Martínez

Figura 3 Comparativa entre la Escuela Tradicional-Pasiva y la 82 Escuela Nueva

María Cecilia Jorquera Jaramillo

Figura 4 Fuentes sonoras para la exploración en clave pedagógica

Figura 5 Tendencias en el aprendizaje por descubrimiento, 93 recepción, mecánico y significativo

John Childs

Josep Lluís Zaragozà

Figura 6 El proceso de significación en procedimientos musicales 121 concretos Juan Carlos Montoya Rubio

Figura 7 Cine pedagógico o educativo. Clasificaciones Julián Juez Vicente

Figura 8 Influencias externas e internas de los vídeos formativos $y$ 130

de enseñanza Juan de Pablos Pons

Figura 9 Redes cognitivas de profesor y alumno ante un resorte 157 significativo

Josep Lluís Zaragozà

Figura 10 Tipos de producciones para el conocimiento musical a 160 través del audiovisual

Juan Carlos Montoya Rubio

Figura 11 Esferas para el conocimiento musical a partir de "Los 180 chicos del coro"

Juan Carlos Montoya Rubio

Figura 12 Ámbitos de aprendizaje musical a través de la teleserie 181 "Patito Feo"

Juan Carlos Montoya Rubio

Figura 13 Estructura didáctica a partir de un tópico musical en la 188 serie "Bob Esponja" Juan Carlos Montoya Rubio

Figura 14 Aplicaciones de una música hecha tópico con diferente 189 carácter

Juan Carlos Montoya Rubio

$\begin{array}{cc}\text { Figura } 15 & \text { "Forma sonata" en la película "Sentido y Sensibilidad" } \\ \text { Robynn J. Stilwell }\end{array}$

Figura 16 Componentes, tipos y subtipos de la canción publicitaria

Figura 17 Ejemplo práctico de extrapolación sobre el "Tema de 201 María Pardavila Neira Hedwig" de "Harry Potter" Audición (I) Juan Carlos Montoya Rubio

Figura 18 Ejemplo práctico de extrapolación sobre el "Tema de Hedwig" de "Harry Potter". Audición (II) 
Figura 19 Ejemplo práctico de extrapolación sobre el "Tema de

211

Hedwig" de "Harry Potter". Audición (III)

Juan Carlos Montoya Rubio

Figura 20 Ejemplo práctico de extrapolación sobre el "Tema de

Hedwig" de "Harry Potter". Audición (IV)

Juan Carlos Montoya Rubio

Figura 21 Ejemplo práctico de extrapolación sobre el "Tema de

Hedwig" de "Harry Potter". Danza

Juan Carlos Montoya Rubio

Figura 22 Ejemplo práctico de extrapolación sobre el "Tema de

Hedwig" de "Harry Potter". Canto

Juan Carlos Montoya Rubio

Figura 23 Ejemplo práctico de extrapolación sobre el "Tema de

Hedwig" de "Harry Potter". Flauta

Juan Carlos Montoya Rubio

Figura 24 Ejemplo práctico de extrapolación sobre el "Tema de

Hedwig" de "Harry Potter". Pequeña percusión

Juan Carlos Montoya Rubio

Figura 25 Metodología didáctica sobre el "Tema de Hedwig" de

"Harry Potter" (I)

Almudena Mosquera Fernández

Figura 26 Metodología didáctica sobre el "Tema de Hedwig" de "Harry Potter" (II)

Almudena Mosquera Fernández

Figura 27 Metodología didáctica sobre el "Tema de Hedwig" de 216

"Harry Potter" (III)

Almudena Mosquera Fernández

Figura 28 Metodología didáctica sobre el "Tema de Hedwig" de "Harry Potter" (IV)

Almudena Mosquera Fernández

Figura 29 Metodología didáctica sobre el "Tema de Hedwig" de "Harry Potter" (V)

Almudena Mosquera Fernández

Figura 30 Metodología didáctica sobre el "Tema de Hedwig" de Harry 217 Potter (VI)

Almudena Mosquera Fernández

Figura 31 Metodología didáctica sobre el "Tema de Hedwig" de "Harry Potter" (VII)

Almudena Mosquera Fernández

Figura 32 Musicograma de seguimiento para un fragmento de "Los aristogatos"

Raquel Bravo Marín

Figura 33 Diseño práctico sobre la música de un anuncio publicitario Juan Carlos Montoya Rubio

Figura 34 Musicograma de seguimiento sobre un fragmento de la 221 obertura de "La Gazza Ladra" de G. Rossini José Manuel Francés Ariño

Figura 35 Interpretación de figuras y alturas de sonido para el musicograma sobre "La Gazza Ladra" de G. Rossini 
Figura 36 Aplicación con instrumentos de altura indeterminada para la actividad sobre "La Gazza Ladra" de G. Rossini

223

Víctor Manuel Montoya Rubio

Figura 37 Diseño práctico sobre la música de un cortometraje de dibujos animados

Juan Carlos Montoya Rubio

Figura 38 Puzzle musical sobre el "Finale" de "Guillermo Tell" de G. Rossini

Juan Carlos Montoya Rubio

Figura 39 Diseño práctico sobre la combinación de la música de un anuncio televisivo y un cortometraje de dibujos animados

Juan Carlos Montoya Rubio

Figura 40 Ejercicio de contrafacta sobre la selección de cortes audiovisuales para la obertura de "El barbero de Sevilla" de G. Rossini (I)

Juan Carlos Montoya Rubio

Figura 41 Ejercicio de contrafacta sobre la selección de cortes 229 audiovisuales para la obertura de "El barbero de Sevilla" de G. Rossini (II)

Juan Carlos Montoya Rubio

Figura 42 Metodología para la extrapolación de melodías y 232 aplicaciones pedagógicas a partir de una película con música preexistente

Juan Carlos Montoya Rubio

Figura 43 Ordenación de los cortes musicales en "La locura del rey Jorge"

Juan Carlos Montoya Rubio

Figura 44 "The Madness of King George Front Titles". Musicograma de seguimiento

Juan Carlos Montoya Rubio

Figura 45 "Smile, it's what you're paid for". Razonamiento de una prosodia en forma de fuga

Juan Carlos Montoya Rubio

Figura 46 "Smile, it's what you're paid for". Prosodia en forma de 238 fuga (I)

Juan Carlos Montoya Rubio

Figura 47 "Smile, it's what you're paid for". Prosodia en forma de fuga 239 (II)

Juan Carlos Montoya Rubio

Figura 48 "Greensleeves". Ejercicio para ejecución con "cotidiáfonos" Juan Carlos Montoya Rubio

Figura 49 "A family matter" \& "London is flooded". Estructuración de 240 temas musicales y visuales

Juan Carlos Montoya Rubio

Figura 50 "A family matter" \& "London is flooded". Práctica del solfeo relativo

Juan Carlos Montoya Rubio

Figura 51 "Prelude". Inicio de actividades de dictados rítmicos y melódicos

Juan Carlos Montoya Rubio 


\begin{tabular}{|c|c|c|}
\hline Figura 52 & $\begin{array}{l}\text { "Starting to recover", "We have no time" y "The Prince } \\
\text { Regent". Narración dramatizada } \\
\text { Juan Carlos Montoya Rubio }\end{array}$ & 245 \\
\hline Figura 53 & $\begin{array}{l}\text { "The Chancellor drives to London". Ejercicio de canto } \\
\text { practicando una contrafacta }\end{array}$ & 247 \\
\hline Figura 54 & $\begin{array}{c}\text { "Opening the houses of Parliament". Aplicación para } \\
\text { pequeña percusión de altura indeterminada (I) } \\
\text { Juan Carlos Montoya Rubio }\end{array}$ & 249 \\
\hline Figura 55 & $\begin{array}{l}\text { "Opening the houses of Parliament". Aplicación para } \\
\text { pequeña percusión de altura indeterminada (II) } \\
\text { Juan Carlos Montoya Rubio }\end{array}$ & 250 \\
\hline Figura 56 & $\begin{array}{l}\text { "A family matter" \& "London is flooded". Práctica del solfeo } \\
\text { relativo } \\
\text { Juan Carlos Montoya Rubio }\end{array}$ & 251 \\
\hline Figura 57 & $\begin{array}{l}\text { "The concert". Aplicación para percusión de altura } \\
\text { determinada } \\
\text { Juan Carlos Montoya Rubio }\end{array}$ & 252 \\
\hline Figura 58 & $\begin{array}{c}\text { "Mr. and Mrs. King". Juego de audición por piezas } \\
\text { Juan Carlos Montoya Rubio }\end{array}$ & 254 \\
\hline Figura 59 & $\begin{array}{l}\text { "He will be restrained" \& "The Madness of King George } \\
\text { End Credits". Guía de seguimiento textural por bloques } \\
\text { temáticos y compases } \\
\text { Juan Carlos Montoya Rubio }\end{array}$ & 256 \\
\hline Figura 60 & $\begin{array}{l}\text { "He will be restrained" \& "The Madness of King George } \\
\text { End Credits". Incipit de cada bloque textural con referencia } \\
\text { por colores } \\
\text { Juan Carlos Montoya Rubio }\end{array}$ & 257 \\
\hline Figura 61 & $\begin{array}{l}\text { Guión para secuencias sonorizadoras en las aulas de } \\
\text { educación musical } \\
\text { Juan Carlos Montoya Rubio }\end{array}$ & 269 \\
\hline Figura 62 & $\begin{array}{r}\text { Guía de seguimiento para un vídeo promocional (I) } \\
\text { Juan Carlos Montoya Rubio }\end{array}$ & 283 \\
\hline Figura 63 & $\begin{array}{r}\text { Guía de seguimiento para un vídeo promocional (II) } \\
\text { Juan Carlos Montoya Rubio }\end{array}$ & 285 \\
\hline Figura 64 & $\begin{array}{l}\text { Resultado global de la sonorización } \\
\text { Juan Carlos Montoya Rubio }\end{array}$ & 286 \\
\hline Figura 65 & $\begin{array}{r}\text { Sonorización para un fragmento de "The Opry House" (I) } \\
\text { Juan Carlos Montoya Rubio }\end{array}$ & 288 \\
\hline Figura 66 & $\begin{array}{r}\text { Sonorización para un fragmento de "The Opry House" (II) } \\
\text { Juan Carlos Montoya Rubio }\end{array}$ & 288 \\
\hline Figura 67 & $\begin{array}{r}\text { Sonorización para un fragmento de "The Opry House" (III) } \\
\text { Juan Carlos Montoya Rubio }\end{array}$ & 289 \\
\hline Figura 68 & $\begin{array}{r}\text { Sonorización para un fragmento de "The Opry House" (IV) } \\
\text { Juan Carlos Montoya Rubio }\end{array}$ & 289 \\
\hline Figura 69 & $\begin{array}{r}\text { Sonorización para un fragmento de "The Opry House" }(\mathrm{V}) \\
\text { Juan Carlos Montoya Rubio }\end{array}$ & 290 \\
\hline Figura 70 & $\begin{array}{r}\text { Sonorización para un fragmento de "The Opry House" (VI) } \\
\text { Juan Carlos Montoya Rubio }\end{array}$ & 291 \\
\hline Figura 71 & $\begin{array}{r}\text { Sonorización para un fragmento de "The Opry House" (VII) } \\
\text { Juan Carlos Montoya Rubio }\end{array}$ & 292 \\
\hline Figura 72 & $\begin{array}{r}\text { Sonorización para un fragmento de "The Opry House" (VIII) } \\
\text { Juan Carlos Montoya Rubio }\end{array}$ & \\
\hline
\end{tabular}




\begin{tabular}{|c|c|c|}
\hline Figura 73 & $\begin{array}{r}\text { Sonorización para un fragmento de "The Opry House" (IX) } \\
\text { Juan Carlos Montoya Rubio }\end{array}$ & 294 \\
\hline Figura 74 & $\begin{array}{l}\text { Guía por equipos para la sonorización de "The Opry } \\
\text { House" } \\
\text { Juan Carlos Montoya Rubio }\end{array}$ & 296 \\
\hline Figura 75 & $\begin{array}{l}\text { Sonorización en cuatro bandas: sonido original, locución y } \\
\text { traducción, música y efectos }\end{array}$ & 298 \\
\hline Figura 76 & $\begin{array}{l}\text { Final de la composición escolar "Sintonía" } \\
\text { Santiago Molas y Lluís Marc Herrera }\end{array}$ & 300 \\
\hline Figura 77 & $\begin{array}{l}\text { Sonorización del anuncio publicitario "Sony Bravia" a } \\
\text { aplicar sobre la música de G. Rossini } \\
\text { Juan Carlos Montoya Rubio }\end{array}$ & 303 \\
\hline Figura 78 & $\begin{array}{l}\text { Sonorización del anuncio publicitario "The cog" a aplicar } \\
\text { eliminando los sonidos originales } \\
\text { Juan Carlos Montoya Rubio }\end{array}$ & 305 \\
\hline Figura 79 & $\begin{array}{l}\text { Selección de imágenes sobre instrumentos y efectos } \\
\text { sonorizadores } \\
\text { Gabriel Plana Rius }\end{array}$ & 309 \\
\hline Figura 80 & 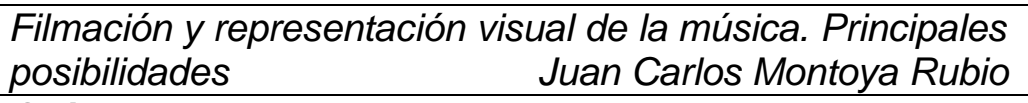 & 315 \\
\hline Figura 81 & $\begin{array}{r}\text { Guía para el seguimiento auditivo y visual de un videoclip } \\
\text { Ana María Sedeño Valdellós }\end{array}$ & 324 \\
\hline Figura 82 & $\begin{array}{r}\text { Teoría cinematográfica del montaje vertical } \\
\text { S. M. Eisenstein }\end{array}$ & 325 \\
\hline Figura 83 & $\begin{array}{l}\text { Tipos de musicogramas a partir del uso audiovisual en } \\
\text { función de su contenido } \\
\text { Juan Carlos Montoya Rubio }\end{array}$ & 329 \\
\hline Figura 84 & $\begin{array}{l}\text { Resultado final de musicogramas con movimiento a partir } \\
\text { del poema sinfónico "Don Quixote" de } R \text {. Strauss } \\
\text { Juan Carlos Montoya Rubio }\end{array}$ & 330 \\
\hline Figura 85 & $\begin{array}{r}\text { Posicionamiento empático directo } \\
\text { Juan Carlos Montoya Rubio }\end{array}$ & 370 \\
\hline Figura 86 & $\begin{array}{l}\text { Diálogo extraído de la serie "Marco, de los Apeninos a los } \\
\text { Andes" } \\
\text { Cap. } 20 \text { "Noche de tormenta", Dir. Isao Takahata (1976). }\end{array}$ & 371 \\
\hline Figura 87 & $\begin{array}{r}\text { Ejemplo procedimental sobre "Mickey’s Man Friday" } \\
\text { Juan Carlos Montoya Rubio }\end{array}$ & 376 \\
\hline Figura 88 & $\begin{array}{l}\begin{array}{l}\text { Guión para el análisis sonoro comparativo en clave } \\
\text { intercultural } \\
\end{array} \\
\text { Juan Carlos Montoya Rubio }\end{array}$ & 380 \\
\hline Figura 89 & $\begin{array}{l}\text { Comparativa del tratamiento de elementos clave en } \\
\text { "Oriente es Oriente" y "El próximo Oriente" } \\
\text { Juan Carlos Montoya Rubio }\end{array}$ & 381 \\
\hline Figura 90 & $\begin{array}{l}\begin{array}{l}\text { Tratamiento musical en relación al nudo argumental en } \\
\text { "Oriente es Oriente" } \\
\text { Juan Carlos Montoya Rubio }\end{array} \\
\end{array}$ & 382 \\
\hline Figura 91 & $\begin{array}{l}\begin{array}{l}\text { El desarrollo de las unidades didácticas en educación } \\
\text { musical y compensatoria } \\
\text { Juan Carlos Montoya Rubio }\end{array}\end{array}$ & 385 \\
\hline Figura 92 & $\begin{array}{l}\text { Propuesta metodológica para la acción compensatoria } \\
\text { combinando dos diseños prácticos } \\
\text { Juan Carlos Montoya Rubio }\end{array}$ & 390 \\
\hline
\end{tabular}


\begin{tabular}{cc}
\hline Figura 93 & $\begin{array}{l}\text { "You'll Never Walk Alone". Arreglo sencillo para } \\
\text { instrumental escolar (I) }\end{array}$ \\
\hline Figura 94 & "You'll Never Walk Alone". Arreglo sencillo para
\end{tabular}

391

instrumental escolar (II)

Juan Carlos Montoya Rubio

Figura 95 Tarea de aprendizaje lingüístico y musical. Canto sobre el original y su traducción

Juan Carlos Montoya Rubio

Figura 96 Tarea de aprendizaje lingüístico y musical. Vocabulario 396 básico y posiciones de la flauta

Juan Carlos Montoya Rubio

Figura 97 Tarea de aprendizaje lingüístico y musical. Secuencias 396 melódicas de "You'll Never Walk Alone"

Juan Carlos Montoya Rubio

Figura 98 Tarea de aprendizaje lingüístico y musical. Vinculación 397 campo semántico - registro musical Juan Carlos Montoya Rubio

Figura 99 Tarea final. Musicograma que describa el contenido 398 musical de "You'll Never Walk Alone" Juan Carlos Montoya Rubio

Figura 100 Planteamiento metodológico del diseño I (Música y 399 Compensatoria) Juan Carlos Montoya Rubio

Figura 101 Ejemplo procedimental para del diseño I (Música y 399 Compensatoria)

Juan Carlos Montoya Rubio

Figura 102 Tarea de mediación. Trabajo sobre melodía y traducción 402 de una canción

Juan Carlos Montoya Rubio

Figura 103 "Los Aristogatos". "Escalas y Arpegios". Alemán con 403 subtítulos en alemán

Juan Carlos Montoya Rubio

Figura 104 "Los Aristogatos". "Escalas y Arpegios". Francés con 403 subtítulos en francés e inglés

Juan Carlos Montoya Rubio

Figura 105 "Los Aristogatos". "Escalas y Arpegios". Versión Karaoke / Instrumental Juan Carlos Montoya Rubio

Figura 106 "Los Aristogatos". "Escalas y Arpegios". Versión 404 instrumental para adición vocal

Juan Carlos Montoya Rubio

Figura 107 "Los Aristogatos". "Escalas y Arpegios". Obstinato y 405 fragmento instrumental

Juan Carlos Montoya Rubio

Figura 108 "Los Aristogatos". "Escalas y Arpegios". Fragmentos de la 405 versión multilingüe

Juan Carlos Montoya Rubio

Figura 109 Materiales alojados en la página web. Presentación Juan Carlos Montoya Rubio

Figura 110 Materiales alojados en la página web. Vínculos a la guía didáctica y el cuestionario 


\begin{tabular}{|c|c|c|}
\hline Figura 111 & $\begin{array}{r}\text { Materiales alojados en la página web. Menú principal } \\
\text { Juan Carlos Montoya Rubio }\end{array}$ & 417 \\
\hline Figura 112 & $\begin{array}{l}\begin{array}{l}\text { Materiales alojados en la página web. Sonorización (I). } \\
\text { Vídeos } \\
\text { Juan Carlos Montoya Rubio }\end{array}\end{array}$ & 418 \\
\hline Figura 113 & $\begin{array}{l}\text { Materiales alojados en la página web. Sonorización (II). } \\
\text { Vídeos y vínculo a la ficha didáctica } \\
\text { Juan Carlos Montoya Rubio }\end{array}$ & 419 \\
\hline Figura 114 & $\begin{array}{l}\text { Materiales alojados en la página web. Sonorización (III). } \\
\text { Vídeos y vínculos a las fichas didácticas } \\
\text { Juan Carlos Montoya Rubio }\end{array}$ & 420 \\
\hline Figura 115 & $\begin{array}{l}\text { Materiales alojados en la página web. Extrapolación. } \\
\text { Fichas didácticas y audición } \\
\qquad \text { Juan Carlos Montoya Rubio }\end{array}$ & 421 \\
\hline Figura 116 & $\begin{array}{l}\text { Materiales alojados en la página web. Musicogramas y } \\
\text { movimiento. Selección de vídeos } \\
\text { Juan Carlos Montoya Rubio }\end{array}$ & 422 \\
\hline Figura 117 & $\begin{array}{l}\text { Materiales alojados en la página web. Conocimiento } \\
\text { musical a través del audiovisual. Vídeo y ficha didáctica (I) } \\
\text { Juan Carlos Montoya Rubio }\end{array}$ & 423 \\
\hline Figura 118 & $\begin{array}{l}\text { Materiales alojados en la página web. Conocimiento } \\
\text { musical a través del audiovisual. Vídeos y ficha didáctica } \\
\text { (II) Juan Carlos Montoya Rubio } \\
\text { Juan }\end{array}$ & 424 \\
\hline Figura 118 & $\begin{array}{l}\text { Materiales alojados en la página web. Conocimiento } \\
\text { musical a través del audiovisual. Vídeos, audición y fichas } \\
\text { didácticas (III) } \\
\text { Juan Carlos Montoya Rubio }\end{array}$ & 425 \\
\hline Figura 120 & $\begin{array}{l}\text { Extracto de la estructura del cuestionario para la } \\
\text { investigación } \\
\qquad \text { Juan Carlos Montoya Rubio }\end{array}$ & 429 \\
\hline Figura 121 & $\begin{array}{r}\text { Resultados obtenidos. Sonorización. Aplicabilidad } \\
\text { Juan Carlos Montoya Rubio }\end{array}$ & 432 \\
\hline Figura 122 & $\begin{array}{r}\text { Resultados obtenidos. Sonorización. Significatividad } \\
\text { Juan Carlos Montoya Rubio }\end{array}$ & 433 \\
\hline Figura 123 & $\begin{array}{l}\begin{array}{l}\text { Resultados obtenidos. Sonorización. Integración en } \\
\text { unidades didácticas } \\
\text { Juan Carlos Montoya Rubio }\end{array} \\
\end{array}$ & 434 \\
\hline Figura 124 & $\begin{array}{r}\text { Resultados obtenidos. Sonorización. Globalización } \\
\text { Juan Carlos Montoya Rubio }\end{array}$ & 434 \\
\hline Figura 125 & $\begin{array}{r}\text { Resultados obtenidos. Sonorización. Utilización previa } \\
\text { Juan Carlos Montoya Rubio }\end{array}$ & 435 \\
\hline Figura 126 & $\begin{array}{l}\text { Resultados obtenidos. Conocimiento musical a través del } \\
\text { audiovisual. Aplicabilidad } \\
\text { Juan Carlos Montoya Rubio }\end{array}$ & 436 \\
\hline Figura 127 & $\begin{array}{l}\text { Resultados obtenidos. Conocimiento musical a través del } \\
\text { audiovisual. Significatividad } \\
\text { Juan Carlos Montoya Rubio }\end{array}$ & 436 \\
\hline Figura 128 & $\begin{array}{l}\text { Resultados obtenidos. Conocimiento musical a través del } \\
\text { audiovisual. Integración en Unidades Didácticas } \\
\text { Juan Carlos Montoya Rubio }\end{array}$ & 437 \\
\hline
\end{tabular}


Figura 129 Resultados obtenidos. Conocimiento musical a través del

438 audiovisual. Globalización

Juan Carlos Montoya Rubio

Figura 130 Resultados obtenidos. Conocimiento musical a través del audiovisual. Utilización previa

Juan Carlos Montoya Rubio

Figura 131 Resultados obtenidos. Musicogramas y movimiento.

Aplicabilidad

Juan Carlos Montoya Rubio

Figura 132 Resultados obtenidos. Musicogramas y movimiento.

Significatividad

Juan Carlos Montoya Rubio

Figura 133 Resultados obtenidos. Musicogramas y movimiento.

Integración en unidades didácticas

Juan Carlos Montoya Rubio

Figura 134 Resultados obtenidos. Musicogramas y movimiento.

441

Globalización

Juan Carlos Montoya Rubio

Figura 135 Resultados obtenidos. Musicogramas y movimiento.

442

Utilización previa

Juan Carlos Montoya Rubio

Figura 136 Resultados obtenidos. Extrapolación. Aplicabilidad

Figura 137 Resultados obtenidos. Extrapolación. Significatividad Juan Carlos Montoya Rubio

Figura 138 Resultados obtenidos. Extrapolación. Integración en unidades didácticas

Juan Carlos Montoya Rubio

Figura 139 Resultados obtenidos. Extrapolación. Globalización Juan Carlos Montoya Rubio

Figura 140 Resultados obtenidos. Extrapolación. Utilización previa Juan Carlos Montoya Rubio

Figura 141 Resultados obtenidos. Relación entre el uso de materiales y la estimaron de su potencial

Juan Carlos Montoya Rubio

Figura 142 Resultados obtenidos. Comparativa de aplicabilidad en cada procedimiento

Juan Carlos Montoya Rubio

Figura 143 Resultados obtenidos. Comparativa de significatividad en 450 cada procedimiento

Juan Carlos Montoya Rubio

Figura 144 Resultados obtenidos. Comparativa de integración en 451 unidades didácticas en cada procedimiento Juan Carlos Montoya Rubio

Figura 145 Resultados obtenidos. Comparativa de globalización en 452 cada procedimiento

Juan Carlos Montoya Rubio

Figura 146 Resultados obtenidos. Comparativa de utilización previa en cada procedimiento 


\title{
CAPÍTULO 1
}

\author{
INTRODUCCIÓN. \\ FUNDAMENTOS PARA UNA \\ INVESTIGACIÓN INTERDISCIPLINAR
}


MÚSICA Y MEDIOS AUDIOVISUALES.

PLANTEAMIENTOS DIDÁCTICOS EN EL MARCO DE LA EDUCACIÓN MUSICAL. Juan Carlos Montoya Rubio 


\section{INTRODUCCIÓN. FUNDAMENTOS PARA UNA INVESTIGACIÓN INTERDISCIPLINAR}

\subsection{CARACTERÍSTICAS, POTENCIALIDADES Y LÍMITES DE LA INVESTIGACIÓN}

\section{Acerca de la elección del tema}

El estudio que se presenta es el resultado de un conjunto de circunstancias que, de un modo más o menos directo, han acabado forjando el perfil académico de quien escribe. Así, el hecho de conjugar prácticamente a partes iguales música y educación supone reflejar la amalgama de mis tendencias formativas más influyentes. El uso audiovisual, por otro lado, implica la búsqueda de una aplicación de técnicas y métodos novedosos en los campos de actuación antes citados.

En este sentido, al margen de aspectos que penetran directamente en el ámbito de la didáctica, hemos de reseñar como primera fuente en la elaboración del presente escrito la musicología, tramo en el que tomé contacto por vez primera con la música de los medios audiovisuales, en ese caso, específicamente cinematográfica. No obstante, la ausencia de una corriente universitaria que diera continuidad en los planes de estudio a dicha aproximación dificultaba hondamente la formación más allá del empeño personal.

Por otro lado, la otra gran vertiente que focaliza mi interés es la educación. De hecho, la labor docente ha compartido dedicación con todas las investigaciones realizadas hasta el momento $\mathrm{y}$, bien desde las aulas de primaria, secundaria o universitarias, ha servido para implementar un punto de realidad a aquello que, en ocasiones, pudiera resultar extremadamente teórico. De hecho es desde la experiencia propia desde donde nacen y se nutren la gran mayoría de los contenidos que se presentan. 
Además, es justo resaltar que la perspectiva de análisis del proceso de enseñanzaaprendizaje varió sensiblemente a raíz de mi contacto con la antropología. Desde ese momento, mis primeros estudios de corte antropológico me invitaron a mirar desde otro prisma los centros docentes en general y las aulas de música en particular, y a valorar los materiales audiovisuales como un medio singular tanto de registro como, sobre todo, de interpretación de la realidad. El hecho de poder realizar propuestas pedagógicas que se sirvieran de un material utilizado con asiduidad por el alumnado haciendo ver que algunas de las premisas que le hacen omnipresente en nuestra sociedad pueden ser razonadas, hacía que la tarea adquiriese matices de descifrado a través de la particular "mirada antropológica" que, como apuntaremos a lo largo del texto, se transforma tomando prestados sus postulados en una necesaria "mirada pedagógica". En la combinación de todos los elementos anteriores comencé a vislumbrar el inmenso panorama de posibilidades que se estaba configurando ante mí.

Así pues, hemos de buscar en los textos relacionados con la música de los medios audiovisuales un primer marco de aproximación temática. Sin duda, el aumento de la literatura referida a este campo, con especial desarrollo en lo que respecta a la música de cine, es un reflejo de la importancia que está tomando y favorece que se puedan buscar implicaciones pedagógicas que se desprendan de dichas reflexiones. Junto al incentivo que supone esta realidad, pretendemos participar activamente en los procesos de renovación y en sus planteamientos didáctico-musicales, los cuales sufrieron una auténtica revolución en el pasado siglo y beben aún, en la mayoría de los casos, de los efluvios de unas metodologías aún válidas pero cada vez más clásicas.

La necesidad de hacer de la música un campo expresivo y perceptivo acorde con los tiempos que corren queda de manifiesto en el incremento puntual de prácticas didácticas que parten, de uno u otro modo, del formato audiovisual y sus propios códigos. No obstante, a pesar de que las diferentes leyes educativas desde la década de los 90 han amparado el tratamiento de los medios audiovisuales, en la práctica se atestigua una falta de sistematización y de rigor a la hora de tratar los elementos que componen el lenguaje musical inserto en ellos. De esta impresión surge la necesidad de elaborar un texto que conjugue todas las vías posibles de actuación dentro de la educación musical. De este modo, a la recopilación de experiencias que se han puesto en conocimiento de la comunidad científica, se añadirán otras elaboradas ex profeso y 
testadas en las aulas para ejemplificar el abanico de posibilidades didácticas que ofrecen los recursos de este tipo en la educación musical. Todo ello con el fin de ilustrar el amplio espectro metodológico al que se puede aspirar, a pesar del estrecho margen al que se relega a la música desde las diferentes administraciones educativas.

Se precisan, en cualquier caso, unas breves acotaciones en lo que respecta al contenido que a continuación se desarrollará. La primera observación versa sobre la aplicación del concepto de "medio audiovisual". Entendiendo que enunciado de manera genérica su extensión y potencial es sumamente amplio, restringimos su uso en torno a la música que realmente sea fructífera en su hipotética aplicación en las aulas de educación musical. Por ello, en aras de la funcionalidad que enmarcará el presente texto, serán objeto de estudio los sonidos que acompañan a realizaciones propias del cine (películas de diferente metraje y temática) o de la televisión (incluyendo vídeos, música del ámbito publicitario, sintonías, música incidental para series...), así como determinados soportes multimedia que favorezcan claramente la significatividad en los alumnos al tiempo que permitan desarrollar los bloques de contenido propios de la enseñanza de la música en las etapas obligatorias dentro del contexto español. Otros espacios de utilización audiovisual -reseñados con meridiana claridad por Josep Lluís i Falcó$^{1}$-, como puedan ser los videojuegos o las páginas web, serán valiosos en tanto en cuanto nos sirvan como medio de acceso y reproducción de información o documentos (audiovisuales o no) al respecto, pero su magnitud como fuente de elaboración pedagógica será tratada de manera tangencial ${ }^{2}$.

La segunda precisión se centra en determinar los niveles de aplicación de las propuestas que se presenten y la flexibilidad de las mismas. En principio, la franja educativa que más nos interesa a la hora de encuadrar las reflexiones venideras será la de la educación obligatoria, inscrita en nuestro país desde el primer curso de Educación Primaria hasta el final (cuarto nivel) de Educación Secundaria Obligatoria. En cualquier caso, propugnamos unos contenidos abiertos, cuya maleabilidad permita (si así se

\footnotetext{
${ }^{1}$ LLUÍS i FALCÓ, J. (2009): "Contra una historia monumental de la música en el audiovisual. Más allá del cine y las estrellas". OLARTE MARTÍNEZ, M. (Ed.) Reflexiones en torno a la música y la imagen desde la musicología española. Salamanca: Plaza Universitaria Ediciones, pp. 45-81.

${ }^{2}$ Artículos como el de Julio Montero facilitan el acceso al mundo del videojuego y a su tratamiento desde técnicas similares a las que expondremos en capítulos sucesivos: MONTERO RODRÍGUEZ, J. (2009): "Pautas compositivas en los videojuegos del siglo XXI". OLARTE MARTÍNEZ, M. (Ed.) Reflexiones en torno a la música y la imagen desde la musicología española. Salamanca: Plaza Universitaria Ediciones, pp. 585-598.
} 
requiere) exceder estos límites y, además, trasvasar procedimientos de uno a otro nivel dentro del marco que establecemos. Hace tiempo que, en diferentes foros y escritos, huimos de la delimitación y consiguiente correspondencia entre determinadas praxis educativas y su aplicación forzada en unas edades o ciclos específicos. La heterogeneidad que se dibuja en nuestros centros de enseñanza hace que, a través de un trabajo de mediación por parte del profesor responsable del grupo, se puedan abordar de manera tan sorprendente como efectiva unos mismos contenidos en uno u otro nivel. Además, este procedimiento goza de la ventaja de integrar mejor los conocimientos de todos fomentando su participación, en tanto en cuanto el docente se encarga de proponer los medios necesarios para que todos formen parte de las realizaciones que se propongan.

Igualmente, hemos de hacer referencia a que los criterios de selección de material no serán objeto primordial del estudio, sino más bien las técnicas y los métodos en que el audiovisual puede ser integrado en los contextos educativos. Obviamente, al trabajar con materiales pedagógicos y referirnos a ellos ejemplificando en muchos casos, aludiremos a una serie de criterios generales en la selección de material de inexcusable observación para cualquier práctica educativa (de manera general: la temática, las dificultades que presenta, las actividades que puede llevar asociadas, la motivación que genera o su carácter globalizador y generalizante). En todo caso, ello no implica exclusión taxativa, ya que entendemos que las estrategias que cada docente pudiera esgrimir para generar aprendizajes, incluso volteando el significado de lo que se muestra en formato audiovisual, no nos puede hacer repudiar, a priori, ningún tipo de contenido concreto.

Consecuentemente con las ideas expuestas, el trabajo que sigue enfatizará la elaboración de estrategias procedimentales a partir no tanto de elementos empíricos como de la comprensión y reorientación de las situaciones de aula manifestadas de diferente modo. Defendemos que una investigación centrada en la actualización de criterios pedagógicos que se han mostrado solventes en otros momentos pero que comienzan a renquear hoy en día, ante la falta de un espacio robusto dentro de la educación obligatoria española, ha de partir de la observación de la problemática existente. A partir de ese punto, una vez identificado el convulso panorama investigador en el marco de la educación musical, será más pertinente abordar el modo de incluir el 
audiovisual en él. Entendemos la investigación, de acuerdo con Tomasi y Vanmaele, como un "estudio basado en la comprensión sistemática y la conciencia crítica del conocimiento" y en ningún caso "con un sentido restringido o referido a un método científico tradicional" "3. Consideramos que la apreciación es importante porque en el proceso de búsqueda y generación de recursos no pretendemos encorsetar a la educación musical a unos límites en los que ya, en la práctica, suele encontrarse. El hecho de querer abrir el campo a otros medios implica que el proceso de elaboración de la investigación doctoral no responda exclusivamente a criterios empíricos sino que se sirva, en gran medida, de las sensaciones y experiencias que han sido registradas especialmente en artículos que muestran propuestas de aula vivenciadas con alumnos. Por ello, la descripción y la interpretación jugarán un papel determinante, y el hecho de incluir elementos cuantitativos quedará subordinado a la importancia que la comprensión cualitativa desprenda de ellos.

\section{Objetivos}

La pretensión fundamental en torno a la cual ha gravitado esta investigación ha sido la de establecer una tipología de procedimientos musicales con sólidos vínculos al hecho audiovisual que pudieran ser aplicables de manera real y efectiva a las aulas de música del presente. Al margen de divagaciones acerca de lo que debería ser una educación musical basada en la comunicación audiovisual o en el conocimiento de los códigos que rigen en el compendio formado por sonidos e imágenes, el objetivo primordial es el de rescatar (y en su caso elaborar) propuestas pedagógicas para las aulas de música de la sociedad actual, con las limitaciones y potencialidades que todo ello lleva consigo. Obviamente, de esta finalidad se desprenden una serie de objetivos adosados que cobran especial relevancia tanto en su consecución autónoma como en relación con el éxito final que supone participar del objetivo principal, enunciado anteriormente. Son detallados en los siguientes párrafos.

\footnotetext{
${ }^{3}$ TOMASI, E. y VANMAELE, J. (sin año): "Doctoral Studies in the field of music-current status and latest developments". Erasmus TNP Polifonia, p. 11. Disponible en: $\langle$ http://tuning.unideusto.org/tuningeu/index.php?option=content\&task=view\&id=219\&Itemid=243> [Consulta 9-II-10]. Traducción del inglés de GUTIÉRREZ BARRENECHEA, M. (2008): "Desafíos y oportunidades para la investigación musical en el horizonte del proceso de Bolonia". ÁLAMO, A. y LUCEÑO, M. Actas del I Congreso de Investigación y Educación Musical. Madrid: Enclave Creativa Ediciones, p. 369.
} 
En primer lugar, urge el establecimiento de vínculos entre las teorías que orientan la investigación en el campo de la música de los medios audiovisuales con las metodologías activas propias de la educación musical moderna. A partir de un granado número de ejemplos trataremos de mostrar que esta vinculación no sólo es apropiada sino que además se torna básica para una educación musical renovada sobre los fundamentos audiovisuales. En este sentido, es frecuente que desde determinados estudios que se centran, por ejemplo, en la música de cine, se desprendan elementos que puedan ser objeto directo de tratamiento pedagógico o, invirtiendo los términos, una articulación didáctico-musical sea susceptible de realizarse a partir de la estructuración que desarrollan los planteamientos de la teoría de la música de cine. Consideramos altamente interesante rescatar esas propuestas o, en caso de no tratar directamente elementos aplicables a las aulas de educación musical, orientarlas por medio de un trabajo de análisis, reflexión y adaptación. Todo ello incidirá en la renovación de los enfoques pedagógico-musicales que hoy día viven aún bajo el influjo de las metodologías activas que han marcado la práctica musical de las últimas décadas.

Para llevar a cabo planteamientos como los anteriores, otro de los objetivos elementales que hemos de perseguir es el rastreo y toma en consideración de las prácticas preexistentes a partir de la bibliografía que nos remita a ellas. Como decimos, en este proceso se antoja ineludible la detección y puesta de manifiesto de experiencias musicales que, en el marco del audiovisual y orientadas a la práctica educativa, puedan ser de utilidad a la hora de afrontar planteamientos pedagógicos. Es relativamente frecuente encontrar en revistas especializadas o en publicaciones colectivas algunas de estas articulaciones didácticas, de las cuales obtener un buen número de ejemplos que se instauran en contextos educativos concretos. No obstante, no es en absoluto habitual enlazar varios artículos que desarrollen una temática similar dentro de un mismo compendio bibliográfico, así como tampoco suele ser fácil hallar taxonomías acerca del significado y las posibilidades al trabajar la música desde los medios audiovisuales. Por ello, entre los objetivos aledaños a la idea principal de la presente tesis destaca el de ocupar el espacio que deja dicha omisión, aportando un referente al que poder acudir en caso de optar por trabajar desde estos postulados la educación musical.

Por otro lado, es preciso añadir al proceso deíctico y amplificador reseñado en el párrafo anterior un matiz creativo. Este objetivo tratará de cumplir una doble faceta: 
ejemplificante (en tanto en cuanto aclarará los términos que se quieren mostrar) y enriquecedora (en el sentido de que tratará de aumentar el número de realizaciones pedagógicas que, en ocasiones, podrá ser muy limitado). Debido a esta última observación, la determinación de una estructura que defina los distintos tipos de aplicación didáctico-musical desde los medios audiovisuales no podrá sustentarse únicamente sobre las experiencias publicadas en los últimos tiempos, ya que su generación será ínfima en comparación con otros tipos procedimentales. De este modo, será común encontrar actividades musicales a las que aludir que muestren el potencial de los medios audiovisuales, por ejemplo, desde el trabajo sobre la trama argumental de una película o serie televisiva, pero es posible constatar una tendencia a dejar huérfana la parte referida al descifrado de la música inserta en propios discursos audiovisuales y sus consecuencias dentro del aula. Por ello, allá donde se precise, se desarrollarán herramientas de trabajo pedagógico en torno a la música contenida en los medios audiovisuales, destacando los diferentes tipos de aplicación en función de las necesidades educativas que se tengan y de las posibilidades que ofrezca cada formato audiovisual. Así pues, apuntamos la generación de orientaciones pedagógicas concretas como otro de los objetivos a conseguir.

Además, si pretendemos hacer que el trabajo beba del realismo de las estructuras generadas por la administración para la enseñanza de la música en las etapas obligatorias, no podemos dejar de lado, como objetivo inexcusable, que las posibilidades pedagógicas que se pudieran argumentar tuvieran como referencia las especiales circunstancias de la docencia musical actual. La constatación del debilitamiento, especialmente en cuanto al horario lectivo, de lo musical en el organigrama educativo habrá de hacernos reflexionar sobre el mejor modo de plantear recursos pedagógicos. Por ello, postulamos la necesidad de orientar las metodologías musicales hacia la faceta tecnológica y de la información que pueden aportarnos los contenidos audiovisuales. La tendencia a la baja que podríamos encontrar en el tratamiento general de la educación musical en este particular contexto podría verse frenada e impulsada hacia la dirección opuesta por el concurso de los recursos tecnológicos, que viven un momento de emergencia en la educación actual, debido a que se atisba su gran potencial, ya sin tantos reparos como años atrás. Por tanto, contagiar a la educación musical del entusiasmo con que es vista la aplicación de las 
Tecnologías de la Información y la Comunicación en las aulas vertebra otro de los objetivos más esperanzadores del presente estudio.

En íntima relación con la consideración anterior, reseñamos como necesario establecer criterios metodológicos y modelos de enseñanza que conecten con los intereses del alumnado y sus vivencias, a través del uso de elementos cercanos e inteligibles por ellos. Sin duda, el desarrollo de un marco de actuación bien definido y estructurado en torno a los medios audiovisuales dotará a la educación musical de un atractivo mayor, de modo que se facilite al alumno la decisión de acceder con mayor interés al conocimiento que se pretende impartir, por lo que en esa configuración hallamos un objetivo sumamente motivador.

El siguiente objetivo lo concretamos en la propia naturaleza de los contenidos que tratamos de poner de relieve. Así, a pesar de proponernos una renovación de la educación musical para la enseñanza obligatoria, no buscamos el desmoronamiento de los axiomas pedagógico-musicales actuales, sino su reorientación. Por ese motivo, el trabajo a realizar no desechará los materiales y prácticas que ya son clásicos, sino que los reconducirá hacia el uso audiovisual, en una enriquecedora labor de actualización. Entre las ventajas de las metodologías conocidas y usadas por los docentes (en cierto modo homogéneas en cuanto a su difusión por todo el territorio nacional) encontramos su susceptibilidad para la reconversión y la adaptación a los procesos imaginativos que, partiendo de la realidad del aula, hacen que el docente pueda tomar aquello que le es útil de cada una de ellas direccionándolo hacia las habilidades y motivaciones del propio alumnado. Por tanto, reseñamos la actualización enriquecedora que recicle los elementos válidos de las prácticas de aula y los potencie por medio del acercamiento al mundo del discente.

Por último, el objetivo que describimos hace referencia al fomento del sesgo transversal, entendido como desarrollo intercultural o compensador dentro de la llamada escuela inclusiva. La música, tantas veces ponderada como lenguaje universal y positivo, no queda no obstante al margen de manipulaciones y distorsiones que pueden residir en el tratamiento que de ella se hace en los medios de comunicación. Un estudio como el que presentamos no puede obviar este aspecto, por lo que perfilamos como objetivo esgrimir modos de actuación que palien esta circunstancia y faciliten al alumno un posicionamiento crítico ante la información, no sólo visual, sino también sonora que 
es asimilada y no siempre razonada. Asimismo, las prácticas musicales habrán de servir para la consecución de los paradigmas educativos actuales que postulan relaciones entre iguales basadas en la cooperación. Todos estos elementos, que tendrán un capítulo de desarrollo casi autónomo, representarán una vía más de ubicación real con la sociedad multicultural que vivimos.

\section{Criterios metodológicos}

Teniendo en cuenta el contenido de la presente investigación, la metodología a utilizar ha de orientarse a la sistematización de procedimientos didácticos a través de su organización y puesta en conocimiento de la comunidad científica. Como ya apuntamos, se puede argumentar que la metodología está encaminada a establecer unas líneas de actuación, a través de las cuales los materiales pedagógicos tradicionales de la educación musical no se sustituyan sino que se aderecen con la aportación de los audiovisuales. El modo de llevar a cabo dicha empresa se organizará de acuerdo con las directrices de los siguientes párrafos.

En primer lugar, una vez delimitados los márgenes de la investigación se reflexionará brevemente sobre las vicisitudes que supone aproximarse al estudio de la educación musical y su potencial llegada hacia el audiovisual como entorno novedoso de enseñanza-aprendizaje. Todo ello, que conforma el primer capítulo, posee como principal intención el emplazar adecuadamente los contenidos que seguirán en apartados sucesivos y que, en cierto modo, quedan condicionados por las contingencias que se van enumerando.

En el segundo capítulo se articulará un marco teórico-referencial que sirva para circunscribir los planteamientos prácticos en nuestra realidad educativa en particular y social en general mientras que, por otro lado, se construirá la clasificación de elementos pedagógicos que se desprendan de las reflexiones iniciales y se puedan inscribir en ellas. Así, amparado por las crecientes potencialidades que desde la legislación se otorga al ámbito audiovisual y bajo las asfixiantemente reducidas posibilidades a que se encamina la educación musical, una primera parte de este bloque (que abarcaría los tres primeros apartados) se adentra en algunos elementos que constatan la necesidad de abordar estrategias de cambio, especialmente desde el perfil que hoy en día ofrecen 
alumnos, docentes y recursos educativos. Reconocido el terreno, la segunda mitad del capítulo se centra en la justificación de una enseñanza musical desde la participación audiovisual, como fundamento de aprendizaje significativo. Para ello, resultará útil la observación de teorías cinematográficas y educativas, con el fin de que la exploración de la didáctica de los medios audiovisuales en las diferentes áreas de conocimiento logre extraer posibles vías de actuación en el ámbito de la música. Como se infiere, este apartado supone un esfuerzo por cruzar referencias venidas de los diferentes campos de actuación que nos atañen directamente: la música de los medios audiovisuales, la didáctica de los audiovisuales (cuya literatura suele omitir el elemento sonoro) y las Tecnologías de la Información y la Comunicación aplicadas a la educación musical. La consecución de las ideas anteriores ha de capacitarnos para establecer las líneas básicas de lo que debe ser una educación musical basada en la utilización de los medios audiovisuales, es decir, "a través" de ellos o "con" ellos, y no tanto "de" dichos medios.

Una vez elaborado este marco teórico nos serviremos, desde otro prisma, de aquellos escritos que, de manera central o tangencial, hayan desarrollado elementos propios del discurso musical inserto en el visual. Desde este momento, al abrir el tercero de los capítulos, la atención prioritaria será la de determinar los métodos y técnicas pedagógicas en la utilización musical de los medios audiovisuales, suscitando nuestro interés aquellas praxis que, bien nos conducen al aprendizaje musical a través de estos medios bien nos llevan al desarrollo didáctico de otros contenidos no musicales, pero para lo cual han de valerse del hecho sonoro.

El trabajo de rastreo y muestra de material didáctico conducente a la elaboración tipológica se desarrolla, básicamente, en una doble vertiente. En primer lugar se articulan un compendio de experiencias preexistentes derivadas de múltiples lecturas. Este paso permite constatar la existencia de procedimientos educativos que, instaurados en el ámbito de la educación musical, se sirven de los medios aludidos. Igualmente, arroja luz acerca de aquellas prácticas que, aunque posibles en tanto en cuanto existen recursos materiales, son minoritarias. A continuación se procede al trabajo de creación, mediante el cual se completen aquellos procedimientos que no son tan habituales tal vez, a causa de falta de herramientas conceptuales apropiadas en la secuencia de elaboración didáctica. 
En este sentido, se tiende a explorar y experimentar sobre las diferentes estrategias de educación musical resultantes de la aplicación pedagógica de la banda de sonido del audiovisual. El resultado que emerge tras esta reflexión abre las posibilidades metodológicas en función de diferentes campos de utilización didáctica, ejemplificándose aquellos apartados que resultan de las taxonomías realizadas. Entre otras, se aportan posibilidades para el conocimiento y comprensión musical por medio del audiovisual, para la extrapolación de una o varias melodías de una banda de sonido, para la sonorización o adición musical -total o parcial- a un fragmento visual prefijado, y para la filmación y representación visual de elementos sonoros preexistentes. La intención primordial de esta delimitación es la de procurar una clasificación en la cual tuviera acomodo cualquier procedimiento de raíz audiovisual que pudiera insertarse en la práctica educativa musical.

El cuarto capítulo se dedicará a mostrar algunas posibilidades de actuación didáctica teniendo como referente principal la interculturalidad, germen y columna vertebral de la escuela inclusiva. Ante la inmensa cantidad de bibliografía que el término en cuestión ha generado en los últimos años, y debido a que nuestro foco de interés no radica en su estudio detallado, optamos por reseñar aquellas características interculturales que pueden ser trabajadas con mayor ahínco desde el audiovisual, ya que éste es un escenario que puede generar, tanto desde lo visual como desde lo sonoro, el caldo de cultivo propicio para asignar estereotipos a la alteridad. Definidos los ámbitos de interés al principio de este capítulo, los dos apartados finales se ocuparán de establecer metodologías que, a partir de la vivencia del hecho intercultural desmonten falacias asumidas, especialmente sobre el contacto cultural. Por medio de la música del audiovisual se buscará atender al modo en que son retratadas otras culturas y a lo irreal de la situación, al tiempo que se establecerán procedimientos concretos para el trabajo compensador entre alumnos de diversa procedencia.

Como epílogo a la investigación, y antes de las conclusiones que se puedan extraer del conjunto de la misma, añadimos un estudio empírico encaminado a evaluar los tipos de procedimientos que se establecieron en el capítulo tercero. Las aportaciones del profesorado en torno al conocimiento que de ellos se tiene, su nivel de utilización, o su grado de conformidad o disconformidad con su uso redondearán las perspectivas trazadas en el inicio del diseño de la tesis doctoral, esto es, testar la pertinencia en un 
contexto real de unos procesos pedagógicos que pudieran propiciar un nuevo impulso a la educación musical.

\section{Estado de la cuestión}

Ya ha sido argumentada la ausencia de planteamientos teóricos o prácticos que aglutinen un número amplio de publicaciones relacionadas con la didáctica de la música de los medios audiovisuales, o de alguna de sus vertientes más utilizadas como pueda ser la pedagogía a partir de la música de cine. En consecuencia, ha quedado igualmente de manifiesto la necesidad de articular un discurso a partir de fuentes cercanas al tema principal pero de diversa índole.

Así, entre las incursiones en la didáctica musical en conjunción con las teorías audiovisuales encontramos una minoría de fuentes que puedan atañer al tema central de la tesis. Es el caso de la obra de Amparo Porta Músicas públicas, escuchas privadas: hacia una lectura de la música popular contemporánea, publicada en 2007 a partir de un buen número de publicaciones anteriores de la autora ${ }^{4}$. Ejemplos como éste son paradigmáticos en lo que se refiere al tratamiento de elementos musicales insertos en el audiovisual, aunque no obstante resultan extremadamente cercanos a la didáctica en algunos de sus capítulos y algo más alejados en otros.

Ante la carencia de manuales al respecto, para hallar escritos con validez total en cuanto a correspondencia con nuestro campo de interés es preciso remitirse a las revistas científicas especializadas en música y educación, ya que de su lectura se pueden extraer experiencias que sirvan como ejemplo y matriz de alguno de los apartados a desarrollar. Ante la comentada complejidad en la investigación desde la educación musical, hemos decidido hacer de ella un inicio de los planteamientos para nuestro estudio en el siguiente apartado del presente capítulo. No obstante, en este momento y para remarcar el estado de la cuestión, podemos apuntar que el vaciado de revistas especializadas en este ámbito, tales como Música y Educación, LEEME, Eufonía o Revista Electrónica Complutense de Investigación en Educación Musical podrán

\footnotetext{
${ }^{4}$ Las referencias de este apartado aparecerán citadas en su totalidad en la bibliografía final.
} 
aportarnos valiosos ejemplos llevados a cabo por docentes sobre los que realizar la categorización de tipos musicales audiovisuales ${ }^{5}$.

En este sentido, dentro del variado haz de temáticas que mueven la enseñanza de la música, existen experiencias puntuales que resultan altamente aprovechables para nuestros intereses. Tal es el caso de artículos que desarrollan propuestas pedagógicas de docentes en activo dentro del tramo educativo obligatorio (lo cual ancla en la realidad que buscamos nuestra investigación), como "Amadeus. Una visión del genio a través del cine", aportado por Dusil Diéguez (2007) en Música y Educación, o teóricas y firmadas por docentes universitarios, como "Las Tecnologías de la Información y la Comunicación en el aula de música”, de Aróstegui Plaza (2005) en Musiker, cuya observación serviría para complementar desde otro plano aquello que se pretende investigar. Junto a ejemplos como los descritos, son igualmente rescatables publicaciones similares con aportaciones que, sin tratar directamente la inclusión de la música del audiovisual en las aulas de educación musical, sirven para explorar técnicas extrapolables a nuestro ámbito de estudio. Sirva como ejemplo "Cuentos musicales para los más pequeños", escrito por Arguedas Quesada (2006) en Revista Actualidades Investigativas en Educación.

Otro ámbito de referencia ineludible es la teorización desarrollada en los últimos tiempos en la vertiente musicológica que se ocupa de los medios audiovisuales. Existen ya un buen número de manuales que sirven para generar un marco de actuación válido, desde donde rescatar las funciones de la música del cine y a partir de las que desarrollar hipotéticas implicaciones en lo educativo. Es de justicia comenzar resaltando el impulso que ha recibido este apartado desde la publicación de las actas de los simposia salmantinos La Creación Musical en la Banda Sonora (los dos primeros en la publicación de 2005 titulada La música en los medios audiovisuales y los dos

\footnotetext{
${ }^{5}$ Tomamos como principales referencias estas publicaciones en acuerdo con Fernando Bautista Vizcaíno, quien vislumbra en ellas la emergencia de la educación musical, si bien de manera desigual (teniendo en cuenta que algunas como 12 notas dedican a la investigación algún artículo esporádico y otras como Eufonía han planteado monográficos específicos para dicho tema). El autor referenciado, además, en un texto cuya principal misión es la de mostrar el advenimiento de los trabajos de investigación en el ámbito de los conservatorios, explica las vías principales por las que se ha vehiculado la labor investigadora musical en España. Este apartado al que nos referimos, altamente interesante por lo sintético y esclarecedor, enfatiza la importancia que para el alumbramiento de una corriente de pedagógico-musical en nuestro entorno tuvieron determinadas jornadas de investigación musical, así como la continuidad de publicaciones periódicas referidas a nuestro ámbito de estudio: BAUTISTA VIZCAÍNO, F. (2008): "La investigación entra en los conservatorios: El caso canario”. ÁLAMO, A. y LUCEÑO, M. Actas del I Congreso de Investigación y Educación Musical. Madrid: Enclave Creativa Ediciones, pp. 347-348.
} 
siguientes, en los que la vertiente didáctica ya posee un capítulo con entidad, en la fechada en 2009 Reflexiones en torno a la música y la imagen desde la musicología española, en ambos casos bajo la edición de Matilde Olarte Martínez). Afortunadamente, la aparición del apartado didáctico-musical en estos foros parece tener continuidad, lo cual es otra muestra de sensibilidad desde la musicología hacia la pedagogía musical basada en sus propios parámetros. Además, desde el referente musicológico serán muchas las influencias que una investigación como ésta pueda recibir ${ }^{6}$. En este sentido, entre los pioneros es habitual recurrir a la obra de Kurt London y a la de Adorno y Eisler (respectivamente Film Music, 1936 y El cine y la música, 1944), pero para las derivaciones didácticas que buscamos serán mucho más útiles otros que nos acerquen a una realidad más actual del fenómeno en cuestión. Entre los manuales que recopilan ejemplos y de los cuales se pueden extraer casos para aplicaciones concretas destacan las obras de Padrol (Diccionario de bandas sonoras, 2007), Navarro Arriola y Navarro Arriola (Música de cine: historia y coleccionismo de bandas sonoras, 2003), Russell y Young (Bandas sonoras, 2000), Cueto (Cien bandas sonoras en la historia del cine, 1996) y Benítez y Carmona (Nombres de la banda sonora. Diccionario de compositores cinematográficos, 1996). Además, resultan muy apropiados por su contenido explicativo otros que, en mayor o menor medida, se han erigido en clásicos en nuestra lengua ante la inexistencia de un mayor grupo de publicaciones. Es el caso de los textos de Padrol y Valls Gorina (Música y cine, 1986 con ampliación de 1990), Pachón Ramírez (La música en el cine contemporáneo, 1992 con revisión de 1998), Colón Perales (Introducción a la historia de la música en el cine. La imagen visitada por la música, 1993), Colón Perales, Infante del Rosal y Lombardo Ortega (Historia y teoría de la música en el cine. Presencias afectivas, 1997), Xalabarder (Enciclopedia de las bandas sonoras, 1997; Música de cine. Una ilusión óptica, 2006). Junto a este tipo de manuales, conviene tener en cuenta otros escritos que penetran en una faceta más teórica y que, tal vez, puedan alentar desde ella la generación de un marco mixto al cruzarse con referencias educativas. En este apartado destacamos a Román (El lenguaje musivisual: Semiótica y estética de la música cinematográfica, 2008), Radigales (La música en el cinema, 2007; Sobre la música.

\footnotetext{
${ }^{6}$ Debido a su objeto de estudio más centrado en estos aspectos, una enumeración más exhaustiva de los estudios centrados exclusivamente en música de cine puede encontrarse en la tesis doctoral de Teresa Fraile Prieto La creación musical en el cine español contemporáneo. Defendida en la Universidad de Salamanca en 2009.
} 
Reflexions a l'entorn de la música i l'audiovisual, 2002; Llenguatge musical: una aplicació audiovisual, 2000), De Arcos (Experimentalismo en la música cinematográfica, 2006) Gèrtrudix Barrio (Música y narración en los medios audiovisuales, 2003), Romaguera i Ramió (El jazz y sus espejos, 2002), Morin (El cine o el hombre imaginario, 2001), Chion (La música en el cine, 1997; La audiovisión. Introducción a un análisis conjunto de la imagen y el sonido, 1993), Lack (La música en el cine, 1997), Nieto (La música para la imagen. La influencia secreta, 1996), Zunzunegui (Pensar la imagen, 1995) y Beltrán Moner (La ambientación musical en radio y televisión, 1984, reeditado en 2005).

Igualmente reseñables son aquellas obras que atañen a la didáctica del cine. Estas suelen omitir, o tratar muy someramente, el contenido didáctico-musical, pero a cambio ejemplifican sobre diversas posibilidades de aplicación pedagógica de medios como el cine que pueden ofrecer un campo muy provechoso en una perspectiva interrelacional como la que pretendemos. Entre las más relevantes están las publicaciones periódicas o monográficas del Grupo Comunicar, destacando la obra fechada en 2002, Aprender de cine, aprender de película, de Martínez-Salanova Sánchez o Comprender y disfrutar el cine, de Amar Rodríguez, de 2003, al margen de las innumerables referencias que podrán ser extraídas de la propia revista Comunicar. En una línea similar se encuadra Cine y educación. El cine en el aula de primaria y secundaria, de Alba Ambrós (2007), y otros textos con algo más de antigüedad: Jiménez Pulido (coord.) El cine como medio educativo (1999), Romaguera, Riambau, Lorente y Solà El cine en la escuela. Elementos para una didáctica (1989), Fernández Ibáñez y Daso El cine en el aula (1982) y Flores Auñón El cine, otro medio didáctico (1982). Además de ellos, configuran la situación que envuelve a esta investigación doctoral los escritos de determinados autores incansables en la elaboración de artículos vinculados con la pedagogía en torno al cine (como es el caso de Pereira Domínguez), la televisión (de cuyas derivaciones pedagógicas se ocupa sistemáticamente Aguaded Gómez) o el vídeo (por ejemplo Ferrés i Prats). Del mismo modo, las reflexiones sobre estrategias de aprendizaje de De la Torre (por ejemplo su coordinación Cine formativo. Una estrategia innovadora para los docentes, 1996) o las posturas de otros como De Pablos Pons sobre el cine didáctico y la educación, principal baluarte y faro de posteriores estudios al respecto (Cine y enseñanza, 1986; Cine didáctico, 1980) y que, como otros foráneos 
(como el caso de Millerson: Técnicas de realización y producción en televisión, 1983 o Coopen: Utilización didáctica de los medios audiovisuales, 1978), han influenciado grandemente la literatura pedagógico-audiovisual del presente.

Todo este compendio de referencias que definen el estado de la cuestión estaría incompleto si no se hiciera mención a volúmenes que traten específicamente la educación musical. No hemos de olvidar que el presente texto trata de instaurarse dentro de las corrientes pedagógicas del presente para, desde ellas, realizar un trabajo de actualización y ubicación en la nueva realidad social. Por ello, es necesaria la observación de manuales de este calado, aunque en esta materia trataremos de servirnos siempre de referentes de gran difusión. Entre muchos otros, apuntamos en estas líneas iniciales obras inexcusablemente notorias en nuestro contexto como las pioneras de Oriol y Parra (La expresión musical en la educación básica, 1979), las de autores de relieve en los últimos años (como Hemsy de Gainza, por ejemplo Nuevas perspectivas de la educación musical, 1990) o las traducciones de autores de referencia en el contexto europeo, tales como Willems (entre otras Las bases psicológicas de la educación musical, 1963; El valor humano de la educación musical, 1994; El oído musical. La preparación auditiva del niño, 2001), Murray Schafer (sumamente concretas, como por ejemplo Limpieza de oídos, 1969 o El compositor en el aula, 1965) o Maneveau (Música y educación, 1993), Además, es preciso, ante escritos ya consagrados, atender a otros novedosos cuyas aportaciones sirven para aportar elementos teóricos o prácticos, como el completo volumen de Zaragozà Didáctica de la música en la educación secundaria. Competencias docentes y aprendizaje (2009), la concisa coordinación de Díaz y Giráldez Aportaciones teóricas y metodológicas a la educación musical (2007), la obra de Childs, traducida al castellano Haciendo especial la música. Formas prácticas de hacer música (2005) o el manejadísimo manual de Pascual Mejía Didáctica de la música (2002).

El complemento a estas referencias vendrá dado por obras que, desde la didáctica general, observen elementos de inclusión del audiovisual, sin centrarse en la propia enseñanza de la música. Entre ellas, por su difusión e influencia, destacan textos como los dirigidos por Roig Vila (Investigar desde un contexto educativo innovador, 2009), o los elaborados por García-Valcárcel Muñoz-Repiso (Tecnología educativa. Implicaciones educativas del desarrollo tecnológico, 2003), Alonso y Gallego (Medios 
audiovisuales y recursos didácticos en el nuevo enfoque de la educación, 1993), Campuzano Ruiz (Tecnologías audiovisuales y educación. Una visión desde la práctica, 1992), Alonso y Matilla (Imágenes en acción. Análisis y práctica de la expresión audiovisual en la escuela activa, 1989) y Giacomantonio (La enseñanza audiovisual. Metodología didáctica, 1979).

En suma, ante la imposibilidad para encontrar un corpus teórico uniforme, el resultado de cruzar cada uno de los campos de conocimiento referidos nos aproxima al estado de la cuestión del tratamiento pedagógico de la música contenida en los medios audiovisuales. 


\subsection{LA INVESTIGACIÓN EDUCATIVA MUSICAL EN LA VERTIENTE AUDIOVISUAL DE LAS TICS}

\section{Breve aproximación a una queja fundada}

Una investigación que se centre en la realidad de la educación musical obligatoria en España no puede dejar de lado una serie de consideraciones que, de manera efectiva, hacen que el proceso de enseñanza-aprendizaje quede condicionado de inicio. Entender este tipo de elementos en el contexto investigador nos capacitará para saber de qué modo será más conveniente incluir el audiovisual en él. Así, las singularidades del entorno al que nos vemos abocados hacen que sea propicia una mirada especial y particular al marco educativo musical español. En este sentido, la investigación en educación musical se topa con determinadas trabas que no son comunes a todas las especialidades educativas, por lo que es habitual encontrar entre las referencias de los estudios educativo-musicales una retahíla de premisas que hacen especial el abordaje de estos temas. El hecho de manifestarlas en estas líneas preliminares se debe a la necesidad de identificar claramente la problemática, lo cual posee fundamentalmente una doble finalidad. Por un lado, ubicaremos en las dificultades del contexto pedagógico nuestra investigación $\mathrm{y}$, por otro, mantendremos la referencia de dichas trabas a la hora de establecer criterios metodológicos que puedan resultar realistas y accesibles a un alumnado a quien le llegan, de manera indefectible, las consecuencias de esta estructura piramidal que tiene su vértice superior en la investigación y una ancha base en las prácticas musicales cotidianas.

La primera de las consideraciones que se vislumbran es la desproporción entre los estudios centrados en lo musical y aquellos que abordan otras facetas del espectro educativo. Ello, en todo caso, podría parecer una situación normal si se tiene en consideración el amplio recorrido de otras áreas a lo largo de la historia, pero el sesgo interpretativo que se suele otorgar a esta contingencia es la escasa rentabilidad de la investigación educativa musical, en tanto en cuanto su peso en el currículo general es menor: 
"Entre profesores, investigadores y educadores existe un amplio acuerdo sobre la importancia vital de educar a los niños en el terreno artístico: las artes proporcionan ocasiones únicas para el desarrollo de cualidades personales como la expresión creativa natural, los valores sociales y morales y la autoestima. Paradójicamente, hay también un acuerdo general en que, hoy día, esta educación no se lleva a cabo de la forma adecuada: la educación artística aparece en segundo plano respecto a otras áreas del currículum como matemáticas, lectura o ciencias" $"$.

Como vemos, el lamento que tantas veces se arguye entre docentes a pie de aula tiene su reflejo, nítido y efectivo, en la producción científica. Tristemente, se constata que sigue siendo una constante la necesidad de justificar los contenidos musicales como parte intrínseca de un currículum integral:

“La fuerza con la que está arrancando la investigación educativa-musical en nuestro país resulta, en este sentido, alentadora en cuanto indica la expectativa de interés y de seriedad, de buena salud profesional del profesorado. Con todo resulta fastidioso que este reto no tenga que afrontarlo más que la educación musical. Hecho que en cierto modo se está dando también entre nosotros, en la actuación diaria de muchos profesores de música; sin explicitarlo del todo se espera que muchos especialistas de música demuestren a la dirección del centro, a los otros colegas, a los padres y a los alumnos por qué su tarea es tan importante como las demás, por qué hay que dedicar un aula para la música, por qué merecen disponer de más o menos horario. Lo que supone una carga añadida a su actividad docente. Para otras materias, ni de lejos, se plantea algo semejante. [...] En este contexto, el comentario ¡qué bien os lo pasáis en la clase de música! daría para una tesis doctoral"

\footnotetext{
${ }^{7}$ HARGREAVES, D. J. (1997) (Ed.): Infancia y educación artística. Madrid: Morata, p. 11.

8 PASTOR i GORDERO, P. (2004): "Las marías.www.marchitopensil.boe.es". Revista de la Lista Europea de Música en la Educación 14, p. 7. Disponible en:
} 
Obviamente no pretendemos que éste sea el ejemplo que sirva para ratificar de manera empírica la apostilla final, pero ciertamente es una sensación tan generalizada que dejar constancia de ella ayuda a entender el surrealismo de algunas situaciones que se han de vivir en la docencia de la música. Junto con esta cuestión, la cual sembla el mayor de los problemas (intuimos que el mayor pues afecta a niveles simbólicos difícilmente modificables en el imaginario de aquellos ajenos al plano docente musical), se atisban otros elementos que, igualmente, trazan el esbozo de las investigaciones en educación musical. En segundo lugar se suele argumentar la juventud de la propia especialidad dentro de nuestro marco normativo. En perspectiva histórica, las características de la investigación en educación musical pueden quedar resumidas del siguiente modo:

“...la investigación en Educación Musical en nuestro país no tiene la tradición ni el bagaje que pueden tener otras disciplinas. Es pues, un campo de conocimiento relativamente joven [...]. Es interesante constatar que se escribían muy pocos artículos para dar a conocer las innovaciones (la mayoría de los materiales no pasaba nunca la fase de borrador), aunque, como vemos, funcionaba mucho la transmisión oral. También remarcar la poca relación con la investigación. De hecho, en nuestro país, hay muy poca investigación en el campo de la educación musical" 9 .

Entre las conclusiones que se desprenden de aseveraciones como la anterior es que la investigación en torno a la educación musical en nuestro ámbito está en proceso de definición. O en palabras más vehementes, "en mantillas"10. Son muchos los autores

<http://musica.rediris.es/leeme/revista/pastor04.pdf > [Consulta 9-II-10]. Publicado anteriormente con el mismo título en Eufonía 14, pp. 91-98.

9 Aunque centrado en el ámbito catalán, entendemos que estas reflexiones sirven para radiografiar igualmente la situación general en toda España: BARNIOL i TERRICABRAS, E. (2000): "Reflexiones en torno a la innovación y la investigación en la enseñanza de música en Cataluña". Revista de la Lista Europea de Música en la Educación 5, p. 2. Disponible en:

$<$ http://musica.rediris.es/leeme/revista/barniol00.pdf > [Consulta 9-II-10].

${ }^{10}$ RODRÍGUEZ QUILES y GARCÍA, J. A. (2000): "Investigación cualitativa en educación musical: un nuevo reto en el contexto educativo español". Revista de la Lista Europea de Música en la Educación 5, p. 1. Disponible en <http://musica.rediris.es/leeme/revista/rodriguezja00.pdf> [Consulta 9-II-10]. 
que constatan que sólo una minúscula parte de la producción intelectual educativa se focaliza en la educación musical. Se precisa, por tanto, verter sobre las revistas especializadas un buen número de ideas que actualicen la labor pedagógica en este contexto, con el fin de avivar el interés de todos por la educación musical en general, poblando poco a poco de recursos cercanos al alumno aquello que hace no mucho era un territorio yermo sobre el que se erigieron las pedagogías activas del siglo XX.

La reflexión del párrafo anterior abre una tercera vía de aspectos espinosos: la diseminación de publicaciones. Siguiendo con autores referenciados:

“...la investigación en el ámbito de la educación musical se caracteriza particularmente por una profusión de estudios pequeños y cerrados, que a menudo, no se relacionan entre ellos de forma muy coherente. Se trata de investigación en muchos casos aplicada, y por tanto, cualitativamente diferente, que utiliza parámetros que la Universidad clásica rechaza y no valora"11.

En un ámbito en el que la teoría y la práctica habrían de conjugarse a la perfección, la dispersión de prácticas es otra de las características más notorias. Tomando un ejemplo experimental, en su análisis de la base de datos ERIC, Galera Núñez y Pérez Ceballos ${ }^{12}$, constatan que la investigación en educación musical se caracteriza por contribuciones unipersonales y esporádicas. Por tanto, no es descabellado pensar que dicha investigación, en general, tenga como seña de identidad la diseminación ${ }^{13}$, la cual induciría a un irremisible aislacionismo. Este hecho se apoya en la inconsistencia de las traducciones al castellano de obras muy representativas a este respecto:

\footnotetext{
${ }^{11}$ BARNIOL i TERRICABRAS, E. (2000): Op. cit., p. 3.

12 GALERA NÚÑEZ, M. M. y PÉREZ CEBALLOS, J. (2008): "La investigación en educación musical en la base de datos ERIC". Revista de la Lista Europea de Música en la Educación 22, p. 11. Disponible en 〈http://musica.rediris.es/leeme/revista/galeraetal08.pdf> [Consulta 9-II-10].

${ }^{13}$ A pesar de que investigaciones recientes realzan las nuevas oportunidades de conectividad con el resto de Europa que se abren a partir de las modificaciones legislativas en curso: GUTIÉRREZ BARRENECHEA, M. (2008): Op. cit.

Ejemplos de ello, en el mismo volumen, los destaca PASTOR COMÍN, J. J. (2008): "Didáctica de la música: Oportunidades para una investigación coordinada”. ÁLAMO, A. y LUCEÑO, M. Actas del I Congreso de Investigación y Educación Musical. Madrid: Enclave Creativa Ediciones, pp. 464-473.
} 
"Las ediciones en idioma español tienen una gran deuda con el numeroso público formado por los educadores musicales: la ostensible carencia de traducciones importantes de obras fruto de la investigación musical que resultan sustanciales para la didáctica de la música" ${ }^{\text {14. }}$.

Así, aunque es cierto que muchos estudios como el que se presenta, tratan de centrarse específicamente en el contexto español actual, no cabe duda de que, por ejemplo, el conocimiento que los docentes tenemos de las pedagogías del siglo XX parte no tanto de las publicaciones originales como de interpretaciones y reelaboraciones que aluden a ellas.

Fronterizo con los elementos anteriormente descritos como la conformación del campo de estudio, el cuarto estilete que apunta directamente a las estructuras musicales es la limitada proyección y repercusión:

"En nuestro país estamos ahora [1998] intentando fortalecer un proceso de jerarquización en nuestro campo, de definiciones, de explicaciones y de demostraciones de los contenidos y de la relevancia de estos quehaceres, aclaraciones y puntualizaciones que siguen siendo indispensables para identificar y definir los profundos valores de metas y de logros del quehacer educativo musical: es decir, de nuestro hacer como músicos y docentes"15.

La imperiosa necesidad de hacer que las propuestas generadas tengan una adecuada difusión es un elemento esencial en la interpretación de la autora recién citada. Como trataremos en el transcurso del presente escrito, este aspecto es especialmente

\footnotetext{
${ }^{14}$ MALBRÁN, S. (2007): "Teorías, modelos y métodos en investigación musical. Hacia la recuperación de sus figuras prominentes". DÍAZ, M. y GIRÁLDEZ, A. (coord.) Aportaciones teóricas y metodológicas a la educación musical. Barcelona: Graó, p. 115. En cualquier caso, la tendencia es hacia la apertura, como muestran algunas recientes publicaciones: LINES, D. K. (2009) (comp.) La educación musical para el nuevo milenio: El futuro de la teoría y la práctica de la enseñanza y del aprendizaje de la música. Madrid: Morata, del original Music education for the New Millenium.

${ }^{15}$ FREGA, A. L. (1998): "La investigación en las enseñanzas musicales". Revista de la Lista Europea de Música en la Educación 1, p. 2. Disponible en 〈http://musica.rediris.es/leeme/revista/frega98.pdf> [Consulta 9-II-10].
} 
notorio en el caso de la didáctica del elemento audiovisual. Así, Espino Barahona ${ }^{16}$ entiende que uno de los inconvenientes más acuciantes en este aspecto es la falta de un proyecto difusor de las propuestas nacidas en el ámbito educativo que permitan al colectivo docente generar estrategias para leer la imagen.

Por último, una quinta consideración remitiría a la aproximación interdisciplinar al hecho musical en clave pedagógica. Las investigaciones más recientes en el ámbito nacional referidas a la educación musical buscan, de acuerdo con premisas y marcos de actuación tomados de otros contextos, la observación de un enfoque pluridisciplinar que haga del conocimiento sonoro una herramienta para la aplicación práctica ${ }^{17}$. Sin perjuicio de lo manifestado, es preciso resaltar que la investigación interdisciplinar, que en nuestro caso supone combinar planteamientos musicológicos en torno al audiovisual con la educación musical, encuentra problemas serios que socavan su consolidación, debido esencialmente a que nos encontramos, todavía en la fecha actual, en la periferia de unos campos científicos que generan incomodidades y reticencias ${ }^{18}$.

En este sentido, si las limitaciones de la investigación en la enseñanza musical han sido prolijamente señaladas, desde la vertiente musicológica se constata la pertinaz dificultad para hacer ver que las aproximaciones científicas a la música del cine o del resto de audiovisuales son tan pertinentes como cualquier otro análisis centrado en lo musical:

"La inercia de una historiografía que aún hoy bebe los vientos por exhumar obras y autores olvidados -genios dormidos- continúa echando tierra sobre quienes abrigan la esperanza de dedicarse a otra cosa [...]. Algunas de aquellas jóvenes disciplinas dedicadas al estudio de fenómenos musicales que no fueran la

\footnotetext{
${ }^{16}$ BARAHONA, E. A. (2006): “ 'Cuando la cámara habla...': propuesta didáctica para la lectura del film”. Educación y Educadores 9, v. II, p. 51.

${ }^{17}$ Por ejemplo, los campos de la biología, la antropología, las ciencias cognitivas y la pedagogía musical son los esgrimidos como referentes por CORBALÁN ABELLÁN, M. (2008): "Música y representación cognitiva: un enfoque psicopedagógico". ÁLAMO, A. y LUCEÑO, M. Actas del I Congreso de Investigación y Educación Musical. Madrid: Enclave Creativa Ediciones, pp. 10-24.

${ }^{18}$ En su enumeración de tesis doctorales dedicadas a la investigación musical en la última década en España (siguiendo la fuente del programa TESEO), Nicolás Oriol puntualiza que "La clasificación de los temas de música está más allá de una simple comparación entre la musicología y la pedagogía, términos con el que suele separar el profesorado la temática al hablar de trabajos de investigación: ORIOL DE ALARCÓN, N. (2009): "La investigación musical en España: tesis doctorales y temática en la última década”. Eufonía 45, p. 59.
} 
vida y obra del compositor de turno, han resistido el envite y dado pruebas de querer cambiar las cosas en un panorama en el que la rutina no suele dejar títere con cabeza"19.

Tal vez, esta escasez de miras venga determinada por la propia consideración de la composición para el audiovisual, igualmente denostada de manera tradicional en determinados foros que aluden la funcionalidad directa de estas composiciones como su principal lastre. Ello, en todo caso, es una falacia puesta al descubierto en innumerables ocasiones $^{20}$. Además, es necesario recordar que el estudio en torno al audiovisual no puede darse sino es desde la interdisciplinariedad que implica inmiscuirse de uno u otro modo en planteamientos de diferente procedencia ${ }^{21}$. No ahondaremos mucho más en las consideraciones metodológicas que se desprenden de ello, afortunadamente los especialistas actuales siguen preocupados por poner el dedo en la llaga para arrojar luces donde otros sólo traslucen sombras. De cualquier modo, si se hacen converger todas y cada una de las problemáticas investigadoras sobre el objeto de estudio que nos ocupa, esto es, una investigación sobre la autóctona educación musical, vista como advenediza, junto con otros estudios, los de la música del audiovisual, para los que siempre habrá quien desde la musicología los estigmatice como huérfanos de referentes válidos, alumbramos una didáctica de la música de, con, para o desde el audiovisual (en este preciso instante de manera indistinta) que ha de salvar tantos inconvenientes para su existencia que supone un reto añadido a la osadía de trabajar con exclusividad uno u otro campo.

\footnotetext{
${ }^{19}$ GÓMEZ RODRÍGUEZ, J. A. (2005): “ ‘Lo que no venda, cántelo’. Algunas reflexiones sobre el papel de la música en la publicidad: de los viejos pregones a los spots de televisión". OLARTE MARTÍNEZ, M. (Ed.) La música en los medios audiovisuales. Salamanca: Plaza Universitaria Ediciones, p. 225.

${ }^{20}$ La funcionalidad, por ejemplo de la música de cine, es muy similar a la de otras manifestaciones musicales históricas. Entre los últimos ejemplos que constatan tal particularidad destacamos por su aportación de ejemplos y claridad: LLUÍS i FALCÓ, J. (2009): Op. cit.

${ }^{21}$ Tal y como lo constata VEGA TOSCANO, A. (2001): "Música y creación audiovisual". LOLO, B. (Ed.) Campos interdisciplinares de la Musicología, v. 1, Madrid: Sociedad Española de Musicología, pp. 699-709.
} 


\section{Derivaciones para un estudio musical desde el audiovisual}

El final del apartado anterior comenzaba a encauzar la filosofía del presente estudio doctoral en su canalización hacia el uso del audiovisual. En cualquier caso, y siempre desde la experiencia docente personal desde la que se escribe, no está en nuestro ánimo dibujar un paisaje musical apocalíptico sino constructivo, desde el respeto y la pasión por la pedagogía de la música vista a través de los ojos del alumnado. Por ello encontramos necesario resaltar que, ante dificultades como las expuestas, se pueden hallar elementos lo suficientemente consistentes para articular estrategias que superen los aspectos negativos. De hecho, trabajando desde la música y con niños y jóvenes no sólo es posible sino además necesaria una postura optimista. Algunas de estas particularidades que hagan ver el vaso medio lleno pueden obtenerse, directamente, de las carencias observadas. Así por ejemplo, el propio Pastor i Gordero, sumamente incisivo en las citas anteriores, considera que la ausencia de una tradición investigadora en educación musical puede enfocarse desde un plano positivo, ya que permite no desgajar la teoría de la práctica y hacer más efectivos, de este modo, los planteamientos objeto de investigación ${ }^{22}$. De manera similar, los testimonios de Frega ${ }^{23}$ marcan la misma dirección, a modo de foco luminoso al final de un túnel, destacando que el campo de estudio de la educación musical, pese a ser en ocasiones poco percibido, existe, y lo hace en tanto en cuanto se apoya no tanto en publicaciones como en un "caudal de experiencias acumulado", de modo que se postula como necesaria la vinculación entre la investigación desde el plano docente-universitario y la recogida de procedimientos en el campo, esto es, las aulas.

Por todo ello esta investigación trata de conjugar la vertiente teórica, generada desde las publicaciones especializadas, con las experiencias que bien se reflejan en dichos textos bien son el resultado de un trabajo de introspección de la propia práctica docente. En este sentido, al referirnos a los investigadores especializados en música no hemos de caer en la tentación de olvidar que, en muchos casos, se está llevando a cabo una faceta docente paralela, lo cual deja interesantes aspectos sobre el tapete. Tal vez, la

\footnotetext{
${ }^{22}$ PASTOR i GORDERO, P. (2002): “La investigación educativa musical”. Eufonía 26, pp. 84-88.

${ }^{23}$ FREGA, A. L. (1998): Op. cit.
} 
primera de ellas sea la búsqueda de la solución a las diatribas internas que el propio investigador vive:

“...o se es maestro o se es investigador o se es investigador y maestro o se es maestro investigador, [de modo que] los límites entre el oficio de investigar, el oficio de enseñar y el oficio de formar se hagan difusos"24.

Llevado al ámbito de la pedagogía musical las cuestiones planteadas no varían en exceso. Además, enfocando el caso de manera práctica y antes de las reformas que puedan modificar la estructura fijada en la primera década del siglo XXI, los estudios de musicología abren un nicho laboral muy específico: el de la enseñanza dentro de los niveles obligatorios. Este espacio no se circunscribe solamente a la docencia en la etapa de educación secundaria y bachillerato, sino que es frecuente que un abultado número de estudiantes que han accedido al segundo ciclo de la licenciatura en Historia y Ciencias de la Música hayan realizado previamente estudios de Magisterio, por lo que están habilitados para atender igualmente a alumnos dentro de la enseñanza primaria ${ }^{25}$. Por todo ello se precisa de una ligazón, si cabe más persistente, que atice el fuego de las prácticas del aula por medio de marcos referenciales ajustados a la sociedad actual:

"La Didáctica de la Música es una disciplina que tiene sentido en base a su aplicación, ya sea proponiendo innovaciones didácticas, ya sea analizando la realidad de las aulas. Desde esta perspectiva resulta pertinente preguntarse por la relación entre investigadores y docentes. Y, teniendo en cuenta que la universidad asume gran parte de la investigación en didáctica de la música, es fundamental conocer cómo se construyen los puentes entre los dos colectivos. En otras palabras: ¿hasta qué punto los investigadores necesitan la contribución

\footnotetext{
${ }^{24}$ ANCÍZAR MUNEVAR MOLINA, R. y QUINTERO CORZO, J. (2000): "Investigación pedagógica y formación del profesorado". Revista Iberoamericana de Educación Sin número de volumen, sección digital, p. 1. Disponible en <http://www.rieoei.org/deloslectores/054Ancizar.PDF> [Consulta 9-II-10].

${ }^{25}$ Los cambios que se implementan a partir de este momento auguran un futuro todavía incierto. Ante dichas modificaciones, algunos artículos especializados reseñan la importancia de mantener una formación sólida específica para los docentes de educación musical: ARÓSTEGUI PLAZA, J. L. (2006): "La formación del profesorado en educación musical ante la convergencia europea en enseñanzas universitarias". Revista de Educación 341, pp. 829-844.
} 
de los que dominan el campo? Y ¿en qué medida es positivo que los maestros sean no sólo receptores de unas conclusiones, sino partícipes del proceso que les ha suscitado?", 26

La urdimbre que se ha de instituir entre los niveles teóricos y la praxis directa, por tanto, será una de las direcciones primordiales de la investigación doctoral que se presenta $^{27}$. Por ello, enfocado desde un plano positivo, es preciso evidenciar que en estas situaciones se genera el caldo de cultivo propicio para que la investigación ilumine a la teoría y ella, en consecuencia, retroalimente a la práctica ${ }^{28}$, de forma y manera que las programaciones didácticas que desde la enseñanza de la música integran el audiovisual tengan cabida fuera de los márgenes de la propia docencia no universitaria. Los motivos esenciales por los cuales la práctica del aula ha de perfilar los estudios e investigaciones generando nuevos marcos de actuación son resumidos por Díaz Iglesias y Guerra Iglesias ${ }^{29}$ del siguiente modo:

\footnotetext{
${ }^{26}$ CASALS IBÁÑEZ, A. y VILAR i MONTMANY, M. (2008): "De la investigación universitaria a la aplicación escolar: Introducción de la canción improvisada en una escuela primaria”. ÁLAMO, A. y LUCEÑO, M. Actas del I Congreso de Investigación y Educación Musical. Madrid: Enclave Creativa Ediciones, pp. 106-107.

${ }^{27}$ Entendida desde la figura del profesor-investigador de su propia práctica docente que puede orientar, dentro del paradigma de la investigación-acción, no sólo su praxis sino en consecuencia todo el proceso: LATORRE, A. (2003): La investigación-acción. Conocer y cambiar la práctica educativa. Barcelona: Graó.

${ }^{28}$ SWANWICK, K. (2000): "Research and the music curriculum”. Revista de la Lista Europea de Música en la Educación 5, Disponible en 〈http://musica.rediris.es/leeme/revista/swanwick00.pdf> [Consulta 9II-10].

${ }^{29}$ DÍAZ IGLESIAS, S. y DÍAZ GUERRA, R. (2000): "El papel del maestro en la investigación en educación musical". Revista de la Lista Europea de Música en la Educación 5, p. 1. Disponible en $<$ http://musica.rediris.es/leeme/revista/diazetal00.pdf> [Consulta 9-II-10].
} 


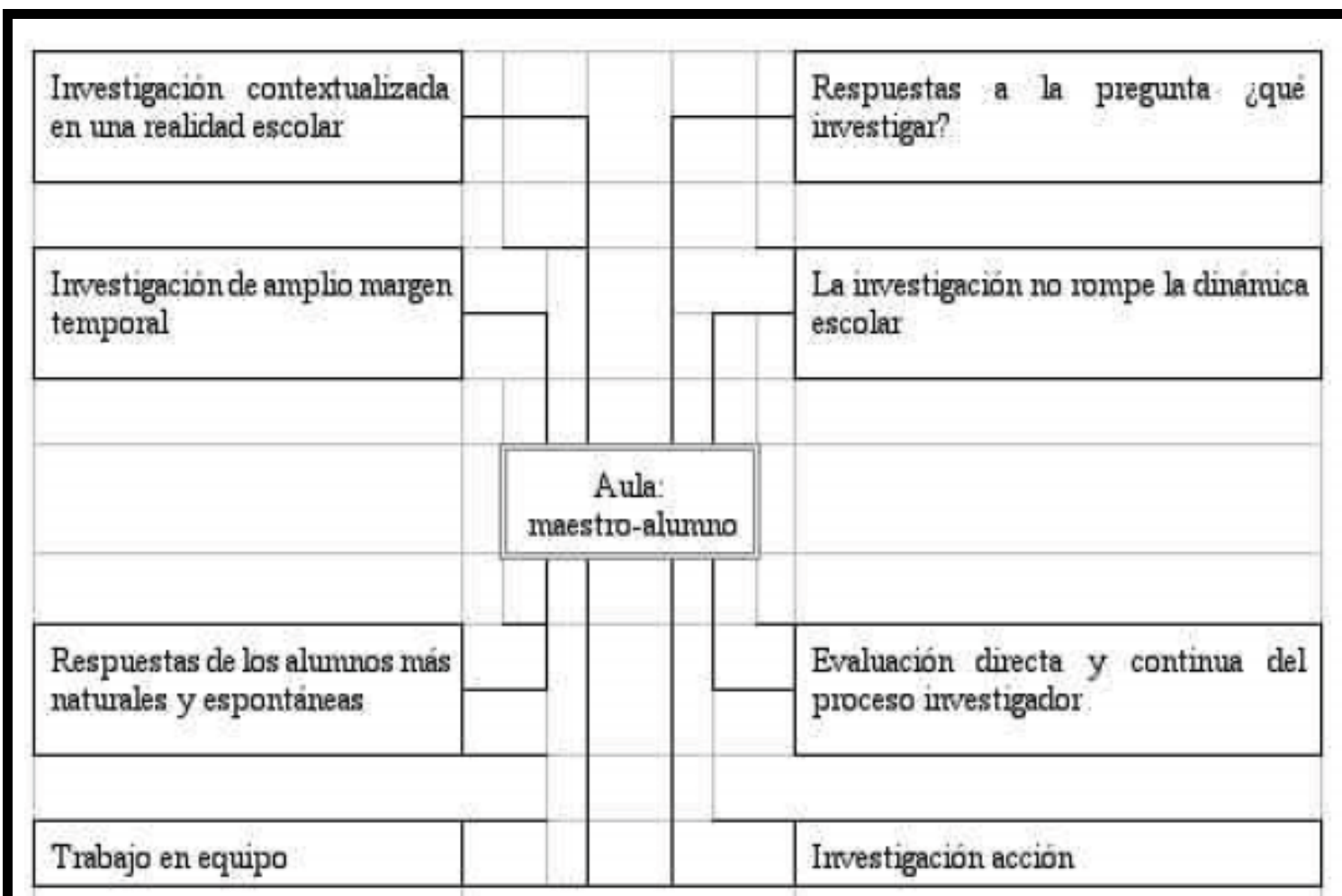

Fig. 1. Investigación en educación musical a partir de la interacción maestro - alumno Sebastián Díaz Iglesias y Rosario Díaz Guerra

Dentro de este contexto, las motivaciones que inducen a la investigación en el plano educativo musical, siguiendo a Subirats, bien podrían resumirse en estas tres:

“...la primera, es que nuestra investigación sobre la enseñanza de la música y propia práctica profesional, puede ser ayudada y puede iluminar nuestra propia práctica profesional, la segunda, es que no debemos olvidar que la comunidad profesional está sostenida por el conocimiento y la comprensión, la tercera entre otras cosas hace que nosotros estemos mucho mejor preparados para responder a los cambios hacia una mejor planificación y preparación" 30.

30 SUBIRATS, M. Á. (2000): "La investigación en educación musical: perspectivas desde el Departamento de Didáctica de la Expresión Musical y Corporal de la Facultad de Formación de Profesorado en la Universidad de Barcelona".Revista de la Lista Europea de Música en la Educación 5, p. 2. Disponible en <http://musica.rediris.es/leeme/revista/subirats00.pdf > [Consulta 9-II-10]. 
En clave audiovisual estas tres motivaciones alimentan enormemente el interés por hacer de los medios audiovisuales una espoleta que multiplique las posibilidades de innovación pedagógica. Así, el hecho de que teoría y práctica sean dos caras de una misma moneda se torna evidente en un terreno todavía en definición ${ }^{31}$. Por otro lado, es preciso plantear que la investigación centrada en lo musical, si pretende calar en el sistema educativo actual, habrá de anclarse sólidamente en elementos de referencia significativos para todos aquellos que participan del proceso de enseñanza-aprendizaje:

"Una futura y satisfactoria educación musical mirará hacia una era de la educación musical informada por la investigación básica y aplicada que se va más allá de un entretenimiento monodimensional y vincula las habilidades musicales relativas a la producción, percepción y reflexión hacia la cultura musical" ${ }^{\prime 2}$.

En este punto se abre el campo de la didáctica de la música desde el audiovisual, como un escenario de innegable potencial de crecimiento que pueda articular, desde teoremas teóricos y realidades prácticas, todas y cada una de las dimensiones que se pide a un alumnado tan diverso como la propia sociedad. En consecuencia, en la generación de nuevos marcos de conocimiento de la realidad, difícilmente podríamos encontrar otro aspecto más rabiosamente actual que el que pretendemos poner en práctica. Por ello, en aras de una mejor adaptación a la sociedad cambiante y a los contextos plurales, los contenidos audiovisuales pueden mostrar la maleabilidad suficiente para hacerse más apropiados que otros con menor capacidad de maniobra. En todo caso, el uso de los medios audiovisuales ha de entenderse como un hecho natural adaptado a las sociedades y tiempos contemporáneos, que perfilan su propia forma. De hecho, el profesor ha de hacer propios los métodos y recursos que tiene a su alcance para, a partir de ellos, desarrollar su práctica docente:

\footnotetext{
31 En educación musical es aún más evidente la necesidad de conectar teoría y práctica, ya que determinados autores constatan que existe una vinculación casi intuitiva entre estrategias trazadas en los estratos universitarios y los docentes que desarrollan estrategias a pie de aula, pero no siempre se consigue trasvasar los conocimientos de unos con los procedimientos de otros: MALBRÁN, S. (2007): Op. cit., p. 115.

${ }^{32}$ DAVIDSON, L. y SCRIPP, L. (1997): "Educación y desarrollo musicales desde el punto de vista cognitivo". HARGREAVES, D. J. (Ed.). Infancia y educación artística. Madrid: Morata, p. 110.
} 
"Los medios -incluyendo la telefonía y todas las maravillas tecnológicas de las llamadas autopistas- son eso, medios. Como lo fue el libro, gracias a la multiplicación lograda por la imprenta. Ahora bien, la sociedad ha dado profesionales para transmitir su saber acumulado y sus modelos; nosotros los maestros, en nuestro caso, los músicos-maestros, nos preparamos con el conocimiento específico a transmitir y con los medios pedagógico-didácticos para hacerlo, 33 .

Con todo, el desarrollo de proyectos que indaguen en la didáctica de la música del audiovisual encuentra, esencialmente, dos trabas que, mal detectadas, pueden llegar a asfixiar su desarrollo. En primer lugar, la era tecnológica parece haber cedido el interés que el audiovisual suscitó años atrás a favor de otros postulados emergentes hoy en día:

"Situándonos en la perspectiva histórica de la Tecnología Educativa, encontramos que en su conformación disciplinar los contenidos relativos al cine en la escuela, luego a la televisión y al vídeo, ocupaban un lugar central. Más tarde, la carrera tecnológica llevó a que los estudios del área se ocuparan principalmente del impacto de las últimas tecnologías en el ámbito educativo, trocando así su objeto de estudio. Una revisión de las producciones académicas de los últimos tiempos da cuenta de ello: la mirada se centra fundamentalmente en los problemas suscitados en torno a la Informática educativa (Internet, Multimedia) y Teleformación. De esta manera, los investigadores han colocado en segundo plano a la problemática de los medios audiovisuales $\mathrm{y}$, en nuestra opinión, algunas cuestiones referentes a su enseñanza no han sido suficientemente explicadas" ${ }^{, 34}$.

\footnotetext{
${ }^{33}$ FREGA, A. L. (1998): Op. cit., p. 6.

${ }^{34}$ LUNA, M. R. (2009): "La enseñanza del lenguaje audiovisual: Una propuesta didáctica de evaluación". BAUTISTA, A. y ATRIO, S. (2009) Actas del I Congreso Internacional sobre Antropología Audiovisual e Investigación en Tecnología Educativa. Madrid: RUTE Universidad Complutense. Recurso Digital, p. 1.
} 
La segunda de las dificultades a afrontar tiene como epicentro el reflejo de las consecuencias anteriores llevadas al campo de lo musical. Investigar en el marco de los medios audiovisuales y la enseñanza musical supone descubrir nuevos procedimientos ya que cualquier conato de emergencia de las Tecnologías de la Información y la Comunicación se asocia al mundo de los editores de partitura o sonido, y no tanto a los referidos contenidos audiovisuales. Aróstegui Plaza abunda en la ausencia de investigación del plano audiovisual de las Tecnologías de la Información y la Comunicación, en contraposición a su pariente próximo, la informática musical:

"En pedagogía, la enseñanza de los medios audiovisuales está comprendida dentro de la rama denominada de "nuevas tecnologías" o de las “tecnologías de la información y la comunicación”. La parte dedicada a los ordenadores y a internet está mucho más desarrollada e investigada. La de los medios audiovisuales, cuando se trabaja en el aula, está dedicada a la parte visual. Existe, pues, una necesidad por explicitar una música que suele pasar desapercibida para la mayor parte del público"35.

Los proyectos investigadores comienzan a atisbar cambios en torno a la enseñanza de lo musical que, a la luz de la LOE, emprende su andadura a través del desarrollo de competencias $^{36}$. La prueba fáctica de lo aludido es el modelado de las metodologías activas del siglo XX hacia una mayor efectividad en todos y cada uno de los contextos

\footnotetext{
35 ARÓSTEGUI PLAZA, J. L. (2005a): "La música en el cine español contemporáneo”. OLARTE MARTÍNEZ, M. (Ed.) La música en los medios audiovisuales. Salamanca: Plaza Universitaria Ediciones, p. 333.

${ }^{36}$ Teniendo en mente el horizonte del desarrollo de las mismas, determinadas investigaciones (extraídas del mismo volumen) centran el objeto de estudio en los futuros docentes de música para optimizar su formación a través del nivel de utilidad de los materiales que manejan, los "estilos de aprendizaje" que muestran o las propias asignaturas que cursan. Respectivamente: ESTEVE FAUBEL, J. M., MOLINA VALERO, M. A. y ESPINOSA ZARAGOZA, J. A. (2008): "Los materiales de autoaprendizaje musical en el ámbito del EEES en la Universidad de Alicante”. ÁLAMO, A. y LUCEÑO, M. Actas del I Congreso de Investigación y Educación Musical. Madrid: Enclave Creativa Ediciones, pp. 45-54; DE MOYA MARTÍNEZ, M. V., BRAVO MARÍN, R. y GARCÍA LÓPEZ, F. J. (2008): “Análisis de los estilos de aprendizaje de los estudiantes de magisterio (educación musical)". ÁLAMO, A. y LUCEÑO, M. Actas del I Congreso de Investigación y Educación Musical. Madrid: Enclave Creativa Ediciones, pp. 76-88; HERNÁNDEZ BRAVO, J. R. y HERNÁNDEZ BRAVO, J. A. (2008): "La didáctica de la expresión musical en la Escuela Universitaria de Magisterio siguiendo el modelo de los créditos europeos ECTS. Un reto formativo para los profesores de música". ÁLAMO, A. y LUCEÑO, M. Actas del I Congreso de Investigación y Educación Musical. Madrid: Enclave Creativa Ediciones, pp. 115-121.
} 
en que se desarrollan. La esperanza de que la inclusión de estos criterios penetre sigilosamente en el núcleo duro de conocimientos no es tan osada. De hecho, empieza a ser aceptado sin reparos que el acercamiento tecnológico conlleva ese tipo de consecuencias $^{37}$. Por consiguiente, ello no implica que el uso de estos recursos en el aula de educación musical responda a una moda o capricho por la novedad, sino que su integración depende de una labor justificada, por medio de la cual los logros pedagógicos se consiguen con mayor precisión ${ }^{38}$.

${ }^{37}$ Como atestiguan CABERO ALMENARA, J.; LLORENTE CEJUDO, M. C. y ROMÁN GRAVÁN, P (2007): "La tecnología cambió los escenarios: el efecto Pigmalión se hizo realidad". Comunicar 28, pp. $167-173$.

${ }^{38}$ La adecuación tecnológica a las aulas es una constante que, desde los parámetros de optimización de los procesos educativos, encuentra un acomodo justificado: SAN MARTÍN ALONSO, A. (1994): "El método y las decisiones sobre los medios didácticos". SANCHO GIL, J. M. (coord.) Para una tecnología educativa. Barcelona: Horsori, pp. 61-85. 


\section{CAPÍTULO 2}

MARCO TEÓRICO - REFERENCIAL.

LA MÚSICA Y LOS MEDIOS AUDIOVISUALES:

ELEMENTOS PARA UNA APROXIMACIÓN

EN CLAVE PEDAGÓGICA 
MÚSICA Y MEDIOS AUDIOVISUALES.

PLANTEAMIENTOS DIDÁCTICOS EN EL MARCO DE LA EDUCACIÓN MUSICAL. Juan Carlos Montoya Rubio 


\section{MARCO TEÓRICO - REFERENCIAL. LA MÚSICA Y LOS MEDIOS AUDIOVISUALES: ELEMENTOS PARA UNA APROXIMACIÓN EN CLAVE PEDAGÓGICA}

\subsection{LA EDUCACIÓN MUSICAL ACTUAL Y SU CANALIZACIÓN HACIA LOS MEDIOS AUDIOVISUALES}

De dónde venimos y, sobre todo, hacia dónde vamos.

"La triste herencia actual del abandono y de la abulia de cincuenta años de retraso con respecto a Europa en las dos primeras etapas [hasta 1965-70 y hasta 1990] ahí la tenemos hoy: la mayoría de nuestros dirigentes políticos, intelectuales y ciudadanos de veinte o veinticinco años para arriba, prácticamente no han tenido ningún contacto ni sensibilización musical alguna" 39 .

La música, como parte del organigrama educativo español, no termina de instalarse como un referente inequívoco y necesario. Desde su implantación ${ }^{40}$, muchos han sido los despropósitos que han hecho que no acabe de calar como lo que es, un agente perceptivo y expresivo sin igual. En la fecha actual, finalizando la primera década del siglo XXI se palpa un contexto de cambio, debido fundamentalmente a los procesos de convergencia europea $^{41}$, pero tal vez no de inflexión, en tanto en cuanto la

\footnotetext{
39 PÉREZ GUTIÉRREZ, M. (1994): "Breve reseña histórica sobre la educación musical en España y comparación con otros países”. Música y educación 17, p. 21.

${ }^{40}$ Véase al respecto, por su sintética exposición, ROMERO CARMONA, J. B. (2005): "La música en la escuela y su tratamiento histórico". Música y Educación 62, pp. 43-58. La actualización hasta nuestros días puede consultarse en MORALES FERNÁNDEZ, Á. (2008): "La formación musical en los maestros para la etapa de educación primaria en la LOGSE y la LOE”. ÁLAMO, A. y LUCEÑO, M. Actas del I Congreso de Investigación y Educación Musical. Madrid: Enclave Creativa Ediciones, pp. 25-38.

${ }^{41}$ Un resumen actualizado de la nueva disposición de la enseñanza musical desde la universidad española, a raíz de los cambios perpetrados por el conocido comúnmente como "Proceso de Bolonia", quedan de manifiesto muy gráficamente en: DÍAZ MOHEDO, M. T. (2009): "La educación musical en la universidad española: claves de futuro". Ecos, revista de música 2, pp. 12-20. Dicho artículo
} 
pendiente descendente que se observa en torno al tratamiento de lo musical no parece albergar mejores expectativas a corto plazo.

En todo caso, entendemos que la mejor manera de propiciar el impulso que precisa la educación musical para volver a ser protagonista de las aulas del presente y del futuro pasa por robustecer sus fundamentos a partir de su acercamiento a esferas educativas que sí poseen el favor de la sociedad en la actualidad, por las grandes potencialidades que se les suponen. Nos referimos esencialmente a las Tecnologías de la Información y la Comunicación, única estrategia que, a día de hoy, se antoja lo suficientemente potente como para producir la catarsis necesaria que logre regenerar algunos de los anquilosados principios pedagógico-musicales.

Es preciso tener en mente que, de cualquier modo, aquello que se postula como necesario es, fundamentalmente, un cambio de dirección en parte de los medios de actuación, pero no tanto en la definición de objetivos, los cuales no pueden alejarse de los principios de percepción y expresión en la búsqueda del desarrollo armonioso y global del individuo en sociedad. Por ello, los apartados que se irán configurando tratarán de encajar en prácticas preexistentes que beben de metodologías probadamente acertadas, pero que se están desarrollando en un entorno tan dispar al que las vio nacer que no pueden explotar toda su efectividad.

Por otro lado, que los alumnos que se sientan en los pupitres de la enseñanza obligatoria poseen un bagaje musical previo muy específico y que éste no está siendo explotado debidamente es otra realidad que puede ayudar a encontrar luz al final del túnel de la significación en educación musical, tantas veces ponderada y no siempre hallada con fortuna. En esta dimensión cobra especial relevancia la inclusión de los audiovisuales en el engranaje educativo musical, como parte integral de las Tecnologías de la Información y la Comunicación pero diferenciada de la informática musical. En cierto modo, aunque los alumnos actuales tienen un contacto directo con los recursos cibernéticos, bien a través de ellos bien desde otros medios de comunicación, los audiovisuales son tanto más utilizados como ellos. Por tanto, la constatación de esta

complementa el publicado tres años antes: DÍAZ MOHEDO, M. T. (2006): "La educación musical en la Europa del futuro". Música y educación 68, pp. 33-48. En todo caso, el periodo de redefinición en torno a la especialidad está servido, como lo manifiestan las dudas de publicaciones recientes al respecto: ESTEVE FAUBEL, J. M., MOLINA VALERO, M. Á. y LÓPEZ DE REGO, C. (2007): "El futuro de los estudios de maestro especialista en música". Música y educación 72, pp. 21-34. 
nueva realidad por parte del profesorado y el cambio de perspectiva al respecto se va a mostrar como vital para conseguir la implantación de nuevos modelos que vinculen al alumno con el aula de educación musical, y a esta con los sonidos de la sociedad.

\section{¿A quién no le gusta la música?}

Investigaciones centradas en el uso y consumo de los medios de comunicación en los jóvenes detectan aquello que ya se percibía de manera intuitiva: la música es uno de los elementos más ampliamente utilizados y reconocidos como propio ${ }^{42}$ lo cual, conjugado con otros datos relevantes (como el aumento del interés por internet como medio de diversión y conexión con el mundo) ha de guiar la práctica docente, especialmente dentro del panorama actual en el cual los medios audiovisuales pueden jugar el papel de lucha contra la desmotivación del alumnado, esto es, "educar al aburrido" ${ }^{43}$. Partimos pues de sensaciones que se constatan en diferentes estudios:

"El valor que se le asigna a la música, su significación y el acercamiento a ella en su entorno cotidiano forma parte de la experiencia musical de los jóvenes. Además, la música en la vida de los adolescentes es parte de un contexto más amplio que juega un papel importante en las distintas actividades que realizan éstos a lo largo del día y en ambientes diferentes" $"$.

Con el peligro que implica la generalización, es cierto que uno de los principales elementos que desde la docencia actual urge paliar es la falta de motivación en el alumnado. Es cierto que la música ha ofrecido tradicionalmente un marco de desarrollo lúdico muy valorado, pero no es menos cierto que existen muchas ocasiones en las que esta faceta interactiva que le otorga a la materia su principal activo no siempre se ha explotado de la manera más adecuada. Como expondremos a lo largo del capítulo, cobra especial relevancia el hecho de incidir en el modo en que se llevarán a cabo los

\footnotetext{
42 Elemento bastante evidente que se muestra, por ejemplo, en BALLESTA, J. (coord.) (2004): El consumo de medios en los jóvenes de secundaria. Madrid: CCS, p. 246.

${ }^{43}$ FUNES, V. (2005): "Espectadores, los alumnos del siglo XXI". Comunicar 24, p. 107.

44 CREMADES ANDREU, R. y LORENZO QUILES, O. (2007): "Familia, música y educación informal". Música y educación 72, p. 40.
} 
aprendizajes, ya que en ello irá gran parte de la meta o recompensa final que hará que el alumno sienta la motivación necesaria para implicarse en la acción educativa ${ }^{45}$. Muy acertadamente, Zaragozà se lanza la pregunta acerca de ¿a quién no le gusta la música? para compendiar algunas de las ideas sobre las que elaboraremos el discurso actual:

"El aprendizaje musical en el aula y el gusto por la música de los alumnos no siempre han formado un dúo bien avenido. Lo que en realidad debería ser una espiral hacia la excelencia por el conocimiento y el placer musical, a menudo se ha convertido en un cruce de caminos divergentes: una cosa es la música (mi música), y otra muy distinta la clase de música (la música del profesor). Las razones del desencuentro entre lo que quisiera el alumnado y lo que les ofrece el docente son evidentes, pero atendiendo al principio de que este último es el responsable de guiar el proceso de aprendizaje, debemos encontrar el terreno común para iniciar juntos el proyecto de enseñar y aprender música en el aula, siguiendo las orientaciones del currículo y valiéndonos de las competencias didácticas necesarias para que la música sea de todos y para todos" ${ }^{\text {. }}$.

Toma vigencia pues, para su superación, la afirmación de Malbrán, Furno y Espinosa quienes apuntaban que en ciertos casos "la música gusta a los jóvenes fuera del aula y aburre en clase" ${ } 47$. Por todo ello, desde la enseñanza de la educación musical hemos de ser capaces de vincular los intereses del alumnado con las propuestas pedagógicas que cumplan con nuestros objetivos didácticos, para lo cual, es interesante observar que entre los alumnos, desde las edades más tempranas hasta la secundaria (momento en el que marcamos el límite de nuestra investigación), hay una galopante tendencia al uso de la vertiente informática de las Tecnologías de la Información y la Comunicación. A lo largo de mi carrera como docente he podido constatar la sensación

\footnotetext{
${ }^{45}$ De acuerdo con Alonso, será pertinente plantearse antes de abordar los procedimientos qué espera el alumno de cada uno de ellos, ya que la comprensión de las metas del aprendizaje nos hará partícipes de sus intereses y nos capacitará para orientarlos: ALONSO, J. (1998): Motivación y aprendizaje en el aula. Cómo enseñar a pensar. Madrid: Santillana.

46 ZARAGOZÀ, J. L. (2009): Didáctica de la música en la educación secundaria. Competencias docentes y aprendizaje. Barcelona: Graó, p. 96.

${ }^{47}$ MALBRÂN, S. y FURNÓ, S. (1990): "La música en la enseñanza secundaria”. Música y educación III (2), p. 371.
} 
que intuitivamente se percibe a este respecto, y este uso tecnológico por parte del alumnado, lejos de minimizarse en comparación con el caso de los docentes, en ocasiones, se muestra con mayor intensidad. No es extraño pues encontrar testimonios que nos conduzcan a cómo los discentes dominan mucho mejor que sus propios profesores todo tipo de programas y herramientas derivadas del mundo informático. El uso efectivo de estos elementos, constatado ampliamente, ha de servir como una primera guía hacia los métodos y recursos que habremos de habilitarles dentro del aula de educación musical, pero nuestro interés se centra especialmente en una segunda tendencia de este tipo de tecnologías, igualmente utilizada de manera consciente e inconsciente pero menos tratada en clave pedagógica: los medios audiovisuales. En este sentido, es preceptivo entender que aquellos que hipotéticamente pudieran ser atendidos en la enseñanza obligatoria tienen, por un lado, la inercia al desarrollo audiovisual, bien por su propia iniciativa, bien por su contacto desde la educación no formal o bien, de manera creciente, por el uso que de estos medios se trata de dar en los centros educativos, especialmente fuera del ámbito de la música ${ }^{48}$. Las mejoras en todos los órdenes desde la observación de estos criterios pueden ser inimaginables. En estos términos lo plantea David Martín Félez al comprobar cómo sus alumnos de primaria respondían a los estímulos audiovisuales en el aula de educación musical:

"Ha habido un cambio general hacia la consideración del área, del maestro y sobre todo a entender que el alumno puede aprender música divirtiéndose y es la manera más eficaz de enseñarla [...]. Lo que más satisfacción me produce es que el trabajo que he realizado ha sido reconocido por alumnado y profesorado, y que se ha visto una mejora en la atención, en el clima del aula y en la facilidad a la hora de trasmitir contenidos que ofrecen los medios audiovisuales [...] y desde el aula de música, he conseguido que la música deje de ser la última asignatura dentro del centro, a la que menos importancia se le prestaba y la que peores resultados siempre ha obtenido en el centro debido a la insistencia de mantener los

\footnotetext{
${ }^{48}$ Hace más de una década que la renombrada "brecha digital" recuerda que los centros docentes de enseñanza obligatoria no están preparando debidamente a unos alumnos que dedican gran parte de su tiempo a aproximarse a medios que son, en cierto modo, ajenos al organigrama educativo: IGLESIAS, M. L. y RAPOSO, M. (1998): "El papel del profesorado ante la influencia de la televisión". Comunicar 11, pp. $142-148$.
} 
métodos de enseñanza equivocados, y pase a ser una de las que los alumnos estén más orgullosos de recibir" 49 .

En el sondeo a jóvenes de diversa edad (cursando estudios desde la secundaria obligatoria hasta universitarios), Pereira Domínguez y Urpí Guercia ${ }^{50}$ desvelan ciertas actitudes de éstos hacia el cine para mostrar el poder de lo audiovisual como fuente de conocimiento, reflexión y recuerdo, en el cual "prevalece lo que se ve sobre lo que se lee" ${ }^{, 51}$. Las autoras citadas destacan cómo se puede generalizar la idea de gusto por el cine entendido como forma de diversión y no tanto de expresión artística, por lo que los posibles aprendizajes derivados de los visionados se obtendrían desde el plano de lo emocional o lo afectivo. Extraemos de estas ideas que se requiere, en nuestro ámbito de actuación, aunar las expectativas de goce anímico con las analíticas, con el fin de poder actuar pedagógicamente con éxito sobre la banda de sonido.

Por otro lado, también se destaca que, incidiendo en la premisa de actuación didáctica sobre la virtualidad cinematográfica (lo real y lo irreal), es altamente aprovechable el hecho de que el cine puede ser capaz de provocar cambios de actitudes tras un trabajo de mediación. Si, como las mismas autoras indican, la información que reciben en torno a aquellas películas que ven es externa, un trabajo de focalización en el ámbito educativo debidamente inducido podría explotar determinadas características a desarrollar en forma de procedimientos relacionados con el currículo.

De las observaciones anteriores se desprende la necesidad de reconocer en la práctica educativa, al menos, cuatro elementos que enmarcarán la actuación docente. Por un lado, los jóvenes "han crecido inmersos en y con los medios audiovisuales",52, lo cual conlleva que estamos ante un lenguaje conocido y familiar, a través del cual se pueden canalizar determinados planteamientos pedagógicos con relativa facilidad. En consecuencia y como segunda premisa, no sólo hablamos de la educación que se base

\footnotetext{
${ }^{49}$ MARTín FÉLEZ, D. (2009a): "Experiencia innovadora de música de cine en la escuela: proyecto de innovación 'La influencia de la comunicación audiovisual en el alumnado de educación primaria' ". OLARTE MARTÍNEZ, M. (Ed.) Reflexiones en torno a la música y la imagen desde la musicología española. Salamanca: Plaza Universitaria Ediciones, p. 773.

50 PEREIRA DOMÍNGUEZ, C. y URPÍ GUERCIA, C. (2005): "Cine y juventud: una propuesta educativa integral”. Revista Juventud 68, pp. 73-89.

${ }^{51}$ Ibíd., p. 76.

${ }^{52}$ Ibíd., p. 75.
} 
en los medios audiovisuales por su grado de significatividad, sino que se trata de un medio que los alumnos utilizan constantemente en sus aprendizajes informales de manera que resulta muy indicado para sacar partido de ello ${ }^{53}$. Preguntémonos cómo se genera la música que escuchan los niños y jóvenes que asisten a las clases y desde qué herramientas están construyendo su propio archivo sonoro y nos acercaremos de manera cierta y segura a la "audiovisualización" del hecho musical ${ }^{54}$. Además, en tercer lugar, el cine les da acceso a experiencias acordes con su edad y nivel de desarrollo, por lo que como estrategia de actuación, se erige como elemento privilegiado. A consecuencia de lo anterior, el cine sirve para integrar al alumno en la vida adulta a la que su propia evolución le va a guiar. Por último, al margen de la conveniencia de atender a los aspectos anteriores, la cuarta consideración nos remite a la importancia de entender que la integración de lenguajes que representa el cine puede interpretarse como una metáfora de la educación integral que se ha de recibir en el contexto escolar.

Sin embargo, aunque la literatura explicativa parezca acercarnos con mayor insistencia hacia el medio cinematográfico, los modos de aproximarse al audiovisual por parte de niños y jóvenes no sólo se dan a través del cine. Es más, podría argumentarse que esa es sólo una de las facetas en las que éstos se relacionan con el audiovisual, en tanto en cuanto hay otros formatos al menos tan accesibles y atractivos. La televisión e internet han forjado un gusto por los entramados audiovisuales que supera, en muchos casos, el conocimiento de los propios docentes. En este sentido será capital reconducir los aprendizajes valiéndose de dichos medios, aunque para ello haya que luchar contra el aura de superficialidad que en ocasiones arrastran recursos como los que postulamos:

\footnotetext{
${ }^{53}$ BOZA, L. (2005): "Proyecto educativo, herramientas de educación audiovisual". Comunicar 25, pp. 177-180. Por otro lado, la importancia del mundo sonoro que rodea a los jóvenes y la relación que se establece con la consideración que de la música se tiene puede encontrarse argumentada en MARTÍNEZ VALCÁRCEL, N. y CUADRADO CAPARRÓS, M. D. (2003): "La construcción del conocimiento musical en alumnos de $2^{\circ}$ de la E.S.O. en contextos no escolares: un estudio realizado en dos aulas de marcos socio-económicos-culturales diferentes". TOHARIA CORTÉS, M. Actas del Congreso La Ciencia es cultura: II Congreso sobre Comunicación Social de la Ciencia (2001). Disponible en $\langle$ http://www.um.es/docencia/nicolas/menu/publicaciones/propias/docs/valencia/MUSIC1.pdf $>$ [Consulta 9-II-10]

54 RADIGALES, J. y FRAILE PRIETO, T. (2006): "La música en los estudios de comunicación audiovisual. Prospecciones y estado de la cuestión”. Trípodos 19, pp. 98-112.
} 
"El cine, la televisión o el vídeo son considerados como 'medios auxiliares' de la educación, en tanto soportes de contenidos de diferentes asignaturas, sin embargo el conocimiento de pedagogos y maestros puede hacer que los medios de comunicación como colaboradores del proceso docente no se limiten al empleo de éstos como meras ilustraciones.

Resulta obvio el valor que tienen como instrumentos de trabajo docente, pues además de posibilitar la reducción del tiempo destinado al tratamiento de los temas, incrementan la efectividad de las clases"

Consecuentemente, resultará muy interesante acercarse al modo en que los niños y jóvenes se vinculan con los medios audiovisuales. Determinados autores resaltan que el hecho de hacer accesible el modo de aproximarse a la música facilita enormemente que éstos puedan desarrollar en el futuro aptitudes musicales, de forma que en lugar de partir de esas supuestas capacidades es necesario plantearse antes cómo se puede generar el escenario propicio para su desarrollo ${ }^{56}$. Sin duda desde el audiovisual se puede indagar si se pretende buscar esa plataforma desde la que hacer emerger una educación musical significativa, ya que de su buen desarrollo se podrán llegar a obtener mayores y mejores beneficios en forma de alumnos bien instruidos y motivados por el arte musical, debido a que se lograría conectar con unas preferencias musicales disponibles para un amplio segmento poblacional en todo el mundo que está modelando la cultura juvenil ${ }^{57}$.

En todo caso, la heterogeneidad de posibles contextos y situaciones hace que tengamos presente que la elaboración de un texto que logre condensar actividades que pudieran ser aplicadas con un mínimo de universalidad en las aulas de nuestro país es poco menos que una utopía. Las inmensas diferencias tipológicas entre centros educativos, barrios, poblaciones y comunidades autónomas hacen imposible una

\footnotetext{
${ }^{55}$ TRÁPAGA, F. (1997): “¡Escuela e imagen, hoy!”. Comunicar 8, p. 53.

${ }^{56}$ Elementos especialmente notorios en la investigación desde otros contextos como es el caso del británico, rastreados en la obra de Susan Hallam por ARAMBERRI, M. J. (2007): "Susan Hallam". DÍAZ, M. y GIRÁLDEZ, A. (coord.) Aportaciones teóricas y metodológicas a la educación musical. Barcelona: Graó, pp. 189-201.

${ }^{57}$ Como arguyen Hargreaves y North en sus conclusiones al respecto de los condicionantes sociales de unos alumnos inmersos en la sociedad digital actual: HARGREAVES, D. J. y NORTH, A. C. (2001) (Eds.): Musical Development and Learning. The International Perspective. London, New York: Ed. Continuum, p. 221.
} 
generalización. Pongamos por caso qué implicaría buscar unos procedimientos de este tipo a partir del cine como fenómeno social. Según Redondo:

"La escuela donde estudian los niños es otra variable muy discriminante: los alumnos de colegios privados frecuentan bastante más el cine y las multisalas que sus colegas de los públicos. La superioridad está relacionada con que los padres del primer caso tienen frecuentemente mayor posición social y mayor nivel de ingresos, de forma que pueden pagar una educación más cara a los hijos, y, a su vez, financiarles mejores actividades lúdicas. La superioridad se acentúa en los colegios privados no concertados, donde la matrícula suele ser más costosa. Aunque este último grupo sea líder de asistencia sobre cualquier corte sociodemográfico, su tamaño es muy reducido" ${ }^{\text {. }}$.

Igualmente, el autor señala el hábitat como determinante (a mayor población mayor número de visitas al cine) tratando de dibujar unos patrones de comportamiento $\operatorname{condicionados}^{59}$. Todo ello, no obstante, es bastante predecible y no será nuestra intención en ningún momento de la investigación tender a la homogeneización. Por el contrario, pretendemos poner sobre el tapete una serie de procedimientos que se están llevando a cabo en diferentes ámbitos y que, mediada una modificación de mayor o menor calado por parte del profesorado de música, pudieran ser utilizables en diferentes contextos.

De hecho, de acuerdo con las ideas desarrolladas en las líneas precedentes, ya ha quedado apuntado que toda la tipología de alumnos que podamos imaginar accede y se relaciona con los medios audiovisuales, de una u otra manera, por lo que sí será materia del estudio entender de qué modos se puede aprovechar el potencial motivador de los mismos y no tanto establecer secuencias pedagógicas concretas e inalterables.

\footnotetext{
58 REDONDO, I. (2000): Marketing en el cine. Madrid: Pirámide, pp. 158-160 (esta breve cita se extiende no obstante en tres páginas por la inclusión de una tabla de datos).

${ }^{59}$ Como se desprende del estudio, dependerá de muchos factores (nivel cultural, tamaño de la ciudad..., más que del poder adquisitivo de los habitantes) lo cual hace difícil establecer una línea unívoca de interpretación.
} 


\subsection{PROFESORADO: CONTINGENCIAS PARA UN CAMBIO}

\section{El reto de no permanecer impasibles}

"Las personas que cada mañana toman posesión de un aula no son las mismas ni lo hacen de la misma manera que las que ocupaban los pupitres y sillas hace treinta años. [...] Sin embargo, en los programas académicos este fenómeno no se contempla, no se ha planteado reelaborar el proceso educativo en función de la nueva realidad comunicacional" ${ }^{\prime 60}$.

Aún entendiendo que sí existe cierto desarrollo legislativo respecto a la implantación de los elementos audiovisuales en las aulas, coincidimos plenamente con las autoras de la cita precedente en que no se ha gestado, todavía, el cambio que propicie una nueva modalidad de los procesos de enseñanza-aprendizaje. El profesorado ha de ser uno de los principales agentes que propicien dicha metamorfosis, ya que el proceso de afloramiento de nuevos criterios metodológicos bebe directamente de su participación. Despojarse pues de la responsabilidad transitiva, que hace que se vean carencias en los procesos educativos de manera exclusivamente exógena al propio estimulador de ellos es un punto preliminar a considerar.

Por otro lado, suele argumentarse que las variables necesarias para que se introduzcan los medios tecnológicos en general y audiovisuales en particular en las aulas oscilan en función de unos parámetros, tales como su presencia, su coste de mantenimiento y actualización, la formación del profesorado, el modelo de organización del centro y la cultura escolar ${ }^{61}$. Afortunadamente, estamos ante unos recursos que en muchos casos ya dotan los centros docentes y, en otros, podrían hacerlo sin grandes

\footnotetext{
${ }^{60}$ SOLÁ ARGUIMBAU, A. y SELVA MASOLIVER, M. (1996): “El cine: imagen y conocimiento". DE LA TORRE, S. (coord.) Cine formativo. Barcelona: Octaedro, p. 47.

${ }^{61}$ CABERO ALMENARA, J. (1998): "Usos e integración de los medios audiovisuales y las nuevas tecnologías". PÉREZ, R. (comp.) Educación y tecnologías de la comunicación. Oviedo: Servicio de Publicaciones, pp. 47-67.
} 
sobresaltos. La cuestión radica en redimensionar los parámetros que hacen referencia al profesorado y su entorno, los cuales serán el verdadero impulso para esta nueva actualización metodológica ${ }^{62}$.

Tomemos pues como primera referencia el profesorado y su formación:

“...una de las más grandes dificultades para los jóvenes pedagogos deseosos de llevar a cabo la nueva educación consiste en liberarse mentalmente de su educación tradicional [porque] muchos son los principios, las ideas que hay que renovar y, a veces, cambiar de un modo radical" ${ }^{\prime 63}$.

"Conviene que seamos lógicos: si queremos favorecer la creatividad, nuestra propuesta significa de entrada que esta creatividad no debe referirse únicamente a los alumnos, sino que antes que nada debe entenderse referida también a los profesores"

Estas aseveraciones procedentes de dos grandes referentes de la teoría pedagógica musical pueden, fácilmente, tornarse en máxima de nuestros planteamientos. No es complicado encontrar investigadores en el contexto español que se cuestionen lo ajustado de la formación del profesorado en relación con la realidad sonora que nos envuelve en nuestros días ${ }^{65}$ y las dificultades de este profesorado para cambiar sus anteojos apriorísticos ${ }^{66}$. En todo caso, parece evidente que desde la generación teórica se admite sin reparos que el estímulo creativo en la educación ha de jugar un papel

\footnotetext{
${ }^{62}$ Para el citado Cabero Almenara el énfasis habría de canalizarse hacia la formación inicial y perfeccionamiento continuado del profesorado: CABERO ALMENARA, J. (1997): "Más allá de la planificación en la 'Educación en Medios de Comunicación' ". Comunicar 8, pp. 39-48. Por otro lado, publicaciones recientes incluyen de manera más o menos tímida la adquisición de competencias básicas a adquirir por el profesorado actual: MONTOYA VILAR, N. (2005): Comunicación audiovisual en la educación. Madrid: Laberinto.

${ }^{63}$ WILLEMS, E. (1994): El valor humano de la educación musical. Barcelona: Paidós, p. 46.

${ }^{64}$ MANEVEAU, G. (1993): Música y educación. Madrid: Rialp, p. 251.

${ }^{65}$ Entre ellas es destacable la de RODRÍGUEZ QUILES y GARCÍA, J. A. (2003): "(Sub)culturas musicales juveniles y la formación del profesorado de música". VV. AA. Participación, convivencia y ciudadanía. Granada: Ediciones Osuna, pp. 361-367.

${ }^{66}$ ZARAGOZÀ, J. L. (2000): "La competencia afectiva del docente de música es un arma cargada de futuro". Eufonía 18, pp. 63-70.
} 
determinante desde la propia disposición del profesor. La diatriba pues, está en encontrar el método adecuado de llevar a cabo este cambio:

"El maestro debe ser consciente de la importancia de su trabajo ante la creatividad infantil y de la necesidad de poseer ciertas destrezas, técnicas y conocimientos integrados en su repertorio de conducta para este fin. [...] El docente debe observar para captar sus habilidades y planificar experiencias que exijan un pensar creativo. [...] La metodología a utilizar debe consistir en una enseñanza más creativa recurriendo al aprendizaje autoiniciado por los alumnos [...]. Además, el maestro debe ser capaz de inventar sus propias técnicas creativas como parte de las operaciones didácticas específicas habituales de la clase" ${ }^{\text {}}$.

Por ello, cobra especial relevancia que las nuevas generaciones de docentes encargados de lo musical adquieran criterios actualizados de acuerdo con las sociedades y tiempos que corren. Así, aunque la tipología de profesionales que tradicionalmente ha accedido a la docencia musical se caracterice por la heterogeneidad y disparidad en todos los aspectos, especialmente en cuanto a su bagaje musical ${ }^{68}$, el énfasis en la formación de dichos jóvenes habrá de radicar no sólo en su competencia musical, aspecto ineludiblemente importante, sino también (tal vez a partes iguales) en su capacidad para amoldarse a las situaciones extremadamente cambiantes que las sociedades contemporáneas generan. De este modo, la expresión musical no puede permitirse quedar inmóvil ante los retos que le acechan, especialmente desde el reconocimiento de que la música que se deriva de la sociedad ha experimentado grandes cambios $^{69}$ y su abordaje en clave pedagógica habrá de ir de la mano de dichas alteraciones.

En este sentido, una de las primeras situaciones a solventar es el rechazo, cada vez menor pero aún persistente en determinados casos, hacia el uso de las Tecnologías de la

67 EPELDE LARRAÑAGA, A. (2007): "Creatividad musical en educación primaria”. Música y educación 69 , p. 65.

${ }^{68}$ ALONSO MARÍN, M. J. (2004): "Perfil musical y rendimiento académico en los alumnos de música de magisterio". Música y Educación 57, pp. 77-102.

${ }^{69}$ ROMERO CARMONA, J. B. (2004): "Las nuevas tecnologías y la expresión musical, otros lenguajes en la educación". Comunicar 23, pp. 25-30. 
Información y la Comunicación, objeciones en gran parte derivadas de la falta de conocimiento de los rudimentos que hacen operativos tales recursos ${ }^{70}$. La naturalización de los procedimientos es algo que ha de macerarse a lo largo del tiempo, pero que ha de partir del convencimiento de su efectividad para poder llevarse a cabo en plenitud. El hecho real, es que todavía hoy un nutrido grupo de docentes no sienten ni el interés ni la necesidad de abordar la educación desde la clave interpretativa que pueden aportar los medios audiovisuales. Como hace una década explicitó Fombona Cadavieco:

“...no contemplan en la práctica los medios audiovisuales como materia y recurso clave en su estudio intrínseco, ni tampoco lo usan adecuadamente como ayuda en el resto de aprendizajes (porque nadie les enseñó)" ${ }^{\text {,71 }}$.

De este modo, aunque no sea preciso un conocimiento extremadamente profundo de las interioridades de los medios audiovisuales para manipular sus parámetros hacia un fin didáctico, sí se requiere cierta predisposición que ampare un mínimo acercamiento necesario $^{72}$, para lo cual es preciso salvar las dificultades derivadas de las reticencias expuestas ${ }^{73}$.

\footnotetext{
${ }^{70}$ ÁLVAREZ, I, y KILBOURN, B. (2005): "La integración de las tecnologías de la información y la comunicación en la formación del profesorado: desafíos para la enseñanza y el aprendizaje constructivista". Revista Iberoamericana de Educación 36. Disponible en $<$ http://www.rieoei.org/deloslectores/1206Alvarez.PDF> [Consulta 9-II-10].

${ }_{71}$ FOMBONA CADAVIECO, J. (1999): "Análisis de documentos audiovisuales para el aula". Comunicar 13, p. 227.

${ }^{72}$ Acercamiento que en determinados casos se defiende como más profundo: PEREIRA DOMÍNGUEZ, C. (2003): "El cine nuevo escenario de la educación". ROMAÑÁ BLAY, M. T. y MARTÍNEZ MARTÍN, M. (Eds.) Otros lenguajes en educación. Barcelona: Universitat de Barcelona.

${ }^{73}$ En todo caso éstas siempre existirán y limarlas será un arduo trabajo, tal y como refleja Paynter en referencia a los problemas que se establecen para generar cambios curriculares en los parámetros que mueven a la educación musical: PAYNTER, J. (1999): Sonido y estructura. Madrid: Akal.
} 


\section{Enseñar música hoy. De la disposición a la predisposición}

Tradicionalmente se ha entendido, sin grandes discusiones al respecto, cuáles eran las características que habría de tener un docente de educación musical ${ }^{74}$. A partir de ellas, se ha configurado un ideal del cual cualquier desviación suponía pérdidas en su competencia didáctico-musical. Por tanto, las potencialidades y características del perfil que se supone al docente de música no han sufrido grandes modificaciones con el paso de los años ${ }^{75}$. Así, sigue vigente la idea de que es esencial en el profesor la posesión de unas cualidades específicas que se adjunten a una actitud positiva ante el hecho musical y que partan del conocimiento del niño para, desde la constatación de las capacidades musicales previas, construir aprendizajes. Oriol y Parra ${ }^{76}$ las enunciaron hace tres décadas $\mathrm{y}$, con pocas variantes, se han ido corroborando a lo largo de los años de desarrollo musical en España. Estas serían valoración positiva de lo musical, conocimiento profundo del niño y sus posibilidades, capacidad para partir de su nivel musical y dominio general de los elementos propios del lenguaje musical, el cual habrá de ser complementado con un buen oído, afinada entonación y correcta ejecución instrumental $^{77}$. En la actualidad, el desglose de estas características, según Concha Carbajo, sería el siguiente ${ }^{78}$ :

\footnotetext{
74 Enfatizándose elementos de índole personal, musical y pedagógica, como muestra PRIETO ALBEROLA, R. (2001): "El perfil del maestro de primaria especialista en educación musical". Revista Interuniversitaria de Formación de Profesorado 40, pp. 175-186.

${ }^{75}$ Lo cual no implica que no se hayan desarrollado patrones que traten de explicar los comportamientos y resultados de diferentes tipos de conductas docentes también en el ámbito de la música. Algunas de las que han llegado a nuestros días manteniendo desigual grado de vigencia (teoría proceso-producto, en busca del "profesor eficaz"; teoría mediacional, basada en la importancia de los pensamientos y conductas del docente; teoría del profesional reflexivo, enfatizando la necesidad de reflexionar sobre la propia práctica docente; las teorías implícitas del profesorado, fundamentado en los procesos no razonados desde los que el docente desarrolla su labor; la metacognición, que parte de la introspección para el conocimiento no sólo de fenómenos sociales o naturales sino también psicológicos o mentales) son resumidas por ZARAGOZÀ, J. L. (2009): Op. cit., pp. 105-113.

${ }^{76}$ ORIOL, N. y PARRA, J. M. (1979): La expresión musical en la educación básica. Madrid: Alpuerto, pp. 30-32.

${ }_{77}$ Otro repaso al modo en que diversos autores plantean las características del docente de educación musical puede encontrarse en VILAR, M. (2003): "El maestro de música en primaria: enfoques y perspectivas". Música y educación 54, pp. 33-56.

78 CARBAJO MARTÍNEZ, C. (2008): “Autopercepción de competencias musicales del docente de música en primaria”. ÁLAMO, A. y LUCEÑO, M. Actas del I Congreso de Investigación y Educación Musical. Madrid: Enclave Creativa Ediciones, pp. 146-147.
} 


\begin{tabular}{c|c|l}
\hline \multicolumn{2}{c}{ Enunciado } & \multicolumn{1}{c}{ Dimensiones } \\
\hline $\mathrm{CM} 1$ & $\begin{array}{c}\text { SOLFEAR y DOMINAR } \\
\text { CONCEPTOS TEÓRICOS }\end{array}$ & $\begin{array}{l}\text { Leer música a primera vista } \\
\text { Dominar los conceptos teórico-musicales }\end{array}$ \\
\hline $\mathrm{CM} 2$ & CANTAR y DIRIGIR & $\begin{array}{l}\text { Cantar con entonación adecuada } \\
\text { Cantar repertorio infantil } \\
\text { Dirigir y organizar coro infantil } \\
\text { Dirigir y organizar grupo instrumental } \\
\text { Dirigir y organizar grupo de danza }\end{array}$ \\
\hline $\mathrm{CM} 3$ & INTERPRETAR Y ACOMPAÑAR & $\begin{array}{l}\text { Interpretar con la flauta el repertorio } \\
\text { Acompañar con instrumento armónico }\end{array}$ \\
\hline $\mathrm{CM} 4$ & ARMONIZAR Y ADAPTAR & $\begin{array}{l}\text { Armonizar canciones infantiles } \\
\text { Adaptar melodias/canciones para uso escolar }\end{array}$ \\
\hline $\mathrm{CM} 5$ & COMPONER E IMPROVISAR & $\begin{array}{l}\text { Componer melodias/canciones para uso escolar } \\
\text { Improvisar acompañamientos } \\
\text { Improvisar melodias }\end{array}$ \\
\hline $\mathrm{CM} 6$ & CONOCER ESTILOS & $\begin{array}{l}\text { Reconocer estilos propia cultura } \\
\text { Reconocer otras músicas }\end{array}$ \\
\hline
\end{tabular}

Como se intuye, el sesgo diferente viene dado por la puesta al día de los referentes didácticos, los cuales, para haberse integrado previamente en las vivencias del alumnado, difieren necesariamente de aquellos que se entendían como pertinentes años atrás. De manera general, se ha de tender a enfatizar la importancia de un docente de música que, en primera instancia, posea unas cualidades comunes al resto de sus compañeros, inherentes a la propia práctica que todos desarrollan. Esta nueva figura parte pues del reconocimiento de su importancia decisiva en el proceso que se lleva a cabo, y de la responsabilidad en su forja:

"El profesorado tenemos tendencia a mirar el proceso de enseñanza desde fuera, excluyéndonos en los planes de mejora: es preciso que los alumnos estudien más, la administración no ayuda, las familias no participan... Mi intención es que ampliemos la mirada y nos incluyamos como una parte y, como en Las Meninas de Velázquez donde el pintor aparece como una parte más del cuadro, observemos que el maestro es un elemento más del proceso de formación, el fundamental, quien lo dirige, quien pinta la escena" ${ }^{, 79}$.

\footnotetext{
${ }^{79}$ VALLS PÉREZ, M. R. (2009): "La importància de les actitudes en la docència. L'actitud del mestre". ROIG VILA, R. (Dir.) Investigar desde un contexto educativo innovador. Alicante: Marfil, pp. 453-459: "El professorat tenim tendència a mirar al procés d'ensenyament des de fora, excloentnos en els plans de millora: cal que els alumnes estudien més, l'Administració no ajuda, les families no participen... La meua intenció és que ampliem la mirada i ens incloguem com a part i, com a Les Menines de Velázquez on el
} 
Sin perjuicio de lo expuesto, las potencialidades de las reflexiones originadas en otros contextos temporales pueden servir para poder interpretar la realidad actual. En este caso, es esencial pues la relectura de los cánones tradicionales para conseguir dar un nuevo sentido en el marco en que nos movemos. Así por ejemplo, es posible seguir tomando al pie de la letra afirmaciones como las de Murray Schafer quien, en torno a la docencia musical aseveraba que el papel del docente no es el de quien dictamina los sucesos sino quien los cataliza ${ }^{80}$.

Así, es preciso relativizar la importancia de los "dominios musicales" que complete el profesor, cuyas virtudes ya están reconocidas y no es necesaria su defensa, enfatizando otros como su capacidad de actualizar y redimensionar intuitivamente su labor pedagógica. De este modo, la actitud reflexiva e investigadora sobre su propia práctica docente y el modo de abordar la materia ha de ser tan tenida en cuenta como cualquier otro aspecto:

“...debemos partir de una formación en la que sea el propio profesor quien de una forma reflexiva, crítica y con un carácter puramente investigador desarrolle por un lado aprendizajes significativos y por otro llegue a conseguir de los alumnos trabajos en equipos para que sea él mismo quien evalúe su propia acción educativa, modificando si procede su intervención en el aula y su propia actitud hacia la enseñanza",81.

De este modo nos acercaremos al perfil del docente afectivo-efectivo ${ }^{82}$, que combina el desarrollo de habilidades conceptuales con otras que regulan el devenir de las situaciones que se dan en el aula. En este sentido, es necesario tener presente que la persona que canaliza los aprendizajes los condicionará de uno u otro modo:

pintor apareix com un element més del quadre, observem que el mestre és un element més del procés de formació, el fonamental, qui el dirigeix, qui pinta l'escena" [traducción propia del valenciano]

${ }^{80}$ MURRAY SCHAFER, R. (1969a): El nuevo paisaje sonoro. Buenos Aires: Ricordi.

${ }^{81}$ PEÑAFIEL MARTÍNEZ, F. y TORRES GONZÁLEZ, J. A. (1996): "El lenguaje audiovisual y la formación del profesorado". Comunicar 7, p. 146.

82 ZARAGOZÀ, J, L. (2009): Op. cit., pp. 127ss. 
“Las creencias y percepciones de los maestros sobre la música y cómo encaja con las necesidades de sus niños determinan su prácticas" ${ }^{, 83}$.

De acuerdo con la cita anterior de Bresler, es en ese punto donde hemos de hacer hincapié, ya que aunque los alumnos sigan siendo seres de edades similares y la enseñanza del arte musical continúe basándose en la organización sonora no todo permanece inmutable. La modificación de la predisposición ante el modelo de aprendizaje hará virar los bloques de contenido hacia una actualización que, de manera consecuente, reavive el proceso de renovación pedagógica. De este modo, la percepción y expresión musical, puntales de las leyes educativas de los últimos años (en concordancia con algunos de los manuales pedagógico-musicales más difundidos en nuestro contexto, como es el caso del firmado por Pascual Mejía ${ }^{84}$ ) son alcanzables con mayor gracilidad y efectividad desde la capacidad creativa del docente, encargado así de redefinir el proceso de enseñanza-aprendizaje $\mathrm{e}^{85}$.

Por otro lado, y sobreentendiendo que dicha predisposición a la búsqueda de vías de mejora se consiguiera generalizar, otra de las trabas a la hora de incluir los procesos audiovisuales en el aula es la falta de un protocolo claramente reglado desde las administraciones en la dirección de incluir dichos procedimientos en las unidades didácticas. El hecho de recomendarse encarecidamente su uso no garantiza que se lleve a cabo, de modo que seguimos insertos en un sistema educativo que ofrece las aplicaciones audiovisuales como una

“opción voluntaria de centros y educadores que lo llevan a cabo de forma personal y con referentes pedagógicos y didácticos poco claros y escasamente estructurados" $" 86$.

\footnotetext{
${ }^{83}$ BRESLER, L. (2004): "Metodología de investigación cualitativa: prestando atención a la música escolar como género en sus macro y micro contextos". Revista Electrónica Complutense de Investigación en Educación Musica 1, p. 4. Disponible en 〈http://www.ucm.es/info/reciem/v1n5.pdf> [Consulta 9-II10].

${ }^{84}$ PASCUAL MEJÍA, P. (2002): Didáctica de la música. Madrid: Prentice Hall.

${ }^{85}$ GARCÍA, M. D. y BENÍTEZ, M. V. (1998): "Formación de profesores en alfabetización audiovisual". Comunicar 11, pp. 202-207.

${ }^{86}$ GABELAS BARROSO, J. A. (2007): "Una perspectiva de la educación en medios para la comunicación en España”. Comunicar 28, p. 71.
} 
Sin duda, este hecho hace lastrar la generalización de las praxis de este calado, pero estimula la figura de un nuevo docente, aquel que trata de vincularse a los intereses de su alumnado para actuar en consecuencia, incluyendo aspectos que pudieran ser relevantes para los discentes al tiempo que aprovechables para la mejora del proceso de enseñanza-aprendizaje. En consecuencia, la nueva dimensión a la que se apela nos conduce a que la observación directa y el reconocimiento del contexto aliente y oriente la significatividad de la práctica docente, de modo que el profesor goce de las ventajas de aquel que ha sido capaz de penetrar en necesidades, vivencias y anhelos de aquellos para quien trabaja. Todo ello, es posible desde la música y es, además, cercano desde la música del audiovisual. La perspectiva apuntada para elaborar nuevos códigos de participación por parte del docente de educación musical, incidiendo en la necesidad de estudiar "en" el grupo y no tanto "al" grupo ${ }^{87}$, deja el aroma casi antropológico del descubrimiento de situaciones latentes que se hacen patentes a partir de la estancia implicada, en suma, de la investigación direccionada hacia la práctica ${ }^{88}$. Por tanto, más allá de las capacidades musicales que se suponen y en las cuales se incide prioritariamente durante la formación del docente de música, éste ha de ser capaz de atender a las relaciones que se establezcan entre todos los agentes del proceso educativo, de modo que se puedan hallar claves interpretativas a partir de las cuales se guíe la práctica, que será tanto más acertada cuanto más imaginativa y próxima al alumnado se muestre.

De acuerdo con lo expuesto, las sendas de actuación metodológica que se exploran en la presente investigación tratan de ser una alternativa a esta búsqueda del ideal pedagógico. En este sentido, es sabido desde el inicio de la utilización tecnológica en clave audiovisual que la eficiencia del profesorado se incrementa con el uso de estas herramientas, ya que se dota al docente de nuevas estrategias para cumplir con los criterios heredados del aprendizaje constructivista, aquellos que le comprometían con la

\footnotetext{
${ }^{87}$ GEERTZ, C. (1987): La interpretación de las culturas. Barcelona: Gedisa, p. 33.

${ }^{88}$ Siempre hemos defendido que el mejor científico social que podría haber en los centros educativos es el profesor, ya que para producir modificaciones en los niveles micro, a pie de aula, sólo aquel que hace comprensible la situación por medio de su implicación puede erigirse en resorte de cambio. Desde esta aproximación al mundo antropológico, en palabras de Michael Carrithers, se trata de hacer lo extraño familiar, inteligible lo ininteligible y coherente lo incoherente: CARRITHERS, M. (1992): ¿Por qué los humanos tenemos culturas? Madrid: Alianza.
} 
necesidad de gestionar el aprendizaje a partir de su papel como dinamizador mientras que, por otro lado, garantiza la innovación metodológica desde su propia inserción en las unidades didácticas ${ }^{89}$. Por todo ello urge adquirir una formación adecuada en el campo de la vinculación música-medios audiovisuales ${ }^{90}$.

\section{Una nueva mirada a Willems, metáfora de cambio}

Recapitulando las ideas expuestas en torno a la necesaria renovación de los elementos que perfilen la figura del docente de educación musical, utilizaremos las ideas de Willems (paradójicamente receloso en su momento ante la inserción de los medios audiovisuales) cuya revitalización nos servirá para plantear, al igual que él hizo, la necesidad de actualizar a los nuevos tiempos tanto la materia como la óptica del docente de educación musical ${ }^{91}$.

Al margen de sus referencias musicales todavía hoy útiles a pesar de la distancia temporal, sus escritos aportan interesantes reflexiones sobre las precauciones que hay que tomar en el uso del audiovisual con el fin de salvaguardar la educación musical por encima de cualquier contingencia. Su relectura pues ha de llevarse a cabo con las reservas propias de su momento de elaboración, en plena efervescencia de las metodologías musicales.

Párrafos atrás utilizábamos palabras del propio Willems para mostrar que el pilar básico de la educación musical sería el cuestionamiento de la metodología a partir de las experiencias actuales, que habrían de superar los conceptos aprendidos desde unos convencionalismos en ocasiones trasnochados. Si el autor consideraba estos planteamientos necesarios ante la rígida instrucción que a buen seguro él sufrió, sus mismos postulados miran hacia una necesaria actualización en los tiempos que corren. La renovación pedagógica, entendida desde sus ideas, ha de emerger como un proceso

${ }^{89}$ CAMPUZANO RUIZ, A. (1992): Tecnologías audiovisuales y educación. Una visión desde la práctica. Madrid: Akal.

90 MARTÍNEZ, J. M. (1996): "Nuevas herramientas para la educación musical: MIDI y nuevas tecnologías". Eufonía 4, pp. 33-45.

${ }^{91}$ Son muchos los autores que, desde la admiración a la obra pedagógica de los grandes maestros del siglo XX y en aras a su intemporalidad, han propugnado una adaptación de sus postulados a la realidad actual. Paradigmático por lo profundo del conocimiento en torno a la didáctica de Orff es la referencia de WUYTACK, J. (1992): “¿Puesta al día de las ideas educativas de Carl Orff?”. Música y educación 12, pp. $11-22$. 
constante, cuya continuidad no se vea frenada por recelos infértiles. Ahora bien, el sentido de la presentación del audiovisual como agente del cambio podría ser un punto de discusión:

"Se habla mucho de medios audiovisuales. ¿Nos damos suficiente cuenta de que cuando la audición y la vista van unidas ésta se beneficia, en general, con el $80 \%$ de la actividad nerviosa y la audición sólo con el 20\% restante? Agreguemos el desconocimiento pedagógico de la música. ¿Qué queda para la verdadera educación musical? [...] ¿En qué se transforma la educación musical tal como la preconizamos, destinada a desarrollar en el ser humano la mayor parte de sus posibilidades dinámicas, auditivas, afectivas, intelectuales y morales?" 92.

Cuando Willems detectaba y ponía de manifiesto las carencias de lo auditivo frente a lo visual estaba luchando, al mismo tiempo, contra una educación musical que no se basaba en lo sensitivo sino en lo repetitivo. En nuestro caso, inmersos en el siglo XXI y avanzando las metodologías activas hemos de luchar, al mismo tiempo, contra las ideas preconcebidas acerca de la preeminencia del sentido de la vista, entendiendo que el desafío estriba en lograr procedimientos capaces de focalizar al alumno hacia lo auditivo, sin necesidad de establecer dicotomías cerradas con lo visual sino comprendiendo el todo como un ente natural del cual los alumnos ya están participando y, además, lo hacen con sumo interés. El reto pues, radica en que los medios de comunicación, entre los cuales desatacaremos los audiovisuales, más allá de adormecer la conciencia musical la postulen como imprescindible y la hagan resorte de aprendizaje sin igual. La integración de los parámetros musicales en aras de un desarrollo integral del alumno no riñe, en ninguno de sus elementos, con el uso audiovisual y, además, favorecerá de manera más efectiva la construcción de nuevos aprendizajes. Entendiendo

\footnotetext{
${ }^{92}$ WILLEMS, E. (1994): Op. cit., p. 35.
} 
pues que "música e imagen son un hecho congénito",93, en palabras de Viñuela y bajo el paraguas ideológico de $\operatorname{Cook}^{94}$ :

"Los estudios de música en la teoría audiovisual ya no buscan la confrontación ni el enfrentamiento entre la música y la imagen para defender la hegemonía de uno sobre el otro, sino que reconocen la entidad de cada lenguaje y su aportación a la creación de un significado nuevo y buscan nuevos enfoques que permitan entender estos fenómenos de otro modo" $"$.

Más trabas a la inclusión de los medios audiovisuales vendrían derivadas de otra perspectiva limitada de su comprensión: el supuesto uso como mero reforzador de otros aspectos a enseñar en cualquier área de conocimiento:

"Una concepción excesivamente novedosa de la educación a lo mejor puede llevar a preferir los procedimientos audiovisuales frente a la palabra. El olvido de que los grandes progresos en educación hasta llegar los medios audiovisuales se han conseguido preferentemente por procedimientos verbales, es un error demasiado frecuente para no denunciarlo aquí. Por consiguiente debe examinarse detenidamente si la pretendida mayor eficiencia de los recursos audiovisuales es real o simplemente relativa" ${ }^{\circ 6}$.

Como ocurre en todos los planteamientos pedagógicos, su efectividad vendrá determinada por la corrección en la secuencia didáctica. Qué duda cabe que ninguna metodología ni ningún recurso, per se, se mostrará acertado sin un proceso previo de

\footnotetext{
${ }^{93}$ RADIGALES, J. y FRAILE PRIETO, T. (2006): Op. cit., p. 102.

${ }^{94}$ COOK, N. (1988): Analyzing Musical Multimedia. New York: Oxford University Press.

${ }^{95}$ VIÑUELA, E. (2008): "Convergencias y divergencias en el estudio de la música en los fenómenos audiovisuales". AYATS, J. y GINESI, G. (Eds.) Quaderns de l'arxiu del so i de la imatge 5. Experiència musical, cultura global. Mallorca: Consell de Mallorca. Departament de Cultura i Patrimoni, p. 360.

${ }^{96}$ FUENTES, P. y CERVERA, J. (1989): Pedagogía y didáctica para músicos. Valencia: Piles, p. 58. A esta perspectiva se une, por ejemplo Norberto Vílchez, quien en su rastreo de medios tecnológicos para la educación apuntala sus postulados señalando que en el audiovisual el sonido participa como mero soporte: VÍLCHEZ FERNÁNDEZ, N. (2000): "Nuevas tecnologías: la didáctica del siglo XXI". Música y educación 44, p. 115.
} 
reflexión que nos avoque a entender por qué es necesario un cambio y la dirección del mismo. No obstante, no hemos de caer en la tentación de entender determinados medios como sustitutivos de otros, ni de postular objetivos novedosos por el simple hecho de serlo. Desde los medios audiovisuales podremos trabajar cualquier contenido que se haya llevado a cabo de forma tradicional, pero imprimiéndole un plus de significatividad inherente al propio proceso que, desde otros planteamientos, resultaría difícilmente conseguible.

La evolución de los materiales vendría determinada por la inclusión de procedimientos extramusicales de apoyo, eso sí inconcebibles en el método de Willems ${ }^{97}$. Con ello, el cambio como adaptación necesaria propugnado por Willems ha de basarse, en nuestros tiempos, en la generación de un proceso verdaderamente significativo que implique que el alumnado adquiera los conocimientos que de él se esperan dentro de un marco de interacción y ludicidad. La participación directa dentro de la educación musical en la generación del conocimiento y la acción y manipulación sobre el material sonoro ha de erigirse pues, en premisa básica de actuación ${ }^{98}$. A todo ello se une, de manera indefectible, la participación del propio alumno, quien dentro de este ambiente de significación decide, desde un prisma más o menos consciente, establecer mecanismos de atención lo suficientemente potentes como para integrar los conocimientos dentro de su mundo sonoro ${ }^{99}$. En ese punto, el concurso audiovisual puede jugar un papel determinante.

Las teorías más actuales en torno a la figura del docente en una sociedad plural y mutable abogan porque el educador se especialice en dos elementos por encima de todos: estimular el aprendizaje y organizar el entorno, para lo cual es preciso adquirir habilidades como mediador del conocimiento, por medio de refuerzos estimulantes, como organizador de actividades, en la búsqueda de la interacción con el material

\footnotetext{
97 WILLEMS, E. y CHAPUIS, J. (1989): "Características del método Willems de educación musical. principios válidos tanto para la iniciación de los niños pequeños como para la preparación al solfeo, instrumento y creación musical". Música y educación II (2), p. 386; WILLEMS, E. y CHAPUIS, J. (1993): “Los ejercicios de audición”. Música y educación 16, p. 18.

98 De acuerdo con trabajos de campo focalizados hacia desentrañar cuáles son los procesos más adecuados de enseñanza musical: VALLS CASANOVAS, A. (2000): "La enseñanza de la didáctica de la música". Revista de la Lista Europea de Música en la Educación 5. Disponible en $<$ http://musica.rediris.es/leeme/revista/valls.htm> [Consulta 9-II-10]

99 RUSINEK, G. (2004): "Aprendizaje musical significativo". Revista Electrónica Complutense de Investigación en Educación Musical 5. Disponible en <http://www.ucm.es/info/reciem/v1n5.pdf > [Consulta 9-II-10]
} 
presentado, como seleccionador de aprendizajes, en un marco de relevancia para los discentes, como microadaptador, tanto de la institución escolar al exterior como de la diversidad en el aula, como diseñador del entorno, la intervención, las experiencias y las actividades de aprendizaje, organizando los recursos en función de la actividad, y como investigador en su aula, evaluando y reformulando los criterios de aplicación ${ }^{100}$.

Para todo ello, es inevitable replantearse el contenido y método de enseñanza:

"Los docentes, por lo general, prefieren decir que consumen sólo obras serias (como los libros) o productos televisivos y fílmicos culturales, escamoteando el consumo de la telenovela, de la comedia y del cine de producción industrial genérico" $"$.

Desterrar el miedo a acercarse al mundo del alumnado para extraer de él consecuencias pedagógicas desde el acercamiento metodológico supone, muy posiblemente, desentenderse de unos anteojos procedimentales fuertemente arraigados. Por otro lado, ser capaces de extraer la música inserta en formatos distintos a los que acostumbramos para el contexto pedagógico puede entenderse, desde perspectivas extremadamente conservadoras, como una minorización del arte musical. Sin embargo, no banalizamos la música en su tratamiento didáctico (cuya finalidad principal sigue siendo la percepción y expresión a través del hecho sonoro) y servirnos del audiovisual tampoco ha de verse como un elemento de trivialización. La configuración mayestática de determinadas obras musicales hoy no refleja con exactitud el grado de aceptación y el valor que, bien en su origen bien a lo largo del tiempo, se les otorgó ${ }^{102}$.

Exploremos pues, en el siguiente apartado, el otro puntal de la docencia musical en las etapas obligatorias: los criterios metodológicos.

\footnotetext{
100 GARCÍA MARTÍNEZ, J. (2009): "Profesionalidad docente y gestión del cambio en contextos complejos". ROIG VILA, R. (Dir.) Investigar desde un contexto educativo innovador. Alicante: Marfil, pp. 192-193.

${ }_{101}^{10}$ FUNES, C. (2005): Op. cit., p. 109.

${ }^{102}$ Como constatan con flagrantes ejemplos RADIGALES, J. y FRAILE, T. (2006): Op. cit., p. 101.
} 


\subsection{VIRAJES METODOLÓGICOS EN EDUCACIÓN MUSICAL}

\section{La Escuela Nueva y sus consecuencias}

"Los educadores tenemos la necesidad, incluso la obligación, de conocer todo lo que podamos sobre las metodologías activas que han aparecido a lo largo de todo este siglo. [...] Igualmente hay que llegar más allá de los métodos y desarrollar la autonomía que la experiencia nos puede ofrecer" ${ }^{203}$.

Sin intención de desviarnos demasiado del objeto de estudio, es necesario recordar que la enseñanza de la música dentro de los márgenes de la educación obligatoria guarda su sustrato más evidente en los criterios que vieron emerger unas metodologías que, de manera ideal, recogieron postulados de la llamada "Escuela Nueva" y los transportaron al mundo de la pedagogía artística en general y musical en particular para que, de este modo, lo sensitivo y vivencial se hicieran el hueco necesario entre los planteamientos eruditos y las prácticas de aprendizaje repetitivas y plenas de tosquedades. Desde esta nueva perspectiva, es el niño el que se erige como eje fundamental de la educación y, por él y a partir de él, se persigue una configuración acompasada de sus capacidades para conseguir, en última instancia, el desarrollo integral de su personalidad. Por supuesto, ello no implicaría dejar de hacerse con los conocimientos y rudimentos básicos y precisos de la educación musical, sino que el cambio habría de radicar en el modo en que esas potencialidades del alumno serían vehiculadas hacia un fin a todas luces loable. No cabe duda que la filosofía de estas posturas puede tener vigencia, eso sí, desde otros marcos de actuación que adapten recursos y materiales a la sociedad de la información que vivimos en el siglo XXI y a que los niños y jóvenes están abocados.

${ }^{103}$ SANUY, M. (1999): "La música como elemento integral en la educación escolar". Música y educación 37, p. 44. 
En cualquier caso, la adopción de estos criterios no ha de llevarnos a la confusión de buscar causalidades solamente en lo musical, de hecho estos aspectos se desarrollaron básicamente al margen de nuestro objeto de estudio y su influencia, aunque patente, fue indirecta:

"La denominación de métodos activos nos lleva a colocarlos inmediatamente con el movimiento de la Escuela Nueva, que promovía precisamente los métodos de enseñanza paidocéntricos, en contraste con las prácticas escolares anteriores, de tipo magistral, magistocéntricas. Por los datos que disponemos, es difícil establecer una relación directa entre la Escuela Nueva y los métodos activos de educación musical: no es posible afirmar con seguridad que los autores de los métodos activos en educación musical hayan tenido una relación directa con los pedagogos de la Escuela Nueva"104.

Con el ánimo de ser sintéticos en este apartado, mostramos la tabla con la que la propia $\mathrm{M}^{\mathrm{a}}$ Cecilia Jorquera Jaramillo ${ }^{105}$, en su discurso sobre la educación musical, compara las dimensiones básicas de la escuela tradicional-pasiva y la escuela nueva.

104 JORQUERA JARAMILLO, M. C. (2004): "Métodos históricos o activos en educación musical". Revista de la Lista Europea de Música en la Educación 14, p. 24. Disponible en $<$ http://musica.rediris.es/leeme/revista/jorquera.pdf> [Consulta 9-II-10]. 105 JORQUERA JARAMILLO, M. C. (2004): Ibíd., p. 14; a partir de mostradas por Ansay-Terwagne en su cita a Titone: TITONE, R. (1981): Metodología didáctica. Madrid: Rialp. 


\begin{tabular}{|c|c|}
\hline $\begin{array}{l}\text { Escuela tradicional-pasiva } \\
\end{array}$ & Escuela Nueva \\
\hline $\begin{array}{l}\text { 1. Base: el programa } \\
\text { E1 valor intelectual es la medida para la acumulación de } \\
\text { materiales. }\end{array}$ & $\begin{array}{l}\text { 1. Base: el niño } \\
\text { Aquello que importa es la evolución normal de los } \\
\text { intereses favorecida por el alimento apropiado para cada } \\
\text { uno. }\end{array}$ \\
\hline $\begin{array}{l}\text { 2. El niño-homúnculus } \\
\text { Un adulto en miniatura. }\end{array}$ & $\begin{array}{l}\text { 2. El niño, ser sui géneris } \\
\text { Perfectamente preparado para adaptarse a cada una de las } \\
\text { fases del desarrollo. }\end{array}$ \\
\hline $\begin{array}{l}\text { 3. Disociación de la inteligencia en facultades } \\
\text { Valor de las disciplinas ante cada una de las facultades. }\end{array}$ & $\begin{array}{l}\text { 3. La inteligencia, funcionalmente una } \\
\text { E1 material es percibido según los intereses y según una } \\
\text { mentalidad caracteristica. }\end{array}$ \\
\hline $\begin{array}{l}\text { 4. Principio } \\
\text { De lo simple (abstracto) a lo compuesto (concreto). }\end{array}$ & $\begin{array}{l}\text { 4. Principio: seguir los intereses } \\
\text { Primero aparecen los intereses concretos. }\end{array}$ \\
\hline $\begin{array}{l}\text { 5. Clasificación adulta del saber en especialidades de } \\
\text { estudio } \\
\text { Es sintesis de las experiencias de la especie. }\end{array}$ & $\begin{array}{l}\text { 5. Estudio de las cosas } \\
\text { La totalidad, ordenadas en clasificaciones rudimentales y } \\
\text { personales; después, mediante comparaciones entre ellas, } \\
\text { hasta llegar a una sintesis de experiencias personales. }\end{array}$ \\
\hline $\begin{array}{l}\text { 6. Proceso abreviado de las adquisiciones mentales } \\
\text { De las intuiciones a la generalización de la lección. }\end{array}$ & $\begin{array}{l}\text { 6. Proceso natural } \\
\text { Sostenido mediante los intereses concreto-analítico- } \\
\text { sintéticos en el proceso de escolaridad. }\end{array}$ \\
\hline $\begin{array}{l}\text { 7. Enseñanza verbal } \\
\text { Colectiva, a nivel de alumno medio. }\end{array}$ & $\begin{array}{l}\text { 7. Enseñanza mediante la vida, individualizada } \\
\text { De acuerdo con las reacciones propias de cada uno y } \\
\text { mediante el uso de juegos educativos. }\end{array}$ \\
\hline $\begin{array}{l}\text { 8. El maestro enseña al alumno pasivo } \\
\text { Es el maestro quien impone el proceso de aprendizaje. }\end{array}$ & $\begin{array}{l}\text { 8. El alumno se autoeduca activamente } \\
\text { E1 alumno sigue sus intereses como propulsores }\end{array}$ \\
\hline $\begin{array}{l}\text { 9. Las técnicas son finalidades a las que es necesario } \\
\text { someterse } \\
\text { Metodologia }\end{array}$ & $\begin{array}{l}\text { 9. Las técnicas son instrumentos } \\
\text { Para perfeccionar la conducta, que es la finalidad. }\end{array}$ \\
\hline 10. Disciplina represiva, constricción & 10. Libertad guiada - educación social. \\
\hline
\end{tabular}

Fig. 3. Comparativa entre la Escuela Tradicional-Pasiva y la Escuela Nueva María Cecilia Jorquera Jaramillo

Como apostillamos, la revisión metodológica que se propugna con la implantación del audiovisual implicaría una aceptación de los elementos derivados de las premisas de la Escuela Nueva con la inclusión de una tercera columna que agrandaría las perspectivas y posibilidades de la educación musical. La primera de las premisas hace referencia a los intereses del niño, a su visión del mundo y sus necesidades como germen de los aprendizajes por construir, por lo que difícilmente puede intuirse lastre alguno en la adición de los medios audiovisuales a los recursos tradicionales (entendidos ahora ya como los planteados por la Escuela Nueva). La multiplicidad de materiales y adaptaciones en función de la edad y los intereses del alumnado son otra baza favorable para acceder al mundo tecnológico audiovisual, por lo que la unicidad del alumno en su propio desarrollo tampoco ofrece dudas al respecto. En lo referente al tercer apartado, si lo adoptamos como enteramente acertado, habríamos de acelerar los procesos de cambio hacia los materiales que propugnamos, en tanto en cuanto en las aulas de nuestros días esos materiales son, sin duda, los que un mayor nivel de aceptación tendrían. Tampoco se encuentra traba alguna en la aplicación 
del cuarto y quinto puntos, ya que el seguimiento de los intereses y la gradación y ordenación de recursos es perfectamente compatible con los axiomas básicos de la inclusión audiovisual. Por otro lado, si nos remitimos a la realidad social del alumno, a sus vivencias y contingencias sociales, hemos de entender como adecuada la formación basada en la construcción natural de aprendizajes, para lo cual, los medios audiovisuales ofrecen un buen escenario, en tanto en cuanto permiten trabajos de todo tipo, de la inducción a la deducción. En cuanto a la inserción de juegos educativos y realidades lúdicas como herramientas de aprendizaje, es reseñable la propia esencia atractiva de este nuevo modelo de enseñanza. Además, la autoeducación entendida como posicionamiento crítico tiene un gran margen de actuación a partir de los discursos audiovisuales, así como el aprendizaje a partir del propio medio, reseñado en el noveno de los apartados ${ }^{106}$. Por último, no se nos ocurre mejor manera de guiar el aprendizaje autónomo que el estudio sobre la realidad que se asimila durante todo el día y no siempre se razona a partir de los medios de comunicación, por lo que el estudio musical inherente al conjunto audiovisual puede y debe ser observado como obvio.

De acuerdo con lo expuesto, parece necesario detenerse y meditar acerca de las metodologías que se vienen usando y el modo en que éstas colaboran o no a la deriva que en el plano legislativo la materia viene sufriendo en los últimos tiempos. Cuestionarse el modo en que los docentes venimos reproduciendo discursos musicales y con ello ahondando en el levantamiento de modelos no siempre meditados no ha de entenderse como un ejercicio de desprecio sino de responsabilidad por la labor que se realiza $^{107}$. De hecho, llama poderosamente la atención que

“en la España de hoy se siguen considerando 'modernos métodos de educación musical' aquellos que otros países europeos vieron nacer en las primeras décadas [del siglo XX]. Este dato es preocupante por sí mismo ¿cómo es posible que se piense que no ha ocurrido prácticamente nada en educación musical a lo largo de

\footnotetext{
${ }^{106}$ Un ejemplo práctico para alumnos de secundaria, sobre la adquisición de esta perspectiva crítica a partir de la publicidad (y con especial atención al caso de la música como parte del currículo general) lo encontramos en: GUERRERO SERRANO, P. y MOYANO CONDE, M. A. (1994): "Unidad didáctica: la publicidad". Comunicar 3, pp. 118-128.

${ }^{107}$ El robustecimiento de los discursos pedagógico-musicales preexistentes y la falta de cuestionamiento de los mismos es una de las tesis centrales en la obra de Lucy Green. Destacamos en ese sentido la obra que inicia tal controversia: GREEN, L. (1988): Music on Deaf Ears. Musical Meaning, Ideology and Education. Manchester, New York: Manchester University Press.
} 
casi un siglo (sin remontarnos más atrás en el tiempo)? ¿No será más bien que no se ha reflexionado seriamente sobre ello?"108.

La cita anterior no representa una sensación aislada dentro de la pedagogía musical actual, desde la cual se trata de implementar un nuevo giro a la enseñanza de la música. Esta tendencia a la revolución en las prácticas musicales, especialmente desde la inclusión razonada de las Tecnologías de la Información y la Comunicación, precisa de una profundización y reflexión intensa acerca del modelo de educación musical que se pretende para los alumnos que ahora se están atendiendo ${ }^{109}$. Los cambios de paradigma, también en lo pedagógico-musical, surgen desde la interdisciplinariedad y hacen evolucionar a la propia materia. Como ocurrió tras el desarrollo de las primeras metodologías abiertas, en torno a la década de los setenta se produjo el advenimiento de otros postulados que, desde su vinculación con ellos, daban una nueva vuelta de tuerca a la enseñanza de la música desde la actividad:

"De manera similar a lo que ocurrió con la revolución de la psicología cognitiva dando su aportación a la educación general al profundizar en principios y ordenamientos psicopedagógicos, la nueva pedagogía musical surgida en los años sesenta del siglo pasado, se ocupó más del sonido y de sus soportes o de las herramientas aportadas a la construcción de nuevos lenguajes que del discurso audiovisual configurado sobre la base de consignas en las que el interés se centra

\footnotetext{
${ }^{108}$ RODRÍGUEZ QUILES y GARCÍA, J. A. (2000): Op. cit., p. 1.

${ }^{109}$ Así lo atestigua, por ejemplo, José Luis Aróstegui en su vinculación entre el desarrollo de los medios audiovisuales y la enseñanza de la música: ARÓSTEGUI PLAZA, J. L. (2005b): "Las Tecnologías de la Información la Comunicación en el aula de música". Musiker, Cuadernos de Música 14, pp. 173-189. Por otro lado, resulta de gran utilidad la reflexión de Margarit Dalmau, quien al respecto de la educación musical hace especial énfasis en la necesidad de que las investigaciones en torno a la ella no sólo se circunscriban al ámbito de los criterios metodológicos, sino también a la búsqueda introspectiva sobre el contenido de la propia materia: MARGARIT DALMAU, J. (2000): “Aplicación de la investigación en teoría de la música a la educación musical: la globalidad como contenido básico". Revista de la Lista Europea de Música en la Educación 5. Disponible en <http://musica.rediris.es/leeme/revista/margarit00.pdf > [Consulta 9-II-10]
} 
en el aprendizaje de la tradición occidental y en su transmisión e interpretación unívoca", ${ }^{\prime 10}$.

\section{Reflexión, reactivación y reinvención metodológica}

En todo caso, para poder establecer taxonomías audiovisuales válidas y sustentarlas sólidamente de manera teórica es preciso realizar un sucinto recorrido, no tanto por los métodos activos que han ido incidiendo las aulas de educación musical ${ }^{111}$, como por las consecuencias que su activación ha provocado en los contextos y el imaginario docente e infantil. Con ello, hemos de recordar que fue en la década de los noventa, con la llegada y aplicación de la LOGSE cuando hubo una mayor activación y generalización de los elementos metodológicos que con anterioridad habían sido objeto de desarrollo en otros países europeos. Investigaciones recientes constatan la sospecha que un pequeño muestreo o que la mera observación en diferentes contextos de la geografía española evidenciaría: el empleo y conocimiento de una serie de orientaciones metodológicas reiterativas, derivadas de los postulados -esencialmente- de Orff, Kodály, Dalcroze o Willems, así como la generación de una metodología propia que conjuga a los anteriores con otros de aparición más reciente como Murray Schafer o Wuytack, de manera que se constata la omisión de métodos creados para el aprendizaje en España (Elizalde, Segarra o Llongueres) a favor de los de procedencia centroeuropea ${ }^{112}$. Así, determinados modelos comienzan a tomar cuerpo a través de los docentes de la especialidad mientras que los alumnos empiezan a descubrir una nueva música, alejada de rigideces e incomprensiones y llena de un sinfín de instrumentos de fácil manejo y

110 ESPINOSA, S. (2007): “Creación y pedagogía: los compositores van al aula”. DÍAZ, M. y GIRÁLDEZ, A. (coord.) Aportaciones teóricas y metodológicas a la educación musical. Barcelona: Graó, p. 103.

111 Este esfuerzo no tiene cabida dentro de la investigación presente, ya que por otro lado ha sido abordado en repetidas ocasiones en artículos de diverso calado y en publicaciones concretas. Entre las últimas, siempre centrándonos en nuestro contexto más inmediato, destacamos la ya mencionada: DÍAZ, M. y GIRÁLDEZ, A. (2007) (coord.): Aportaciones teóricas y metodológicas a la educación musical. Barcelona: Graó.

112 Aunque de manera intuitiva se sabe cuáles son las metodologías más utilizadas en los diferentes contextos, su nivel de uso es presentado sintéticamente por ORIOL DE ALARCÓN, N. (2005): "La música en las enseñanzas de régimen general en España y su evolución en el siglo XX y comienzos del XXI". Revista de la Lista Europea de Música en la Educación 5. Disponible en

$<$ http://musica.rediris.es/leeme/revista/oriol2.pdf > [Consulta 9-II-10]. Una breve prospección de estos y otros métodos de raíz española firmada por el mismo autor puede consultarse en ORIOL, N. (2007): “Enseñanza musical en España”. DÍAZ, M. y GIRÁLDEZ, A. (coord.) Aportaciones teóricas y metodológicas a la educación musical. Barcelona: Graó, pp. 87-93. 
técnicas participativas. La necesidad hace que se tomen como referencia criterios derivados de la efervescencia metodológica que hizo del siglo pasado el momento culminante de la teoría pedagógico - musical:

"Hay razones evidentes para calificar al siglo XX, cunado éste llega a su punto final, como el siglo de oro de la pedagogía musical, calificación bastante justificada, al ser cierto que a lo largo de este tramo de tiempo se han sucedido una serie de aportaciones ricas en esta materia" ${ }^{\prime 13}$.

Ciertamente, en la adopción de estos criterios nos hallamos ante un panorama de constantes trasvases y amalgamas. No es común encontrar realizaciones pedagógicas que, al modo de un método en su sentido más literal, realicen uno tras otro los pasos que se suponen derivarían en la asimilación de contenidos musicales, sino que más bien los diferentes contextos y la predisposición docente configuran su propio estilo de enseñanza. En esta dirección, Jorquera Jaramillo ${ }^{114}$ indica que la denominación de métodos, referidos a lo musical, tenían su sentido en un tiempo como "secuencias ordenadas de ejercicios, desde el punto de vista de un autor específico", por lo que un uso más adecuado a lo que en realidad entendemos como real en las aulas a partir de las metodologías activas tal vez sería, para ella, el de "modelos" o el de "conceptos"115.

Ahora bien, ¿qué implica todo ello en la realidad escolar musical de los últimos veinte años? En primera instancia que, al margen de su nivel de utilización (que no de utilidad, que está contrastada) los instrumentos de láminas (carillones, xilófonos, metalófonos) y una cantidad creciente de agentes productores de sonido indeterminado de diversa forma y calado empiezan a hacerse realidad dentro de las aulas de educación musical (creadas igualmente ex profeso). De acuerdo con esta última idea, además, se requieren espacios para utilizar artilugios como los aros que respondan a las necesidades de movimiento dalcroziano. En esencia, entre los primeros cambios patentes por volumen es destacable la constatación de la propia existencia de lo musical en el

\footnotetext{
113 ANGULO, M. (1999): "La educación musical: nuevas alternativas”. Música y educación 37, p. 69. 114 JORQUERA JARAMILLO (2004): Op. cit., p. 23.

115 Para lo cual la autora sigue la obra de ABEL-STRUTH, S. (1985): Grundriss der Musikpädagogik. Mainz: Schott Music.
} 
entramado educativo. De manera desigual en función de la heterogeneidad educativa que vivimos, dotación material y configuración física del aula son señas de identidad que empiezan a hacer reconocible lo musical ${ }^{116}$. En todo caso, es curioso observar cómo en su traslación a los medios audiovisuales, se está estableciendo una cesura entre la importancia que se le concede dentro de las aulas y la que, de facto, tienen fuera de ellas $^{117}$.

\section{La redimensión de los materiales pedagógicos}

En la selección de material habrá de considerar factores de índole general y específicamente relacionados con la implementación musical. En todo caso, un correcto proceso selectivo evitará que aflore el rechazo que los alumnos pudieran haber acumulado hacia los contenidos académicos ${ }^{118}$. Es importante tener en cuenta que no siempre ambos criterios pueden converger en una misma producción y que aquello que pudiera resultar muy útil en el trabajo de elementos extramusicales no tiene por qué serlo cuando queramos abordar uno u otro tipo de trabajo didáctico en relación con lo musical. Por otro lado, es también necesario recordar que no nos referimos a cine didáctico al uso ${ }^{119}$, de modo que aunque un docente no intuya las posibilidades pedagógicas, por ejemplo, de una película, éstas pueden estar presentes para su desarrollo y son susceptibles de ser descubiertas en ulteriores realizaciones didácticas. Además, suele ocurrir que la atención hacia el producto potencialmente pedagógico se centra hacia aquello con connotaciones infantiles ${ }^{120}$ pero esto no siempre ha de ser así.

\footnotetext{
${ }^{116}$ En artículos paralelos los siguientes autores constatan cómo se forja la creación de los espacios musicales teniendo en cuenta su instrumental: LORENZO YANES, A. I. y RACIONERO LLORENTE, D. E. (1999): "Las condiciones de la docencia musical en primaria: el aula de música". Eufonía 14, pp. 81-90; LORENZO YANES, A. I. y RACIONERO LLORENTE, D. E. (2000): "El aula de música". Revista de la Lista Europea de Música en la Educación 5. Disponible en

$<$ http://musica.rediris.es/leeme/revista/lorenzoetal00.pdf > [Consulta 9-II-10]

${ }^{117}$ Esta brecha entre el aprendizaje a través de los medios audiovisuales fuera de las aulas y su omisión dentro de las mismas es discutida y criticada por DE PABLOS PONS, J. (1996): Tecnología y educación. Una aproximación sociocultural. Barcelona: Cedecs.

${ }^{118}$ Como deja patente en sus criterios de selección de contenidos curriculares GARCÍA MARTÍNEZ, J. (2009): Op. cit., p. 197.

${ }^{119}$ De cuyas particularidades se ocupó en su momento DE PABLOS PONS, J. (1986): Cine y enseñanza. Madrid: MEC, Centro Nacional de Investigación y Documentación Educativa.

${ }^{120}$ Por ejemplo las propuestas de PEREIRA DOMÍNGUEZ, C. (2005a): Los valores del cine de animación. Propuestas pedagógicas para padres y educadores. Barcelona: PPU.
} 
Algunos autores se han aventurado a especificar por ciclos, dentro de la educación formal, propuestas de contenidos. Sin duda es meritorio el esfuerzo por acotar los procedimientos audiovisuales dentro de las capacidades de los alumnos en función de su desarrollo, aunque estas parcelaciones habrán de tomarse, obviamente, con las debidas cautelas y flexibilidad. Entre estos ejemplos destacamos el caso de Campuzano Ruiz ${ }^{121}$, quien propone, con independencia del área curricular que se trate, aspectos como grabaciones y reproducciones audiovisuales simples en asociaciones de imágenes y sonidos (educación infantil), operaciones sencillas con equipos de registro (primer ciclo de primaria), manejo de equipos audiovisuales en su vinculación con los medios de comunicación de masas, producción de imágenes y análisis publicitario (segundo y tercer ciclo de primaria) u operaciones complejas de registro, almacenamiento y reproducción, así como la estimulación a través de ello del espíritu crítico (educación secundaria).

En todo caso siempre será una idea acertada hacer ver que a través de la utilización de materiales sonoros integrados en el audiovisual podemos acceder a todos los bloques de contenido que tradicionalmente forman parte de las enseñanzas obligatorias en el plano musical, desde el recorrido más teórico en el plano histórico hasta la formación vocal, auditiva, instrumental o la danza y el movimiento.

Por otro lado, el conocimiento del entorno sonoro del niño habrá de guiar la elaboración de materiales que cumplan con las expectativas de todos los agentes inmersos en el proceso de enseñanza-aprendizaje. La especificidad del alumnado que se atiende en cada contexto es tal que la generación de materiales habrá de responder a dicha heterogeneidad, lo cual lucha frontalmente contra el inmovilismo y el conformismo docente. Prieto Alberola introduce una de sus obras enfatizando la necesidad de enriquecer la práctica del alumnado y la propia del docente desde la innovación y la reinvención constante:

"El profesor de música, de cualquier nivel académico, puede conformarse con utilizar sólo el repertorio que venga en el libro elegido para ese año, repetir las mismas canciones del curso anterior, puesto que los alumnos son diferentes, o

${ }^{121}$ CAMPUZANO RUIZ, A. (1992): Op. cit., pp. 78-80. 
intentar buscar músicas que le resulten atractivas a él y a sus alumnos. Esta última alternativa le permite divertirse más al cambiar el repertorio cada curso, al pasárselo mejor transmitirá ese mismo estado de ánimo a sus alumnos y también tendrá la oportunidad de participar en la parte creativa de ese material" ${ }^{\prime 22}$.

En este sentido, se ha asumido con naturalidad que dar rienda suelta a la imaginación y la creatividad del docente es una de las mejores herramientas de trabajo, lo cual se ha visto plasmado, especialmente, en la producción de artilugios sonoros de diferente tipo que han servido para cumplir con numerosos objetivos musicales. Son los conocidos como "cotidiáfonos"123. Estamos en camino de avanzar en el reconocimiento de nuevas formas de expresión musical que reflejen este despunte de la creatividad docente y se fundamente en la esfera sonora del niño. Así, aún no es sistemático (de hecho tampoco suele ser común) otorgar una importancia similar a evolucionar materiales a partir de melodías cinematográficas o espacios televisivos o cibernéticos, pero sin duda ahí se muestra una de las grandes posibilidades de desarrollo imaginativo de lo musical en el futuro.

Hoy por hoy, la docencia de la educación musical, si pretende centrarse en la didáctica de los medios audiovisuales o, simplemente, si tiene la intención de tocarla tangencialmente, habrá de partir, en ambos casos, de una elaboración propia de materiales por parte del especialista en educación musical. Así pues, sigue siendo necesario la confección propia, lo cual es un mal endémico de la educación musical: ir por detrás de los paradigmas que ocupamos. Simple pero no exenta de razón es la afirmación al respecto de los materiales didácticos para la audición por parte de Edgar Willems:

"En muchos casos es necesario creárselo porque el comercio no siempre ofrece las cosas preparadas como uno desearía. [...] Además, la vida es rica en

\footnotetext{
${ }^{122}$ PRIETO ALBEROLA, R. (2008): What a Wonderful World. Alicante: Editorial Club Universitario, p. 7.

123 AKOSCHKY, J. (1988): Cotidiáfonos: instrumentos sonoros realizados con objetos cotidianos, confección y sugerencias didácticas. Buenos Aires: Ricordi.
} 
posibilidades, y quienes buscan a partir de los propios, tendrán pronto con qué salir del paso" ${ }^{\prime 24}$.

En este mismo volumen, Willems hace referencia a otra obra de su cuño, igualmente paradigmática ${ }^{125}$, en la cual muestra diversas posibilidades de confección de material el cual, aunque obviamente no se relaciona directamente con la didáctica específica que nosotros desarrollamos, si puede adoptarse como apoyo a actividades creativas relacionadas con la música de cine ${ }^{126}$.

Por tanto, entendiendo que un cambio moderado supone aprovechar aquello que es útil y actualizar allá donde se considere necesario, es pertinente acentuar el hecho de que existen infinidad de postulados metodológicos y de recursos efectivos, reales e insertos en las aulas actuales, que no sólo no son desdeñables sino que además son extremadamente útiles y provechosos, y pueden tener un nuevo impulso a partir de una nueva funcionalidad. La tarea desde la esfera investigadora puede centrarse desde esos parámetros:

"Aunque poco a poco parece que se va aumentando el material, lo cierto es que escasea [...]. Este punto podría subsanarse, en parte, con un plan incentivador de la investigación educativa, que contemplara la posibilidad de que hubiese un grupo importante de profesionales que pudiesen invertir tiempo en proponer materiales pedagógicos adecuados como punto de referencia y para asegurar unos mínimos dignos que ahora no se tienen"127.

Desde las primeras aproximaciones a la música como elemento didáctico, se han buscado una serie de premisas que tienen que seguir siendo garantes de la educación musical que se anude al audiovisual. Así, extender el hecho sonoro y su aprendizaje más

\footnotetext{
${ }^{124}$ WILLEMS, E. (1994): Op. cit., p. 45.

${ }^{125}$ WILLEMS, E. (2001): El oído musical. La preparación auditiva del niño. Barcelona: Paidós.

126 Aunque hemos desarrollado varios materiales al respecto, tal vez el más conciso sea MONTOYA RUBIO, J. C. (2007a): "La música de cine como estrategia educativa". Ensayos 22, pp. 99-124.

127 ESTÉVEZ VILA, J. (2002): "Del Plan 66 al Plan LOGSE: aspectos positivos y problemáticos". Música y educación 49, p. 47.
} 
allá de la propia materia, aplicar enfoques progresivos o integrales, dotar de una mayor importancia a la vivencia frente a la docencia magistral y trabajar todos los bloques de contenido musical que sean posibles siguen siendo cuestiones de capital relevancia ${ }^{128}$. Para ello, puede resultar de gran utilidad analizar el modo en que se produce la interacción visual y auditiva en el mundo actual y la derivación pedagógica que ello puede suponer en el viraje de las metodologías preexistentes dentro de las cuales pretendemos enmarcar la investigación. En este sentido, Pep Alsina ${ }^{129}$ enfatiza la importancia que para la educación musical del presente habrá de tener no tanto el seguimiento de un método de autoría concreta sino el conocimiento de los principios básicos de aquellas estrategias procedimientales que se han mostrado como eficientes y su posterior adaptación a la realidad.

\section{De Kodály a la "Sinfonía del Mundo Nuevo"}

Volviendo la mirada hacia aquello que ya es tradicional dentro de la modernidad que supusieron las metodologías activas del siglo pasado, una de las referencias más citadas en la literatura relativa a la educación musical es la del pedagogo insignia de dichos planteamientos, Zoltan Kodály:

"Hace más o menos 16 años durante una conferencia sobre educación musical organizada por la UNESCO se me preguntó: ‘¿Cuándo conviene iniciar el estudio de la música?’ y respondí: 'nueve meses antes del nacimiento'. Si hoy

\footnotetext{
${ }^{128} \mathrm{Y}$ es preciso tener en cuenta, que fueron enunciados en términos similares hace ya cuarenta años: ORIOL, N. y PARRA, J. M. (1979): Op. cit., pp. 14-16.

${ }^{129}$ ALSINA, P. (2007): "Métodos de enseñanza musical. Algunos puntos de contacto". DÍAZ, M. y GIRÁLDEZ, A. (coord.) Aportaciones teóricas y metodológicas a la educación musical. Barcelona: Graó, pp. 15-21. En su capítulo introductorio a este compendio, además de referirse a la necesidad de conocer los rudimentos metodológicos para activarlos hipotéticamente, Alsina nos induce a siete parámetros a partir de cuyo cumplimiento se accedería a una música más cercana, apreciada y disfrutada en el contexto escolar: aprendizaje desde lo sensitivo, motivación y estimulación, creatividad, desarrollo de capacidades sensoriales y perceptivas, estímulo de las posibilidades rítmicas, capacitación en el plano de la entonación y simplificación del lenguaje musical. Tomando como buenas las premisas del autor, las cuales por otro lado están ampliamente razonadas, no es complicado convenir en que la implementación de los medios audiovisuales en el aula de música no trabaría la observación de estos procesos sino que además facilitaría el desarrollo de los mismos.
} 
me volviesen a hacer la misma pregunta, respondería: 'nueve meses antes de nacer la madre,$" 130$.

Es relativamente frecuente encontrar, en los diversos ámbitos de conocimiento, la reiteración de anécdotas o citas que vienen a condensar todo un corpus teórico y que nos remiten a una imagen idealizada que logra que retengamos de manera más efectiva aquello que se quiere transmitir. Este es el caso del "niño de Kodály"131 el cual, a buen seguro, no guarda estrechas similitudes con el que pueda venir al mundo en nuestros días. Con el paso de los años, tal vez sea pertinente reflexionar al respecto y tener en cuenta que tanto las madres que han engendrado a un niño como los propios niños desde el momento en que nacen empiezan a integrar la música de otro modo, a través de los escaparates visuales acompañados de sonidos que les rodean de manera inconsciente. El alumno que llega a las aulas ha asimilado unos códigos sonoros a los que se puede (se debe) volver para aprovechar su potencial y hacer más pertinente y crítica su escucha:

"Lleven un diario del sonido del mundo. Donde quiera que vayan tomen nota de lo que oyen. Estamos todos en la sinfonía del mundo"132.

Sin duda hay enunciados contrarios al respecto. Desde el prisma a veces apocalíptico a que puede ser llevado la inercia de la sociedad actual, se asume que el niño está condicionado por estos estímulos pero no siempre se opta por buscar en la

\footnotetext{
${ }^{130}$ Reproducido por SANUY, M. y GONZALEZ SARMIENTO, L. (1969): Orff-Schulwerk. Música para niños. Madrid: Unión Musical Española, pp. 15-16.

${ }^{131}$ De este modo plasmé la sensación de que todos los docentes de educación musical, hayan leído o no referencias al respecto, conocen de qué trata y sintetizan, a partir de ello, las líneas metodológicas del pensamiento del autor. Como metáfora de cambio, en la misma referencia hice énfasis en que Kodály no podía imaginar que ese niño que antes de nacer llevaba nueve meses de retraso en su aprendizaje si su madre no se había preocupado de cantarle en el vientre materno hoy en día "oye" la radio mientras su madre embarazada desarrolla su actividad vital (en casa, conduciendo, etc.), "se acostumbra" al hilo musical de un centro comercial o "se familiariza" con sintonías televisivas; cfr. MONTOYA RUBIO, J. C. (2009a): "Kodály, Orff y Willems van al cine. Metodologías de enseñanza musical desde los medios audiovisuales". ROIG VILA, R. (Dir.) Investigar desde un contexto educativo innovador. Marfil: Alicante, p. 288. En todo caso, ello no va en detrimento de la sensación que embebía toda la metodología de Kodály y que ha de enmarcar cualquier trabajo pedagógico-musical todavía hoy: "la música pertenece todos", como observa en su análisis de la metodología del autor SUBIRATS, M. Á. (2007): "Zoltán Kodály". DÍAZ, M. y GIRÁLDEZ, A. (coord.) Aportaciones teóricas y metodológicas a la educación musical. Barcelona: Graó, p. 66.

${ }^{132}$ MURRAY SCHAFER, R. (1969a): Op. cit., p. 76.
} 
asociación con ellos nuevos escenarios de aprendizaje, sino la superación de los $\operatorname{mismos}^{133}$. Bajo nuestra perspectiva, consideramos que son mucho más fructíferos aquellos posicionamientos que tratan de "hacer especial la música" desde la observación de todo el imaginario sonoro que convive con nosotros y de manera especial con los alumnos. John Childs identifica al menos cinco fuentes de sonidos de los que sacar partido a la hora de explotar las cualidades sonoras de los discentes, mostrándolo en forma de listados abiertos a completar en función de la experiencia vital ${ }^{134}$ :

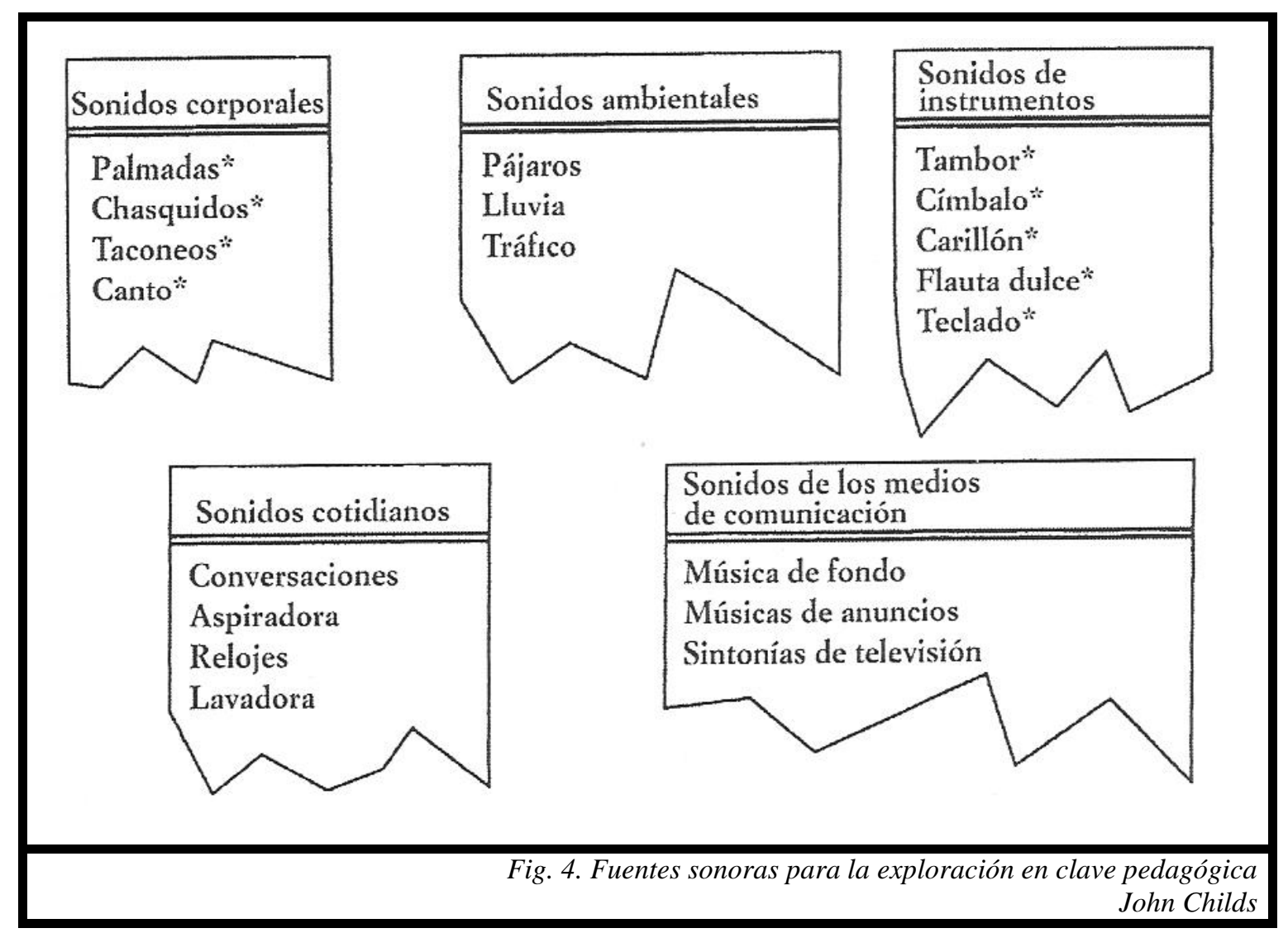

Como se intuye, el quinto de los escenarios, el más relevante para nosotros, está obviamente incompleto y la lista, por consiguiente, es susceptible de ampliarse sin problema alguno, pero lo realmente atractivo es la observación de estos nuevos escenarios de percepción y expresión musical como válidos para la educación en los sonidos circundantes.

133 Posicionamientos arraigados en algunas de las evoluciones de los pensamientos de Willems y defendidos por pedagogos de gran importancia en la actualidad como CHAPUIS, J. (1995): "El papel de la música en la vida del niño". Música y educación 22, pp. 87-91.

${ }^{134}$ CHILDS, J (2005): Haciendo especial la música. Formas prácticas de hacer música. Madrid: Akal, p. 15. 
Así pues, la labor a desempeñar habría de fundamentarse en la actualización de los contenidos en función de los nuevos contextos de enseñanza y aprendizaje:

“Así, desde el punto de vista de los contenidos, ni el folklore es ya - como afirmara Kodály- la lengua materna musical de nuestros niños, ni la música culta occidental ocupa el vértice de la pirámide en las preferencias de nuestros jóvenes. En consecuencia, la relevancia vital de lo aprendido en el aula de música es algo que ha de ser considerado y discutido en el centro escolar mismo y, desde luego, no a espaldas del alumnado"135.

Es evidente que los códigos icónicos de entendimiento del mundo por parte de los jóvenes hacen de esta vía una fuente inacabable de recursos. Sin duda,

“con la imagen se aprende, se descubre, se entiende y se conoce. Por ello, no debe ser utilizada solamente para reforzar o subrayar lo que la palabra refleja"136.

No obstante, educar para, en o con los medios audiovisuales requiere, tal vez, centrar la atención hacia los aspectos sonoros de los mismos, y no tanto hacia los visuales, en tanto en cuanto estos últimos tienen gran parte del terreno ganado ${ }^{137}$. Además, es evidente que la parte auditiva ha sido tradicionalmente desatendida con respecto al resto de lenguajes que integran el todo audiovisual, debido tal vez a que está constantemente "expuesta" a todo lo que nos rodea y ello ha conllevado una falta de atención continuada.

"El oído, a diferencia de otros órganos sensoriales, está expuesto y es vulnerable. El ojo puede ser cerrado a voluntad, mientras que el oído está siempre

\footnotetext{
${ }^{135}$ RODRÍGUEZ QUILES y GARCÍA, J. A. (2004): Op. cit., p. 6.

${ }^{136}$ MENA MERCHÁN, B., MARCOS PORRAS, M. y MENA MARCOS, J. J. (1995): Didáctica y nuevas tecnologías en educación. Madrid: Escuela Española, p. 144.

137 ZARAGOZÀ, J. L. (2009): Op. cit., p. 97. El autor constata en este punto de su discurso la depreciación del oído y la preponderancia de lo visual, lo cual sería una oportunidad para dirigir la atención del alumnado hacia hábitos de escucha saludables.
} 
abierto. El ojo puede ser enfocado y orientado a voluntad; el oído capta todo lo que suena hasta el horizonte acústico, en todas direcciones" ${ }^{\prime 138}$.

Ahí radica una de las grandes problemáticas del trabajo auditivo acompañado del factor visual, pero es ahí precisamente donde también podemos encontrar una potencialidad enorme. Es preceptiva pues, la concienciación de la importancia del factor auditivo. El hecho descrito, ampliamente constatable, es debido, muy posiblemente (además de al auge de la informática en muchos campos), a las dificultades aparentes a que la parte auditiva del hecho audiovisual somete a análisis, de modo que, como ya advertía Edgar Morin lo visual

"nos revela la decadencia del oído (inadecuación de la fuente sonora con las fuentes visuales, aproximaciones de doblaje, esquematización de la mezcla, etc.), al mismo tiempo que asienta su imperio a partir de los poderes concretos y analíticos del ojo" $" 139$.

Indagando aún más en derivaciones hacia el audiovisual, como hacía Morin en su obra recién citada, las apreciaciones de Fernando Palacios son si cabe más radicales:

"La primera batalla entre ojo y oreja se libró ya hace tiempo, cuando nuestra sociedad impuso la ciudad al campo; fue entonces cuando el oído se sumergió en la confusión de la maquinaria y el ruido, cediendo un importante terreno ante la vista. La segunda batalla la estamos viviendo ahora, dentro de la explosión de los medios audiovisuales -mejor dicho audioVisuales-; evidentemente también la va ganando la visión. Pero ¿ganará la guerra en un futuro? ¿Conseguirá el ojo aplastar definitivamente al oído, relegándolo a simple acompañante de sus destellos? [...] Dependerá de nosotros, los educadores, que tal cosa no ocurra"140.

\footnotetext{
${ }^{138}$ MURRAY SCHAFER, R. (1969b): Limpieza de oídos. Buenos Aires: Ricordi, p. 12.

${ }^{139}$ MORIN, E. (2001): El cine o el hombre imaginario. Barcelona: Paidós Comunicación, p. 188.

${ }^{140}$ PALACIOS, F. (1997): Escuchar. 20 reflexiones sobre música y educación musical. Las Palmas de Gran Canaria: Fundación Orquesta Filarmónica de Gran Canaria, p. 40.
} 
Las prácticas pedagógicas pues, habrán de saber superar los miedos a articular lo visual y lo sonoro, preguntándose de manera constructiva por el modo en que ambas dimensiones deben asociarse ${ }^{141}$. Ello no implica en modo alguno que se denosten elementos insignia de metodologías señeras, como es el caso del canto y su temprana estimulación propugnada por Kodály, sino que se busque su complementación desde otros medios más adecuados a la sociedad del presente ${ }^{142}$. Estudios sistemáticos actuales ratifican que elementos como los citados siguen siendo esferas indispensables en la creación de hábitos y capacidades intelectuales en los niños ${ }^{143}$, lo cual no implica que el modo de llegar a ellos tenga que permanecer inmutable.

${ }_{141}^{141}$ DELGADO, P. E. (2000): El cine de animación. Madrid: Ediciones JC, Colección imágenes 28, p. 51. ${ }^{142}$ La problemática de la enseñanza del canto a docentes y discentes es mostrada hoy en día en paralelo a la importancia del mismo: CASTILLO FERREIRA, M., MORALES VILLAR, M. C. y COMINO CRESPO, F. J. (2008): "La educación musical del alumnado universitario en la titulación de maestro en educación musical: problemas, retos y soluciones". ÁLAMO, A. y LUCEÑO, M. Actas del I Congreso de Investigación y Educación Musical. Madrid: Enclave Creativa Ediciones, pp. 68-75.

143 TAFURI, J. (2006): ¿Se nace musical? Cómo promover las aptitudes musicales de los niños. Barcelona: Graó. 


\subsection{LA PROBLEMÁTICA DE LA EDUCACIÓN MUSICAL ACTUAL Y EL USO DE LAS TICS}

\section{Motivaciones para un cambio}

Un factor determinante al abordar la aplicación práctica de investigaciones teóricas a la educación musical es la problemática que envuelve a la música, como parte del entramado educativo en que se integra y a las Tecnologías de la Información y la Comunicación, como incipiente marco de aplicación en todas las áreas de conocimiento en la práctica real:

"Toda crisis involucra un desafío. ¿Seremos capaces de resolver la problemática que nos plantea nuestra propia educación musical, en estos tiempos en que se enfrentan y superan problemas de gran envergadura en el campo de la ciencia y la tecnología?

No existen motivos concretos, salvo aquéllos de índole política, naturalmente, que impidan actualizar y elevar la calidad de la educación musical, para ponerla a tono con el nivel de progreso que se observa en otras áreas de aprendizaje" ${ }^{\prime 14}$.

El primer elemento nos hace constatar, de manera apesadumbrada, una realidad a la que ceñirnos. Entre todos aquellos que evidencian la situación, sirvan las palabras de Pastor i Gordero para sintetizar la sensación de malestar y reconocer las fuentes de dicha zozobra:

"Lo cierto es que, refiriéndonos a la educación musical (y aún más a la plástica y a la dramatización), lo que tenemos es todavía una implantación

144 HEMSY DE GAINZA, V. (2002): Pedagogía musical. Dos décadas de pensamiento y acción educativa. Buenos Aires-México: Lumen, p. 135. 
incompleta y que, además, grava a los especialistas de música respecto a su horario lectivo, al número de grupos diferentes y de alumnos que han de atender, a la persistente carencia de aula propia en muchos centros, etc. Este despropósito incurriría en una triple incoherencia: epistemológica [produciendo dicotomías entre artes y ciencias], pedagógica [minorizando unos contenidos frente a otros] y educativa [en tanto en cuanto atenta contra la globalización de aprendizajes y la importancia de los códigos expresivos]" ${ }^{\prime 145}$.

Ciertamente, la educación musical se ubica en un momento clave para su desarrollo dentro del organigrama educativo estatal. La caída libre a que está siendo sometida ha de ser frenada y, a partir de un proceso de catarsis, ha de ser capaz de forjar una estructura sólida que le dé aliento en un futuro próximo. Sin más resquicios que su capacidad intrínseca para desarrollar la personalidad de los alumnos, es necesario superar las dificultades de una senda llena de inseguridades y problemas, nutridos en gran medida por las restricciones horarias ${ }^{146}$. En todo caso, es justo señalar que no todos identifican del mismo modo la problemática, pero sí las consecuencias de la misma:

“...nunca ha tenido en España la música, en el currículum académico de los niveles educativos citados [infantil, primaria y secundaria], el peso y la presencia que tiene en estos momentos. Como también es cierto que nunca antes de 1990 ha habido un número tan elevado de profesores especializados dedicados exclusivamente a ella. [...] Otra cuestión es si dicha educación, en nuestro país, se corresponde con los objetivos propuestos [...], si responde a las necesidades de nuestro tiempo, y si los profesores, los alumnos, los padres, las administraciones

\footnotetext{
145 PASTOR i GORDERO, P. (2004): Op. cit., p. 3.

${ }^{146}$ De hecho, es frecuente constatar que el plano legislativo, en cuanto a objetivos y contenidos puede resultar manifiestamente suficiente para lograr acceder a una educación musical integral pero ello, de manera poco comprensible, se ve mermado por una insuficiente carga lectiva. Esta paradoja la refleja para la educación secundaria obligatoria Zaragozà, quien además ahonda en otras cuestiones relevantes para entender los condicionamientos a los que nos conduce el currículo musical de la actualidad: ZARAGOZÀ, J. L. (2009): Op. cit., p. 60.
} 
educativas y la sociedad en general son conscientes del sentido, alcance e importancia que la educación musical tiene en nuestras sociedades"147.

Para que hallemos un verdadero punto de inflexión al alza, entendemos como fundamental apostar por una nueva revolución en la estructura pedagógico-musical que llega a nuestros alumnos, es decir, por rentabilizar al máximo los espacios otorgados a la música para, a partir de ellos, propiciar otra sensibilidad hacia la materia. La reformulación de las premisas básicas musicales, si se pretende conectarlas con la sociedad actual y, por ende, con los alumnos, ha de pasar por abrazar el uso tecnológico desde todas sus facetas, convirtiéndose la audiovisual en un pilar fundamental. De este modo, al hablar de continuidad en las "modernas pedagogías musicales" hemos de ser capaces de entender dicha modernidad como capacidad de maleabilidad para adaptarse a los nuevos tiempos y a las contingencias cambiantes de un mundo en frenético desarrollo.

Por tanto, no puede pretenderse una educación musical desligada de los propios sujetos a los que va a ir dirigida y, en consecuencia, en lo sucesivo no plantearemos desarrollos procedimientales que se alejen de una aplicación real y práctica, ya que elucubrar acerca de lo que la música en los centros educativos de enseñanza obligatoria habría de ser con un alumnado modélico o idílico y unos recursos inexistentes o difícilmente accesibles no tendría sentido alguno. De la investigación, desde estas premisas, habrá de subyacer el contexto efectivo en que la música se viene aplicando, para evitar llegar a unas conclusiones distorsionadas por improbables ${ }^{148}$.

De acuerdo con ello, la necesidad de cambio que se hace patente partirá de una matriz teórica que muestre verdadera intención práctica en un ámbito de aplicación real. La recreación de lo que todos los agentes implicados en la educación somos y nos ocurre $^{149}$ habrá de guiar las experiencias hacia la vivencia del hecho musical y no tanto

\footnotetext{
${ }^{147}$ VIÑAO, A. (2000): "Una educación musical para todos". VV.AA.: Actas de las I Jornadas sobre la Música y la Juventud. Nuevos horizontes en Educación Musical. Murcia: Universidad de Murcia, p. 10. ${ }^{148}$ COX, G. (2006): “Transforming Research in Music Education History”. COLWELL, R. (Ed.) MENC Handbook of Research Methodologies. New York: Oxford University Press, pp. 73-94.

${ }^{149}$ Como se postula para el contexto pedagógico desde planos más sensitivos: JÓDAR, F. (2007): Alteraciones pedagógicas. Educación y políticas de la experiencia. Barcelona: Laertes.
} 
hacia la retórica en torno a él ${ }^{150}$. Violeta Hemsy de Gainza lo expone del siguiente modo:

“...la educación musical impone dos tareas esenciales y complementarias al docente: por una parte, dar experiencia, mediante la presentación de nuevos materiales sonoros, y por otra, dar conciencia de los materiales, estructuras y procesos musicales interiorizados de manera empírica y espontánea. A partir del manejo de lo propio, de lo cercano y de lo conocido (lo cual implica la valoración por parte del maestro de la experiencia prevista del niño), se tenderá a ampliar paulatinamente el ámbito de la experiencia musical, integrando aspectos y materiales sonoros que, por encontrarse en un tiempo o en un espacio mediato trascienden la experiencia personal de los alumnos" $" 151$.

Se abre pues la vía de la interacción y la respuesta a las necesidades del alumnado como elemento a seguir desarrollando, ya que desde el ahondamiento en esas facetas se pretende la generación de los nuevos recursos que postulamos. Es sabido que el siglo XX supuso una revolución para la pedagogía musical, especialmente en dos aspectos fundamentales. Por un lado, se definen unas nuevas metodologías basadas en la actividad y, por otro lado, más allá de la instrucción, se intenta acceder al sesgo humano y sensitivo de la música ${ }^{152}$. Es hora de canalizar las potencialidades de estas estrategias, por supuesto todavía válidas, al siglo de la tecnología y la información, en el cual nuestros alumnos ya han tomado un contacto directo (aunque no siempre razonado) con elementos auditivos. Bien conducido, ser capaces de abrirse al mundo sonoro de los

\footnotetext{
${ }^{150}$ En este sentido nos mostramos cautos a la hora de pautar los modelos de expresión, producción, interpretación y análisis crítico que, como pasos sucesivos, sí enuncia PORTA NAVARRO, A. (2009): "La banda sonora del cine y la televisión infantil. Nuevos textos para nuevos paradigmas". OLARTE MARTÍNEZ, M. (Ed.) Reflexiones en torno a la música y la imagen desde la musicología española. Salamanca: Plaza Universitaria Ediciones, pp. 781-786.

${ }^{151}$ HEMSY DE GAINZA, V. (1989): "La iniciación musical del niño y desarrollo del oído". Música y educación II (2), p. 412.

${ }^{152}$ DÍAZ GÓMEZ, M. (2005): "La educación musical en la escuela y el espacio europeo de educación superior". Revista Interuniversitaria de Formación de Profesorado 19, pp. 23-37.

25. Al igual que teoriza el autor, el éxito en los planteamientos didáctico-musicales que apliquemos radicará en la capacidad que los propios docentes mostremos a la hora de integrar aquello que nos ha dejado, pedagógicamente hablando, el siglo XX, es decir, las metodologías activas y dimensión sensorial de la música.
} 
alumnos y sus modos de reproducción habría de ser directamente proporcional a las formas en que éstos hacen lo propio con los postulados docentes ${ }^{153}$.

No obstante, a la hora de abordar este tipo de contenidos, nunca será suficiente la precaución con que se integren, ya que se precisa explicar muy detenidamente que su inclusión no supone ningún tipo de ruptura drástica con elementos musicales que deberían seguir siendo señeros en la enseñanza musical, sino que en esencia se trata de servirse de unos medios habituales en la vida cotidiana de los alumnos que pueden ayudar a favorecer sus procesos de aprendizaje. Detengámonos en la reflexión acerca de la siguiente referencia:

“Los 'Power Rangers' y las 'Tortugas Ninja' invaden el patio de juego. Los niños se inventan y emulan diferentes variedades de 'supermanes' olvidando los mágicos poderes de hadas y duendes de antaño. Un pequeño grupo chapurrea canciones de los 'Back Street Boys', otros compiten por realizar exóticas coreografías individuales para ilustrar ritmos de las 'Spice'. Apartados de la multitud, unos pocos se retiran para presumir de sus habilidades con la 'Game Boy' o de sus excelentes atenciones al 'Tamagochi'... ¡Vaya cambio de diversiones!" 154 .

Qué duda cabe que este paisaje sonoro podría corresponderse con cualquier localidad que tengamos en mente (tal vez con la actualización de algunos de los "héroes" que se citan, ya con diez años de antigüedad desde la referencia). Además, no puede sino desdeñarse el aislacionismo que pudieran llevar implícitos determinados juegos o el sentimiento de vacío que proporciona el resquebrajamiento del mundo tradicional, haciendo olvidar melodías de corte popular. No obstante, sí es discutible que no puedan ser canalizados estos "artilugios" o esas "canciones de moda" hacia el desarrollo de criterios pedagógicos que alienten una nueva educación musical renovada. En el plano docente, la sociedad actual dibuja una serie de elementos que dejan su

\footnotetext{
${ }^{153}$ Gran parte de la obra de Keith Swanwick se basa en este acercamiento al discente y la música como hecho social: SWANWICK, K. (1999): Teaching Music Musically. London: Routledge.

${ }^{154}$ BLANCO GARCÍA, C. (1999): "Cuentos, juegos y canciones tradicionales en educación infantil". Música y Educación 39, p. 35.
} 
huella dentro de las aulas y que han de ser resorte de aprendizaje, de modo que el universo sonoro infantil refleja su propia experiencia vital ${ }^{155}$.

Por otro lado, es sabido que el acercamiento al mundo simbólico del alumnado favorecerá la labor de mediación entre conocimiento a impartir-aprender y construcción significativa del mismo ${ }^{156}$. Ese elemento será de vital importancia en la defensa del audiovisual como la chispa que prenda la significatividad. Es preciso observar que, acerca del futuro de la educación musical, hay que tener en cuenta que es cierto que

"si los seres humanos estamos dotados para conocer el mundo por medio de nuestros sentidos, sentimientos e intelecto, la educación musical contribuirá de manera fundamental en este proceso integrador" ${ }^{, 157}$,

lo cual no puede hacerse desde la omisión de la música con que se convive, sino desde su reconocimiento, análisis y comprensión. En este camino no sólo cabe la revisión de métodos, sino que es perentoria su actualización.

Pero el recorrido anterior sólo puede explorarse a través de la vivencia y es preciso articular escenarios pedagógicos en los que ese axioma sea el que reine. Desde su crítica a determinados planteamientos educativos occidentales, Christopher Small ${ }^{158}$ aporta algunas ideas al respecto al incidir en "la monotonía general de la mayoría de los ámbitos escolares" derivada de una "falta de interés por la experiencia" que no proporciona "la oportunidad de crear", sino la de "consumir conocimientos". Así pues, en el proceso de enseñanza y aprendizaje de la música ha existido siempre una necesidad hacia la "manipulación" y acercar el objeto de estudio a través de su aprehensión práctica. Todas las metodologías en boga inciden en este aspecto. De hecho, el ideal al que los profesionales de la educación musical hemos de aspirar es al de facilitar el acceso del alumno a las bondades directas e indirectas que se producen en torno a la comprensión del hecho sonoro, experimentando con todos sus parámetros de

155 PORTA NAVARRO, A. (1999): "Pedagogía musical y cambio de contexto sonoro en educación infantil". Eufonía 14, pp. 59-81.

${ }_{156}$ MARTÍ, E. (1993): Aprender con ordenadores en la escuela. Barcelona: Horsori.

${ }^{157}$ DÍAZ GÓMEZ, M. (2005): Op. cit., p. 27.

${ }^{158}$ SMALL, C. (1989): Música, sociedad, educación. Madrid: Alianza. 
un modo similar al que se haría en un laboratorio ${ }^{159}$. Las metodologías activas, pues, trazan la silueta del alumno que modela contenidos. Es por ello que postulamos evitar caer en la contemplación, de forma que los constantes adelantos que nos permiten los medios audiovisuales y las tecnologías innovadoras habrían de ser fomentadas en su vertiente interactiva y comunicadora, de tal modo que se ratifica que

"la tendencia hacia donde camina la enseñanza de los medios audiovisuales desde una perspectiva pedagógica es la de cerrar la separación que existe entre el análisis y la práctica" ${ }^{, 60}$.

Sin dejar, por ello, de acceder a los mismos bloques de contenido procedimental necesarios para la formación integral del alumno a partir de la música. Se trata pues de

“vivenciar la expresión musical, estimulando las áreas de la audición, la rítmica, el canto, la lecto-escritura, la ejecución instrumental y la apreciación musical, mediante estrategias interesantes de manera lúdica" ${ }^{\prime 161}$.

No es ninguna novedad el hecho de postular la musicalidad frente a la aprehensión teórica. Con mayor o menor acierto, determinadas propuestas abogan por este planteamiento de actualización de contenidos a través de la interactividad, en cualquier campo competente de la educación musical, desde el lenguaje musical estandarizado hasta la propia historia ${ }^{162}$. La evolución, por tanto, implica ajustes:

\footnotetext{
159 La metáfora que Silvia Malbrán ofrece para refrendar este postulado es muy descriptiva, ya que imagina la experimentación a partir de lo musical entendida como un laboratorio de químicas: MALBRÁN, S. (1996): "Los atributos de la audición musical. Notas para su descripción”. Eufonía 2, pp. 55-68.

160 GUTIÉRREZ SAN MIGUEL, B. (1999): “La investigación cinematográfica desde la interdisciplinaridad". Comunicar 13, p. 217.

161 ARGUEDAS QUESADA, C. (2006a): "Vivencias de la expresión musical: áreas y estrategias metodológicas". Actualidades Investigativas en Educación 6, pp. 19ss. Disponible en $<$ http://revista.inie.ucr.ac.cr/articulos/3-2006/vivencias.php > [Consulta 9-II-10].

${ }^{162}$ Algún ejemplo destacable: TORRES OTERO, L. (2006): "Consideraciones sobre historia de la música en primaria: una propuesta sobre audiciones musicales activas”. Eufonía 37, pp. 119-125.
} 
“Al integrar la tecnología en los procesos de enseñanza-aprendizaje, habría que examinar sus características y los valores esenciales que debería aportar. Algunos profesores de música tienden a enseñar según el método con el que aprendieron; así, algunos de los programas musicales educativos para ordenador adaptan las nuevas tecnologías a los métodos de enseñanza tradicional. Pero las formas tradicionales de aproximación a la educación y desarrollo auditivo, dominio instrumental y teoría de la música podrían no ser la forma más efectiva para adquirir dichos valores"163.

Con todo, hemos comenzado a apuntar el tipo de cambio que se precisa en educación musical. Las aportaciones de todos aquellos pedagogos que de uno u otro modo han ido sazonando las prácticas educativas musicales de los últimos tiempos, las cuales han sido comúnmente ponderadas por el impulso que supusieron, son pues el punto de partida de una nueva mirada a la pedagogía de la música del siglo XXI. Los docentes de esta centuria de la que ya desgajamos la primera década somos herederos de estas propuestas y, más aún, debemos a ellas el interés y auge que en determinado momento se vivió por lo musical en las aulas, lo cual no debe cercenar nuestras expectativas de futuro. Para ello, entendiendo que la educación musical no puede continuar con una tendencia a la infravaloración, se precisan nuevos caminos para atisbar la emergencia de la vivencia lúdica en lo musical desde parámetros que aúnen lo mejor de las prácticas que se vienen realizando con elementos que muestran su pujanza día a día: es el caso de las Tecnologías de la Información y la Comunicación.

Convenir que todas las áreas de conocimiento, en la sociedad actual, han de beber de los recursos tecnológicos para fomentar su desarrollo parece inevitable. Ahora bien, es necesario atender al modo en que esos modelos pueden producir recursos efectivos que propicien la construcción de aprendizajes elementales en los alumnos y que, al tiempo, sirvan para estimular las facetas expresivas y perceptivas que los mismos currícula se ocupan de establecer. Como venimos manteniendo, el desarrollo tecnológico actual, que ha derivado en la conocida como Web 2.0, guarda estrechos paralelismos con lo que se quiere para la educación musical del presente. Los teóricos

163 TEJADA GIMÉNEZ, J. y ANGULO SÁNCHEZ-PRIETO, C. (1993a): "El ordenador y las nuevas tecnologías en la enseñanza de la música". Música y educación 13, p. 50. 
más recurrentes al respecto ${ }^{164}$, reiteran que la utilización de estos recursos posee como característica diferencial su posicionamiento respecto a ellas, esto es, suponen más una actitud que un tipo de tecnología concreta. La música a enseñar a unos alumnos alumbrados en una sociedad tan distinta a las pretéritas, por su parte, ha de tener en el punto de mira el uso que se hace de ella y los modos de recepción y asimilación, con el fin de poder valorizar en su justa medida el hecho sonoro ${ }^{165}$. Además, con ello se lograría incidir en la consideración aceptada para lo musical en términos pedagógicos según la cual la verdadera importancia del devenir didáctico radica no tanto en el producto como en el proceso, esto es, en los medios a partir de los cuales se construyen los fines ${ }^{166}$.

\section{Música y TICs: Vertiente informática}

Aplicar recursos tecnológicos a cualquier área curricular conduce, de manera intuitiva, al uso de la informática ${ }^{167}$. Los ordenadores son vistos, desde la innovación educativa, como la semilla desde la cual fortalecer esta esfera. El caso de la música no suele distar demasiado de esta percepción. Las Tecnologías de la Información y la Comunicación en educación musical habrían de pasar por su utilización y manejo, con toda la carga de dificultades que, según para quienes, esto puede suponer. En cualquier

\footnotetext{
${ }^{164}$ Señalamos a Pere Marqués y sus aportaciones en su web <www.pangea.org/peremarques>. Por otro lado, la idea expuesta se muestra, entre otras publicaciones pero de manera especial en MARQUÉS GRAELLS, P. (2007): "La Web 2.0 y sus aplicaciones didácticas".

$<$ http://peremarques.blogspot.com/search/label/WEB2> [Consulta 9-II-10]. En el ámbito de la pedagogía musical, es necesario hacerse eco de los trabajos de Peter Webster, quien reitera la necesidad no sólo de conocer el medio con que trabajar sino de implementar una mirada especial a dichos recursos para hacer que la vinculación de los alumnos con la música sea más fructífera: WEBSTER, P. (2002): "Computerbased technology and music teaching and learning". COLWELL, R.; RICHARDSON, C. (Eds.) The New Handbook of Research on Music Teaching and Learning. New York: Oxford University Press, pp. 416439.

${ }^{165}$ Ideas extraídas de la lectura de N. Cook, de cuya interpretación se deriva que en ocasiones, el espectro musical es mucho más amplio de lo que los docentes nos obstinamos en presentar: COOK, N. (2001): De Madonna al Canto Gregoriano. Una breve introducción a la música. Madrid: Alianza. Ello, en todo caso, no postula ningún tipo de música en concreto para el aprendizaje en las aulas de primaria y secundaria. Como el citado Zaragozà indica el dilema que se plantea no es el que atañe al uso de música "clásica" o "actual", sino al medio y las estrategias que hagan que el alumnado despierte interés por lo que se escucha: ZARAGOZÀ, J. L. (2009): Op. cit., pp. 100-101.

${ }^{166}$ Este aspecto, para el ámbito de la educación musical centrada en la música de cine, fue apuntada en su día por TÉLLEZ, E. (1996): "La composición musical al servicio de la imagen cinematográfica". Eufonía 4 , p. 58.

${ }^{167}$ Es común entender que los nuevos modelos de aprendizaje vendrán dados a partir de la conversión de las tecnologías informáticas en herramientas al servicio de la enseñanza. En esta dirección se mueve parte del trabajo de GARCÍA-VARCÁRCEL MUÑOZ-REPISO, A. (2003): Tecnología educativa. Implicaciones educativas del desarrollo tecnológico. Madrid: La Muralla.
} 
caso ha sido una constante entender como principal vía de actuación el uso cibernético de esta vertiente tecnológica como activo esencial para el desarrollo de la educación musical $^{168}$. En este sentido, desde la década de los noventa afloran con relativa constancia experiencias basadas en estos recursos ${ }^{169}$. A partir de ellos, suele entenderse que los usos del ordenador en el aula son $\operatorname{cinco}^{170}$ : como entorno educativo, como herramienta, como instructor, como aprendiz y como propio objeto de la instrucción, pero llevado al ámbito de lo musical y acotando las posibilidades todas ellas se reducen, de manera general, al manejo de secuenciadores, editores de partituras o programas concretos de contenido musical ${ }^{171}$ :

"Los programas secuenciadores nos permiten grabar sobre varias pistas contenidos musicales diferentes. El proceso de grabación puede ser a tiempo real, similar a un magnetófono multipista, o paso a paso, es decir, nota a nota o acorde a acorde $[\ldots]$.

Los programas notadores o editores de partituras nos permiten crear una partitura e imprimirla. También "importa" grabaciones realizadas en un secuenciador, convirtiéndolas en partituras [...].

Los programas específicamente educativos son tutores que cubren una amplia gama de ejercicios y desarrollo de destrezas; identificación de intervalos, identificación de acordes (con sus clases y sus inversiones), dictados rítmicos y melódicos, teoría de la música (pentagrama, claves, nombre de notas,

\footnotetext{
${ }^{168}$ Las principales aplicaciones que se le daban casi veinte años atrás eran ya las de herramienta o auxiliar didáctico y elemento para la formación integral de usuarios competentes: GOLDBERG DE BERNASCONI, S. A. (1992): "La computadora en la educación musical”. Música y educación 12, p. 22. 169 Entre ellos, unidades didácticas concretas u organizaciones de materiales de aula, como los procedimientos expuestos en revistas especializadas en educación musical en España, bien en monográficos bien en artículos insertos en volúmenes más abiertos, de temática miscelánea: ROCA VIDAL, F. (1998): "La informática musical en el aula de música". Eufonía 13, pp. 37-48; FREGA, A. L. (1996): "Nuevas tecnologías en la educación musical". Eufonía 4, pp. 7-20; MARTíNEZ, J. M. (1996): Op. cit.; DÍAZ LARA, G. (1996): "Música y ordenador en la educación primaria". Eufonía 4, pp. 105116.

${ }^{170}$ PÉREZ, C. (1990): Creatividad, ordenador y escuela. Propuestas para el desarrollo de la creatividad. Murcia: Secretariado de Publicaciones de la Universidad, p. 64.

${ }^{171}$ Otros autores optan por desglosar alguno de esos tres grandes bloques generando, de ese modo, un mayor número de elementos. Es el caso de ARÓSTEGUI PLAZA, J. L. (2005b): Op. cit.
} 
ritmificación, etc.), posiciones y nombres de acordes y notas en la guitarra, tutores de interpretación para pianistas, etc." ${ }^{172}$.

Secuenciadores y editores de partituras tienen un nivel de aplicación relativamente escaso, lo cual es comprensible si se tiene en cuenta que en muchos casos se trata de recursos que han sido conocidos por los profesores desde el uso privado (no docente) y, en ocasiones, su aplicación muere en dicho uso ${ }^{173}$. Los elementos que pueden ser trabajados en educación musical a partir de los últimos recursos (programas específicos) son muchos y muy variados ${ }^{174}$, desde aplicaciones muy simples basadas en los parámetros del sonido o el lenguaje musical elemental hasta otras más complejas que atañan a contenidos más complicados, por lo que el nivel de dificultad y adquisición de conocimientos que puede ser alcanzado por estos recursos varía en función de las necesidades del docente que puede azuzar hasta límites lejanos a los alumnos ${ }^{175}$. Manuel Gèrtrudix Barrio los encasilló en su día en cinco grandes bloques, los que trabajaban la educación auditiva, la enseñanza del solfeo, la composición interactiva, el

172 TEJADA GIMÉNEZ, J. y ANGULO SÁNCHEZ-PRIETO, C. (1993a): Op. cit., pp. 52-53. En este artículo los autores desgranan las tres opciones presentadas tras aproximarse al MIDI. En las publicaciones sucesivas que sirven como complemento al artículo en cuestión continúan forjando las posibilidades de estos recursos: en el artículo del siguiente volumen ( $\left.\mathrm{n}^{\circ} 14\right)$ se centran, especialmente, en la explicación del MIDI, en el $\mathrm{n}^{\circ} 15$ ratifica la clasificación en tres grandes compartimentos (secuenciadores, editores de partituras y editores de sonido) ejemplificando con programas en uso, mientras que en el $\mathrm{n}^{\circ} 16$ buscan una agrupación de estos contenidos en función de los ámbitos de enseñanza para los que son aplicables: TEJADA GIMÉNEZ, J. y ANGULO SÁNCHEZ-PRIETO, C. (1993b): "El ordenador y las nuevas tecnologías en la enseñanza de la música (II). La comunicación de los instrumentos musicales electrónicos entre sí y con el ordenador. MIDI y dispositivos.". Música y educación 14, pp. 33-47; TEJADA GIMÉNEZ, J. y ANGULO SÁNCHEZ-PRIETO, C. (1993c): "El ordenador y las nuevas tecnologías en la enseñanza de la música (III). Ordenadores y sus aplicaciones musicales". Música y educación 15, pp. 49-74; TEJADA GIMÉNEZ, J. y ANGULO SÁNCHEZPRIETO, C. (1993d): "El ordenador y las nuevas tecnologías en la enseñanza de la música (y IV). Aplicaciones en la educación musical". Música y educación 16, pp. 41-50.

${ }^{173}$ Según se infiere de PÉREZ, H. M. (1997): “Nivel de uso pedagógico de los medios de comunicación en Educación Primaria”. Comunicar 9, pp. 183-190. En todo caso, es oportuno reseñar la existencia de prácticas aisladas pero exitosas, como la expuesta para segundo curso de Educación Secundaria por SARFSON GLEIZER, S. (2002): "Internet y editores de partituras en la didáctica de la música en la ESO”. Música y educación 50, pp. 85-92. Por su parte, en otros ámbitos como los conservatorios estas herramientas parecen no ser explotadas tampoco al máximo, como indica FERNÁNDEZ DE SEVILLA VELLÓN, M. Á. (2002): "Informática musical al servicio de la formación de profesionales". Música y educación 49, pp. 69-81.

${ }^{174}$ Así lo atestiguan SUSTAETA, I. y DOMÍNGUEZ-ALCAHUD, M. P. (2004): "Aplicaciones didácticas de la informática musical". Revista Electrónica Complutense de Investigación en Educación Musical 4. Disponible en 〈http://www.ucm.es/info/reciem/v1n4.pdf> [Consulta 9-II-10]

${ }^{175}$ Reseñamos al respecto por su gran importancia el Proyecto MOS, originado por el Centro Nacional de Información y Comunicación Educativa, donde se pueden encontrar materiales didácticos interactivos de diverso calado: 〈http://recursos.cnice.mec.es/musica > [Consulta 9-II-10] 
análisis musical y la ayuda a la interpretación ${ }^{176}$. Recursos basados en la experimentación del usuario como por ejemplo "DanceMusic"177, sirven a esa gradación de dificultad en el trabajo sobre canciones, ritmos, escalas o instrumentos de percusión.

La utilización de este tipo de recursos es aceptable, ya que es relativamente conocida por algunos docentes que encuentran en ellas estrategias de aprendizaje motivadoras ${ }^{178}$. Además, las propias editoriales de libros de texto suelen incluir, no sólo discos compactos con canciones para desarrollar las unidades didácticas sino que, junto con ello, se suele presentar un CD-Rom que complemente todas las explicaciones con actividades anejas.

En todo caso, y pese a que se ha refrendado el mayor uso informático que audiovisual en las aulas, es necesario recordar que ninguno de los dos ha conseguido afianzarse todavía de manera general, debido esencialmente a que a las dificultades de implantación se unen otras que beben directamente de las inconveniencias que la música sufre y que han sido referidas. Incluso los convencidos de la aplicación de este tipo de estrategias metodológicas dudan, a tenor del marco normativo oficial, de la posibilidad de llevar a buen puerto procedimientos de este tipo. En palabras de Tejada Giménez:

"Piénsese en la consideración que la música tiene como área curricular en el sistema educativo español y entre los propios docentes de otras áreas curriculares. Téngase en cuenta el horario escolar dedicado a la música. Véanse también los últimos recortes y el giro operado en la orientación de los contenidos mínimos de la música en la E.S.O., una actuación realizada por la administración educativa contra lo que denominó un empobrecimiento de la formación humanística y de la calidad en la escuela pública española. Préstese atención a las condiciones en que se imparte la música en Educación Primaria: aulas con acústica inaceptable, inadecuadas para actividades de movimiento, carentes de un número suficiente de

176 GÈRTRUDIX BARRIO, M. (2003): Música y narración en los medios audiovisuales. Madrid: Laberinto, pp. 89-90.

${ }^{177}$ Un ejemplo de su uso en <http://www.xtec.es/dnee/udc/> [Consulta 9-II-10]

${ }^{178}$ Todo ello favorecido porque algunos de estos recursos, en realidad, no son nuevos, sino que hace ya años se vislumbraron las posibilidades de utilización que tenían: TEJADA GIMÉNEZ, J. (2001a): "El adiestramiento auditivo y la teoría de la música en los programas informáticos". Música y Educación 47, pp. 101-107. además, se han descrito instrumentos útiles para desarrollar herramientas basadas en el protocolo MIDI: TEJADA GIMÉNEZ, J. (2001b): MIDI para el Conservatorio, la Escuela y el Instituto: Encore, Finale, Band in a Box. Valencia: Piles. 
instrumentos para prácticas de conjunto [...]. ¿La presencia de ordenadores en el aula suplirá las carencias curriculares, de infraestructuras y de medios?"179.

De este modo, se continúa intuyendo la complejidad estructural y la exigencia y apremio por modular poco a poco la situación.

\section{Música y TICs: Vertiente audiovisual}

No obstante, la informática musical es un campo que posee características que, en algunos casos más que en otros, se alejan de las pretensiones de esta investigación. Además, el auge de la vertiente informática, no sólo en educación musical, es considerable y sostenido a lo largo de los últimos tiempos. Sin embargo, no puede decirse lo mismo del desarrollo tecnológico musical desde el audiovisual en su plano didáctico, de modo que la música inserta en los medios audiovisuales requiere una especial mirada, no sólo ya por la desatención que haya podido sufrir -lo cual ha propiciado, en muchas ocasiones su desaparición como parte de las tecnologías aplicables al aula de música ${ }^{180}$-, sino por el inmenso campo de acción que nos abre. La realidad, en todo caso, es la que apuntamos al abordar la investigación en el marco de la educación musical: existe una tendencia a entender que la tecnología musical se identifica con la vertiente informática de las Tecnologías de la Información y la Comunicación y se descuida, en cierto modo, el potencial del audiovisual ${ }^{181}$.

Además de ello, al remitirnos a los medios audiovisuales y mantenerse una vinculación estratégica de ellos con la informática, como elemento de trasvases inexcusables, el audiovisual en educación acarrea algunos de los prejuicios que conserva todavía la informática, especialmente, el uso concreto que se pueda hacer del medio:

179 TEJADA GIMÉNEZ, J. (2004): "Música y mediación de la tecnología en sus procesos de aprendizaje". Educación XXI 7, p. 24. Disponible en <http://www.uned.es/educacionXX1/pdfs/0701.pdf> [Consulta 9-II-10].

${ }^{180}$ FUERTES ROYO, C. (1996): "Las tecnologías en el aula de música”. Eufonía 4, pp. 21-31.

${ }^{181}$ ARÓSTEGUI PLAZA, J. L. (2005a): Op. cit., p. 333. 
“podríamos hablar del paradigma del ordenador que se resumiría en la ecuación ordenador $=$ teclado + pantalla + ratón y como corolario tenemos que el ordenador debe manejarse sentado, con las manos, mirando a la pantalla"182.

Por lo tanto, desde el ánimo de impulsar la vertiente audiovisual de las Tecnologías de la Información y la Comunicación y salvando las dificultades que la falta de una formación específica ha provocado, ha de cobrar fuerza el trabajo manipulativo en torno a la música del audiovisual como agente de cambio y significación en las aulas de educación musical. No obstante, es preciso en esta parte de la investigación, en la que todavía no se han abordado los métodos y técnicas específicas de desarrollo musical, constatar que las dificultades son y serán muchas y variadas en un hipotético proceso de generalización.

En este sentido, el menoscabo del audiovisual es un hecho constatado que viene a potenciarse por las peculiares características de la materia musical. No parece circunstancial que la música, como parte integral de la educación artística, sea un campo propicio para esta infravaloración de los medios audiovisuales. Al contrario, tanto la falta de adecuación en el uso de los recursos como la ausencia de una formación específica orientada al aprovechamiento del audiovisual desde la música son elementos determinantes para que dichas estrategias metodológicas suelan omitirse a favor de otras que, en ocasiones, no hayan mostrado una efectividad mayor. Las limitaciones en la formación desde las esferas universitarias ${ }^{183}$, en todo caso no exclusivas de lo musical, hacen que las posibilidades que se ofrecen por el creciente número de recursos de todo tipo no sean siempre aprovechadas. Si a ello añadimos que estamos ante un campo que precisa de una voluntad meridianamente clara de aceptación las cuestiones a solventar son dispares:

\footnotetext{
${ }^{182}$ FONOLL i SALVADOR, J. (2008): "Explorando los límites para superar limitaciones". HURTADO MONTESINOS, M. D. y SOTO PÉREZ, F. J. (coords.) La igualdad de oportunidades en el mundo digital. Cartagena: Servicio de Publicaciones de la Universidad Politécnica, p. 153.

${ }_{183}$ Apuntadas en cierto modo por CABERO, J. et als. (2003): "Las nuevas tecnologías en la actividad universitaria". Píxel-Bit: Revista de Medios y educación 20, pp. 81-100. Disponible en $<$ http://www.sav.us.es/pixelbit/articulos/n20/n20art/art2008.htm> [Consulta 9-II-10]
} 
"El aprendizaje de la imagen y del sonido no es sencillo. Se requiere de un lento proceso de apropiación de conceptos y, sobre todo, de un afinamiento perceptual que no suele darnos la escuela. Y esto vale tanto para los niños como para los adultos, incluidos entre estos últimos muchos educadores" ${ }^{184}$.

De acuerdo con ello, cuando se arguyan hipotéticas dificultades en las aplicaciones audiovisuales habrá que contraponer el amplio margen de aceptación que encontraremos en el alumnado $\mathrm{y}$, en consecuencia, la facilidad con que se podrá penetrar en determinados aprendizajes a partir de estas estrategias metodológicas. Extraer de melodías cinematográficas o sintonías y anuncios publicitarios (incluso cortinillas) con origen televisivo una propuesta didáctica supondrá un incentivo para la actuación pedagógica no siempre conseguido con otras actividades de motivación, ya que hablamos de formas naturales de aproximarse a una realidad sonora asimilada en torno a la cual no suele haber una mínima reflexión ${ }^{185}$. Por otro lado, como trataremos de evidenciar en el siguiente capítulo de la investigación, el proceso de elaboración y puesta en funcionamiento de los materiales reseñados no ha de ser extremadamente dificultoso o alejado de las prácticas habituales en el aula de educación musical, por lo que se habilita a todo docente a participar de recursos que, en muchos casos, no distan en su generación de aquellos que sí conocen con mayor profundidad ${ }^{186}$. En suma, nos hallamos ante una reorientación del proceso de enseñanza-aprendizaje en torno a lo musical que puede entenderse como una herramienta que, bajo unas premisas concretas, adhiere a las mejores posibilidades de la educación musical ya tradicional el atractivo de unos medios que excitan la imaginación del alumnado por su novedad y cercanía.

Consecuentemente, llama poderosamente la atención que estando vigentes los axiomas de ludicidad y aproximación a los intereses y códigos del alumnado se continúe

\footnotetext{
184 PRIETO, D. (1997): "El aprendizaje de la televisión en escuelas de Mendoza en Argentina". Comunicar 8, p. 134.

185 Sin duda, resultaría extremadamente jugoso inducir a los alumnos a, por ejemplo, identificar regularidades en la aplicación musical publicitaria, extrapolando y adaptando algunas ideas del amplio modelo de análisis de GÓMEZ RODRÍGUEZ, J. A. (2005): Op. cit.

${ }^{186}$ Tratando de seguir los criterios de "simplicidad, usabilidad y accesibilidad" que, según De Pablos Pons, constituyen unas máximas que ayudan a garantizar el éxito de un proceso pedagógico basado en los medios audiovisuales: DE PABLOS PONS, J. (2008): "Nuevas formas de trabajo en las aulas universitarias con el soporte de las Tecnologías de la Información y la Comunicación". DEL MORAL PÉREZ, M. E. y RODRÍGUEZ GONZÁLEZ, R. (coord.) Experiencias docentes y TIC. Barcelona: Octaedro, p. 55.
} 
dejando de lado la vertiente audiovisual de las Tecnologías de la Información y la Comunicación y que, cuando esto no suceda, el tratamiento que vienen recibiendo sea generalmente marginal, representando pequeñas pinceladas dentro de extensas programaciones basadas en otros planteamientos metodológicos. Es preciso recordar que las estrategias que serán apuntadas en ningún caso tendrán que reñir con otros desarrollos derivados de la pedagogía activa del siglo pasado, por lo que la incomprensión en torno a la falta de utilización se hace si cabe más patente.

Como síntesis a algunas de las ideas expuestas, puede argumentarse que, independientemente de la mayor o menor edad o capacidad del educando, los objetivos que las nuevas propuestas suelen enunciar reiteradamente tienen como referente, en la mayoría de los casos, aspectos ya conocidos, tales como la interacción entre los agentes educativos, la implicación en el proceso por parte del alumno o dotar de tanta importancia al "escuchar" como al hecho de "realizar" 187 . Todo ello puede ser llevado a cabo desde la música del audiovisual sin grandes dificultades.

Así, el sesgo que aportamos es la consecución de esas estrategias a través de los medios audiovisuales. En el capítulo segundo de la emblemática obra de Valls Gorina y Padrol, Música y cine ${ }^{188}$, se destaca un esfuerzo por desmitificar la exclusividad de la música desligada de función más allá de su propia existencia, lo cual para estos autores además de una falacia (difícilmente se encuentran músicas ajenas a una funcionalidad concreta) coarta las posibilidades de las mismas. Por todo ello, si la música de cine sirve a las imágenes (y se sirve de ellas) la didáctica de la música de cine supone un tercer nivel de manipulación sobre el material sonoro tan apropiado y legítimo como cualquier otro $^{189}$. Pero, en cualquier caso, es preceptiva la aplicación de una mirada que aporte interacción a los procedimientos, evitando así caer en un proceso de enseñanzaaprendizaje magistral trasladado al marco del audiovisual. Por ello, el docente ha de ser capaz de dotar de los instrumentos necesarios al alumno para que este sea protagonista en dicho proceso:

\footnotetext{
${ }^{187}$ MALAGARRIGA i ROVIRA, T. (2000): "Audición musical, producciones sonoras y aproximación a la lectura en los niños de 5 años". Revista de la Lista Europea de Música en la Educación 5. Disponible en <http://musica.rediris.es/leeme/revista/malagarriga00.pdf > [Consulta 9-II-10]

188 PADROL, J. y VALLS GORINA, M. (1990): Música y cine. Barcelona: Ultramar.

${ }^{189}$ MONTOYA RUBIO, J. C. (2009b): "Didáctica de la música de cine: la música preexistente como pretexto pedagógico". OLARTE MARTÍNEZ, M. (Ed.) Reflexiones en torno a la música y la imagen desde la musicología española. Salamanca: Plaza Universitaria Ediciones, pp. 669-704.
} 
"El uso exclusivo de los medios audiovisuales por parte del profesor es el propio de una pedagogía dirigista y autoritaria, es la nostalgia de la tarima. Una pedagogía activa y participativa requiere que el alumno no sólo pueda entender perfectamente el lenguaje en que le hablan, sino que debe tener la capacidad y la posibilidad de contestar de la misma manera y con los mismos medios. Los medios audiovisuales deben ser compartidos en el aula por profesores $y$ alumnos" $" 190$.

Con ello, queda abierta pues la puerta a los entresijos de un aprendizaje musical efectivamente significativo, que rescate en los medios educativos todo el potencial que lo sonoro tiene en las vivencias cotidianas de los alumnos y lo focalice hacia objetivos expresivos y perceptivos específicos.

${ }^{190}$ CAMPUZANO RUIZ, A. (1992): Op. cit., p. 67. 


\subsection{APLICACIONES PRÁCTICAS DESDE EL PARADIGMA DEL APRENDIZAJE SIGNIFICATIVO}

\section{La significatividad desde el audiovisual}

"En la actualidad, las aportaciones teóricas relacionadas con el estudio de la motivación sugieren un enfoque que integre la motivación en el proceso global de aprendizaje, en relación con el resto de variables que forman parte del proceso educativo. [...] Las variables externas, procedentes del contexto, influyen en el estudiante, que interactúa con ellas: el grupo clase, la relación profesorado/alumno y una serie de estímulos múltiples que se encuentran más allá de las condiciones “objetivas" de las situaciones de enseñanza y aprendizaje tienen también influencia en el estudio de la motivación"191.

“...de una manera u otra, siempre ha existido aquello que ahora denominamos aprendizaje significativo. Lo que ocurre es que lo que antes era implícito y, como consecuencia, apenas se trataba o se debatía, ahora se ha convertido en un conocimiento encarnado que permite tratarlo y debatirlo, con la doble ventaja que ello supone. Por una parte, enriquecer las perspectivas del conocimiento y, por otra, ofrecer instrumentos para la acción y la reflexión didáctica"192.

Lejos de ser un campo virgen, las teorías psicológicas sobre la adquisición de patrones musicales sí han sido desarrolladas con cierta profusión ${ }^{193}$. Tradicionalmente

\footnotetext{
191 ARRIAGA SANZ, C. (2006): "Importancia de los condicionantes contextuales en la educación musical”. Música y educación 68, p. 132.

192 ZARAGOZÀ, J. L. (2009): Op. cit., p. 163. En líneas sucesivas el autor desentraña los atributos del aprendizaje significativo, desde su origen en la teoría lingüística de Ausubel en 1963 hasta implicaciones actuales en el aula de música.

193 Tanto la influencia práctica de la música en el alumno como los métodos de su aplicación son objeto de diferentes posturas profundizadas en determinadas publicaciones. Un ejemplo que acaba derivando en
} 
se entiende que el acercamiento al mundo sonoro del alumno incentivará su motivación y con ella, por consiguiente, los procesos de adiestramiento musical serán más agradecidos para profesores y alumnos ${ }^{194}$. Aunque la relevancia de vincular adecuadamente los conocimientos almacenados por el alumno a través de los procesos educativos reglados e informales es un criterio compartido y valedero para todas las áreas de conocimiento ${ }^{195}$, llevado al plano educativo-musical no sólo no es una presunción gratuita sino que la fundamentación teórica del paradigma del aprendizaje significativo cobra aquí especial vigor. Saber aproximarse al mundo sonoro del alumnado al que nos dirigimos canalizará un alto porcentaje del éxito de la realización pedagógica y la justificará en gran medida ${ }^{196}$, ya que permitirá que podamos calzar cualquier tipo de aprendizajes (por dificultosos que parezcan desde una ardua explicación teórica) en hormas que sí permiten una entrada apropiada. El hecho de hacer de los recursos focos de significatividad no supone una novedad grandiosa en el plano educativo $^{197}$, pero su observación y actualización constante sí implica un esfuerzo que vale la pena desarrollar. Muy gráficamente, tratando de llevar la explicación al campo audiovisual que es el que nos interesa, Ferrés i Prats recurre a Eric Satie para metaforizar sobre aquello en lo que de manera general todos convenimos:

“ 'Imagino una obra de teatro para perros: se levanta el telón... y aparece un hueso...' El interés de un discurso, de cualquier discurso, se basa necesariamente en la capacidad de movilizar los sentimientos íntimos del destinatario, de implicarlo emotivamente. Si el auditorio es de perros, sólo

el aprendizaje melódico es LACÁRCEL MORENO, J. (1995): Psicología de la música y educación musical. Madrid: Visor.

${ }^{194}$ FUERTES ROYO, C. (1998): "La telemática en la educación musical”. Comunicación y pedagogía 151 , pp. 75-78.

${ }^{195}$ Suele ser recurrente atender a los posicionamientos teóricos que al respecto se muestran en obras como: AUSUBEL, D. P., NOVAK, J. D. y HANESIAN, H. (1983): Psicología Educativa. Un punto de vista cognoscitivo. México: Trillas; NOVAK, J. D. (1998): Conocimiento y aprendizaje. Madrid: Alianza.

${ }^{196}$ Como expone desde la práctica VILAR i TORRENS, J. M. (1997): "La utilización de las músicas del entorno del alumnado en el aula y algunos parámetros de etnomusicología". Eufonía 6, pp. 101-109.

${ }^{197}$ Cuando nos referimos a esta tesis es común aludir a los clásicos postulados de Ausubel: AUSUBEL, D. (1963): The Psychology of Meaningful Verbal Learning. New York: Grune \& Stratton; AUSUBEL, D. (1968): Educational Psychology: A Cognitive View. New York: Holt, Rinehart \& Winston. 
presentándole un hueso se les puede implicar. En esto deberían coincidir la televisión comercial y la educativa"198.

Los grupos humanos que los docentes manejan dentro de las aulas de educación musical se caracterizan por tener una vinculación activa y pasiva con la música, tan intencionada en unas ocasiones como despreocupada e incluso aleatoria en otras. Según Gabriel Rusinek ${ }^{199}$, no siempre la educación orienta hacia la relación vivencial sino todo lo contrario. Para él no es determinante el hecho de que los aprendizajes musicales se lleven a cabo por descubrimiento o por recepción conceptual, sino que el grado de significatividad vendrá determinado por otras contingencias. Es evidente que la segunda de las vías mencionadas, enunciada rígidamente, no posibilita la construcción de aprendizajes significativos, pero la orientación hacia el contenido a aprender, sin más, también precisaría de una mediación importante. Zaragozà ${ }^{200}$ lo ilustra del siguiente modo:

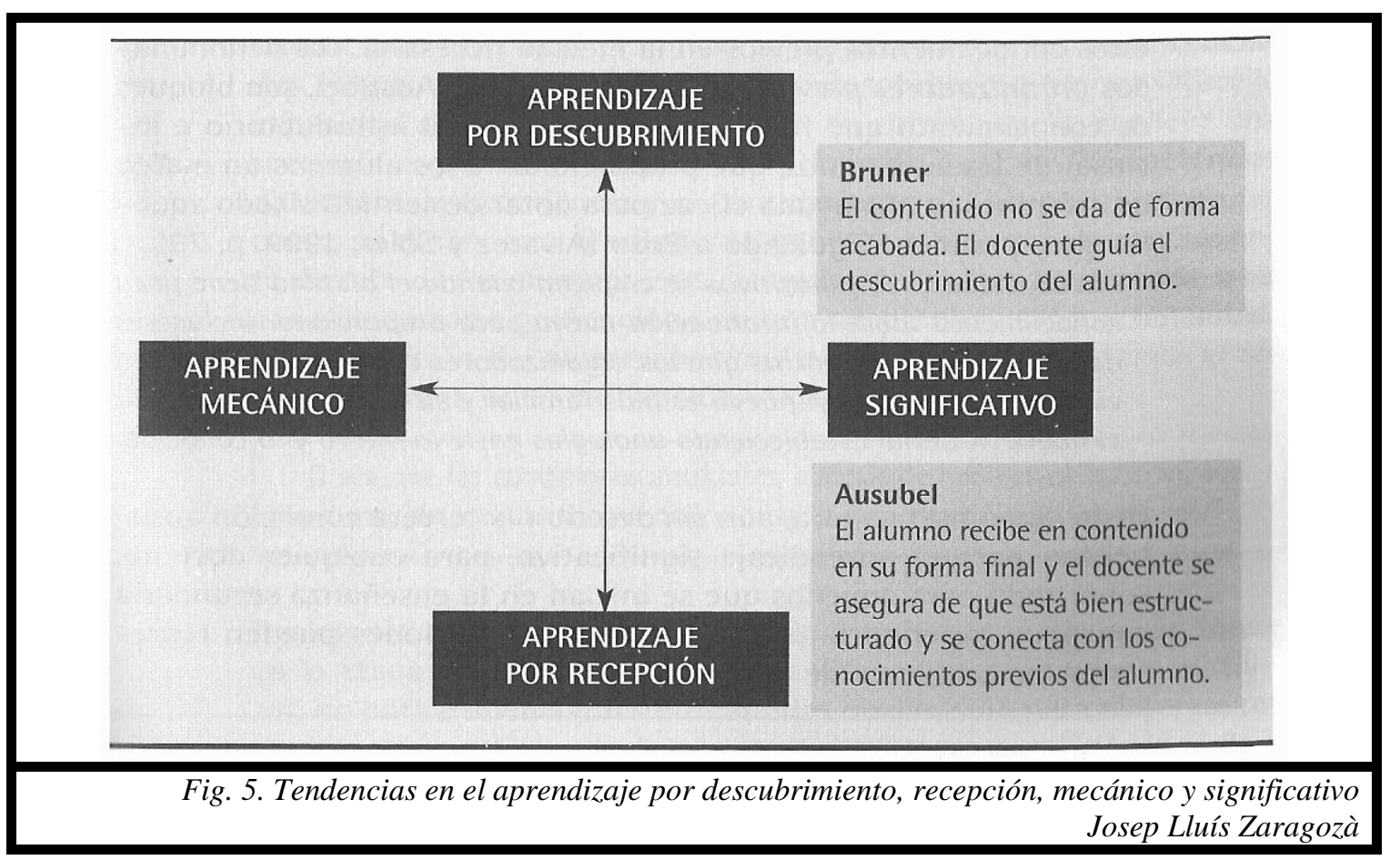

198 FERRÉS i PRATS, J. (2003): "El estilo comunicativo en la televisión educativa”. Red Digital 4, p. 4. Disponible en <http://reddigital.cnice.mecd.es/4/firmas/ferres_ind.html> [Consulta 9-II-10].

${ }^{199}$ RUSINEK, G. (2004): Op. cit.

${ }^{200}$ ZARAGOZÀ, J. L. (2009): Op. cit., p. 167. En líneas sucesivas (pp. 218ss.) el autor revela cómo el balanceo hacia la recepción o el descubrimiento ha de tener como meta la llegada a la significatividad. 
En este punto retoma fuerza la idea según la cual se han de enfatizar los medios de aprendizaje, en los cuales habría de radicar la dosis adecuada de acercamiento al mundo sonoro del alumno. De este modo, despojándonos en cierto sentido del matiz teleológico de un enfoque por tareas ceñido a la consecución de un solo fin, conectar con el grupo de alumnos en los modos de presentar la información será tanto más relevante que conducirlos hacia los aprendizajes. La base pues de la actuación pedagógica-musical que pretenda adherirse a criterios inequívocamente motivadores radica en la movilización de los instintos de los propios alumnos, invitándoles a formar parte del proceso que les interesa (al menos) tanto como al docente:

"Si entendemos que quien aprende es el aprendiz y que sólo él es quien decide realizar el esfuerzo necesario para aprender, tenemos que entender las motivaciones que le llevan a tomar tal decisión [...] La motivación tiene que ver con los significados que se van construyendo en un aula, es decir, con la significatividad que tienen las experiencias musicales para los propios alumnos [...] Los niños y los adolescentes contemporáneos rechazan sentarse quietamente a escuchar discursos durante seis horas al día. Los alumnos de nuestras escuelas e institutos, abrumados por el exceso de información que reciben de los medios de comunicación masiva, se van convirtiendo poco a poco en filtradores intuitivos, y finalmente se niegan a procesar datos a los que no asignen un significado importante en sus vidas es por eso que la atribución de significado es fundamental para entender la motivación, ya que nos esforzamos por aquellas cosas que tienen un sentido para nosotros. $\mathrm{Y}$ es por eso que los profesores debemos entender los significados que los alumnos, individual y grupalmente, asignan a sus experiencias de aprendizaje en el aula. Desde esta perspectiva se entiende la advertencia de Bruner (1990) de que no es suficiente explicar lo que los alumnos hacen: es necesario interpretar lo que creen que hacen, y sus razones para hacerlo",201.

${ }^{201}$ Ibíd., pp. 2-9. 
Conduciendo las ideas del propio Bruner hacia nuestro contexto, Zaragozà ${ }^{202}$ muestra cómo es preciso llegar a una situación desencadenante y funcional que promueva la significación y con ella la optimización de la práctica docente a través de la convergencia entre los objetivos de enseñanza del docente y los de los alumnos, ya que a medio camino entre los unos y los otros podemos establecer un compartimento de significados comprensibles por ambos. Dentro de nuestro ámbito, el autor indica que los intereses musicales y educativos del docente han de establecerse dialógicamente con los de los discentes, con lo cual, a través de este camino de ida y vuelta, el contenido a enseñar parte del propio alumno por la observación del profesor $\mathrm{y}$, consecuentemente, ese punto de partida es el comienzo de la gestión de un proceso que aproxima a los intereses educativos generales. A partir de estas reflexiones no es complicado sostener que una cuidada selección de productos audiovisuales puede suponer un granero de incalculable valor para favorecer la implicación del alumnado en la decisión de hacer suyo el proceso:

"La posibilidad de elección es fundamental también, en este concepto de educar. El alumno deliberadamente y voluntariamente elige ajustar el significado recientemente comprendido a lo que ya sabe. Cuando el aprendizaje emprende una vida propia, otras elecciones se hacen reconocibles. No sólo puede uno empezar a elegir qué tópicos estudiar, qué intereses seguir, qué talentos específicos desarrollar, sino que uno también puede elegir aprender sobre el aprendizaje. Y después de que se alcance este punto uno puede conscientemente elegir ser educado"203.

\footnotetext{
${ }^{202}$ ZARAGOZÀ, J. L. (2009): Op. cit., pp. 88 y 99. El razonamiento expuesto explica los cuadros 14 y 19 que expone el autor a la hora de mostrar el incremento de las posibilidades pedagógicas desde la interpretación de la enseñanza y el aprendizaje partiendo de los intereses del alumno.

${ }^{203}$ GONZÁLEZ, F. M. y NOVAK, J. D. (1996): Aprendizaje significativo. Técnicas y aplicaciones. Madrid: Ediciones Pedagógicas, pp. 57-58. Aseveraciones como la expuesta son ratificadas por otras tantas que nos inducen a pensar en la importancia de la "voluntad explícita" de aprender del discente para que se lleve a cabo el proceso con éxito, y es esfuerzo del docente por propiciar tal situación: ZARAGOZÀ, J. L. (2009): Op. cit., p. 216.
} 
Sin duda, podemos especular sobre qué tipo de educación audiovisual sea capaz de reforzar los contenidos musicales, pero el propósito de esta investigación es indagar e instaurarse, en términos reales, en la problemática actual. Se precisa pues partir de

“la comprensión de la 'música escolar' como un género requiere la comprensión de los contextos que la determinan y definen", ya que "a diferencia de la música clásica, la música escolar funciona en contextos que no son comerciales ni elitistas. [...] (Sus) actuaciones son exclusivas de las escuelas, y sirven a sus fines en contenidos, formatos y estilo"204.

Por ese motivo, en concordancia con la premisa de especificidad en torno al aprendizaje de lo musical, es relevante tener en cuenta los principios de la enseñanza programada, tendente a otorgar un alto nivel de significatividad al proceso educativo general, y comprobar de qué modo converge con una educación musical nortada en el audiovisual $^{205}$ :

1. Principio de pequeñas dosis. El alumno aprende mejor cuando el aprendizaje se cumple gradualmente. Las estrategias de aprendizaje que iremos desarrollando serán susceptibles de fraccionamiento y, en consecuencia, de gradación en cuanto a dificultades.

2. Principio de la respuesta activa. El alumno aprende mejor si tiene que responder a cuestiones relativas a lo que está estudiando. El hecho de que se pretenda una vinculación efectiva entre lo que se estudia y el bagaje sonoro del alumnado hace que la respuesta activa encuentre un camino perfecto por el que vehicular los contenidos de rango conceptual inmanentes a la propia materia.

3. Principio de evaluación inmediata. El alumno aprende mejor cuando puede verificar, inmediatamente, la exactitud de su trabajo. Es el caso de la tipología de contenidos que se presentarán en el próximo capítulo, muy apropiados para retroalimentar el trabajo futuro a través de la eficacia evaluadora del presente.

\footnotetext{
${ }^{204}$ BRESLER, L. (2004): Op. cit.

${ }^{205}$ Para ello utilizamos la referencia de Bernardo Carrasco a la que añadimos los puntos de interés para nuestro estudio: BERNARDO CARRASCO, J. (1991): Técnicas y recursos para el desarrollo de las clases. Madrid: Rialp, pp. 23ss.
} 
4. Principio de la velocidad propia. El estudiante aprende mejor cuando puede estudiar según su propio ritmo, lento o rápido, conforme a sus posibilidades y a su voluntad de trabajo. Aunque pudiera parecer complejo, en realidad las prácticas que se diseñarán buscarán el respeto por los diferentes ritmos de trabajo y capacidades, ya que la labor cooperativa en un ambiente de intercambio será un elemento primordial.

5. Principio del registro de resultados. El aprendizaje se hace más eficiente si el estudiante va conociendo sus progresos y sus errores. En cuanto a estos últimos, una vez identificados, él puede efectuar revisiones para eliminarlos. Los planteamientos didácticos basados en la reiteración de visionados, puestas en común y búsqueda de alternativas potenciarán el éxito de este principio en las aplicaciones que postulamos.

6. Principio de los indicios o insinuaciones. Cuanto menos yerra el alumno, mejor: de ahí la conveniencia de ofrecer indicios, sugerencias e insinuaciones que conduzcan a respuestas acertadas. La concepción general de la enseñanza musical con un referente audiovisual se fundamenta, entre otros parámetros, en el papel orientador y participativo del docente, quien habrá de tener claro desde el primer instante las posibilidades de los procedimientos que lleva a cabo.

7. Principio de la redundancia. El aprendizaje se realiza y se fija mejor cuando el asunto desconocido es asociado con uno conocido o, asimismo, si se dan repeticiones; de ahí la preocupación de asociar lo nuevo a lo viejo y de repetir todo constantemente. Son comunes las vinculaciones entre músicas en principio desconocidas por los alumnos pero escuchadas inconscientemente a través de los medios audiovisuales que dan lugar a aplicaciones pedagógicas concretas. Explotar esta faceta es otra de las grandes virtudes del método audiovisual.

8. Principio del éxito. El alumno, al advertir que está progresando, esto es, que está obteniendo éxito en sus estudios, se interesa más por los mismos y se siente motivado para seguir estudiando. La consecuencia última es un fin forjado a través de medios igualmente exitosos. Engarzar con la significatividad musical supondrá facilitar ulteriores realizaciones de similar fundamento y estructura. 
En resumen, se ha ido perfilando el modo por el cual podamos articular aplicaciones prácticas desde la convergencia entre el paradigma de significatividad teniendo como referente a los medios audiovisuales. Convenimos en que entre las mejores formas de integrar la teoría con la investigación y la práctica está aquella que parte de la curiosidad o la necesidad de comprensión, y se sirve de actividades investigadoras para, a partir de ellas, ajustar la teoría, o bien de la detección de una situación que requiere cambios y que, a través de una razonada toma de decisiones orienta hacia la solución satisfactoria ${ }^{206}$.

\section{Propuesta de actuación didáctica en educación musical}

De este modo, al margen de secuencias concretas que tomen cuerpo en unidades didácticas y estrategias determinadas que exploren una u otra aplicación de los potenciales usos del audiovisual, el proceso de desarrollo pedagógico bien podría servirse de una serie de pasos que partieran del reconocimiento de un elemento que encienda la significatividad en el alumnado, su refuerzo en aras de una orientación pedagógica, el avance procedimiental en el cual los alumnos experimentaran sobre él y la consolidación de los aprendizajes. A partir de ejemplos prácticos que establecían conexiones entre el aprendizaje de la ópera a través del audiovisual, las ideas básicas descritas fueron experimentadas meses atrás ${ }^{207}$ :

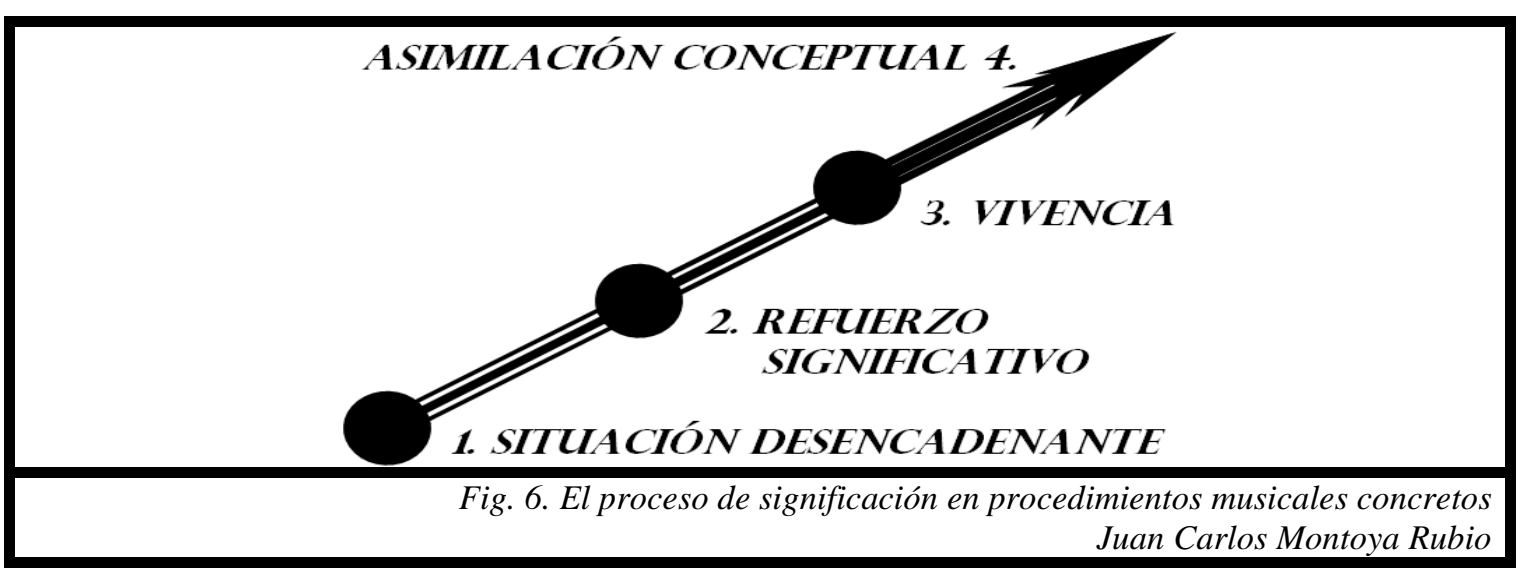

\footnotetext{
206 PEIRÓ i GREGÒRI, S. (2009): “Teoría, investigación y práctica en educación”. ROIG VILA, R. (Dir.) Investigar desde un contexto educativo innovador. Alicante: Marfil, pp. 346ss.

${ }^{207}$ Se presenta con ligeras variantes un esquema presentado y debatido en un reciente foro de educación musical cuyo desarrollo puede ser consultado en MONTOYA RUBIO, J. C. (2008a): "Viejas y nuevas claves para la formación del profesorado universitario en educación musical: aprendizaje significativo a través de los medios audiovisuales". ÁLAMO, A. y LUCEÑO, M. Actas del I Congreso de Investigación y Educación Musical. Madrid: Enclave Creativa Ediciones, pp. 55-67.
} 
El plan urdido para llevar a cabo experiencias como la esquematizada era el que partía de un desencadenante, un resorte significativo. Éste puede entenderse como el pilar de la realización didáctica, ya que sobre él descansa en gran medida la efectividad que pueda tener en el alumnado. Se trata de cualquier elemento que, desde el audiovisual, llame poderosamente la atención del discente y le conduzca con cierta facilidad a aceptar como propio el desarrollo pedagógico que se elaborará a continuación. En este primer estadio de detección de elementos singulares, juega un papel crucial la intuición del docente y su capacidad para alertarse ante cualquier estímulo que contenga música y que pertenezca al imaginario del grupo de referencia con el que está trabajando. Una sintonía de un programa televisivo que visionen con total seguridad, un videoclip del grupo de moda, un anuncio televisivo con gancho que es tarareado casi inconscientemente por los alumnos, esto es, cualquier elemento con capacidad de levantar las inquietudes de aquellos a quien se dirigen las propuestas didácticas son marcos de actuación válidos ${ }^{208}$. Por supuesto, cobra especial importancia, amén del trabajo de reflexión, la receptividad del docente, quien habla, consulta y propone directamente a sus alumnos, primeros interesados en el trance. Sirva para resaltar la importancia capital de esta fase la reflexión de Alsina:

"Una sesión puede empezar de cualquier manera menos de una forma preestablecida. Posiblemente el día de otoño que tenemos pensado enseñar una canción sobre la lluvia saldrá el sol; [...] si hemos previsto empezar por una audición relajante, el alumnado estará peleándose porque han perdido un partido; o si para tratar la música rock empezamos poniendo una pieza de Hendrix a todo volumen resulta que ese día están adormilados" 209.

\footnotetext{
${ }^{208}$ Se constata que los gustos audiovisuales del alumnado no tienen por qué converger, por ejemplo, con la programación televisiva de corte pedagógico que se pudiera pensar para ellos, tal y como lo muestra SEVILLANO, M. L. (1997): "La aventura del saber: Análisis del programa educativo de televisión española". Enseñanza 15, pp. 193-208.

${ }^{209}$ ALSINA, P. (1997): El área de educación musical. Propuestas para aplicar en el aula. Barcelona: Graó, p. 125. Obviamente ello no ha de ir en detrimento de la programación que el docente preestablezca, pero sí puede servir para reorientar las siguientes sesiones. La importancia de estos momentos en los que se pasa del intercambio de ideas desde el plano informal al desarrollo de las actividades queda patente en MARTÍNEZ VALCÁRCEL, N., MIRALLES MARTÍNEZ, P. y NAVARRO MEDINA, E. (2009):
} 
Tras el "resorte significativo" actúa el "refuerzo significativo". En este momento el alumno siente que se le ha presentado algo que no esperaba que pudiera aparecer como parte integrante de una realización pedagógica y es hora de canalizar toda su predisposición hacia los objetivos didácticos que se requieren conseguir. Es tarea del docente articular unos contenidos que, por un lado, guarden relación con el desencadenante de la situación y, por otro, sigan otorgando pistas significativas en torno a ello, con el fin de consolidar la estructura a desarrollar. Es por tanto tiempo de acometer procedimientos que empiecen a destacar lo musical de aquello que era sólo una pretensión en estado embrionario, de modo que la atención de los alumnos habrá de dirigirse sigilosamente hacia los elementos que deseen ser trabajados, multiplicando el poder de lo sonoro por medio de un "bombardeo" de referentes similares que sumen información relevante sobre ello ${ }^{210}$. Siguiendo con la coherencia significativa propuesta, esta reiteración de elementos que potencian la idea primera ha de servirse, igualmente, del componente audiovisual, ya que ese canal generará que se siga manteniendo la atención lograda y evitará, de llevarse con las debidas precauciones, la evasión o la pérdida de interés ${ }^{211}$.

La perpetuación de los contenidos en el quehacer cotidiano puede responder a criterios conocidos por los alumnos o, por el contrario, explorar nuevas posibilidades de actuación pedagógica. Siempre es aceptable rescatar todo aquello que se ha mostrado como efectivo de las estrategias de aprendizaje musical preexistentes, así como adecuar los bloques de argumento musical (que implicarán tradicionalmente actividades de movimiento, percusión, canto, etc.) a los contenidos presentados, dando un nuevo impulso a los mismos. Será la propia intención del docente la que incline este tercer momento hacia unos u otros procedimientos, siempre en función de las pretensiones propias y la lógica descrita en su programación de aula.

\footnotetext{
"Análisis de cómo los docentes plantean el inicio de las clases desde la perspectiva del alumnado". Revista de educación 349, pp. 413-433.

${ }^{210}$ MONTOYA RUBIO, J. C. (2008a): Op. cit., p. 60.

${ }^{211}$ En este sentido Ruiz Rubio enfatiza la necesidad de establecer unos pasos preliminares que dejen de lado las hipotéticas preconcepciones que puede llevar acarreadas un visionado a quienes no están acostumbrados a tratar con el rigor debido con elementos audiovisuales: RUIZ RUBIO, F. (1998): "Preliminares para una didáctica del cine: la detección de ideas previas". Comunicar 11, pp. 37-42.
} 
La asimilación conceptual se entiende, como es natural, como un proceso inacabado al que volver de forma recurrente cuando el devenir de las clases así lo recomiende. En todo caso, es necesario recordar que los conocimientos trasladados a los alumnos no tienen por qué diferir en exceso de los que pudieran adquirirse por otro tipo de medios, siendo en el procedimiento en el que reside la notoria diferencia, ya que este enfoque busca a partir de elementos significativos en los medios una plasmación efectiva y duradera. Por ello, no discute en ningún momento con la aplicación de competencias y criterios pedagógicos que, de manera general, se suelen observar en los procesos de enseñanza-aprendizaje en el ámbito musical. 


\subsection{EL USO DEL AUDIOVISUAL COMO RECURSO PEDAGÓGICO. CLASIFICACIONES Y POSIBILIDADES}

\section{Intentos de acotación}

Observadas las diatribas teóricas y las complejidades del contexto en el que nos circunscribimos, constatamos que existen, en función de autores y tendencias, diversos modos de categorizar la utilización del audiovisual desde el plano pedagógico. De manera general, es común encontrar que la aproximación a estas esferas se lleva a cabo desde una triple dimensión ${ }^{212}$ : el audiovisual como arte y expresión cultural, lo cual derivaría en el análisis de los contenidos que se transmiten a partir de dicho medio ( (siendo su forma paradigmática el cinefórum ${ }^{213}$ ), la generación de recursos en las aulas para propiciar, a partir de ello, un aprendizaje de los rudimentos de producción audiovisual, y por último, desde el llamado "cine didáctico" que, como veremos, adquiere diferentes matices.

Para mostrar otros modelos de actuación pedagógica, partimos de las formulaciones de Pereira Domínguez y Urpí Guercia ${ }^{214}$, quienes arguyen la existencia de dos pasos sucesivos de actuación, los cuales irían desde la educación para el cine (aprendizaje de elementos técnicos fílmicos) hasta la educación con el cine (centrada en la construcción didáctica sobre el espectador y las posibilidades formativas del propio medio). Educar para el cine implicaría ser capaz de acometer el descifrado de la lectura audiovisual, la cual iría de la observación de la imagen desposeída de otro tipo de adiciones a, en último extremo, la adquisición de los matices psicológicos que se sumergen tras la integración de lenguajes en el medio cinematográfico, entendido ahora

\footnotetext{
${ }^{212}$ En su estudio de los métodos de aprendizaje desde el audiovisual, Alonso y Gallego nos aproximan a tres perspectivas que identifican no tanto con el audiovisual en general como con el cine en particular. En todo caso, en su exposición cabe la posibilidad de ampliar a otros recursos de este tipo: ALONSO, C. M. y GALLEGO, D. J. (1993): Medios audiovisuales y recursos didácticos en el nuevo enfoque de la educación. Madrid: C.E.C.E-I.T.E., pp. 104ss.

${ }^{213}$ Para lo cual son útiles listados de productos audiovisuales que se enmarquen dentro de una u otra área del conocimiento, como ilustra Romaguera i Ramió en su "propuesta de videoteca 'fílmica' educativa": ROMAGUERA i RAMIÓ, J. (1991): El lenguaje cinematográfico. Gramática, géneros, estilos y materiales. Madrid: Ediciones de la Torre, pp. 109-120.

${ }^{214}$ PEREIRA DOMÍNGUEZ, C. y URPÍ GUERCIA, C. (2005): Op. cit., p. 79.
} 
en la globalidad que lo conforma. Entre los objetivos educativos que se obtienen de este tipo de educación para el cine destacan el dominio de los códigos fílmicos, la capacitación para la aludida lectura audiovisual, el desarrollo de estrategias de comprensión, descifrado e interpretación cinematográfica y la capacidad para producir posicionamientos críticos al respecto de la narratividad de una película ${ }^{215}$. Por su parte, la educación con el cine plantearía, tanto el desarrollo del gusto estético como el enriquecimiento personal y el posicionamiento crítico a través de la interpretación de la manifestación artística que supone.

También desde dos y no tres planos pedagógicos enfoca su teoría Aróstegui Plaza $^{216}$ : pedagogía de los medios audiovisuales y pedagogía con los medios audiovisuales, lo cual guarda estrechos paralelismos con las reflexiones acerca de los fines educativos de la informática extraídos, por ejemplo, por Martí ${ }^{217}$ a partir de las teorías de Gross $^{218}$ y Taylor ${ }^{219}$, o echando la vista más atrás con los planteamientos de Worth $^{220}$ que en su día reflejó De Pablos Pons ${ }^{221}$. Para Aróstegui, pedagogía de los medios audiovisuales implica la alfabetización dentro de los parámetros insertos en el audiovisual y, muy especialmente, en el caso de la faceta auditiva por su propensión a inadvertirse $^{222}$. Por su parte, cuando el autor nos remite a la pedagogía con los medios audiovisuales nos aproximaría al uso de materiales tecnológicos con finalidad pedagógica. En el ámbito educativo general y de manera práctica, se correspondería en cierto modo con el tercer nivel expuesto por Alonso y Gallego al principio del apartado, esto es, la extracción de consecuencias dignas de mención del argumento de un audiovisual por su especial capacidad para inducir a aprendizajes. Esta categorización es

\footnotetext{
${ }^{215}$ Ibíd., p. 79.

${ }^{216}$ ARÓSTEGUI PLAZA, J. L. (2005b): Op. cit.

${ }^{217}$ MARTÍ, E. (1992): Op. cit.

${ }^{218}$ GROS SALVAT, B. (1987): Aprender mediante el ordenador. Posibilidades pedagógicas de la informática en la escuela. Barcelona: Promociones y Publicaciones Universitarias.

${ }^{219}$ Quien remite al uso informático como "fin" o como "medio": TAYLOR, R. P. (Ed.) (1980): The Computer in the School: Tutor, Tool, Tutee. New York: Teachers College Press.

${ }^{220}$ Enseñanza a través del cine o acerca del cine: WORTH, S. (1974): "The Uses of Film in Education and Communication”. OLSON, D. (Ed.) Media and Symbols: The Forms of Expression, Communication and Education. Chicago: Chicago University Press, pp. 271-301.

${ }^{221}$ DE PABLOS PONS, J. (1986): Op. cit., p. 57.

${ }^{222}$ De acuerdo con Leo Masterman, por cuyas palabras se guía Aróstegui, una vez proporcionadas las herramientas conceptuales para decodificar el medio en cuestión, formaría parte del espíritu crítico de cada alumno la interpretación del fragmento audiovisual: MASTERMAN, L. (1993): La enseñanza de los medios de comunicación. Madrid: Ediciones de la Torre.
} 
seguida intuitivamente por Ruiz Rubio en su rastreo de usos didácticos del material cinematográfico en diferentes áreas curriculares, para lo cual atestigua que

"la función de la escuela en relación con el cine, tal como se desprende en los diseños curriculares, debe manifestarse en dos actuaciones bien diferentes:

1) Conocimiento de las características del medio cinematográfico.

2) Uso didáctico del material cinematográfico",223.

La perspectiva teórica que mueve la primera de las premisas emparenta con acercamientos ampliamente difundidos como los de Romaguera i Ramió et als. ${ }^{224}$ o las aproximaciones al mundo de la didáctica para la secundaria de Alonso y Matilla ${ }^{225}$. Desde el aula de música, en el primero de los apartados bien podrían seguirse propuestas como la de Arredondo y García ${ }^{226}$, los cuales instarían a sus alumnos a buscar determinados aspectos sonoros insertos en el cine, tales como el "valor añadido" (atendiendo a cómo varía la producción con o sin sonidos), la función unificadora del flujo de imágenes por sonido (buscando el empaste entre ambas dimensiones o el apoyo de los enlaces visuales a través de lo sonoro ${ }^{227}$ ), la función puntuadora del sonido (reconociendo leitmotiv si lo hubiera), la función de anticipación (observando cómo se generan expectativas por la música), los modos de expresar el silencio (explorando el uso de sonidos tenues o reverberaciones para determinadas escenas), los puntos de sincronización de la imagen sonora y visual (efectos como golpes, disparos, etc.) o la localización de la fuente sonora (esencialmente en la diferenciación de música diegética e incidental ${ }^{228}$. Por su parte, en el último apartado, el proceso pedagógico lograría dotar

\footnotetext{
${ }^{223}$ RUIZ RUBIO, F. (1994): “Cine y enseñanza”. Comunicar 3, p. 77.

${ }^{224}$ ROMAGUERA, J.; RIMBAU, E.; LORENTE, J.; SOLÀ, A. (1989): El cine en la escuela: Elementos para una didáctica. Barcelona: Ed. Gustavo Gili.

225 ALONSO, M. y MATILlA, L. (1989): Imágenes en acción. Análisis y práctica de la expresión audiovisual en la escuela activa. Madrid: Akal.

${ }^{226}$ ARREDONDO, H. y GARCÍA, F. J. (1998): "Los sonidos del cine”. Comunicar 11, pp. 101-105.

227 Al modo que lo expresara GORBMAN, C. (1987): Unheard Melodies. Narrative Film Music. Bloomington: Indiana University Press.

${ }^{228}$ Mucho más ambiciosa, profunda y rigurosa es la propuesta de análisis de Teresa Fraile y esa virtud hace que no la describamos con detalle al abordar meras aproximaciones pedagógicas en las aulas de primaria y secundaria. En todo caso, de ella se pueden extraer valiosos aspectos a implementar didácticamente, especialmente, en relación con lo expuesto en el texto, a partir de su análisis funcional o músico-cinematográfico: FRAILE PRIETO, T. (2009b): "De nuevo el dedo en la llaga. Algunas
} 
al alumnado de herramientas útiles para favorecer un posicionamiento crítico frente a lo que se le presenta para su análisis ${ }^{229}$. En última instancia, se buscaría el abordaje de contenidos específicos en los cuales los recursos audiovisuales sirvieran como intermediario para conseguir un acceso efectivo al concepto a aprender.

\section{En la busca de una clasificación funcional}

A partir de estructuraciones como las anteriores se han ido generando, bien desde el plano cinematográfico bien desde acercamientos en la televisión u otros audiovisuales, clasificaciones acerca de la inclusión de estos medios en las aulas en general, y con menor incidencia en el ámbito de lo musical. Ello, en todo caso, puede ser cruzado con referencias bibliográficas que informan acerca del aumento de elaboraciones didácticas amparadas en el cine o la televisión ${ }^{230}$.

Existen ideas recurrentes acerca de la capacidad pedagógica del cine (como audiovisual más ampliamente abordado ${ }^{231}$ ). Sin embargo, no se puede argumentar que haya un consenso, ni en la teoría ni en la práctica, en torno a los márgenes de la didáctica del cine, ni mucho menos en lo que se refiere a didáctica de la música de cine. En general, hemos de partir de la idea ya atisbada hace décadas en el campo de la pedagogía del audiovisual según la cual "el método de explotación depende del objetivo

reflexiones metodológicas sobre el estudio de la música cinematográfica”. OLARTE MARTÍNEZ, M. (Ed.) Reflexiones en torno a la música y la imagen desde la musicología española. Salamanca: Plaza Universitaria Ediciones, pp. 83-103.

${ }^{229}$ Un ejemplo práctico en el ámbito de la historia del cine sería ALFONSO ESCUDER, P. (1998): “iNos gusta tanto hacer pedazos el cine!”. Comunicar 11, pp. 21-25; En referencia a otro tipo de aprendizajes, combinando elementos históricos y rudimentos internos cinematográficos: DE PABLOS PONS, J. (2003): "La enseñanza del cine". BLÁZQUEZ, F. (coord.) Las nuevas tecnologías en los centros educativos, Mérida: Consejería de Educación, Ciencia y Tecnología de la Junta de Extremadura, pp. 197227.

${ }^{230}$ Aunque todavía escasa, existe una creciente bibliografía que invita a ser optimistas en cuanto al establecimiento de nuevos escenarios de aprendizaje musical tomando como referencia el audiovisual. Sirva como ejemplo desde el mundo cinematográfico: DUSIL DIÉGUEZ, R. (2007): “Amadeus. Una visión del genio a través del cine". Música y Educación 70, pp. 47-58. Igualmente, la producción especialmente de artículos que reflexionan en torno al audiovisual y que pueden ser utilizados como marco teórico-referencial en hipotéticos planteamientos didácticos también supone un avance constante. Centrados en los anuncios televisivos y los vídeos musicales reseñamos: GUSTEMS CARNICER, J. (2005): "Escuchar los anuncios: una aproximación al uso de la música y del sonido en la publicidad televisiva". Eufonía 34, pp. 91-100; SEDEÑO VALDELLÓS, A. M. (2004a): "Recorrido histórico por las relaciones entre música e imagen: el videoclip musical”. Música y Educación 58, pp. 67-84.

${ }^{231}$ Ejemplificado en casos concretos por ejemplo por REIA-BAPTISTA, V. (2005): "O valor pedagógico do cinema: Os casos Edison e Lenin". Ámbitos 13-14, pp. 213-229. 
educativo" 232 , por lo que es pertinente un estudio pormenorizado de las posibles taxonomías para poder determinar, a partir de ellas, la operatividad de las mismas.

En este sentido, siempre ha llamado la atención el hecho de que haya productos audiovisuales más o menos indicados para el alumnado que se atiende en las aulas de la enseñanza obligatoria. Así, es reveladora la apostilla de Edgar Morin al referirse a las experimentaciones cinematográficas y su correspondencia con el uso didáctico:

"Cabe preguntarse [...] por qué se muestran a los niños aburridos filmes llamados pedagógicos" ${ }^{233}$.

Ciertamente, desde sus anteojos que abogaban por hacer verosímil aquello que atañía al mundo interior de quien visionaba, Morin tenía en mente la necesidad de entender como didáctico un proceso que desde el audiovisual involucrase subjetivamente al alumno. De ahí que lo que nos interesa de su reflexión es el modo en que se cuestiona lo que es realmente pedagógico en un film, de forma y manera que algo que puede tener mucho contenido pero se presenta tediosamente no es pedagógico, mientras que si lo presentado fuera altamente motivador podría ser, aunque en origen no tuviera esa intención, una herramienta pedagógica funcional, siempre que el docente se capacitase para explotar sus posibilidades. Así, acceder a la composición del audiovisual tiene como principal objetivo entender la globalidad de la obra cinematográfica como conjunto de lenguajes, pero en el plano de la educación musical la ambición ha de ser mayor y más vinculada con el currículo, esto es, experimentar e interactuar con el producto audiovisual, de modo que lo receptivo pasa a ser manipulado.

Dentro de nuestro contexto geográfico y desde un plano temporal relativamente cercano, los estudios pioneros en el tratamiento riguroso del uso didáctico del cine se deben, especialmente, en la década de los ochenta a Juan de Pablos Pons. Desde los objetivos de nuestra investigación, resulta especialmente atractivo el énfasis por la clasificación de los diferentes tipos de cine y su invitación a cruzarlos con las

\footnotetext{
${ }^{232}$ COPPEN, H. (1976): Utilización didáctica de los medios audiovisuales. Salamanca: Anaya, p. 143.

${ }^{233}$ MORIN, E. (2001): Op. cit., p. 174 [nota a pie de página].
} 
características del alumnado. La perspectiva de la que parte en su Cine didáctico ${ }^{234}$ es la búsqueda de la acotación del mismo con el fin de poder implementar nuevos planteamientos que mejoren su eficacia. Así, el cine didáctico queda como un compendio de productos diferenciados de otros (ficción, bélico, etc.). La aparición seis años después de Cine y Enseñanza $a^{235}$ supuso un enfoque más amplio y sistemático al tema en cuestión, ya que el abordaje de cuestiones teóricas se vio complementada por un amplio esfuerzo experimental. De su lectura se advierte cómo del interés por la estructuración de los diferentes modelos fílmicos subyace la búsqueda de una aplicación práctica que condujera a los centros educativos a un uso razonable de los medios audiovisuales. En su argumentación y repaso bibliográfico ${ }^{236}$, rescata el diagrama de los tipos de cine educativos o pedagógicos generado a mediados de siglo pasado por Julián Juez Vicente ${ }^{237}$ :

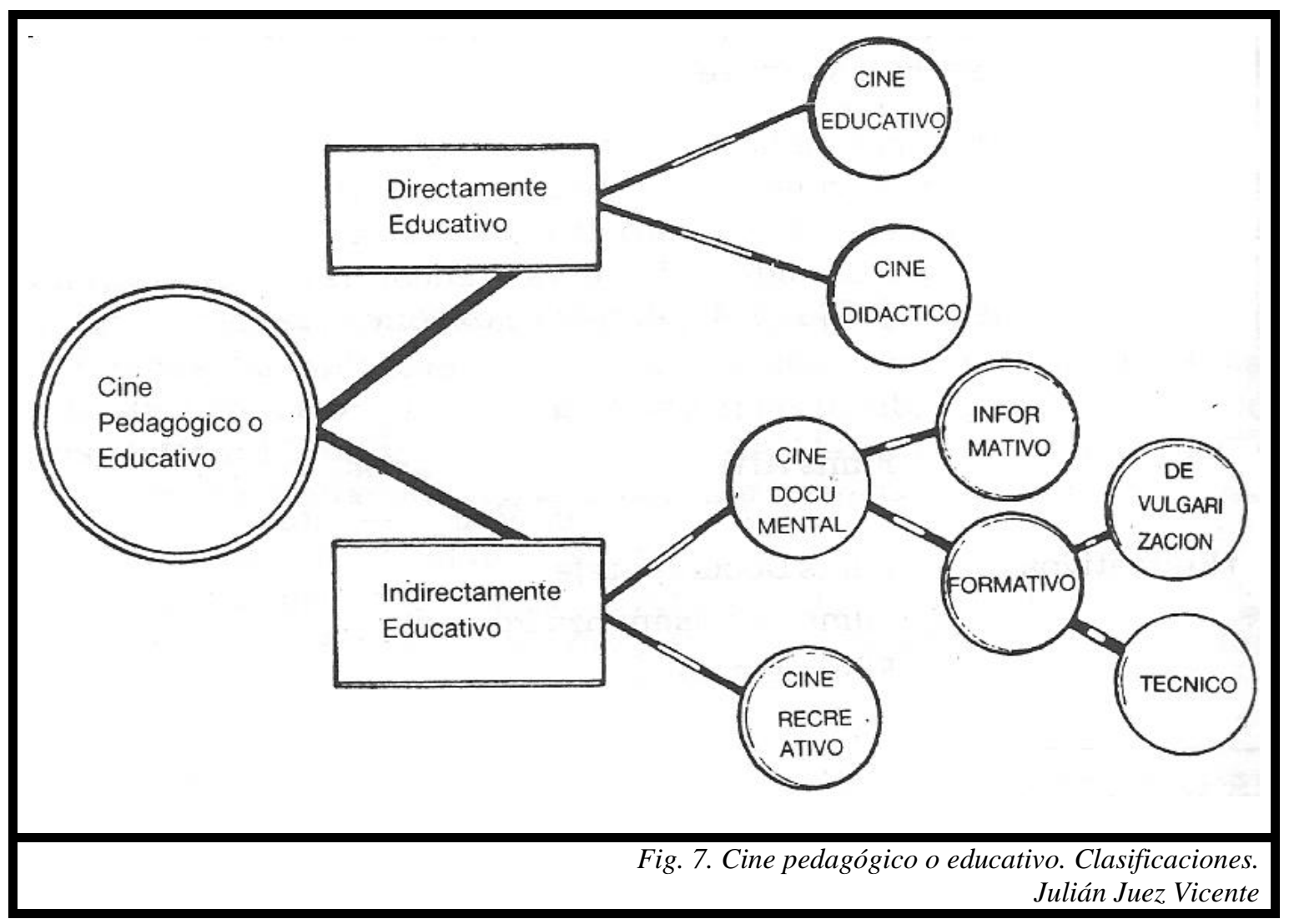

\footnotetext{
${ }^{234}$ DE PABLOS PONS, J. (1980): Cine didáctico. Posibilidades y metodología. Madrid: Narcea.

${ }^{235}$ DE PABLOS PONS, J. (1986): Op. cit.

${ }^{236}$ Ibíd., pp. 68ss.

${ }^{237}$ JUEZ VICENTE, J. (1951): “El cine y su utilización en los centros de enseñanza”. Revista Española de Pedagogía 34, pp. 205-224.
} 
Aunque alejado temporalmente, a partir de modelos como el expuesto se puede evolucionar hacia una educación, en este caso musical, que tienda a abarcar todos los modelos apuntados en revertirlos en contenidos de matriz educativa. Por otro lado, también resulta altamente interesante atender a cómo su estudio parte de elementos fundamentales de la teoría cinematográfica, lo cual, unido a la referencia ineludible que supone la obra en cuestión, hace que ratifiquemos la pretensión de la presente investigación en asirse sólidamente sobre conceptos no sólo pedagógicos sino también audiovisuales y, en el caso que nos ocupa, musicológicos.

Otro modo de abordar la cuestión de la transmisión de conocimientos es haciendo voltear, a la inversa, lo que son las categorías cinematográficas. Es lo que lleva a cabo Juan Carlos Marcos Recio ${ }^{238}$ al preguntarse qué aporta el cine a la educación, conviniendo en los siguientes elementos que comentamos brevemente:

a) Cultura general y global. Para el autor el resultado de la cultura visual que vivimos hoy día, vía cine y televisión, supone uno de los principales avances estructurales a reseñar. En nuestro caso, la utilización musical en los medios audiovisuales se entiende como un referente de la música contemporánea.

b) Formas de presentar y ver la realidad. Entendiendo que desde la faceta expositiva se incluyen reflejos de la sociedad, la política, la educación, etc.

c) Productos propios educativos. Abarcaría los documentales centrados en ofrecer claves interpretativas de algún concepto concreto.

d) La formación global de las escuelas de cine. Como marco de formación y presentación de contenidos.

e) Educación interna que luego se transmite al espectador. Desde la educación no formal.

f) Las apuestas nuevas en varios ámbitos. Siendo el cine un campo de pruebas o tendencias que, con posterioridad, tienen su reflejo en la sociedad.

g) Las películas con fin educativo. Entendidas por el autor como aquellas que tratan acerca de las realidades de los centros educativos y sus habitantes.

\footnotetext{
${ }^{238}$ MARCOS RECIO, J. C. (2000): "Europa quiere preservar su identidad lingüística y social. Cine y televisión educativa: mito o realidad". Cuadernos de documentación multimedia 11. Disponible en <http://www.ucm.es/nfo/multidoc/revista/num11/paginas/atei/jmarcos.pdf > [Consulta 9-II-10]
} 
Como puede observarse, dentro de este conjunto de avances adheridos a la educación encontramos un amplio abanico dentro del cual el trabajo pedagógico a partir del audiovisual, enmarcado en el séptimo punto, supondría una parte relativamente mínima.

El autor recoge la idea extendida según la cual

"en todo caso, el cine para que ofrezca este tamiz educativo ha de situarse en las diferentes realidades en las que se desenvuelve, tales como: las geográficas (películas que explican una cultura determinada); las locales (aspectos muy insignificantes para ciertos espectadores, pero decisivos para la defensa de esa pequeña población); las ideológicas (con un fin propagandístico concreto); religiosas (en defensa de una idea religiosa concreta); económicas (aunque no se pueda apreciar a veces de forma significativa); artísticas (defendiendo el arte del cine y el teatro) e incalificables (aquellas películas que no siguen los cánones clásicos y que apoyan aspectos parciales de la vida diaria)"239.

No obstante, pretendemos postular que todas y cada una de las otras dimensiones que el propio Marcos Recio apunta tienen desarrollo didáctico desde el compendio audiovisual, incluyendo la música. Por ello la posibilidad de carácter pedagógico ha de superar el tratamiento de un tipo específico de cine o producto audiovisual.

En este sentido, el paradigma del uso pedagógico de filmes que esencialmente desarrollan una temática orientada a lo escolar limita otras aplicaciones que utilizan otros materiales no indicados, en primera instancia hacia la docencia, lo cual enriquece el espectro de posibilidades y aumenta considerablemente la generación de materiales en todos los campos.

Entendemos pues que es preciso fijarnos no sólo en aquellos productos audiovisuales que son vehementemente didácticos sino que, de acuerdo con los criterios de conexión con los intereses del alumnado, cabe la posibilidad de abarcar otro tipo de

${ }^{239}$ Ibíd., p. 28 del recurso digital. 
discursos -películas, series o cualquier otro formato- que aliente el trabajo dentro de las aulas. En este sentido, encontramos visiones ${ }^{240}$ que extraen tantas más posibilidades pedagógicas, por ejemplo, en el "cine formativo" (como un recurso audiovisual al mismo nivel que cualquier otro que podamos hallar en el contexto educativo) que en el "cine educativo", utilizado con más asiduidad en su relación con los elementos instructivos que contiene, de modo que la resultante de recursos susceptibles de uso formativo puedan ser:

- El género didáctico: allá donde se palpa notoriamente la finalidad instructiva del producto audiovisual.

- El género cultural: basado en filmes que permiten de manera sencilla establecer vínculos con contenidos científicos o humanísticos.

- Los contenidos audiovisuales comerciales con mensajes constructivos: en aquellas cintas en las cuales la finalidad última, la comercial, no está reñida con el desarrollo de contenidos pedagógicos.

- Los contenidos audiovisuales de difícil justificación formativa: que englobarían aquellos productos que precisan de un arduo trabajo de mediación para provocar el acceso dirigido a ellos.

Llevado al terreno del uso cotidiano, J. Ignacio Aguaded $^{241}$ explora algunas de las aproximaciones más interesantes al fenómeno de la televisión en su relación con la educación, lo cual sirve para que afinemos poco a poco en nuestra taxonomía de aplicación didáctica. De la extrapolación de aspectos derivados de dicha relación podemos reconocer cómo la preocupación básica de aplicación de los medios audiovisuales es la de imbricar su contenido intrínseco con aquel a enseñar. En este sentido, muestra la postura de Dieuzeide ${ }^{242}$ quien nos acercaría a:

- Televisión documental o de enriquecimiento, con la principal pretensión de favorecer el desarrollo de las actividades de clase.

\footnotetext{
${ }^{240}$ DE LA TORRE, S. (coord.) (1996): Cine formativo. Una estrategia innovadora para los docentes. Barcelona: Octaedro, pp. 19 y sigs.

${ }^{241}$ AGUADED GÓMEZ, J. I. (2005): "Estrategias de edu-comunicación en la sociedad audiovisual". Comunicar 24, pp. 25-34.

${ }^{242}$ Algunos de sus postulados básicos en DIEUZEIDE, H. (1965): Les techniques audiovisuelles dans l'ensegnement. París: Presses Universitaires de France.
} 
- Televisión sustitutiva o paliativa, cuya misión es la de subsanar las hipotéticas carencias de un profesorado que pudiera no estar bien preparado.

- Televisión de desarrollo, la cual se entendería como un medio de alfabetización autónomo, sustitutivo del sistema de enseñanza.

Asimismo, otras perspectivas que teorizan en torno a los ámbitos de la televisión cultural, educativa o escolar ${ }^{243}$, inciden igualmente en el carácter de enseñanza intrínseca de los conocimientos que abordan. De menor a mayor grado de transmisión específica de contenidos, la televisión cultural tomaría la forma prototípica de reportaje, la educativa desarrollaría elementos formativos o educativos desde un sistema informal de escolarización y en la escolar existiría una correspondencia total con los elementos curriculares a desarrollar.

Otro campo de reflexión que nos ayude a establecer una clasificación válida en el uso del audiovisual como recurso pedagógico es la bibliografía referida al vídeo didáctico $^{244}$. Entre las tipologías encontradas destaca la gráfica exposición de Ferrés, quien propone seis tipos de materiales:

"Vídeo-lección: exposición sistematizada de contenidos, tratados con una cierta exhaustividad. Sería el equivalente a una clase magistral.

Vídeo-apoyo: equivalente a las diapositivas de apoyo, se usa acompañado de la exposición verbal del profesor o del alumno.

Vídeo-proceso: se refiere al uso de la cámara de vídeo como una dinámica de aprendizaje, en la cual los alumnos se sienten implicados y protagonistas del acto creativo.

Programa motivador: un audiovisual destinado a suscitar un trabajo posterior al visionado, con el objeto de motivar la acción educativa.

\footnotetext{
${ }^{243}$ CASADO, J. M. (1996): "Canal Sur y el desarrollo de la televisión educativa andaluza". Comunicar 6, pp. 57-62; MARTÍNEZ SÁNCHEZ, F. (1992): "Producción de vídeo y televisión con fines educativos y culturales”. DE PABLOS, J. y GORTARI, C. (Eds.) Las nuevas tecnologías de la información y la comunicación. Sevilla: Alfar, pp. 77-99; ALBERO, M. (1987): La televisión didáctica. Barcelona: Mitre.

${ }^{244}$ Nos ceñimos a las modalidades del vídeo omitiendo las posibilidades de su inserción en las aulas y las ventajas e inconvenientes derivados de ello. Un resumen acerca de ello puede encontrarse en DE PABLOS PONS, J. y CABERO ALMENARA, J. (1990): "El vídeo en el aula I. El vídeo como mediador del aprendizaje". Revista de Educación 291, pp. 351-370.
} 
Programa monoconceptual: se trata de programas breves, generalmente mudos, que abordan un solo concepto, un aspecto parcial o concreto de un tema.

Vídeo-interactivo: nace del encuentro entre la tecnología del vídeo y la informática. Incluye la bidireccionalidad haciendo posible el diálogo usuariomáquina, ofreciendo información progresiva en función del nivel de comprensión y de la capacidad de aprendizaje de cada alumno"245.

Conocida la parcelación anterior, De Pablos y Cabero $^{246}$ enfatizan que las funciones didácticas del vídeo bien podrían ser las de medio de expresión, mediador de aprendizajes diversos, instrumento de conocimiento, referencia evaluadora, apoyo a la formación del profesorado e instrumento para la investigación.

Desde una perspectiva más sintética, Alonso y Gallego ${ }^{247}$ establecen que los enfoques del uso didáctico del vídeo sean tres: la utilización didáctica de materiales pregrabados (parcelados en las diferentes áreas curriculares), las pequeñas grabaciones y vídeo-feedback (registro de actividades con posterior debate y conclusiones) y, por último, la producción del vídeo (incluyendo los siguientes pasos: idea inicial, sinopsis, investigación, redacción del guión literario, redacción del guión técnico, grabación, edición y visionado evaluativo para ulteriores correcciones).

Todas las taxonomías descritas dejan abierto el debate postulado en páginas precedentes acerca de la necesidad de aprovechar, en el contexto musical, no sólo los documentos audiovisuales con carácter eminentemente instructivo sino que, en función de las posibilidades y demandas del profesorado, la práctica totalidad de fragmentos audiovisuales pueden dirigir la atención hacia uno u otro aspecto que pudiera hipotéticamente resultar pedagógico por medio de su inclusión guiada dentro de aula. Es una constante en la obra de Juan de Pablos Pons atisbar este potencial aunque, al no tratar directamente sobre el complejo audiovisual sino sobre el argumental, se centra en dos tipos de producciones videográficas:

\footnotetext{
245 FERRÉS i PRATS, J. (1992): Vídeo y educación. Barcelona: Paidós. En concordancia con la publicación de referencia anterior: FERRÉS i PRATS, J. (1988): Cómo integrar el vídeo en la escuela. Barcelona: CEAC.

${ }^{246}$ DE PABLOS PONS, J. y CABERO ALMENARA, J. (1990): Op. cit.

${ }^{247}$ ALONSO, C. M. y GALLEGO, D. J. (1993): Op. cit., pp. 79ss.
} 
“... un primer tipo de materiales audiovisuales que permiten un uso pedagógico [son aquellos que] su estructura audiovisual admite una utilización educativa por parte de sus usuarios. El profesor al utilizar pedagógicamente este tipo de material en su aula "superpone" una estructura didáctica que el vídeo en principio no tiene obligatoriamente que contener. [...] Sin embargo, cuando el contenido de un vídeo también aporta una estructura pedagógica (tal como hacen los libros de texto), nos encontramos con el vídeo de enseñanza, identificado en términos de producción que tiene como objetivo explícito 'generar procesos de aprendizaje en los alumnos'. En este caso estaríamos ante una estructura pedagógica interna, contenida en el vídeo, mientras que en el caso de los vídeos formativos la estructura pedagógica es externa al aportarla el profesor utilizando el vídeo integrado en su diseño curricular.

El siguiente esquema sintetiza estos conceptos" ${ }^{248}$ :

\begin{tabular}{|l|c|c|}
\cline { 2 - 3 } \multicolumn{1}{c|}{} & EXTERNA & INTERNA \\
\hline VIDEO FORMATIVO & $\mathbf{X}$ & - \\
\hline VIDEO DE ENSEÑANZA & - & $\mathbf{X}$ \\
\hline
\end{tabular}

Fig. 8. Influencias externas e internas de los vídeos formativos y de enseñanza Juan de Pablos Pons

La educación musical podría encajar perfectamente, al igual que otras áreas curriculares, en cualquiera de los dos estadios formativos. Así por ejemplo, vídeos formativos podrían considerarse documentales acerca de cualquier elemento que se trate como complemento pedagógico (biografías de compositores, documentos que inicien en las estructuras formales de la música, grabaciones de conciertos didácticos como los

${ }^{248}$ DE PABLOS PONS, J. (1995): "El vídeo: Usos didácticos fundamentales". RODRÍGUEZ DIÉGUEZ, J. L. y SÁENZ BARRIO, Ó. (dir.) Tecnología Educativa. Nuevas tecnologías aplicadas a la educación. Alcoy: Marfil, pp. 243ss. [La imagen referente a los vídeos formativos y de enseñanza se incluye igualmente en la cita referenciada] 
desarrollados por Leonard Bernstein, a los que luego me referiré, etc.) mientras que los vídeos de enseñanza estarían destinados al desarrollo de aspectos íntimamente ligados al diseño curricular (programas didácticos específicos). De este modo, queda el amplio margen del tratamiento auditivo en relación con el visual inserto en el propio discurso. El mismo autor al que aludimos especifica la necesidad de investigar la convergencia entre los códigos audiovisuales (montajes visual y sonoro) con los pedagógicos (que incluyen el trabajo previo y el posterior), y deja abierta la posibilidad que nosotros apuntamos en el contexto musical: extraer del contenido sonoro en su relación con el visual elementos pedagógicos.

Por ello, una nueva categoría tendría cabida dentro de esta catalogación dicotómica entre el vídeo formativo y el de enseñanza. Teniendo en cuenta su procedencia extraeducativa, bien podría integrarse en la primera de las categorías (vídeo formativo) aunque por su carácter originario -aún más ajeno a este contexto- podría articular un nuevo apartado, que tomaría las mejores virtudes de cada uno de los dos compartimientos anteriores. Se trataría de un vídeo (en este caso concreto) potencialmente didáctico $^{249}$.

\section{La plasmación en secuencias didácticas}

Seleccionadas algunas formas de aproximación a la ingente tipología audiovisual en su aplicación a las aulas, tratamos ahora de buscar, a través de experiencias testadas, acercamientos al uso del audiovisual (en ocasiones desde áreas curriculares ajenas a la música) para, a partir de ellas, esgrimir ciertas estrategias de aproximación al audiovisual en el aula de música. El hecho de buscar metodologías que hayan podido tener cierto desarrollo a partir de otras materias, recuerda la necesidad de abogar por la interdisciplinariedad, enfatizando que lo musical, dentro del entramado educativo, no ha de representar un islote con procedimientos y marcos de desarrollo desconectados del proyecto educativo que rige al centro. Entendemos pues el desarrollo de elementos que puedan tener su inspiración en áreas de conocimiento dispares es un ejercicio de transversalidad sumamente alentador.

\footnotetext{
${ }^{249}$ Un caso práctico para la elaboración de vídeos educativos lo encontramos en ROLDÁN CASTRO, I. y CÁRDENAS SÁNCHEZ, T. (1994): "Teoría y práctica en la producción de un vídeo educativo". Comunicar 3, pp. 43-49.
} 
El modo de presentar cualquier fragmento audiovisual más o menos extenso para extraer el máximo de contenido pedagógico varía en función de factores como el área curricular o el enfoque de trabajo que se aplica. En aquellas películas en las que lo fundamental es incidir sobre el argumento suele ser habitual un trabajo de visionado previo y preparación de material para que los alumnos vean la película con herramientas conceptuales elementales y puedan llevar a cabo un debate que derive en un juicio crítico y razonado al final del proceso. Por desgracia, son amplia minoría los casos en que se tiene en cuenta el factor sonoro en estos análisis. En cualquier caso, muchos de los procedimientos metodológicos de acercamiento por parte del docente pueden servir de guía para estructurar los mecanismos de aproximación desde el ámbito musical. Ahí radica la necesidad de que atendamos, si bien de manera más somera que otros apartados, a las técnicas metodológicas para el abordaje de productos fílmicos desde otras áreas de conocimiento.

Frecuentemente se recurre a los medios audiovisuales como estigmas impregnados de elementos fuertemente estereotipados ${ }^{250}$. De manera general, es comúnmente aceptada la posición de Amar Rodríguez en torno a las posibilidades del cine en la forja de caracteres desde su conexión con el mundo en que se genera:

"Para muchos, el cine siempre fue un arte joven, con la continua necesidad de fagocitar las enseñanzas de otras manifestaciones artísticas. Su mirada, no sólo se contentaba con la pantalla, sino que tenía siempre presente las manifestaciones sociales, incluyéndose las artísticas, en que se desenvolvía. Justo a esto, el cine se alía con los movimientos estéticos procurando siempre aprender para, luego, poder enseñar" ${ }^{251}$.

Por ello se ha entendido que tanto éste como el resto de audiovisuales representan medios sin parangón para trabajar elementos como el consumismo, la discriminación

\footnotetext{
${ }^{250}$ En palabras de Felicidad Loscertales Abril, es tarea del docente conocer el medio en que se desarrollan los fenómenos de socialización para saber encauzar los procesos educativos a través de ellos: LOSCERTALES ABRIL, F. (1999): "Mitos, estereotipos y arquetipos de la educación en los medios". Comunicar 12, pp. 15-18.

${ }^{251}$ AMAR RODRÍGUEZ, V. M. (2003): Comprender y disfrutar el cine. La gran pantalla como recurso educativo. Huelva: Grupo Comunicar Ediciones, p. 106.
} 
sexual o la agresividad ${ }^{252}$. Como exponemos, los ámbitos de aprendizaje pueden ser de lo más variado ${ }^{253}$, desde la música, por supuesto hasta campos tan aparentemente distantes como el derecho ${ }^{254}$. Entre ellos destacamos, a modo de ejemplo, la educación social $^{255}$, la pedagogía aplicada a la salud ${ }^{256}$, la educación en valores ${ }^{257}$, la ética ${ }^{258}$ o la historia $^{259}$, ya que la conexión del cine con los hechos sociales hace que éste sea un campo ampliamente desarrollado en clave didáctica en contextos dispares $\mathrm{y}$ extrapolables a nuestro ámbito ${ }^{260}$.

Las consecuencias que arrojan estas posturas son ejemplos prácticos que dejan entrever las posibilidades de técnicas derivadas, en primera instancia, del cinefórum ${ }^{261}$. Por ejemplo, Campo-Redondo ${ }^{262}$ centrado en trabajar la violencia familiar por medio del cine extrae el desarrollo de las siguientes potencialidades en el recurso:

\footnotetext{
${ }^{252}$ Como muestra de manera práctica MORO RODRÍGUEZ, M. M. (2007): "Educación en valores a través de la publicidad en televisión". Comunicar 28, pp. 183-190.

${ }^{253}$ Ejemplo de este eclecticismo es la obra de PLA, E. y TORRENT, K. (2003): Taller de cine. Una propuesta didáctica para apoyar el uso del cine en las aulas. Huesca: Gobierno de Aragón.

${ }^{254}$ RIVAYA, B. y DE CIMA, P. (2004): Derecho y cine en 100 películas. Una guía básica. Valencia: Tirant Lo Blanch.

${ }^{255}$ PEREIRA DOMÍNGUEZ, C. (2005b): "Cine y educación social". Revista de Educación 338, pp. 205228.

${ }^{256}$ AMEIJEIRAS, S., PEREIRA, C., SUEIRO, E. y VILLAR, P. (2000): “Cine y salud. Aproximación a un programa de acción socio-educativa y cultura en los ámbitos formal y no formal”. CARIDE, J. A. (coord.) Educación social y políticas culturales. Santiago de Compostela: Servicio de Publicaciones, pp. 593-607.

${ }^{257}$ AMEIJEIRAS, S. PEREIRA, C., VILLAR, P. (2001): "Evaluación y análisis de una propuesta de intervención pedagógica en educación y valores. El Programa Cine y Salud”. NÚÑEZ CUBERO et als. (eds.) Evaluación de políticas educativas. Huelva: Servicio de Publicaciones de la Universidad de Huelva; HUERTA, R. (1999): "Imágenes que nos suenan. Aprender a conocer los sonidos del cine y la televisión". Eufonía 16, pp. 65-71.

${ }^{258}$ ORTIGOSA LÓPEZ, S. (2002): "La educación en valores a través del cine y las artes". Revista Iberoamericana de Educación 29. Disponible en <http://www.rieoei.org/rie29a07.htm> [Consulta 9-II10]; DEL MORAL, A. M. (1997): “Aproximación al análisis de películas en las aulas de Ética”. Comunicar 9, pp. 149-152.

${ }^{259}$ VALERO MARTÍNEZ, T. (2005): "Cine e historia: una propuesta didáctica". Making of 35, pp. 2127; SÁNCHEZ ALARCÓN, I. (1999): "El cine, instrumento para el estudio y la enseñanza de la historia". Comunicar 13, pp. 159-164.

${ }^{260}$ Como atestigua TUCHO, F. (2006): "La educación en comunicación como eje de una educación para la ciudadanía”. Comunicar 26, pp. 83-88.

${ }^{261}$ Entre los manuales para su desarrollo destacamos: GUTIÉRREZ, D. J. (1980): Cine-forum. Teoría y funcionamiento. Madrid: Claret Films.

${ }^{262}$ CAMPO-REDONDO, M. S. (2006): "El cine como recurso tecnológico en la creación de conocimiento: estudio de caso en la enseñanza de la orientación de la violencia familiar". Enl@ce: Revista Venezolana de Información, Tecnología y Conocimiento, v. 3 3, pp. 11-31. Puede descargarse desde los portales de Dialnet y Redalyc

$\langle\underline{h t t p}: / /$ dialnet.unirioja.es/servlet/fichero_articulo?codigo=2223270\&orden=73395> [Consulta 9-II-10] $<$ http://redalyc.uaemex.mx/redalyc/src/inicio/ArtPdfRed.jsp?;Cve=82330302> [Consulta 9-II-10]
} 
- Un proceso de aprendizaje personal, en tanto en cuanto se manejan conceptos referidos al tema que se esté trabajando.

- Un proceso de innovación, al usar las Tecnologías de la Información y la Comunicación como estrategia didáctica.

- Un proceso de generación de materiales (generalmente textos) que puedan servir de punto de partida para los aprendizajes de otros.

Este modelo, basado en la sinopsis argumental y los comentarios que la rodean, queda definido del siguiente modo por Prats:

"Si queremos lograr que sean adultos equilibrados y responsables; que se interesen por los demás y lo demuestren; que tengan ideales nobles; que sean realistas, resistentes a las desilusiones, flexibles y capaces de adaptarse a lo que venga; que sean capaces de un amor sacrificado y generoso que les dé la indispensable estabilidad emocional, necesitan un espejo donde ver lo que esperamos de ellos. Además de nuestra propia conducta contamos con este medio estupendo para que tomen ejemplo de los protagonistas de buenas películas"263.

En consonancia con lo anterior, el citado Ortigosa López ${ }^{264}$ presenta los siguientes pasos, aplicados al campo de la ética pero extrapolables a las aplicaciones didácticas que inciden en el argumento. Estos son, por un lado, el visionado por parte del docente, quien en varias ocasiones trata de aprehender el film que se proyectará, elaborando un amplio cuestionario y eligiendo razonadamente la película según criterios apropiados para el nivel de los alumnos y características del área a trabajar. Por otro lado, se precisa también explicar los contenidos conceptuales y exponer la relevancia del argumento, insistiendo en el hecho de que este procedimiento es tan importante como cualquier otro trabajo didáctico que no se sirva de medios audiovisuales. Además, los alumnos deberían tomar notas que les sean útiles para el debate guiado posterior.

\footnotetext{
${ }^{263}$ PRATS, L. (2005): Cine para educar. Guía de más de 200 películas con valores. Barcelona: Belacqva, p. 23.

${ }^{264}$ ORTIGOSA LÓPEZ, S. (2002): Op. cit.
} 
Otras aproximaciones optan por encuadrar de manera más amplia la introducción del cine en el entramado educativo. Desde una propuesta llevada a cabo para alumnos desde el segundo ciclo de primaria en adelante, Bellido López enumera los pasos sucesivos para el aprovechamiento de los visionados cinematográficos ${ }^{265}$ :

- Reunión del equipo. Ciclos previstos para cada nivel.

- Preparación de materiales. Coordinación de las sesiones.

- Presentación de las películas antes de la proyección.

- Proyección.

- Coloquios, para lo cual el alumnado se repartía en grupos reducidos.

- Trabajo posterior en cada colegio con el alumnado. Cuestionarios. Estudios posteriores sobre los filmes.

Para García Domene ${ }^{266}$ se pueden deducir pedagógicamente elementos derivados del cineasta que se estudia (reconstrucción de biografías, análisis del guión, rastreo de su filmografía) o se pueden tratar aspectos pedagógicos temáticos, venidos en todo caso de las tramas argumentales que se traten. Es de suma importancia resaltar que este tipo de aproximaciones, absolutamente ajenas a la pedagogía musical, pueden revertir en adquisiciones en este campo ya que, como mostraremos, también por medio del análisis sonoro de un film se pueden trabajar temáticas como las que ejemplifica este autor, relacionadas con aspectos como los mecanismos de exclusión, la inmigración, la drogadicción, etc. Además, como el propio autor indica en sus "sugerencias didácticas", su perspectiva permite un amplio margen de aplicación, desde los niveles de educación secundaria obligatoria hasta la formación del docente, pasando por etapas intermedias como el bachillerato o la universidad, lo cual cumple con los criterios de flexibilidad que nos habíamos propuesto en un principio.

Ejemplos como el anterior son profusamente reproducidos. Ya sea bajo la funcionalidad de introducción, motivación, aclaración o recapitulación y dentro de películas denominadas monográficas (permiten centrar la atención en un tema), monoconceptuales (se ocupan exclusivamente de un aspecto) o complementarias

\footnotetext{
${ }^{265}$ BELLIDO LÓPEZ, A. (1998): "El aprendizaje del cine”. Comunicar 11, pp. 17-18.

${ }^{266}$ GARCÍA DOMENE, J. C. (2004): El cine de Ken Loach. Murcia: Foro Ignacio Ellacuría, p. 30-31.
} 
(amplían información) los pasos metodológicos en el uso del cine didáctico podrían $\operatorname{ser}^{267}$ :

- Visionado de la película por parte del docente. En el intento por insertar el filme dentro de una clasificación previa que responda a modelos ya elaborados.

- Integración del filme en el proceso didáctico que se está siguiendo actualmente en la clase. Sin duda, es de resaltar la necesidad de hacer converger la programación general de aula con los contenidos audiovisuales. La educación musical habrá de forjar su esqueleto conceptual desde la previsión de este tipo de recursos.

- Preparación física del aula. Entendida como la adaptación de los materiales disponibles al espacio con el fin de rentabilizar al máximo el proceso pedagógico.

- Preparación de los alumnos. Presentación y focalización de la atención del alumno hacia los temas de interés.

- Proyección del filme en las mejores condiciones posibles de calidad de sonido e imagen. Lo cual es una consecuencia de las fases anteriores.

- Análisis individual o grupal de la película según las orientaciones dadas antes de proyectarla. En música, será de suma importancia ir resaltando aquellos aspectos a trabajar o que conduzcan a las reflexiones que interesen al docente.

- Si es preciso, volver a proyectar el filme o alguna parte concreta de él. Del mismo modo, la educación musical puede servirse de pistas de audio que complementen aquello que ha sido presentado en conjunto con lo visual.

- Realización de actividades concretas acerca de la película y la temática que se está estudiando. Tomado al pie de la letra, esta apostilla nos aproximaría al trabajo de extrapolación de melodías, aspecto que será abordado con posterioridad.

267 ALONSO, C. M. y GALlEGO, D. J. (1993): Op. cit., p. 109. Proponemos la cita textual de los apartados de Alonso y Gallego introduciendo ideas que los vinculan con nuestra investigación. 
- Presentación de los trabajos o actividades, resumen, puesta en común..., paso al tema siguiente. En este sentido, como quedó patente al principio de estas recomendaciones pedagógicas, es preciso integrar las actividades ideadas en la programación general, de modo que no se trate de un elemento aislado dentro del devenir pedagógico sino que responda a un proceso de reflexión y a una filosofía de enseñanza.

En lo referente a la organización en unidades didácticas, un ejemplo bastante recurrente podría ser la que sigue ${ }^{268}$ :

- Cuestionario inicial de detección de conocimientos previos.

- Detección y clasificación del periodo histórico que se trabaja.

- Selección de imágenes en función de su significatividad y adición de textos.

- Realización de preguntas para constatar la asimilación de contenidos.

- Elaboración de herramientas en busca de un trabajo autónomo e inductivo.

Este tipo de praxis, que pretende una educación general e integral comparte, no obstante, con la especificidad de la didáctica de la música de los audiovisuales una serie de elementos, como puedan ser la selección razonada del material, la generación de claves de comprensión guiadas, el trabajo colectivo y de reflexión o la evaluación de la actividad $^{269}$. Además, se vería beneficiada en nuestro caso concreto de otras aportaciones que tienen como principal interés la búsqueda de significados ocultos al conjunto audiovisual $^{270}$.

Por tanto, la traslación de procedimientos como los anteriores podría dar lugar a un primer modo de aproximación a la música de un discurso audiovisual como agente didáctico. No obstante, hay que precisar que, al igual que ocurre con el resto de áreas en las propuestas descritas con anterioridad, el trabajo sobre la música ha de ser sistemático y claramente definido. En caso contrario, la labor se puede ver gravemente

${ }^{268}$ ALBARRÁN DEZA, F. J., MARTÍNEZ GIMENO, M., MENÉNDEZ GARCÍA, M. V., VICENTE MARTÍN, F. (2007): “Aplicaciones didácticas del cine en la enseñanza de las lenguas". Idea La Mancha 4, pp. 202-205.

${ }^{269}$ Como sugiere ALMACELLAS BERNARDÓ, M. A. (2004): Educar en el cine. 22 películas. Madrid: Ediciones Internacionales Universitarias, pp. 30-31.

${ }^{270}$ Sirva como ejemplo la disección que a un anuncio publicitario (con observación de secuencias, imágenes y sonidos) realizan CABERO ALMENARA, J. y LOSCERTALES ABRIL, F. (Eds.) (1998): ¿Cómo nos ven los demás? La imagen del profesor y la enseñanza en los medios de comunicación social. Sevilla: Secretariado de Publicaciones de la Universidad, pp. 374ss. 
comprometida ya que el devenir general del producto a estudiar no suele invitar a la reflexión sobre elemento sonoro sino a su consumo directo. Por todo ello, si el desarrollo pedagógico se va a llevar a cabo desde el aula de música, se han de explicitar muy bien los objetivos y las vías de acceso a los mismos. En este sentido, cuando el docente de educación musical encuentre aplicaciones educativas que parezcan centrarse en su materia, a través de análisis más o menos superficiales, habrá de ampliar allá donde estime oportuno las mismas.

\section{Aportaciones y beneficios}

Por último, a modo de resumen, cerraremos el apartado enunciando algunas de las virtudes que se pretenden conseguir con el trabajo sobre la música del audiovisual, en todas sus dimensiones. Se trata de algunos aspectos generales que tratan de compendiar los parabienes propugnados desde la educación musical con los elementos que, de manera distintiva, pueden ser abordados con una metodología como la que tratamos de describir. Con ello tratamos de constatar que las intenciones de las metodologías activas del siglo pasado pueden seguir vigentes, eso sí, a partir de otros medios actualizados de activación. A continuación enumeraremos algunas de las más relevantes a partir de mi experiencia propia con estos medios que han sido filtradas y discutidas para su mejora en diversos congresos y otros foros, especialmente, educativos ${ }^{271}$ :

- El uso de materiales accesibles, novedosos y significativos. La utilización de recursos que difieren de los que han sido empleados tradicionalmente es un hecho que poco a poco va ganando terreno en las aulas del siglo XXI. La aplicación de los medios audiovisuales supone el desarrollo de una triple perspectiva eminentemente atractiva. Por un lado, se trata de materiales accesibles, es decir, los docentes tienen hoy día a su disposición una amplia gama de productos de todo tipo sobre los cuales poder implementar su sello personal, buscando los planteamientos pedagógicos que pretendan en cada caso. Las herramientas de publicación de información en internet,

\footnotetext{
271 Algunos de estos planteamientos fueron someramente apuntados en investigaciones anteriores centradas en el potencial de la música de cine aplicada al aula: MONTOYA RUBIO, J. C. (2007a): $O p$. cit.
} 
singularmente Youtube aunque no de manera exclusiva, conforman un paquete de recursos sólo imaginado años atrás:

"El fenómeno Youtube ("si no estás no existes") nos permite anexar una gran cantidad de material que ha sido producido por diferentes personas que están en la red. Si necesitamos el audio de una obra o el audio y las partituras, la obra dirigida por Karajan, todo está allí, a un link de distancia, este espacio es una gran oportunidad para la educación musical, solamente debemos definir y generar rúbricas de los aprendizajes esperados, y un uso metodológico de éste"272.

En segundo lugar, los materiales que se emplean son novedosos, no tanto en referencia a su invención sino en cuanto al tipo de uso que se les da. La aplicación de un nuevo prisma en torno a lo audiovisual hará primar la actualización de todos los recursos (materiales y personales) que inciden en las aulas. Por último, es evidente que estamos ante elementos significativos. No ahondaremos más en torno a este aspecto, profusamente tratado, sino que simplemente atestiguaremos en este apartado reservado a enfatizar la importancia de estos materiales su singular capacidad como elemento dinamizador en las aulas.

- La vivencia u observación del criterio de "manipulación activa" sobre el agente sonoro. Como describiremos de manera inmediata, el reconocimiento de los elementos musicales insertos en cualquier tipo de audiovisual no es sino el primer paso de una actividad constante e interactiva, en cuyo proceso el alumno, por medio de su propia experiencia, dotará de nuevos sentidos a aquello que ha reconocido en formato audiovisual. Las tradicionales ventajas que se adjuntan al criterio vivencial, el hecho de paliar la timidez y fomentar la desinhibición, se ven aumentadas por el uso de unos materiales como éstos, altamente significativos y que favorecen, igualmente, el trabajo grupal y la

${ }^{272}$ CHÁVEZ, F. (2009): "Las tecnologías de la información y la comunicación en el aula, un desafío con premura para la educación musical”. Ecos, revista de música 2, p. 52. 
aprehensión de parámetros musicales de forma conjunta. Encontramos pues, en este placer por la práctica en equipo, otra ligazón más con algunos de los postulados más emblemáticos de las metodologías activas ${ }^{273}$.

- La tendencia a unir las experiencias vitales de los alumnos, rodeados de estímulos audiovisuales en su vida extraescolar, con el conocimiento que se imparte dentro de los centros educativos. Se trata del famoso acercamiento a la realidad, en el cual la tarea de mediación que se supone al docente parte, de este modo, del reconocimiento de los métodos más adecuados, aquellos que se aproximan al mundo infantil, para conseguir una familiaridad con los agentes detonantes del aprendizaje, cuyos conceptos, en cualquier caso, no tienen que distar obligatoriamente de aquellos que vienen siendo desarrollados en la práctica habitual.

- En íntima relación con el postulado anterior, la interactividad entre todos los agentes que participan en el proceso. Los medios audiovisuales nos van a permitir que tanto docentes como alumnos desarrollen un rol alejado de la enseñanza magistral, tan en desuso en los últimos tiempos. Las posibilidades de aplicación de estos medios son tales que, en cualquier tipo de forma que adquiera, permite al docente dinamizar de manera atractiva los contenidos a presentar y al alumno sentir como propio un proceso pedagógico cercano e identificable. Con ello, vivencia e interactividad permitirán que la propia práctica se consolide como parte esencial del corpus teórico, de modo que lo uno se conjugue con lo otro sin problema alguno en la búsqueda de la significatividad a través de los medios audiovisuales.

- El estímulo de la creatividad y la imaginación del alumnado para integrar sus propias propuestas en los desarrollos pedagógicos. Es común entender que no sólo no se ha de coartar la capacidad creativa de los discentes sino que, en la medida de lo posible, las aportaciones imaginativas de ellos puedan ser resorte en la construcción de nuevos aprendizajes. Si en cualquier área de conocimiento se entiende como necesario fomentar este espíritu de creación,

\footnotetext{
${ }^{273}$ Especialmente patente en algunas de ellas, como es el caso de la metodología Orff-Schulwerk, tal y como lo atestigua en su análisis de la misma LÓPEZ IBOR, S. (2007): "Carl Orff". DÍAZ, M. y GIRÁLDEZ, A. (coord.) Aportaciones teóricas y metodológicas a la educación musical. Barcelona: Graó, p. 74.
} 
en la educación musical nos hallamos ante una necesidad intrínseca a su propio contenido epistemológico. En este sentido, es común que se trate de implicar a los docentes en la estimulación de la imaginación y la creatividad del alumnado como punto de partida de su desarrollo competencial ${ }^{274}$. Por ello, será frecuente que, en el ámbito en que desarrollamos este escrito, los propios alumnos sean los que aporten ideas sobre los materiales que utilizar o el modo de desarrollarlos, siempre bajo la atenta mirada del docente ${ }^{275}$. Asimismo, hemos de propiciar que las actitudes creativas impregnen también los materiales y recursos. En su teoría del desarrollo de la creatividad y la imaginación, Childs nos conduce a este uso creativo de los medios de comunicación:

"Los medios de comunicación se han vuelto feroces consumidores de música creativa y ofrecen muchos ejemplos para nosotros mismos y para los chicos. La mayor parte de lo que escuchamos es cliché y pastiche. No obstante, si tomamos nota de lo que está ocurriendo podemos obtener información e ideas y adquirir algunos modelos básicos apropiados. Cualquier música contiene ideas creativas: observa cómo se utiliza la música para realzar efectos visuales o para manipular emociones. Copia elementos de cualquier idea y observa en qué medida nos dejamos influir por la moda. Busca ideas que podamos desarrollar en nuestro trabajo, teniendo en cuenta que algunas técnicas y habilidades están fuera de nuestro alcance"276.

- La ludicidad como base del aprendizaje. Generalmente, se entiende que tanto más adecuada será una práctica cuanto mejor consiga transmitir sus

\footnotetext{
${ }^{274}$ Como pone de manifiesto DE MOYA MARTÍNEZ, M. V. (2005): "Creatividad y docencia. Aprender a ser creativos para enseñar a ser creativos". GERVILLA CASTILLO, E. (coord.) Creatividad: aspectos psicológicos, educativos y sociales. Málaga: Dykinson, pp. 281-296.

${ }^{275}$ DÍAZ, M., y FREGA, A. L. (1998): La creatividad como transversalidad al proceso de educación musical. Vitoria: AgrupArte. Desde un punto de vista ágil, a veces en forma de entrevistas entre las autoras, y atendiendo a casos prácticos, desglosan las cuestiones más relevantes en torno a la creatividad en el aula de música.

${ }^{276}$ CHILDS, J. (2005): Op. cit., p. 97.
} 
contenidos de un modo lúdico y ameno. Se suele aceptar que el alumno ha de mantener una postura implicada a través de la aceptación de las actividades.

Qué duda cabe que la ludicidad, como medio de aprendizaje significativo, se ve estimulada por unos contenidos enfocados desde una cuidada selección de materiales conocidos por los alumnos, bien sean películas, series televisivas, anuncios publicitarios ${ }^{277}$, etc.

- La generalización de la enseñanza musical y la participación de todos, mejor o peor dotados. En este sentido, una de las máximas más recurrentes de las metodologías activas del siglo XX fue el propiciar la participación de la globalidad del grupo. Ello se venía consiguiendo, habitualmente, por medio de la adaptación de materiales y ritmos para casos con dificultades evidentes. El trabajo sobre la música del audiovisual no sólo no interfiere esta diversidad en los tiempos del trabajo sino que, además, al poder desarrollarse actividades de diferente calado y grados de complejidad de manera simultánea, se promueve que todos participen de las realizaciones colectivas. La democratización de las prácticas educativas musicales imbuye, por tanto, los procedimientos que abordamos en el presente estudio.

- La conexión de los diversos bloques de contenido musical. Pudiera parecer que las limitaciones de la música contenida en el audiovisual son muchas para trabajar, por ejemplo, bloques de contenidos a priori tan dispares como la formación vocal y auditiva, la práctica instrumental, el movimiento y la danza o, por citar algunos de los más recurrentes, el lenguaje musical. Nada más lejos de la realidad. La capacidad de estos procedimientos para amoldarse a todos y cada uno de los tipos de aprendizaje quedará evidenciada y, por otro lado, todos estos núcleos temáticos se trabajarán en una íntima ligazón, de modo que el alumno no siempre tenga la conciencia de parcelar las actividades que realiza (de canto, de seguimiento, de instrumentación...) y las lleve a cabo de manera interrelacionada.

\footnotetext{
277 Si la música de cine o la televisión no ocupa un lugar de privilegio en las actividades de corte musical que se realizan en las aulas, la publicidad está casi olvidada, lo cual supone un grave error, ya que no sólo no tiene por qué tender al consumismo exacerbado sino que es capaz de estimular un cúmulo de aprendizajes de gran calado. Encontramos interesantes reflexiones al respecto en: MARTÍNEZ SÁNCHEZ, E. (1994): "La publicidad y su integración en las aulas. No es tan fiero el león como lo pintan”. Comunicar 3, pp. 65-73.
} 
- La globalización entre áreas de conocimiento. La legislación vigente en materia educativa otorga un sesgo transversal al tratamiento de la comunicación audiovisual y las Tecnologías de la Información y la Comunicación:

"Sin perjuicio de su tratamiento específico en algunas de las áreas de la etapa, la comprensión lectora, la expresión oral y escrita, la comunicación audiovisual, las Tecnologías de la Información y la Comunicación y la educación en valores se trabajarán en todas las áreas" ${ }^{, 278}$.

En este sentido, es constatable un evidente interés desde las administraciones educativas por no dejar de lado este tipo de elementos en un mundo interconectado:

"Desde la perspectiva de la administración, se parte de la necesidad que tiene el sistema educativo de estar al día, cuando no por delante, de los cambios del conjunto de la sociedad y de la necesidad de que las escuelas funcionen de acuerdo con los contextos en los que se inscriben. Todos los profesores no reconocerán, entenderán o desearán, necesariamente esos cambios, pero tendrán que amoldarse a ellos y pensar cuidadosamente en cómo podrían afectar a los intereses de los alumnos. El sistema educativo necesita de una constante reorientación en función de los cambios culturales, económicos y tecnológicos que tienen lugar en la sociedad"279.

\footnotetext{
${ }^{278} \mathrm{La}$ importancia que se le concede a estos conocimientos queda plasmada de la forma que se enuncia en la Ley Orgánica 2/2006 de 3 de mayo de Educación, en su Artículo 19.2 (Principios pedagógicos). A continuación, el Real Decreto 1513/2006 de 7 de diciembre, por el que se establecen las enseñanzas mínimas en la Educación Primaria en el marco de la LOE (Artículo 4.5, Áreas de Conocimiento), ratifica de manera literal lo que ya quedó dispuesto en la Ley Orgánica.

${ }^{279}$ MARTÍNEZ VALCÁRCEL, N. (1994): Los grupos de trabajo de C.E.P. y el perfeccionamiento del profesorado: un estudio evaluativo. Murcia: Centro de Profesores de Murcia, p. 62.
} 
Por ello es de vital importancia hacer de estas estrategias de aprendizaje la piedra angular de determinados conocimientos, ya que ello redundará en el beneficio global de la enseñanza. Más allá de una aproximación teórica a un marco preestablecido, la propia experiencia docente en todos los tramos de la enseñanza obligatoria nos ayuda a tener una perspectiva clara al respecto: a través de la música de cualquier soporte audiovisual es sumamente sencillo promover el aprendizaje en varias áreas de conocimiento y, como veremos en el capítulo cuarto del presente texto, se podrá llegar incluso a generar estructuras de aprendizaje intercultural de evidente valor formativo. 


\section{CAPÍTULO 3}

MÉTODOS Y TÉCNICAS EN TORNO A LA

INSERCIÓN DEL AUDIOVISUAL EN LAS AULAS DE EDUCACIÓN MUSICAL 
MÚSICA Y MEDIOS AUDIOVISUALES.

PLANTEAMIENTOS DIDÁCTICOS EN EL MARCO DE LA EDUCACIÓN MUSICAL. Juan Carlos Montoya Rubio 


\section{MÉTODOS Y TÉCNICAS EN TORNO A LA INSERCIÓN DEL AUDIOVISUAL EN LAS AULAS DE EDUCACIÓN MUSICAL}

\subsection{IDEAS PRELIMINARES. TRANSITANDO ENTRE INQUIETUDES Y OQUEDADES}

\section{La apertura de nuevas vías de actuación}

El capítulo anterior finalizaba esbozando criterios metodológicos para el desarrollo de unidades didácticas basadas en el audiovisual, fundamentalmente a partir del cine. Proponemos como tarea del presente capítulo adentrarnos en el modo en que esas estructuras procedimientales tienen su reflejo en el aula de educación musical. Por ello, estableceremos diferentes niveles de aproximación al hecho musical desde el audiovisual, pretendiendo que dentro de las categorías que serán presentadas quepan todas las hipotéticas prácticas que abarquen el desarrollo de la música del audiovisual como resorte de aprendizaje dentro de la enseñanza obligatoria.

Establecer una taxonomía de los métodos y técnicas que puedan ser utilizados en el aula de música, partiendo del audiovisual, no deja de ser una labor que difícilmente contente a todos. Como exponemos, los criterios que seguiremos partirán de la intención de incluir todas y cada una de las prácticas posibles dentro de alguna de las categorías que postulemos teniendo en cuenta que, en ocasiones, habrá algún tipo de actividad que pueda solaparse e incluirse, eventualmente, en varios de estos compartimentos que, a pesar de parecer cerrados, dejan rendijas por las que poder filtrar nuevas prácticas que vayan surgiendo. Uno de los ejemplos más claros de esta imposibilidad de cerrar totalmente una estructura como la que comenzamos a describir 
lo aporta la propia música de cine, la cual, en función de autores, encuentra diferentes sutilezas para definir uno u otro tipo de músicas en su vinculación con la imagen ${ }^{280}$.

Continuando con el ánimo interdisciplinario que mueve la totalidad del estudio, algunas de las líneas maestras que configuran el esqueleto de la argumentación de este capítulo se pusieron recientemente a disposición de la comunidad científica musicológica $^{281}$, raíz que consideramos inexcusable en la generación del texto en su globalidad.

No son muchas las fuentes en las que encontrar referencias sobre la utilización, de manera genérica, de la música de los medios audiovisuales en el aula de educación musical en nuestro ámbito de actuación. A pesar de su mérito, cuando las hay, estas referencias son excesivamente generales y no tienen la continuidad necesaria para erigirse en metodologías de actuación global. En este sentido, la implementación del sonido en clave didáctica no es fácilmente rescatable en obras dedicadas con exclusividad a ello ${ }^{282}$.

Entre las primeras líneas escritas al respecto rescatamos las ideas de Enrique Téllez $^{283}$, quien en poco más de una página resume desde su punto de vista las posibilidades de la música, en este caso de cine. El texto supone uno de los primeros esfuerzos por vincular música y cine desde una perspectiva pedagógica. El intento, a pesar de su gran valor como anticipo a posteriores realizaciones, se ocupa fundamentalmente de aspectos funcionales de la música en el discurso cinematográfico (para lo cual han ido surgiendo numerosas obras más amplias) y sólo apunta sucintamente los métodos de aplicación didáctica del cine en relación con la música. En cualquier caso ha de ser tomado como referencia de una nueva perspectiva de actuación en el plano de la educación. Con ello, el mayor mérito de sus reflexiones es el de centrarse en el trabajo didáctico sobre la música que está inserta en el discurso cinematográfico o que puede incluirse en él, omitiendo casi por completo la faceta

\footnotetext{
${ }^{280} \mathrm{Y}$ además con diferente grado de acierto, como indica OLARTE MARTÍNEZ, M. (2001): “Existe una frontera en la música aplicada a la imagen como elemento expresivo y estructural?’. LOLO, B. (Ed.) Campos interdisciplinares de la musicología, v. 1. Madrid: Sociedad Española de Musicología, p. 746.

${ }^{281}$ A través de un panel que, de manera esquemática, disertaba sobre las posibilidades de la aplicación audiovisual en el ámbito de la música: MONTOYA RUBIO, J. C. (2009c): "La investigación en el ámbito de la didáctica de la música de cine. Experiencias y posibilidades". Póster presentado en el VII Congreso de la Sociedad Española de Musicología (en prensa).

${ }^{282}$ Una aproximación, entre técnicas de secuenciación y análisis visual, puede encontrarse en ALONSO, M. y MATILLA, L. (1989): Op. cit.

${ }^{283}$ TÉLLEZ, E. (1996): Op. cit., pp. 56-57.
} 
didáctica más desarrollada $\mathrm{y}$, tal vez, menos productiva de estos planteamientos pedagógicos: el uso musical a partir de los conocimientos que se derivan de la propia trama argumental ${ }^{284}$. El hecho de focalizar sus esfuerzos hacia los sonidos que forman parte del audiovisual se debe a que

"la mejor práctica educativa en el ámbito de la realización audiovisual, será la que contenga una elaboración participativa del alumnado en todas y cada una de las fases de creación: redacción de un guión literario, asignación de papeles interpretativos, filmación, sonorización, etc., hasta la finalización del proceso

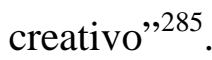

Por todo ello, como decíamos, el autor indica como vías exclusivas en el uso didáctico de los medios audiovisuales aquellas que bien se dirigen al consumo de productos ya elaborados bien a la creación de nuevos materiales de corte audiovisual y, a la hora de desglosar estos dos grandes bloques, únicamente apunta posibilidades. Estas son:

- "Sonorización por distintos procedimientos de una filmación que ha sido realizada por los estudiantes.

- Realización de un montaje audiovisual sobre diapositivas de carácter histórico.

- Realización de un cortometraje a partir de un espectáculo diseñado en clase con marionetas.

- Realización de un documental sobre las preocupaciones sociales culturales y políticas de los protagonistas del trabajo (drogas, desempleo, marginación social, medio ambiente...)

- Filmación y sonorización de un trabajo sobre la vida interna del centro educativo (relaciones alumno-profesor, actividades complementarias, trabajos creativos desarrollados, debates sobre régimen interno....)"286.

\footnotetext{
${ }^{284}$ Entiéndase la denominación de "menos productiva" en referencia a la omisión de la integración de lenguajes del cual participa la música en el audiovisual, lo cual hace que no se extraigan todas las potencialidades con que lo musical grava al filme. Por otro lado, su mayor desarrollo que otros procesos como la sonorización o la filmación en el ámbito didáctico hace que, al menos en este aspecto, sí pueda considerarse como altamente productivo el conocimiento musical a través del argumento.

${ }^{285}$ Ibíd., p. 56.

${ }^{286}$ Ibíd., p. 56.
} 
Se observa, de este modo, cierto aporte en cuanto a temáticas e ideas pero escaso bagaje en lo que se refiere a técnicas concretas de sonorización o realización integral de recursos audiovisuales. Tomando prestadas estructuras generales de actuación didáctica no referidas exclusivamente a la música ${ }^{287}$, observamos que es ya tradicional el entendimiento de varios planos de aplicación del elemento audiovisual en las aulas. Este abanico se abriría en el registro del "mundo de la clase"288, esto es, la filmación de hechos de interés, y pasaría por el uso de la estructura fílmica bien como herramienta por parte del docente bien como instrumento de aprendizaje a partir de la acción del propio alumno. Desde estas teorías clásicas podemos inferir algunas estrategias trasladables al ámbito pedagógico musical: el registro guarda estrechos paralelismos con la filmación apuntada por Téllez en las líneas precedentes y el trabajo autónomo del alumnado con la sonorización, mientras que el uso de materiales audiovisuales como guía docente quedará patente en procedimientos que irán apareciendo a lo largo del capítulo presente, siendo tal vez el recurso del "musicomovigrama"289 el que más fielmente refleje la extrapolación de las ideas señaladas al principio del párrafo por Jacquinot.

Por otro lado, entre las nuevas tendencias de aplicación didáctica en el aula de música, es posible encontrar ejemplos en los cuales, en plena búsqueda de nexos con los alumnos, se llegue a abordar de manera más o menos directa elementos de procedencia audiovisual. En los siguientes ejemplos Zaragozà ${ }^{290}$ plantea hipotéticas redes cognitivas de docentes de música y alumnos en torno al elemento seleccionado por él, "Stradivarius":

\footnotetext{
${ }^{287}$ JACQUINOT, G. (1977): Image et pédagogie. París: Presses Universitaires de France.

${ }^{288}$ DE PABLOS PONS, J. (1980): Op. cit., p. 26. En la misma línea de la publicación reseñada y enfatizando los postulados del citado Jacquinot, De Pablos continúa indagando en esta propuesta en DE PABLOS PONS, J. (1989): "La diegésis cinematográfica y sus implicaciones didácticas". Enseñanza: Anuario interuniversitario de didáctica 7, pp. 9-15.

${ }^{289}$ HONORATO, R. (2001): “Trabajando con musicomovigramas". Revista de la Lista Europea de Música en la Educación 8. Disponible en 〈http://musica.rediris.es/leeme/revista/honorato01.pdf> [Consulta 9-II-10].

${ }^{290}$ ZARAGOZÀ, J. L. (2009): Op. cit., pp. 190-191. El autor comienza este ejemplo prototípico a partir de imágenes de conciertos solistas y grossi, verdadero núcleo que plantea para la actuación pedagógica. El uso del audiovisual queda justificado desde la importancia del formato visual.
} 


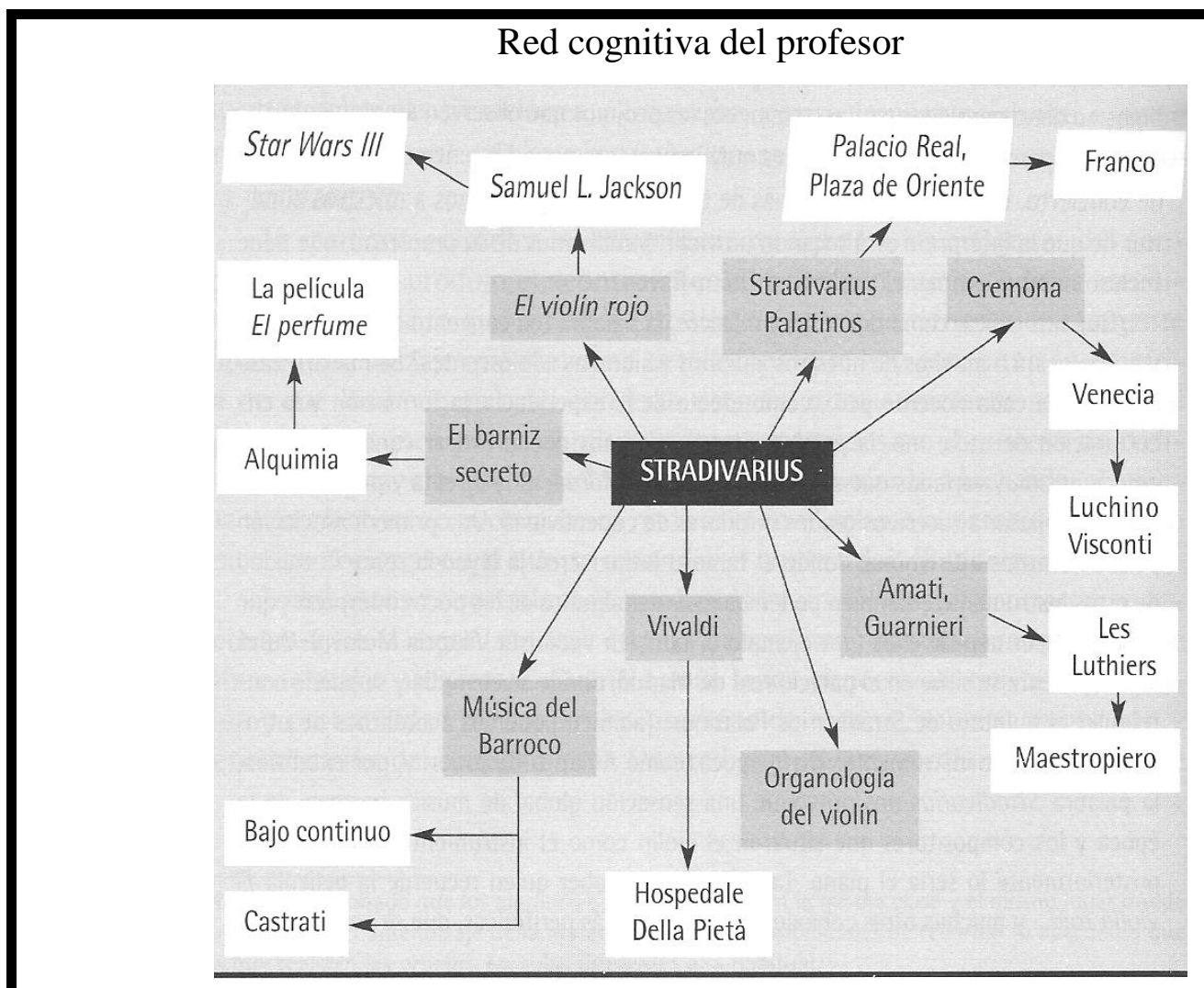

Red cognitiva del alumno

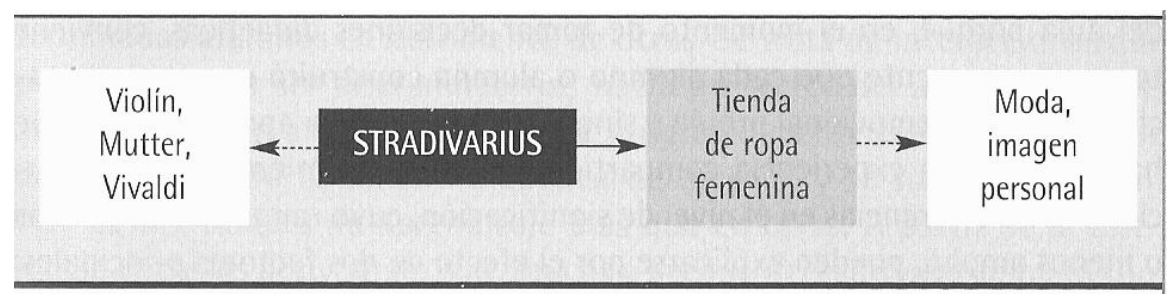

Fig. 9. Redes cognitivas de profesor y alumno ante un resorte significativo Josep Lluís Zaragozà

De planteamientos como el anterior podemos extraer varias consecuencias que atañen directamente a nuestro objeto de estudio:

- El uso constante de la música derivada de audiovisuales como medio de conexión con el alumnado. Las dimensiones a que remite el cuadro ideado para el docente muestra que los alumnos podrían penetrar sin dificultad alguna en varios de los dominios que se muestran, tales como las películas a las que se alude. 
- La posibilidad de indagar más en clave audiovisual. La práctica totalidad de los conceptos apuntados permiten un gran desarrollo desde el audiovisual. Así, si nos ceñimos con exclusividad al formato de conocimiento musical a través del audiovisual la profundización en torno a "castrati" o "luthiers" se antoja relativamente accesible desde el cine.

- La carencia de un desarrollo más profundo desde elementos que podrían potenciar la significatividad del aprendizaje. De este modo, si partimos de la red cognitiva trazada para el alumno, las posibilidades de ahondar desde los supuestos "tienda de ropa femenina" o "moda, imagen personal" son muy grandes, incentivando en este caso realizaciones de sonorización o filmación, ambas utilizadas con relativa escasez en las aulas de educación musical.

\section{El etiquetado de las prácticas audiovisuales en el aula de música}

Debido a que no son mayoría, es muy provechoso identificar y clasificar las hipotéticas prácticas audiovisuales que pudieran dar pie a desarrollos procedimientales en el aula de música. De ahí que "etiquetar" dichas prácticas, lo cual no suele ser visto con entusiasmo en el plano educativo, pueda resultar muy provechoso en el ámbito en el que desarrollamos la investigación. Con ello, de manera general, se puede entender que, con mayor o menor intensidad, la música inserta en los medios audiovisuales ha tenido un espacio de desarrollo dentro de las realizaciones didácticas en la enseñanza de la música desde la adaptación de los materiales preexistentes y su reorientación.

En este sentido, un primer núcleo de actuaciones son aquellas que se han centrado en el uso de productos audiovisuales con contenido musical concreto (películas, documentales, series monográficas...) a partir cuyo argumento se han articulado las claves de actuación dentro del aula. La facilidad en su uso (no se precisan grandes medios) hace que nos hallemos ante una de las herramientas más recurrentes. En cualquier caso, pese a sus grandes posibilidades, que serán expuestas en breve, dejan atisbar una rémora ya apuntada que no ha de pasar inadvertida: omite la especificidad de la música como parte integral de los lenguajes que compendian el audiovisual. El trabajo sobre el argumento o la explicación directa que se presenta hace que el elemento sonoro, presente a pesar de no parecerlo para quien no se detiene ante él, no sea núcleo de desarrollo pedagógico. Por este motivo las aplicaciones pedagógicas basadas en el 
contenido más evidente del audiovisual no distan en exceso de otras que se trabajan en otras áreas de conocimiento y, consecuentemente, la enseñanza de la música con la participación audiovisual, vista de manera exclusiva desde estos parámetros, se asemejaría mucho a los modelos de enseñanza de la historia, la ética o la salud, por citar algunos de los más recurrentes ya comentados en al apartado anterior. En lo sucesivo, hablaremos de conocimiento y comprensión musical a través del audiovisual y de extrapolación de elementos sonoros extraídos del audiovisual. Estas serán las dos primeras categorías a abordar las cuales, como decimos, representan -dentro de la escasez general- la mayor parte de las experiencias que podemos encontrar en la actualidad. Como será abordado en breve, en este tipo de procedimientos no hay una vinculación precisa entre el lenguaje audiovisual y la praxis pedagógica, sino que más bien podríamos hablar de un uso "argumental" o "circunstancial" (según casos) del mismo. Será en los siguientes apartados, especialmente el dedicado a la sonorización y en menor medida el focalizado en la filmación, en los que se encuentren mayores incursiones en el papel determinante de la música como forjadora del compendio audiovisual. En ese momento, los procesos pedagógicos ofrecerán la posibilidad de abrirse a la comprensión de la globalidad que representa el producto cinematográfico o televisivo. 


\subsection{CONOCIMIENTO Y COMPRENSIÓN MUSICAL A TRAVÉS DEL AUDIOVISUAL}

\section{Tipología de casos}

Un primer apartado de este desarrollo metodológico lo abordamos desde el prisma del conocimiento musical a través del audiovisual. Si hasta ahora habíamos atendido al modo en que la música de cine y resto de audiovisuales podían incidir en las aulas, de una manera más o menos directa, ahora la cuestión que se trata de solventar es la que nos conduce al tipo de productos con que se alcanza el conocimiento musical, cuáles son y qué características tienen, de modo que se puedan establecer diferentes rangos en su uso práctico. Así, sirviéndonos de un estudio pormenorizado de casos que son susceptibles de alcanzar conocimientos musicales a través de los argumentos audiovisuales, se destacan las siguientes categorías explicadas brevemente a continuación del esquema, el cual bascula desde una mayor o menor intencionalidad didáctica del producto en su origen, lo que, en consecuencia, provoca que el trabajo de mediación por parte del docente que quiera aproximar a su alumnado a uno u otro formato sea inversamente proporcional a dicha potencialidad:

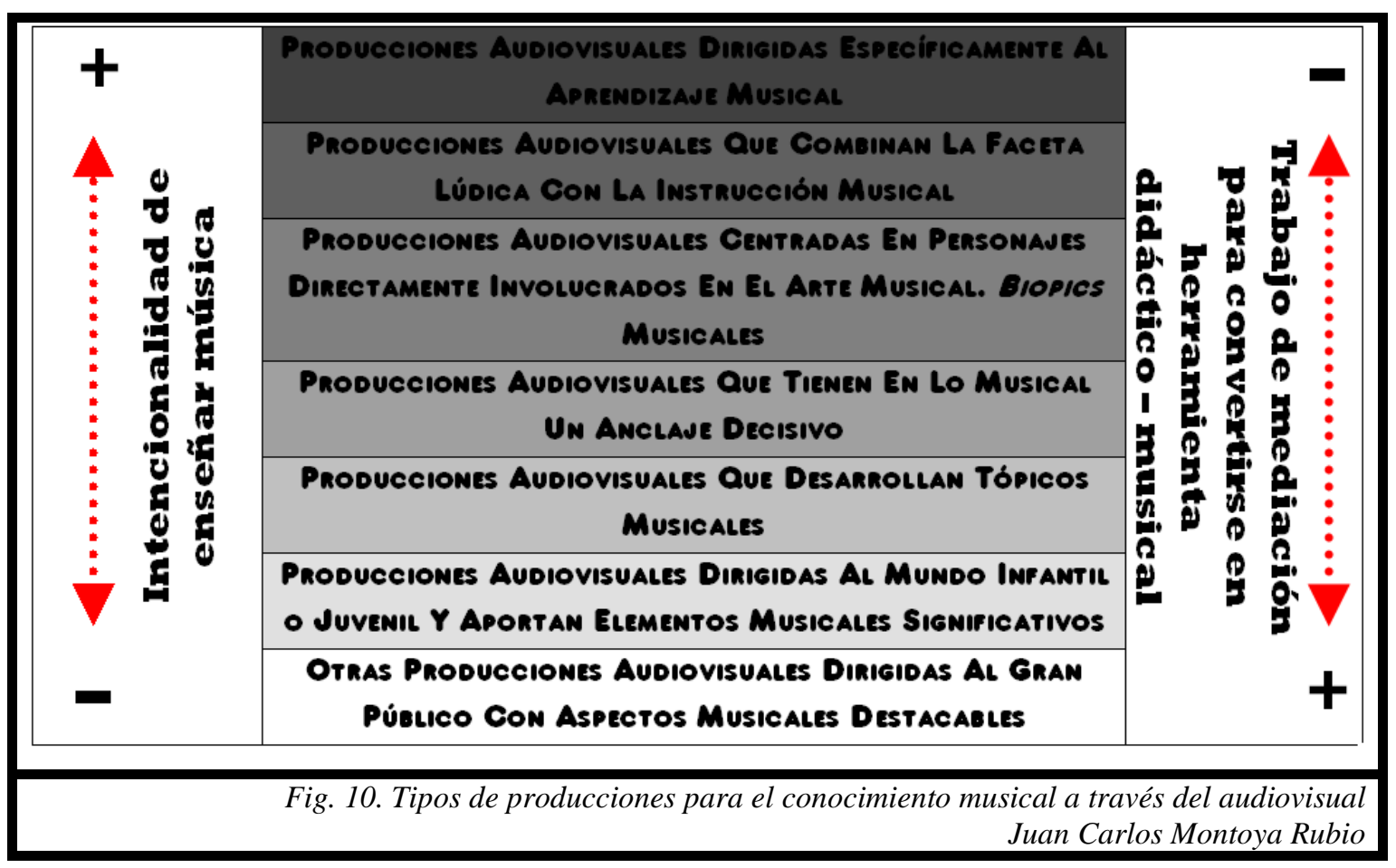


- Productos audiovisuales dirigidos específicamente al aprendizaje musical, incluyendo programas educativos cuya principal finalidad es la de transmitir un conocimiento específico dentro de la esfera musical en cualquiera de sus dimensiones (histórica, formal, de habilidades específicas...). El caso paradigmático de este tipo de realizaciones tal vez sean los conciertos didácticos de Leonard Bernstein $^{291}$.

- Productos audiovisuales cuya principal misión es el entretenimiento pero que abordan, de manera inequívoca y profusa, el aprendizaje de contenidos musicales. En este tipo de realizaciones se conjugan, por tanto, varios de los intereses inherentes al audiovisual. Entre los ejemplos más palmarios destaca la serie Little Einsteins $^{292}$, en la cual dentro de una temática infantil cada episodio se centra en rescatar melodías de insignes maestros de la historia de la música, aunque, en cualquier caso, no sea comparable la simplicidad de la temática argumental de las tramas con la complejidad de algunas de las músicas presentadas. En estos casos, se precisa de un trabajo de mediación por parte del docente mucho mayor que en el ejemplo anterior.

- Productos audiovisuales centrados en personajes susceptibles de una fácil extracción de elementos para orientar a la pedagogía de la música. Nos referimos, fundamentalmente, a los biopics musicales, entendiendo que dentro de ellos existe una gran variedad (músicos clásicos, cantantes pop, artistas folklóricos, etc.) y que toda ella puede ser encasillada dentro de este grupo.

- Productos audiovisuales no centrados en figuras relevantes de la música en los cuales, sin embargo, existe una trama que evidencia un contenido musical útil para el desarrollo en clave didáctica. Es el caso, por ejemplo, de Los chicos del coro ${ }^{293}$. Dentro de esta categoría tendrían cabida, igualmente, aquellos audiovisuales que por su vinculación con una época concreta insertan elementos musicales en su discurso y promueven, de este modo, el abordaje de cuestiones de este tipo. La locura del rey Jorge $^{294}$, a trabajar con detenimiento en el apartado de extrapolación sonora ${ }^{295}$,

\footnotetext{
${ }^{291}$ Roger Englander, Estados Unidos.

${ }^{292}$ El primer capítulo data de octubre de 2005, dirigido por Olexa Hewryk.

${ }^{293}$ Dir. Christophe Barratier, 2004.

${ }^{294}$ Dir. Nicholas Hytner, 1994.

${ }^{295}$ Cfr. MONTOYA RUBIO, J. C. (2009b): Op. cit.
} 
puede erigirse como un ejemplo significativo del tratamiento decisivo de la música händeliana en un largometraje.

- Productos sin aparente relación con lo musical que desarrollan, no obstante, importantes y preexistentes tópicos musicales, bien sea a partir del uso de música clásica $^{296}$ bien sea desde los paralelismos con clichés procedentes de la propia música cinematográfica. Aunque los ejemplos son muchos y algunos de ellos serán abordados de forma práctica en líneas sucesivas, vale la pena remitir a la serie Los Simpson ${ }^{297}$, la cual se nutre constantemente (ya no sólo desde el plano sonoro sino también desde la concepción argumental) de unos y otros tópicos.

- Productos audiovisuales dirigidos al mundo infantil-juvenil. En ocasiones, la música contenida especialmente en películas que llaman la atención de un determinado grupo de edad, goza de una autonomía tal que permite a los docentes reconducir sus postulados hacia la focalización de sus melodías. Uno de los casos actuales más significativos es la saga de Harry Potter ${ }^{298}$, como hace unos años lo ${\text { fue } \text { Titanic }^{299} \text { y aún antes Superman }}^{300}$ o La Guerra de las Galaxias ${ }^{301}$.

- Otros productos audiovisuales dirigidos al gran público. De manera general, cualquier sintonía, anuncio, serie televisiva, documental, película, etc. es susceptible de encauzarse debidamente hacia el conocimiento musical, siempre y cuando los intereses docentes converjan con una mínima observación de adecuados criterios de selección, que desechen producciones inadecuadas por cualquier motivo.

Se genera así una suerte de clasificación, siempre subjetiva por lo difícilmente mensurable, que establece la mayor o menor predisposición de unos productos audiovisuales en función de los diferentes niveles de exposición de lo musical por

\footnotetext{
${ }^{296}$ Entiéndase el término siempre desde las cautelas a las que nos remite RADIGALES, J. (2005a): "Usos y abusos de la música "clásica" en el cine. Estudio de casos". OLARTE MARTÍNEZ, M. (Ed.) La música en los medios audiovisuales. Salamanca: Plaza Universitaria Ediciones, pp. 13-32.

${ }^{297}$ En el caso de los tópicos musicales de origen cinematográfico es tan sorprendente como genial una de las muchas referencias a Psicosis (Dir. Alfred Hitchcock, 1960) en el caso concreto del episodio The Sprinfield Files (Dir. Steven Dean More, 1997). En referencia a tópicos "históricos", rescatamos la parodia de Mozart en Margical History Tour (Dir. Mike B. Anderson, 2004). Una aplicación didáctica para esta última referencia fue desarrollada en MONTOYA RUBIO, J. C. (2009d): "La sonorización del audiovisual como fuente de aprendizajes musicales". OLARTE MARTÍNEZ, M. (Ed.) Reflexiones en torno a la música y la imagen desde la musicología española. Salamanca: Plaza Universitaria Ediciones, pp. 705-746.

${ }^{298}$ Iniciada por Harry Potter y la piedra filosofal (Dir. Chris Columbus, 2001)

${ }^{299}$ Dir. James Cameron, 1997.

${ }^{300}$ Dir. Richard Donner, 1978.

${ }^{301}$ Dir. George Lucas, 1977.
} 
medio, esencialmente, de sus argumentos. Por tanto, como puede observarse, se trata de establecer una categorización en la cual se apunte el grado de intencionalidad pedagógico-musical en el producto, lo cual no implica que con las producciones situadas en los estratos superiores del esquema anterior se logre siempre una mayor efectividad o aprendizaje musical, sino más bien una predisposición. La profundidad del proceso de enseñanza-aprendizaje dependerá más del enfoque que el docente imprima sobre el producto que de las propias características de éste. Cuando el alumno es capaz de captar, a través de la mediación guiada del docente, las sutilezas de este tipo está inmerso en un proceso de comprensión a gran escala que le hará disfrutar de aquello que detecta $^{302}$, capacitándose para entender la globalidad de la obra de arte que representa la conjunción de lenguajes en el compendio audiovisual.

\section{A. Producciones audiovisuales dirigidas específicamente al aprendizaje musical}

Existen realizaciones que tienen como principal misión transmitir uno $\mathrm{u}$ otro conocimiento. Son muy recurrentes los documentales que se centran en un aspecto concreto para que su simple visionado logre, por sí solo y al margen de otras posibles actividades que pudieran acompañarle, hacer llegar mensajes al alumnado acerca de cualquier elemento a aprender. La utilización de estos documentos audiovisuales es, probablemente, la más clásica, extendida y conocida. Por otro lado, este procedimiento, obviamente, no es exclusivo de la parcela musical, pero ha sido utilizado también en ella. De manera prototípica suele entenderse que

"un vídeo didáctico se podría definir como un mensaje audiovisual cuya función esencial es producir aprendizajes en los usuarios"

Aunque no sólo nos ciñamos a vídeos, la definición anterior podría presuponer que todo aquello inserto en él (también sus sonidos) pueden hacer que éste adquiera el sesgo de didáctico, lo cual entraña una falacia. De hecho, la inmensa mayoría de las referencias como la citada tienden a buscar la construcción de aprendizajes

\footnotetext{
302 ALSINA, P. y SESÉ, F. (1994): La música y su evolución: historia de la música con propuestas didácticas y 49 audiciones. Barcelona: Graó.

${ }^{303}$ GARCÍA-VALCÁRCEL MUÑOZ-REPISO, A. (2003): Op. cit., p. 232.
} 
exclusivamente sobre la temática, es decir, en este caso el mensaje que el vídeo pudiera transmitir y no tanto la conjunción de lenguajes que lo integra. Así, al referirse a las pautas evaluativas de este tipo de medios, la autora recién citada reseña que, fundamentalmente, habría que observar tres elementos: la relevancia de la explicación que transmiten, la estructura organizada de la información y la existencia de materiales complementarios, facilitadores del aprendizaje ${ }^{304}$.

En este apartado, nos centramos pues en cualquier formato que, por medio de una focalización argumental específica, persigue unos aprendizajes concretos. Como apuntamos previamente, amén de reportajes temáticos independientemente de su lugar de origen, destacan por su éxito y operatividad, especialmente hace unos años, la serie de conciertos didácticos en los que Leonard Bernstein ${ }^{305}$ tan pronto glosaba un periodo musical como una técnica compositiva o un estilo concreto. Así, bien como ampliación explicativa bien como acicate para el alumnado, pueden entenderse como elementos de enseñanza basados en su argumento.

\section{B. Producciones audiovisuales que combinan la faceta lúdica con la instrucción musical}

Los esfuerzos por acercar las estructuras del lenguaje musical al niño por medio de programas infantiles que atrajeran su atención han tenido su culminación en la serie Little Einsteins ${ }^{306}$. Debido a su emergencia en los últimos tiempos, especialmente por la generalización de canales temáticos accesibles por la televisión digital terrestre, son muchos los docentes de educación musical que tratan de captar sus particularidades para adaptarlas al aula, ya que ven como, de manera indistinta, pueden poner en contacto a los alumnos con música de cualquier compositor como mostrarles las interioridades de sus partituras. De hecho, el nudo en torno al cual gira cada capítulo es precisamente la utilización de un fragmento, no obligatoriamente conocido para el profano, que forma parte de la historia que se narra y que, como principal aportación, es presentado sobre pentagrama, iluminando aquella nota que suena en cada momento ${ }^{307}$. No obstante,

\footnotetext{
${ }^{304}$ Ibid., p. 232-233.

${ }^{305}$ Roger Englander, Estados Unidos.

${ }^{306}$ Op. cit.

${ }^{307}$ Entre los interesados por la evolución de estos materiales en el plano musical, y por la música de cine y su orientación didáctica general, hacemos referencia a cómo docentes que trabajan con las edades propias de la enseñanza primaria, como es el caso de David Martín Félez, manifestaron en el IV Simposio
} 
superada la perplejidad de encontrar una mina de este calibre en el panorama de las programaciones infantiles, surgen dificultades derivadas de su puesta en marcha en forma de desarrollos procedimientales reglados. La principal carencia que se observa es la de querer conjugar unos dibujos animados que atraen principalmente a niños de muy corta edad con elementos musicales significativos pero a menudo complejos ${ }^{308}$.

Por otro lado, sagas como Érase una vez la música ${ }^{309}$, con materiales interactivos que se introducen en el campo informático, aún partiendo de métodos distintos, poseen intenciones similares.

\section{Producciones audiovisuales centradas en personajes directamente involucrados en el arte musical. Biopics musicales.}

\section{El tratamiento didáctico del biopic. La dupla significatividad / falacias.}

Como decimos, la traslación de la utilidad de las películas en otras áreas pedagógicas a la de música da como consecuencia que ésta pueda ser tratada del mismo modo que las anteriores. Insistimos en que al hablar de este tipo de aproximación, no incidimos directamente sobre el concepto de didáctica de la música del audiovisual sino que, más bien, el aprovechamiento pedagógico viene determinado por la trama y no por la música que la acompaña aunque ésta determine el resultado del audiovisual en cuestión. De este modo, si en el cine histórico esto ocurre con películas que narran los acontecimientos relevantes ocurridos en una determinada franja temporal y el documental hace lo propio con un contenido específico, los paradigmas de estas aplicaciones didácticas serían películas que abordasen la vida de músicos insignes, esto es, biopics musicales. Estas cintas, sin ser en origen pedagógicas, servirían para ilustrar una época musical, el entorno vital de un compositor, su obra, etc.

Existen ejemplos publicados al respecto, que explicitan un método de trabajo bastante habitual (dentro de la escasez de planteamientos metodológico-musicales en

\footnotetext{
"La creación musical en la banda sonora" (Salamanca, 2008) su predisposición al uso de estos materiales de manera expresa.

${ }^{308}$ Por citar algunas de las muchas composiciones que se abordan, apuntamos las que inician cada temporada: Temporada $1^{a}$ (Episodio "Ring around the planet") Sinfonía 9, del Nuevo Mundo, de A. Dvorák; Temporada 2a (Episodio "Quincy and the magic instruments") Suite El lago de los cisnes, de P. I. Tchaikovsky. En todo caso, el recorrido por la historia de la música y las aportaciones en clave pictórica paralelas son innumerables.

${ }^{309}$ Colección de 13 libros y otros tantos discos compactos editados por Planeta.
} 
torno a la música de cine). Así por ejemplo, Dusil Diéguez ${ }^{310}$ a través de una propuesta práctica muestra cómo Amadeus $^{311}$ puede ser utilizada para estructurar el conocimiento de determinadas construcciones adheridas a la vida y obra de Mozart. En el artículo al que hacemos referencia, la autora defiende cinco marcos de actuación sobre el discurso audiovisual: el contexto histórico-musical, la situación del músico, el proceso compositivo, los ideales clásicos, la relación padre-hijo y la figura de Salieri. Como puede apreciarse, en su aplicación pedagógica no existe en ningún momento interacción con la banda sonora que igualmente argumenta la película, debido a que el interés se centra en dar claves explicativas al margen de patrones audiovisuales, los cuales pasan inadvertidos por irrelevantes para el caso concreto que esta autora aborda.

El valor de los biopics y otras producciones audiovisuales similares, por tanto, reside también en el volteo de su orientación inicial hacia un fin didáctico. Este proceso de mediación, podrá ser más o menos dificultoso en ocasiones, debido a las propias características del biopic. Así, en determinados niveles de la educación primaria se pueden abordar, por ejemplo, por medio de dibujos animados orientados a estas edades $\mathrm{y}$, en años sucesivos, la tipología de películas puede ganar en profundidad $\operatorname{argumental}^{312}$. En cualquier caso, la determinación en el uso de actividades previas y posteriores dependerá del grado de profundización al que desee llegar el docente y la intención pedagógica con que observa el producto audiovisual, es decir de un mero entretenimiento a una poderosa arma de actuación general.

Tenido ello en cuenta, son muchas las herramientas que el trabajo a partir del argumento capacita al docente para usar estrategias de aplicación dentro de las aulas de educación musical, siendo los enfoques que puedan adoptarse muy variados. Se constata pues la existencia de un vasto campo de recursos. Reproducimos un fragmento de García Laborda al respecto:

"La vida de los grandes músicos clásicos, especialmente la de los más célebres, es suficientemente interesante como para ser llevada a la pantalla con más o menos carga de ficción, por lo que los cineastas se han sentido atraídos

\footnotetext{
${ }^{310}$ DUSIL DIÉGUEZ, R. (2007): Op. cit.

${ }^{311}$ Dir. Milos Forman, 1984.

${ }^{312}$ En ambos extremos, por ejemplo, podríamos situar alguna de las "Animated Heroes Series" (como sería el caso específico de Beethoven) puestas en funcionamiento por el canal Discovery Education y Todas las mañanas del mundo (Dir. Alain Corneau, 1991), en torno a la figura de Marin Marais.
} 
por el tema y ha hecho uso abundante de este género, con acomodación e inserción de contenidos más o menos ficticios. Este tema es amplísimo y permite varios planos de análisis según las distintas perspectivas que pueden aparecer en el tratamiento del mismo:

- clase de música: clásica, jazz, rock, pop, etc.

- tipos profesionales de músicos: compositores, cantantes, directores o intérpretes, etc.

- tipo de producto que emerge: documental, biopic, película, series en la televisión, vídeos, etc.

- tratamiento del tema: biográfico o semibiográfico, aspectos generales sobre vidas de músicos o sobre personas concretas históricas, etc."313.

Con ello, las películas que utilizan alguno de estos aspectos son una fuente inestimable de acercamiento a lo musical en el plano educativo. De entre la amplia gama de filmes potencialmente utilizables, cumplen con la máxima docente de conexión con el alumnado 1) aquellos que se centran en las peripecias de músicos extremadamente famosos (en tanto en cuanto pueden erigirse en sujetos de aprendizaje significativo con relativa facilidad) y 2) aquellos que, además, han supuesto un éxito de taquilla y son relativamente cercanos en el tiempo (ya que implica que los alumnos puedan, igualmente, saber de la existencia de la película e incluso la hayan visto proyectada con anterioridad a la propuesta didáctica que se articule para ellos).

Para desentrañar el razonamiento anterior podríamos argumentar que hay infinidad de películas que se han servido, por ejemplo, de la música de Mozart $^{314}$ y varias de ellas han vertebrado apartados más o menos extensos de la vida del genio de Salzburgo, pero no todas tendrán el mismo potencial significativo al abordarlos dentro del aula de educación musical ${ }^{315}$. Que Mozart es un "personaje de cine” es un hecho. Radigales lo ratifica del siguiente modo:

313 GARCÍA LABORDA, J. M. (2005): "Músicos en el cine (biografías cinematográficas de músicos)". OLARTE MARTÍNEZ, M. (Ed.) La música en los medios audiovisuales. Salamanca: Plaza Universitaria Ediciones, p. 376.

${ }^{314}$ XALABARDER, C. (1997): Enciclopedia de las bandas sonoras. Barcelona: Ediciones B, p. 468.

${ }^{315} \mathrm{Al}$ margen, por supuesto, de que gran parte del éxito de las realizaciones pedagógicas va a depender del modo en que se presente el material en cuestión. 
"Qué duda cabe que la biografía mozartiana, riquísima en su variedad de marcos geográficos (los viajes de la infancia), vastísima en su anecdotario y perfectamente documentada a través de un copioso epistolario, responde perfectamente a las pretensiones del imaginario cinematográfico" ${ }^{316}$.

Del mismo modo, el autor reseñado atestigua la existencia de un nutrido grupo de cintas que se acercan a su figura más allá de Amadeus, aquella que mayor éxito comercial ha tenido. No obstante, si en el plano pedagógico buscamos la significación, y entendemos como quedó patente en el capítulo anterior la importancia de que el propio alumno sea protagonista en la activación de los procesos de enseñanza, es preciso reconocer que este largometraje parte con la ventaja de ser más accesible que otras producciones posiblemente más fidedignas o ajustadas a la realidad vital del compositor en cuestión.

En todo caso, entendiendo el material como pertinente, una primera precaución al respecto será la que evite que los docentes caigamos en la falacia que representa el constructo del cine en general, es decir, asumir que lo que ocurre es auténtico y transmite un significado más o menos objetivo. En esos casos, ante la imposibilidad de encontrar un biopic plenamente fidedigno ${ }^{317}$, será tarea del docente articular las estrategias necesarias para hacer útil aquello que podría llevar a equívocos y ratificar los elementos que pudieran ser provechosos para nuestros fines. De hecho, al trabajar con música y películas (y ya no sólo con música de cine) hay que tener claro que no siempre -tal vez rara vez- el argumento de las mismas guardará una estricta verosimilitud con la realidad.

En ejemplos especialmente notorios como el que citamos anteriormente, la vertiente comercial del cine ha de quedar fuera de duda, por lo que, a pesar de los desmanes que se puedan narrar en el nudo argumental, se entiende el posicionamiento del docente que argumenta que:

"nunca hubiese utilizado esta película en el aula si la considerase dañina hacia la figura de ese músico tan admirado, y si lo he hecho durante muchos años, ha sido

\footnotetext{
${ }^{316}$ RADIGALES, J. (2009a): "Mozart en el cine: del biopic a la ópera filmada". OLARTE MARTÍNEZ, M. (Ed.) Reflexiones en torno a la música y la imagen desde la musicología española. Salamanca: Plaza Universitaria Ediciones, p. 168.

${ }^{317}$ Ibíd., p. 172.
} 
porque vez a vez se me confirmaba que los alumnos eran precisamente quienes sabían suprimir todo lo que de anecdótico tenía la película y quedarse con una profunda admiración por la personalidad y obra de W. A. Mozart”318.

Como venimos exponiendo, la labor del profesional de la educación es la de no caer en la tentación de hacer propio el discurso del filme y observarlo desde herramientas pedagógicas específicas de análisis para, en su caso, reconducirlo cara al alumnado.

\section{Ejemplo procedimental: las figuras de Mozart y Beethoven}

La clave teórica-interpretativa de aproximaciones didácticas como la que sigue, siempre ligadas al elemento audiovisual, será el sometimiento al que la saturación y la reiteración de información reduccionista induce al espectador, de modo que la forja de determinados clichés haga sencillo su aprovechamiento en el plano cinematográfico. Más allá de la censura de dicho proceso (no es este el interés que mueve la reflexión pedagógica) adquiere relevancia el hecho de detectar los modelos por los cuales la inserción sonora ratifica estos paradigmas y los robustece. Especialmente, resulta edificante para el universo educativo musical la constatación del trasvase de unas hipotéticas características innatas de compositores cuya imaginada experiencia vital quedaría esculpida en su música.

Amalgamando las ideas anteriores procedentes de los argumentos (figuras musicales insignes, ambientes de recreación histórica musical, referencias a obras clave, descripción de estructuras formales a partir del audiovisual...) tomaremos como baremo las imágenes de Mozart y Beethoven para establecer un ejemplo de realización pedagógica. Como apuntamos, en ella nos centraremos en la imagen entendida como representación que se transmite de cada uno de los genios musicales, de modo que el discurso audiovisual quede articulado a partir de las referencias al supuesto carácter de ambos, trasladable a sus obras. A partir de ese punto, la labor de conocimiento musical a través del audiovisual será una herramienta más de reflexión en el contexto educativo.

\footnotetext{
${ }^{318}$ GARBAYO MONTABES, F. J. (2005): “Amadeus (1984) e Inmortal [sic] Beloved (1994); El papel de la banda sonora en la creación de una ficción cinematográfica”. OLARTE MARTÍNEZ, M. (Ed.) La música en los medios audiovisuales. Salamanca: Plaza Universitaria Ediciones, p. 57.
} 
La pretensión principal es la de hacer que los alumnos, por medio de un acercamiento crítico al producto audiovisual, puedan comprobar hasta qué punto las obras de compositores como los reseñados representan el carácter que se les supone, de forma que la aplicación de una música de Mozart crea unas expectativas concretas y la inserción de sonidos que remitan a Beethoven hagan lo propio pero, de manera general, en un sentido expresivo opuesto. Un pequeño trabajo de campo arrojaría un buen número de características asociadas a lo mozartiano o lo beethoveniano, seguramente, sin grandes diferencias en la definición de lo primero como alegre, vivaz y divertido y lo segundo como profundo, esforzado o trascendente. Partamos pues de unas reflexiones previas acerca del aura que rodea a ambos referentes de la música occidental:

"La facilidad con la que pensamos que Mozart compuso su música queda reflejada en la asociación que hacemos de él con lo dulce, como lo hace patente el mercadeo mozartiano con los chocolates Mozartkugeln, los licores y la infinidad de Mozartcafés y tiendas de dulces que llevan su marca en todo el mundo. Con respecto a Beethoven, el compositor esforzado, tan sólo he sido capaz de encontrar un restaurante de carne con patatas y una compañía de transporte de pianos. Ello a pesar del hecho de que él -en su vida y en su música- fue un hombre, sin lugar a dudas, con un claro sentido del humor"319.

"Bart Simpson es Mozart. Es la estrella televisiva de vida fácil: arrogante, libertino y soez ha sido bendecido con un talento infinito que no ha ganado a pulso. Bart toca la 'Marcha Turca', parte destacada del hit parade de la época, a un público entregado a su brillantez. Su hermana Lisa queda relegada al envidioso papel de Salieri, trabajador infatigable y carente de chispa. ¿Quién es Beethoven? Nelson, quien conjuga brillantez al piano tañendo la 'Novena Sinfonía' con irracionalidad maleducada, riendo del poco talento ajeno con las cuatro notas características de su 'Quinta Sinfonía'. Pocas veces como en el episodio 'Margical History Tour' de Los Simpson ${ }^{320}$ un fragmento audiovisual podría condensar todo

\footnotetext{
319 NETTL, B. (2003): "Reflexiones sobre el siglo XX: el estudio de 'los Otros' y de 'nosotros' como etnomusicólogos". TRANS-Revista Transcultural de Música 7, Artículo 6. Disponible en <www.sibetrans.com/trans/trans7/nettl.htm> [Consulta 9-II-10].

${ }^{320}$ Dir. Mike B. Anderson, 2004.
} 
aquello que se quiere expresar, referido tanto a compositores como a sus obras" 321 .

En ocasiones, la presentación de personajes que derivan de una realidad pasada implica caer en simplificaciones que, repetidas con frecuencia, toman la enjundia suficiente como para perpetuarse. Al margen de la pertinencia del uso del término "romántico", no cabe duda que las características que se adhieren a la música del siglo XIX quedan tan patentes en algunas obras mozartianas (especialmente en cumbres dramáticas como Don Giovanni, K. 527) como pueda ocurrir en la obra de Beethoven $^{322}$. No obstante, la impresión generalizada es la de asociar al primero con la cuadratura perfecta, de la cual no fue el único paradigma, y al segundo con la transgresión de las fronteras formales estandarizadas. Si se quiere, el plan reduccionista puede llegar al contenido en sí de la obra, la del salzburgués fue pensada para disfrutarla inmediatamente en oposición a la beethoveniana, cuyo placer radicaría en acceder a ella tras un complicado razonamiento. Todo ello, por supuesto, amparado por la idea de que la dificultad explicativa de la obra de uno venía determinada por su galopante sordera y la graciosa delicadez del otro por su carácter infantil, que le acompañaría durante toda su vida. Nettl lo expresa haciendo referencia a que

"a pesar de que el historiador serio podría describir perfectamente a estos dos compositores en similares términos -ambos creadores dotados y talentosos, ambos adictos al trabajo, ambos creadores de una música de una elevadísima complejidad y capaces de resolver problemas significativos- la forma en que se presenta a Mozart y Beethoven a los estudiantes y el público lego muestra contrastes significativos" 323 .

Otros autores, como Cook, lo señalan del siguiente modo:

\footnotetext{
321 MONTOYA RUBIO, J. C. (2009e): "Música de cine: imágenes ilusorias del binomio MozartBeethoven”. DE LA PEÑA, C., PÉREZ, M., ALBERO, M. M., MARÍN, M. T. y GONZÁLEZ, J. M. Actas del Congreso Internacional Imagen y Apariencia. Murcia: Editum, Servicio de Publicaciones de la Universidad de Murcia, Recurso digital.

${ }^{322}$ Para ampliar este concepto, cfr. nuestro artículo MONTOYA RUBIO, J. C. (2008b): "El romanticismo de 'Don Giovanni' desde los medios audiovisuales hasta el aula de educación musical'. Ensayos 23, pp. 103-123.

${ }^{323}$ NETTL, B. (2003): Op. cit.
} 
“Tanto Mozart como Beethoven resaltan cómo pueden 'ver' o 'contemplar' la música con sólo echar un vistazo, y la comparan con una imagen [...]. Y ambos insisten en que el verdadero trabajo de composición se realiza en la mente, ya que anotarlo pasa a ser un asunto trivial" 324 .

Por los motivos expuestos, al abordar la estela de estas figuras del plano musical desde la aproximación discursiva que suponen los medios audiovisuales es preciso evidenciar la importancia del "mundo del que se habla", como parte integral del "mundo en que hablamos" ${ }^{\text {} 325}$ y que tiene como componente importante la representación de una realidad de otro tiempo. En este sentido, volviendo de nuevo a reflexiones de Bruno $\mathrm{Nettl}^{326}$, es necesario marcar la distancia conceptual entre la vida acaecida y la componenda que supone reedificar imágenes que se han desvanecido, en tanto en cuanto el Mozart vivo y el vivido "son parientes próximos y dependen el uno del otro, pero no son el mismo". Con ello, del mismo modo que en los espacios físicos se elaboran escenarios para ser vistos por visitantes y, adrede, se ocultan otros ${ }^{327}$, el plano musical es uno de los ejemplos más evidentes en los que la representación que se muestra supone un escaparate que sirve para esconder un sinfín de connotaciones y matices que, generalmente, pasan inadvertidos o quedan desvirtuados por el poder de atracción de la idea que se presenta con más consistencia. La insistencia en la reiteración discursiva no hace sino acuñar unas premisas difícilmente rompibles, en tanto en cuanto viven de unos vínculos establecidos a base de una metagramática aplastante ${ }^{328}$ pervirtiendo, desde su silente pero sonoro discurso, el sentido original que $\operatorname{poseen}^{329}$.

Así, plantearemos como punto de partida el hecho de que la música del audiovisual, entendida como un producto que contiene sus propios elementos

\footnotetext{
${ }^{324}$ En estos términos, referidos a la notación musical, Cook constata desde testimonios de los propios autores hasta qué punto los procedimientos de composición de ambos pueden resultar similares: COOK, N. (2001): Op. cit., p. 86.

${ }^{325}$ GARCÍA CALVO, A. (1989): Hablando de lo que se habla. Estudios de lenguaje. Madrid. Lucina.

${ }^{326}$ NETTL, B. (1989): "Mozart and the Ethnomusicological Study of Western Culture (An Essay in Four Movements)". Yearbook for Traditional Music 21, p. 3.

${ }^{327}$ MacCANNELL, D. (1973): "Staged Authenticity: Arrangements of Social Space in Tourist Settings". American Journal of Sociology 79 (3), pp. 589-603.

${ }^{328}$ FOUCAULT, M. (1979): Microfísica del poder. Madrid: La Piqueta.

329 MANDLY ROBLES, A. (1996): "El cante contra el discurso". 'Echar un revezo'. Cultura: razón común en Andalucía. Málaga: Servicio de Publicaciones de la Diputación Provincial de Málaga, p. 210.
} 
ideológicos, no es impermeable a la parcelación discursiva de las distintas disciplinas intelectuales, que acaban por darle espesor, consistencia y, en última instancia, por legitimarla ${ }^{330}$. En todo este proceso cobra, por tanto, especial relevancia la generación del mito según Barthes, quien lo entiende como un conjunto de representaciones mentales que influyen en la manera en que se perciben y elaboran todo tipo de relaciones, dotando a disposiciones conceptuales de una asombrosa naturalidad que, no obstante, es artificial ${ }^{331}$. En este punto, especialmente desde los trabajos etnográficos de Steven Feld ${ }^{332}$, se constata que las sociedades se sirven del mito para alimentar unos criterios de actuación altamente potentes y difíciles de derruir, ya que su existencia garantiza la continuidad de la sociedad en los términos que se ha dado para funcionar.

De acuerdo con las reflexiones que enmarcan esta parte del trabajo, no es desnortado comenzar inquiriendo al alumnado acerca de lo que pueden esperar al ver un producto audiovisual que se aproxime a las figuras musicales reseñadas en marco de la "biografía de ficción"333 como pueda ser Amadeus 334 o Amor Inmortal ${ }^{335}$, definidas como una combinación de hechos históricos e inventados que acaban por configurar una "semificción" en la cual participan, en su plano musical, algunos de los mejores intérpretes del momento. El trabajo pedagógico sobre el film de Milos Forman es casi inevitable si se quiere abordar desde el prisma que se está haciendo la imagen de Mozart: estamos ante una obra que, tras su paso del teatro a la gran pantalla ha popularizado y tal vez estigmatizado la imagen construida del salzburgués endeble y colosal, que repartía a partes iguales risas esperpénticas y genialidades. Por su parte, Amor Inmortal no puede considerarse como un largometraje que haya impactado lo suficiente como para equipararse al nivel de atracción que supuso la irrupción de Amadeus diez años antes, pero sí es posible que, a partir de las características que se deriven de esta obra en conjunción con otra más reciente, Copying Beethoven ${ }^{336}$, se puedan establecer los criterios didácticos que pretendemos que los alumnos desenmarañen.

\footnotetext{
${ }^{330}$ FOUCAULT, M. (1999): El orden del discurso. Barcelona: Tusquets.

${ }^{331}$ BARTHES, R. (1980): Mitologías. México: Siglo Veintiuno Editores.

332 FELD, S. (1982): Sound and sentiment. Birds, Weeping, Poetics, and Song in Kaluli Expression. Philadelphia: University of Pennsylvania Press.

${ }^{333}$ GARCÍA LABORDA, J. M. (2005): Op. cit., p. 378.

${ }^{334}$ Milos Forman, 1984.

${ }_{335}$ Bernard Rose, 1994.

${ }^{336}$ Agnieszka Holland, 2006.
} 
En el caso de Beethoven, la ligazón música-vida tendrá su vínculo más estrecho en la aludida sordera, aunque también habrá espacio para otros asuntos como

"su relación con sus hermanos y en especial con su sobrino Kaspar, su admiración y posterior desprecio por Napoleón, el carácter huraño y misántropo, y desde luego, el carácter apasionado de su correspondencia"337.

Por tanto, desde el inicio de cualquier discurso audiovisual se entiende que habrá una serie de ideas preconcebidas en torno al carácter del compositor que guiarán tanto la trama del filme como la presentación de sus obras. Maliciosamente, en el caso de Copying Beethoven puede intuirse, tal vez con demasiada carga de presunción, que incluso el título de la película alude no sólo a la copista que copotragoniza el largometraje sino que la polisemia del término "copying" (con la adición de la conjunción "with") puede conducirnos a interpretar que, además, el meollo del film es "tratando con" o "enfrentándose con" Beethoven, suposición impensable desde el prisma de Mozart, el otro gran genio que nos hemos dado como punto de partida de la aplicación.

El ejercicio pues consistiría en presentar al alumnado una serie de dimensiones relevantes en los largometrajes reseñados para, a partir de ellos, desmontar si fuera preciso las ideas preconcebidas y tratar con mayor rigor cada una de las situaciones, aplicaciones musicales o cualquier otra faceta. No se trataría tanto de perseguir el rigor histórico de los hechos que se narran en el filme, como de realizar un trabajo de reflexión e investigación sobre la asimilación de planteamientos que pudieran penetrar aviesamente generando ideas distorsionadas de la realidad. Algunas de ellas podrían circular en torno a las tramas, los posicionamientos de los personajes ante el valor estético ajeno, la interpretación de los momentos musicados del producto audiovisual y el legado que los protagonistas dejarían a las futuras generaciones.

a) Las tramas.

La música de Mozart viene directamente de Dios, y el compositor simplemente se limita a proyectar los efluvios divinos y plasmarlos en el pentagrama (de modo que todo

${ }^{337}$ GARBAYO MONTABES, F. J. (2005): Op. cit., p. 55. 
es revelado con gran nitidez), mientras que las partituras beethovenianas son el resultado de un arduo esfuerzo mental y su acabado, por tanto, es tan perfecto que precisa de una labor de mediación para entenderlas en su plenitud.

En este sentido, respecto al primero son comunes aseveraciones altamente estereotipadas como la que sigue:

“[Mozart] no hace teología sino que deja pasar a través de él en su música 'algo’ que viene más allá de sí mismo y que, al mismo tiempo, brota de lo más profundo de sí. Mozart no sabe que su música dice a Dios -o a la creación resucitada- o si lo sabe, es con un saber inconsciente, un 'saber ignorante' ,338.

Amadeus nos presenta a un compositor que, arrogantemente, es capaz de constatar la trascendencia de su genial música, pero que, para su desgracia, desconoce los rudimentos que le han hecho llegar a tan privilegiada posición. Por su parte, el actor Ed Harris, protagonista de Copying Beethoven, atestigua la presencia de Dios en su obra a través de la búsqueda de la divinidad, por lo que estamos ante un camino inverso al anterior, el trabajo de Beethoven consistiría en llegar a la deidad a través de un duro esfuerzo: "las vibraciones en el aire son el aliento divino hablando con alma de hombre, la música es el lenguaje de Dios, los músicos estamos tan cerca de Dios como es capaz de estarlo un hombre, oímos su voz, leemos sus labios, damos salud a los hijos de Dios para su alabanza, eso es lo que somos los músicos Anna, y si no somos eso no somos nada" (Copying Beethoven).

Los ejemplos para nutrir la explicación alrededor de la idea de la transferencia de la iluminación de uno y otro son constantes en los tres largometrajes seleccionados, y sería relativamente sencillo urdir una red de secuencias valederas para tratar el asunto dentro de las aulas. En Amadeus, tal vez sea el uso del personaje creado para Antonio Salieri el que con más recurrencia nos conduzca a esa perspectiva (hay que recordar que a través de él Dios se torna en un personaje más de la trama) en tanto en cuanto constata una y otra vez que todos los elementos musicales generados por el salzburgués no podían provenir de un "mono amaestrado" y que, en realidad, tras ellos sólo era posible entrever la figura de Dios. En contraposición, tanto Amor Inmortal como Copying

${ }^{338}$ ORTEGA, F. (2006): “Mozart, amado de Dios". Revista Teología 90, p. 345. 
Beethoven nos hacen testigos del esfuerzo más terrenal por explorar los métodos de acceso a los destellos divinos. La desesperación y las dificultades son parte integral del proceso compositivo beethoveniano el cual, literalmente, se suda nota a nota.

En suma, todos los argumentos cinematográficos ratificarían las ideas que la literatura explicativa ha ido generando durante años y años: Beethoven representa "el esfuerzo de un corazón salvaje por dominar todas las pasiones" y Mozart posee una claridad "regalada", que no ha de ser conquistada ${ }^{339}$, de modo que

“mientras que las óperas de Mozart revelaban la plenitud de su genio, la ópera de Beethoven era la demostración de que ni siquiera con mejores textos hubiera podido revelar en ellas el suyo. No soportaba éste la amalgama de la ópera, mientras que la música absoluta era para él un oro líquido que sólo parecía aguardar que sus manos lo acuñaran",340,

por lo que la manera más lógica de proceder bien podría ser la siguiente:

"Beethoven encuentra un tema; no está contento; lo cambia hasta que puede utilizarlo; un procedimiento que apenas si cabe señalarlo en Mozart. Éste procedía como el físico Gauss, de quien es la frase: 'El resultado ya lo tengo, y ahora sólo me falta la prueba', ,341.

No cabe, dentro de los estrechos márgenes que se presentan, huecos para la inspiración de uno (únicamente perceptible si esforzado) y la perseverancia y el trabajo duro del otro (sólo comprensible desde el fluir de notas carentes de reflexión). Por todo ello es perentorio que el alumnado se aproxime, igualmente, a textos que induzcan a explicaciones alternativas, que reflejen las dudas y dificultades de Mozart en la composición $^{342}$, que descubran enmiendas, tachaduras y equivocaciones, que constaten su esfuerzo intelectual por, por ejemplo, acoplar los elementos musicales a los

\footnotetext{
${ }^{339}$ LUDWIG, E. (1994): Beethoven. Madrid: Anaya \& Mario Muchnik, p. 235.

${ }^{340}$ Ibíd., p. 210.

341 Ibíd., p. 217.

${ }^{342}$ Por ejemplo al comentar a su padre las dificultades que encontraba al armonizar determinados pasajes manteniendo indemnes los parámetros expresivos: MOZART, W. A. (1997): Cartas. Barcelona: Siruela, p. 195.
} 
caracteres dramáticos ${ }^{343}$, o que muestren cómo el camino del ingenio y las obras sublimes venían de la mano de mucho trabajo y dudas, como fue el caso de la soberbia composición final de aria "Deh vieni, non tardar, o gioia bella", de Las bodas de Fígaro $^{344}$. En tanto en cuanto no son expresiones propias del Mozart que nos ha llegado, su valor pedagógico es aún mayor.

b) Posicionamientos ante el valor estético ajeno.

El modo en que son presentadas las figuras de Mozart y Beethoven en los casos reseñados suele ser bastante uniforme. A ambos se les capacita, como no puede ser de otro modo, para reconocer el verdadero calado de las producciones musicales ajenas, identificando cuando éstas tienen valor y cuando son meras realizaciones automáticas, exentas de contenido trascendente. No obstante, la respuesta de cada uno de los personajes será bien distinta. Por un lado, el salzburgués, dentro de la chabacanería perfilada para él, supera intuitivamente los patrones que se le presentan (recordemos por ejemplo la tan referida escena de Amadeus cuando a partir de una pieza para piano de Salieri, Mozart monta toda una estructura musical que dará pie, de manera impensada, a un esbozo de su singspiel El rapto en el serrallo). Por su parte, Beethoven, en innumerables ocasiones, bien se mofa de la poca expresividad de aquello que tiene ante sí (como ocurre con la composición que su entusiasmada copista le ofrece) bien se muestra iracundo y desgarrador ante la incomprensión que le supone tener que dar mérito a realizaciones que, desde su punto de vista, no la tienen (como ocurre al destrozar, también en Copying Beethoven, una maqueta arquitectónica argumentando que está carente de alma).

c) La música y los silencios contenidos en el producto audiovisual.

La aplicación musical en referencia a Mozart va a enfatizar la vivacidad y alegría que se supone al personaje y su vida ${ }^{345}$, mientras que la música asociada a Beethoven

\footnotetext{
${ }^{343}$ ROBBINS LANDON, H. C. (1990): Mozart. Los años dorados 1781-1791. Barcelona: Destino, pp. 67 ss.

${ }^{344}$ KUNZE, S. (1990): Las óperas de Mozart. Madrid: Alianza, p. 333.

${ }^{345}$ Es curioso observar que casi con exclusividad se logran derruir estas concepciones apriorísticas en realizaciones muy concretas que buscan, por medio de un razonamiento profundo, que la fusión de música y cine se haya de entender desde un plano intelectual elevado. Testigo de esta superación son obras de Pier Paolo Pasolini, tal como pusieron de relieve RADIGALES, J. (2009a): Op. cit., p. 170; SOLANAS DÍAZ, V. (2009): "Teorema, de Pier Paolo Pasolini: Estudio de la banda sonora musical".
} 
nos trasladará al pensamiento profundo a partir de la razón que él mismo aplicaba a todo lo que su atormentado mundo interior le llevaba.

Como es de esperar, todo tratamiento audiovisual que aluda tan directamente a la vida y obra de compositores de este tipo ha de nutrirse, por motivos de eficacia y concordancia, con música acuñada por ellos. Esta manera de proceder, con altos toques de operatividad, gana en significatividad y narratividad cuando las obras que se incluyen sirven para definirse no sólo a sí mismas sino, especialmente, al carácter de su autor. Por tanto, es sumamente interesante atender al modo en que los sonidos dejan de denotar y pasan a connotar, esto es, cómo la música de cada autor deja de ser un marco genérico que apunta, indica o aclara y se torna en agente de adición de sentidos escondidos, los cuales son los verdaderamente importantes, debido a su ocultamiento tras la supuesta denotación. Con ello dejamos de lado el mero acompañamiento sonoro, nos centramos pues en el contenido expresivo de la propia música ${ }^{346}$.

d) El legado.

En este aspecto, es de realzar la sensación de que aquello que Mozart realizaba formaba parte de un presente vital, al que éste se circunscribía en tanto en cuanto la música le fluía, mientras que en Beethoven siempre existía un poso de trascendencia razonada, entendida por el propio autor. Frente a expresiones mozartianas (tal vez sería más correcto "amadeusianas") como "yo puedo ser vulgar, os aseguro que mi música no lo es" (aludiendo a la incomprensión que en el propio autor suponía su obra, venida del más allá), Beethoven se presenta como el buscador de ensamblajes con la posteridad desde lo humano, presentando un legado para el hombre desde lo terrenal. Las influencias de estas presunciones en la música de uno y otro han llegado hasta nuestros días y han perfilado nuevos discursos que, apoyados en sus músicas, llenan películas, sintonías y anuncios. Por ello, sería conveniente hacer que el alumno fuera capaz de atisbar las derivaciones efectivas que toda esta idealización conlleva en las sociedades

OLARTE MARTÍNEZ, M. (Ed.) Reflexiones en torno a la música y la imagen desde la musicología española. Salamanca: Plaza Universitaria Ediciones, pp. 859-874.

${ }^{346}$ Elemento profusamente tratado y muy claramente argumentado en OLARTE MARTÍNEZ, M. (2002): "La música incidental en el cine y el teatro". BANÚS, E. (Ed.) El legado musical del siglo XX. Pamplona: Ediciones de la Universidad de Navarra, pp. 151-179; OLARTE MARTÍNEZ, M. (2001): Op. cit. 
actuales, en las cuales el conocimiento toma cuerpo, en repetidas ocasiones, en ámbitos informales procedentes de los medios de comunicación ${ }^{347}$.

En suma, y tratando de resumir los puntales elementales de la argumentación anterior, se observa como la música de uno u otro autor pueden ser objeto de una interpretación muy concreta, y más allá de su propia aparición casual es reincidente la causalidad de dichas apariciones. En otro plano estilístico estos mecanismos serían similares a los expuestos tan acertada como ingeniosamente por Judith García Martín ${ }^{348}$ para las transferencias que se suceden en la interpretación de melodías que implican inequívocamente una significación extra, la que aporta la corporerización de las ideas sonoras.

\section{Producciones audiovisuales que tienen en lo musical un anclaje argumental decisivo}

Por supuesto, se sobreentiende como anclaje o fundamento decisivo aquel que se sustenta en el argumento del producto audiovisual. Como no puede ser de otro modo, entendemos que toda realización que combina sonidos e imágenes poseen un "anclaje decisivo" tanto en lo uno como en lo otro. Hecha la pertinente aclaración, nos referimos a aquellas producciones en las cuales lo musical emerge como parte consustancial al propio argumento. Para partir de un prototipo que evidencie el grupo de audiovisuales a que nos referimos, citaremos la película de dibujos animados El $_{\text {cisne }}$ mudito ${ }^{349}$, cuyo título original en inglés The Trumpet of the Swan, deja más claves interpretativas al respecto de su argumento: un pequeño cisne que, debido a su problema para articular sonidos y entenderse con sus iguales, aprende (entre otras cosas como leer y escribir) a tocar la trompeta, lo cual le lleva a triunfar como instrumentista. De su visionado los alumnos podrían alcanzar conocimientos relativos, por ejemplo, al funcionamiento y timbre organológico del viento-metal o a aspectos derivados de la cultura musical como los macroconciertos y espectáculos musicales.

\footnotetext{
${ }^{347}$ Un acercamiento a muchos de los ejemplos de esta idealización en MONTOYA RUBIO, J. C. (2009e): Op. cit.

${ }^{348}$ GARCÍA MARTÍN, J. H. (2009): “What a Wonderful World' o la construcción de mundos simbólicos”. OLARTE MARTÍNEZ, M. (Ed.) Reflexiones en torno a la música y la imagen desde la musicología española. Salamanca: Plaza Universitaria Ediciones, pp. 903-919.

${ }^{349}$ Dir. Terry L. Noss y Richard Rich, 2001.
} 
Ahondando entre los innumerables ejemplos extrapolables al aula de educación musical, destacamos uno con cierta actualidad y repercusión entre los más pequeños: Barbie y el castillo de diamantes ${ }^{350}$, en el cual las canciones son la piedra angular de la amistad entre las protagonistas y la música la que mueve toda la trama. Más cercano a un alumnado de mayor edad es el contexto mostrado en cintas como Los chicos del coro $^{351}$, lo cual puede servir para aproximar a los discentes a innumerables ámbitos musicales, tales como los gestos básicos de dirección coral (detallados con gran claridad por el protagonista), el estudio de tipológico de las voces humanas (a partir de la observación del nítido timbre infantil), las agrupaciones corales (especialmente el coro de voces blancas), elementos derivados de la técnica vocal (impostación y proyección de la voz, resonancia, fraseo...), el carácter que se asocia a los cambios de tempi sobre una misma melodía (en este caso muy reiterativa), las texturas de las diversas composiciones musicales (ejemplos notorios, principalmente, de homofonía y entradas en estilo fugado) o a dar sentido a términos que aparecen en el transcurso de la película, todos ellos referidos a la comprensión de la música como lenguaje.

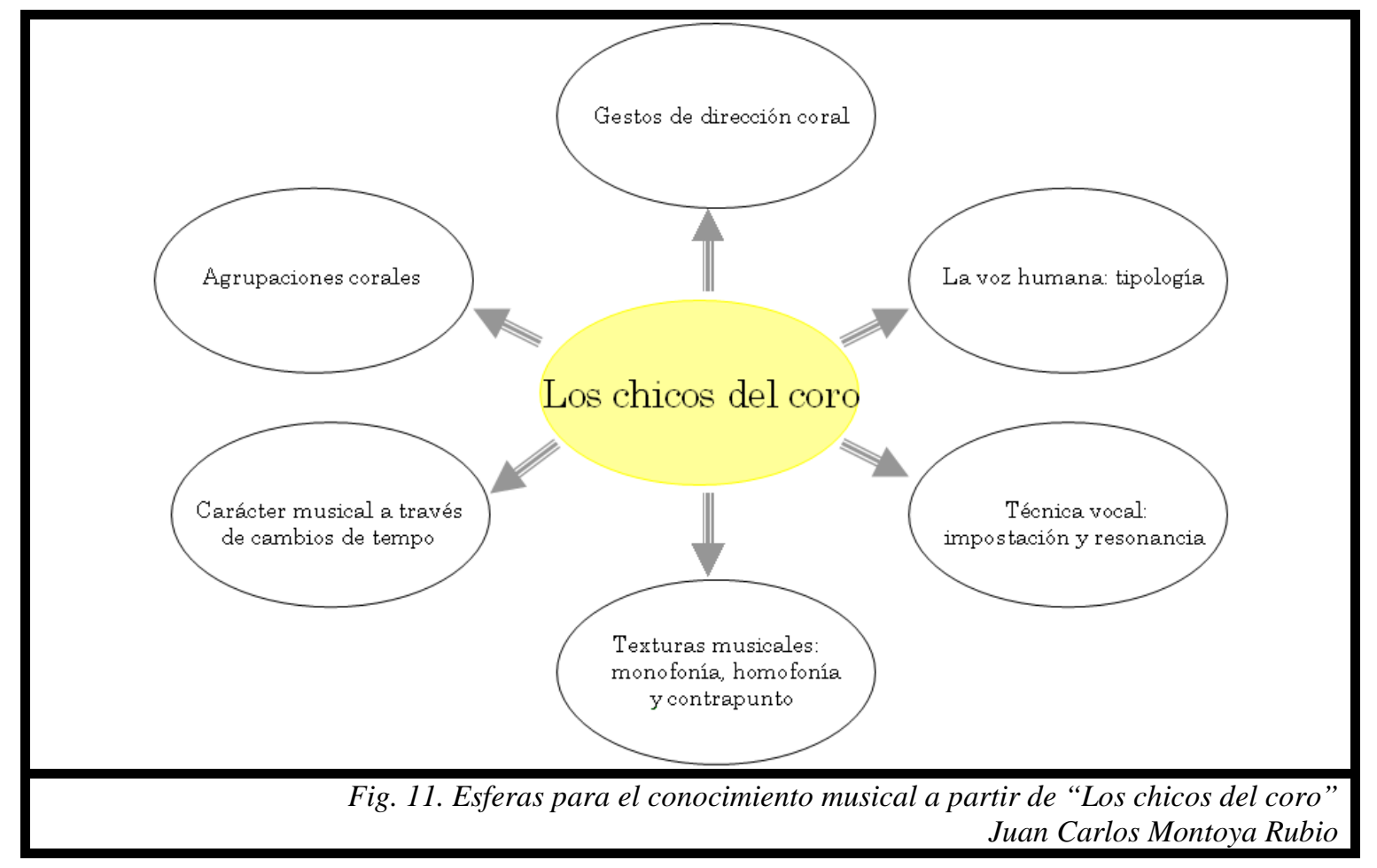

\footnotetext{
${ }^{350}$ Dir. Gino Nichele, 2008.

${ }^{351}$ Dir. Christophe Barratier, 2004.
} 
A pesar de la evidente carga de significatividad del ejemplo anterior, tal vez, uno de los casos de mayor actualidad sea el fenómeno de la teleserie argentina Patito Feo ${ }^{352}$, que causa auténtico furor entre niños con un rango de edad muy amplio. En esta producción, las vivencias de los adolescentes protagonistas se desenvuelven en el marco de un colegio donde prima lo musical, el canto y el baile. Como puede intuirse, a partir de esa combinación de elementos puede resultar relativamente sencillo encaminar algunos de sus elementos al conocimiento musical dentro de las aulas. Apuntamos un ejemplo en la siguiente imagen:

\begin{tabular}{|c|c|}
\hline \multicolumn{2}{|c|}{ Patito feo } \\
\hline ELEMENTOS DE LA TELESERIE & DERIVACIÓN DIDÁCTICA \\
\hline $\begin{array}{l}\therefore \text { Cuadros con imágenes de compositores pendiendo de las } \\
\text { paredes de los despachos y salones }\end{array}$ & $\therefore$ Conocimiento de la historia de la música \\
\hline$\therefore$ Entorno: El "Pretty Land School of Arts" & $\begin{array}{l}\because \text { Conocimiento de las instituciones que se dedican a la } \\
\text { enseñanza de la música }\end{array}$ \\
\hline $\begin{array}{l}\therefore \text { Desarrollo de diversas canciones por parte de los } \\
\text { protagonistas }\end{array}$ & $\begin{array}{l}\therefore \text { Conocimiento de estructuras formales, intervalos concretos, } \\
\text { tipos de voces... }\end{array}$ \\
\hline$\therefore$ Apariciones de cantantes famosos (Fito Páez, Juanes...) & $\begin{array}{l}\because \text { Conocimiento de estilos y músicas propias de los autores en } \\
\text { cuestión }\end{array}$ \\
\hline$\therefore$ Fragmentos de música incidental & $\begin{array}{l}\because \text { Conocimiento y distinción entre los modelos culto y popular } \\
\text { a través de la organología que trata de identificarlos }\end{array}$ \\
\hline
\end{tabular}

Lo mostrado no es más que una aproximación que puede ser llevada tanto más lejos como el docente estimase oportuno, ya que en nuestra intención sólo está señalar las líneas maestras del tipo de producción a la que nos referimos. Los cinco elementos destacados en la imagen anterior son:

Primeramente, la aparición de cuadros en los que se intuye, porque no es habitual verlos con nitidez, el rostro de grandes genios de la música occidental. Obviamente el tipo de conocimiento que se puede obtener focalizando la atención del alumnado hacia ellos es el que los aproxime a la historia de la música a través de sus nombres más relevantes. En segundo lugar, reseñamos el entorno en que se desarrolla la acción, un peculiar colegio donde prima la música, especialmente en sus formas de canto y baile,

${ }^{352}$ Dir. Jorge Montero, 2007. 
por encima de cualquier otra contingencia. A partir de la observación de este contexto se puede llegar, por ejemplo, al comentario sobre las instituciones musicales y el modo en que éstas desarrollan su labor. Mucho más atractivo para el alumnado suele ser partir de la tercera de las dimensiones apuntadas, las canciones y coreografías que aparecen en todos los episodios de la serie. En este sentido, planteamos la posibilidad-siempre ampliable- de detenerse en determinados aspectos como las estructuras formales de la composición, los giros interválicos, la técnica de vocalización, etc. Como cuarto elemento, llamamos la atención de la inclusión de estrellas de la música invitadas a determinados episodios y que pueden dar lugar a encaminar los conocimientos musicales hacia aspectos más alejados de las esferas sonoras que se manejan en la teleserie. Los ejemplos referidos de Fito Páez o Juanes aluden a dicha distancia estilística. Por último en el esquema presentado, se fija la atención en los instrumentos que acompañan de manera incidental a alguna de las escenas que, prototípicamente, suelen remitir a timbres más o menos "clásicos", en función de la sonoridad que se consigue a través de la asociación de unos u otros instrumentos musicales.

Como quedó expuesto, se trata sólo de aproximaciones manifiestamente ampliables no sólo ya desde el plano musical, sino incluso desde el de la transversalidad, trabajando derivaciones como por ejemplo la educación para el consumo responsable, a partir de la ingente cantidad de productos comercializados bajo el paraguas de los personajes de la teleserie (cromos, álbumes, accesorios escolares, etc.).

\section{E. Producciones audiovisuales que desarrollan tópicos musicales}

Antes de abordar desde la aproximación metodológica-musical los tópicos que se adhieren al audiovisual conviene acotar a qué nos estamos refiriendo exactamente. Destacamos dos acercamientos al respecto, el primero extraído de la reflexión y el conocimiento de posturas teóricas concretas y un segundo que parece fundamentarse en la particular visión del autor de la cita:

"Códigos culturales. Son los tópicos, clichés o códigos musicales que transportan significados implícitos, por lo que el auditor familiarizado con el 
lenguaje de dichos códigos musicales les asocia 'significados secundarios'. Pueden ser desde estructuras motívicas concretas hasta el timbre de un instrumento. La mayoría fueron establecidos en los principios del cine, aunque muchos provienen del siglo XIX. En este sentido es interesante observar cómo se asocian a géneros cinematográficos" 353 .

"Calificamos de tópico a aquellas músicas estandarizadas que se utilizan siempre en lugares comunes. En documentales: el pasodoble en los toros; la marcha americana en el fútbol; la polca rápida en las carreras ciclistas; la marcha nupcial en las bodas, etc., son tópicos que debemos eludir. Bien es verdad que la sustitución de estas músicas "tradicionales" resulta aventurada especialmente si no se acierta con una buena alternativa. Además, hay que reconocer que los códigos culturales de nuestra civilización, la occidental, nos transmiten conceptos y sentimientos difícilmente sustituibles, cosa que no ocurrirá si son aplicados a otras colectividades con diferente cultura. Pero no es imposible. Para ilustrar la filmación de una corrida de toros, por ejemplo, siempre que el ambiente no tenga que se objetivo, tendremos presente cómo está desarrollada la faena: con animación, con apatía, con solemnidad, atropelladamente... en definitiva la situación ambiental concreta, y entre la música de estilo español, buscaremos aquella que mejor encaje en lo que estamos presenciando. Lo único que debemos respetar, en este caso, es el código cultural (estilo español) para que la innovación no esté completamente fuera de lugar.

Para otras ambientaciones donde el tópico es habitual procederemos del mismo modo, pero, siempre dejando un punto de contacto que psicológicamente nos una a lo tradicional que, por serlo, se supone congruente. De no respetar este punto el espectador al encontrar "extraña" aquella ambientación, desentendiéndose momentáneamente de lo que ocurre en la pantalla, en detrimento de la imagen y la locución.

\footnotetext{
${ }^{353}$ FRAILE PRIETO, T. (2009b): Op. cit., p. 92. La autora llama la atención sobre la nomenclatura de "style topics" y "cultural musical codes" que éstos reciben respectivamente en los siguientes textos: NEUMEYER, D. y BUHLER, J. (2001): "Analytical and Interpretative Approaches to Film Music: Analysing the Music". DONNELLY, K. L. (Ed.) Film Music. Critical Approaches. New York: Continuum International, pp. 16-38; GORBMAN, C. (1987): Op. cit.
} 
En programas dramatizados los tópicos quedan patentes en la utilización de melodía de violines en escenas amorosas; trinos en la tesitura aguda de la cuerda en los momentos de tensión; redobles de timbal para los trágicos; etc., efectos musicales fácilmente sustituibles por poco que utilicemos la imaginación. Debería bastar con ser conscientes de su existencia para desechar cualquier tópico musical"354.

Sin duda, de la primera cita, que acoge una definición del tópico como portador de elementos secundarios a su demonización en la segunda hay una amplia distancia que, en todo caso, no nos incumbe rastrear en un estudio como éste en el cual, básicamente, interesa el tópico como realidad que está presente y puede ser dirigida hacia el aprendizaje musical. Desde nuestra óptica, lo relevante de los tópicos musicales es que impregnan de manera irremisible la configuración de los contenidos audiovisuales. Su canalización hacia estructuras didácticas de contenido musical supone un problema relativo, ya que aunque es cierto que no nos encontramos ante productos que tienen intencionalidad pedagógica, de ellos subyacen una serie de elementos que pueden ser, a la vez, motivadores y catalizadores de aprendizajes varios. De hecho, en los tópicos podemos encontrar una buena manera de articular unidades didácticas específicas.

Entre los aspectos que sí pueden resultar interesantes para nuestros postulados teóricos y prácticos está la cuestión de la existencia de estos referentes musicales en producciones de corte infantil o juvenil, ya que no tienen por qué ser captados por los niños en los audiovisuales pero, a pesar de ello, tienen una presencia importante. De las aproximaciones teóricas que profundizan en la generación de tópicos musicales que se adhieren a determinadas producciones de corte infantil pero con trasluz adulto (porque requiere saberse la referencia primera para llegar a comprender plenamente la situación) destacamos, por su aportación de ejemplos que puedan servir como modelos de extrapolación en las aulas, los planteamientos de Mônica de A. Duarte, expuestas casi milimétricamente en dos artículos aparecidos en los últimos años ${ }^{355}$. De su lectura se

\footnotetext{
${ }^{354}$ BELTRÁN MONER, R. (2005): La ambientación musical en radio y televisión. Selección, montaje y sonorización. Madrid: Instituto Oficial de Radio y Televisión, pp. 37-38.

${ }^{355}$ DUARTE, M. A. (2009): "Un análisis retórico del proceso de creación de la banda sonora en un programa televisivo infantil (Río de Janeiro, Brasil)". OLARTE MARTÍNEZ, M. (Ed.) Reflexiones en torno a la música y la imagen desde la musicología española. Salamanca: Plaza Universitaria Ediciones,
} 
destacan algunos criterios básicos que, en cierto modo, se resumen en la siguiente afirmación:

"La producción de tópicos implica elecciones representativas del material sonoro en función de un determinado auditorio [...] [y esos tópicos] deben vigilar la eficacia del mensaje que se busca difundir" 356 .

De la cita anterior se deriva la principal controversia que la autora detecta: que el tópico inteligible sólo por un público adulto, cuando se introduce en un formato audiovisual dirigido a un público infantil, hace chirriar la teoría según la cual este elemento sonoro sirve para dar pistas interpretativas a la audiencia. Tras la aportación de algunos ejemplos, Duarte considera que es extraño aplicar este tipo de tópicos a los programas infantiles. Guiada por dichos ejemplos expone su planteamiento:

"Ante estas referencias distantes histórica y culturalmente del público infantil brasileño, nos causa extrañeza el hecho de que ese dibujo animado [Bob Esponja] sea difundido en un programa distinto a aquel público. A partir del análisis de los tópicos musicales de la banda sonora del programa, verificamos que la ironía, figura retórica, traspasa el desarrollo del argumento, siendo, sin embargo, esa ironía percibida sólo por el grupo reflexivo que tiene los elementos de información que lo capacita para tal, es decir, el público adulto"357.

En nuestra opinión, no es tan aventurado aceptar la inclusión de este tipo de técnicas, ya que su aplicación, posiblemente, no responda sólo a criterios de conexión con un grupo específico preparado para asimilar todos y cada uno de los estímulos que puedan hacer referencia, a modo de símbolo, a cualquier otro elemento, sino que tal vez puedan esgrimirse criterios de economía de medios u operatividad en su inserción. En

pp. 787-806; DUARTE, M. A. (2006): "Músicas y modas. La creación a través de la teoría de las representaciones sociales". Comunicar 27, pp. 69-77.

${ }^{356}$ DUARTE, M. A. (2006): Ibíd., p. 73.

${ }^{357}$ DUARTE, M. A. (2006): Ibíd., p. 74. 
este sentido, como hipótesis explicativas, pueden argumentarse tantas posibilidades como capacidad tengamos para indagar en el mundo de lo subjetivo. Desde nuestro punto de vista, a modo de ejemplo, apuntamos como posibles modos de entender la situación:

- Las producciones infantiles no sólo se dirigen a un público en edad infantil, sino que abren sus puertas a otro tipo de espectadores, por lo que la gama de sutilezas a presentar puede ser mayor, ya que serán captadas en una u otra medida desde las experiencias previas de cada cual.

- En íntima relación con la hipótesis anterior, la sociedad actual ha generado espacios en los que el visionado de producciones audiovisuales, especialmente cinematográficas infantiles, pueda llevarse a cabo en compañía de adultos, por lo que se pretende agradar no sólo al destinatario principal sino también al resto de “colaboradores necesarios" para que los primeros accedan al audiovisual.

- Con evidentes diferencias de unos a otros, los arreglistas y los compositores de música de cine se manejan con una serie de criterios que, llevados al extremo, pueden resultar muy complejos pero también muy simples. Abogando por el último de los casos, se puede llegar a pensar que un modo efectivo de que los responsables de implementar el sonido tengan herramientas conceptuales para hacerlo es recurrir, de uno u otro modo, a clichés.

- Sin reparar en exceso en ello, la inercia a potenciar determinados elementos sonoros y estigmatizarlos bajo un significado añadido hace que se vaya formando un público que, ya desde la infancia, empieza a asimilar claves de interpretación que le serán útiles cuando éstas se consoliden en su interior.

Por todo ello, junto con las dudas y la extrañeza que planteaba Duarte, no parece descabellado buscar claves de interpretación en la propia sociedad que vivimos:

"Hay que asumir que el nuevo entorno cultural televisivo que socializa a los niños se encuentra entremezclado con los adultos"358.

${ }^{358}$ QUIROZ, M. T. (1997): “Propuestas para la educación y la comunicación”. Comunicar 8, p. 37. 
"El devenir histórico de los medios audiovisuales demuestra que la animación, como el cine de acción real, comenzó siendo un juguete para adultos, y no tiene por qué dejar de ser motivo y motor de emociones para todos. Cualquier objeto o figura puede ser animado mediante alguna técnica específica, y las diferencias entre lo artístico y lo simplemente curioso van a estar dadas por nuestra capacidad emocional”359.

El trabajo de conocimiento musical a través de los tópicos musicales insertos en el audiovisual puede ser de muy diverso tipo. Partamos, por ejemplo, de un caso planteado por la propia Duarte reiteradamente en los dos artículos de su cuño a los que hemos hecho referencia. Acerca de la serie de dibujos animados Bob Esponja ${ }^{360}$, la autora encuentra que el recurrentemente utilizado "sonido producido con el deslizamiento de un tubo de metal sobre las cuerdas de una guitarra típica de Hawai" 361 es suficiente material para ubicar espacialmente la serie en un contexto tropical. A partir de esa conjetura, la cual sin duda parece acertada, podríamos elaborar estrategias educativas para el aula de educación musical. Éstas partirían del reconocimiento del tópico para interpretar los motivos de su inserción y aplicar derivaciones pedagógicas en relación con dichos motivos. Finalmente se plantearía la adecuación o no del tópico aplicado:

\footnotetext{
${ }^{359}$ MALETÁ COCIÑA, J. (2009): "La banda sonora en los dibujos animados: del tópico a la brevedad". OLARTE MARTÍNEZ, M. (Ed.) Reflexiones en torno a la música y la imagen desde la musicología española. Salamanca: Plaza Universitaria Ediciones, p. 583.

${ }^{360}$ Creado por Stephen Hillenburg, 1999.

${ }^{361}$ DUARTE, M. A. (2006): Op. cit., p. 73.
} 


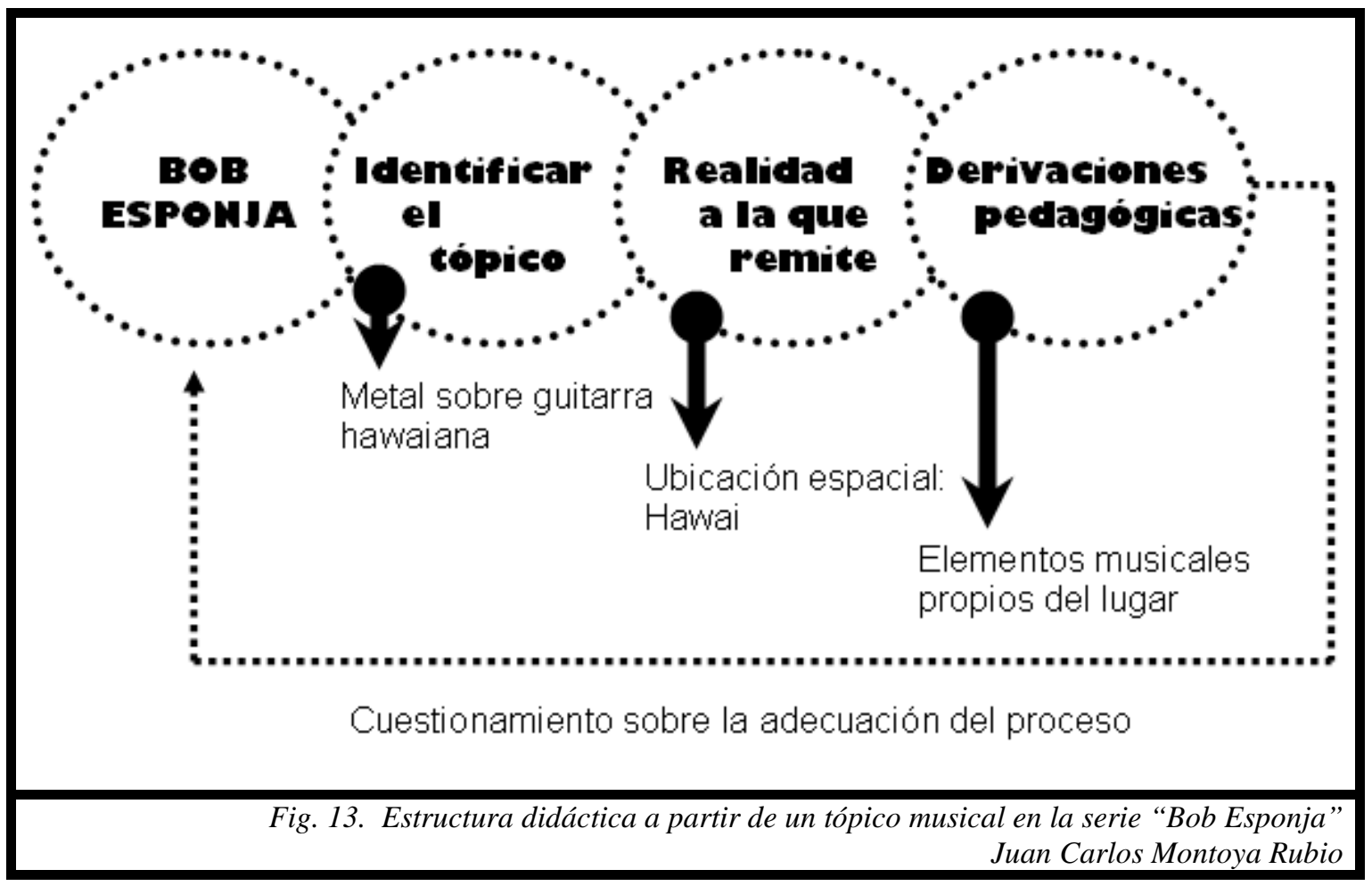

El ejemplo mostrado es un caso que remite a la generación de un tópico que raramente se encuentra en otro producto, esto es, que viene determinado por su origen ajeno al audiovisual (el aludido deslizamiento del tubo de metal no es un referente lo suficientemente potente como para encontrarse en un grupo numeroso de ejemplos). Sin embargo, la mayoría de estos tópicos tienen un origen determinado, bien desde las tradiciones musicales occidentales (y en menor medida del resto del mundo) bien desde a propia cinematografía, que se ha encargado de acuñar clichés que han sido y siguen siendo reiterados hasta la saciedad y que, inmediatamente, remiten a una realidad específica encarnada por su primera aparición. Entre los primeros, la aproximación a obras como Pompa y Circunstancia (Op. 39), de Edgard Elgar cuya primera marcha ilustra irremediablemente una graduación (ejemplos entre películas de animación se encuentran, entre otros, en Shrek The Third ${ }^{362}$ o Bee Movie ${ }^{363}$ ) o, entre los segundos, la inserción sonora a la famosísima escena de la ducha de Psicosis ${ }^{364}$ para mostrar lo peligroso de una situación (aludida, por ejemplo, en Buscando a $\mathrm{Nemo}^{365}$ ) son casos

\footnotetext{
${ }^{362}$ Chris Miller, 2007.

${ }^{363}$ Dir. Steve Hickner y Simon J. Smith, 2007.

${ }^{364}$ Dir. Alfred Hitchcock, 1960.

${ }^{365}$ Dir. Andrew Stanton y Lee Unkrich
} 
notorios de aplicaciones procedentes de fuera del imaginario del niño que, sin embargo, va incorporando poco a poco. Todo ello, al igual que se mostró en el ejemplo anterior, es susceptible de aplicación pedagógica en clave de conocimiento musical a través de estas producciones.

En ocasiones, un mismo ejemplo musical puede actuar como tópico que aporte elementos suficientes para discutir dentro de las aulas sobre el porqué de su aplicación. Es el caso de La cabalgata de las Walkyrias, de Richard Wagner, la cual siguiendo el contexto infantil que nos hemos marcado para este apartado puede mostrar la hostilidad de un personaje o, si partimos de la generación del tópico en el cine (Apocalipse $N o w^{366}$ ), definiendo una situación en la que participan helicópteros:

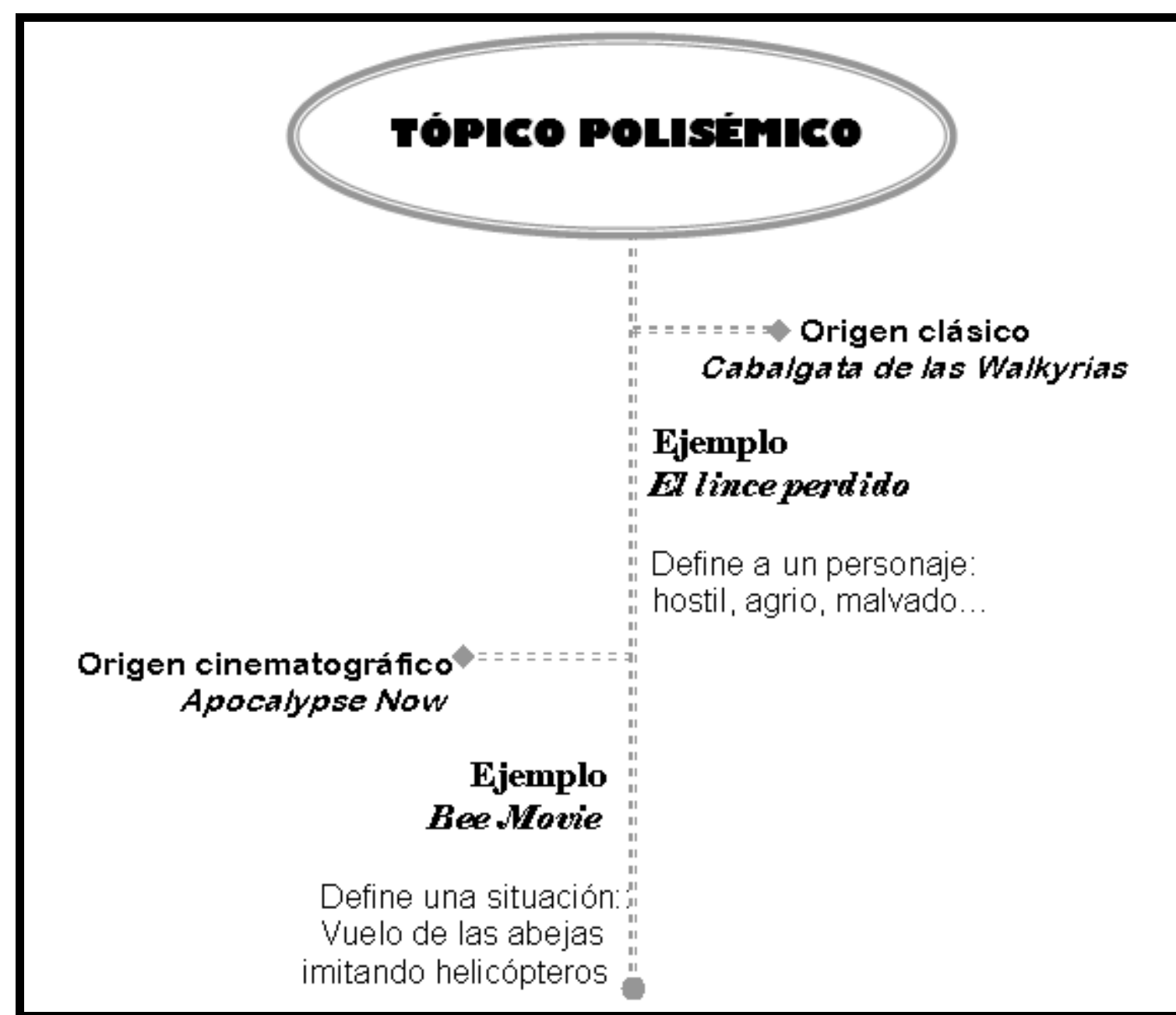

Fig. 14. Aplicaciones de una música hecha tópico con diferente carácter Juan Carlos Montoya Rubio

${ }^{366}$ Dir. Francis Ford Coppola, 1979. 


\section{F. Producciones audiovisuales dirigidas al mundo infantil - juvenil que aportan elementos musicales significativos}

"El valor formativo de un espacio no depende únicamente del contenido del documental emitido, sino de cómo se introduzca, cómo se oriente, qué alcance se le quiera dar. De ahí la importancia de incorporar algún tipo de indicador. A veces basta un simple signo o comentario para que un espacio adquiera un sentido diferente. Cuando alguien nos comenta que una novela o una película es interesante por algún motivo, adquiere nueva relevancia. Esa información nos proporciona un ángulo diferente al leerla o verla" ${ }^{\text {367 }}$.

"La música, a través del cine, ha tenido y sigue teniendo, quizás inconscientemente, una función macrosocializadora y divulgadora, más allá de la pantalla o los intereses estéticos que puede crear una determinada partitura"368.

Conjugando las ideas de las citas precedentes se articula gran parte del ideario de este apartado. Por un lado, en pedagogía no habrá de ser determinante sólo el contenido del audiovisual sino la perspectiva con que se trate de acuerdo a unos fines didácticos previos. Por otro, existen suficientes ejemplos constatables que informan acerca de cómo una u otra melodía o personaje han sido popularizados a partir de su aparición estelar en una película o programa televisivo.

Al referirnos a este tipo de audiovisuales pretendemos acercarnos a aquellas producciones que despiertan un interés especial en el público infantil o juvenil y, por su alto grado de conectividad con el alumnado, sirven para ir desentrañando elementos musicales que pudieran dar lugar a aprendizajes específicos. A diferencia de experiencias didácticas basadas en grandes genios de la música o en aquellas en que la trama bebe directamente de lo musical, en estos casos no es el hecho sonoro el que vehicula la trama de manera explícita, pero sí puede resultar altamente atractiva su focalización y ulterior tratamiento. Así por ejemplo, cualquier formato de este tipo en el

\footnotetext{
${ }^{367}$ DE LA TORRE, S. (1996a): "Películas formativas. Un apunte para su utilización". Cine formativo. Barcelona: Octaedro, pp. 55-86.

${ }^{368}$ RADIGALES, J. (2008): Op. cit., p. 56.
} 
que puntualmente se muestre una orquesta en imagen, puede dar pie a aprendizajes referidos a la organología en general, las agrupaciones instrumentales, las formas musicales, etc. Si ello se apoya en análisis venidos desde el campo musicológico y derivados en la pedagogía musical el beneficio reportado puede ser todavía mayor. Un ejemplo evidente de teoría musical desde el cual articular elementos pedagógicos en esta dirección podría ser el estudio realizado por $\mathrm{M}^{\mathrm{a}}$ Antonia Gil Seara, quien en su análisis de composiciones para la gran pantalla de Shirley Walker se detiene en Batman: Mask of the Phantasm ${ }^{369}$, para aportar datos referidos al uso organológico que pueden derivar en posteriores trabajos pedagógicos con un breve proceso de mediación:

"El tema principal de esta película de animación, 'Main Title', incluye coros que sobresalen por encima de la orquesta, la cual desarrolla el tema del hombre murciélago y de la ciudad de Gotham. A lo largo del argumento se desarrolla con acierto el misterio y el suspense del fantasma que persigue y descubre Batman. Esto se refleja con acierto en temas que hacen uso de las Ondas Martenot, como en la pista 4 'Phantasm's Graveyar Murder', en el que este instrumento electrónico anuncia la aparición del asesino fantasmagórico con sed de venganza. En 'First Love' (pista 5) describe de nuevo un impresionante paisaje sonoro con la utilización del arpa, las campanas tubulares y los coros reforzando la idea de amor con Andrea Beaumont. Otro recurso es emplear las campanas y la sorpresa como en el caso del tema que representa al personaje del Joker en 'Phantasm and Joker Fight' (pista 9), jugando con las maderas o buscado el dramatismo y a la vez el carácter circense con las sordinas en los metales" ${ }^{\text {370 }}$.

Los niveles de exigencia y análisis que alcanzar con aspectos como los mostrados anteriormente pueden ser muy amplios. Por otro lado, el aprendizaje de los diferentes estilos musicales se puede extraer no sólo de las fuentes cinematográficas sino también

\footnotetext{
${ }^{369}$ Dir. Eric Radomski, Bruce W. Timm, 1993. En esa misma línea pueden utilizarse otros trabajos extraídos del mismo volumen. Para el caso de ET el extraterrestre (Dir. Steven Spielberg, 1982): MARTÍN SÁNCHEZ, D. (2005): “Aspectos analíticos del sinfonismo de John Williams". OLARTE MARTÍNEZ, M. (Ed.) La música en los medios audiovisuales. Salamanca: Plaza Universitaria Ediciones, pp. 449ss.

370 GIL SEARA, M. A. (2009): "El legado de Shirley Walker". OLARTE MARTÍNEZ, M. (Ed.) Reflexiones en torno a la música y la imagen desde la musicología española. Salamanca: Plaza Universitaria Ediciones, pp. 618-619.
} 
de otros medios audiovisuales, tales como la televisión. Así por ejemplo, programas (de corte infantil o no) y anuncios televisivos pueden erigirse en estructuras de aprendizaje formal. Uno de los casos más cercanos al mundo infantil de nuestro entorno que resalta con mayor vehemencia esta conexión tal vez sean Los Lunnis, ese "entretenimiento inteligente" 371 . Junto con melodías que conectan directamente con el público infantil al que se dirigen ${ }^{372}$ se ofrecen otras que pretenden un desarrollo de saberes concretos, bien derivados de otras áreas de conocimiento ${ }^{373}$ bien como soporte a contenidos actitudinales y transversales ${ }^{374}$. Todas estas referencias son susceptibles de trabajo específico, especialmente desde el plano de la forma musical, aunque para ello los creadores de esta serie han ideado ya canciones que permiten esta labor pedagógica de forma aún más evidente ${ }^{375}$. Especialmente motivadoras son aquellas que, además, sirven para acceder a cuentos populares o a obras literarias de gran entidad ${ }^{376}$. En cualquier caso, aquellos que nos ocupan más directamente son los que persiguen un aprendizaje musical más o menos intenso no sólo a partir del medio en sí, la canción, sino desde sus estrategias compositivas. Así, podemos encontrar ejemplos basados en diferentes estilos (desde la rumba hasta el rock pasando por toda una gama de sonidos del mundo) ${ }^{377}$.

\footnotetext{
${ }^{371}$ ARROYO ALMARAZ, I. (2003): "Entretenimiento inteligente o consumo infantil en los programas contenedor". Revista de Tecnologías de la Información y Comunicación Educativas 4. Disponible en $<$ http://reddigital.cnice.mecd.es/4/firmas/isidoro ind.html> [Consulta 9-II-10].

372 Destacamos "Dame tu mano" (Roselló y Llobell, 2007), "Cumple Cumpleaños" (Cerdá y Copons, 2005), "Despierta ya" (Cerdá, Copons y Callieri, 2004) o "Nos vamos a la cama" (Cerdá y Copons, 2004).

${ }^{373}$ Como es el caso de la lengua: "Sin letras no hay palabras" (Albert, Lladó y Copons, 2004).

${ }^{374}$ Por ejemplo "Los piojos" (Albert, Lladó y Shaaff, 2004) o "La rumba del semáforo" (Albert, Lladó y Cama, 2005).

375 "Somos Lunnis" (Cerdá y Copons, 2004), basada en la reiteración de un mismo bloque musical (A-A'A"'...); "La canción de las campanas que paseaban los domingos" (Surroca y Anglás, 2004), en la cual los parámetros del sonido pueden ser trabajados de manera muy profusa con una pequeña labor de mediación por parte del docente; "La danza es muy divertida" (Surroca y Cabrero, 2005), la cual, como puede intuirse, se pueden implementar movimientos sin problema alguno.

376 "Las sirenas" (Surroca y Maroto, 2004), inserta en el relato sobre "La Odisea" de Homero; "El Quijote" (Cerdá y Copons, 2005) o "Dulcinea" (Cerdá y Copons, 2005), dentro de la narración de la novela cervantina. En cuanto a otras narraciones "Lulo de los bosques" (Cerdá y Copons, 2005) o "El tesoro de Rapunzel" (Surroca y Cama, 2005)

377 Sirvan como ejemplo "La rumba del cohete" (Albert, Lladó y Virgili, 2004 ), "Los huevos" (Hernández y Surroca, 2004), con alusiones a músicas celtas o irlandesas, "El vals de Lupita" (Iglesias, 2007), "La tarantela de Lumbrela" (Pardo y Cortés, 2004), con evidentes conexiones formales, o ejemplos de bases rítmicas y melódicas más actuales, como es el caso de "El ska de Lucho" (Iglesias y Hernández, 2004), "El globo amarillo" (Pardo, Gil, Gnutti, Meroño y Cerdá, 2004) con paralelismos con la mítica melodía de Los Beattles o "Lublú, rey del rock" (Pardo, Gil, Genutti y Copons, 2004).
} 


\section{G. Producciones audiovisuales dirigidas al gran público con aspectos musicales destacables.}

En reiteradas ocasiones ha quedado patente que la manera más habitual de utilizar el cine (como audiovisual más extendido en este contexto) en el ámbito educativo responde a la adecuación de películas no pedagógicas con matices que pudieran hacerlas modificar esta orientación:

"Es difícil descubrir un solo tema o núcleo de contenidos que no esté tratado de alguna forma en el cine. Siempre es posible encontrar películas o documentales que permitan su utilización como punto de partida en un debate, o como rasgo, dato o documento en una investigación o estudio, ${ }^{\text {378 }}$.

Un ejemplo paradigmático al respecto es el análisis de la música compuesta por Anton Karas para El tercer hombre ${ }^{379}$ cuyos pasos procedimientales enuncia MartínezSalanova Sánchez en los siguientes términos ${ }^{380}$ :

- Oír la banda sonora. Investigar sobre el autor, su música, la cítara, etc.

- Identificar la música de cítara. Señalar cómo el motivo musical se utiliza cada vez que sale el personaje que interpreta Orson Welles.

- Apreciar los momentos musicales en relación con estados de ánimo, suspense, actitudes, etc.

- Identificar los diversos sonidos de la película en relación con la valoración que se ha realizado de los personajes.

El fragmento anterior está inserto en una de las más completas guías de actuación pedagógica sobre cine y educación en castellano. En este volumen se relacionan visionados con actividades prácticas, lecturas y otros elementos que incitan a la investigación en el aula. Desgraciadamente, lo reproducido es la única referencia al análisis específico de la banda de sonido y, como puede apreciarse, el procedimiento

378 MARTÍNEZ-SALANOVA SÁNCHEZ, E. (2002): Aprender de cine, aprender de película. Una visión didáctica para aprender e investigar con el cine. Huelva: Grupo Comunicar Ediciones, p. 25. Un esbozo anterior a esta publicación lo encontramos en MARTÍNEZ-SALANOVA SÁNCHEZ, E. (1997): "El valor de la imagen en movimiento". Comunicar 9, pp. 23-35.

${ }^{379}$ Dir. Carol Reed, 1949.

${ }^{380}$ MARTÍNEZ-SALANOVA SÁNCHEZ, E. (2002): Op. cit., p. 318. 
que se sigue sirve para desarrollar fundamentalmente elementos extramusicales. A pesar de tratarse de un valioso modo de aproximación, precisa de un acercamiento mayor a la materia para poder desentrañar más aspectos propios del área así como para entender las relaciones que se establecen entre lo visual y lo sonoro. En caso contrario, la utilidad en nuestro ámbito se ciñe a la observación de elementos que no atañen directamente a los objetivos clásicos enunciados en los diferentes currícula de educación musical pero sí al discurso cinematográfico. Por tanto, a actividades como las anteriores se podrían añadir otras que guarden relación, tales como el rastreo de los momentos en que la música es utilizada para condensar o alargar el tiempo en escena ${ }^{381}$ o el análisis detenido de determinados elementos sonoros significativos ${ }^{382}$.

Por otro lado, son crecientes las publicaciones que pueden ayudar a elaborar discursos pedagógicos que inviten al alumnado a una mayor comprensión musical desde la esfera subjetiva con que se enlaza a determinados personajes ${ }^{383}$. Además, la música es, por supuesto, capaz de explicar en el audiovisual nuestras sociedades desde el contenido musical de determinadas películas y todo ello es trasladable al conjunto del alumnado. Por ejemplo, para comprender estéticas como las que describe Fiebre del sábado noche ${ }^{384}$ habrá que acceder al núcleo de su pretendida justificación, en la cual

"las discotecas necesitaban un ídolo con caderas de barro y nació John Travolta: el macarra hortera, lustroso y botarate que olvida las miserias de su vida cuando llega la noche del sábado, amartilla el dedo y deja que su cuerpo se contorsione por las pistas de baile a los sones de canciones febriles" ${ }^{385}$.

\footnotetext{
381 Del modo que delata muy gráficamente FRAILE PRIETO, T. (2005): "Aproximación a los mecanismos temporales de la música de cine”. OLARTE MARTÍNEZ, M. (Ed.) La música en los medios audiovisuales. Salamanca: Plaza Universitaria Ediciones, pp. 213-224.

${ }^{382}$ XALABARDER, C. (2005): "Principios informadores de la música de cine". OLARTE MARTÍNEZ, M. (Ed.) La música en los medios audiovisuales. Salamanca: Plaza Universitaria Ediciones, pp. 155-204.

${ }^{383}$ Véase, por ejemplo, el rigor en la retahíla de apreciaciones que Marcos Azzam realiza en torno a la filmografía de Ingmar Bergman y sus usos musicales. Desprender de estudios de este tipo estructuras pedagógicas se antoja un esfuerzo sumamente agradecido: AZZAM GÓMEZ, M. (2009): "La música como factor estructural y dramático en el cine de Ingmar Bergman”. OLARTE MARTÍNEZ, M. (Ed.) Reflexiones en torno a la música y la imagen desde la musicología española. Salamanca: Plaza Universitaria Ediciones, pp. 817-857.

${ }^{384}$ Dir, John Badham, 1977.

${ }^{385}$ PERTIERRA, T. (1999): Pasión de cine. Barcelona: Alba Editorial, p. 114.
} 
Algo similar podría argumentarse de productos como Grease ${ }^{386}$ o con mitos que influenciaron a toda una época como Elvis Presley o el propio James Dean, referente de una generación de jóvenes norteamericanos. Así pues, para acceder al meollo del ideario que movía a esta sociedad habría que inmiscuirse en el valor de las representaciones que se daban en estas películas, las cuales combinaban cueros y motocicletas con músicas incisivas y radicalmente novedosas ${ }^{387}$.

Pero no sólo este tipo de estéticas son rescatables para el estudio a través del argumento de un discurso audiovisual. En el extremo opuesto, desde el análisis de Nobleza Baturra ${ }^{388}$, David Martín Félez propone un acercamiento al folklore aragonés desde clasificaciones de las diferentes modalidades de jota y el análisis de la estructura musical del filme ${ }^{389}$. Además, siguiendo la vertiente costumbrista y al tiempo aproximándonos a hipotéticos intereses del alumnado, cabe la posibilidad de extrapolar músicas de películas con esta temática que resulten más atractivas por su cercanía temporal $^{390}$.

Por otro lado, escenas extremadamente importantes dentro de películas amparadas por el concurso de lo musical, y ampliamente conocidas y trabajadas en diferentes ámbitos, pueden servir para comenzar, enfatizar, desarrollar o concluir propuestas didácticas basadas en compositores, obras o estilos. Un ejemplo evidente, es el desplante que Andy Dufresne, el protagonista de Cadena Perpetua ${ }^{391}$, infringe a sus

\footnotetext{
${ }^{386}$ Dir. Randal Kleiser, 1978.

387 SEDEÑO VALDELLÓS, A. M. (2002): "Música e imagen. Aproximación a la historia del video musical". Área Abierta 3. Disponible en

<http://revistasucm.es/inf/1578393/articulos/ARAB002230002A.PDF> [Consulta 9-II-10].

${ }^{388}$ Dir. Florián Rey, 1935.

${ }^{389}$ MARTÍN FÉLEZ, D. (2009b): "La banda sonora de Nobleza Baturra: monumento a la figura del baturro y los estilos de jota”. OLARTE MARTÍNEZ, M. (Ed.) Reflexiones en torno a la música y la imagen desde la musicología española. Salamanca: Plaza Universitaria Ediciones, pp. 357-374. No obstante, sus derivaciones pedagógicas no se limitan sólo a lo musical, es más, parecen tener más peso elementos extramusicales que facilitarían un trabajo globalizado sobre la película en cuestión, ya que postula focalizar la atención en aspectos como el subrayado de expresiones populares, el rastreo de fiestas y tradiciones arraigadas en la zona, el conocimiento de oficios y otras labores del campo, la observación de los valores que se derivan de los personajes, el análisis de los trajes regionales y la búsqueda de información sobre director y protagonistas.

390 Como las que muestra en su recorrido por el que denomina "cine folklórico" ENCABO FERNÁNDEZ, E. (2009): "Nuevas películas, viejas canciones: La cuestión del repertorio en el cine folklórico español de los noventa”. OLARTE MARTÍNEZ, M. (Ed.) Reflexiones en torno a la música y la imagen desde la musicología española. Salamanca: Plaza Universitaria Ediciones, pp. 439-459.

${ }^{391}$ Dir. Franck Darabont, 1995.
} 
vigilantes haciendo escuchar a todos los reclusos por los altavoces un fragmento de Las bodas de Fígaro de Mozart ${ }^{392}$.

Pero en todo caso, la puntualidad con la que se ofrece una obra paradigmática en un punto de inflexión dentro de un film para su posterior uso didáctico no es más que un uso "pretextual" del mismo y, sin embargo, puede resultar mucho más productivo encontrar paralelismos en clave estructural entre la banda sonora de determinadas películas y los referentes musicales que utiliza. Enlazando con la ópera mozartiana con que concluíamos el párrafo anterior, hemos de hacer referencia al uso musical que se ofrece en Entre pillos anda el juego ${ }^{393}$ y las suculentas consecuencias que para el aula se pueden desprender de dicho largometraje $\mathrm{e}^{394}$. A lo largo de la investigación, se han realizado varias alusiones a la importancia de considerar las fuentes musicológicas como facilitadoras de un supuesto trabajo de mediación hacia lo pedagógico. Tal vez haya pocos ejemplos tan diáfanos como el que tratamos ahora:

"La justificación de esta elección [Las bodas de Fígaro] por parte del compositor y de Landis [el director] resulta obvia: el paralelismo argumental de la película y la ópera es evidente. Toda una serie de personajes de clase inferior [...] luchan por recuperar su dignidad contra la clase superior [...]. Si a ello le añadimos todas las peripecias de engaños, enredos de comedia (con papeles verdaderos y falsos que vuelan de un lado a otro) y la utilización del disfraz (de importancia crucial en el final de la ópera y la película) no tenemos más que elogiar la elección de la ópera de Mozart - Da Ponte"395.

\footnotetext{
${ }^{392}$ A pesar de ello las experiencias didácticas centradas en esta película no suelen atender al espectro musical, que por otro lado es determinante, y comúnmente se ocupan de otros elementos que tienen que ver con los derechos humanos: SABIDÓ DASANOVA, S. (1996): "Cadena perpetua". DE LA TORRE, S. (coord.) Cine formativo. Barcelona: Octaedro, pp. 167-171.

${ }^{393}$ Dir. John Landis, 1983.

${ }^{394}$ Los razonamientos que se muestran se encuentran en GALBIS LÓPEZ, V. (2009a): "La música preexistente en la comedia americana de los años ochenta: Trading Places (1983)". OLARTE MARTÍNEZ, M. (Ed.) Reflexiones en torno a la música y la imagen desde la musicología española. Salamanca: Plaza Universitaria Ediciones, pp. 217-223. Como el propio autor de la ponencia en cuestión hace constar en las líneas introductorias de la misma, se antoja mucho más adecuado al juego de espejos que se desarrolla a partir de la música el título original antes que la banalización perpetrada en su traducción al castellano.

${ }^{395}$ Ibíd., p. 219. No mostramos más que el inicio de toda la serie de paralelismos puestos de manifiesto por el autor.
} 
Trazar similitudes entre las líneas argumentales puede ser de gran efectividad didáctica. Desde el descubrimiento de la urdimbre que se forja tras la aplicación musical en la banda sonora hasta los pretextos con que se pueden establecer analogías entre ambas producciones, pasando por las innumerables actividades de extrapolación, nos vemos abocados a pensar que nos hallamos ante una fuente inagotable de recursos para un profesor interesado en hurgar en ello.

Del mismo modo, la antológica escena de El hombre que sabía demasiado ${ }^{396}$, en la cual una orquesta ejecuta una pieza íntimamente ligada con el argumento puede servir a fines pedagógicos concretos. De hecho, en este caso el propio director de la película ayuda a esta tarea al reconocer la necesidad de dar claves a la audiencia en general para la comprensión de elementos no siempre conocidos por todos, por lo que la labor didáctica sería la de ampliar información -hasta el punto que se estime oportunoacerca de esos aspectos musicales:

“Tenía que hacerse así para que el público participara completamente. Probablemente hay personas entre el público que no saben lo que son los címbalos y, para éstos, era conveniente mostrar a la vez el instrumento y la palabra 'címbalos' escrita con todas sus letras; después era preciso que el público fuese capaz no sólo de identificar el sonido de los címbalos, sino incluso de imaginarlo por anticipado y por lo tanto de esperarlo. Este condicionamiento del público es la base misma de la creación del suspense.

Los compases de la cantata que se oyen dos veces en el disco están destinados a evitar cualquier confusión en la mente del espectador sobre lo que sucederá a continuación" ${ }^{397}$.

Por todo ello, la especificidad de los contenidos musicales puede ser entendida no sólo desde un acercamiento organológico como sucedió en los párrafos precedentes, sino en relación con el elemento histórico-comprensivo con el lenguaje musical. En referencia a este último, las dificultades de acceso tal vez sean mayores para un público en ocasiones excesivamente lego como el que pretendemos abarcar. En todo caso, quede constancia de la posibilidad de implicar al alumnado en la comprensión fílmica a través

\footnotetext{
${ }^{396}$ Dir. Alfred Hitchcock, 1956.

${ }^{397}$ TRUFFAUT, F. (1998): El cine según Hitchcock. Madrid: Alianza, pp. 85-86.
} 
del conocimiento del lenguaje musical. Al respecto de $A z u l^{398}$, Eduardo Viñuela describe del siguiente modo el proceso de comprensión holista de la escena ${ }^{399}$ :

"Nos encontramos en estos casos con un ejemplo de música 'muda', que está presente a través de su codificación gráfica pero no suena; solamente un espectador con competencias en la lectura de notación musical puede reconocer al instante que lo que allí está escrito es la música que se escucha varias veces en el film, ${ }^{, 00}$.

Además, podemos indagar otros aspectos formales de la música derivados de la propia estructura fílmica. Un ejemplo al respecto es el que aporta Robynn J. Stilwell ${ }^{401}$ en torno a la película Sentido y Sensibilidad ${ }^{402}$. Al margen de otros interesantes análisis que se adentrarían en el campo de la narratividad musical, es destacable cómo el autor ilustra, de manera muy evidente, la estructura de la forma sonata en el devenir de la historia. Su "forma sonata" queda reflejada del siguiente modo ${ }^{403}$ :

\footnotetext{
${ }^{398}$ Dir. Krystof Kieslowski, 1993.

399 Tomamos la licencia de importar el término "holismo" desde los muros antropológicos para intentar expresar la mayor capacidad posible de comprensión de la obra en los términos que se presenta en imágenes.

${ }^{400}$ VIÑUELA SUÁREZ, E. (2009): "La inter-acción de la música de cine. Relación multimedia en Azul de Kieskowski”. OLARTE MARTÍNEZ, M. (Ed.) Reflexiones en torno a la música y la imagen desde la musicología española. Salamanca: Plaza Universitaria Ediciones, p. 882.

${ }^{401}$ STILWELL, R. J. (2000): "Sense \& Sensibility. Form, Genre and Function in the Film Score". Acta Musicológica 72, pp. 219-240.

${ }^{402}$ Dir. Ang Lee, 1995.

${ }^{403}$ Ibíd., p. 225.
} 


\begin{tabular}{|c|c|c|c|c|c|}
\hline & \multicolumn{3}{|c|}{ Exposición } & \multicolumn{2}{|c|}{ Desarrollo } \\
\hline Introduc ción lenta & $\begin{array}{c}\text { Primer } \\
\text { tema }\end{array}$ & $\begin{array}{l}\text { Segundo } \\
\text { tema }\end{array}$ & $\begin{array}{l}\text { Tema de } \\
\text { cierre }\end{array}$ & & Transición \\
\hline $\begin{array}{c}\text { Muerte y } \\
\text { desheredación }\end{array}$ & $\begin{array}{c}\text { Elinor } \\
\& \\
\text { Edward }\end{array}$ & $\begin{array}{c}\text { Marianne } \\
\& \\
\text { Willoughby }\end{array}$ & $\begin{array}{l}\text { Brandon, } \\
\text { resignado }\end{array}$ & Trastorno & $\begin{array}{l}\text { Enfermedad } \\
\text { de Marianne }\end{array}$ \\
\hline \multirow[t]{5}{*}{ Norland } & Norland & Barton & Barton & Londres & Cleveland \\
\hline & \multicolumn{3}{|c|}{ Reexposición } & & \\
\hline & $\begin{array}{c}\text { Segundo } \\
\text { tema }\end{array}$ & $\begin{array}{c}\text { Primer } \\
\text { tema }\end{array}$ & $\begin{array}{c}\text { Tema de } \\
\text { cierre }\end{array}$ & & \\
\hline & $\begin{array}{c}\text { Marianne } \\
\& \& \\
\text { Brandon }\end{array}$ & $\begin{array}{c}\text { Elinor } \\
\& \\
\text { Edward }\end{array}$ & $\begin{array}{l}\text { Brandon, } \\
\text { casado } \\
\text { (Willoughby } \\
\text { resignado) }\end{array}$ & & \\
\hline & $\begin{array}{l}\text { Barton } \\
\text { (jardin) }\end{array}$ & $\begin{array}{l}\text { Barton } \\
\text { (salón) }\end{array}$ & $\begin{array}{l}\text { Barton/ } \\
\text { Delaford } \\
\end{array}$ & & \\
\hline
\end{tabular}

Metodológicamente, encontramos paralelismos con la estructura puesta al descubierto por Radigales cuando atestigua en el inicio de la película Amadeus ${ }^{404}$ la visualización del esquema de forma sonata en la Sinfonía $n^{\circ} 25$ del salzburgués:

"Este es el caso de la sinfonía que, siguiendo la forma sonata que presenta el bitematismo establecido entre el tema A (en la tónica) y el tema B (en la dominante), ha tenido usos audiovisuales realmente conseguidos. [...] Mientras que el tema A (en sol menor) de la sinfonía subraya la tragedia del compositor italiano con las imágenes de Salieri postrado en una camilla, el tema B (en Re mayor) coincide con unas imágenes, en montaje paralelo, de una fiesta de carnaval en el interior de un palacio" ${ }^{405}$.

\footnotetext{
${ }^{404}$ Dir. Milos Forman, 1984.

${ }^{405}$ RADIGALES, J. (2005a): Op. cit., p. 16. Rescatamos este fragmento no por su vinculación temática, ya que se incluiría dentro del apartado de biopics de esta investigación, sino por su funcionalidad como elemento paralelo al mostrado por Stilwell. Radigales retoma de nuevo el planteamiento en la publicación reseñada del 2009a.
} 
Otra posibilidad sumamente rentable en términos didácticos es la focalización en una sola estructura formal reiterada en diferentes fragmentos audiovisuales ${ }^{406}$. Por otro lado, son muchas las referencias del anterior autor a las vinculaciones y fricciones que se pueden establecer en la relación entre la banda sonora y la ópera ${ }^{407}$. Un trabajo de mediación didáctica puede dar pie a aproximaciones que potencien estos vínculos y hagan accesible el lenguaje operístico desde los discursos audiovisuales ${ }^{408}$.

Mucho más común es el uso de formas simples en los anuncios televisivos ${ }^{409} \mathrm{o}$, de manera aún más recurrente, estructuras formales de pequeña entidad asociadas a la imagen. Así,

"la publicidad utiliza sencillas melodías compuestas según cánones de composición tradicionales, en los que la innovación es mínima. Su forma musical es, generalmente, una frase musical de ocho compases en tempo andante con acentuación binaria y melodía cantada por voz humana, hombre o mujer, dependiendo del producto que vendan. La frase es repetida, varias veces, sin estrofas intercaladas, hasta la última vez que, súbitamente, la melodía se quiebra en una cadencia suspensiva, si es que la hay, con la que finaliza el anuncio"410.

A pesar de la generalización que supone estandarizar de tal modo, la autora referida con anterioridad muestra en el mismo volumen varios ejemplos de la

\footnotetext{
${ }^{406}$ Sería el caso, por ejemplo, del uso de alguno de los ejemplos más accesibles de los mostrados por Yaiza Bermúdez en su repaso al tango en la gran pantalla: BERMÚDEZ CUBAS, Y. (2009): "El tango en el cine: Carlos Gardel en la cinematografía de los años noventa", en OLARTE MARTÍNEZ, M. (Ed.) Reflexiones en torno a la música y la imagen desde la musicología española. Salamanca: Plaza Universitaria Ediciones, pp. 967-988.

${ }^{407}$ Destacamos entre las últimas publicaciones referidas al mundo cinematográfico y operístico: RADIGALES, J. (2009b): "Lo cinematográfico en Puccini. Lo pucciniano en el cine". OLARTE MARTÍNEZ, M. (Ed.) Reflexiones en torno a la música y la imagen desde la musicología, pp. 197-215.

${ }^{408}$ MONTOYA RUBIO, J. C. (2008a): Op. cit. En la publicación en cuestión, partíamos de un fragmento televisivo conocido por el alumnado, perteneciente a un programa en el cual una persona sin ningún aparente don para la música se transforma, de súbito, en el afamado Paul Potts, a partir de la interpretación de un fragmento del aria Nessun dorma, de la pucciniana Turandot. Desde ese momento se abriría la vinculación entre otros fragmentos audiovisuales tal vez menos conocidos pero igualmente significativos y el mundo operístico.

${ }^{409}$ En su estudio en torno a la influencia publicitaria audiovisual en niños, Norminanda Montoya resalta la sutil relevancia del plano sonoro como inductor del proceso general: MONTOYA VILAR, N. (2007): La influencia de la publicidad audiovisual en los niños: Estudios y métodos de investigación. Barcelona: Ed. Bosch.

${ }^{410}$ PORTA NAVARRO, A. (2007): Músicas públicas, escuchas privadas: hacia una lectura de la música popular contemporánea. Valencia: Universitat de Valencia; Castellón: Universitat Jaume I; Bellaterra: Universitat Autónoma de Barcelona; Barcelona: Universitat Pompeu Fabra, p. 43.
} 
elaboración compositiva musical en relación con la imagen en el medio publicitario televisivo ${ }^{411}$ que tal vez pudieran ser desarrollados en combinación con otros niveles de análisis específicos como los mostrados por María Pardavila ${ }^{412}$ :

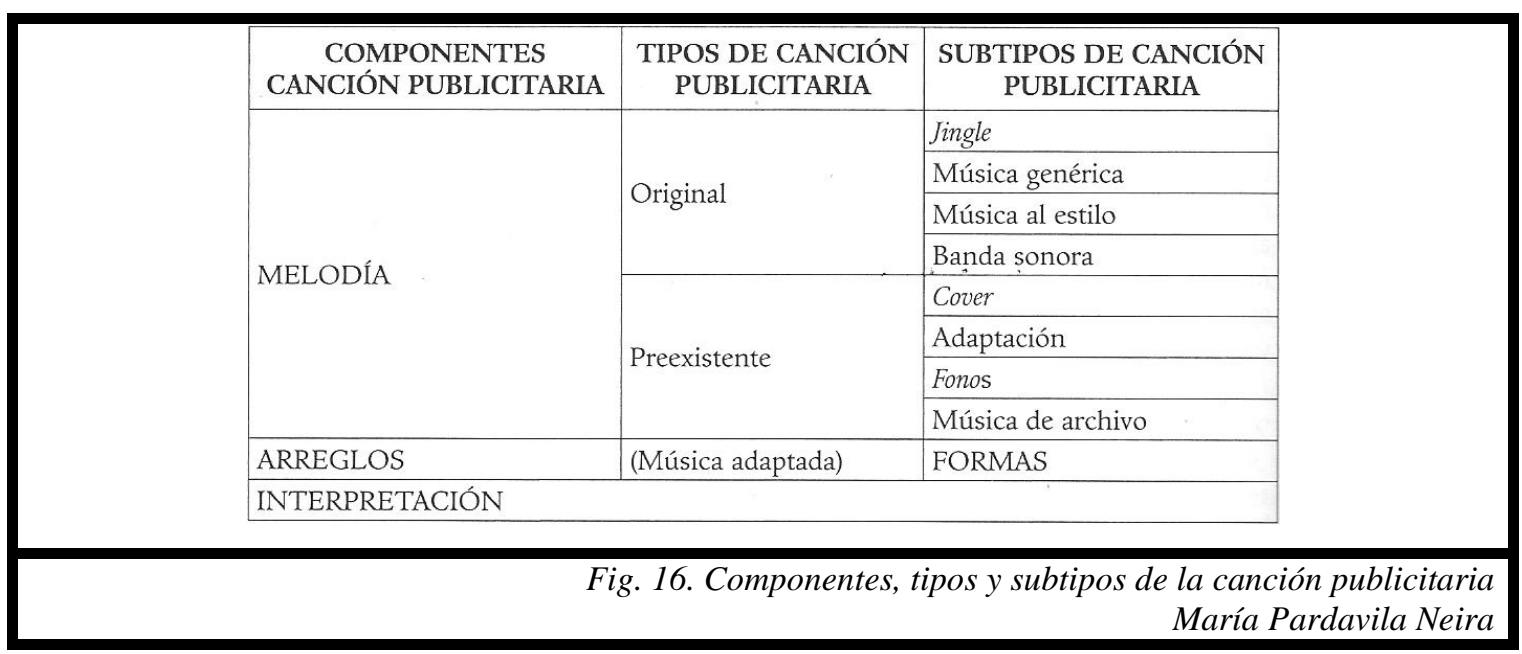

Ejemplos como los anteriores, los cuales mayoritariamente no se postularon con finalidad pedagógica, pueden ser reconducidos hacia este ámbito con un pequeño trabajo de mediación e inventiva. Mediación en lo que a hacer accesible al alumnado el significado de lo que se pretende inculcar (preparar la explicación formal antes de la proyección y el razonamiento sobre la misma) e inventiva en lo que se refiere a elaboración de materiales imaginativos que hagan posible una propuesta didáctica específica. Es importante reseñar que desde esos medios el alumno puede llegar, en determinados momentos, a vincularse anímicamente por los sonidos que los forman y hacer que el proceso pedagógico sea aún más efectivo ${ }^{413}$.

411 Ibíd., pp. 96-115.

412 PARDAVILA NEIRA, M. (2009): "Las primeras creaciones musicales para publicidad en radio y televisión en España: El jingle (1950-1960)". OLARTE MARTÍNEZ, M. (Ed.) Reflexiones en torno a la música y la imagen desde la musicología española. Salamanca: Plaza Universitaria Ediciones, p. 1000.

413 Vinculación anímica entendida como "empatía" en la propuesta de BERG, M. (2008): "La improvisación como recurso para el desarrollo de la ejecución instrumental en el segundo ciclo de educación primaria”. ÁLAMO, A. y LUCEÑO, M. Actas del I Congreso de Investigación y Educación Musical. Madrid: Enclave Creativa Ediciones, pp. 322-328. 


\subsection{EXTRAPOLACIÓN DE ELEMENTOS SONOROS EXTRAÍDOS DEL AUDIOVISUAL}

\section{La diatriba de la música preexistente}

La extrapolación de melodías procedentes de fuentes como el cine es, dentro del cúmulo de posibilidades que ofrece la didáctica musical asociada a la vertiente audiovisual, la más recurrente ${ }^{414}$. Así, reconocer melodías típicas de una u otra procedencia y extraerlas de su contexto original para, con posterioridad, elaborar actividades aisladas o unidades didácticas a partir de ellas suele ser una manera de proceder bastante común, dentro de las limitaciones con que se actúa en estas prácticas educativas. Con ello, el trabajo fundamental que se postula desde este tipo de aplicaciones será el de reconocer y utilizar elementos musicales que se desarrollan en un discurso audiovisual para su asimilación, focalizándose todo el devenir posterior hacia actividades prototípicas de las aulas de educación musical, es decir, ejercicios muy similares a los que están habituados a realizar los alumnos.

Entendemos que "la reacción espontánea a la música oída"415 es un aspecto esencial en la didáctica de la música. Si este hecho se da, se activa un proceso del cual podremos extraer extraordinarios activos para dotar de significativiadad a los procedimientos pedagógicos. Así, sabiendo conocida una melodía procedente de un medio audiovisual, se puede entender éste como punto de partida de adquisiciones múltiples. Valls Gorina y Padrol ${ }^{416}$ ya advertían de la pérdida de sentido global cuando se extrapola una composición fuera del ámbito cinematográfico y se inserta en la sala de conciertos o, si se prefiere, de la adquisición de un nuevo sentido en dicha reposición, en la cual destaca la evocación. En el ámbito educativo, una nueva funcionalidad se

\footnotetext{
${ }^{414}$ Aunque es cierto, como bien señala Matilde Olarte, que la emergencia de determinados programas televisivos musicales han revitalizado hasta tal punto otros formatos que éstos son tan utilizados para cualquier otro fin como lo son los medios cinematográficos: OLARTE MARTÍNEZ, M. (2009a): "La inserción del número musical como elemento recurrente en las películas: ¿Una nueva tipología Nowadays Musical?". Reflexiones en torno a la música y la imagen desde la musicología española. Salamanca: Plaza Universitaria Ediciones, p. 495.

${ }^{415}$ ORIOL, N. y PARRA, J. M. (1979): Op. cit., p. 190.

${ }^{416}$ PADROL, J. y VALLS GORINA, M. (1990): Música y cine. Barcelona: Ultramar, pp. 17-18.
} 
torna esencial en esta reconstitución de la obra musical cinematográfica: la ligazón entre la significatividad de la obra atrayente y la construcción de aprendizajes musicales de diversa índole.

En este sentido, la extrapolación de melodías supone interpretar de un nuevo modo una música preexistente, creada ex profeso para el audiovisual en cuestión o incluso con anterioridad, si hablamos de la música preexistente. En el primero de los casos, la música extraída del audiovisual, sea cual sea su origen (únicamente precisa cumplir con los criterios generales prototípicos de la selección de material, especialmente en cuanto a adecuación temática y significatividad) voltea su carácter primitivo y se muestra como referente de la práctica educativa. Por su parte, cuando hablamos de uso de música que a su vez fue utilizada en otro contexto (por ejemplo la música preexistente de cualquier película) las posibilidades en el desarrollo son aún mayores, ya que la actuación puede darse tanto sobre la melodía original como sobre su adaptación al audiovisual, generándose un tercer nivel de manipulación sobre el material sonoro ${ }^{417}$, es decir, música en su contexto original, adaptación al filme o producto audiovisual y adecuación al contexto didáctico. En este último caso se reproduce el procedimiento por el cual el compositor estima conveniente, se supone que movido por la simbiosis de aquello que quiere expresar con sonidos conocidos por él, adoptar unas composiciones determinadas para que pasen a formar parte del todo audiovisual y desarrollen su potencial desde otro prisma.

En suma, la aplicación del sesgo pedagógico no hace sino fomentar el constante cambio de la obra musical para acceder a otros objetivos, en este caso relacionados con el currículo del grupo de alumnos con que se esté trabajando. Como expusimos en la obra referenciada ${ }^{418}$, es preciso que, al hablar de extrapolación en forma de música preexistente, se alcance previamente la comprensión de los dos niveles previos (la composición en su contexto original y la que ha formado el segundo nivel, la adaptación a la pantalla) para poder explotar convenientemente y en un grado óptimo todo el potencial de la música en cuestión. Además, también reseñamos que el término “manipulación" aplicado al material sonoro de esta procedencia es asumido en positivo, esto es, no tanto como pervertimiento de la obra original (elemento por otro lado

\footnotetext{
${ }^{417}$ El desarrollo de la idea del tercer nivel de manipulación sobre el material sonoro se expuso en el III Simposio "La Creación Musical en la Banda Sonora" (Salamanca, 2006), cfr. MONTOYA RUBIO, J. C. (2009b): Op. cit.

${ }^{418}$ Ibíd., pp. 669-670.
} 
recurrentemente utilizado a lo largo de la historia de la música ¿por qué se habría que demostrar pudor ante ello?) sino en su forma de "experimentación" y "vivencia" del elemento musical, ambos puntales básicos de las metodologías pasadas y futuras ${ }^{419}$. No está de más recordar que la educación a partir de estos parámetros audiovisuales supone una evolución más de los materiales que ha sido continua a lo largo de la historia y que forjan y forman parte de nuestras sociedades:

"La existencia del cine ha obligado a todas las artes anteriores a evolucionar, comenzando por la literatura y terminando por la música [...] A su vez, en el marco de un trasvase lógico, las artes han influenciado en la evolución cinematográfica" ${ }^{, 420}$.

\section{Claves de una praxis relativamente extendida}

Como venimos exponiendo, dentro de la escasa difusión que la música del audiovisual suele tener en las prácticas habituales existe un pequeño margen de maniobra, constatado esencialmente en los manuales para los alumnos. Se trata de la inclusión de música de cine (de manera generalizadora como única posible del audiovisual) en libros de texto, con mayor incidencia en las ediciones más recientes. En estos casos, el trabajo más habitual es el de extrapolación de melodías. A pesar de que ha habido intentos que pudieran germinar en el futuro, es mucho menos extendido el trabajo integral sobre la banda de sonido. Los ejemplos que se pueden encontrar al respecto son minoritarios y han tenido escasa repercusión ${ }^{421}$. En este contexto, el de las publicaciones para el uso directo de los alumnos, se traslucen las intenciones de los autores, los cuales, si están vinculados a la composición para el audiovisual (por tanto una proporción muy escasa), suelen ser más sensibles a la inclusión de estos

\footnotetext{
${ }^{419}$ Entre las aplicaciones didácticas más imaginativas de los últimos tiempos a partir de los conceptos de experimentación y vivencia sobre el material sonoro destaca: MALBRÁN, S. (1996): Op. cit.

${ }^{420}$ PORTER i MOIX, M. (1996): "El cine: una cultura del siglo XX". DE LA TORRE, S. (coord.) Cine formativo. Barcelona: Octaedro, p. 44.

${ }^{421}$ Uno de los primeros intentos por delimitar en fragmentos audiovisuales tipologías musicales (música incidental, música descriptiva...) se encuentra en VV.AA. (2005): Música. $6^{\circ}$ Primaria. Madrid: Santillana Educación, p. 54.
} 
elementos $^{422}$. No obstante, el rastreo por este tipo de prácticas delata que no siempre se trata de conjugar la significatividad de los recursos materiales (el uso del audiovisual) con la de la orientación de los mismos (la selección acertada de fragmentos). Así, no siempre se logra conectar con el entusiasmo que los alumnos pueden llegar a alcanzar al desarrollar aspectos tan imaginativos como los derivados de la música de cine ${ }^{423}$.

Por otro lado, la extrapolación de una o varias melodías implica cercanía y alejamiento del referente fílmico. Cercanía en tanto en cuanto su origen audiovisual es innegable, y sirve como punto de partida de los aprendizajes que se pretenden construir. En este sentido, los alumnos trabajarán sobre la música que está contenida en un producto "manejable" y "visible", que les ha podido atraer la atención por su integración en cualquier medio de difusión. Por otro lado, nos referimos a la lejanía que puede llegar a producirse al extraer la música de un contexto y tratarla de manera aislada. En algún momento de la praxis educativa, la búsqueda de una u otra metodología o el interés por trabajar uno u otro bloque de conocimiento podrá redundar en el olvido del referente de origen, la película, serie o anuncio publicitario en cuestión. Por ello, es preciso entender que dentro de este tipo de aplicaciones basadas en la extrapolación el papel que juega la música procedente del audiovisual es, sobre todo, demarcativo, indicando la fuente y haciendo que aquello que se va a trabajar resulte significativo. En todo caso, será el propio transcurso pedagógico el que dirima si la proximidad al original audiovisual va a ser más o menos relativa y oscile, de este modo, desde una simple referencia hasta una ligazón innegable.

Por todo ello, en el campo de la extrapolación cobra inusitada relevancia la grabación de las bandas sonoras. Si tomamos como referencia la distinción que realiza Lluís i Falcó entre música de cine y banda sonora ${ }^{424}$, encontramos que ambas

\footnotetext{
${ }^{422}$ Es el caso de la compositora Eva Gancedo, quien al hacerse cargo de la autoría de libros de texto de la editorial Anaya intentó aplicar el sesgo audiovisual, eso sí de manera puntual, a alguna aplicación concreta como es la musicalización de cuentos.

${ }^{423}$ A pesar de que siempre será una buena idea su introducción, el uso de estas melodías puede pecar de insistente y por tanto reiterativa, como fue el caso del tema "My heart will go on", a cargo de Celine Dion en Titanic usada cuando los ecos de la misma ya se habían desvanecido: PEÑA NEGUERUELA, M. J. (2006): Flauta fácil 2. Madrid: Pearson Alambra. Por otro lado, también podemos encontrar melodías que, sin un trabajo de mediación absolutamente necesario, no acaban por resultar significativas al alumnado a pesar de su procedencia, como ocurre, por ejemplo, con West Side Story o Sonrisas y Lágrimas, aplicaciones que hallamos en VV.AA. (2002): Música 6. Barcelona: Edebé.

${ }^{424}$ Las distinciones terminológicas que el autor establece son muy funcionales, permiten en el plano de la didáctica un buen punto de partida, a pesar de que el propio autor manifestara el hecho de no ratificar todos y cada uno de los puntos que en su día enunció: LLUíS i FALCÓ, J. (1995): "Paràmetres per a una
} 
dimensiones pueden ser tratadas en clave pedagógica, sin necesidad de inmiscuirnos en consideraciones excesivamente sesudas sobre la pertinencia de una u otra vertiente. Para él, es necesario establecer una distinción entre la banda sonora musical (parte integral de la unión de lenguajes que forman el audiovisual) y la música de cine (susceptible de ser escuchada al margen de ella y cuyo funcionamiento podría llegar a ser autónomo).

A la reflexión anterior hemos de añadir que la banda sonora trabajada en paralelo al producto audiovisual puede multiplicar los beneficios educativos, porque las posibilidades de trabajo de audiciones activas y otros elementos aledaños crecen de forma exponencial. Por otro lado, es de justicia reconocer que la aceptación y recorrido de este tipo de grabaciones aumenta el interés por aquello que se trabaja, y que los alumnos están muy acostumbrados a disgregar la parte auditiva de las bandas sonoras, entendiéndolas como productos autónomos que, en consecuencia, suelen obtener mayor éxito que otras grabaciones procedentes de otros contextos ${ }^{425}$. Desde nuestro punto de vista, el poder evocador de la grabación (especialmente cuando tratamos música preexistente), ya apuntado desde la bibliografía más clásica ${ }^{426}$, permite una vuelta no sólo a la música que los alumnos detectan en el audiovisual, sino que, además, da acceso al campo primero de composición. Piénsese que, con bastante frecuencia, es costoso hacer llegar a los alumnos músicas de épocas y estilos altamente estereotipados o lejanos en el tiempo pero que, a partir de estos recursos, se abre una nueva senda que facilita la elaboración de materiales que remitan a esas franjas temporales. Además, más allá de la capacidad evocadora de la música, suele esgrimirse que este tipo de arreglos posee un plus de fuerza para penetrar en el espectador debido a que es una música esperada $^{427}$. Esto sucede cuando pueden establecerse vínculos entre la adaptación y el contexto original de producción.

En concordancia con el modus operandi que se esgrime, desde la extrapolación se aboga por el desarrollo de contenidos específicamente musicales (de acuerdo con los bloques de contenido que contemple el currículo oficial) a partir de la observación de elementos audiovisuales, de modo que estos últimos sirven como excusa para hacer

anàlisi de la banda sonora musical cinematogràfica". D’Art 21, pp. 169-186. El ajuste de dichos parámetros se muestra en LLUÍS i FALCÓ, J. (2005): "Análisis musical vs. análisis audiovisual: el dedo en la llaga”. OLARTE MARTÍNEZ, M. (Ed.) La música en los medios audiovisuales. Salamanca: Ediciones Plaza Universitaria, pp. 143-153.

${ }^{425}$ OLARTE MARTÍNEZ, M. (2001): Op. cit.

${ }^{426}$ Por ejemplo en PADROL, J. y VALLS GORINA, M. Op. Cit., p. 18.

${ }^{427}$ CHION, M. (1997): La música en el cine. Barcelona: Paidós. 
operativos los objetivos, contenidos y criterios de evaluación en los que se supone han de ser instruidos los alumnos, al margen de la franja de edad a la que pertenecen.

Por último, dentro de los alegatos ineludibles que venimos haciendo a lo largo del texto, hemos de resaltar que estos procedimientos son extremadamente sencillos desde el punto de vista del docente, y que no implican unos conocimientos previos siquiera básicos más allá de los que le han llevado a ser especialista de educación musical. Aquellos profesionales de la educación que no se han iniciado en las Tecnologías de la Información y la Comunicación se encontrarán con que, simplemente, se pide un trabajo de reflexión sobre los contenidos que vienen desarrollando de manera habitual para canalizarlos hacia las necesidades del alumnado. En este sentido, el proceso de elaboración de materiales guarda estrechos vínculos con la realización de los ejercicios a los que diariamente los alumnos se enfrentan en las aulas de educación musical. Confiamos en que los ejemplos que siguen a continuación corroboren tal idea. La especificidad de la música del audiovisual, al hablar de extrapolación, no radica en su componente simbiótico con la imagen, sino en el potencial de su propia estructura interna, lo cual facilita enormemente la labor de aquellos docentes que se aproximan sólo tangencialmente a este mundo. Porta Navarro reconoce igualmente la posibilidad de desgajar los elementos de forma tradicional:

"la finalidad comunicativa y expresiva del medio 'cine' obliga, condiciona y da forma a la banda sonora pero desde su propio lenguaje. Sus elementos musicales constitutivos no son nuevos: las frases, los temas, las cadencias, el leitmotiv, el tema con variaciones, las asociaciones tímbricas y la selección estilística entre los más destacados" 428 .

Por otro lado, tampoco los alumnos han de sentir rechazo por este tipo de procedimientos sino todo lo contrario, debido a que la inclusión del audiovisual (al margen de sugerente, como quedó explicitado en el capítulo anterior) en estos casos es canalizada hacia actividades reconocibles por ellos, muy similares a las prácticas cotidianas.

${ }^{428}$ PORTA, A. (1998): “Cine, música y aprendizaje significativo”. Comunicar 11, pp. 107-108. 


\section{Extrapolación de un fragmento musical paradigmático: el "tema insignia"}

En suma, la justificación en la selección de unos fragmentos musicales derivados de banda sonora para aplicar sobre ellos criterios pedagógicos que transciendan lo audiovisual ha de basarse, fundamentalmente, en aspectos como la relevancia en el alumnado y las posibilidades de profundización didáctica. Lo primero, posibilitará la conexión con el discente; lo segundo, nos habilitará para indagar tanto como precisemos en los bloques de contenido didáctico que se estimen oportunos. Toma especial relevancia para que la activación del proceso sea la adecuada la detección y selección del que llamamos "tema insignia" o "franquicia", esto es, la señal o emblema musical distintivo de una producción audiovisual que sirve para reconocerlo intuitivamente a través de su escucha, sea ésta disociada del audiovisual o no ${ }^{429}$.

Casos manifiestos de este calado pueden ser hallados sin demasiados problemas. Por citar algunos destacamos las melodías más paradigmáticas de $E l$ golpe $e^{430}$, La lista de Schindler ${ }^{431}$ La vida es bella ${ }^{432}$ o Superman ${ }^{433}$, acercándonos algo más al mundo infantil. Otro ejemplo que conjugase las características anteriores sería la famosa melodía franquicia de La muerte tenía un precio $^{434}$, con música de Ennio Morricone, la cual

"sabía con astucia infiltrarse en Bach, en su Toccata y Fuga en Re menor. Camuflarla hábilmente y añadir una pieza silbada que era como un latigazo o un disparo, un estribillo restallante que se adaptaba hipnóticamente a las imágenes y te dejaba una señal en el cerebro que se ha prolongado a lo largo de los años y que todavía surte efecto, cuando en algún momento la volvemos a escuchar,"435.

\footnotetext{
429 Víctor Solanas lo identifica como un "slogan que representa al filme": SOLANAS, V. (2005): "Significados añadidos a través de la música en las películas The Exorcist, Black Angels de G. Crumb y The Devils of Loudun de K. Penderecki”. OLARTE MARTÍNEZ, M. (Ed.) La música en los medios audiovisuales. Salamanca: Plaza Universitaria Ediciones, p. 459.

${ }^{430}$ Dir. George Roy Hill, 1973.

${ }^{431}$ Dir. Steven Spielberg, 1993.

${ }^{432}$ Dir. Roberto Benigni, 1997.

${ }^{433}$ Dir. Richard Donner, 1978.

${ }^{434}$ Dir. Sergio Leone, 1965.

435 SÁNCHEZ GONZÁLEZ, S. y SANZ, B. S. (2006): La melancolía de la revolución. Panorama del cine europeo moderno. Madrid: Fragua, p. 68
} 
En esta misma línea, es posible adecuar materiales de películas eminentemente significativas por los alumnos, con temas centrales fácilmente reconocibles y, a la vez, susceptibles de aplicación en diversos bloques de contenido musical. Además de la utilización de los citados "temas franquicia" por los cuales se reconoce el filme y se le recuerda, el alumno siente que al trabajarlos está relacionándose directamente con la referencia audiovisual. Además, el abordaje de este tipo de melodías suele ser significativo, por su especial carácter de vuelta a experiencias previas cinematográficas satisfactorias y motivadoras.

De acuerdo con los criterios reseñados como necesarios para poder llevar a cabo de manera acertada la extrapolación de un tema procedente de un audiovisual (relevancia de la cinta para el alumnado, capacidad de la melodía principal para ser reconocida, versatilidad de la misma para ser susceptible de aplicarles diferentes niveles de análisis y planos didácticos), en el ánimo de generar materiales que respondieran a estas premisas se publicó, en 2007, una experiencia basada en el tema franquicia de la saga de Harry Potter $^{436}$ (cuya primera aparición, en Harry Potter y la piedra filosofal estaba firmada por el director Chris Columbus). Dicha composición, el "Hedwig Theme", fue compuesto por el versátil y fructífero John Williams. Un resumen de las potencialidades de este tema para llevar a cabo contenidos y materiales musicales es el que pudimos poner en práctica con alumnado de diversas edades con muy aceptables niveles de éxito ${ }^{437}$ :

\footnotetext{
${ }^{436}$ MONTOYA RUBIO, J. C. (2007a): Op. cit.

${ }^{437}$ En la referencia anterior se podrán encontrar explicaciones más extensas referidas a los procedimientos concretos que motivaron que una u otra aplicación acabaran teniendo la forma que se observa en las imágenes, de modo que las adaptaciones textuales, la danza o los ejercicios de práctica instrumental resultaran más accesibles a los alumnos.
} 
- $\quad$ Musicogramas de seguimiento del tema principal y audición guiada ${ }^{438}$.

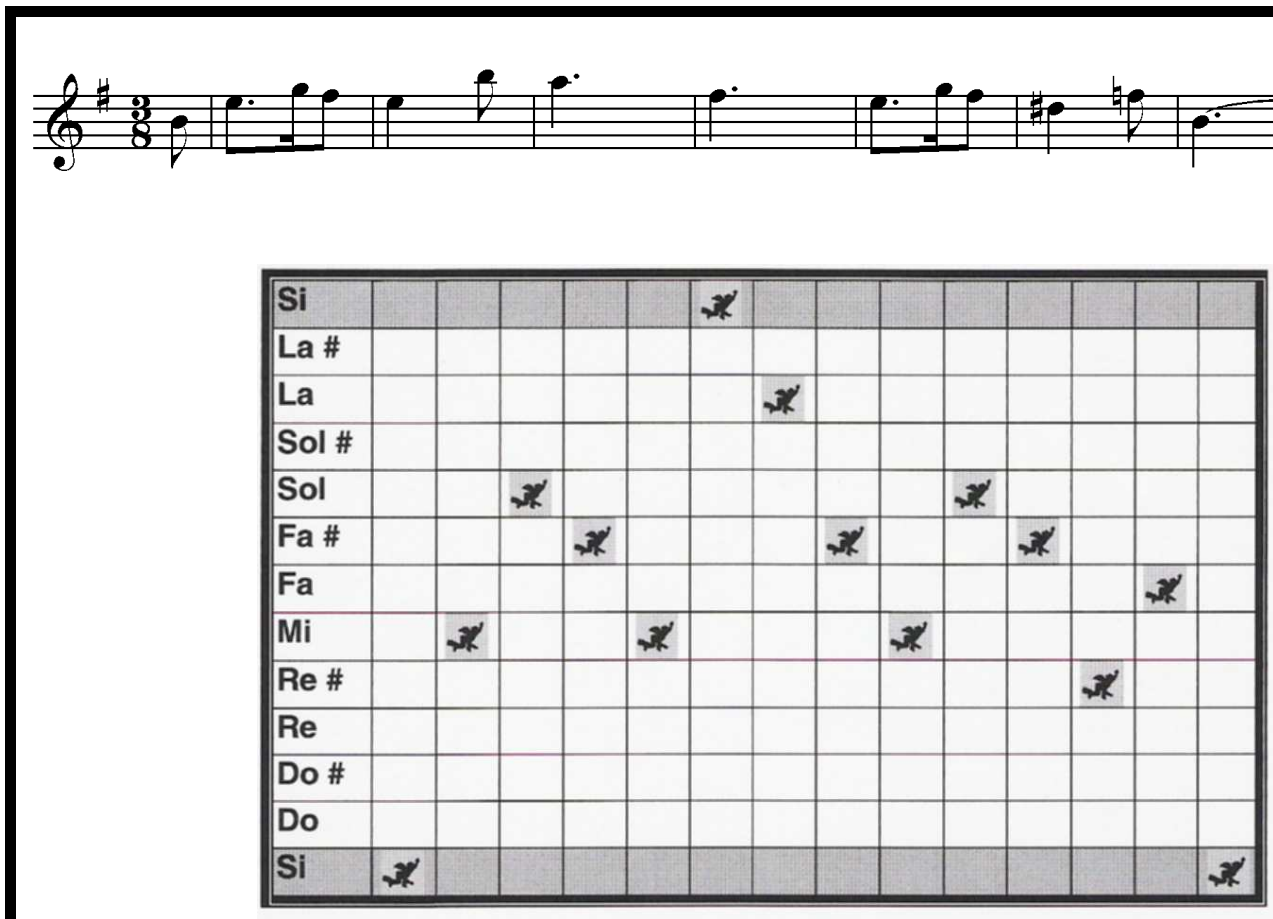

Fig. 17. Ejemplo práctico de extrapolación sobre el "Tema de Hedwig” de "Harry Potter” Audición (I) Juan Carlos Montoya Rubio
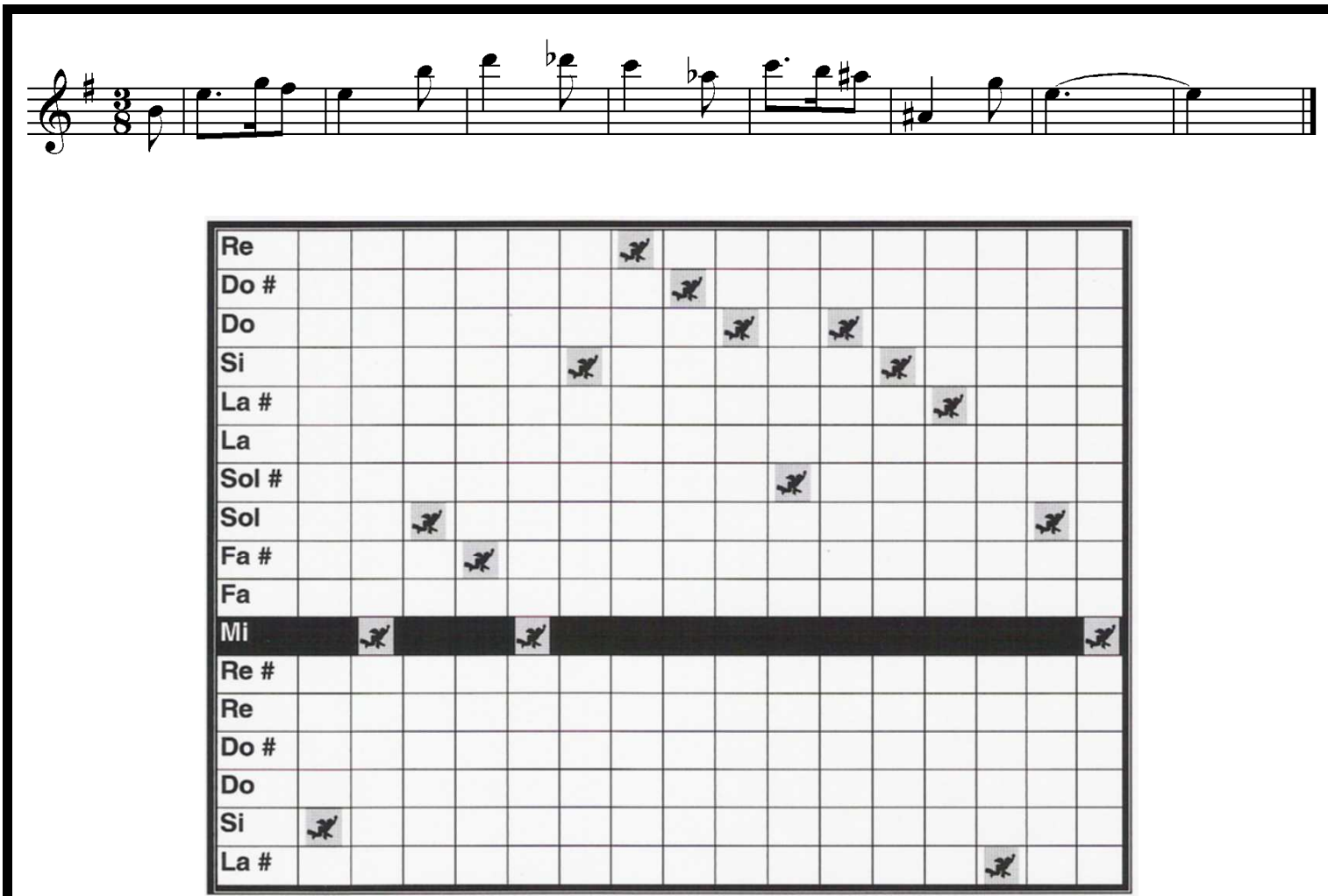

Fig. 18. Ejemplo práctico de extrapolación sobre el "Tema de Hedwig" de "Harry Potter" Audición (II) Juan Carlos Montoya Rubio

${ }^{438}$ Ibíd., pp. 110-113. 

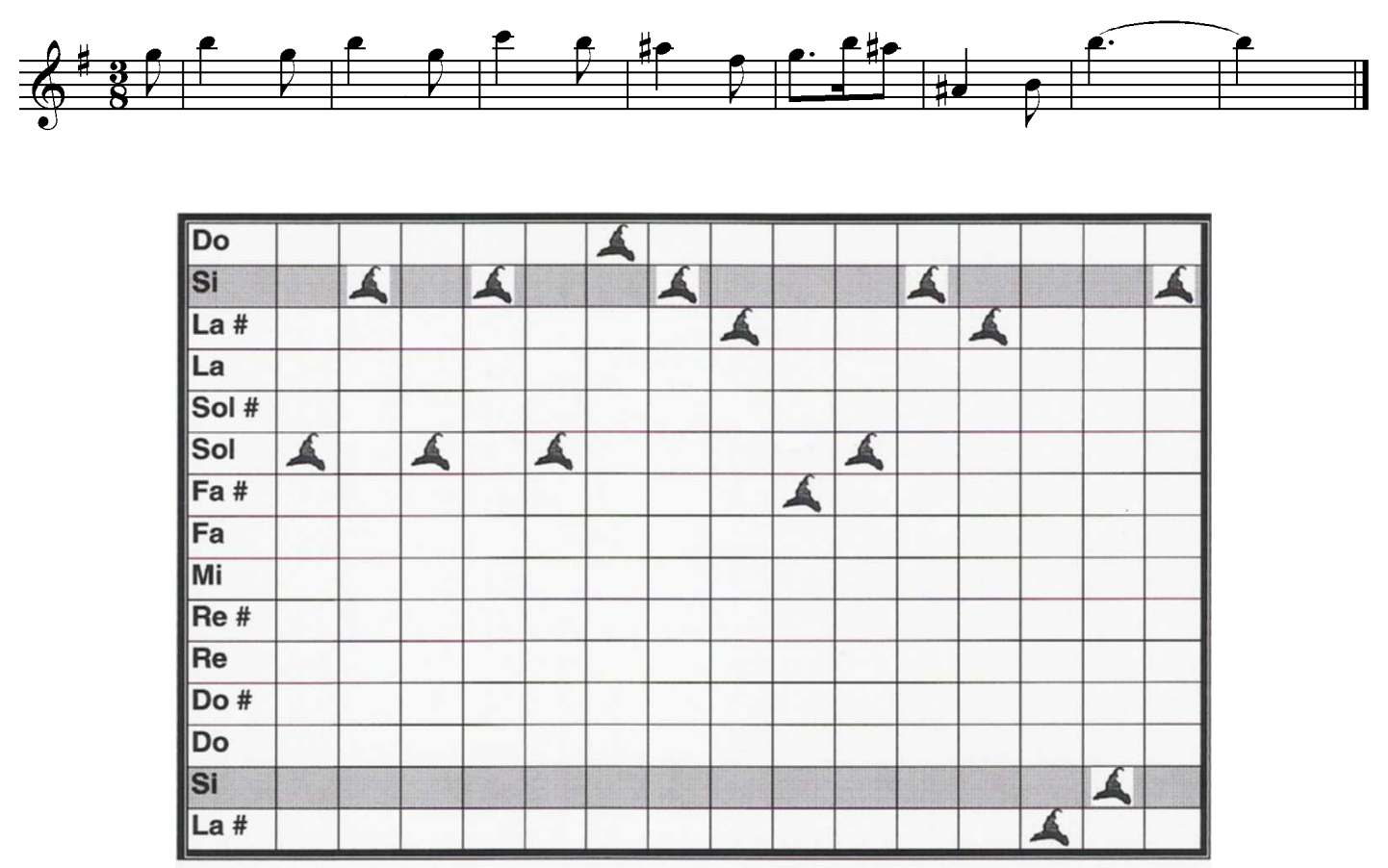

Fig. 19. Ejemplo práctico de extrapolación sobre el "Tema de Hedwig" de "Harry Potter" Audición
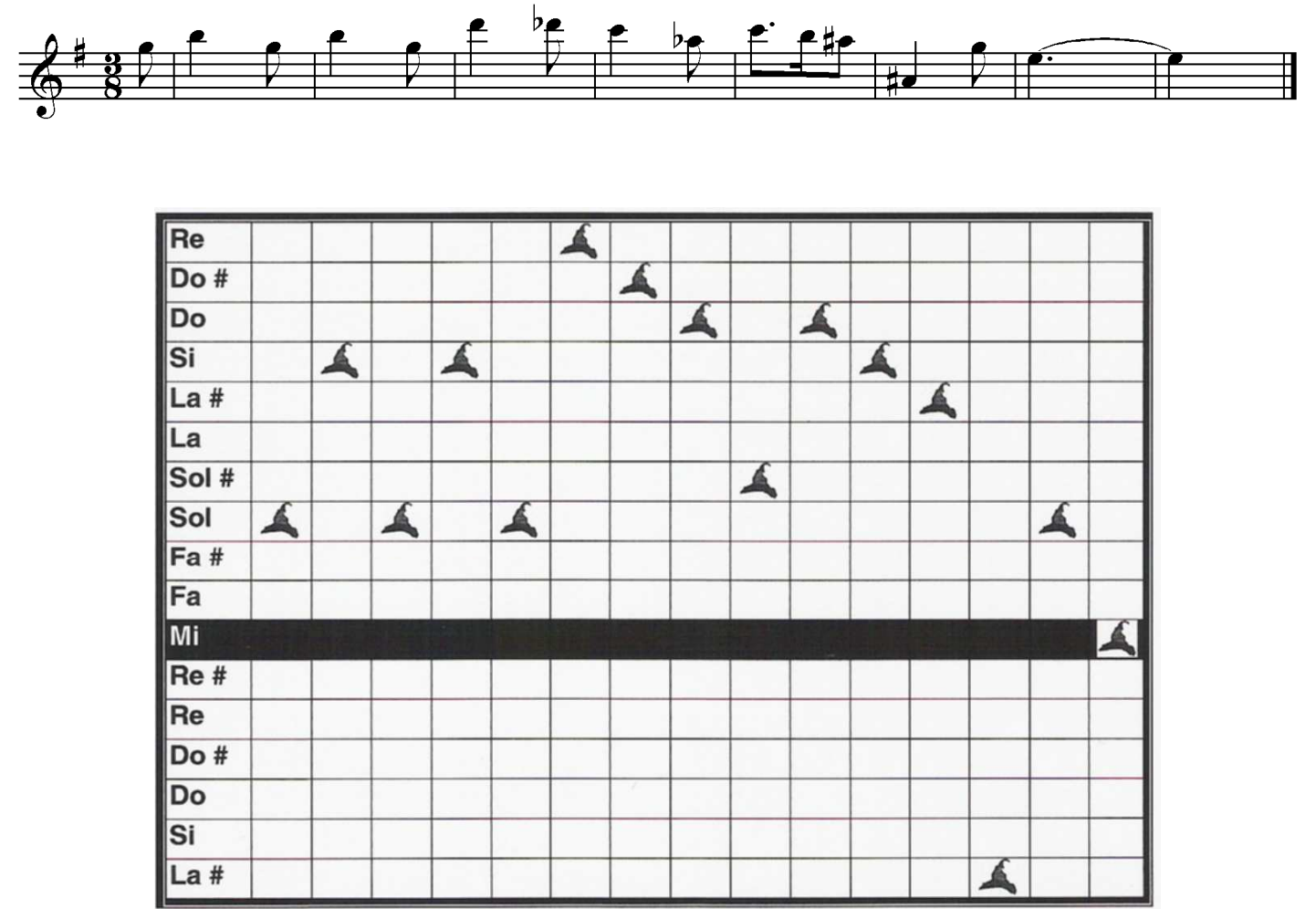

Fig. 20. Ejemplo práctico de extrapolación sobre el "Tema de Hedwig” de "Harry Potter" Audición (IV) Juan Carlos Montoya Rubio 
- $\quad$ Actividades de movimiento y danza siguiendo frases musicales ${ }^{439}$.

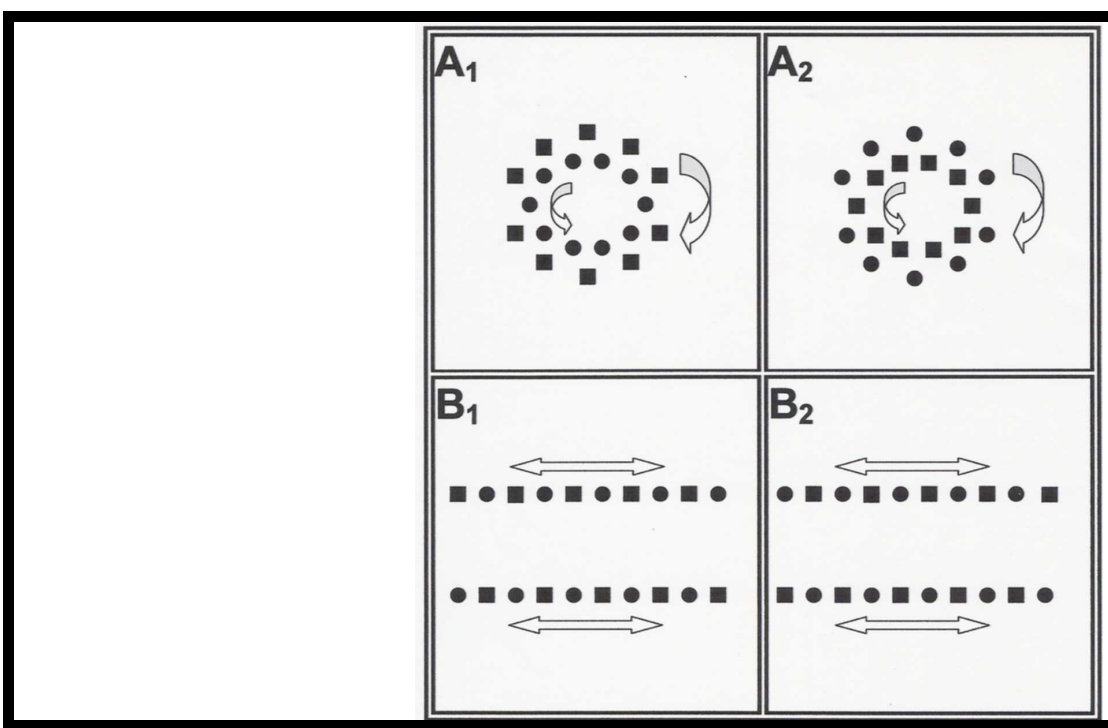

Fig. 21. Ejemplo práctico de extrapolación sobre el "Tema de Hedwig" de "Harry Potter". Danza.

- Actividades de formación vocal ${ }^{440}$.

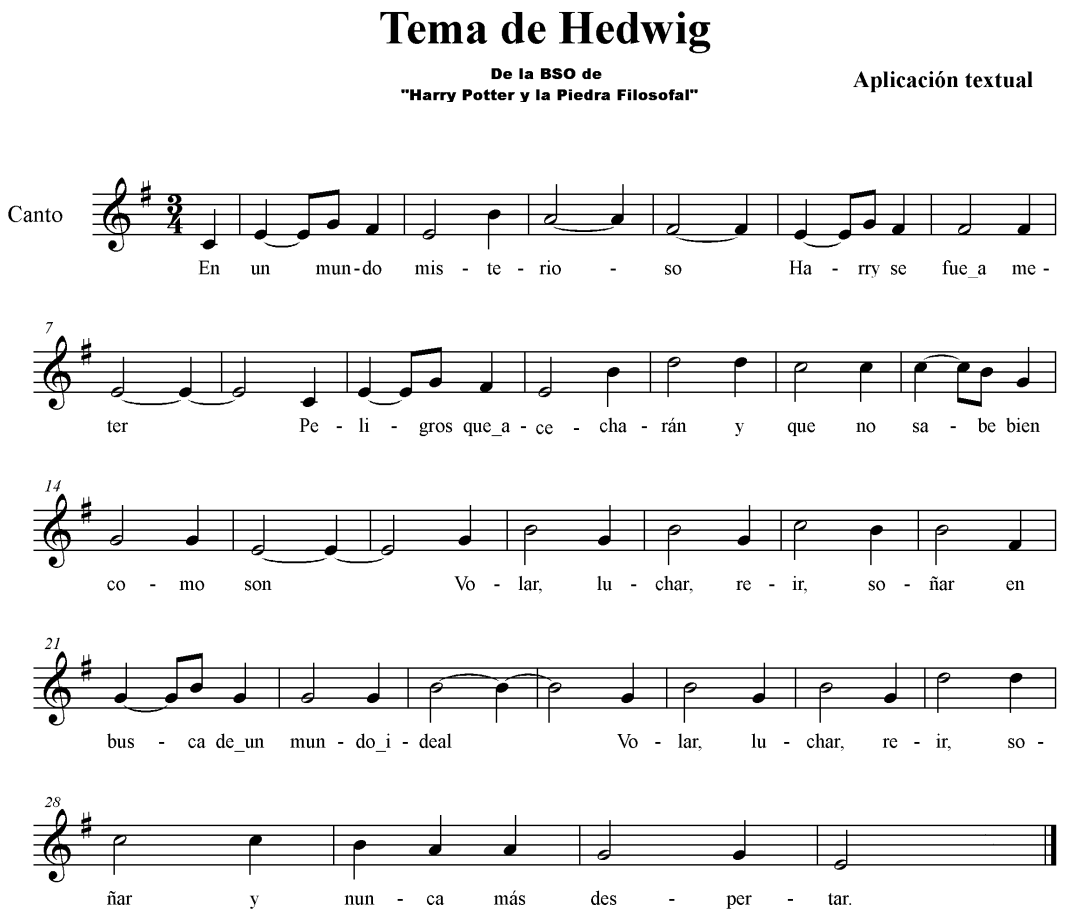

Fig. 22. Ejemplo práctico de extrapolación sobre el "Tema de Hedwig” de "Harry Potter". Canto. Juan Carlos Montoya Rubio

${ }^{439}$ Ibid, p. 116.

${ }^{440}$ Ibíd, p. 119. 
- Actividades de práctica instrumental. Flauta dulce y pequeña percusión ${ }^{441}$.

\section{TEMA DE HEDWIG}

De la Bso de

"Harry Potter y la Piedra Filosofal"

Flauta
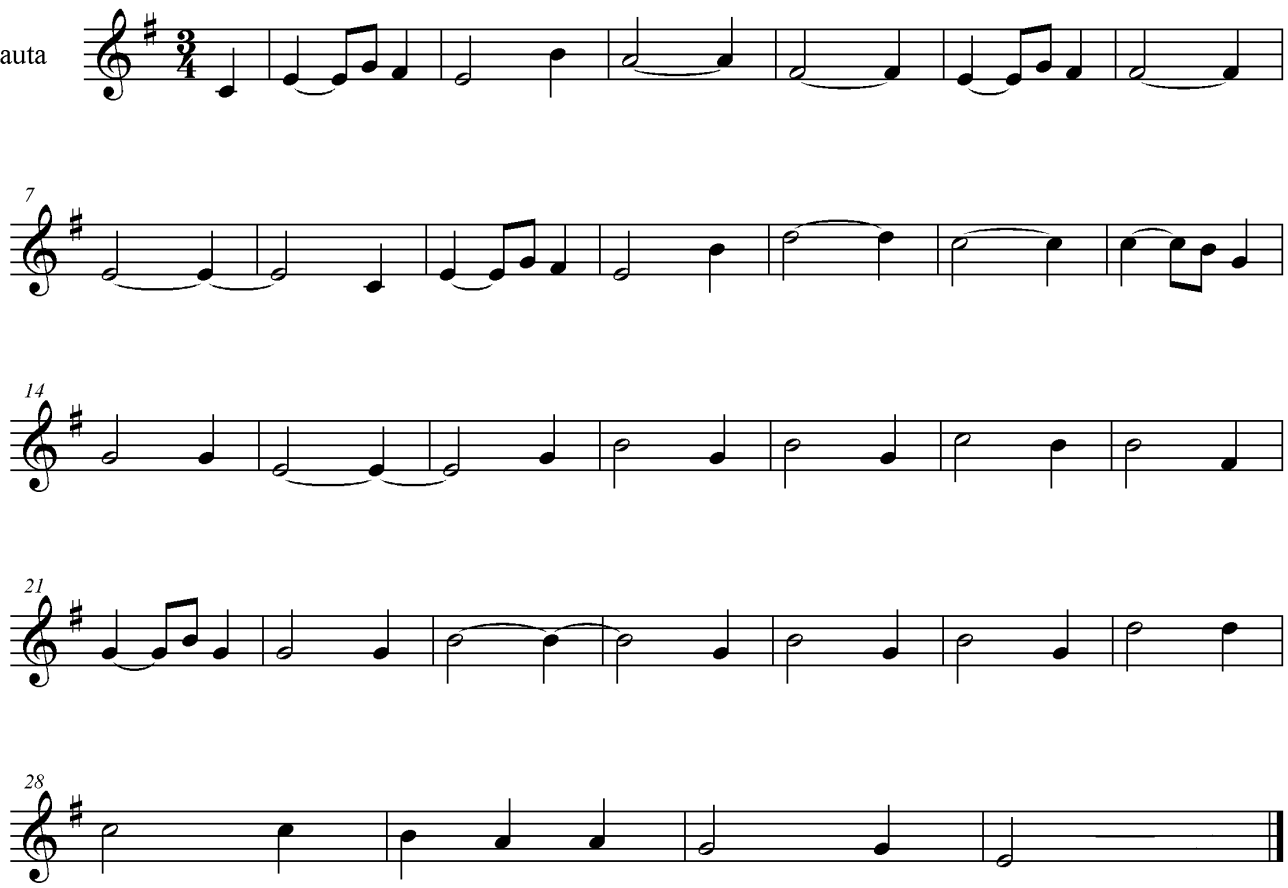

Fig. 23. Ejemplo práctico de extrapolación sobre el "Tema de Hedwig" de "Harry Potter". Flauta. Juan Carlos Montoya Rubio

${ }^{441}$ Ibíd, pp. 117 y 121. 


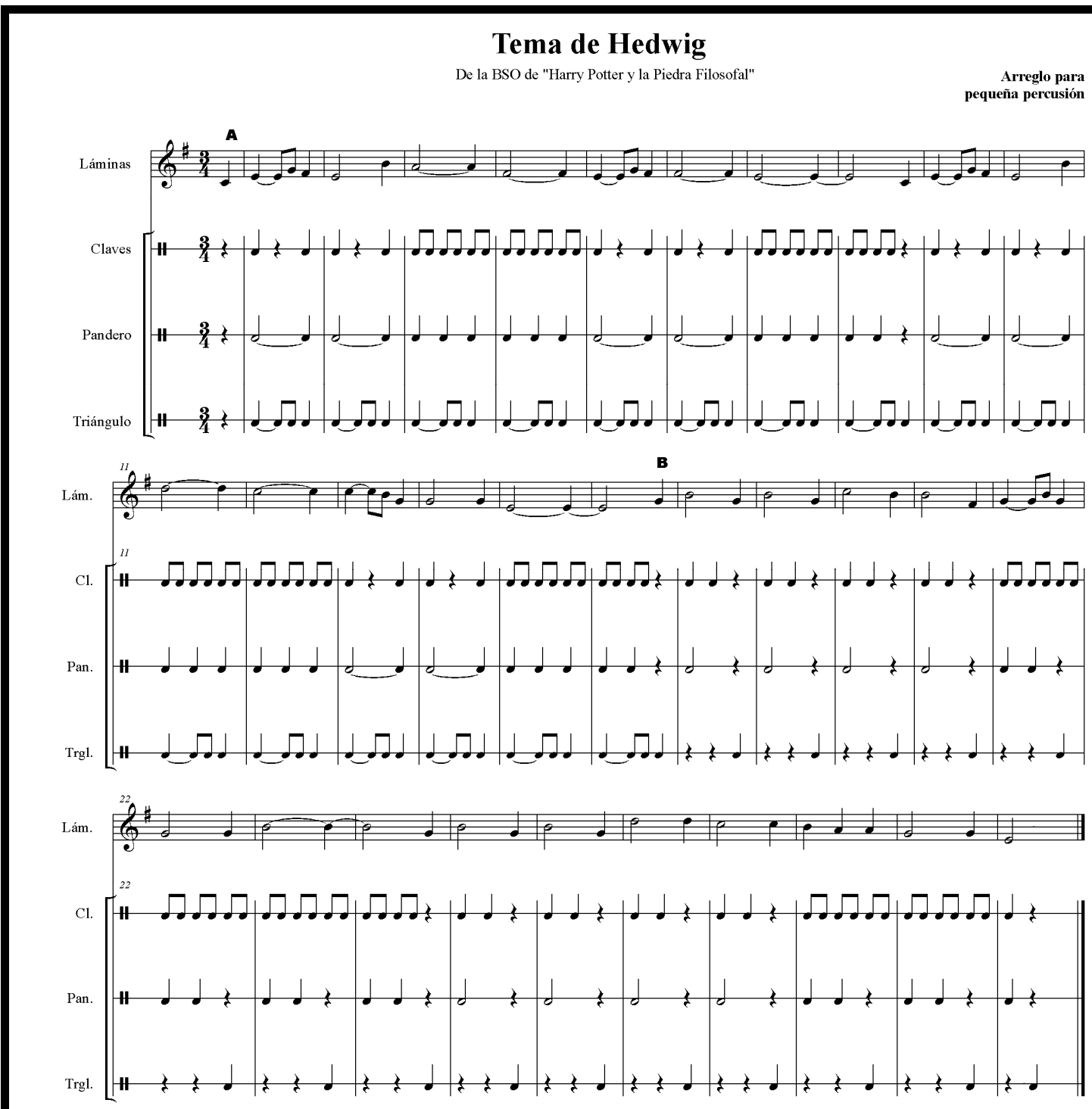

Fig. 24. Ejemplo práctico de extrapolación sobre el "Tema de Hedwig” de "Harry Potter". Pequeña percusión.

Juan Carlos Montoya Rubio

Debido a su componente significativo, el nudo argumental de "Harry Potter" ha sido utilizado profusamente en aplicaciones pedagógicas desde varios campos de conocimiento $^{442}$, pero curiosamente su gran potencial musical no había sido explotado

${ }^{442}$ Por ejemplo, interpretando el halo mágico de su mundo: HEILMAN, E. E. (2003): Harry Potter's World: Multidisciplinary Critical Perspectives. New York: Routledge Falmer; reseñando la importancia general que pudiera tener para el plano educativo: SERNA, J. (2001): “Qué nos enseña Harry Potter?”. Cuadernos de Pedagogía 302, pp. 80-82; o centrándose en áreas de conocimiento específicas LEEDS SALMERÓN, A. (2003): “HHarry Potter habla inglés!”. Cuadernos de Pedagogía 324, pp. 18-19; LACHANCE, A., WAGNER, M. M. y HAMMOND, B. (2004): "Mathematical Adventures with Harry Potter”. Teaching Children Mathematics, v. 10, pp. 274-277; CORRAL, J., DE CASTRO, D. y PAREJO, C. ( $\sin$ año): "Con Harry Potter lee y experimenta". Cfr. en <http://www.profes.net/varios/feria/fichas/secundaria/harrypotter/harrypotter.pdf> [Consulta 9-II-10]. 
con igual determinación. Tal vez, el trabajo más riguroso al respecto desde la educación musical sea la propuesta pedagógica de Almudena Mosquera ${ }^{443}$, quien utiliza esta misma composición, el "Hedwig Theme" que identifica a la lechuza de la película en cuestión, como excusa para llevar a cabo un trabajo de extrapolación extremadamente atractivo por su ligazón entre el desarrollo activo de parámetros musicales y elementos extraídos del filme ${ }^{444}$. La secuencia metodológica que la autora se da para llevar a cabo su trabajo de extrapolación es la siguiente ${ }^{445}$ :

- Estructura de la pieza (por compases)

- General

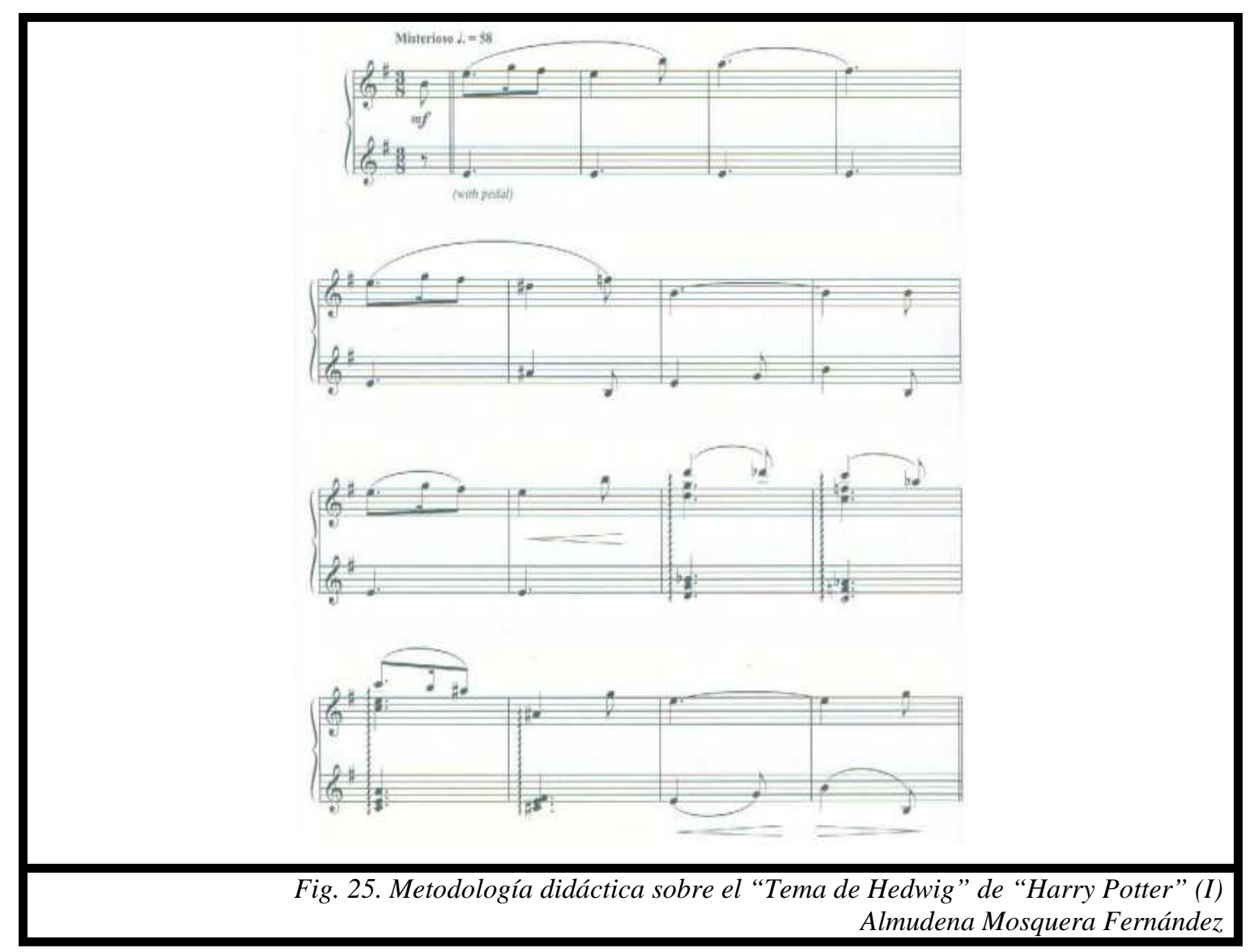

443 A la espera de un estudio más amplio a desarrollar en su tesis doctoral, la principal referencia es MOSQUERA FERNÁNDEZ, A. (2009): "Música incidental para momentos mágicos". OLARTE MARTÍNEZ, M. (Ed.) Reflexiones en torno a la música y la imagen desde la musicología española. Salamanca: Plaza Universitaria Ediciones, pp. 633-667.

${ }^{444}$ Además, se explorarán otro tipo de relaciones muy provechosas para hacer conectar el aprendizaje musical con otro tipo de dimensiones como las literarias. Algunas de estas últimas ideas quedaron expuestas en MOSQUERA FERNÁNDEZ, A. (2005): "Emilia Pardo Bazán y su aportación al cine". OLARTE MARTÍNEZ, M. (Ed.) La música en los medios audiovisuales. Salamanca: Plaza Universitaria Ediciones, pp. 517-521.

${ }^{445}$ MOSQUERA FERNÁNDEZ, A. (2009): Op. cit., p. 642. La selección de imágenes que realizamos a partir de las que la autora utiliza para describir la secuencia metodológica están extraídas del mismo artículo, en sus páginas 643, 649, 657, 658, 664 y 665 . 


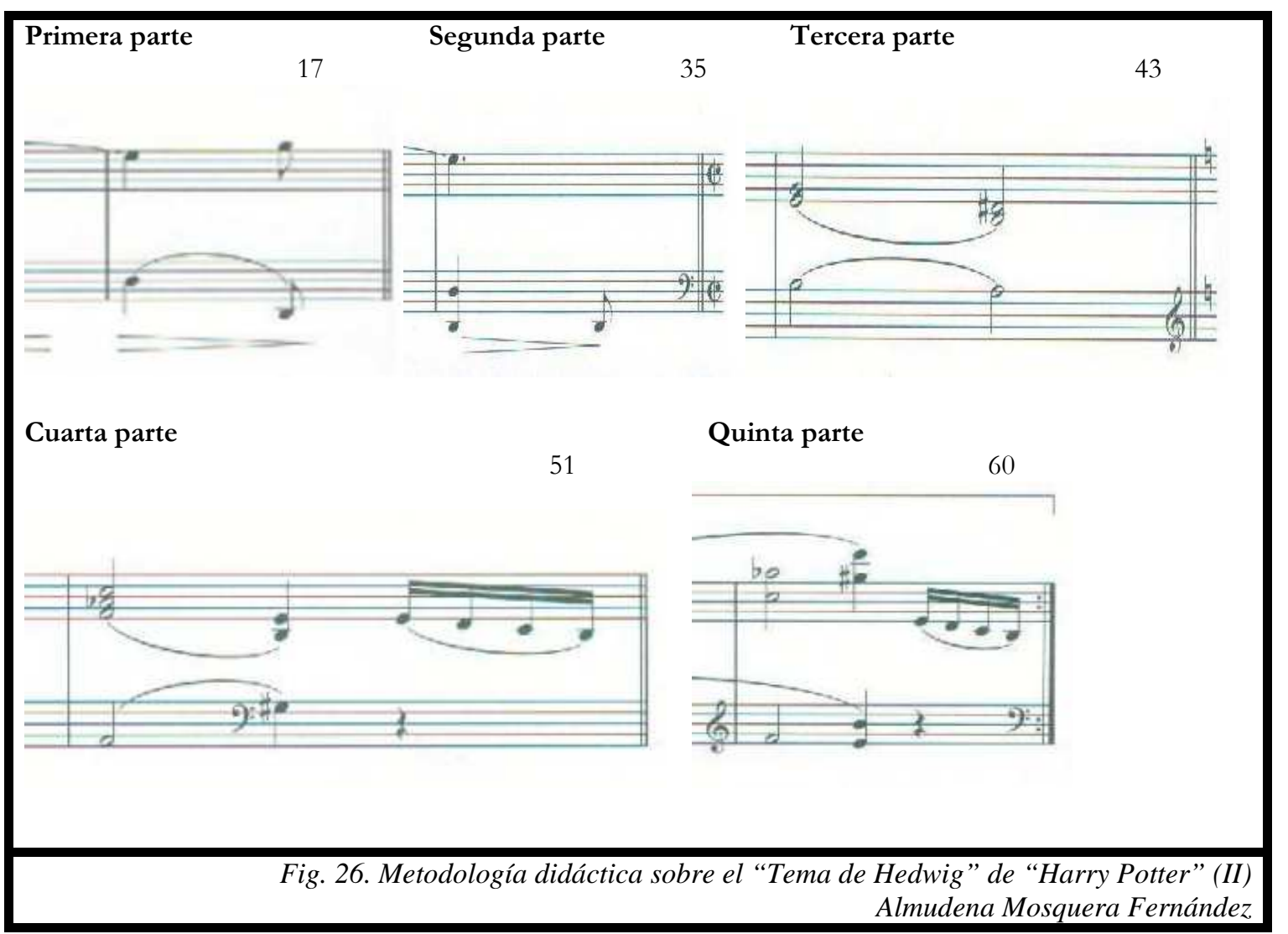

○ Específica

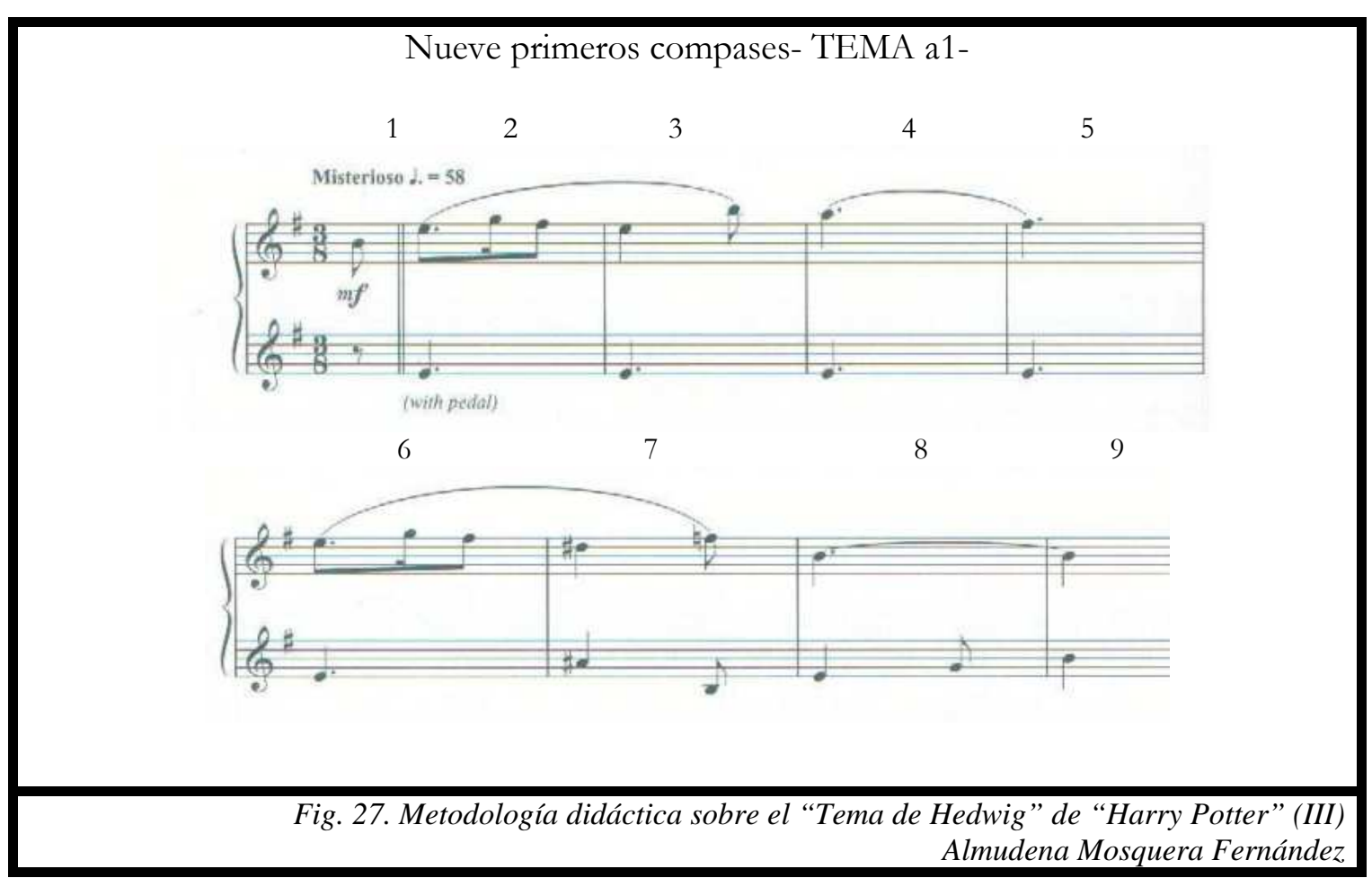


- Instrumentación por familias

$\circ$ En conjunto

\begin{tabular}{|c|c|}
\hline \multicolumn{2}{|c|}{ Primera parte: } \\
\hline PERCUSIÓN & Nueve compases (1-9) \\
\hline PERCUSIÓN & Nueve compases (9-17) \\
\hline & Segunda parte: \\
\hline PERCUSIÓN & Ocho compases (18-25) \\
\hline PERCUSIÓN & Siete compases (25-31) \\
\hline CUERDA, PERCUSIÓN & Cuatro compases (32-35) \\
\hline
\end{tabular}

Fig. 28. Metodología didáctica sobre el "Tema de Hedwig” de "Harry Potter" (IV) Almudena Mosquera Fernández.

○ Voces solistas

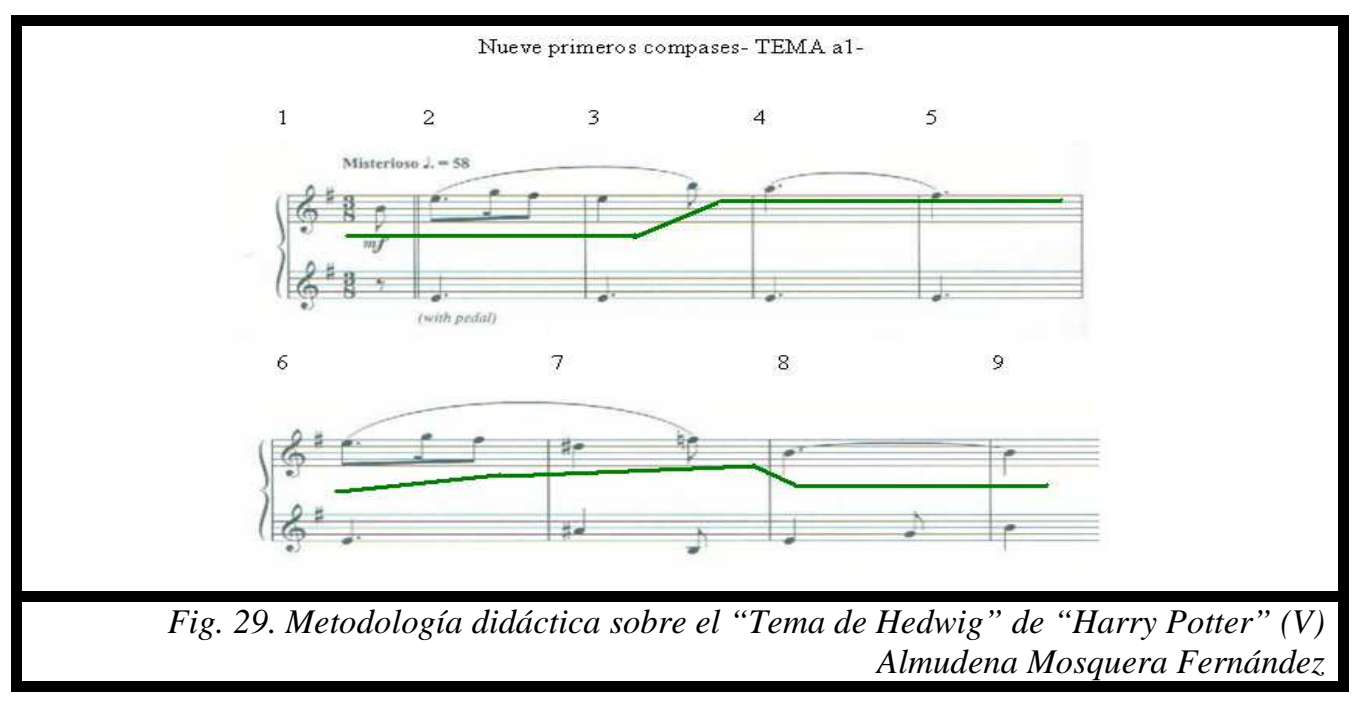

- Lenguaje musical

○ Compás
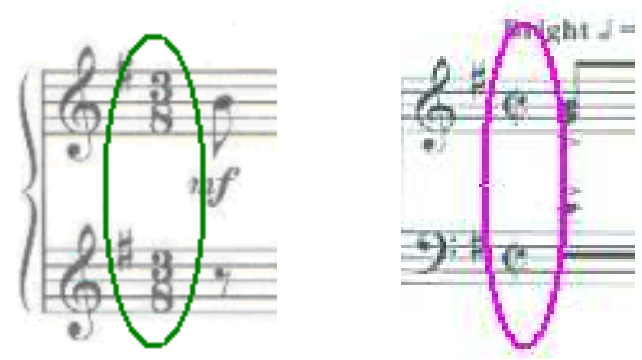

Fig. 30: Metodología didáctica sobre el "Tema de Hedwig" de Harry Potter (VI) Almudena Mosquera Fernández 
- Células musicales

\begin{tabular}{|l} 
Rítmicas \\
\hline Fig. 31. Metodología didáctica sobre el "Tema de Hedwic" de "Harry Potter" (VII) \\
Almudena Mosquera Fernández
\end{tabular}

\section{Extrapolación de un fragmento musical seleccionado ad hoc}

Como venimos exponiendo desde el capítulo anterior, se pretende la activación del resorte significativo para la extracción de melodías que nos sean útiles, en este caso para la extrapolación musical. Hasta ahora se han mostrado ejemplos en los cuales la música, compuesta para su integración en el audiovisual, toma vigor y hace que se pueda extraer de ella la carga emocional que ha provocado en los alumnos al conocerla "fuera de las aulas". Otro modelo de extrapolación es aquel en el cual el producto resulta atractivo pero, en principio, aquel que lo visiona inocentemente no tiende a reconocer en la música, que por otro lado juega un papel vital, la importancia que requiere ${ }^{446}$.

Algunas prácticas concretas muestran la efectividad en el uso de canciones extraídas de películas de temática infantil. El ejemplo más recurrente es el uso cinematográfico de dichas canciones como un paso más de la aprehensión del hecho musical en sí:

“...en las diferentes audiciones mencionadas [de las películas Los aristogatos y La pantera rosa] nos centramos en conocer los instrumentos y características de la música, visualizamos el fragmento de las películas en las que aparecía la canción a trabajar ["Yo quiero ser un gato de Jazz" y tema principal de La pantera rosa],

\footnotetext{
${ }^{446}$ En este sentido, para la citada Nobleza Baturra, MARTín FÉLEZ, D. (2009b): Op. cit., p. 373, propone "el análisis musical de las orquestaciones, y la interpretación de los temas que aparecen en la película con instrumentos escolares", lo cual es un ejercicio evidente de extrapolación dentro de un filme que, a pesar de su amplio contenido musical, sin una adecuada focalización, puede incitar al alumnado a seguir el nudo argumental y no detenerse en su banda sonora.
} 
aprendimos el texto de las diferentes canciones, utilizamos un musicograma para la posterior instrumentación del tema musical, cuyo grado de dificultad dependía del ciclo en el que estuviéramos trabajando" $" 447$.

De acuerdo con la cita anterior, he aquí un ejemplo que extrapola la banda sonora en forma de música de cine para facilitar el seguimiento auditivo:

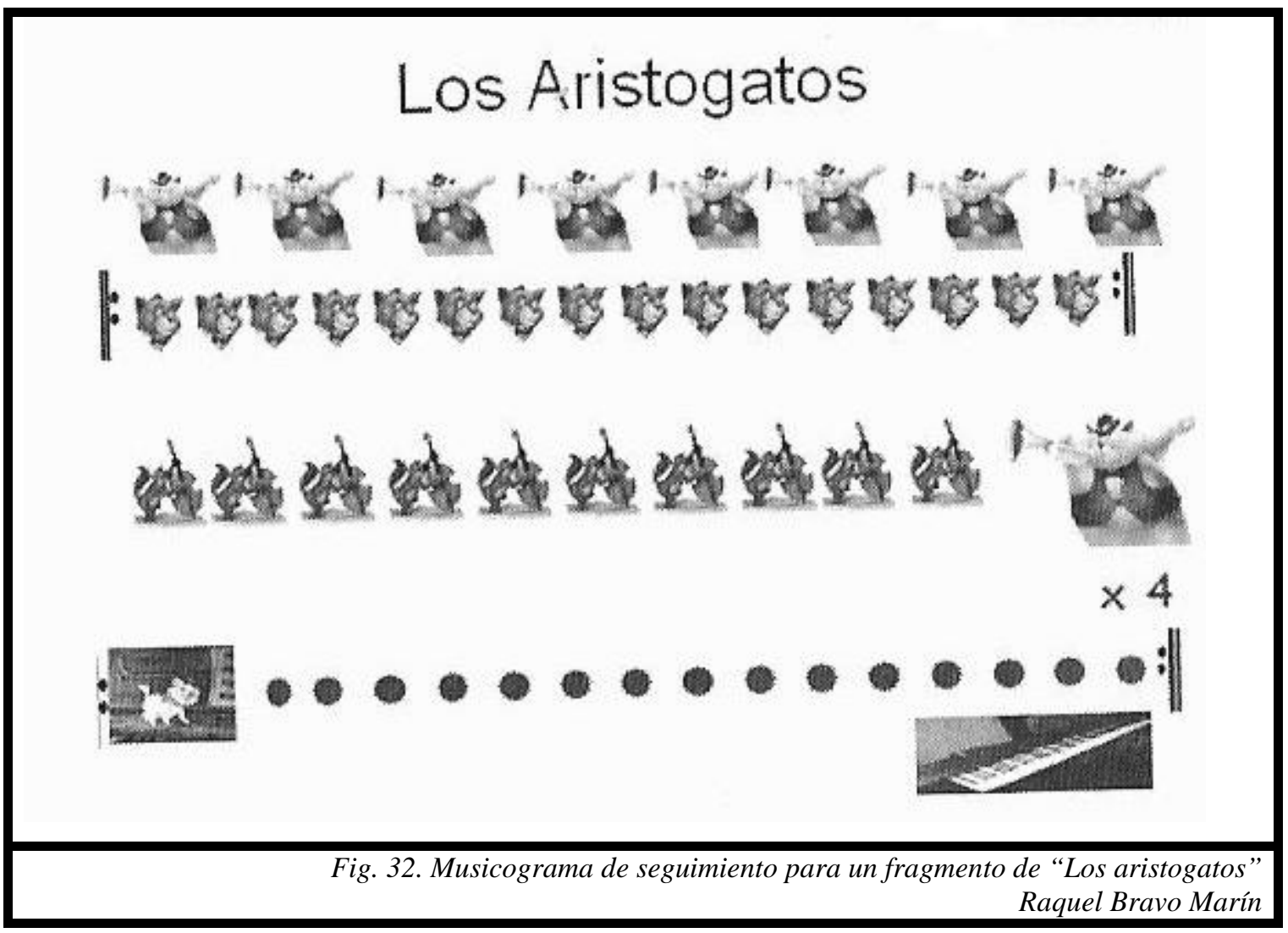

Como se infiere por la explicación que detalla el desarrollo procedimental, estamos ante una aplicación que, buscando la significatividad, se sirve de la extrapolación de melodías de manera puntual, esto es, seleccionando con finalidad pedagógica un determinado fragmento sobre el que actuar. Otras aplicaciones procedentes de la película Los aristogatos, abordada en clave didáctica e intercultural por las autoras puede responder a criterios derivados de la inclusión educativa, a tratar en el siguiente capítulo.

${ }^{447}$ BRAVO MARÍN, R. y DE MOYA MARTÍNEZ, M. V. (2006): "Multiculturalidad musical para las aulas del siglo XXI". Ensayos 21, p. 135. 
Más situaciones muy evidentes desde los cuales se pueden establecer parámetros didácticos son los análisis llevados a cabo por Vicente Galbis, quien al hilo de la música concertística en el cine, rescata algunos ejemplos de los muchos que podrían extraerse para un trabajo como el que proponemos ${ }^{448}$. De los ejemplos propuestos, por lo hilarante de la situación que describe, tal vez sea uno de los más apropiados el acercamiento a un madrigal de Giovanni Gastoldi en Amanece que no es poco ${ }^{449}$, o el trailer que, con música de Carmina Burana de Orff, promocionaba la película La gran aventura de Mortadelo y Filemón ${ }^{450}$.

Así, el tratamiento de temas derivados de la música clásica también tiene su lugar en los desarrollos prototípicos de extrapolación desde el audiovisual. A partir de este tipo de recursos, podremos ocuparnos de realizaciones que permitan extrapolar elementos que habitualmente son más dificultosos en el aprendizaje dentro de la enseñanza obligatoria. Es el caso de la ópera, cuya estética hace que en ocasiones quede alejada de los intereses del alumnado propio de estas edades pero que, bien guiada desde un proceso de significación audiovisual, puede erigirse tanto más como el resto de aspectos musicales en un elemento de asimilación musical ${ }^{451}$. Por otro lado, el trabajo de extrapolación sobre producciones operísticas multiplica las opciones de desarrollo procedimental, en tanto en cuanto permite acceder, no sólo desde el plano sonoro sino también desde el visual, a aspectos como las diferentes versiones y recreaciones ${ }^{452}$. En este sentido, dejamos constancia de varias aplicaciones que responden a estos criterios, fundamentadas en el uso de la música de G. Rossini derivada de la publicidad y los dibujos animados ${ }^{453}$.

\footnotetext{
${ }^{448}$ GALBIS LÓPEZ, V. (2009b): "La música de concierto en el cine español posterior a 1975". OLARTE MARTÍNEZ, M. (Ed.) Reflexiones en torno a la música y la imagen desde la musicología española. Salamanca: Plaza Universitaria Ediciones, pp. 225-244. En el desarrollo de la ponencia que dio lugar al artículo (IV Simposio Internacional La Creación Musical en la Banda Sonora, Salamanca, 2008), el autor resaltaba que la selección que había llevado a cabo podía ser tan extensa como se precisara ya que era tanto el material disponible para su análisis que es obviamente mayor lo que se ha de dejar fuera que lo que se ha de reflejar. En nuestro interés por crear intenciones en el profesorado, sirva el ejemplo como inicio de hipotética actuación.

${ }^{449}$ Dir. José Luis Cuerda, 1988.

${ }^{450}$ Dir. Javier Fesser, 2004. Tal vez, la grandilocuencia del subtítulo, "Misión salvar la Tierra", hizo buscar sonoridades supuestamente ancestrales como la que se insertó.

${ }^{451}$ MONTOYA RUBIO, J. C. (2008a): Op. cit. La propuesta, de manera general, pivotaba entre la ópera rossiniana y pucciniana. El primero de los casos se expone con brevedad mientras que el segundo tiene una prolija bibliografía cinematográfica tras de sí, como atestigua RADIGALES, J. (2009b): Op cit.

${ }^{452}$ MONTOYA RUBIO, J. C. (2008b): Op. cit.

${ }^{453}$ MONTOYA RUBIO, J. C. (2008a): Op. cit.
} 
De acuerdo con los axiomas propuestos, buscamos elementos que puedan dotar de un estímulo añadido al inicio de las realizaciones pedagógicas, por lo que en el primero de los ejemplos dentro de este campo partimos de un anuncio publicitario que nos derive al original rossiniano por medio de un musicograma de seguimiento. Con posterioridad se prevé un ejercicio de sonorización que será expuesto en breve, al abordar dichos procedimientos. Con ello, se trabajaría sobre la obertura de "La Gazza Ladra" utilizada como hilo conductor de la espectacular producción de Jonathan Glazer $^{454}$ con la que, a través de coloridas explosiones de pintura, sincronizar imágenes y sonidos. El razonamiento de este primer ejemplo queda como sigue:

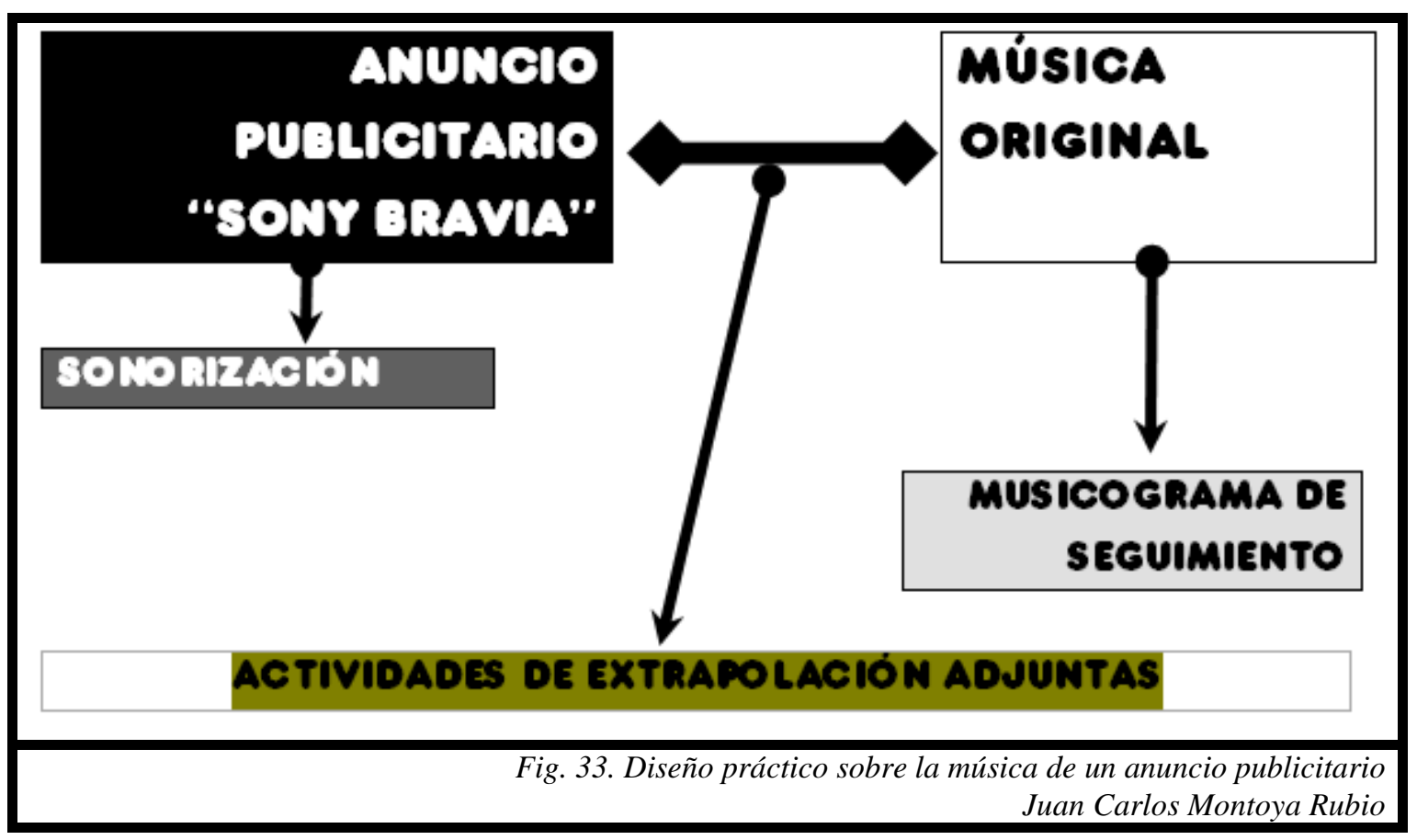

Como apuntamos, la práctica sonorizadora se expondrá dentro del aparatado de esta tesis dedicado a ello, por su parte, el musicograma de seguimiento y el resto de actividades anexas a él podrían responder a criterios como los que hemos elaborado ${ }^{455}$ :

\footnotetext{
454 "Sony Bravia", Dir. Jonathan Glazer, 2005. Disponible en $\langle$ http://www.youtube.com/watch?v=pGL0gdEPCtU > [Consulta 9-II-10].

${ }^{455}$ MONTOYA RUBIO, J.C., MONTOYA RUBIO, V. M. y FRANCÉS ARIÑO, J. M.: "Musicogramas con movimiento, un paso más en la audición activa". Ensayos 24 (en prensa).
} 

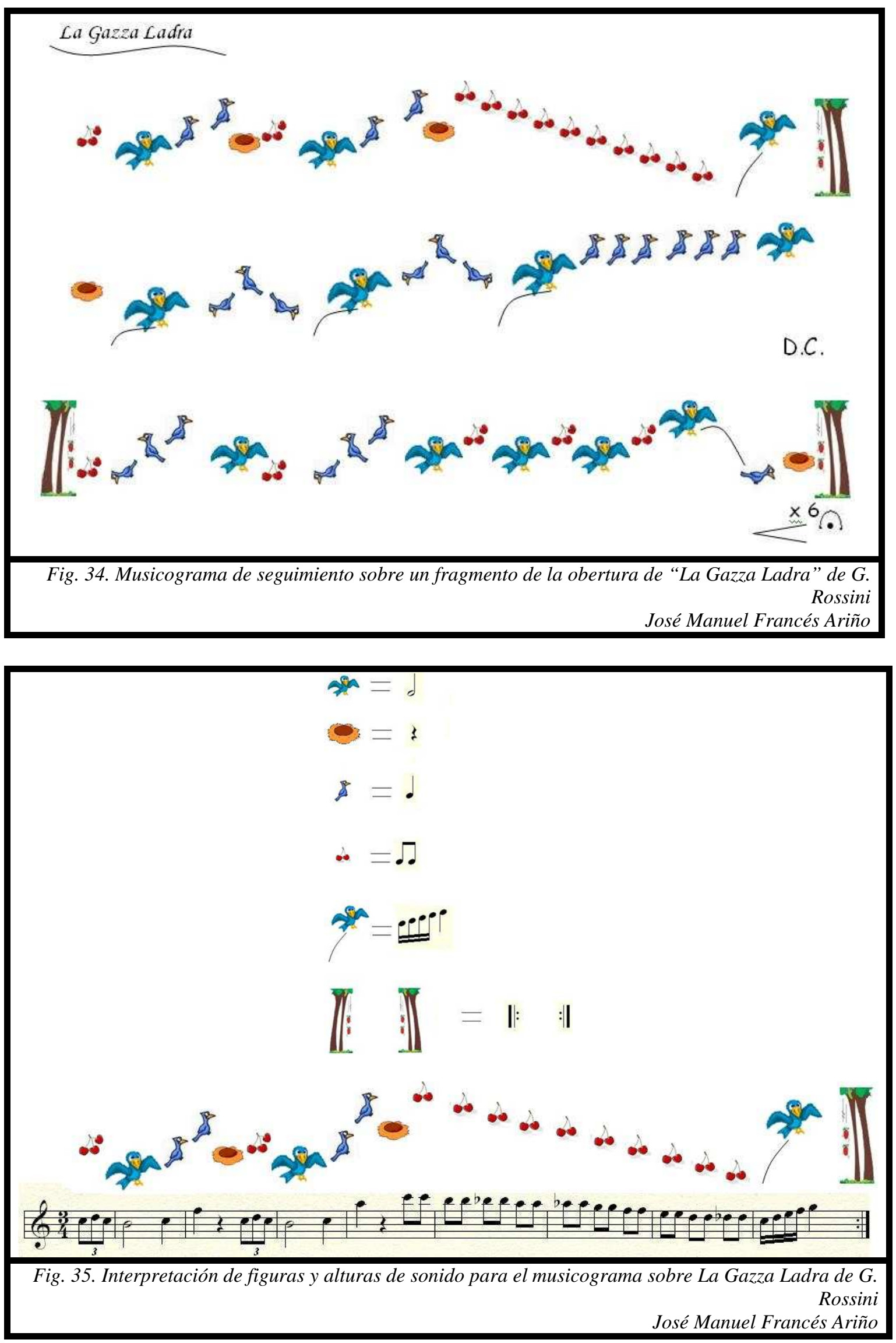


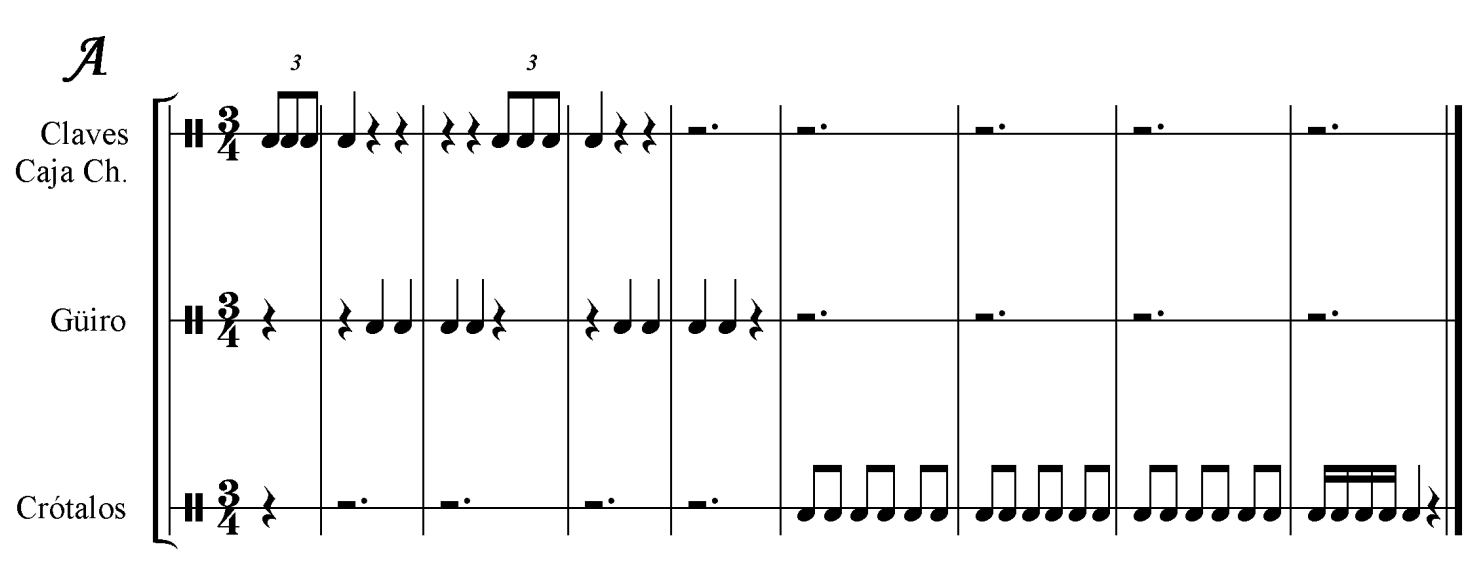

Crótalos

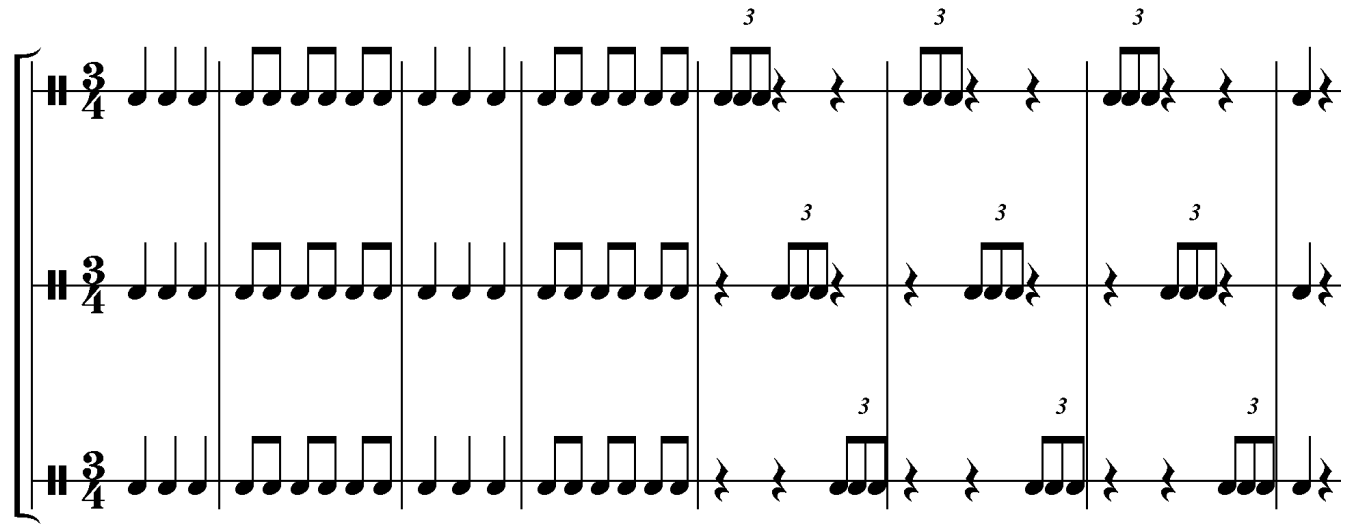

C

Pandereta

Triángulo

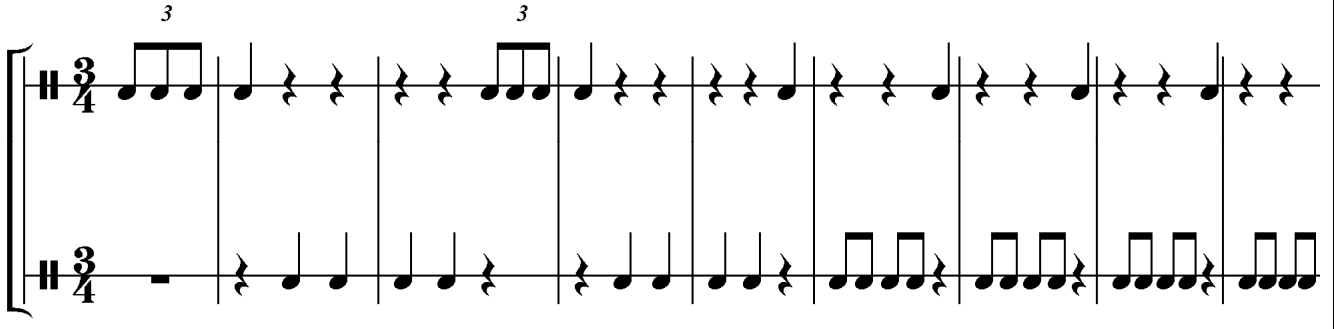

Fig. 36. Aplicación con instrumentos de altura indeterminada para la actividad sobre La Gazza Ladra de G. Rossini

Una segunda aproximación a este tipo de contenidos, en estrecha relación con la anterior fue desarrollada en torno a "The band concert" $" 456$. En ella la observación de diferentes temas de la obertura de Guillermo Tell da paso a actividades de extrapolación musical a partir del original.

${ }^{456}$ Dir. Wilfred Jackson, 1935. 


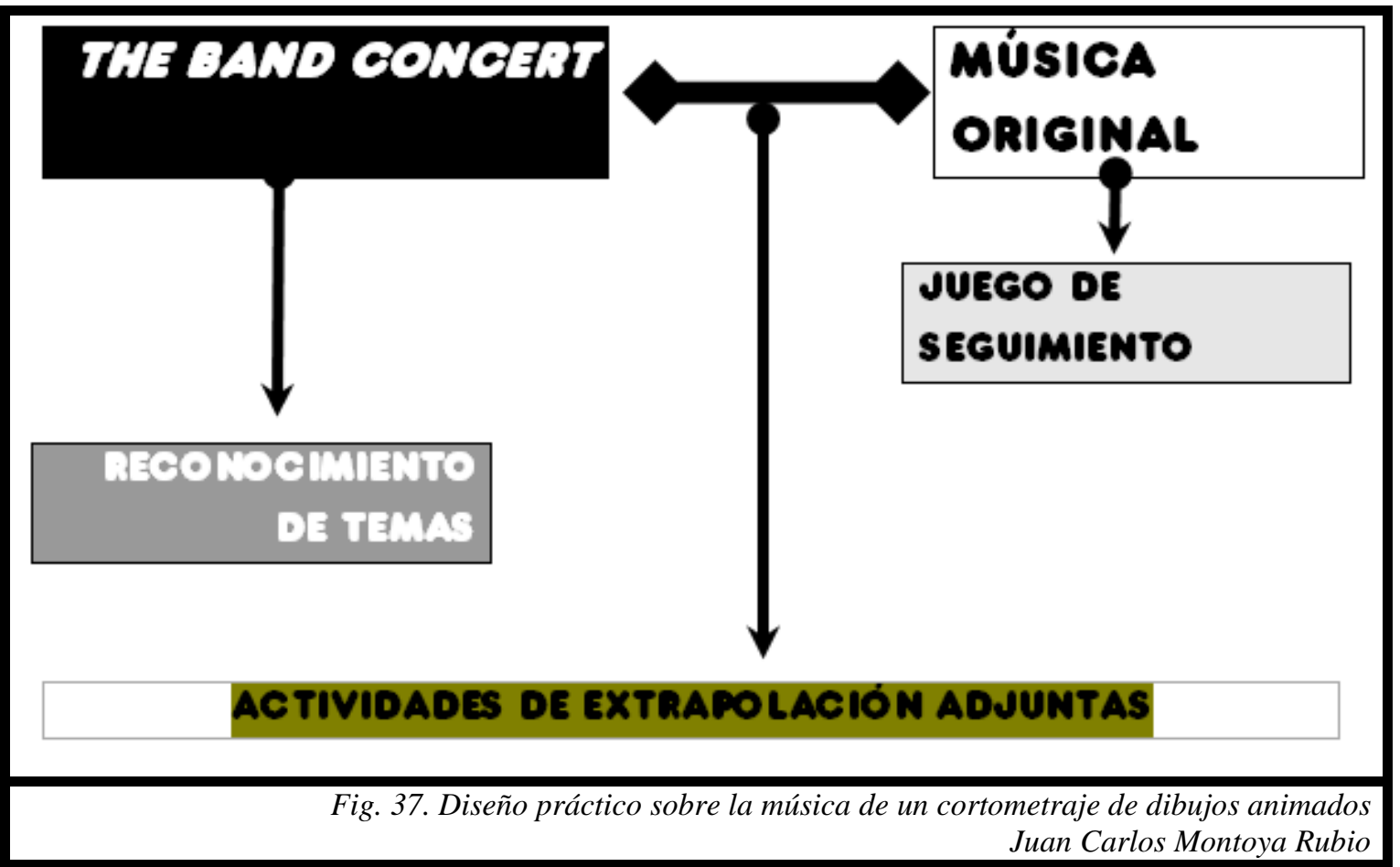

El ejemplo que proponemos es un puzzle que hemos realizado con diferentes partes del apoteósico final de la obra, para hacer trabajar a los alumnos varios aspectos tan relevantes como el seguimiento auditivo, la forma musical o la direccionalidad melódica $^{457}$. Se muestra por tanto el esquema a completar y las piezas que habrán de ir componiendo el juego:

\section{ESQUEMA A COMPLETAR}

\section{ABBCODBBEEFEECODBGGH}

457 Explicaciones adicionales sobre el procedimiento para elaborar estos materiales en MONTOYA RUBIO, J. C. (2008a): Op. cit., pp. 62-63. 


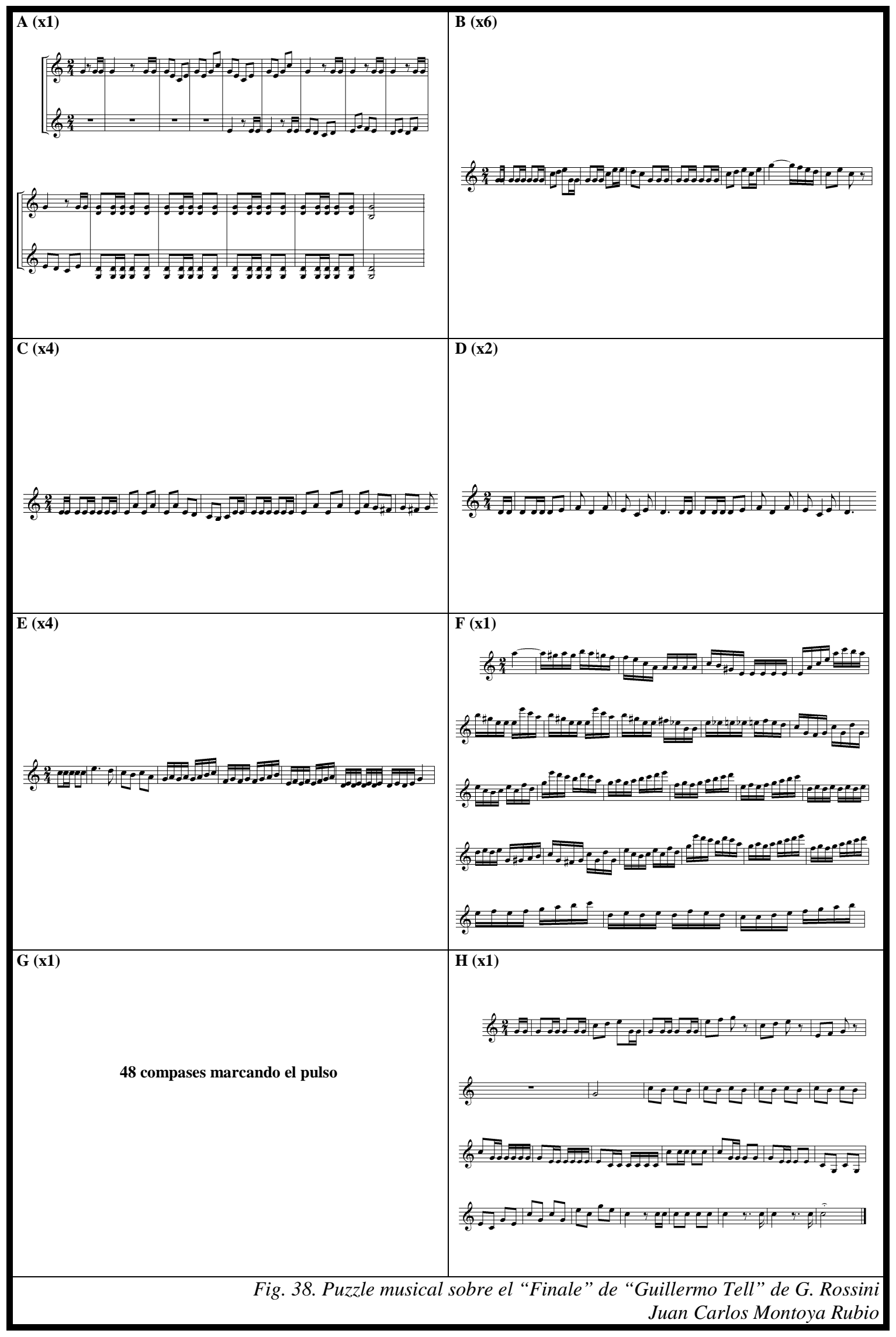


Sobre este mismo cortometraje hemos de constatar la propuesta de David Martín Félez. El interés del autor por centrarse en elementos de la extrapolación por encima de otros parámetros referidos a las posibilidades del audiovisual es evidente:

“...nos va a servir para explicarle a los alumnos diversos contenidos musicales: instrumentos, tiempos musicales, diferencia entre solista y tutti, matices musicales, movimientos de una obra musical, el concepto de melodía y armonía..."458.

En esta gráfica aportación, es subrayable el esfuerzo de Martín Félez por llevar a cabo una propuesta que abarque desde la etapa de infantil hasta el primer ciclo de educación secundaria obligatoria, con todas las ventajas que conlleva hacer converger a todo el centro educativo sobre un mismo material.

Por último, dentro de esta aproximación a la extrapolación en el mundo operístico, más concretamente en el de Rossini, compendiamos las dos vías anteriores (publicidad y cortometraje de dibujos animados clásicos) en la presentación de un fragmento que trabajase, ya no sólo las oberturas, sino también partes vocales. Para ello, seleccionamos como punto de partida The Rabbit of Seville ${ }^{459}$, el cual se verá apuntalado por otros refuerzos publicitarios como "La caña Cruzcampo" 460 , célebre anuncio televisivo que tuvo gran repercusión en el público infantil, si se toma como medida la facilidad con que podíamos encontrarnos, hace unos años durante su irrupción, este canturreo entre niños de distintas edades. En esta última referencia se lleva a cabo un proceso de contrafacta $^{461}$ sobre el célebre "Largo al factotum" de una de las más emblemáticas óperas de Rossini, El barbero de Sevilla. La sorpresa a la presentación del original no debe ser menor para el alumno al reconocerla en el cortometraje aludido, el cual incentiva la significatividad en tanto en cuanto tiene entre sus prioridades la persecución de la diversión por encima de otras contingencias ${ }^{462}$. En él, además del trabajo de

\footnotetext{
${ }^{458}$ MARTÍN FÉLEZ, D. (2009a): Op. cit., p. 775.

${ }^{459}$ Dir. Chuck Jones, 1950.

${ }^{460}<$ http://www.youtube.com/watch?v=VvC6EeTdL-U $>$ [Consulta 9-II-10]

${ }^{461}$ FERNÁNDEZ DE LA CUESTA, I. (1999): "Contrafactum". Diccionario de la música española e iberoamericana, v. III. Madrid: SGAE, pp. 921-922.

${ }^{462}$ RADIGALES, J. (2001): "Creació i muntatge musical en el dibuix animat clàssic". Trípodos 11, pp. $107-122$.
} 
cambio textual que vamos a presentar, quedan abiertas infinidad de posibilidades, desde el reconocimiento de elementos de producción cinematográfica, como el mickeymousing ${ }^{463}$ hasta la observación de la expresividad musical que hace prescindir en ocasiones de la palabra ${ }^{464}$. Todo ello, teniendo en mente la perpetración de un cambio textual similar al que tanto en la versión publicitaria como en la cinematográfica se ha llevado a cabo.

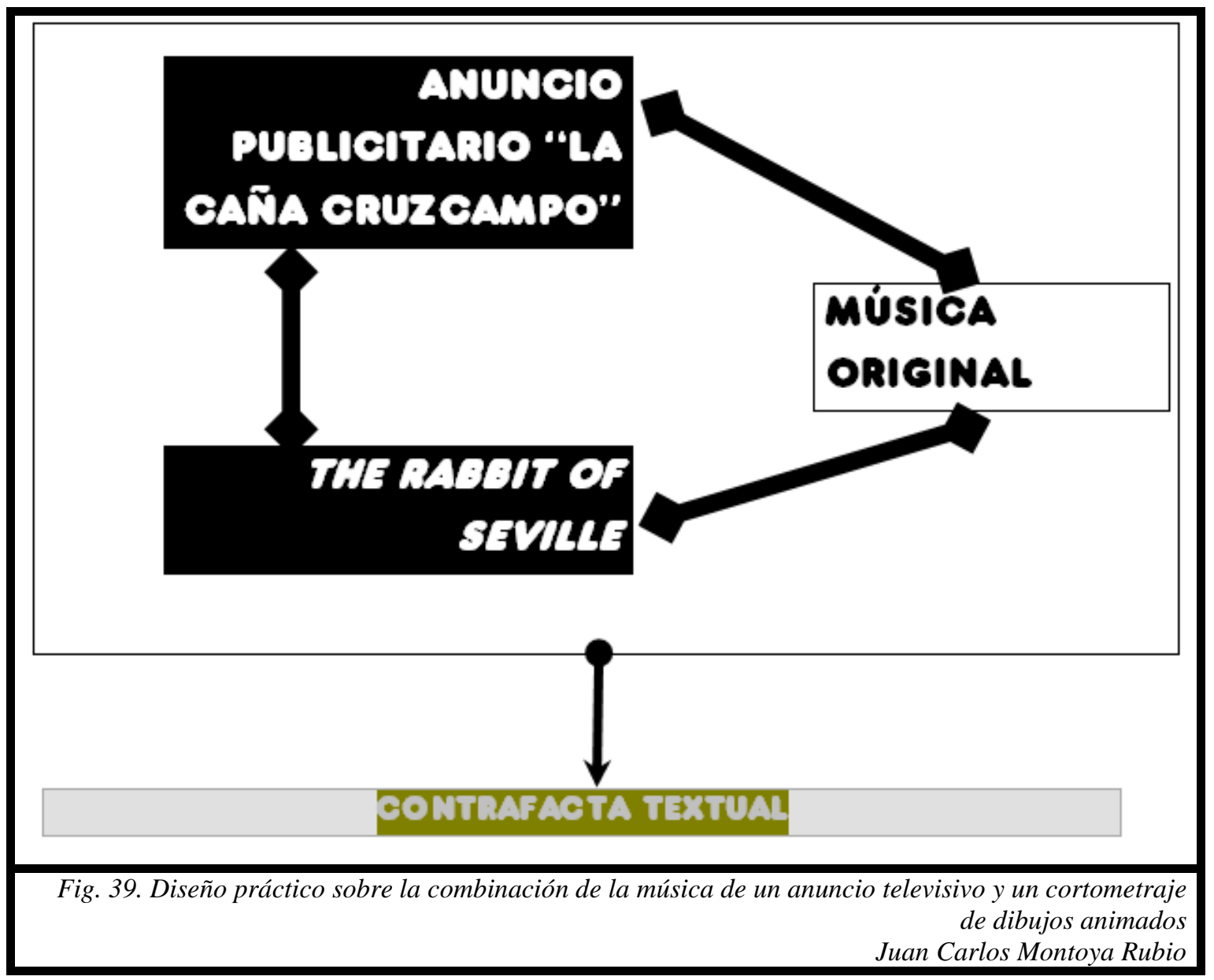

El ejemplo de contrafacta textual que presentamos trabaja, especialmente, las alturas de sonido y las duraciones, haciendo ver a los alumnos de manera relativa la posición de cada sonido ${ }^{465}$ :

\footnotetext{
${ }^{463}$ CHION, M. (1993): La audiovisión. Barcelona: Paidós, p. 117.

${ }^{464}$ OLARTE MARTÍNEZ, M. (2005a): “Aportación femenina a la creación musical cinematográfica”. La música en los medios audiovisuales. Salamanca: Plaza Universitaria Ediciones, p. 373.

${ }^{465}$ MONTOYA RUBIO, J. C. (2008a): Op. cit., p. 67. La propuesta se desarrollaba en torno a grandes cartones que iban mostrando el devenir melódico e iban incitando al canto con un nuevo texto.
} 


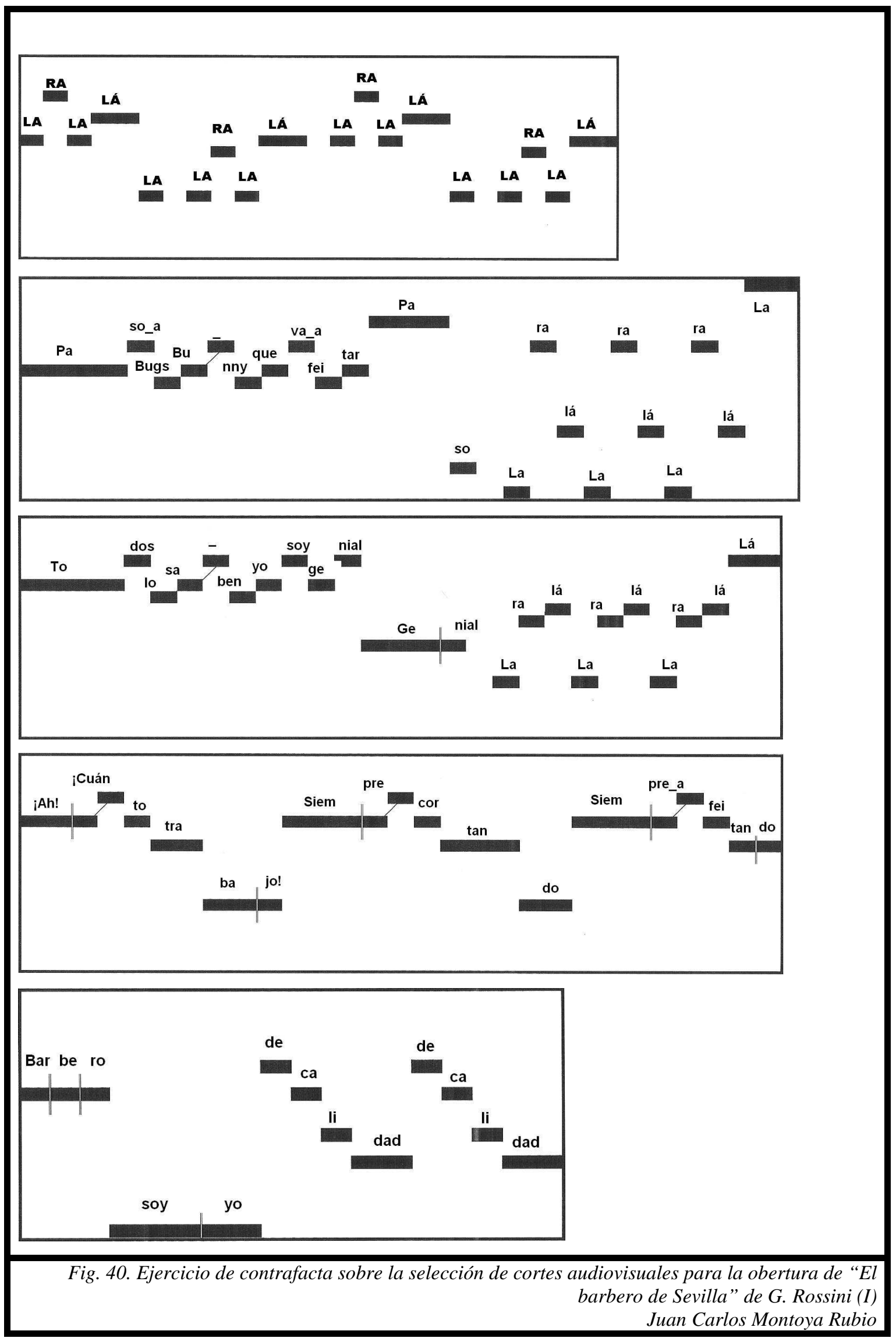




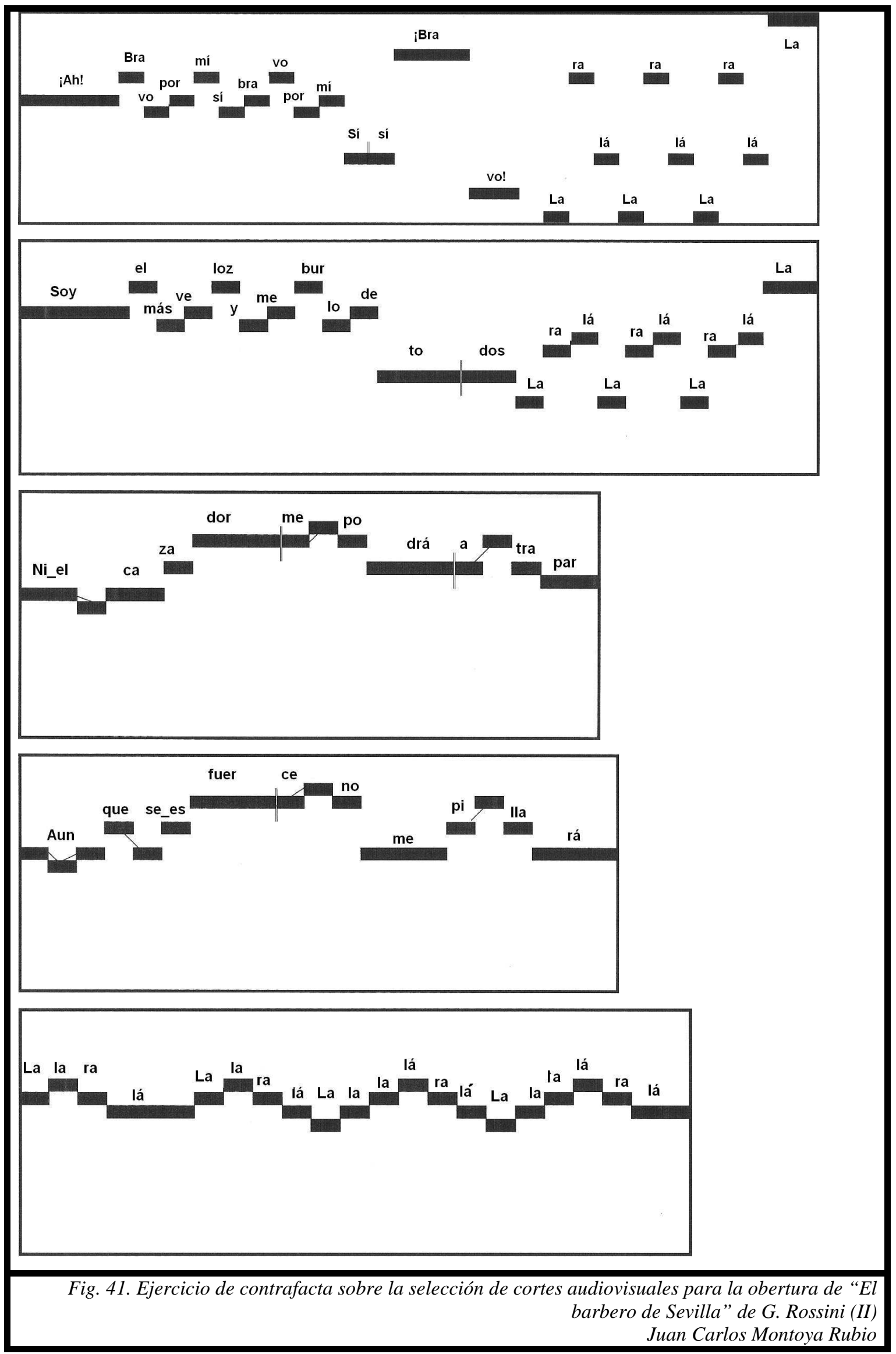




\section{Extrapolación de varios fragmentos musicales que conforman el audiovisual}

Cuando pretendemos el trabajo sobre toda la música contenida en un discurso de dimensiones considerables, como es el caso de un largometraje, uno de los aspectos que acabarán favoreciendo el éxito o fracaso de nuestras aplicaciones pedagógicas será la selección del material, ya que este paso previo es de indiscutible importancia. Es necesario recordar que no sólo las películas específicamente indicadas para desarrollar conceptos musicales nos son útiles ${ }^{466}$, sino que además será posible y necesario escoger películas que puedan permitir aprendizajes donde, en principio, no parece haberlos.

Por ello, en referencia al material seleccionado para su aplicación en las aulas, es absolutamente necesario entender que los aprendizajes pueden llevarse a cabo desde una tipología dispar de discursos audiovisuales, debido a que la importancia no radica tanto en que la temática del filme sea musical, sino en que sea significativa para el alumnado. De este modo, es preciso reconceptualizar el modo de abordar la pedagogía musical cuando ésta bebe del audiovisual. El fin que se persigue es contemplar que no sólo nos aportará beneficios el cine didáctico o el educativo sino otros como el "recreativo" 467 , de modo que el proceso de selección ha de saber conjugar los intereses del docente -el desarrollo de unos bloques de contenido determinados en función de unas edades concretas- con aspectos que resulten atractivos para el grupo de alumnos al que se dirige la experiencia.

Retomamos pues la idea, expuesta con brevedad en al referirnos a los libros de texto, según la cual la selección de fragmentos, si busca enarbolar la bandera de la signficatividad, no debe de partir de referentes que los docentes creamos atractivos desde nuestro propio prisma, sino que resulten motivadores para aquellos a quienes se dirigirá la práctica educativa, los alumnos. Ello no implica que no puedan ser tratados audiovisuales ampliamente conocidos por los profesores y que, a través de una labor de guía y acercamiento, hagan tornar aquello que no era singularmente atractivo en un producto que despierte el interés de los discentes. Esa será una práctica totalmente acertada. No obstante, suele ser bastante rentable acudir directamente a ellos para saber de sus gustos y preferencias, canalizando los aprendizajes. Para ello también es factible

\footnotetext{
${ }^{466}$ Por ejemplo, a partir de los criterios que se muestran en HUERTA, R. (1999): Op. cit.

${ }^{467}$ DE PABLOS PONS, J. (1986): Op. cit, p. 68.
} 
inquirirles acerca de sus experiencias vitales, entre las cuales la música y la imagen juegan un papel decisivo y ello ha de ser otra constante en la labor educativa ${ }^{468}$.

En el campo de la pedagogía musical, es extremadamente extraño encontrar estudios que extrapolen la totalidad de la banda sonora de un audiovisual, especialmente si éste es extenso, como es el caso de los largometrajes. Los trabajos que generalmente se encuentran versan sobre la fracción y disección de algún elemento para su posterior observación y desarrollo pedagógico. Por ello, en este apartado suele ser bastante eficaz hacerse con estudios que sí aborden la complejidad de una banda de sonido del filme en su conjunto, la analicen y expliquen para, a partir de esos razonamientos, instar al docente a que elucubre situaciones de matiz didáctico. Por fortuna, desde el campo de la musicología sí se suele abordar este tipo de análisis ${ }^{469}$, aportando minuciosamente muchos datos sobre unas u otras películas que un docente predispuesto a leer entre líneas puede utilizar con sus alumnos.

Un intento por sistematizar este tipo de prácticas y ponerlas en conocimiento de la comunidad científica fue la aportación que realizamos en 2006 dentro del marco del "III Simposio La Creación Musical en la Banda Sonora", celebrado en Salamanca ${ }^{470}$. No es nuestra intención profundizar ahora en el mecanismo de cada una de las variadas actividades realizadas, sino en el análisis metodológico de la propuesta en su conjunto, con el fin de elaborar un sistema analítico pero también activo para el desarrollo de procedimientos de este tipo. Por ello, de la retahíla de actividades de extrapolación que completaban la banda sonora completa de la película trabajada, La locura del rey Jorge (dirigida por Nicholas Hytner y con adaptación de música händeliana por parte de George Fenton), mostraremos únicamente algunos procedimientos concretos de los

\footnotetext{
${ }^{468}$ Este procedimiento es tan simple como efectivo, y garantiza gran parte del éxito de las hipotéticas futuras elaboraciones pedagógicas, tal y como lo muestran CASTILLO ÁLVAREZ, D. y PRIETO ALBEROLA, R. (2003): "Medios audiovisuales: una estrategia para mejorar la motivación". Música y Educación 56, pp. 83-94.

${ }^{469}$ Entre los últimos publicados destacamos por su detalle y claridad sintética y al tiempo relacional entre filmes parejos DE ANDRÉS BAYLÓN, S. (2009): “¡Glorioso Technicolor!, ¡Impactante Cinemascope!, ¡Sonido estereofónico!: Cole Porter y el cine”. OLARTE MARTÍNEZ, M. (Ed.) Reflexiones en torno a la música y la imagen desde la musicología española. Salamanca: Plaza Universitaria Ediciones, pp. 475494.

${ }^{470}$ MONTOYA RUBIO, J. C. (2009b): Op. cit. La puesta en común tuvo como beneficios fundamentales la constatación del interés que estos temas comenzaban a suscitar entre un buen número de docentes y estudiantes y, a su vez, sirvió para ir perfilando el plano metodológico que actualmente se presenta en esta tesis doctoral.
} 
ejercicios propuestos $^{471}$, ya que lo interesante para el caso que nos ocupa es realizar disquisiciones sobre el razonamiento metodológico que se deriva de toda la propuesta, con el ánimo de establecer un marco de actuación futuro válido para otros productos audiovisuales.

La metodología de actuación será la que se resume en el siguiente esquema:

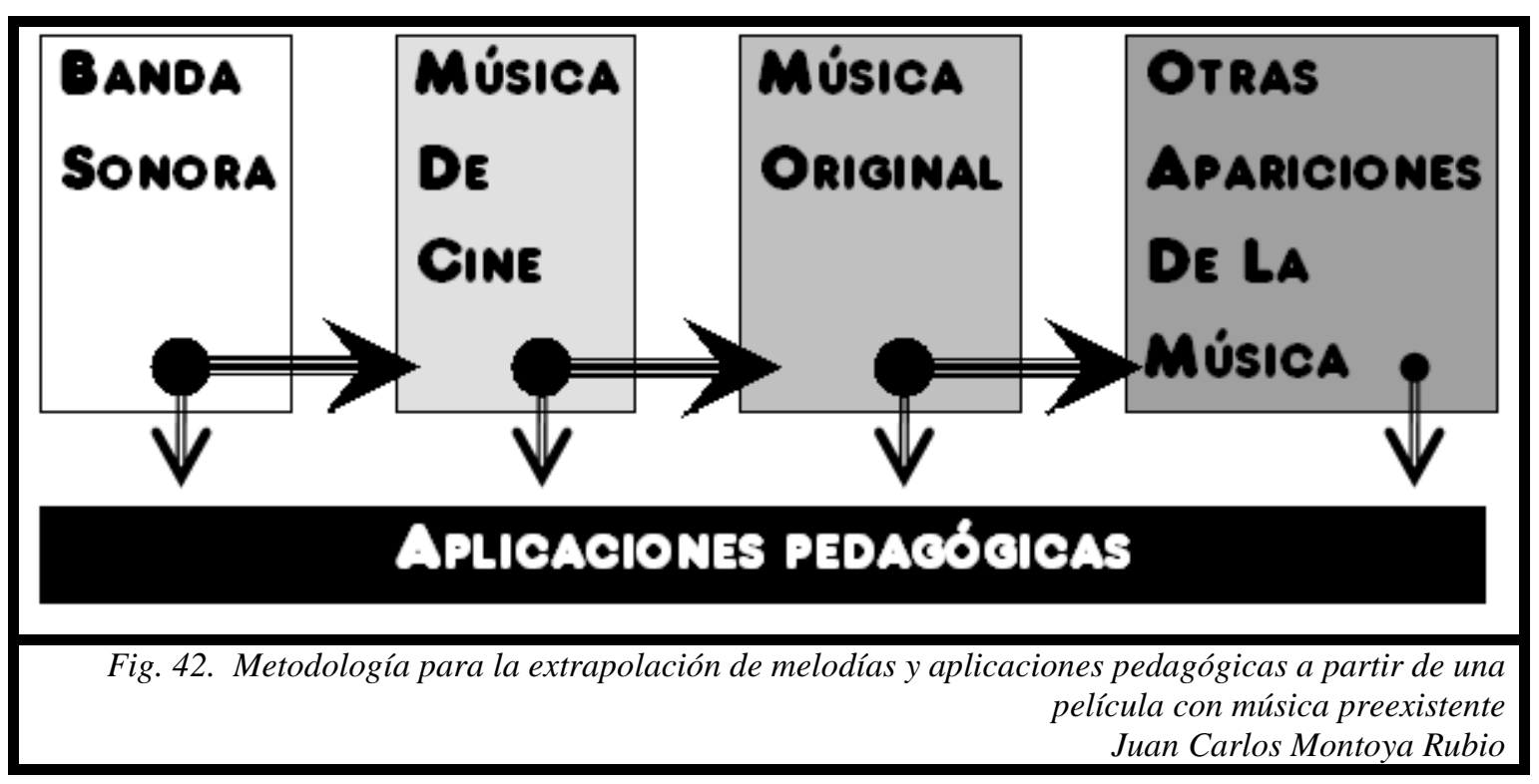

Como puede observarse, recurrimos de nuevo como punto de partida a la categorización de Lluís i Falcó ${ }^{472}$, al considerar que distinguir entre la banda sonora que está inserta en el audiovisual y la música de cine como producto independientemente comercializado puede ser tanto más útil en clave pedagógica que la observación exclusiva del primer elemento. En lo sucesivo, se coloreará aquella de las cuatro dimensiones colocadas en la parte superior del esquema que dé lugar a la aplicación pedagógica, bien sea desde la observación de la banda sonora, de su formato extrapolado en música de cine, del origen primitivo en forma de música original, o de otras versiones o apariciones de la melodía en cuestión.

Cuando pretendemos que un producto que no es didáctico se transforme para su uso en las aulas, el primer aspecto metodológico a cuidar ha de ser el pragmatismo. No todos los momentos musicados de un audiovisual permiten trabajar con igual sencillez

\footnotetext{
471 Las explicaciones detalladas de ejercicios concretos y sus derivaciones posteriores pueden ser consultadas en el artículo nuestro antes citado.

${ }^{472}$ LLUÍS i FALCÓ, J. (1995): Op cit.
} 
dentro de las aulas, ni todos favorecen uno u otro tipo de aplicación, así como tampoco es recomendable obstinarse en trabajar un bloque específico de contenido musical por el mero hecho de que sea eso lo que, de entrada, se pretendiera. Cuando nos hallamos ante un discurso tan amplio, se precisa un estudio pormenorizado previo, que otorgue pistas sobre qué será más conveniente abordar desde el propio filme, desde su versión discográfica o, si los hubiere, desde los referentes originales que les han alumbrado así como de otras derivaciones de esa misma música fuera del discurso audiovisual que se está estudiando. En la práctica totalidad de las ocasiones, esta reflexión inicial economiza esfuerzos optimizando los resultados, ya que el abordaje directo de la música contenida en el audiovisual puede parecer un ahorro de tiempo pero, a la larga, supone cercenar las posibilidades, que son muchas, que un esfuerzo por encontrar la mejor opción nos puede brindar. En este estrato previo de trabajo específicamente del profesor $^{473}$, es sumamente importante establecer una secuenciación acertada en la cual se señalen los momentos musicados, se ubique la posición de los cortes o pistas de la grabación sonora en su momento de aparición, se observen omisiones, adhesiones o añadiduras en uno u otro lugar (en la banda sonora y en la música de cine), etc.

Dentro del ejemplo al que nos estamos refiriendo la nueva ordenación de los cortes musicales, teniendo en cuenta inclusiones de otros inéditos en la versión discográfica y amalgamas de varios de ellos, la hemos elaborado de la siguiente manera $^{474}$ :

\footnotetext{
${ }^{473}$ Como puede inferirse, al hablar de educación obligatoria este paso previo será más adecuado cuanto más y mejor queden perfilados los objetivos a desarrollar, por lo que la encomienda de que sea el docente quien se encargue tiene su lógica. Es de esperar que en etapas posteriores el trabajo conjunto de alumnos y docentes pueda extraer nuevas claves para llevar a cabo aprendizajes que, además de extrapolar, hagan que los alumnos puedan inmiscuirse en el análisis del conjunto audiovisual.

${ }^{474}$ MONTOYA RUBIO, J. C. (2009b): Op cit., pp. 673-674.
} 


\begin{tabular}{|c|c|}
\hline & $\begin{array}{l}\text { Orden de aparición } \\
\text { en la película }\end{array}$ \\
\hline $\begin{array}{l}\text { Pista } n^{\circ} \text { 2. Título: "Prelude". } \\
\text { Origen: "Aure, deh, per pietà spirate al petto mio", de Julius Caesar. }\end{array}$ & 1 \\
\hline $\begin{array}{l}\text { Pista no 3. Título: "The Madness of King George Front Titles". } \\
\text { Origen: "Overture", de Saúl. }\end{array}$ & 2 \\
\hline $\begin{array}{l}\text { Pista } \mathrm{n}^{\circ} \text { 1. Título: "Opening the houses of Parliament". } \\
\text { Origen: "Overture" (Adagio) y "La Réjouissance", de Música para } \\
\text { los Reales Fuegos de Artificio. }\end{array}$ & 3 \\
\hline $\begin{array}{l}\text { Pista } \mathrm{n}^{\circ} \text { 4. Título: "Smile, it's what you're paid for". } \\
\text { Origen: "How Excellent", de Saúl. }\end{array}$ & 4 \\
\hline $\begin{array}{l}\text { Pista } \mathrm{n}^{\circ} \text { 5. Título: "The king goes riding". } \\
\text { Origen: Varios temas de Saúl y "Tu sei il cor di questo core" de Julius } \\
\text { Caesar. }\end{array}$ & 5 \\
\hline $\begin{array}{l}\text { Fuera de la versión grabada de banda sonora. Título: "Greensleeves" } \\
\text { Origen: Popular. }\end{array}$ & 6 \\
\hline $\begin{array}{l}\text { Pista no 7. Título: "The cricket match". } \\
\text { Origen: "Overture" de Sansón. }\end{array}$ & 7 \\
\hline $\begin{array}{l}\text { Pista } \mathrm{n}^{\circ} \text { 8. Título: "The king wakes up early / Do it England". } \\
\text { Origen: "Tu sei il cor di questo core" de Julius Caesar y otros temas } \\
\text { de Händel. }\end{array}$ & 8 \\
\hline $\begin{array}{l}\text { Pista } n^{\circ} 9 . \text { Título: "The concert". } \\
\text { Origen: "Alla Hornipe" de Música Acuática. }\end{array}$ & 9 \\
\hline $\begin{array}{l}\text { Pista } n^{\circ} 6 . \text { Título: "A family matter". } \\
\text { Origen: Varios temas de Händel. } \\
\text { Pista no } 12 . \text { Título: "London is flooded". } \\
\text { Origen: Varios temas de Händel. }\end{array}$ & 10 \\
\hline $\begin{array}{l}\text { Pista } \mathrm{n}^{\circ} 11 . \text { Título: "He will be restrained". } \\
\text { Origen: Zadok the Priest. }\end{array}$ & 11 \\
\hline $\begin{array}{l}\text { Pista } \mathrm{n}^{\circ} \text { 13. Título: "Going to Kew". } \\
\text { Origen: Varios temas de Händel. }\end{array}$ & 12 \\
\hline $\begin{array}{l}\text { Pista n }{ }^{\circ} \text { 14. Título: "Starting to recover". } \\
\text { Origen: "Largo" del Concerto Grosso Op. } 3 n^{o} 2 .\end{array}$ & 13 \\
\hline $\begin{array}{l}\text { Pista no 10. Título: "We have no time". } \\
\text { Origen: "O Lord whose mercies numberless", de Saúl. }\end{array}$ & 14 \\
\hline $\begin{array}{l}\text { Pista } \mathrm{n}^{\circ} \text { 16. Título: "The Prince regent". } \\
\text { Origen: Varios temas de Händel. }\end{array}$ & 15 \\
\hline $\begin{array}{l}\text { Pista no 17. Título: "Mr. and Mrs. King". } \\
\text { Origen: "Mussette" del Concerto Grosso Op. } 6 n^{\circ} 3 .\end{array}$ & 16 \\
\hline $\begin{array}{l}\text { Pista no 15. Título: "The Chancellor drives to London". } \\
\text { Origen: "Empio, dirò" de Julius Caesar. }\end{array}$ & 17 \\
\hline $\begin{array}{l}\text { Pista } \mathrm{n}^{\circ} \text { 18. Título: "The Madness of King George End Credits". } \\
\text { Origen: Zadok the Priest. }\end{array}$ & 18 \\
\hline
\end{tabular}


A partir de este modelo organizativo, fácilmente realizable desde el visionado atento y las referencias de la propia versión discográfica, se observa, por ejemplo, la unión de las pistas 6 y 12, la inclusión de la melodía Greensleeves o el reordenamiento de los cortes para su venta en disco compacto, tal vez siguiendo criterios comerciales.

En todo caso, cada una de las dimensiones reseñadas anteriormente (banda sonora, música de cine o del audiovisual, música original y otras apariciones de la música en cuestión) pueden vehicular, por sí mismas, un camino hacia la aplicación pedagógica en el aula de educación musical. Cuando el recorrido que se da es el mínimo, es decir, cuando desde la propia banda sonora del producto audiovisual se accede directamente a una aplicación pedagógica estamos frente a una aplicación directa, que bebe de manera inequívoca del referente audiovisual y lo necesita para tener sentido. En este primer nivel los alumnos que visionan la película, han de centrarse en una u otra escena guiados por el docente, para extrapolar a partir de ella y construir los aprendizajes a los que hayan de llegar. Del ejemplo citado, extraemos varios casos en los que esta extrapolación se produce directamente. 


\section{A) APLICACIONES PEDAGÓGICAS DERIVADAS DE LA BANDA SONORA}

Extrapolación desde la banda sonora

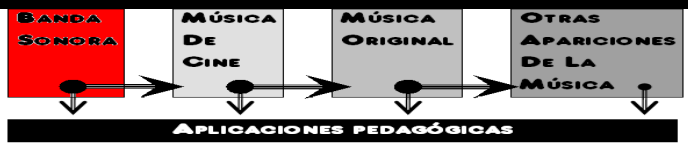

Pista ${ }^{\circ}$ 3. Título: "The Madness of King George Front Titles".

Origen: "Overture", de Saúl.

Orden de aparición: 2

Aplicación didáctica de extrapolación: Musicograma de seguimiento ${ }^{475}$

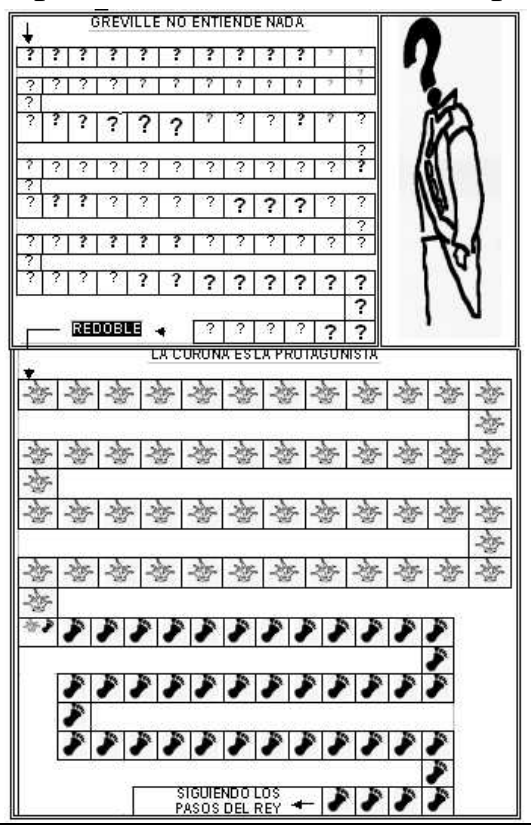

Fig. 44. "The Madness of King George Front Titles".

Musicograma de seguimiento.

Juan Carlos Montoya Rubio

Algunas motivaciones para este desarrollo pedagógico:

- Mostrar la delimitación del corte musical en tres fragmentos claramente diferenciados por su sonoridad.

- Vincular las variaciones en la tipología musical con los cambios en el plano visual, nominando cada una de las tres divisiones que establecemos (siguiendo los pasos del rey, la corona es la protagonista y Greville no entiende nada)

- Trasladar metodologías trabajadas habitualmente por los alumnos, tales como los clásicos musicogramas, al ámbito de la música de cine.

- Facilitar el marcado de pulso o acento a través de la representación icónica.

- Posibilitar que dicha representación, además, informe sobre los matices dinámicos con dibujos de diferente tamaño (signos de interrogación).

475 Ibíd., p. 677. 
Extrapolación desde la banda sonora

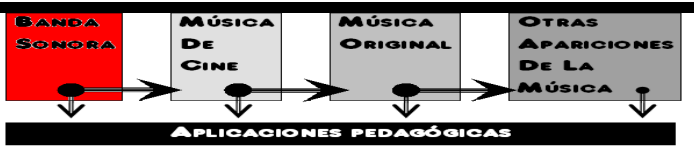

Pista $n^{\circ}$ 4. Título: "Smile, it's what you're paid for".

Origen: "How Excellent", de Saúl.

Orden de aparición: 4

Aplicación didáctica de extrapolación: Prosodia en forma de fuga ${ }^{476}$

Smile, it's what you're paid for

Razonamiento de la fuga

\begin{tabular}{|l|l|l|l|l|l|l|l|l|l|}
\hline 1 & 2 & 3 & 4 & 5 & 6 & 7 & 8 & 9 & 10 \\
\hline
\end{tabular}

\begin{tabular}{|c|c|c|c|c|c|c|}
\hline \multirow[t]{3}{*}{ Sujeto } & Contr. "A" & Contr. "B" & Con & "B" & \multicolumn{2}{|c|}{ Sujeto } \\
\hline & Respuesta & \multicolumn{2}{|c|}{ Contr. "A" } & \multicolumn{2}{|c|}{ Contr. "B" } & \\
\hline & & Respuesta & Cor & "A" & Cor & "B" \\
\hline
\end{tabular}

\begin{tabular}{|l|l|l|l|l|l|l|l|l|l|l|}
\hline 11 & 12 & 13 & 14 & 15 & 16 & 17 & 18 & 19 & 20 & 21 \\
\hline
\end{tabular}

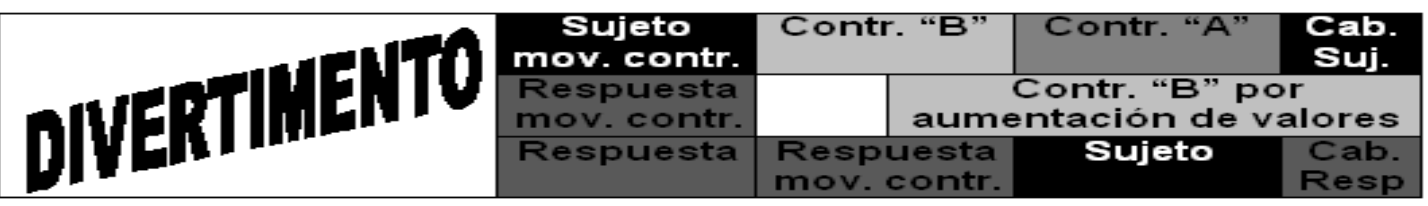

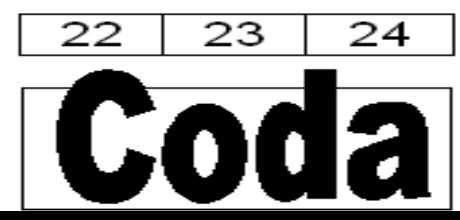

Fig. 45. "Smile, it's what you're paid for". Razonamiento de una prosodia en forma de fuga Juan Carlos Montoya Rubio

${ }^{476}$ Ibíd., pp. 679-681. 


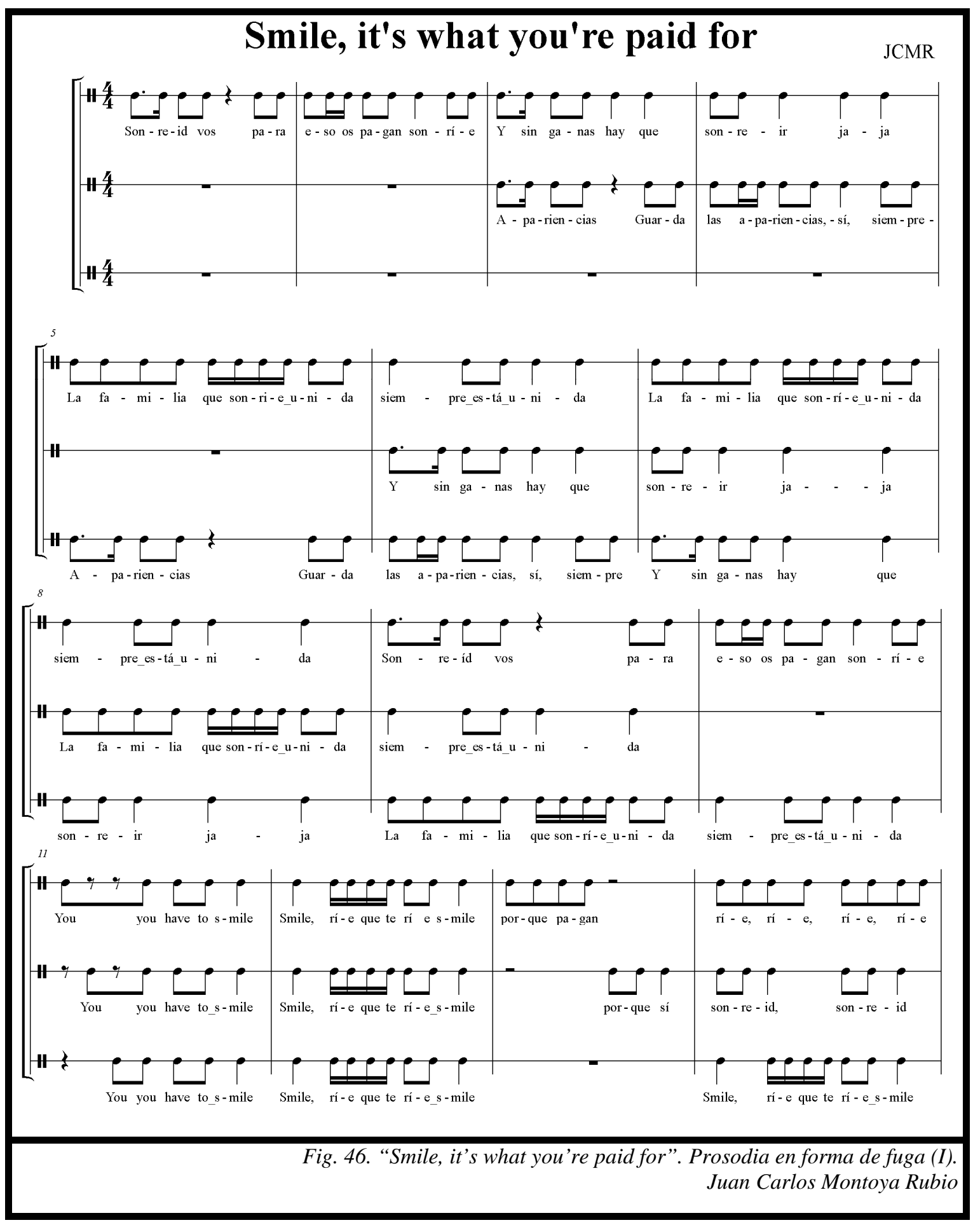




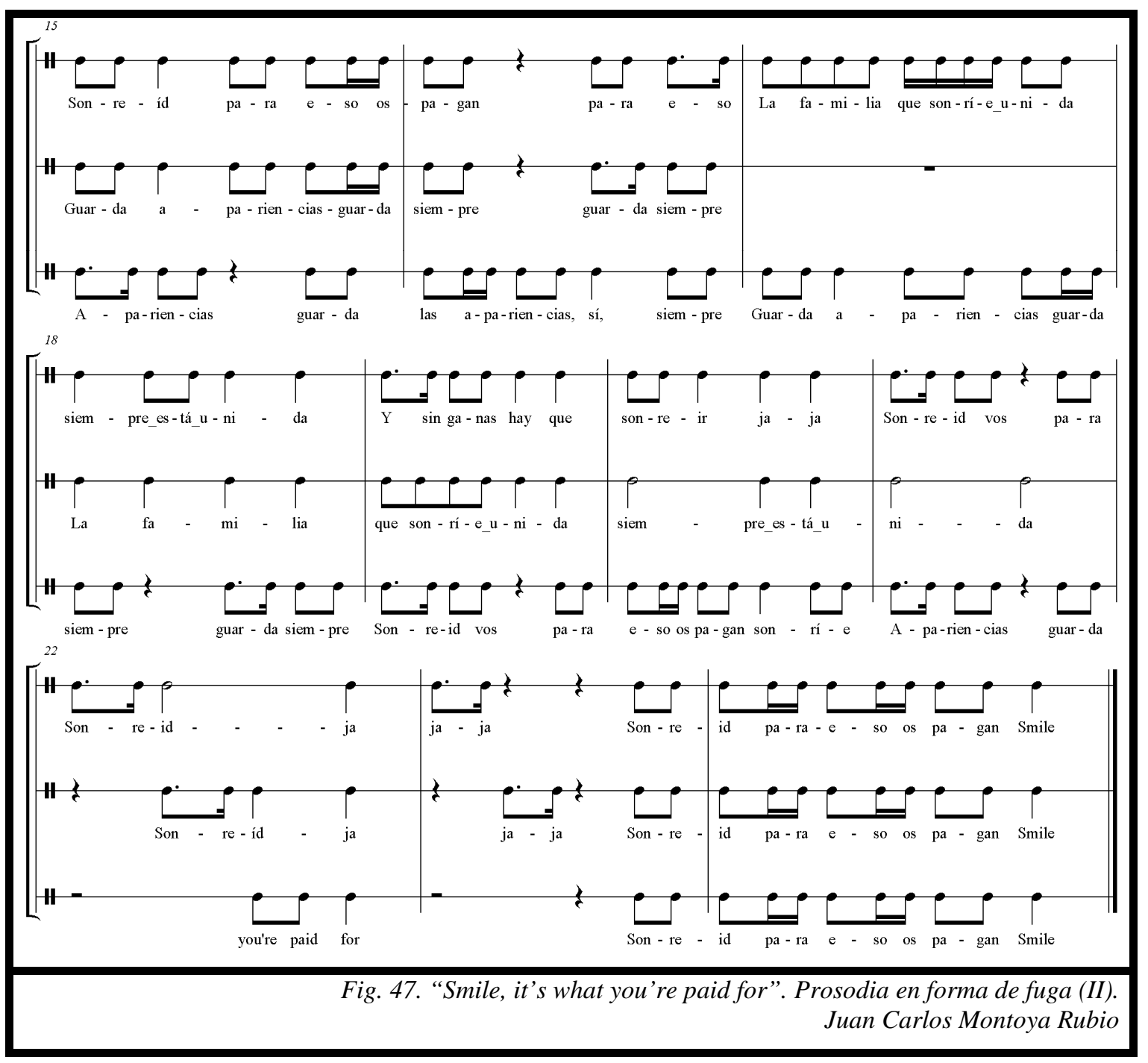

Algunas motivaciones para este desarrollo pedagógico:

- Vincular la educación musical con otras áreas de conocimiento (lenguas extranjeras) para promover el aprendizaje globalizado.

- Rescatar del argumento de la película contenidos para vincularla con los elementos pedagógicos.

- Llevar a cabo prosodias rítmicas, cuyo desarrollo es muy amplio, desde el aprendizaje seccionado de las partes sin inclusión de la voz (solamente a partir de percusiones corporales o con instrumentos de pequeña percusión de altura indeterminada) hasta la incorporación del texto por voces.

- Abrir la posibilidad de cambios textuales relacionados o no con la temática de la película en cuestión. 
- Abordar formas complejas para los alumnos de primaria (incluso de secundaria) como puedan ser las fugas, a partir de criterios de manipulación, vivencia y simplicidad estructural ${ }^{477}$. Así, se conocen las partes de este tipo de composiciones entendiéndolas como un puzzle en el que cada pieza cuadra en relación con el resto.

Extrapolación desde la banda sonora

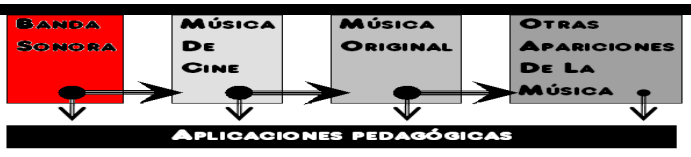

Fuera de la versión comercializada de banda sonora. Título: "Greensleeves".

Origen: Popular.

Orden de aparición: 6

Aplicación didáctica de extrapolación: Reproducción con "cotidiáfonos"478.

\section{Greensleeves}

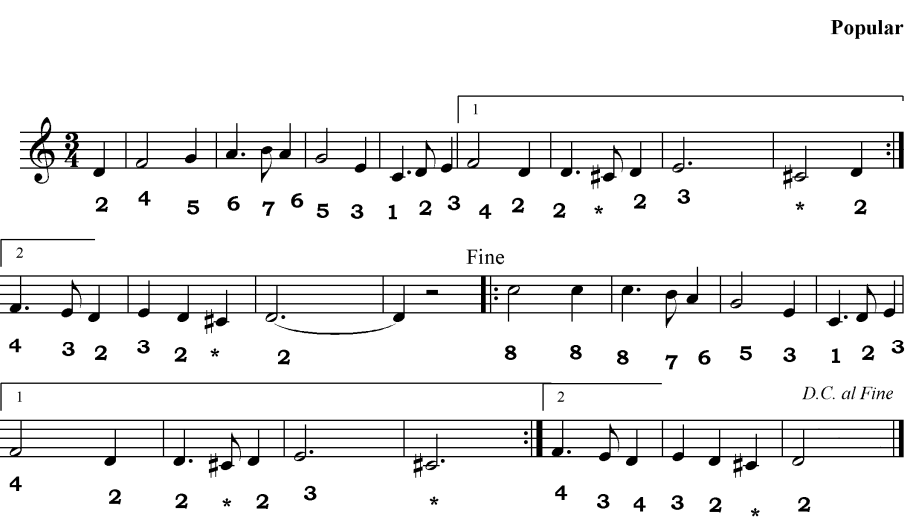

Notación numérica no convencional:

Primera frase: $2-4-5-6-7-6-5-3-1-2-3-4-2-2-*-2-3-*$

Segunda frase: $2-4-5-6-7-6-5-3-1-2-3-4-3-2-3-2-*-2$

Tercera frase: $8-8-8-7-6-5-3-1-2-3-4-2-2-*-2-3-*$

Cuarta frase: $8-8-8-7-6-5-3-1-2-3-4-3-4-3-2-*-2$

Quinta frase: $2-4-5-6-7-6-5-3-1-2-3-4-2-2-*-2-3-*$

Sexta frase: $2-4-5-6-7-6-5-3-1-2-3-4-3-2-3-2-*-2$

Fig. 48. "Greensleeves". Ejercicio para ejecución con "cotidiáfonos" Juan Carlos Montoya Rubio

Algunas motivaciones para este desarrollo pedagógico:

${ }^{477}$ Explicaciones suplementarias sobre procedimientos pedagógicos similares en MONTOYA RUBIO, J. C. (2006a): "Mozart en casa de Bach. Elaboración pedagógica para el tránsito del barroco al clasicismo musical". En Ensayos 21, pp. 141-155.

${ }^{478}$ MONTOYA RUBIO, J. C. (2009b): Op. cit., pp. 683-684. 
- Hacer ver que la banda sonora tiene entidad propia al margen de la versión discográfica, de forma que se pueda abordar independientemente de ésta.

- Aproximar al alumno a estructuras formales sencillas, extraídas de melodías simples de origen popular.

- Llevar a cabo desarrollos pedagógicos similares a los ofrecidos en la pantalla cinematográfica, ya que si en imagen se muestra un concierto con campanas de mano la derivación que llevaremos a cabo se nutrirá de instrumentos cuya escasa manufactura será patente.

- Abordar el uso de "cotidiáfonos" $" 479$ desde un prisma lúdico y participativo.

- Trabajar un lenguaje musical alternativo al convencional, a partir de números, con el único fin de simplificar la ejecución instrumental.

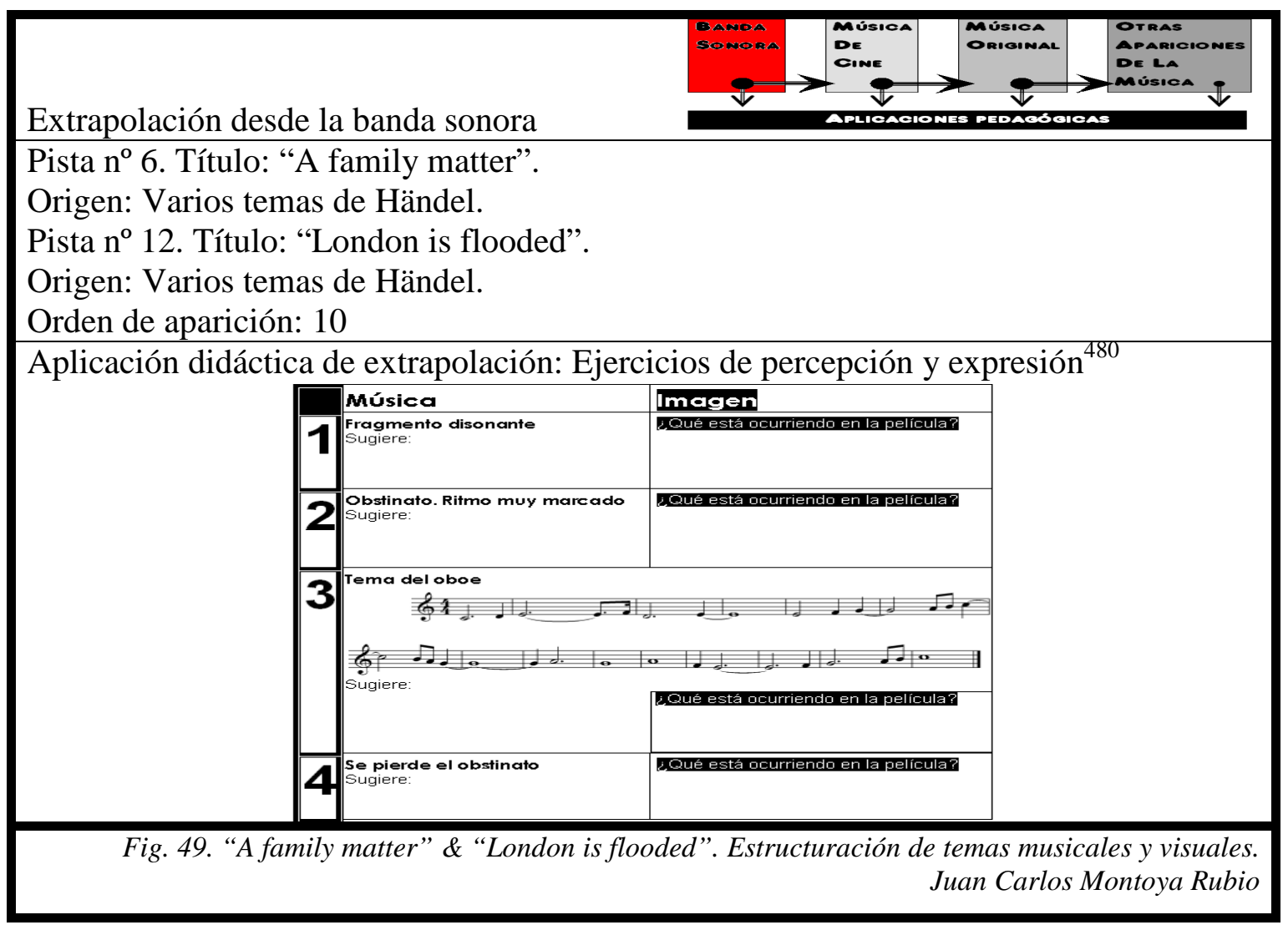

\footnotetext{
${ }^{479}$ AKOSCHKY, J. (1988): Op. cit. En el caso que describimos se cumplirían plenamente las fases en la construcción de estos instrumentos de uso cotidiano, ya que se podría partir de la concepción del instrumento que mejor se adecuara a esta ejecución para seguir con la recogida de materiales por parte del alumno, la transformación de los mismos, el aprendizaje en su manejo y, por último, la integración en el gran grupo. Uno de los ejemplos basados en experiencias prácticas con aportación de un diseño metodológico y varios casos de construcción artesanal en NOVILLO FERTRELL - VÁZQUEZ, M. (2000): "El taller de construcción de instrumentos en el aula de secundaria". Música y educación 44, pp. $61-82$.

${ }^{480}$ MONTOYA RUBIO, J. C. (2009b): Op. cit., pp. 679-681.
} 


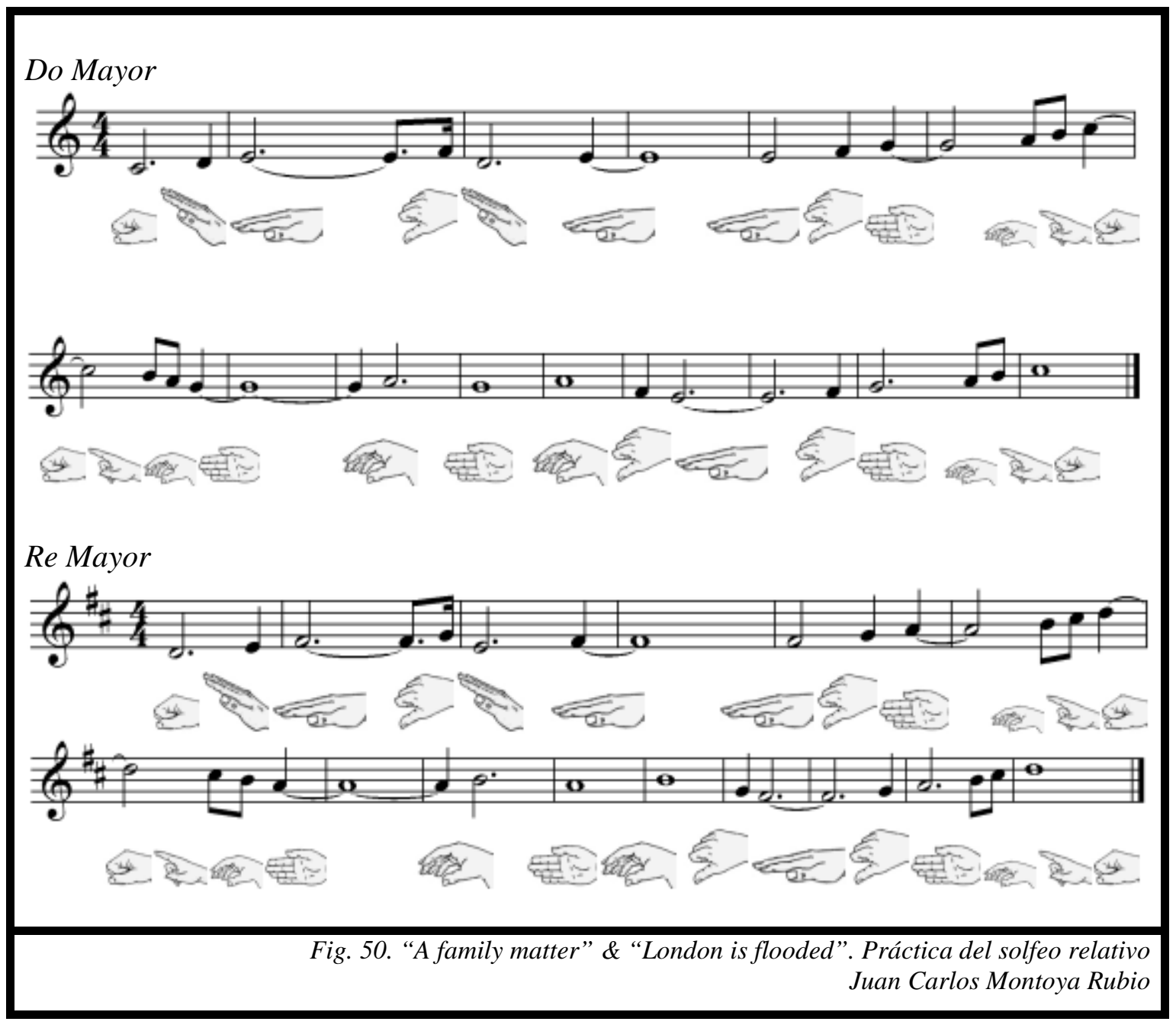

Algunas motivaciones para este desarrollo pedagógico:

- Centrar la atención del alumnado en la expresividad musical, haciéndole ver que si la música "surge de una necesidad expresiva y provoca en el espectador una emoción y una expresión determinadas", lo es porque, a pesar de que "los cánones preestablecidos (modos, timbres, efectos orquestales) contribuyen a estas emociones, el efecto es evidentemente inmediato gracias a una empatía entre la música y la imagen"

- Organizar la escucha de un fragmento que pudiera parecer más complicado formalmente pero cuyo seguimiento puede ser accesible a partir de elementos sonoros especialmente significativos.

- Vincular los ejercicios de extrapolación sonora de los elementos que aparecen en el audiovisual con otros que se están llevando a cabo en las aulas, como son las

${ }^{481}$ RADIGALES, J. (2008): La música en el cine. Barcelona: Editorial UOC, p. 44. 
prácticas fononímicas, en este caso a partir de la metodología de Kodály ${ }^{482}$ por ser una de las más extendidas en el contexto educativo musical español.

- Desarrollar procedimientos de transporte musical siguiendo la solmisación establecida por la misma metodología apuntada con anterioridad.

${ }^{482}$ Algunos manuales con difusión en España al respecto: ÖRDÖG, L. (2000): La educación musical según el sistema Kodály. Valencia: Rivera Editores; HEGYI, E. (1999): Método Kodály de Solfeo (vols I y II). Madrid: Pirámide. 
B) APLICACIONES PEDAGÓGICAS DERIVADAS DE LA MÚSICA DE CINE

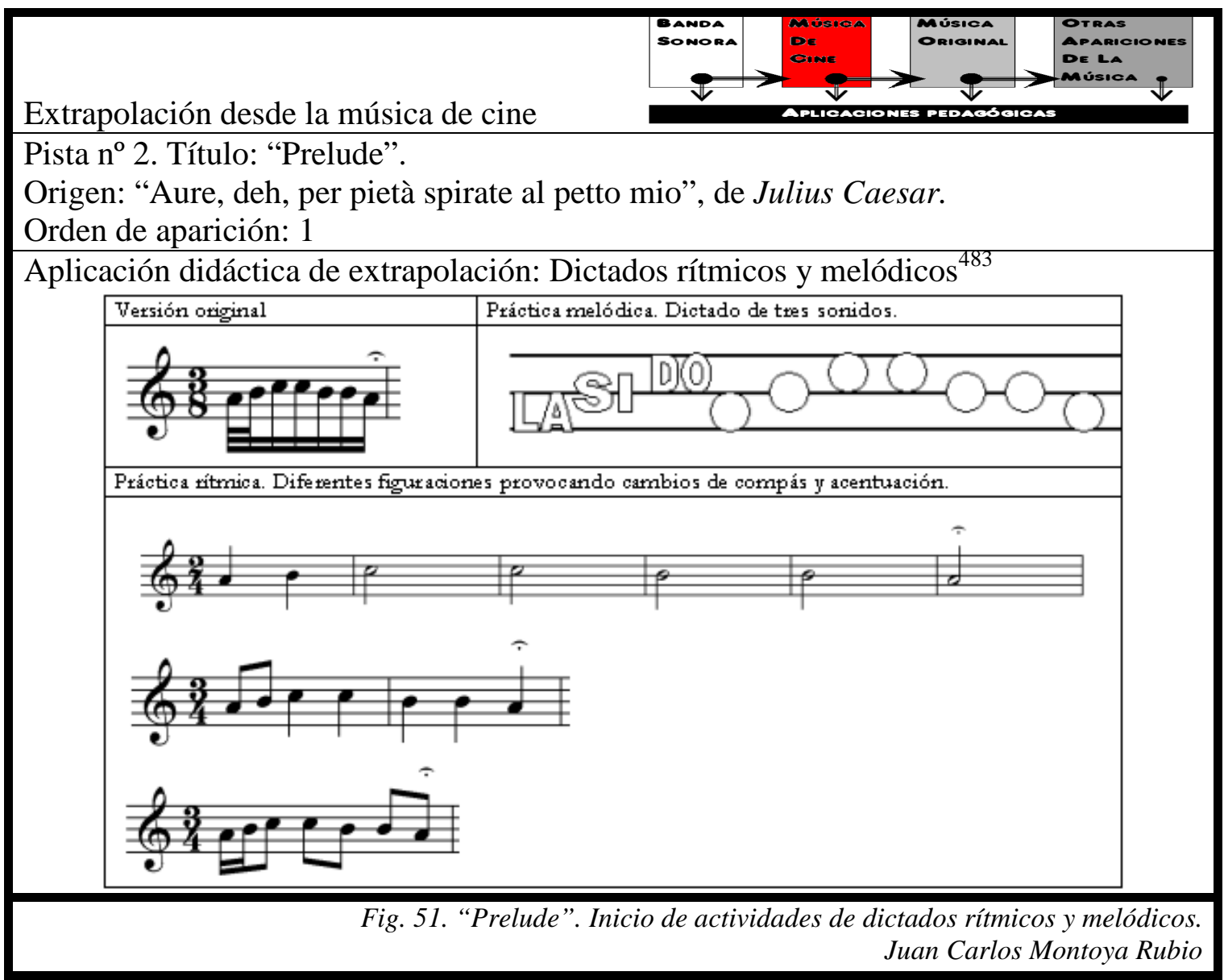

Algunas motivaciones para este desarrollo pedagógico:

- Detenerse en la audición de la banda sonora para identificar distintos tratamientos de un mismo motivo melódico, afianzando la escucha comprensiva.

- Desmitificar el acercamiento a la banda sonora (es el primer corte que se utiliza por orden de aparición), comprobando la accesibilidad de la misma para cualquier oyente atento.

- Llevar a cabo ejercicios de relativa simplicidad a partir de una línea melódica que invita a continuar con un trabajo sencillo pero necesario y eficaz.

- Elaborar materiales que orienten al alumno melódica y rítmicamente en dictados.

- Extrapolar los elementos sonoros de la película para acercar al alumnado a otros aspectos a desarrollar dentro de los bloques de contenido, tales como las acentuaciones en diferentes tipologías de compases.

${ }^{483}$ MONTOYA RUBIO, J. C. (2009b): Op. cit., p. 675. 
Extrapolación desde la música de cine

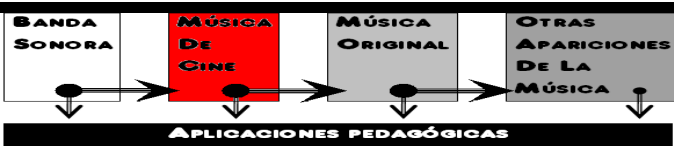

Pista n ${ }^{\circ}$ 14. Título: "Starting to recover".

Origen: "Largo" del Concerto Grosso Op. $3 n^{\circ} 2$.

Pista n 10 . Título: "We have no time".

Origen: "O Lord whose mercies numberless", de Saúl.

Pista $n^{\circ}$ 16. Título: "The Prince regent".

Origen: Varios temas de Händel.

Orden de aparición: 13, 14 y 15

Aplicación didáctica de extrapolación: Dramatización o narración sobre audio ${ }^{484}$

Starting to recover (2:54) We have no time (1:49) The Prince regent (1:40)

Rey Jorge:

(0:08) Algo está pasando.

Algo está cambiando.

(0:16) Estoy aquí pero no

estoy del todo. El trono, la

reina... Algo ocurre.

(0:28) Algo no va bien

todavía.

(0:40) Tal vez

(0:45) las colonias se

perdieron.

(0:56) Quizás

(1:03) era ese el destino

(1:09) Tal vez...

(1:17) Tal vez haya que

acostumbrarse,

(1:30) sólo tal vez

(1:53) Es posible

(1:57) que no esté actuando

como un rey.

(2:01) Es posible

(2:04) que la gente no me

reconozca en mis actos.

(2:10) Tal vez,

(2:16) quizás,

(2:22) es posible

(2:34) Algo está pasando.

(2:38) Algo está cambiando.

(2:45) He de tener

paciencia.
Primer Ministro Pitt:

(0:02) No tenemos tiempo.

(0:06) El médico me

prometió que lo lograría.

$(0: 10)$ El rey aún no está

recuperado.

(0:14) No puede

presentarse así ante el

Parlamento.

(0:20) No, no tenemos

tiempo.

$(0: 32)$ No tenemos tiempo.

(0:36) La oposición quiere

destronarle.

(0:40) Se avecinan grandes reformas.

(0:44) Hay que hacer algo.

(0:50) Pero no, no tenemos

tiempo.

(1:03) No tenemos tiempo.

(1:11) ¡No tenemos tiempo!

(1:19) No tenemos tiempo.

(1:21) El Príncipe está al acecho.

(1:25) Quiere ocupar el

trono a toda costa.

(1:30) Inglaterra está en

peligro.

(1:36) Un poco de tiempo

para recuperar al rey.

(1:41) Tiempo, tiempo,

tiempo...
Príncipe de Gales:

(0:11) Es el momento de votar,

$(0: 19)$ ya queda poco

(0:29) Es el momento de reinar,

$(0: 37)$ ya se acerca

$(0: 43)$ el momento de ser regente.

(0:50) Ya falta poco.

(0:53) Podré decir al mundo

que estoy casado.

(0:56) No importará que

ella sea católica.

(1:01) Yo impondré mi

voluntad.

(1:05) Ya se acerca el

momento.

(1:17) ¡Regente!

(1:21) ¡Rey!

(1:31) Toda Inglaterra a

mis pies.

Fig. 52. "Starting to recover", "We have no time" y "The Prince regent". Narración dramatizada

Juan Carlos Montoya Rubio

${ }^{484}$ Ibíd., pp. 697-699. 
Algunas motivaciones para este desarrollo pedagógico:

- Aunque la dramatización ha salido sigilosamente del abrigo de la educación artística $^{485}$ su desarrollo, como parte integral de los procedimientos de educación musical sigue teniendo vigencia. Por ello se propone explorar las posibilidades de actuación que se esconden tras este tipo de actividades.

- Explotar la capacidad de inventiva del alumnado a partir de la inspiración de cada uno de los tres cortes musicales, haciendo converger la temática del texto que se inserta con lo que se supone expresa cada uno de ellos (el rey se empieza a recuperar, los atribulados fieles del rey y sus complicaciones para que éste vuelva y, por último, las ansias de poder de su hijo mayor)

- Aprovechar para dar a conocer géneros musicales como el melodrama, alejados de la perspectiva infantil pero cuya fuente expresiva puede resultar sumamente adecuada para el desarrollo de elementos pedagógicos en el aula de educación musical.

\footnotetext{
${ }^{485}$ En el contexto español la entrada en vigor de la Ley Orgánica 2/2006 de 3 de mayo de Educación ha supuesto que la tradicional triple dimensión que poseía, englobando música, plástica y dramatización se truncase, manteniéndose las dos primeras dimensiones que, en cualquier caso, han de insertar la tercera de uno u otro modo entre sus bloques de contenido.
} 
C) APLICACIONES PEDAGÓGICAS DERIVADAS DE LA MÚSICA ORIGINAL

Extrapolación desde la música original

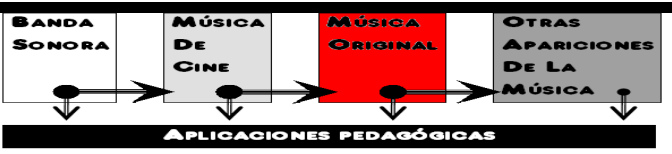

Pista $\mathrm{n}^{\mathrm{o}}$ 15. Título: "The Chancellor drives to London".

Origen: "Empio, dirò" de Julius Caesar.

Orden de aparición: 17

Aplicación didáctica de extrapolación: Práctica de formación vocal ${ }^{486}$.

Texto original:

1. Empio, dirò, tu sei,

2. togliti a gliochi miei,

3. sei tutto crudeltà,

4. sei tutto crudeltà,

5. (melisma)

6. sei tutto crudeltà,

7. empio, dirò, tu sei

8. empio, dirò, tu sei

9. togliti a gliochi miei,

10. sei tutto crudeltà,

11. (melisma)

12. sei tutto crudeltà,

13. empio, dirò, tu sei,

14. togliti a gliochi miei,

15. empio, dirò, tu sei,

16. sei tutto crudeltà,

17. (melisma)

18. sei tutto crudeltà,

19. sei tutto crudeltà.

\section{Texto con fines didácticos} aplicado a la película:

1. Príncipe quieres reinar:

2. pronto estaré yo allí

3. $\quad \mathrm{y}$ te lo voy a impedir

4. $\quad$ y te lo voy a impedir

5.

6. $\quad$ y te lo voy a impedir

7. príncipe quieres reinar

8. príncipe quieres reinar

9. pronto estaré yo allí

10. y te lo voy a impedir

11.

12. y te lo voy a impedir

13. príncipe quieres reinar

14. pronto estaré yo allí

15. príncipe quieres reinar

16. y te lo voy a impedir

17.

18. y te lo voy a impedir

19. y te lo voy a impedir

Fig. 53. "The Chancellor drives to London". Ejercicio de canto practicando una contrafacta Juan Carlos Montoya Rubio

${ }^{486}$ MONTOYA RUBIO, J. C. (2009b): Op. cit., p. 701. 
Algunas motivaciones para este desarrollo pedagógico:

- En íntima relación con el procedimiento anterior, se añade ahora la componente melódica al ejercicio que los alumnos cumplimentan. Así pues, se pretende ante todo integrar el canto adecuándolo a un discurso sonoro preexistente.

- Recurrir a la música operística original (a partir de los fragmentos de la händeliana ópera Julius Caesar) con el fin de establecer vínculos entre banda sonora (la trama que nos habla del apresuramiento con que los partidarios del rey tratan de postularlo de nuevo al cargo) y la música de cine (la versión instrumental urdida por Fenton, la cual en su frenético devenir y transporte al registro de trompa resulta muy clarificadora respecto a determinados giros melódicos)

- A partir de la triple dimensión apuntada, analizar la parte central de la estructura virtuosística con que el aria se desarrolla para observar la traslación de todo ello al discurso adoptado por Fenton y, a su vez, ver cómo en esta manera de proceder se buscan relaciones sinestésicas con el ajetreo de personas y trotes de caballos.

- Reconocer las modificaciones formales entre versión original y adaptación, aprovechando las explicaciones para acercarnos a conceptos como "aria da capo" o "reexposición".

- Conocer las particularidades de los registros vocales y su relación con la tesitura de determinados instrumentos, al tiempo que poder establecer otro tipo de relaciones que informen acerca de la capacidad expresiva del timbre ${ }^{487}$.

487 Elemento, por otro lado, muy propicio para esconder en diferentes ámbitos connotaciones muy dispares, desde la simple necesidad de vigorizar escenas hasta la construcción de características internas de un personaje, grupo o género. Cfr. OLARTE MARTÍNEZ, M. (2005a): Op. cit. 
Extrapolación desde la música original

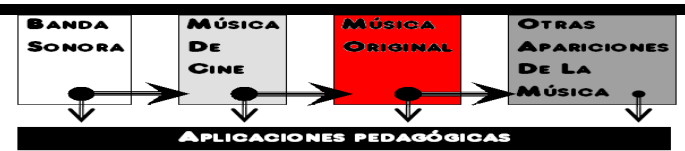

Pista $\mathrm{n}^{\circ}$ 1. Título: "Opening the houses of Parliament".

Origen: "Overture" (Adagio) y "La Réjouissance", de Música para los Reales Fuegos de Artificio.

Orden de aparición: 3

Aplicación didáctica de extrapolación: Instrumentación con P.A.I. ${ }^{488}$.

\section{"La Réjouissance" para pequeña percusión}
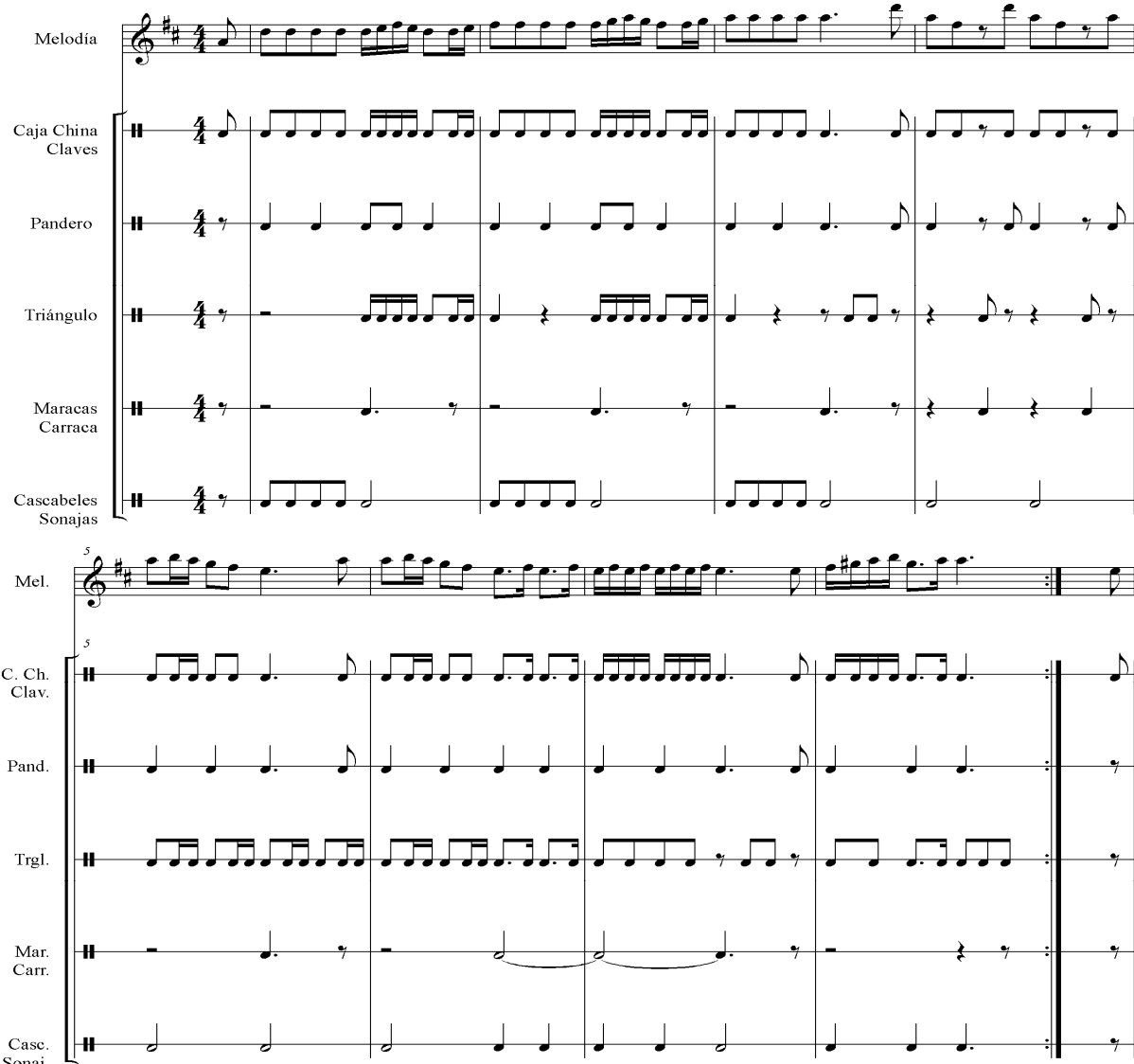

Fig. 54. "Opening the houses of Parliament". Aplicación para pequeña percusión de altura indeterminada $(I)$ Juan Carlos Montoya Rubio

${ }^{488}$ MONTOYA RUBIO, J. C. (2009b): Op. cit., p. 678. Percusión de altura indeterminada. 


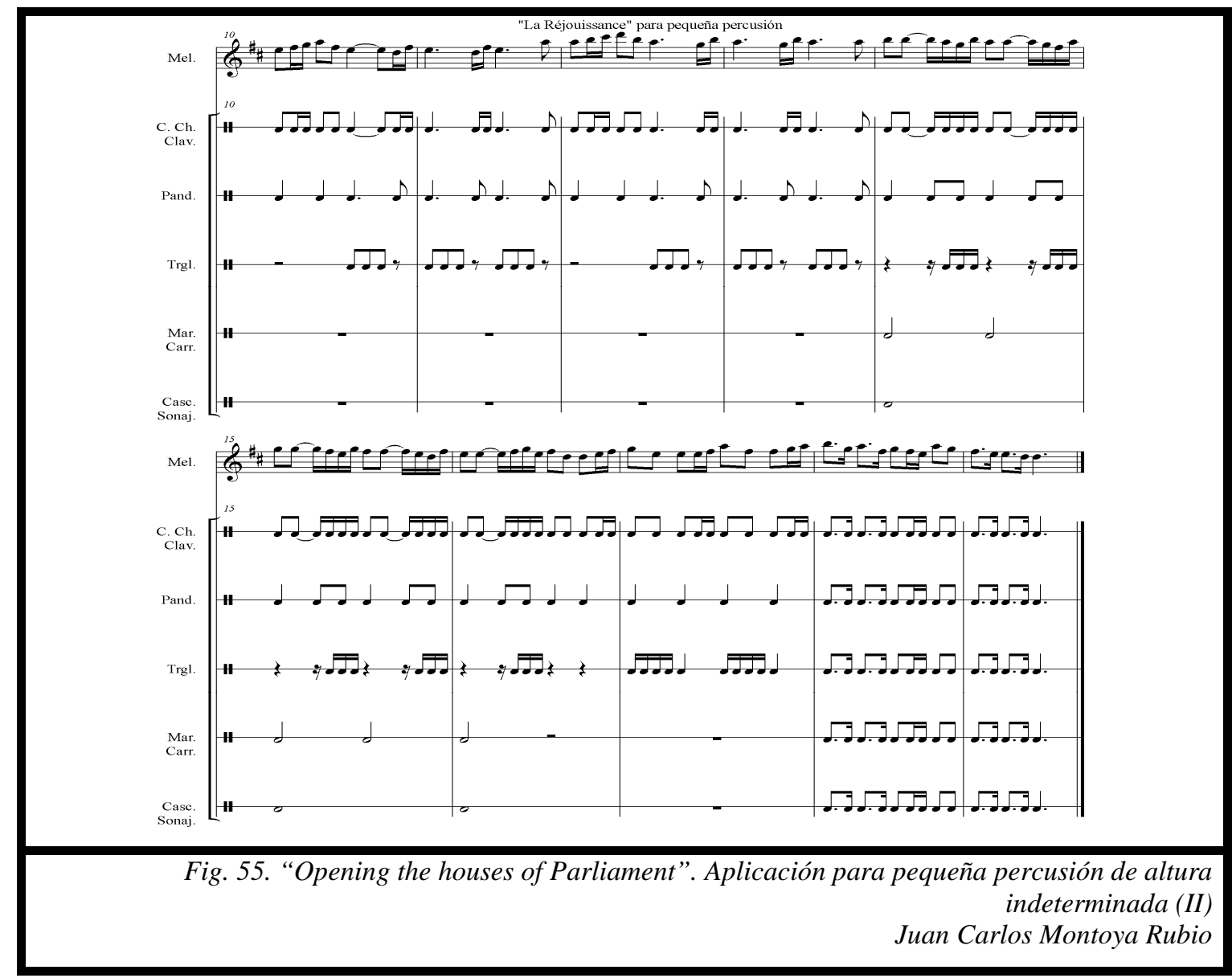

Algunas motivaciones para este desarrollo pedagógico:

- Acercar las melodías extraídas de la música de cine a las realizaciones habituales de los alumnos, acostumbrados a trabajar de un modo muy concreto en su práctica cotidiana, esto es, a partir de los prototípicos instrumentos Orff y sobre audiciones de cierta cuadratura formal.

- Adaptar, por medio de la inclusión de diferentes líneas rítmicas, las posibilidades de actuación a diferentes ritmos y niveles, de modo que se ejecuten unos procedimientos accesibles a todo el alumnado, cumpliendo de este modo con el criterio de generalización postulado por la totalidad de las metodologías modernas.

- Llevar a cabo un trabajo de grandes dimensiones (participa todo el alumnado y se involucra en todo momento activamente) para un fragmento que es, en la imagen cinematográfica, ampuloso. Así, la pompa que rodea a la banda sonora puede llegar a alentar, a partir de esta aplicación con altura indeterminada, ejercicios de sonorización que serán tratados con posterioridad en esta investigación. 
Extrapolación desde la música original

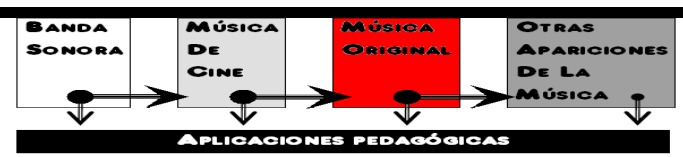

Pista $\mathrm{n}^{\circ}$ 5. Título: "The king goes riding".

Origen: Varios temas de Saúl y "Tu sei il cor di questo core” de Julius Caesar.

Orden de aparición: 5

Aplicación didáctica de extrapolación: Variaciones para instrumentos melódicos ${ }^{489}$ ler nivel: Original de Händel

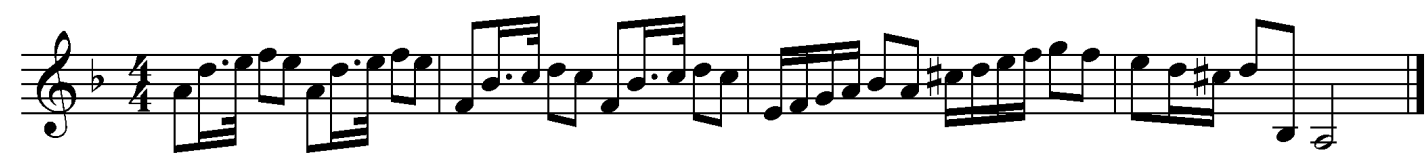

$2^{\circ}$ nivel: Variación más utilizada por Fenton (producida en los compases 3 y 4)

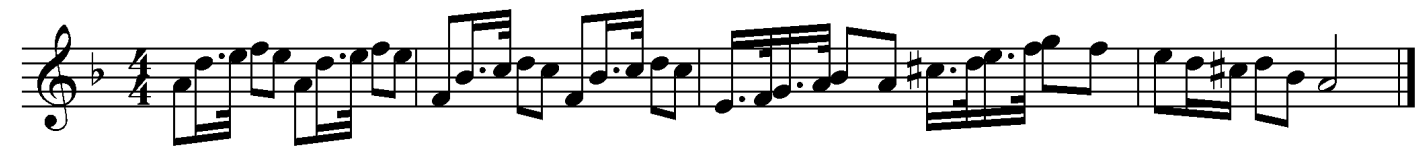

3er nivel: Variación I del tema original:
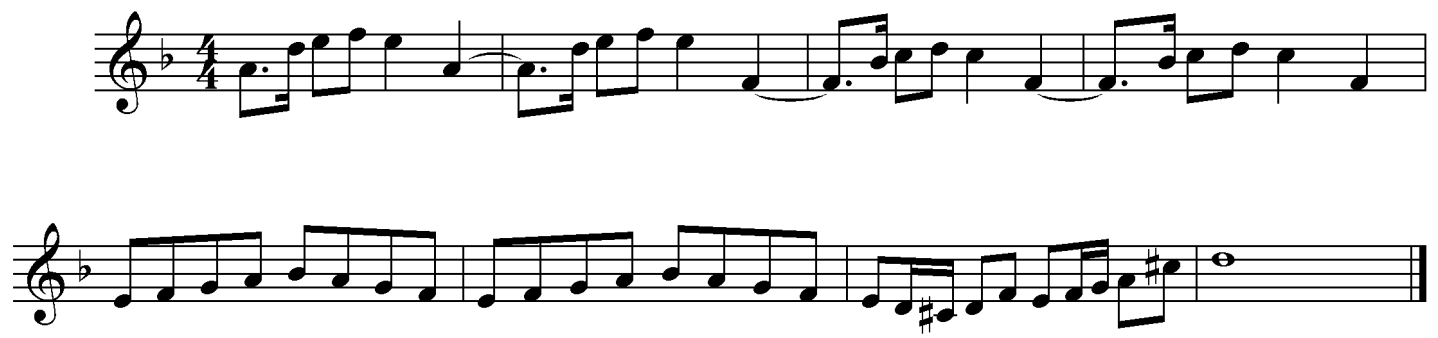

3er nivel: Variación II del tema original:
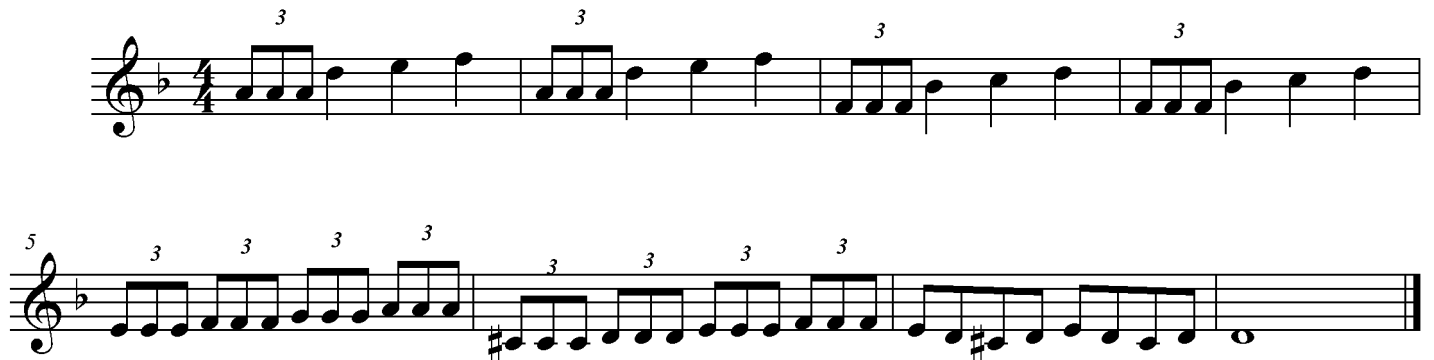

3er nivel: Variación III del tema original:
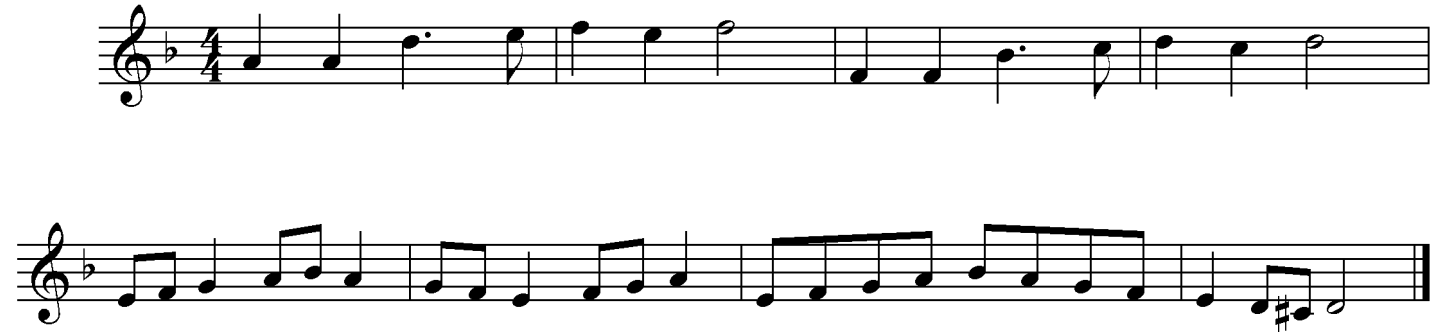

Fig. 56. "A family matter" \& "London is flooded". Práctica del solfeo relativo Juan Carlos Montoya Rubio

${ }^{489}$ Ibíd., p. 682. 
Algunas motivaciones para este desarrollo pedagógico:

- Adaptar los fragmentos musicales que se escuchan al registro y posibilidades de instrumentos escolares melódicos.

- Trabajar la variación como estrategia compositiva básica, de modo que aquello que es hecho por el arreglista para su concepción de la banda sonora sea llevado a cabo, a otros niveles, por los alumnos en el plano didáctico.

- Jugar con los aspectos elementales a través de los cuales se enmascara la melodía original principal y se llega a procedimientos dispares ${ }^{490}$.

- Reconocer variantes rítmicas auditivamente (en la escucha directa) y a partir de la práctica trazada para los alumnos.

Extrapolación desde la música original

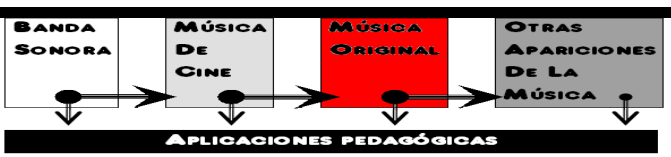

Pista $\mathrm{n}^{\circ}$ 9. Título: "The concert".

Origen: "Alla Hornipe" de Música Acuática.

Orden de aparición: 9

Aplicación didáctica de extrapolación: Armonización para instrumentos P.A.D. ${ }^{491}$
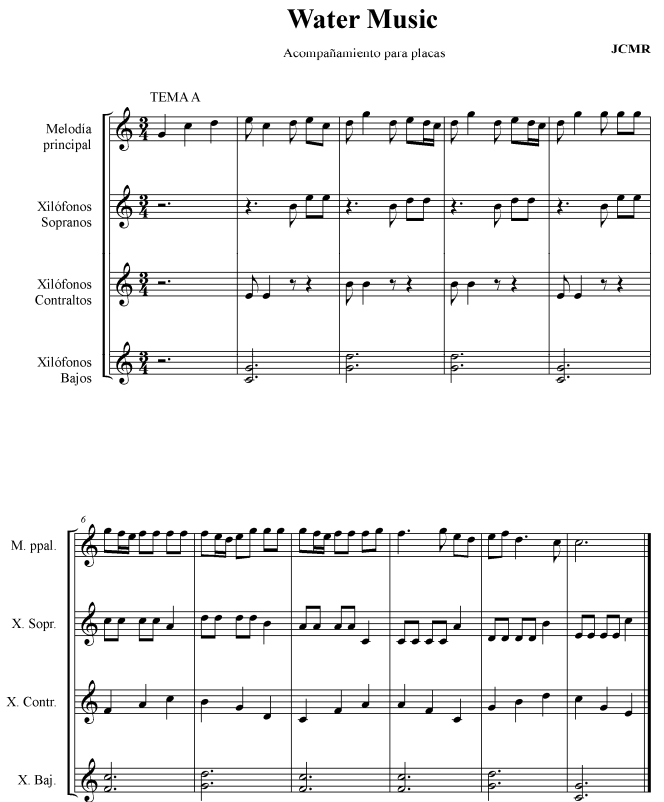

Fig. 57. "The concert”. Aplicación para percusión de altura determinada Juan Carlos Montoya Rubio

\footnotetext{
${ }^{490}$ Una referencia musicológica al respecto la encontramos en GÓMEZ VARAS, P. (2009a): "Recursos compositivos para una secuencia de cine". OLARTE MARTÍNEZ, M. (Ed.) Reflexiones en torno a la música y la imagen desde la musicología española. Salamanca: Plaza Universitaria Ediciones, pp. 39-44. ${ }^{491}$ MONTOYA RUBIO, J. C. (2009b): Op. cit., pp. 687-688. Percusión de altura determinada.
} 
Algunas motivaciones para este desarrollo pedagógico:

- De manera significativa, se podrían reproducir algunas de las motivaciones expuestas para las dos realizaciones anteriores, destacando sobre ellas el uso organológico escolar como medio de sensibilizar al alumno a través de aquellos instrumentos que le resultan familiares. Como nota distintiva, a través de esta tarea se pretende el desarrollo de una mayor complejidad, dado que se precisa de algo más de entrenamiento para ejecutar armonizaciones con instrumentos de láminas, aunque el ejercicio, tal y como se presenta, es sumamente sencillo y responde a los criterios más comunes de los enfoques didácticos que se basan en este tipo de aproximaciones ${ }^{492}$.

- Establecer relaciones directas entre la historia de la música y la trama de la película, a partir de las alusiones directas del rey a Händel. El espesor de la música del maestro alemán en la corte inglesa (incluso tras su muerte) era tal que no es descabellado hacer ver a los alumnos la verosimilitud, si no de la desbocada verborrea del rey en la escena, sí al menos de la inclusión diegética de la música de dicho compositor, cuyas apariciones musicales después de su muerte eran constantes en forma de reposición ${ }^{493}$.

- Aproximar al alumno al conocimiento histórico-musical desde otra vertiente, la metafórica que se establece en la propia película, en la cual se evidencia la decadencia de una potencia que se niega a reconocer (al menos en la figura de su rey) la independencia de las colonias norteamericanas y que muestra paralelismos con el anclaje musical en la gran figura de Händel, ya desaparecida por aquel entonces, sin mostrarse otro tipo de alternativas en músicos autóctonos.

- Conocer los fundamentos de la composición original ${ }^{494}$, aspecto que siempre resulta ser altamente significativo para el alumnado.

\footnotetext{
${ }^{492}$ SANUY, M. y GONZALEZ SARMIENTO, L. (1969): Op. cit.

493 Aunque existen muchos testimonios al respecto, destacamos los estudios de varios especialistas en la materia en una obra que compendia lo afirmado: PRICE, C., MILHOUS, J. y HUME, R. D. (1995): Italian Opera in Late Eighteenth-Century London. The King's Theatre, Haymarket 1778-1791. Oxford: Clarendon Press.

${ }^{494}$ BURROWS, D. J. y HUME, R. D. (1991): “George I, the Haymarket Opera Company and Handel's Water Music". Early Music 19, pp. 323-341.
} 
- Analizar los cambios producidos entre la versión original y la adaptada, reconociendo los procedimientos por los cuales Fenton pretende dar una mayor brillantez a su discurso sonoro.

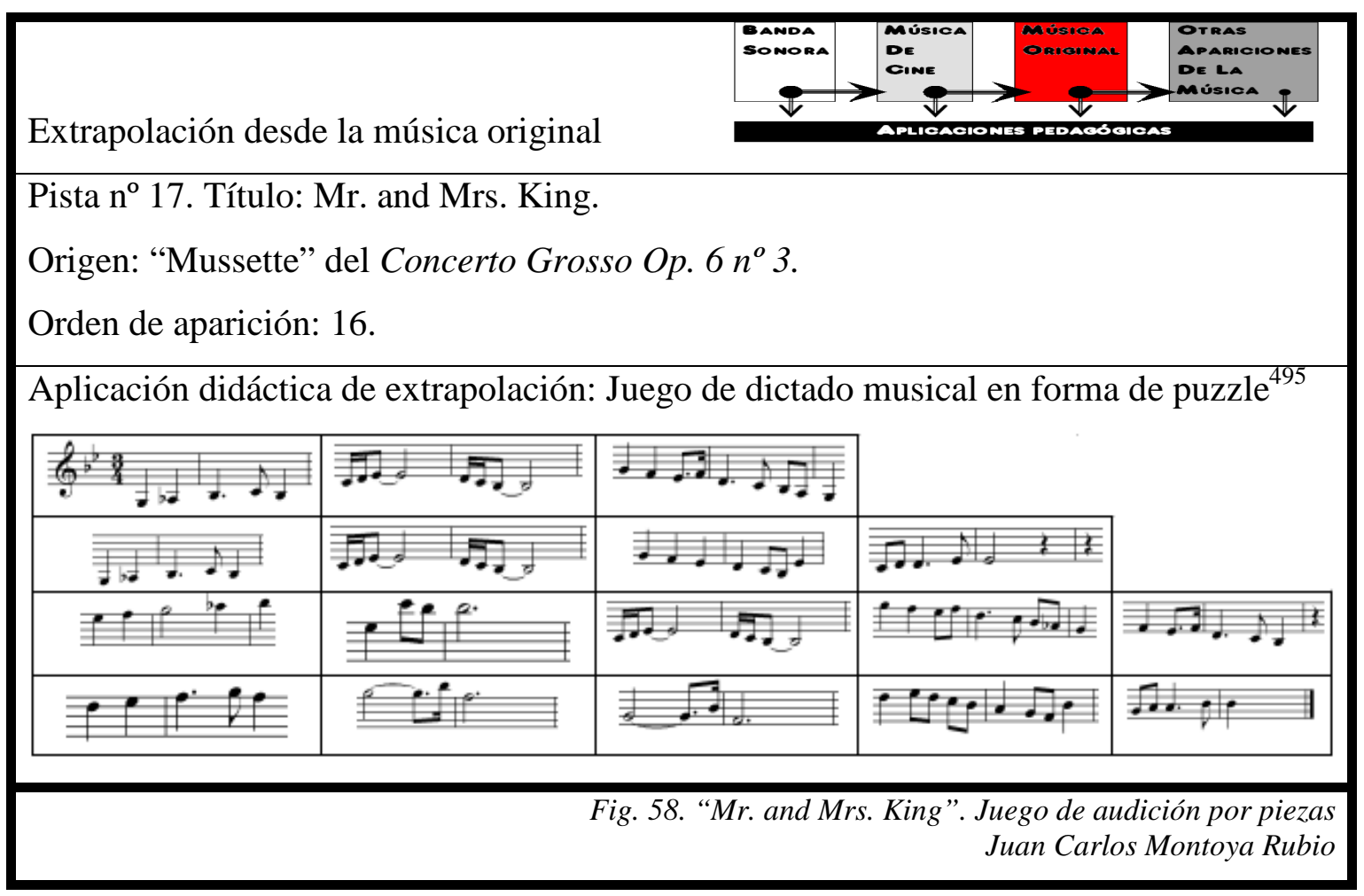

Algunas motivaciones para este desarrollo pedagógico:

- Hacer del lenguaje musical un juego en el que todas las partes de una melodía encajen a partir de la audición. La actualización de los enfoques pedagógicos actuales ha hecho de este tipo de aplicación una variante muy provechosa ${ }^{496}$, por lo que incidir en esas actividades, tomando además como referencia la imagen filmada, goza también de un atractivo especial.

- Conectar la propia realización de la actividad en cuestión con la película, uniendo imágenes fijas de la misma en el anverso de las cartulinas que conforman el puzzle, con el fin de facilitar, según los criterios que desarrolle el docente, la ordenación del mismo.

\footnotetext{
${ }^{495}$ MONTOYA RUBIO, J. C. (2009b): Op. cit., p. 700.

${ }^{496}$ ESPEJO, A. y ESPEJO, A. (2000): Juegos musicales en la escuela. Madrid: CCS.
} 
- Analizar los modelos compositivos de Händel, a partir de las similitudes que se dan entre las cartulinas que dan inicio a cada una de las líneas melódicas o los finales de frase.

- Proponer nuevas fórmulas simplificadas que lleven al alumno a la interpretación guiada, bien con instrumentos al uso bien con otro tipo de percusiones corporales o ruidos. 
D) APLICACIONES PEDAGÓGICAS DERIVADAS DE OTRAS APARICIONES DE LA MÚSICA

Extrapolación desde otras apariciones de la música

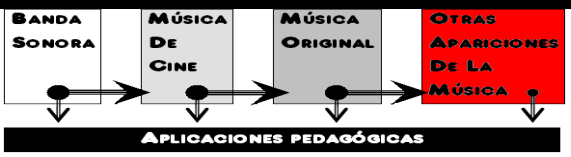

Pista $\mathrm{n}^{\circ}$ 11. Título: "He will be restrained"

Pista $\mathrm{n}^{\circ}$ 18. Título: "The Madness of King George End Credits".

Origen: Zadok the Priest.

Orden de aparición: 11 y 18.

Aplicación didáctica de extrapolación: Seguimientos en música de cine, original y derivación en otros audiovisuales ${ }^{497}$

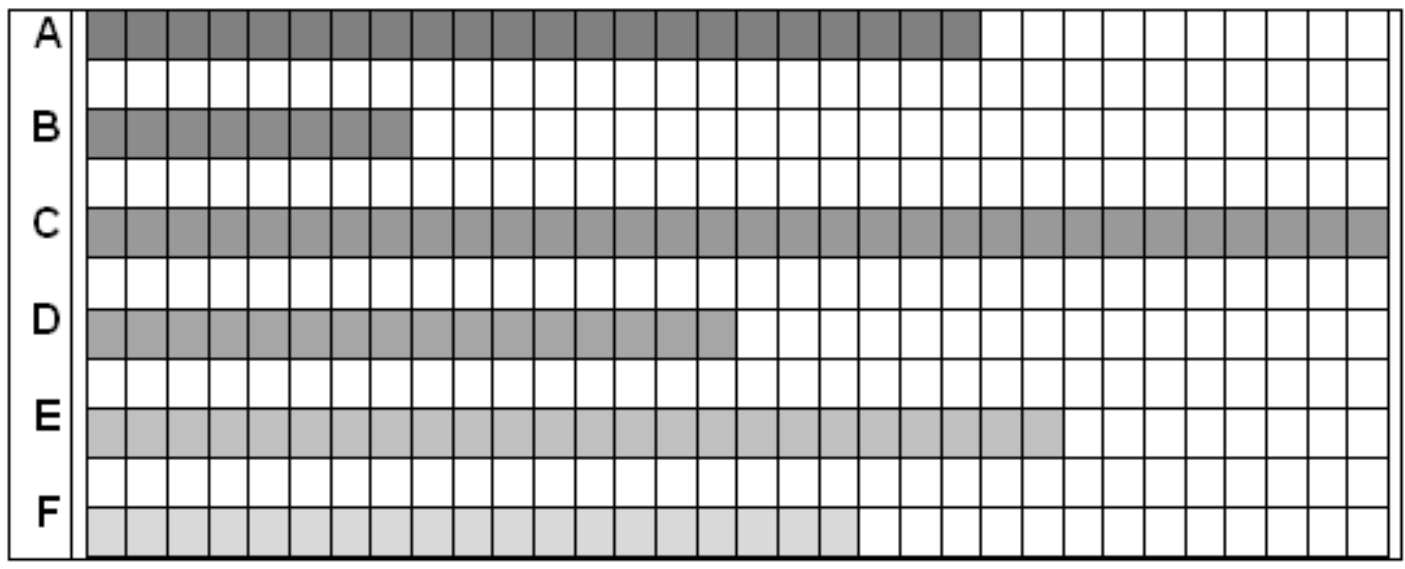

\section{A 22 compases \\ B 8 compases \\ C 32 compases \\ D 16 compases \\ E 24 compases \\ F 19 compases}

Fig. 59. "He will be restrained” \& "The Madness of King George End Credits". Guía de seguimiento textural por bloques temáticos y compases Juan Carlos Montoya Rubio

${ }^{497}$ MONTOYA RUBIO, J. C. (2009b): Op. cit., pp. 692-694. 


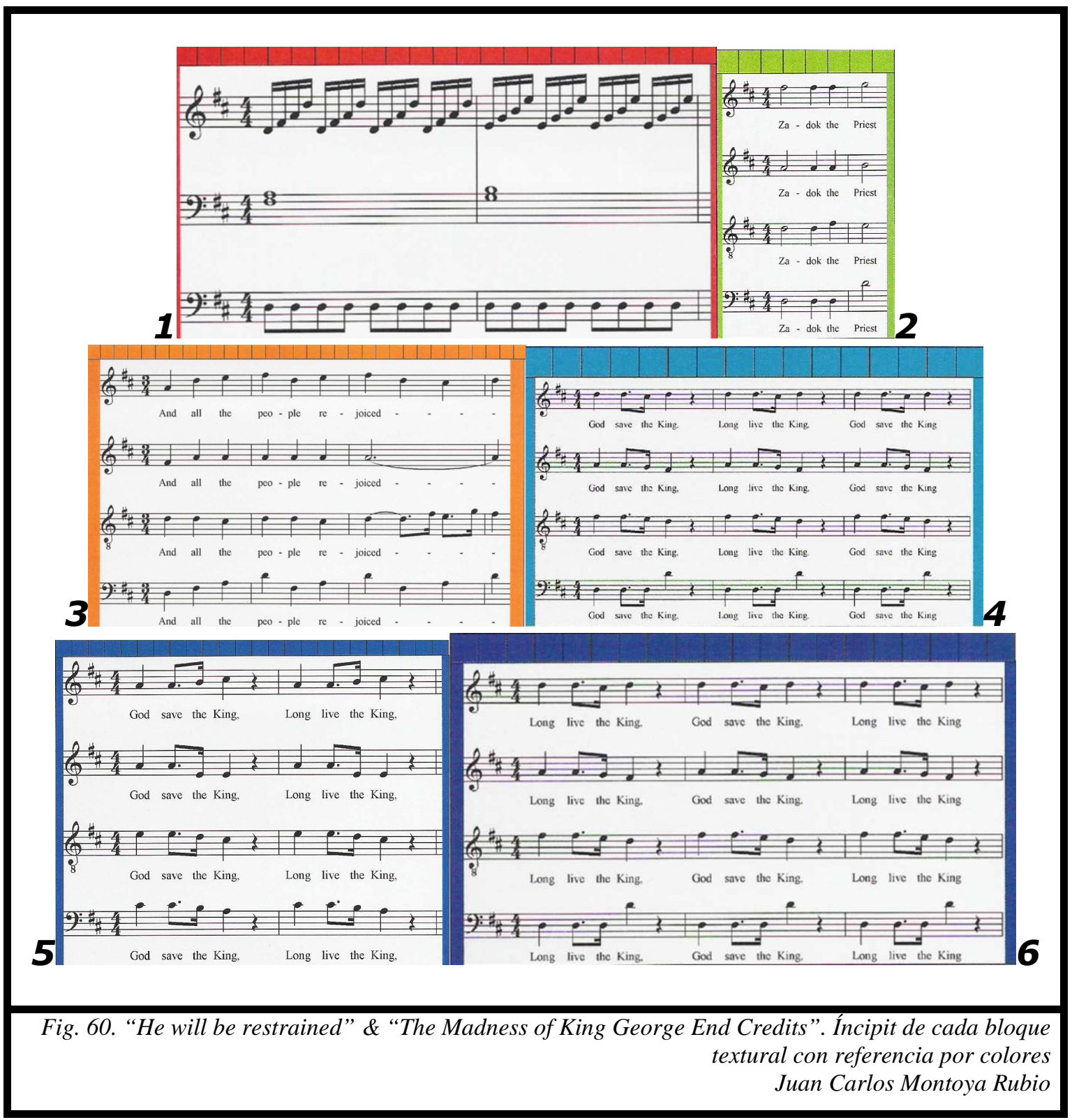

Algunas motivaciones para este desarrollo pedagógico:

- Conectar todas las dimensiones propuestas en principio: banda sonora (el crudo tratamiento de la enfermedad del rey y los créditos finales), música de cine (cortes 11 y 18), originales (el anthem Zadok the Priest) y otras apariciones de la música en formato audiovisual (la adaptación de Tony Britten para la música oficial de la "UEFA Champions League")

- Examinar la temática del original (la usurpación del poder por parte de un hijo al auténtico heredero del rey David, Salomón) y establecer paralelismos con el 
argumento de la película, en el cual se revive una historia, salvando las distancias, con bastantes puntos en común (carácter estructural y narrativo).

- Descifrar las diferentes texturas que integran el original, realizando el seguimiento rítmico por compases atendiendo a la configuración de los diversos bloques de los cuales se les presenta el incipit.

- Procurar que los alumnos "descubran" la adaptación aludida derivada de un espectáculo futbolístico (y por tanto televisivo) para propiciar aprendizajes a partir del resorte significativo explicitado en el capítulo anterior de la investigación.

- Verificar la pertinencia de trabajar con esta música, así como de llevar a cabo realizaciones alternativas propias, ya que todas ellas serán válidas cada una en su contexto.

- Trabajar con diferentes idiomas y sus consiguientes traducciones al castellano, de modo que el aprendizaje se enriquezca también por una hipotética vía intercultural y procurando facilitar la desinhibición en el canto.

- Desmembrar la forma musical de esta novedosa composición en función de la música y con la ayuda textual.

- Establecer paralelismos entre todas las composiciones, desde el original hasta la última derivación propuesta, tratando de descubrir si existen vínculos o no entre lo que se pretende transmitir en cada una de las versiones.

Como puede observarse, son muchas las posibilidades que se esconden tras la extrapolación de los sonidos de un producto audiovisual complejo como es una película. Al margen de elementos como los abordados con mayor detenimiento porque suponen ejemplos claros de actuación, no hemos de dejar caer en saco roto otros procesos que vinculan la dimensión visual dentro de la propia cinta con la sonora. Así, desde la referencia con que ha sido abordado el análisis de esta película, fueron igualmente muy utilizados posicionamientos como los de Conrado Xalabarder, para hacer que el alumno fuera capaz de catalogar la música, por ejemplo, en niveles (según dejaran mayor o menor margen al diálogo sobre ella) o 
en función de su vinculación (siendo "integrada" o "no integrada") entre otros interesantes matices que este autor propone ${ }^{498}$.

${ }^{498}$ XALABARDER, C. (2006): Música de cine: una ilusión óptica. LibrosEnRed. 


\subsection{LA SONORIZACIÓN DESDE UN PRISMA PEDAGÓGICO}

\section{Criterios básicos para la sonorización dentro del aula de educación musical}

"Cuando educandos y educadores puedan penetrar en los vericuetos de la gramática y la sintaxis de imágenes y sonidos [...] se estará produciendo una interacción de la escuela con los medios, elemento transformador hacia una educación plena",499.

Hasta el momento, el capítulo en curso ha presentado un nutrido ramillete de propuestas de diferente dificultad y profundidad. En ellas, no obstante, se ha ido reiterando una carencia esencial: la falta de interacción con las interioridades del producto audiovisual, que todavía es visto como un elemento sorprendentemente atractivo, pero del que no se ha aprovechado completamente su especificidad como parte consustancial del lenguaje audiovisual. Entre los apasionantes desafíos que plantea la práctica educativa actual encontramos la búsqueda de estrategias que hagan que el alumno trabaje directamente sobre los elementos que componen el audiovisual. Así, otro de los ámbitos susceptibles de desarrollo en el plano pedagógico-musical del audiovisual será el de la sonorización, elemento no tan ampliamente desarrollado como pudiera ser, por ejemplo, la extrapolación, pero cuyas virtudes y beneficios para la buena marcha del proceso educativo son tales que superan con creces cualquier batería de objetivos que propongamos desde estos apartados anteriores, ya que en estos casos sí logramos penetrar e interactuar con el audiovisual de manera directa.

Desde la teoría cinematográfica, podríamos empezar a extraer ideas en torno a lo que con posterioridad podremos desmembrar en el plano didáctico. Así, podríamos conducirnos al modo en que se establece

${ }^{499}$ TRÁPAGA, F. (1997): Op. cit., p. 53. 
"una pista sonora orgánicamente coherente, en la que las dialécticas sonidoimagen estén estrechamente asociadas a otras ligando entre sí lo que se puede llamar los tres tipos esenciales de sonido cinematográfico (ruidos "identificables" o no, música, palabras)" ${ }^{, 500}$.

Al remitirnos a un tipo de práctica que como decimos no es la más habitual dentro del tratamiento que se hace de la música del audiovisual en los discursos educativos, proponemos una definición ya puesta en común en diversos foros que empiece a arrojar luz acerca del tratamiento didáctico al que nos estamos refiriendo:

"La sonorización didáctica para el audiovisual consiste en implementar sonidos producidos por instrumentos corporales (incluyendo todo tipo de ruidos, percusiones o voces), escolares o por grabaciones de música adecuadas a un fragmento visual (mudo o sonoro) cuyo origen puede ser didáctico o no, pero cuya finalidad se torna pedagógica en la determinación final del producto a través de una propuesta de objetivos adaptados al nivel del alumnado",501.

Así, nos estamos refiriendo a "la implementación de sonidos", incluyendo por supuesto cualquier clase de música pero también ruidos en conjunción con silencios que fueran necesarios para llevar a cabo el procedimiento didáctico. En lo referente a la producción de dichos sonidos habremos de aceptar todo tipo de agentes productores que, ya hoy día, se están utilizando como parte integral de las metodologías musicales, de ahí que se citen expresamente los producidos corporalmente (lo cual nos derivaría a una inmensa cantidad de posibilidades entre las que cabría esperar la voz así como percusiones de todo tipo), los generados por instrumentos escolares (esto es, todos aquellos que de uno u otro modo tengan cabida en este contexto) y las grabaciones musicales (las cuales posibilitarán un tipo muy específico de sonorización, por inserción de un audio concreto).

\footnotetext{
${ }^{500}$ BURCH, N. (1998): Praxis de cine. Madrid: Fundamentos, p. 101.

${ }^{501}$ MONTOYA RUBIO, J. C. (2009d): Op. cit, p. 711.
} 
En cuanto al material visual se hace referencia a que éste pueda ser mudo o sonoro. Asimismo, es útil en términos pedagógicos la utilización de un vídeo "al uso" al que se le elimina su banda de sonido para cambiarla por otra con intención didáctica. Los fragmentos visuales "mudos", como veremos, serán más apropiados para unas aventuras sonorizadoras que para otras, de igual modo que ocurrirá con la superposición de sonidos a productos audiovisuales que contienen tanto imagen como audio.

Por último, la cita anterior nos remite a la intención o finalidad pedagógica. Como fue expuesto en el capítulo anterior, es de suma importancia no fijar las miras con exclusividad en aquellas producciones que acuñadas bajo el sello de la didáctica. Este hecho será especialmente notorio en el caso de la sonorización, que abrirá la puerta al trabajo con muchos fragmentos audiovisuales que, conectando con el criterio de significatividad, no fueron ideadas en origen como pedagógicas. De ahí que lo realmente importante sea que su finalidad no es sino que "se torna en pedagógica" al aplicarle el docente una mirada especial que acerque el producto a sus alumnos ${ }^{502}$.

Con ello, en este campo, en el cual nos inmiscuimos en los intersticios de los códigos audiovisuales, las posibilidades son muy similares a las que un compositor se plantea a la hora de insertar música a un producto audiovisual cualquiera, con la obvia salvedad de que los materiales, recursos y pretensiones desviarán unas elaboraciones con finalidad comercial de otras, las que nos interesan a nosotros, con fines didácticos. Por ello, sirvan como introducción a estos modos de actuación las reflexiones de Gómez $\operatorname{Varas}^{503}$, quien se cuestiona sobre el papel del compositor ante un encargo sobre el que poner música. Para él $-\mathrm{y}$ seguramente para todo aquel que se acerque más o menos directamente al mundo de la producción musical en el audiovisual- las posibilidades son, básicamente, las siguientes:

a) utilizar música preexistente (clásica o de otra procedencia, como pueda ser otra película) ajustándola en tiempos al nuevo discurso que se pretende configurar.

b) utilizar música preexistente y perpetrar sobre ella los suficientes cambios para no "delatar" el original manteniendo el carácter pretendido.

\footnotetext{
${ }^{502}$ Para Ferrés i Prats, las potencialidades comunicativas de los contenidos, por ejemplo, de la televisión comercial (series, anuncios, etc.) son tan grandes como cualquier otro formato etiquetado como educativo desde su génesis: FERRÉS i PRATS, J. (2003): "El estilo comunicativo en la televisión educativa". Red Digital 4. Disponible en <http://reddigital.cnice.mecd.es/4/firmas/ferres_ind.html $>$ [Consulta 9- II-10] ${ }^{503}$ GÓMEZ VARAS, P. (2009a): Op. cit.
} 
c) elaborar un discurso musical nuevo, utilizando cualquier tipo de recurso y considerando, naturalmente, las influencias que cada compositor puede llevar consigo.

En nuestro caso, pasando todas estas posibilidades por el tamiz didáctico, encontramos que, por un lado, la utilización de música preexistente para aplicarla en cualquier discurso visual ajeno al primero puede ser aprovechado, por cuestiones obvias como son la búsqueda de materiales por el alumnado, el estudio minucioso de los fragmentos, o los intentos por precisar cierta sincronía entre los códigos sonoros y visuales. Por su parte, la elaboración musical sobre música preexistente nos conduciría, en el ámbito pedagógico, al trabajo de extracción de una música para, a partir de las modificaciones pertinentes, incluirla en otro formato. Estos cambios se producirían, preferentemente por su mayor simplicidad, con materiales e instrumentos de aula y podrían ser eventualmente grabados para su posterior inclusión. Por último, la elaboración de un discurso musical nuevo, en el contexto que pretendemos movernos, es si cabe más relevante, ya que muchas de las sonorizaciones que los alumnos puedan perpetrar partirán de estrategias absolutamente novedosas y originales.

Como es habitual en gran parte de esta investigación, para poder hallar una línea lógica que fundamente nuestra argumentación es preciso recurrir a fuentes de diferente procedencia. En este sentido, la sonorización en sí no es un tema novedoso en absoluto, ni en el plano de la didáctica de la música (en el cual se vincula a los cuentos musicados) ${ }^{504}$ ni, por supuesto, desde el acercamiento musicológico ${ }^{505}$. No obstante, sí es bastante poco frecuente encontrar aproximaciones que, desde cualquier área de conocimiento, hablen tácitamente de cómo debería producirse el fenómeno de la sonorización de un audiovisual en el contexto educativo musical. De hecho, como abordaremos en breve, cuando aparecen intentos por explicitar algunos modelos de actuación, nos encontramos ante meros apuntes poco sistemáticos y nada estructurados.

Por un lado, desde el ámbito de la musicología pueden ser de gran utilidad los estudios que nos hablan del modo en que las primeras producciones cinematográficas trataban de integrar el sonido sobre la imagen, ya que entre estos rudimentos se

\footnotetext{
${ }^{504}$ Es cierto que en aplicaciones que abordan la pedagogía del cine en general se pueden encontrar tímidas referencias al montaje cinematográfico y la vinculación imagen y sonido, aseverando, tal vez con demasiada precisión que un buen momento para su aplicación sea el inicio de la Educación Secundaria Obligatoria: SOLÁ ARGUIMBAU, A. y SELVA MASOLIVER, M. (1996): Op. cit., p. 51.

${ }^{505}$ Especialmente interesantes son las aproximaciones que nos introducen a este tipo de fenómenos en los dibujos animados: RADIGALES, J. (2001): Op. cit.
} 
esconden sencillas estrategias de inserción sonora desde la economía de medios perseguida en muchos casos por la didáctica musical. Estos últimos textos, los referidos a las épocas primeras en la sonorización musical, serán de gran utilidad desde una vertiente instrumental (cómo llevar a cabo el proceso) y otra expresiva (informando de estrategias que destaquen por sus posibilidades para transmitir sensaciones).

Por su parte como apuntamos, en el plano de la didáctica de la música otorga como principal baluarte de conocimiento para acceder a la sonorización aquella que tradicionalmente se ha llevado a cabo en la dramatización de cuentos y otras historias, en sus diferentes modalidades ${ }^{506}$, lo cual ha de servir de puente para redimensionar el sentido de la sonorización en pedagogía de la música, para pasar a implementar música no sólo a cuentos o narraciones infantiles sino también a otros recursos de corte audiovisual. En todo caso, al referirnos al tándem formado por la música y la dramatización hemos de tener presente que no siempre se ha teorizado, desde la didáctica, con igual persistencia en uno y otro plano. Así, existen aproximaciones pedagógicas que informan sobre el proceso de dramatización simplificando (u olvidando directamente) el uso sonoro ${ }^{507}$. A pesar de esa carencia, realizando un repaso por las principales fuentes bibliográficas citadas con anterioridad, se pueden extraer una serie de convenciones que la pedagogía musical ha establecido como valederas para la sonorización de cuentos y que, por consiguiente, pueden ser una buena manera de

\footnotetext{
${ }^{506}$ Las primeras aproximaciones a la didáctica de la música ya guardaban resquicios por los que hacer patente la sonorización de cuentos infantiles. En ORIOL, N. y PARRA, J. M. (1979): Op. cit. pp. 79-92, ya se utilizaban todos los recursos que serían prototípicos (instrumentos, efectos de todo tipo, ritmos percutidos, prosodias, etc.) para ejemplificar el modo de proceder sobre el clásico "La cigarra y la hormiga". No obstante, por su influencia en las hornadas actuales de maestros de educación musical preocupados por la sonorización de cuentos, es de justicia citar preferentemente la obra que abrió paso a las posibilidades musicales de las narraciones infantiles: ESCUDERO, M. P. (1988): Cuentos Musicales. Madrid: Real Musical. La observación de sus axiomas básicos y puesta en funcionamiento con posterioridad ha tenido un éxito desigual, en función siempre del resto de criterios en torno a los que se sonorizaba el cuento. Sirva como ejemplo: RAMÍREZ HURTADO, C. (1996): "Apuntes sobre la sonorización del cuento infantil". Música y Educación 27, pp. 57-68; ARGUEDAS QUESADA, C. (2006b): "Cuentos musicales para los más pequeños". Revista Actualidades Investigativas en Educación 6. Disponible en <http://revista.inie.ucr.ac.cr/articulos/1-2006/cuentos.php> [Consulta 9-II-10]; o el uso que, de manera contada, se hace en los libros de texto: PASCUAL MEJíA, P. (2004): La batuta mágica 1. Madrid: Alambra Pearson, pp. 64 (presentación del cuento y elementos a sonorizar), 65 (identificación de personajes con timbres y cotidiáfonos) y 77 (elaboración de materiales complementarios).

507 Acerca de la dramatización y sus posibilidades (como exponemos marginando en cierto modo el factor sonoro aunque curiosamente enfatizando el movimiento) encontramos los trabajos de Juan Cervera, entre los cuales destacan: CERVERA, J. (1996): La dramatización en la escuela. Madrid: Bruño; CERVERA, J. (1986): Cómo practicar la dramatización con niños de 4 a 14 años. Madrid: Cincel-Kapelusz. La carencia que se apunta es especialmente sangrante en tanto en cuanto la importancia de los elementos que componen el proceso dramático llega a campos como puedan ser el vestuario o los decorados: MAINÉ, M. C. (1987): Escenificar un cuento. Barcelona: Hogar del Libro.
} 
comenzar a acotar el modo en que habría de producirse la sonorización audiovisual en clave pedagógica.

De manera preliminar, de acuerdo con las prácticas preexistentes, nos hemos de referir a los ámbitos de sonorización. En este sentido, encontramos que la recreación ambiental es una de las principales encomiendas de la música ${ }^{508}$, pero también lo es el desarrollo de la acción o la identificación de los personajes. Por otro lado, en cuanto a los recursos a utilizar hemos de realizar una distinción que servirá como criterio metodológico en el futuro inmediato de este capítulo: música interpretada en directo versus música grabada. En el primero de los casos, habríamos de trasladarnos al proceso de selección del material sonoro. En lo referente a la música de aplicación directa, como no puede esperarse de otro modo, es muy frecuente la utilización de instrumentos propios del aula de música. Estos instrumentos (basados con pequeñas adiciones en la “Orquesta Orff”) incluirían, además, cualquier otro agente productor de sonido válido para evocar la situación o el personaje que se requiera (incluyendo en este caso tanto los improvisados instrumentos musicales como las voces y percusiones corporales). Por otro lado, de las prácticas existentes inferimos como elementos sustanciales el modo en que se lleva a cabo la selección de materiales y los "tiempos", estrategias y criterios sonorizadores. Ello nos servirá para ir validando una estructura a desarrollar a lo largo del apartado de sonorización que nos ocupa.

En cuanto a la selección de materiales, de acuerdo con lo expuesto, será vital llevar a cabo un trabajo previo de reflexión para desestimar materiales que no sean adecuados, por el motivo que fuere, y extraer aquellos que sí se consideren procedentes, teniendo en cuenta siempre que, al margen de los aspectos de índole general que van a orientar sobre la pertinencia de los materiales, la faceta lúdica y el atractivo de cara a los alumnos será un elemento crucial, por erigirse en resorte de la motivación. Además, la selección de recursos ha de tener en cuenta que el material elegido, al margen de adecuado por temática y atractivo para el alumnado, ha de ser capaz de cumplir con todos los objetivos que tracemos, de forma que sea susceptible de llevar aparejadas actividades variadas (comentarios antes de realizarse, vinculaciones con otros aprendizajes previos, etc.). En este sentido, el material audiovisual no puede concebirse

\footnotetext{
${ }^{508}$ Sin establecer una relación directa entre la fuente sonora y lo que aparece en la narración: GARCÍA JIMÉNEZ, J. (1993): Narrativa audiovisual. Madrid: Cátedra, p. 103.
} 
desde el aislacionismo del docente, sino que ha de inscribirse dentro de las prácticas que ya se están llevando a cabo y, al mismo tiempo, ha de aprovechar los recursos al alcance para dotarlos de un nuevo sentido, de modo que se conecten aprendizajes previos y metodologías preexistentes. Afortunadamente hoy se dispone de conocimiento y se articulan herramientas para disponer de él de manera ágil y efectiva ${ }^{509}$. Por último, es preciso reparar en que la sonorización va a suponer un gran esfuerzo en todos los sentidos (especialmente en cuanto a la atención que se precisa por parte del alumnado), por lo que si no queremos que dicho esfuerzo sea ímprobo y hasta cierto punto baldío habrán de seleccionarse fragmentos, preferentemente, de corta duración y cerrados, esto es, que en el periodo de su realización quede cumplimentada la labor pedagógica.

Pasando a los "tiempos", estrategias y criterios en la sonorización, sabemos que es clave, para poder abordar una sonorización en didáctica de la música, que el estudio previo arroje luz sobre los momentos en los que se precisará una u otra aplicación, así como el modo en que ésta ha de llevarse a cabo. Sin duda, la labor del docente ha de servir para evitar dificultades y clarificar todo el proceso a seguir el cual, al menos, partirá de tres momentos: análisis, aprendizaje y puesta en común ${ }^{510}$. En todo caso, será preciso un ejercicio de fragmentación del corte a sonorizar y de trabajo individualizado por partes, para acceder a la versión en gran grupo. Para Millerson ${ }^{511}$, en la sonorización habrían de contemplarse igualmente tres momentos que precisan de manera clara de la inserción sonora: la intensificación de los sonidos ambientales, la recreación de una situación que precisa de música para transmitir un significado concreto o la huida, por medio de la música, de aquello que se muestra en imágenes y no se quiere reforzar. Algunas estrategias, tan reiteradas que se tornan en convención, serían la aplicación de

\footnotetext{
${ }^{509}$ En su orientación de los recursos tecnológicos actuales hacia la educación, Víctor Manuel Amar sostiene que ésa es una de las grandes virtudes y desafíos de la nueva oleada de recursos que se avecinan en las aulas del siglo XXI: AMAR RODRÍGUEZ, V. M. (2009): "Web 2.0: nueva sintaxis y semántica para la educación”. ROIG VILA, R. (Dir.) Investigar desde un contexto educativo innovador. Alicante: Marfil, pp. 15-24.

${ }^{510} \mathrm{La}$ observación de estos tres momentos es una idea que encontramos en: GALÁN BUENO, C. (2007): "La sonorización del silencio. La improvisación en el cine mudo". Música y Educación 69, pp. 19-47. En este artículo el autor se centra en el uso del piano como instrumento para improvisar sobre escenas de cine mudo, para lo cual establece unos criterios metodológicos basados en tres visionados (estableciendo las relaciones básicas entre los personajes y los ambientes, llevando a cabo el proceso de sonorización al piano y, por último, ejecutando con público). Salvando las distancias con las pretensiones de un trabajo didáctico para la enseñanza obligatoria más allá de tres visionados hablamos de tres momentos (porque entendemos que los visionados podrán ser todos los que se precisen) que, no obstante, sí guardan estrechos paralelismos con las aportaciones de Carlos Galán.

${ }^{511}$ MILLERSON, G. (1983): Técnicas de realización y producción en televisión. Madrid: Instituto Oficial de Radio y Televisión.
} 
determinados timbres para identificar, a modo de rudimentario leitmotiv, a los personajes, así como el uso de los instrumentos de pequeña percusión de altura indeterminada para realizar analogías con los movimientos lentos o rápidos ${ }^{512}$. Por otro lado, es también habitual utilizar un mayor número de instrumentos cuando la escena en cuestión muestre un grupo numeroso de personajes o situaciones varias. Además, al adentrarnos en el mundo de la subjetividad y la expresividad, suele ser común argumentar que la aplicación de uno u otro modo en el proceso sonorización ayudará a crear determinados ambientes $^{513}$. Finalmente, es preciso hablar de la necesidad de redondear la práctica sonorizadora, cuando esta se basa en la grabación, por medio de un proceso de "postproducción" que sirva para decidir sobre la pertinencia de todo aquello que se está generando ${ }^{514}$. En cualquier caso, al igual que sucede en el plano de la sonorización fílmica, en el campo de la didáctica musical que pretendemos abrir

"no existe receta, ni fórmula magistral, que resuelva los innumerables interrogantes que se abren inicialmente en el trance de componer y seguidamente en el de incorporar la música a la película o, mejor, de "integrarla" al complejo fílmico, $" 515$.

Para estos autores, una metodología adecuada (con interesantes ramificaciones que incluimos para adoptar en lo pedagógico) se resumiría del siguiente modo ${ }^{516}$ :

- Determinación de la parte visual a sonorizar.

- Determinación de los momentos de "música ambiental" y "música viva" (en terminología de los citados autores, aquella que crea y determina la escena)

\footnotetext{
512 Aspecto reseñado también por el citado Galán Bueno en referencia a la música pianística, aportando además del uso de las figuraciones rápidas para un mayor movimiento el uso de ostinatos rítmicos, sonidos sincopados y cambios de acentuación.

${ }^{513}$ GALÁN BUENO (2007): Op. cit.; BELTRÁN MONER, R. (2005): La ambientación musical en radio y televisión. Selección, montaje y sonorización. Madrid: Instituto Oficial de Radio y Televisión; CAMPUZANO RUIZ, A. (1992): Op. cit., pp. 84-85.

514 STAIGER, J. (1995): "El modo de producción en Hollywood durante la transición del mudo al sonoro". VV.AA. Historia general el cine, v. VI. Madrid: Cátedra. Signo e Imagen, p. 124.

${ }^{515}$ PADROL, J. y VALLS GORINA, M. (1990): Op. cit., p. 55.

${ }^{516}$ Estrategias metodológicas ya esgrimidas en MONTOYA RUBIO, J. C. (2009d): Op. cit., p. 713.
} 
- Visionado reiterado de la parte visual para anotar (minutar) los puntos de aplicación musical y su carácter.

- Selección e inserción de los fragmentos musicales y, en su caso, composición para útiles e instrumentos escolares de aquellos momentos que así lo precisen.

- Interpretación (grabada o no, según objetivos del docente) del conjunto de manera sincronizada.

De acuerdo con las ideas principales que se pueden extraer de las aportaciones tanto musicológicas como pedagógicas, y partiendo de nuestra experiencia en el aula, entendemos que se puede establecer un guión acerca de los procesos de sonorización dentro de las aulas de educación musical, y proponemos los siguientes pasos para su elaboración ${ }^{517}$ :

${ }^{517}$ Un primer intento por acotar las diferentes tipologías sonorizadoras en las aulas se encuentra en MONTOYA RUBIO, J. C. (2009d): Ibíd., p. 714. En esta nueva aportación se amplían algunas de las dimensiones reseñadas y se condensan categorías, con el fin de hacer más precisa la reflexión que se expone. 


\section{Selección de materiales \\ 1 Criterios pedagógicos generales
$\rightarrow$ Motivación
$\rightarrow$ Dificultades por edades
$\rightarrow$ Actividades vinculadas
$\rightarrow$ Globalización de aprendizajes
$\rightarrow$... \\ $\rightarrow$ Adecuación temática}

\section{Determinación del tipo de inserción sonora}

2
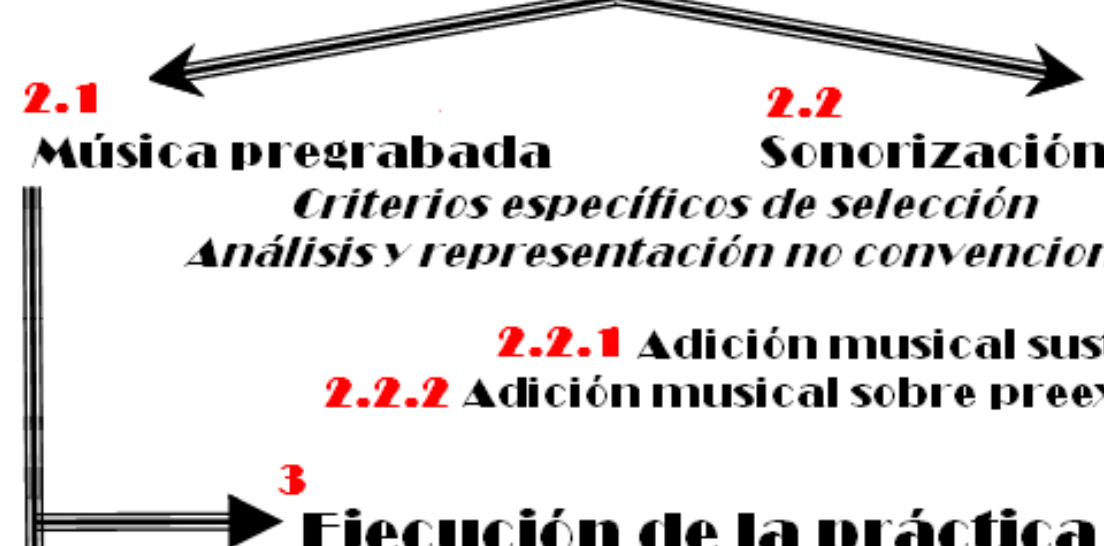

Criterios especificos de selección

Sonorización "en vivo"

Inálisis y representación no convencional

2.2.1 Adición musical sustitutiva 2.2.2 Adición musical sobre preexistente

4

\section{Ejecución de la mráctica}

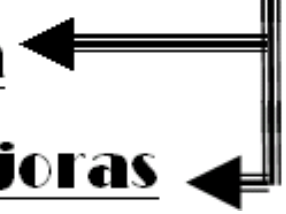

Fig. 61. Guión para secuencias sonorizadoras en las aulas de educación musical Juan Carlos Montoya Rubio

En función del esquema propuesto, un primer paso a tomar en consideración es la selección del material a utilizar. Investigar el complejo música-cine como parte de un proceso que da lugar al "lenguaje audiovisual" puede ser muy útil, así como desmenuzar aquellos materiales que permitan observar con claridad la integración de los parámetros sonoros que entran a participar: música, ruido y silencios ${ }^{518}$, pero todo ello carece de valor si no se estima y prioriza el tipo de material que se visualizará dentro del aula. En este primer apartado, la labor de reflexión corresponde únicamente al docente, quien a pesar de tener en cuenta criterios de significatividad en los que pudieran participar los alumnos ha de ser capaz de encontrar fragmentos visuales (o audiovisuales) que, como se apunta en la imagen, respondan a una serie de elementos extraídos de la pedagogía

${ }^{518}$ HUESO MONTÓN, A. L. (1998): El cine y el siglo XX. Barcelona: Ariel Historia, p. 53. 
general, que nos informen acerca de la conveniencia de su inclusión como materiales propios de los procesos didácticos. Entre estos criterios, se estiman como insoslayables la adecuación temática, evitando que puedan ser presentados elementos que en modo alguno hieran la sensibilidad o se alejen en exceso de los intereses del alumnado; la motivación, de forma que se desestimen aquellos fragmentos en los cuales el profesor sienta incapacidad para buscar conexiones pertinentes con el ideario infantil-juvenil al que se dirige, ya que ello cercenaría sus hipotéticos planes de consecución de objetivos; la dificultad en función del nivel al que se dirija la propuesta, para evitar frustraciones ante lo excesivamente arduo o raramente conseguible porque los alumnos no fueran capaces, en función de su nivel evolutivo y posibilidades, de llevar a cabo la propuesta o por el caso contrario, esto es, que la simplicidad acarree desmotivación o desconexión; la facilidad para insertarle actividades de todo tipo (previas, posteriores, de animación, de vinculación con los conocimientos previos, de desarrollo, de evaluación, etc.), con el fin de que lo previsto no quede como un ejercicio aislado y sin mayor sentido que su propia realización inconexa; la posibilidad de vincular aprendizajes por medio de la globalización con otras áreas de conocimiento, de modo que el aula de música se abra a otras realidades y parcelas que pudieran parecer alejadas (lenguas, matemáticas, aspectos sociales y naturales, etc.) pero que sean realmente fructíferas a la hora de ensamblarse con las tareas musicales; por último, todos aquellos elementos que el sentido común haría recomendar un material para un alumnado concreto (conexión con la programación general, vinculación con la realidad del centro, sorteo de las dificultades generales, etc.) para facilitar el desarrollo integral de la persona.

De este modo, los objetivos didácticos que el docente plantee como necesarios en ese momento de su desarrollo pedagógico y que hagan conveniente un trabajo de sonorización le llevarán a dos grandes posibilidades, señaladas con el punto segundo del esquema numerado de la imagen anterior: utilización de música pregrabada o sonorización "en vivo". Esta determinación del modelo sonorizador tendrá como principal aliciente empezar a perfilar el trabajo directo de los procedimientos específicos. Tanto en una opción como en la otra se habrán de observar, una vez más, ciertos criterios, ahora específicos, en la selección del material. Así por ejemplo, al abordar una sonorización con música grabada previamente (por alumnos o por cualquier otro medio ya "manufacturado") será interesante que el corte que se pretenda utilizar 
presente unas características lógicas para con esta inserción sonora (es decir, que nos permita responder a los objetivos potencialmente abordables) y que, en el caso de una sonorización directa sobre un fragmento visual elegido a tal efecto, éste delimite claramente su estructura y principales rasgos para llevar a cabo una intervención apropiada. Por otro lado, en ambos casos (uso de música previamente grabada o adicionada sobre el vídeo) conviene que los alumnos sean capaces de encontrar una lógica en su devenir. Extrapoladas del mundo de la audición activa, son muy utilizadas en pedagogía de la música las representaciones no convencionales por medio de los musicogramas $^{519}$. Su aproximación al audiovisual, facilitando el seguimiento de manera muy intuitiva, puede trasladar sus grandes beneficios a este campo ${ }^{520}$.

Además, en el caso de la inserción "en vivo", será preciso investigar si el fragmento seleccionado de acuerdo con todos los criterios anteriores que puede ser estructurado para el alumno con cierta facilidad precisa de una inserción sonora sobre el silencio o sobre su propio material sonoro preexistente. En este sentido, analizaremos como, en ocasiones, es más rentable en términos de adquisición de conocimientos omitir la parte sonora original para implementar nuevos sonidos y, en otras, el contenido sonoro perteneciente al corte audiovisual en cuestión aconseja que se trabaje sobre él.

En todo caso, existen dos estadios finales absolutamente necesarios, la puesta en común del trabajo realizado (la cual puede tomar diferentes modalidades, desde la ejecución en el aula hasta la exposición a otros compañeros o personas) y la reflexión sobre el trabajo acometido, con el fin de buscar el análisis de la labor conjunta y de instigar a la búsqueda de mejoras en futuras realizaciones.

Pasamos pues a desmenuzar cada tipo de inserción sonora, reflexionando con mayor detenimiento sobre ellas y aplicando ejemplos extraídos de diferentes fuentes.

\footnotetext{
${ }^{519}$ WUYTACK, J. (1998): Audición Musical Activa. Oporto: Associaçao Wuytack de Pedagogía Musical. ${ }^{520}$ Actividades que ejemplifican este procedimiento serán incluidas en el apartado dedicado a la filmación y recursos audiovisuales de musicogramas con movimiento.
} 


\section{Inserción de música y sonidos pregrabados}

Al aplicar música (o cualquier otro tipo de sonidos o ruidos) a un fragmento visual encontramos, de forma preliminar, una primera variante. La inserción del material sonoro puede producirse aprovechándose recursos ya existentes (archivos de audio) o grabando realizaciones llevadas a cabo por los alumnos e implementándolas con posterioridad a un discurso visual. En este segundo caso, nos acercamos extremadamente a los elementos de producción de la denominada anteriormente "sonorización en vivo", que será expuesta a continuación, por lo que nos ceñiremos, en este momento, a la primera de las tipologías, la aplicación de música recogida a partir de archivos sonoros ya elaborados.

Los objetivos didácticos elementales en la inserción de música y sonidos pregrabados sobre fragmentos visuales los hemos condensado del siguiente modo ${ }^{521}$ :

- Desarrollar la creatividad y la imaginación en la adhesión de elementos sonoros exógenos a determinadas imágenes, produciendo vínculos relevantes entre dos realidades en principio distantes. Así, se entiende que gran parte del trabajo del alumnado consiste en realizar una búsqueda de melodías que se adecuen a cortes visuales, de modo que la presentación de los mismos no sea la principal tarea, sino el recorrido que ha llevado a cabo hasta lograrlo. En este apartado se podrán ver las aportaciones personales y los sesgos que hacen que haya miradas sumamente especiales en el proceso de adición musical ${ }^{522}$.

- Utilizar la información relevante derivada de las Tecnologías de la Información y la Comunicación como acicate del aprendizaje. En una época en la que surgen recelos en el uso de medios informáticos para extraer información (debido a una posible falta de rigor en el modo de introducirlos), tareas como las propuestas facilitarán que sea la propia perspectiva crítica del alumno la que oriente las buenas y malas prácticas. En este sentido, en los foros que se ocupan de dichas tecnologías existe una preocupación creciente

\footnotetext{
${ }^{521}$ Apuntados con mayor brevedad en MONTOYA RUBIO, J. C. (2009d): Op. cit., pp. 718-719.

${ }^{522}$ Hecho puesto de manifiesto repetidamente por Matilde Olarte desde una óptica de género. El ejemplo más actual al respecto: OLARTE MARTÍNEZ, M. (2009b): "Música de cine compuesta por mujeres. La utopía del universo femenino". Reflexiones en torno a la música y la imagen desde la musicología española. Salamanca: Plaza Universitaria Ediciones, pp. 601-612.
} 
por el modo en que éstas pueden ser usadas de manera segura y acertada. Sin duda, estamos frente a una opción que bien dirigida puede resultar muy válida.

- Propiciar que el alumno aporte el máximo en el proceso de enseñanzaaprendizaje. Gracias, sobre todo, a que este procedimiento vincula los conocimientos previos con los contenidos intrínsecos de la materia y el protagonismo del alumno como constructor de su aprendizaje siempre es un criterio a considerar. Es preciso tener en cuenta que una vez se dota al discente de las herramientas de trabajo y se orienta el mismo entramos en una fase de gran autonomía, ya que las principales labores y los establecimientos de vínculos entre sonidos e imágenes pasan a ser responsabilidad del alumno.

- En estrecha relación con la idea anterior, estimular la capacidad de decidir a aprender que ha de ser pulsada para que el alumno aliente su propio aprendizaje ${ }^{523}$. De acuerdo con los postulados enunciados en el capítulo anterior, desde el momento en que el proceso educativo no es guiado en exclusividad por el docente sino que supone una delegación y compromiso mutuo los propios alumnos, al participar activamente, son los responsables, en gran medida, del encauzamiento hacia el éxito del procedimiento.

- Estimular el espíritu crítico a través de la observación, el análisis y la reflexión sobre la labor propia y ajena. De modo que el trabajo en pequeños grupos, muy propio de este tipo de sonorizaciones, sea un escenario propicio para que se muestren alternativas y posicionamientos críticos constructivos.

- Orientar nuevos aprendizajes, ya que se favorece la creación de propuestas didácticas derivadas de la tarea principal. Así, entre los criterios pedagógicos generales se observó la necesidad de que la tarea a desarrollar no supusiera un esfuerzo aislado sino que, por el contrario, formara parte de un plan integral. El uso de músicas preexistentes para la sonorización y reorientación del audiovisual abre la puerta a otras actividades derivadas, esencialmente, del origen de la composición que se extrapola.

${ }^{523}$ RUSINEK, G. (2004): Op. cit. 
Generalmente, nos encontramos con vídeos que, una vez superada la criba de los criterios generales, específicos y la representación o guía para el seguimiento del alumnado, ya poseen una banda de sonido, sea ésta del tipo que sea. Por ello, es importante recordar que la metodología de trabajo en este tipo de realizaciones parte de la supresión de esa música (entiéndase cualquier elemento sonoro) por otra que logre colmar las expectativas que el docente haya diseñado para sus alumnos. A partir de ahí, se abre un apartado de inclusión sonora que supone, por tanto, importar una música preexistente de su contexto original para incorporarla al corte visual deseado forjando, de esta manera, un nuevos significados. En palabras de Reyzábal:

“...el acompañamiento musical de un montaje audiovisual modifica sustancialmente su siginificación, creando un discurso nuevo" 524.

La principal dificultad para los alumnos estriba en adecuar sincrónicamente elementos visuales dados con la búsqueda de un material sonoro que sea capaz de aludir más o menos fehacientemente las particularidades de aquello que se está viendo. A partir de esta técnica y dependiendo del nivel al que se le requiera sonorizar, ese problema será más o menos acuciante. En cualquier caso, el docente ha de ser capaz de programar unos objetivos en los cuales esa no sea la principal encomienda para los discentes, ya que se pueden perseguir otros elementos mucho más productivos y sugerentes al margen de que, como es preciso recordar, no es la faceta más relevante en las franjas de la enseñanza obligatoria en torno a las cuales estamos elaborando estos planteamientos el hecho de buscar sincronías perfectas, sino que la ejecución final, más allá de su precisión y rigurosidad, ha de brillar por el modo en que se ha llevado a cabo todo el recorrido pedagógico, desde la búsqueda de archivos sonoros adecuados hasta el modo de insertarlos en el plano visual. Metafóricamente, Childs guiaba la práctica del docente de educación musical invitándole a permitir cierta holgura en el propio proceso que se desencadenaba:

${ }^{524}$ REYZABAL, M. V. (2002): Didáctica de los discursos persuasivos: la publicidad y la propaganda. Madrid: La Muralla, p. 185. 
"Controlar los sonidos es una tarea que no tiene fin. Un compositor de música para películas estará buscando continuamente sonidos interesantes para intensificar el dramatismo de la acción. A veces, el interés auditivo se logra combinando varios sonidos, de manera que provoquen en el que lo oye un efecto sorprendente. Escucha la forma en que el sonido se utiliza musicalmente en las películas. La música y los sonidos se utilizan ampliamente para influir sobre los estados de ánimo del espectador y enriquecer las imágenes visuales (son un elemento fundamental en las películas de dibujos animados, por ejemplo). Crea tus propias bandas sonoras dentro [de] una atmósfera estimulante. Apoya las experiencias creativas y mantén una relación evidente entre las imágenes auditivas y las visuales, sin salirte en ningún momento del ámbito de comprensión de los jóvenes" $" 525$.

Como tantas veces se ha postulado, es en los medios donde reside la importancia de los aprendizajes y no tanto en el fin último, de modo que en pedagogía musical, se acentúa más el modo de escuchar y lo que se extrae de ello que aquello que en sí se hace escuchar $^{526}$.

Entre las ventajas que quedarán al descubierto destaca la accesibilidad con que hoy en día se puede recurrir a estos materiales:

“en la WWW disponemos de infinidad de secuencias de vídeo y animaciones que podemos utilizar como material básico para trabajar temas vinculados con los audiovisuales y la sonorización de imágenes en movimiento. Aunque muchos de estos trabajos podrán ser también realizados por el alumnado, en ciertas ocasiones el profesor querrá crear sus propios materiales para ilustrar algunos de los conceptos trabajados en el aula"527.

\footnotetext{
${ }^{525}$ CHILDS, J. (2005): Op. cit., p. 17.

${ }^{526}$ En dichos términos se expresaba MANEVEAU, G. (1993): Op. cit., p. 270.

${ }^{527}$ GIRÁLDEZ, A. (2005): Internet y educación musical. Barcelona: Graó, pp. 133-134.
} 
Obviamente, en lo que a sonorización se refiere, entendemos al alumno como principal realizador de la actividad, pero mantenemos la segunda parte de la cita anterior, la que hace referencia a las creaciones por parte del docente, porque suponen un recurso más que es tratado transversalmente en diferentes apartados de esta investigación, desde la producción de vídeos didácticos hasta la de musicogramas en movimiento, a desarrollar en apartados sucesivos.

Además, siguiendo con la argumentación que nos enfatizaba las virtudes de estas prácticas escolares, es destacable como otro punto favorable la búsqueda por parte del alumnado de la simbiosis música-imagen. Al respecto de la reutilización de material sonoro aprovechando su potencial evocador, Matilde Olarte destaca (a través de un buen número de ejemplos) la capacidad de la música para conseguir efectos expresivos a través de su propio código:

“donde debiera haber un diálogo muy expresivo, encontramos una canción con la que el espectador se hace cargo inmediatamente de lo que pasa" ${ }^{, 528}$.

Este bagaje que se le supone a aquel que se acerca a una película no ha de ser menospreciado en el caso de las cintas que sirvan para la trabajar la música de cine en clave pedagógica. De hecho, una de las grandes virtudes del proceso es su carácter dialéctico, que enfatiza la interacción entre audiencia y producto audiovisual ${ }^{529}$.

Por otro lado, a partir de los recursos necesarios, surge de nuevo la controversia apuntada en el apartado anterior, dedicado a la extrapolación, y profusamente tratada desde la musicología que aborda el audiovisual: la pertinencia del uso de música preexistente para aderezar cualquier propuesta visual. Como ocurre en parte de la producción bibliográfica que vincula música y cine ${ }^{530}$, la legitimidad del uso de este

\footnotetext{
${ }^{528}$ OLARTE MARTÍNEZ, M. (2005b): "El género del musical y la utilización de sus melodías con fines expresivos". La música en los medios audiovisuales. Salamanca: Plaza Universitaria Ediciones, p. 110. Este aspecto es debido, según Lumet, a que la generación de clichés cinematográfico-musicales ha sido tal a lo largo del tiempo que en ciertas ocasiones los sonidos, por sí mismos, se bastan para mostrar situaciones más o menos intrincadas: LUMET, S. (1999): Así se hacen las películas. Madrid: Rialp, p. 178.

${ }^{529}$ MASTERMAN, L. (1993): Op. cit.

${ }^{530}$ Por ejemplo, cfr. STILWELL, R. J. (2002): "Music in Films: A Critical Review of Literature, 19801996". The Journal of Film Music I, pp. 19-61.
} 
tipo de composiciones, en nuestro caso trasladadas al ámbito pedagógico habrá de quedar fuera de duda. Sus potencialidades son tales que no contemplamos la posibilidad de denostarla a favor de la música incidental como única y genuinamente de matriz audiovisual. Entendiendo pues que las pretensiones como profesionales de la educación musical han de ser diferentes, no serán tan relevantes las cuestiones en torno a la propiedad o no del uso de música preexistente como su eficacia como resorte de aprendizajes múltiples, lo cual queda fuera de duda. Los elementos básicos a tener en cuenta dentro de este tipo de sonorización didáctica serán, por un lado organizativos y, por otro, metodológicos.

Entre los primeros hemos de tener en cuenta que, pese a los diferentes criterios de agrupamiento propios de la enseñanza en general, en este tipo de realizaciones tal vez sea muy conveniente la creación de grupos que trabajen en equipo y, si es necesario, se distribuyan diferentes roles dentro del colectivo. Para un caso específico de dramatización Álvarez-Nóvoa señalaba que:

“un jefe de sonido se encargará de la realización del proyecto, dirigiendo la grabación o instalando el sonido si la música se ofrece en directo; durante la representación manejará el equipo, con los ayudantes que precise" ${ }^{\text {"531. }}$.

Las tareas esenciales de este paso previo a la realización de la propia sonorización habrían de responder a unas cuestiones elementales, estrechamente ligadas a las que un compositor de música cinematográfica se haría ante un encargo concreto: ¿dónde ubicar música?, ¿cuál es su cantidad dependiendo del tiempo disponible?, ¿cómo habría de ser dicha música?, ¿por qué implementar música en un momento concreto? y ¿cuándo habrá de sonar según criterios estructurales del audiovisual? ${ }^{532}$

En lo referente a elementos metodológicos, que tocan directamente con la práctica de sonorización y su puesta en funcionamiento, es primeramente reseñable el establecimiento de vínculos entre lo que se presenta en imágenes y los sonidos que se le asocian de manera novedosa. Del testimonio de D. Lynch recogido por C. Rodley

531 ÁLVAREZ-NÓVOA, C. (1995): Dramatización. El teatro en el aula. Barcelona: Octaedro, p. 32.

${ }^{532}$ RADIGALES, J. (2008): Op. cit., p. 66. 
extraemos la importancia de no caer en aplicaciones sonoras poco apropiadas o aleatorias:

“...todo el mundo, hasta el más torpe, puede coger una canción y ponerla en una película. Lo que me parece genial es cuando la canción no es algo superpuesto. Tiene que tener determinados ingredientes que realmente se sumerjan dentro de la historia, hasta formar parte de ella. Puede ser de forma abstracta o de forma textual. Entonces es como si no pudieras vivir realmente sin ella. No puede ser un trozo de música sin más" ${ }^{333}$.

Dentro de este ámbito, el del elemento a sonorizar, es preciso señalar que para ser exitosa la aplicación didáctica ha de contemplar, desde nuestro punto de vista, alguno de estos tres supuestos:

- La parte visual se identifica de algún modo con la parte sonorizada, bien por relación ${ }^{534}$ bien por antítesis o negación ${ }^{535}$.

- La incorporación sonora sirve para evocar realidades similares o paralelas ${ }^{536}$.

- La música insertada guarda cierta sincronía (más acertada pues cuanto más estrecha) con el elemento visual ${ }^{537}$.

\footnotetext{
${ }^{533}$ RODLEY, C. (Ed.) (1998): David Lynch por David Lynch. Madrid: Alba Editorial, p. 211.

${ }^{534}$ Como en el ejemplo que presentan Barrio y Pérez, en el cual la intención de la música en la generación de un anuncio publicitario es la de apoyar el resto del discurso: BARRIO, M. y PÉREZ, P. (1997): "Desmitificar la publicidad: lectura crítica de los medios en el aula". Comunicar 9, pp. 130-133.

${ }^{535}$ En lo que Beltrán Moner identifica como "contrastes", Eisenstein denomina como una utilización burlesca, o Chion como anempatía: BELTRÁN MONER, R. (2005): Op. cit., p. 29; EISENSTEIN, S. M. (2001): Hacia una teoría del montaje, v. I. Barcelona: Paidós, p. 81; CHION, M. (1997): Op. cit., p. 233. ${ }^{536}$ No en la línea prácticamente impresionista en que Jean Mitry apuntó en su día, pero sí desde la sensación de analogía visual y musical que recorría su pensamiento cinematográfico: MITRY, J. (1978): Estética y psicología del cine. Madrid: Siglo XXI.

${ }^{537}$ Dentro del marco del IV Simposio "La Creación Musical en la Banda Sonora" (Salamanca, 2008), y tratando de validar estos tres supuestos, se presentaron ejemplos prácticos de cada una de estas tipologías, creados ex profeso o tomados de realizaciones televisivas o cinematográficas. En estos últimos casos, a pesar de la manipulación que la parte visual sufre para adaptarse a las contingencias musicales, son extremadamente gráficos como casos paradigmáticos para el supuesto a) el anuncio televisivo "Harmon Hall, la mejor manera de aprender inglés"; el cual superponía a imágenes de la rehabilitación en La Naranja Mecánica (Dir. Stanley Kubrick, 1976) una canción infantil para, "negando burlescamente", alcanzar el aprendizaje del inglés, para el supuesto b) "Huggies Be Happy", la cual sobre la base sonora silbada de la melodía "Don't worry be happy", popularizada por Bobby McFerrin (1988), unos bebés en pañales no se preocupaban por nada de lo que les acontecía, ya que iban debidamente protegidos; por último en el supuesto c) destacamos el montaje del programa de televisión "Sé lo que hicisteis" (LaSexta.
} 
En cualquier caso, son pocas y tímidas las aproximaciones a la sonorización didáctica en educación musical ${ }^{538}$ y nulas aquellas que, en nuestro contexto más inmediato, traten de apuntalar unos patrones de conducta mínimamente sistemáticos. En referencia al uso de música sinfónica descriptiva para su inclusión sobre elementos visuales, Alcalde de la Isla $^{539}$ reseña unos patrones para su inclusión, tales como la delimitación de los registros graves o agudos y la direccionalidad melódica en función de la existencia de sombras y luces, la inquietud a partir de la disonancia y la estabilidad desde la consonancia, la traslación de estados anímicos a partir del uso tonal o modal, el simbolismo en la aplicación instrumental, o la elaboración temática más o menos desarrollada. Por su parte, en forma de caso prototípico, Andrea Giráldez nos conduce a un ejemplo que nos sirve para recapitular algunas de las líneas fundamentales de este apartado:

"Supongamos que estamos trabajando sobre 'música y publicidad' y queremos demostrar el efecto que produce la utilización de distintas músicas sobre una misma secuencia de imágenes. El primer paso consistirá en seleccionar la secuencia de vídeo de un spot publicitario [...]. Podemos comenzar la búsqueda en un buscador como Altavista <es.altavista.com>, que dispone de una opción para localizar exclusivamente ficheros de vídeo y permite, además, seleccionar los formatos [...]. Una vez elegido el spot, debemos buscar distintos ejemplos musicales que puedan ser utilizados para reemplazar la música utilizada en la banda sonora original. Dichos ejemplos pueden grabarse en discos compactos o descargarse de Internet [...]. Finalmente, deberemos borrar la banda sonora original y reemplazarla, en distintos documentos, por la que hayamos seleccionado" $" 540$.

Disponible en <http://www.youtube.com/watch?v=HLAwUxcoEqc> [Consulta 9-II-10]) que mostraba imágenes de una canción del popular programa infantil Los Lunnis (concretamente de "Dame tu mano", José Llobell Oliver y Andrés Roselló Andreu) a las que se superponía la música del no menos popular "Chiki Chiki" (Barceló et als.) que representó a España en la cita de Eurovisión en 2008. El nivel de sincronía logrado es tal que sirve claramente para incitar al alumnado a buscar elementos de este tipo. ${ }^{538}$ TÉLLEZ, E. (1996): Op. cit.

539 ALCALDE DE LA ISLA, J. (2007): "Pautas para el estudio de los orígenes de la música cinematográfica". Aula Abierta 16, pp. 105-132.

${ }^{540}$ GIRÁLDEZ, A. (2007): Op. cit., p. 134. 


\section{Sonorización "en vivo"}

Entre las más sugerentes posibilidades de sonorización didáctica encontramos la adición directa o sonorización "en vivo". Como toda práctica que tiene como principal argumento su realización instantánea, en el momento justo y por tanto con pocas posibilidades de enmendar errores (salvo repeticiones y ensayos sucesivos), es común que los alumnos encuentren en ella alicientes suplementarios. Por si ellos no fueran suficientes, cabe la posibilidad de recordarles que un largo listado de destacados compositores en el pasado siglo o coquetearon o se dedicaron con entrega a los rudimentos de la sonorización ${ }^{541}$.

Comencemos por dejar constancia del caso más simple y generalizado de aplicación sonorizadora, especialmente sobre sonidos ideados para tal uso: el karaoke. Este tipo de recursos tienen sobrado su potencial, el cual se condensa del siguiente $\operatorname{modo}^{542}$ :

- Facilita la extroversión del alumnado con problemas de este tipo.

- Existen cantidades ingentes de recursos y canciones en formato MIDI para su uso en forma de karaoke, todas ellas accesibles en internet.

- Se puede trabajar cualquier tipo de repertorio que conecte con los intereses del alumnado.

- Se trata de un formato muy adecuado para iniciar el canto en grupo, el cual es un contenido prescriptivo dentro del currículo de educación musical.

- Posibilita el aprendizaje vivencial y activo.

Pasemos pues a otros elementos sonorizadores menos explorados y, tal vez, con potencialidades didácticas si cabe mayores. Básicamente, ya apuntamos con anterioridad dos tipos de adición de sonidos sobre un discurso visual dado. Por un lado, la eliminación de los sonidos (si los hubiere) del fragmento audiovisual para su cambio por otros a ejecutar "en directo" por los alumnos. Esta manera de proceder, la adición musical o sonora sustitutiva, es muy adecuada cuando el elemento musical inserto en el

${ }^{541}$ SEDEÑO VALDELLÓS, A. M. (2004b): "La música contemporánea en el cine”. Revista Historia y Comunicación Social 9, pp. 155-162.

${ }^{542}$ Resumen de las ideas al respecto de ZARAGOZÀ, J. L. (2009): Op. cit., p. 324. 
corte que se seleccionó para trabajar limita las posibilidades de una nueva sonorización de uno u otro modo. Por otro lado, puede suceder que esto no sea así, y que los sonidos que vienen acompañando a las imágenes puedan mantenerse en aras de una mayor efectividad del resultado final. En este último caso la sonorización se implementa sobre la banda de sonido preexistente, adecuándose a ella y haciendo que los objetivos trazados converjan en la observación de todos los elementos de este nuevo compendio audiovisual.

En todo caso, y aunque las posibilidades de inserción musical puedan ser inabarcables, sigue existiendo una matriz visual que hace que la nueva construcción sonora conserve una guía clara que informará acerca del modo en que debe llevarse a cabo la sonorización:

“...el film tiene un discurso propio, con sus tiempos, secciones, clímax, escenas culminantes, instantes de relajación y planteamientos estéticos. Asumiendo su propia trama, planteamos la posibilidad de realizar un discurso sonoro en paralelo al del film de forma sincrónica, que en caso de débito de la imagen, pueda sustentarse en gran medida per se. La consciencia de tamañas limitaciones es primordial para exigirnos una máxima atención, ya que, partiendo de la base de no ser nosotros los promotores de la idea inicial, de los cimientos estructurales y estéticos, tendremos que realizar nuestra propia edificación-sonora, rigiéndonos por el plan arquitectónico dado. Aceptando el compromiso, el resultado podrá ser brillante..."

De acuerdo con las premisas previas de actuación, seguirá siendo sumamente importante atender a una cuidada selección de materiales y a una clara representaciónestructuración del corte seleccionado. Lo primero, que como quedó expuesto corresponde en gran medida al docente, facilitará enormemente el trabajo posterior. Es necesario tener en cuenta que entre los factores que van a hacer considerar como indicado un fragmento destacan la simplicidad y evidente delimitación de las partes a sonorizar. Por otro lado, de estas premisas se deriva la posibilidad de estructurar de

${ }^{543}$ GALÁN BUENO, C. (2007): Op. cit., p. 31. 
manera diáfana, por medio de diagramas u otro tipo de representaciones, las partes de que consta el discurso y el modo de abordarlo. Por tanto, cuanto más evidente sea la estructura global más motivos habrá para aprehenderla y trabajar sobre ella ${ }^{544}$. En cierto modo, existen paralelismos entre estas representaciones y las pretensiones de "montaje horizontal" defendidas por Eisenstein cuando hablaba de la intención de conseguir que

“el movimiento de la música y el movimiento del ojo sobre las líneas de la composición gráfica coincidan"

Como es habitual en el planteamiento metodológico que nos hemos dado desde el principio de la investigación, mostramos pues un ejemplo de aplicación ya testado bajo los criterios de la adición sonora sustitutiva, en este caso sobre elementos de la película Shrek The Third ${ }^{546}$. Aprovechando el elemento significativo que resulta de los propios materiales a utilizar, es factible justificar ante el alumnado y ejemplificar el tipo de trabajo que se pretende llevar a cabo por medio de las secuencias de la propia película, entendiendo que tal vez sean más útiles unas imágenes (con sus sonidos, por supuesto) que mil palabras. De ahí que se pueda llevar al visionado del inicio de la película, en la cual se ilustra un rudimentario teatro de tramoya manual donde no sólo toma importancia la recreación del escenario sino también la adición sonora, que se lleva a cabo "en vivo" (es especialmente resaltable, por su traslación a los parámetros que desarrollaremos el ejemplo de los efectos del trote de caballo utilizando cocos huecos). Asimismo, dentro de la introducción al trabajo sonorizador, pueden ser presentadas muestras elaboradas y a disposición de los alumnos en internet, que dejan al descubierto

\footnotetext{
${ }^{544}$ Un caso paradigmático en el plano infantil es la utilización de la serie de animación Pocoyó, la cual presenta un número limitado de personajes y situaciones susceptibles de sonorizarse con básicos materiales de aula y "cotidiáfonos". Aunque todos los episodios muestran una fácil integración de procesos sonorizadores, destacamos por su evidente conexión con elementos musicales Pocoyo Dance (Dir. David Cantolla, 2005), disponible en 〈http://www.youtube.com/watch?v=bjhTA9mujEU> [Consulta 9-II-10]

545 EISENSTEIN, S. M. (2001): Op. cit, v. II, p. 178.

${ }^{546}$ Chris Miller, 2007. Las imágenes que dan pie al procedimiento en cuestión fueron debatidas y han sido objeto de perfeccionamiento a partir de su exposición en "Ticemur. III Jornadas Nacionales TIC y Educación", Lorca, 2008, a través de la comunicación presentada por nosotros con el título "La vertiente audiovisual de las TIC en educación musical. Usos metafóricos y efectivos de la Web 2.0".
} 
la posibilidad de conseguir resultados altamente interesantes dentro de la sonorización directa (así como con sonidos pregrabados) ${ }^{547}$.

Una vez estimulado el proceso, se selecciona un corte audiovisual. En este caso optamos por un vídeo promocional muy sugerente, en el cual se muestran tres bebés de ogro que bailan o se mueven al son de una música incidental ${ }^{548}$. Al pretender una sonorización "en vivo", esa música será suprimida. Con la intención de conjugar todos los parámetros descritos como necesarios para acceder correctamente al procedimiento de sonorización, la representación icónica que explicite a los alumnos el contenido visual será la siguiente:

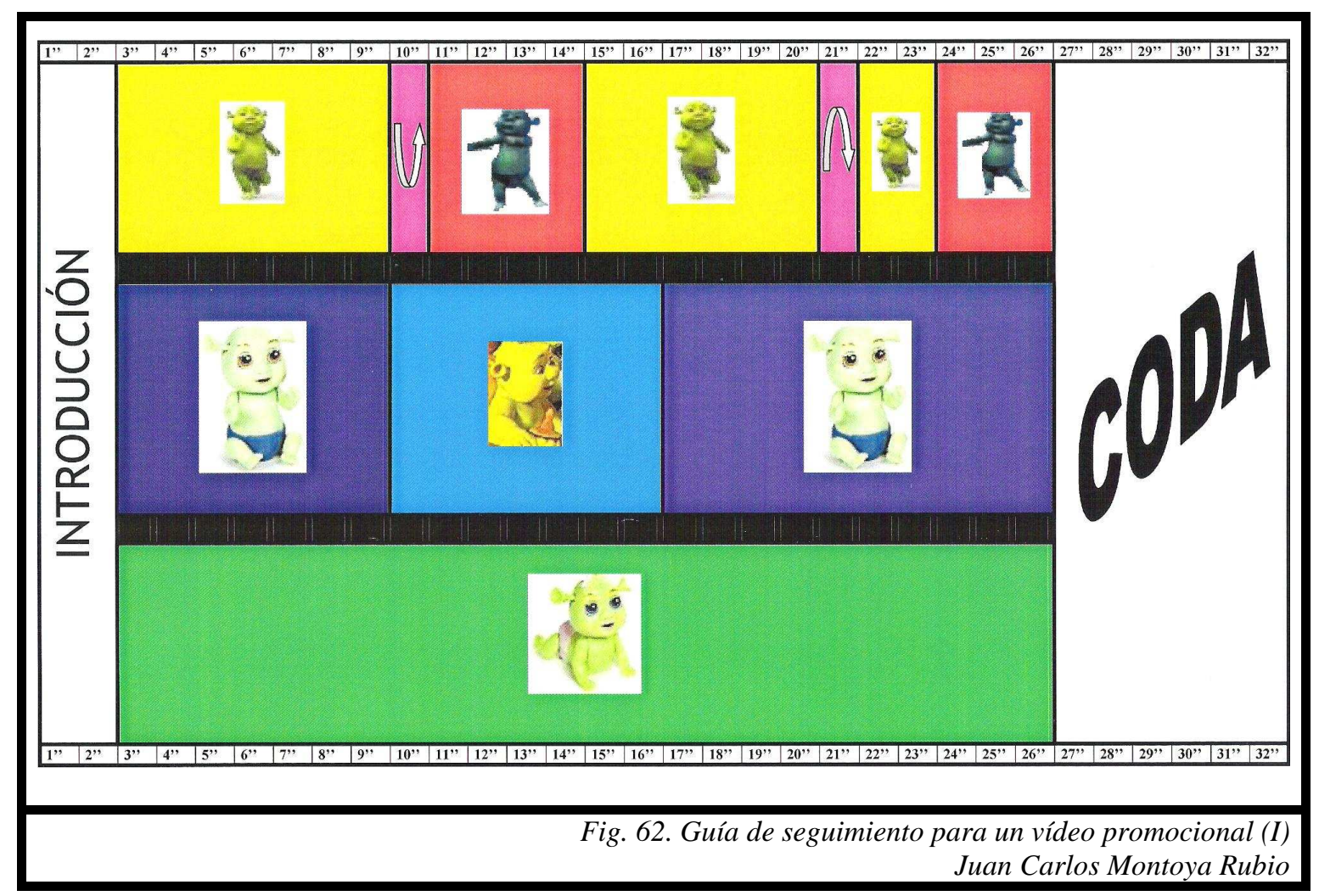

\footnotetext{
${ }^{547}$ En $<$ http://www.youtube.com/watch? $\mathrm{v}=\mathrm{K}-0 \mathrm{jhNawf10}>$ [Consulta 9-II-10] se muestra el inicio de la película de animación a la cual se le ha suprimido la canción que acompaña al ogro en su despertar y ducha por música y efectos creados para tratar de identificar los sonidos que se van produciendo con los generados artificialmente. El ejemplo es sumamente didáctico ya que describe de manera muy evidente lo que se pediría al alumnado.

$548<$ http://www.youtube.com/watch?v=D2UaKykgIT0> [Consulta 9-II-10]
} 
En los márgenes superior e inferior, se colocó la duración del vídeo, para facilitar el seguimiento y para poder, de este modo, observar intuitivamente cómo se van sucediendo los acontecimientos. Como puede verse, los dos primeros segundos del fragmento visual y los seis finales corresponden a momentos en los que no hay en imagen ninguna figura, sino que fueron reservados por los creadores de la promoción para incluir créditos o informaciones escritas. Por ello son rotulados como introducción y coda, trasladando términos musicales a este contexto.

Por lo demás, se incluyen tres franjas horizontales, que representan a los tres bebés que aparecen en el corte audiovisual. La parte superior es reservada para el bebé que figura en primer término de la imagen. Este pequeño ogro es el más activo, su principal movimiento es ilustrado con fondo amarillo mientras que el secundario, por cuanto aparece menos, con fondo rosa. En dos ocasiones, en los segundos diez y veintiuno, realiza unas acrobacias que quedan reflejadas por medio de flechas en uno u otro sentido según éstas estén orientadas. La parte central del mosaico creado se corresponde con la figura sedente que, durante la práctica totalidad del fragmento, bate palmas rítmicamente, cesando dicha percusión cuando, en dos ocasiones mueve el tronco y extiende los brazos. Todo ello queda reflejado, igualmente, en tiempo real y con diferentes tonalidades de azul. Por último, la franja inferior corresponde al tercer bebé, el que entra y sale gateando durante todo el transcurso. Recorre toda la pantalla de derecha a izquierda con un movimiento sistemático, por lo que su representación, sobre fondo verde, es la misma en todo momento. El resultado del razonamiento anterior permite observar, por ejemplo, las correspondencias entre unos y otros giros, qué hace cada bebé cuando el resto realiza movimientos, etc.

Optando por desembarazarnos, en principio, de introducción y coda, que no reflejan movimiento concreto alguno de figuras, comenzaríamos por la práctica segmentada con cada uno de los bebés que aparecen en la imagen. Así, cuando los alumnos han sido capaces de desentrañar las interioridades del elemento visual, están preparados para sustituir cada uno de esos bloques de colores por prácticas instrumentales concretas. En este sentido, el ejercicio propuesto es el que sigue: 


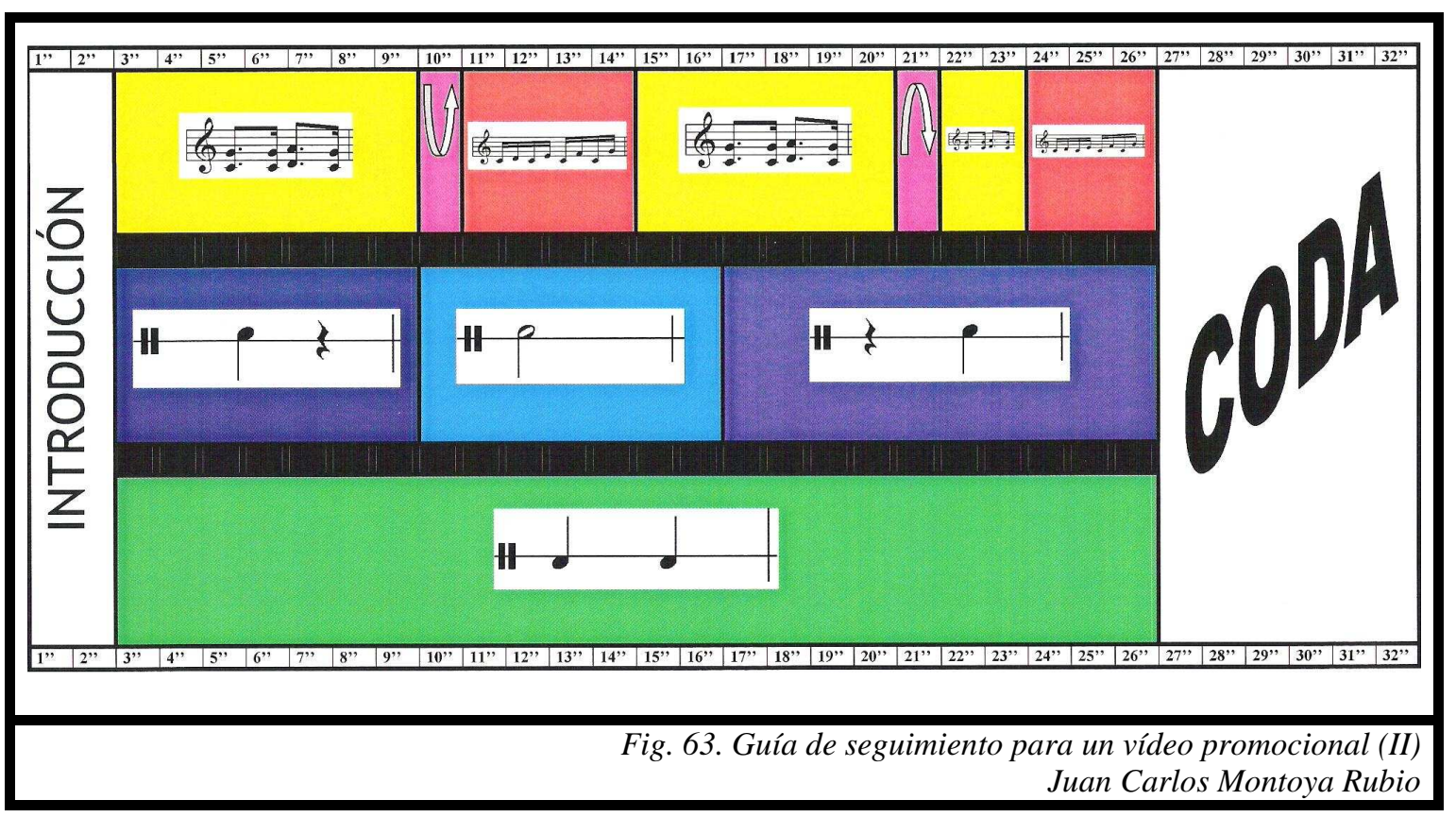

Analizados los movimientos del primer bebé, se estima conveniente utilizar para su sonorización instrumental del aula de percusión de altura determinada, en este caso xilófonos (no siendo especialmente relevante en este caso el tipo dentro de la familia). Los movimientos del baile principal tendrán adjudicado un ostinato concreto, con figuraciones que reflejen la vivacidad del mismo. El baile secundario, que aparece en dos ocasiones, será asociado a otro ostinato de semicorcheas. Por otro lado, las piruetas que ocupan dos breves espacios se marcarán con sendos glissandi, ascendentes o descendentes según indique la flecha. Respecto al segundo de los bebés parece adecuado, igualmente, reflejar las palmadas del inicio y final de su aparición (en el primer caso resultará una percusión a tiempo y en el segundo, sobre el tiempo débil de un compás binario). La parte central, en la cual el bebé ondea los brazos y el tronco, se reserva para realizar silbidos de dos tiempos de duración. Finalmente, con la intención de realizar un trabajo en el que todos puedan participar debido a la gradación de la dificultad que entraña, se marcarán con maracas los pasos del bebé que simplemente gatea, haciendo coincidir cada apoyo en el suelo con golpeos secos sobre el instrumento. El efecto es sumamente atractivo.

El ensayo disociado de cada una de las partes, por pequeños grupos, llevará al montaje final de la sonorización la cual, en este caso, se verá completada por pequeños ajustes para incluir algunos sonidos concretos en la introducción y la coda, resultando 
un ejercicio de aplicación práctica y efectiva de los parámetros teóricos expuestos ${ }^{549}$. El guión de la actividad mostraría todos los elementos por medio de notación convencional:

\section{Los bebés de Shrek}
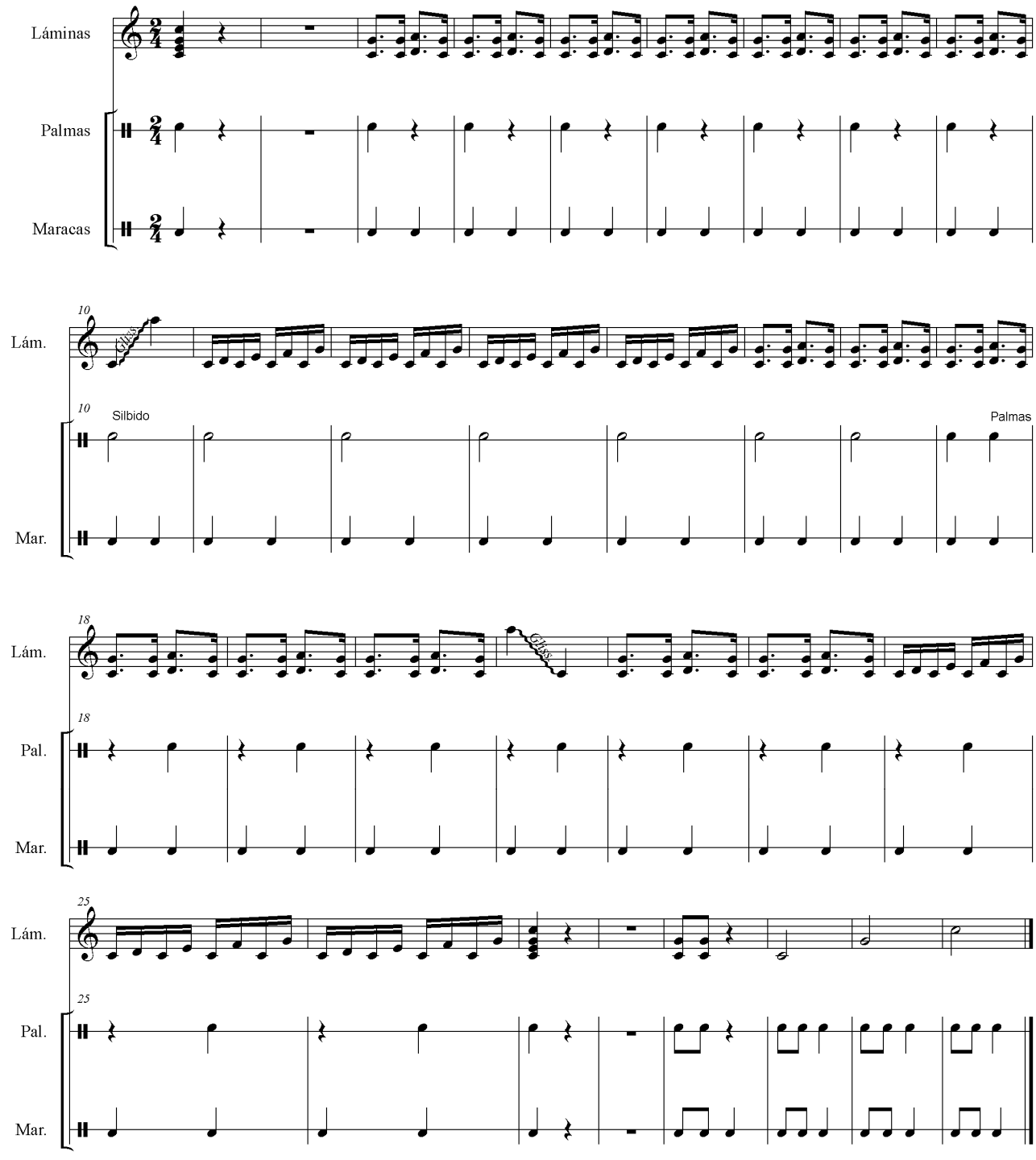

Fig. 64. Resultado global de la sonorización Juan Carlos Montoya Rubio

549 Extrapolando ideas de artículos como el de Javier Campos se pueden extraer algunos consejos prácticos para los ensayos, tales como la disposición de los participantes, la rotación instrumental, los descansos y otros muchos tal vez más alejados de nuestro objeto de estudio: CAMPOS, J. (2002): "Sistemas prácticos para la realización de ensayos en el aula de secundaria". Música y educación 52, pp. 75-98. 
Así, el resultado final es una partitura ajustada a un corte visual que fue seleccionado previamente. Las dimensiones de dicho fragmento eran breves, por lo que se permitía un abordaje directo sobre todo el discurso de manera global. Cuando la decisión sobre el vídeo a tratar nos aboca a una obra de mayores dimensiones, conviene realizar un proceso similar al anterior eso sí, realizando omisiones o fraccionándolo para hacerlo más accesible y lograr los objetivos deseados. Sirven como norma procedimiental en este tipo de casos las reflexiones de Beltrán Moner centradas en su caso en la ambientación musical:

"Cuando se visiona una obra en la que no se ha realizado un estudio previo del guión porque no lo haya habido, o haya sido innecesario, será de mucha utilidad tomar el mayor número posible de detalles referentes al sentido e intención de las secuencias, amén de su duración, para poder recordarlas perfectamente en la posterior elección de música o efectos" ${ }^{\text {} 550}$.

Aunque en nuestro caso no es relevante la grabación en sí sino el procedimiento a desarrollar, es muy útil obrar de manera meticulosa en cuanto a la detección de elementos susceptibles de sonorización. Es por tanto el caso del ejemplo planteado en torno al cortometraje de dibujos animados The Opry House ${ }^{551}$, del cual se redujo una parte que dejaba, sin embargo, un discurso autónomo al corte seleccionado de poco menos de tres minutos ${ }^{552}$.

\footnotetext{
${ }^{550}$ BELTRÁN MONER, R. (2005): Op. cit., p. 18.

${ }^{551}$ Walt Disney, 1929.

${ }^{552}$ El vídeo en cuestión, ya cortado, puede encontrarse en

<http://www.youtube.com/watch?v=o5zdHAspBAQ> [Consulta 9-II-10]. Por otro lado, la presentación de materiales a la que se alude (imágenes que se adjuntan) se pueden consultar en MONTOYA RUBIO, J. C. (2009d): Op. cit., pp. 723-728. Tras las imágenes, en la presente investigación nos centramos en los principios metodológicos y de agrupamiento, no desarrollados con profusión en la reseña anterior.
} 


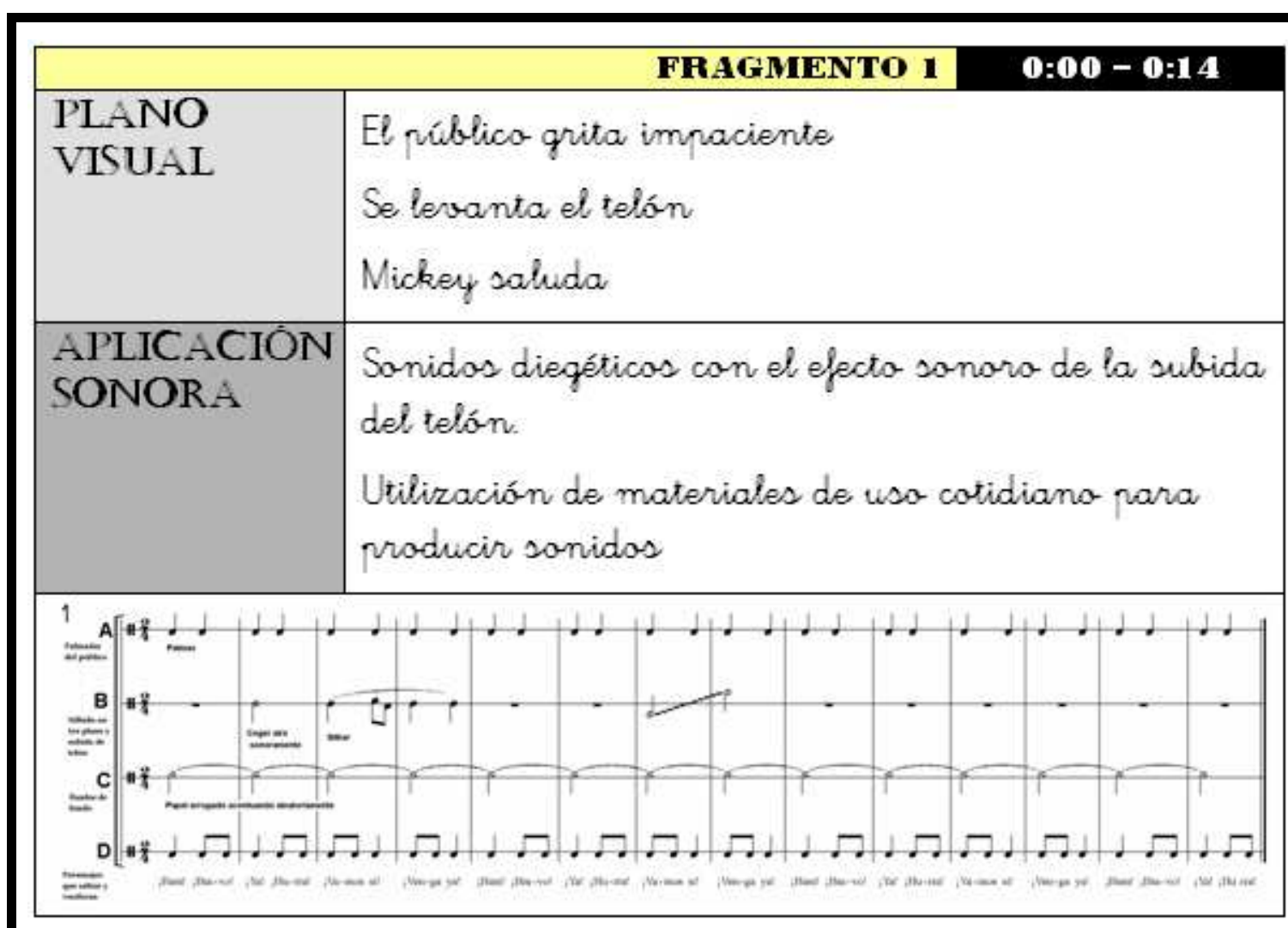

Fig 65. Sonorización para un fragmento de "The Opry House" (I) Juan Carlos Montoya Rubio

\begin{tabular}{|c|c|}
\hline & FRAGMENTO 2 \\
\hline $\begin{array}{l}\text { PLANO } \\
\text { VISUAL }\end{array}$ & Mickery se prepara \\
\hline $\begin{array}{l}\text { APLICACIÖN } \\
\text { SONORA }\end{array}$ & $\begin{array}{l}\text { Se resaltan los efectos de arrastre del piano, atuse } \\
\text { del pelo y movimientos de la cabeza }\end{array}$ \\
\hline 2 B 2 & $\left.\right|_{p}$ \\
\hline
\end{tabular}

Fig. 66. Sonorización para un fragmento de "The Opry House" (II) Juan Carlos Montoya Rubio 


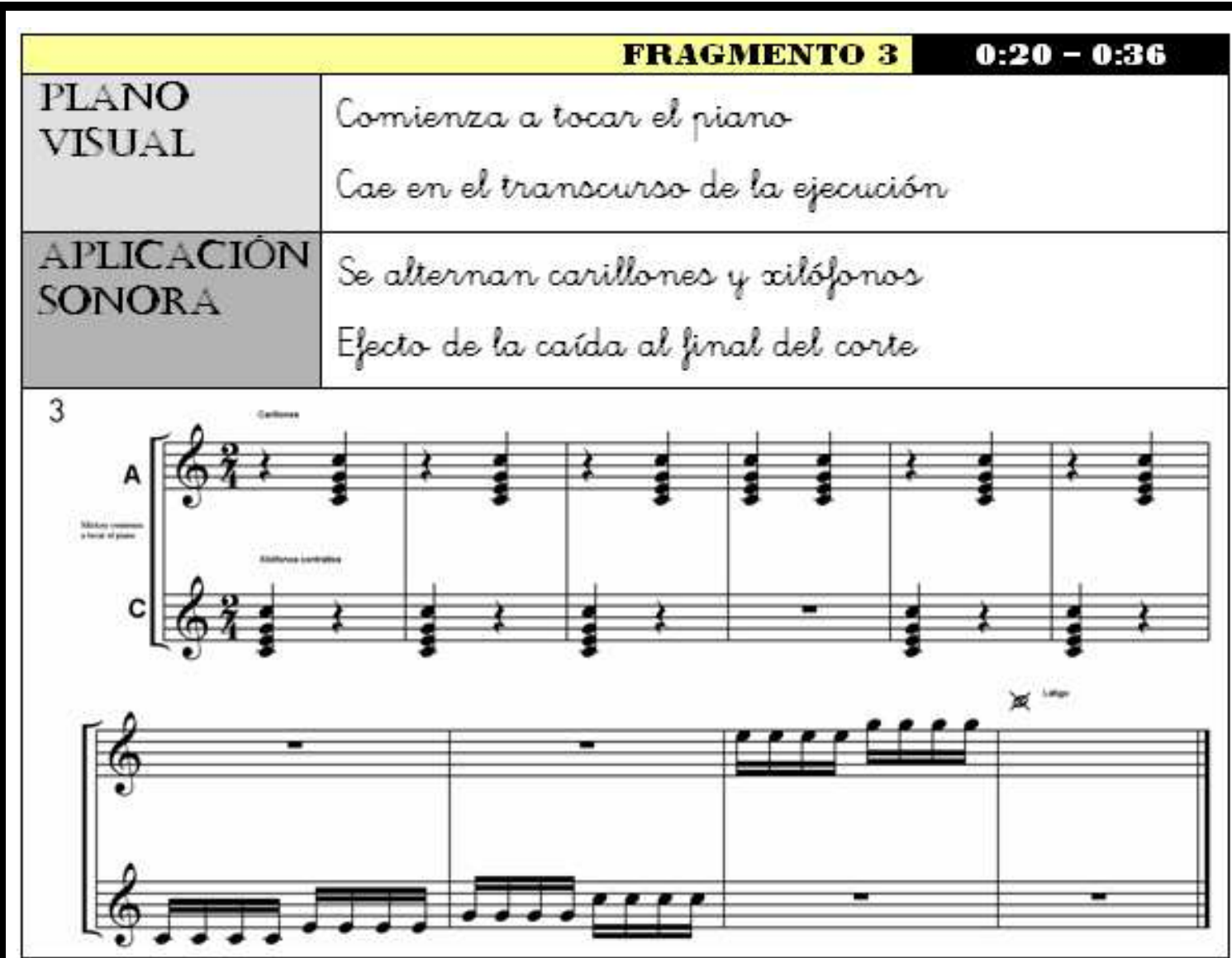

Fig. 67. Sonorización para un fragmento de "The Opry House" (III) Juan Carlos Montoya Rubio

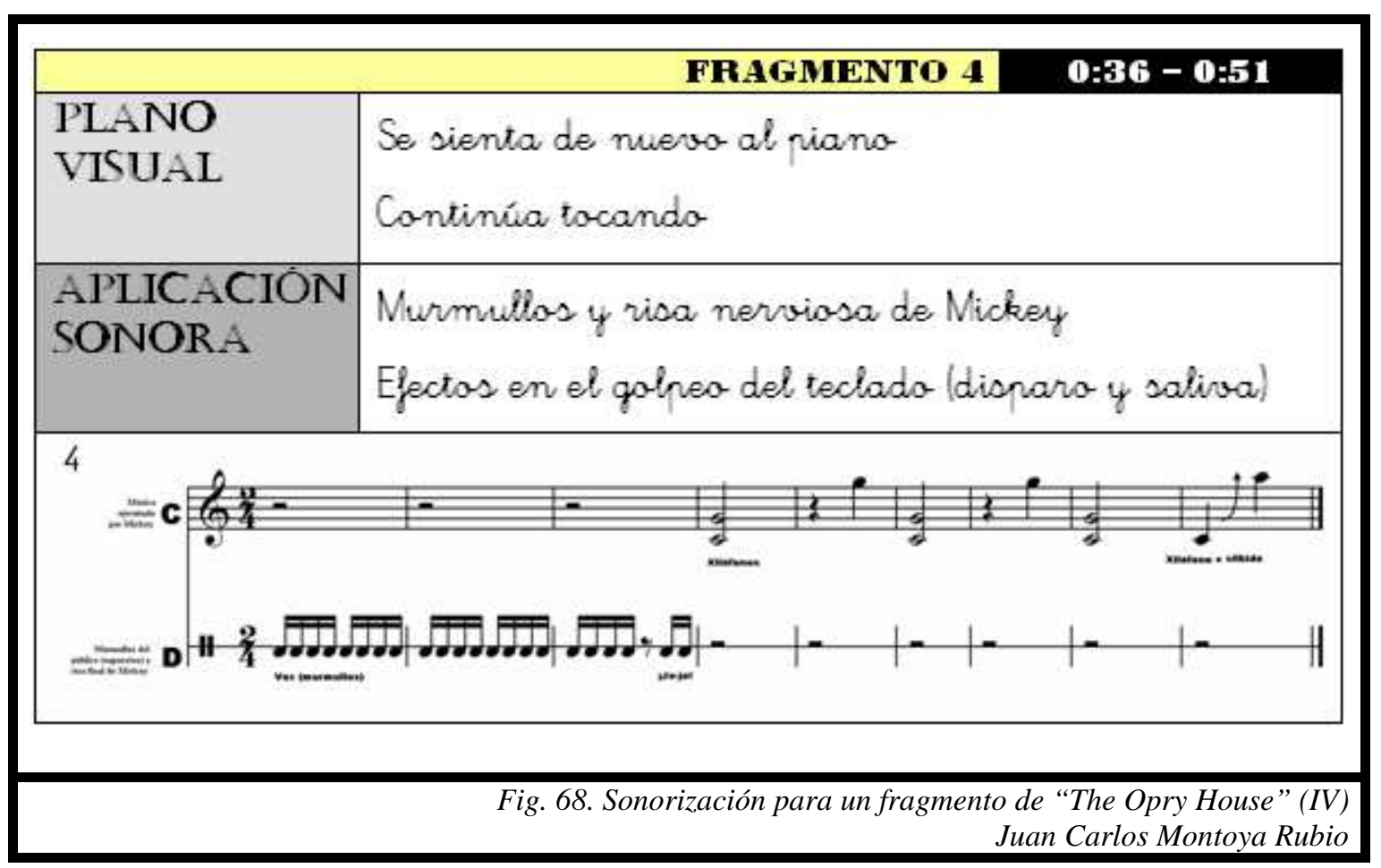




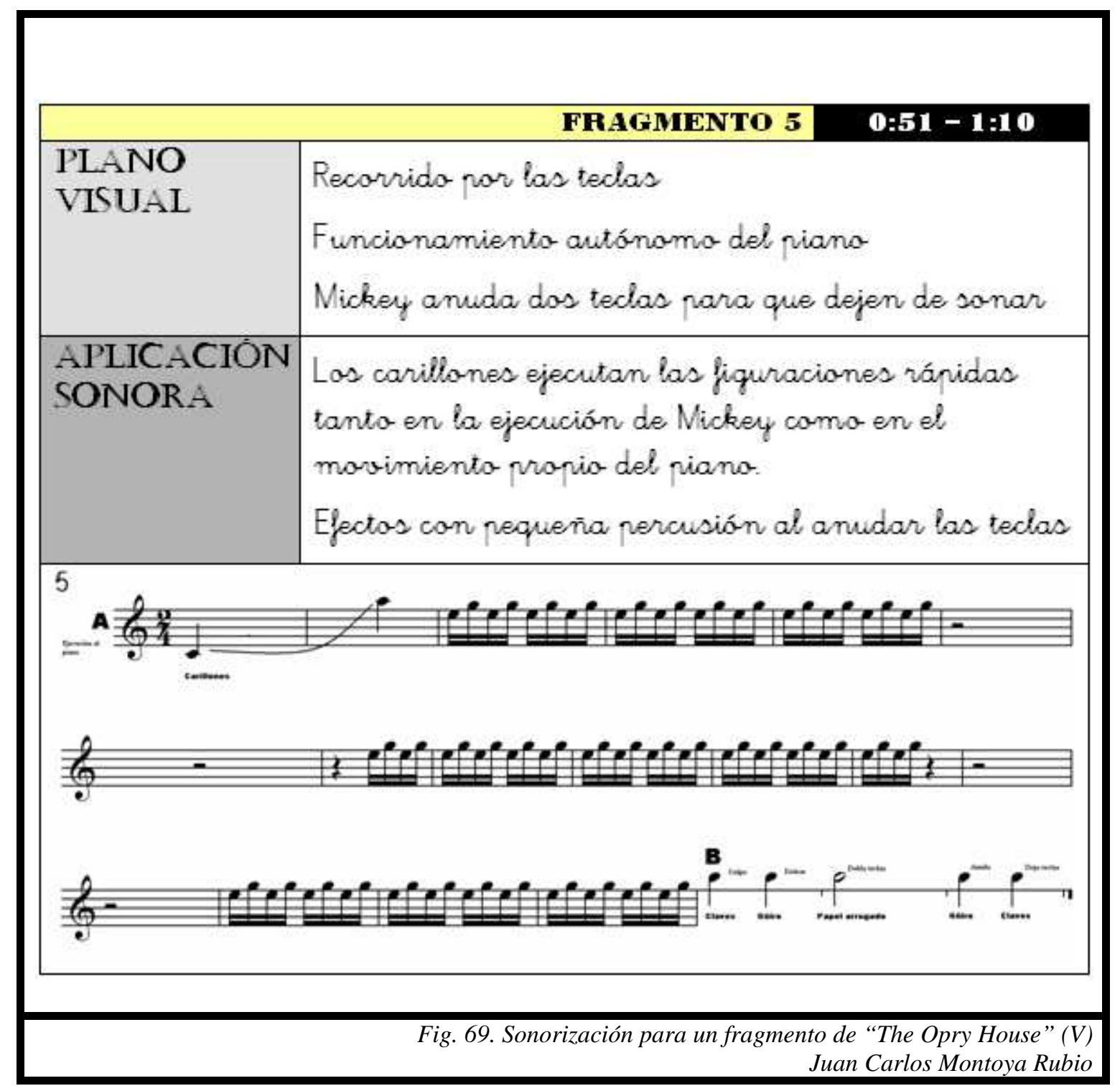




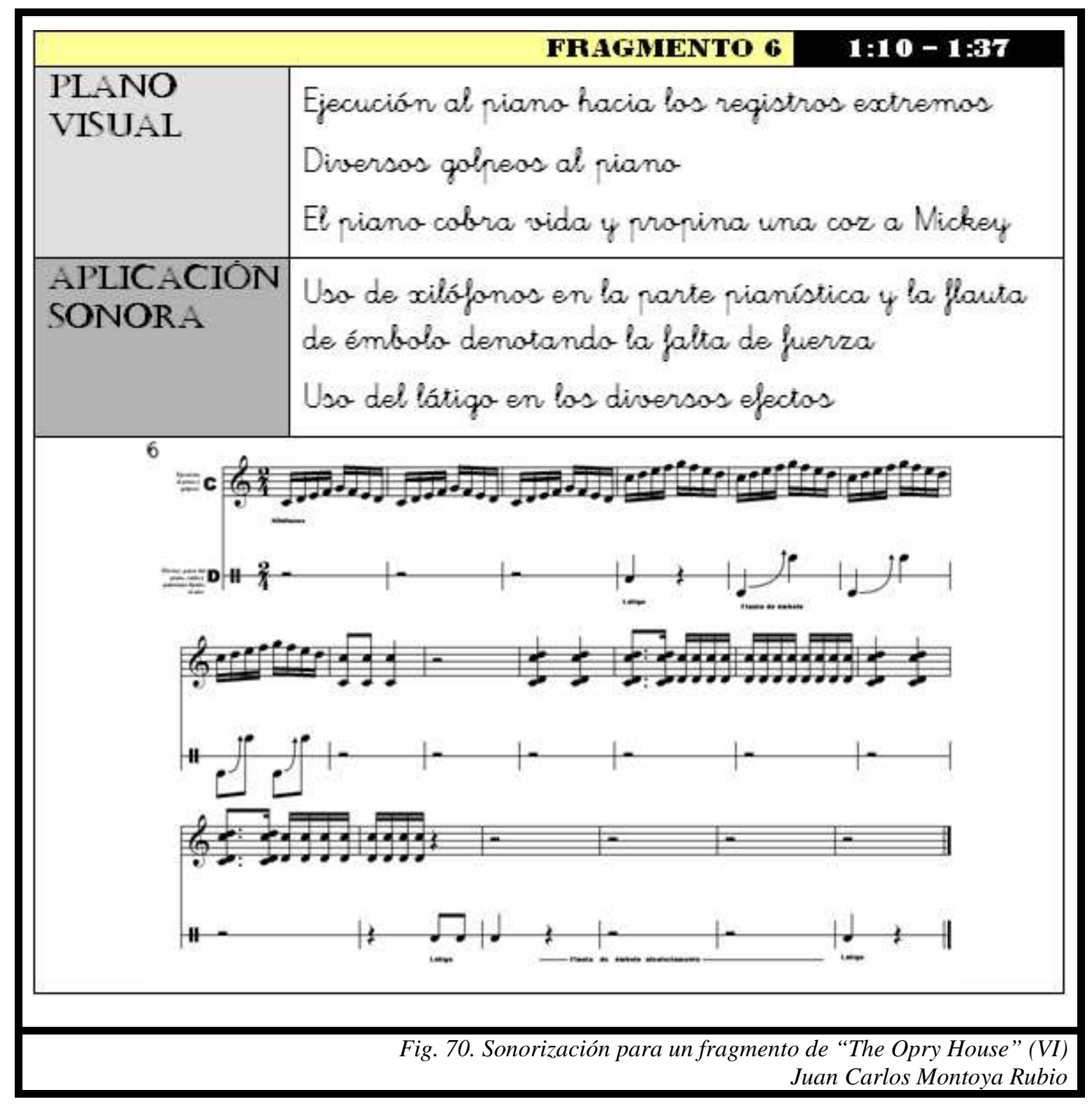




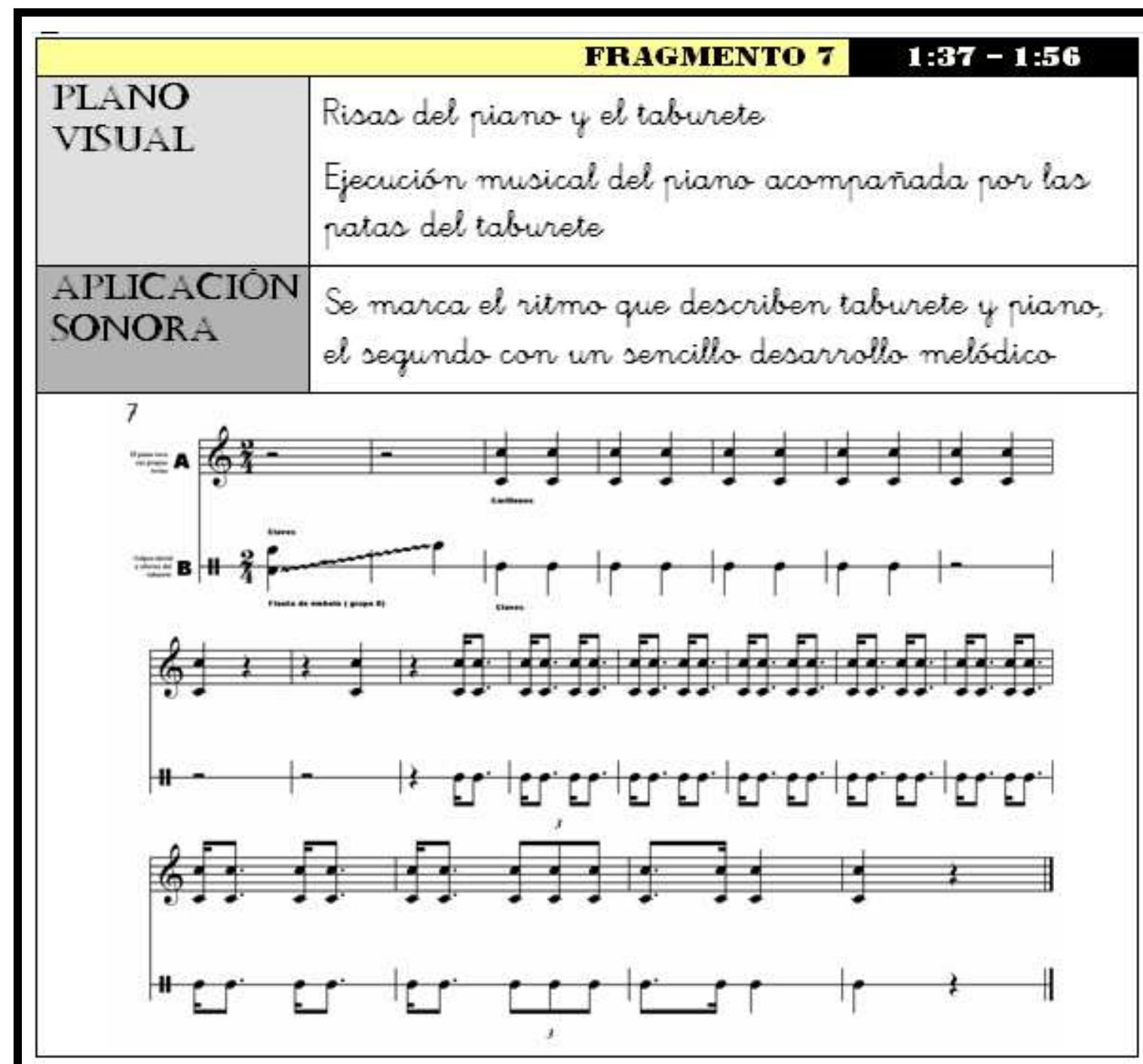

Fig. 71. Sonorización para un fragmento de "The Opry House" (VII) Juan Carlos Montoya Rubio 


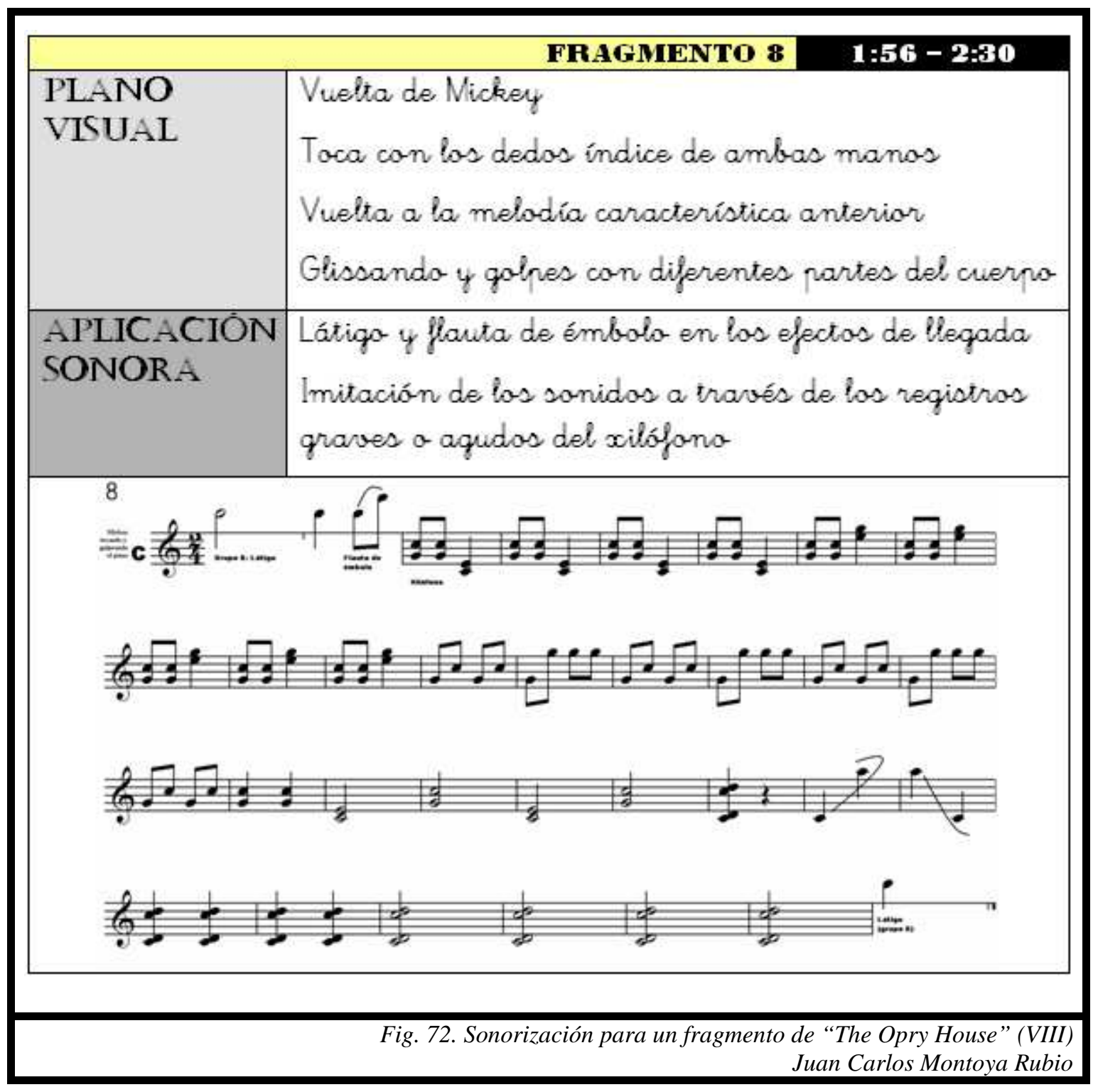




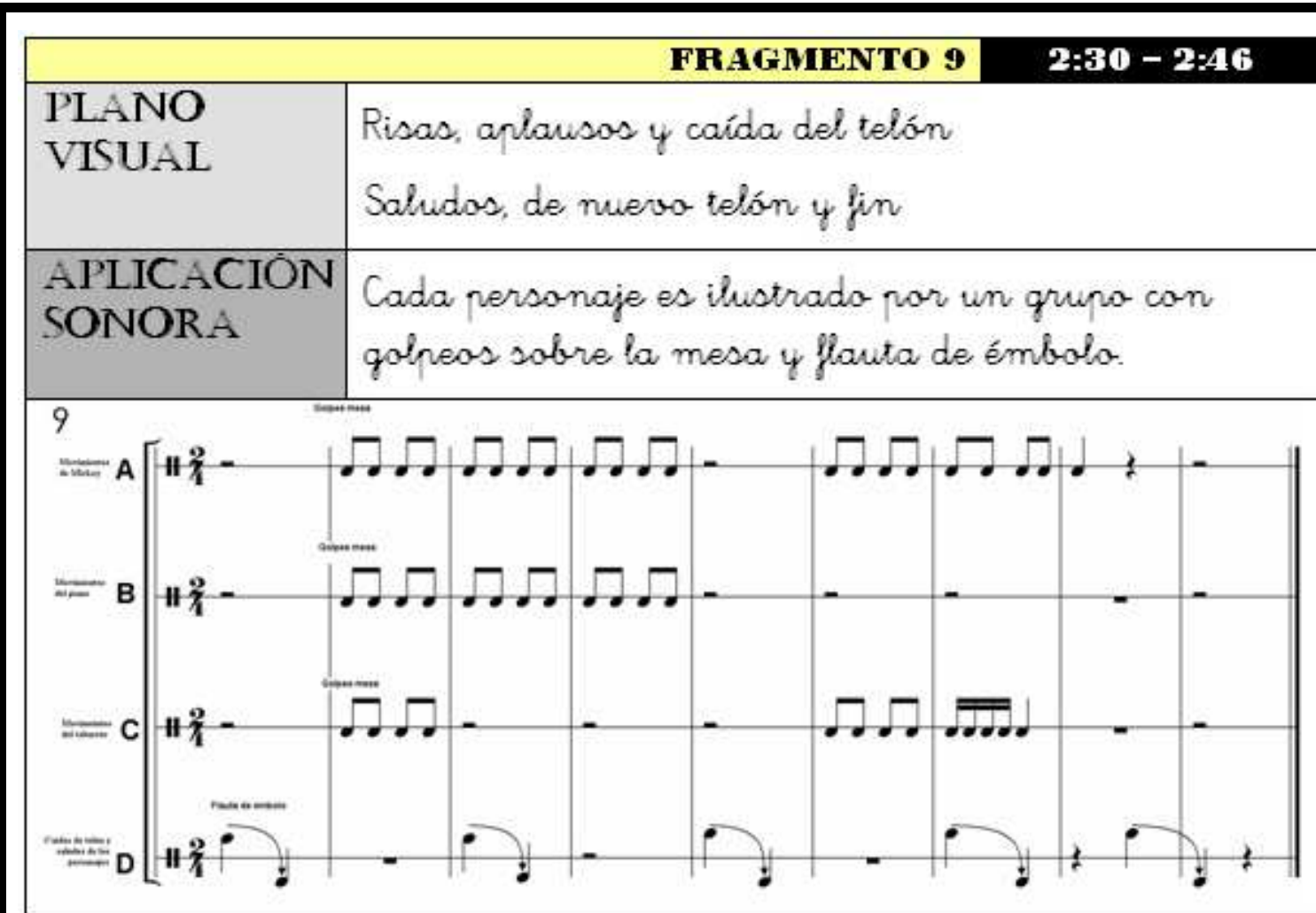

Fig. 73. Sonorización para un fragmento de "The Opry House" (IX) Juan Carlos Montoya Rubio

Como se aprecia, el ejemplo trata de dar respuesta a un mayor número de complejidades. En principio quedan delimitados con mayor nitidez los puntos de adición musical. Siguiendo a Candel en referencia a los dibujos animados:

“...en la sonorización de una película debemos distinguir entre los diálogos, la música y los efectos. Estos tres elementos deben sincronizarse con las imágenes" $" 553$.

${ }^{553}$ CANDEL, J. M. (2005): Arte y técnica de los dibujos animados. Murcia: Consejería de Educación y Cultura, p. 209. En todo caso, son ideas que aparecen con profusión en las teorías que conjugan la implementación de la música a lo visual, por ejemplo en GRIZYK, A. (1984): Le rôle du sons dans le récit cinématographique. París: Minard. Asimismo, estas pautas son retomadas para los sucintos apuntes didácticos que en torno a la sonorización han sido publicados, como es el caso de TÉLLEZ, E. (1996): Op. cit., p. 50. 
Ahí encontramos pues uno de los objetivos planteados al inicio: acceder de manera más precisa a todo aquello que forma el complejo sonoro que enmarca y condiciona al visual $^{554}$. Por otro lado, frente a los tres grupos en que dividíamos el ejemplo anterior, debido a su mayor complejidad, se optó por trabajar con cuatro, los cuales tendrían una misión claramente diferenciada. La principal pretensión es la de conseguir que todos los alumnos sientan que pueden participar (gradando por tanto la dificultad de las aplicaciones a realizar en los cuatro grupos) al tiempo que se permitiera que cada uno de los equipos tuviera tiempo para preparar su entrada (alternando unos y otros según el nivel de participación). A partir de dichos parámetros, se establecería que los equipos "A" y "C" se encargarían, entre otras cosas, de los instrumentos de láminas (por tanto con un mayor grado de complejidad), el equipo "B" esencialmente de la pequeña percusión y el equipo " $\mathrm{D}$ " participaría fundamentalmente con sonidos corporales (voces y percusiones), lo cual facilitaría mucho la labor de este grupo de niños. Además, entre las premisas metodológicas se observa la participación activa de todos tanto en el primer como en el último bloque, así como el uso de instrumentos sugerentes y efectistas como la flauta de émbolo en el último de los equipos para compensar su falta de actividad en otros momentos. Un ejemplo de guión para llevar a cabo este tipo de ejercicios podría resultar como sigue, contemplando en los nueve fragmentos la tarea a sonorizar por cada uno de ellos en función de lo que se muestra en pantalla ${ }^{555}$ :

\footnotetext{
${ }^{554}$ ZUNZUNEGUI, S. (1995): Pensar la imagen. Madrid: Cátedra.

${ }^{555} \mathrm{Al}$ tratarse de una obra seccionada y de poca duración, es pertinente un análisis de este tipo. Al abordar obras de mayor entidad el análisis habrá de ser menos profundo para facilitar la tarea del alumnado. En todo caso, este último tipo de análisis menos riguroso dejará ciertos espacios abiertos a la improvisación. Algunos apuntes sobre el llamado "análisis cronológico" en LÓPEZ HERNÁNDEZ, Á. (2003): "El análisis cronológico-secuencial del documento fílmico". Documentación de las Ciencias de la Información 26, pp. 261-294.
} 


\begin{tabular}{|c|c|c|c|c|}
\hline BLOQUE 1 & EQUIPO A & EQUIPO B & EQUIPO C & EQUIPO D \\
\hline IMÁGENES & $\begin{array}{l}\text { Palmadas del } \\
\text { público }\end{array}$ & $\begin{array}{l}\text { Silbido y subida } \\
\text { de telón }\end{array}$ & Ruidos de fondo & $\begin{array}{l}\text { Personajes que } \\
\text { saltan y gritan }\end{array}$ \\
\hline $\begin{array}{l}\text { EFECTO } \\
\text { SONORO }\end{array}$ & Palmas & $\begin{array}{l}\text { Coger aire y } \\
\text { silbar }\end{array}$ & $\begin{array}{l}\text { Papel arrugado } \\
\text { aleatoriamente }\end{array}$ & Voces \\
\hline BLOQUE 2 & EQUIPO A & EQUIPO B & EQUIPO C & EQUIPO D \\
\hline IMÁGENES & & $\begin{array}{l}\text { Movimientos de } \\
\text { Mickey }\end{array}$ & & \\
\hline $\begin{array}{l}\text { EFECTO } \\
\text { SONORO }\end{array}$ & & $\begin{array}{l}\text { Güiro, maraca y } \\
\text { pandereta. }\end{array}$ & & \\
\hline BLOQUE 3 & EQUIPO A & EQUIPO B & EQUIPO C & EQUIPO D \\
\hline IMÁGENES & $\begin{array}{l}\text { Comienza } \\
\text { tocar el piano }\end{array}$ & Caída final & $\begin{array}{l}\text { Comienza } \\
\text { tocar el piano }\end{array}$ & \\
\hline $\begin{array}{l}\text { EFECTO } \\
\text { SONORO }\end{array}$ & Carillones & Golpe de látigo & Xilófonos & \\
\hline BLOQUE 4 & EQUIPO A & EQUIPO B & EQUIPO C & EQUIPO D \\
\hline IMÁGENES & & Efecto final & Música al piano & $\begin{array}{l}\text { Murmullos del } \\
\text { público y risa }\end{array}$ \\
\hline $\begin{array}{l}\text { EFECTO } \\
\text { SONORO }\end{array}$ & & Silbido final & Xilófonos & Voces \\
\hline BLOQUE 5 & EQUIPO A & EQUIPO B & EQUIPO C & EQUIPO D \\
\hline IMÁGENES & $\begin{array}{l}\text { Ejecución al } \\
\text { piano }\end{array}$ & $\begin{array}{l}\text { Golpes a las } \\
\text { teclas del piano }\end{array}$ & & \\
\hline $\begin{array}{l}\text { EFECTO } \\
\text { SONORO }\end{array}$ & Carillones & $\begin{array}{l}\text { Claves, güiro y } \\
\text { papel arrugado }\end{array}$ & & \\
\hline BLOQUE 6 & EQUIPO A & EQUIPO B & EQUIPO C & EQUIPO D \\
\hline IMÁGENES & & & $\begin{array}{l}\text { Ejecución al } \\
\text { piano y golpes }\end{array}$ & $\begin{array}{l}\text { Movimientos del } \\
\text { piano }\end{array}$ \\
\hline $\begin{array}{l}\text { EFECTO } \\
\text { SONORO }\end{array}$ & & & Xilófonos & $\begin{array}{l}\text { Látigo y flauta } \\
\text { de émbolo }\end{array}$ \\
\hline BLOQUE 7 & EQUIPO A & EQUIPO B & EQUIPO C & EQUIPO D \\
\hline IMÁGENES & $\begin{array}{l}\text { "Autosonidos" } \\
\text { del piano }\end{array}$ & $\begin{array}{l}\text { Golpeo inicial y } \\
\text { taburete }\end{array}$ & & Golpeo inicial \\
\hline $\begin{array}{l}\text { EFECTO } \\
\text { SONORO }\end{array}$ & Carillones & Claves & & $\begin{array}{l}\text { Flauta } \\
\text { émbolo }\end{array}$ \\
\hline BLOQUE 8 & EQUIPO A & EQUIPO B & EQUIPO C & EQUIPO D \\
\hline IMÁGENES & & Caída y subida & Mickey al piano & \\
\hline $\begin{array}{l}\text { EFECTO } \\
\text { SONORO }\end{array}$ & & $\begin{array}{l}\text { Látigo y flauta } \\
\text { de émbolo }\end{array}$ & Xilófonos & \\
\hline BLOQUE 9 & EQUIPO A & EQUIPO B & EQUIPO C & EQUIPO D \\
\hline IMÁGENES & $\begin{array}{l}\text { Movimientos de } \\
\text { Mickey }\end{array}$ & $\begin{array}{l}\text { Movimientos del } \\
\text { piano }\end{array}$ & $\begin{array}{l}\text { Movimientos del } \\
\text { taburete }\end{array}$ & Telón y saludos \\
\hline $\begin{array}{l}\text { EFECTO } \\
\text { SONORO }\end{array}$ & Golpes en mesa & Golpes en mesa & Golpes en mesa & $\begin{array}{l}\text { Flauta } \\
\text { émbolo }\end{array}$ \\
\hline
\end{tabular}


Algunos elementos a tener en cuenta, al margen de los reseñados, son:

- Bloque 1. Se trata de que todos los sonidos que aparecen en imagen tengan algún reflejo de inicio.

- Bloque 2. Con escasa participación sonorizadora puede servir para que, mientras tan sólo tres alumnos se ocupan de su ejecución, el resto prepare próximas entradas.

- Bloque 3. Con tiempo suficiente para su preparación, los equipos encargados de la práctica melódica y armónica comienzan su discurso, cortado finalmente por el golpe del látigo como efecto a la caída.

- Bloque 4. Se conjugan pequeños golpeos al piano con efectos, preparando la entrada de los carillones, los cuales pueden estar listos para el siguiente bloque.

- Bloque 5. El monólogo al piano (carillón) es susceptible de incluir todos los matices que se estimen oportunos. Por otro lado, el equipo encargado de la pequeña percusión remata el fragmento y prepara con tiempo su reaparición en el bloque séptimo.

- Bloque 6. La aplicación melódica busca establecer paralelismos entre el discurrir de los dedos de Mickey por el teclado y las escalas ascendentes y descendentes que se proponen. Además, los golpeos con los puños quedan establecidos a partir de notas disonantes, que hagan de los mismos algo más desagradables.

- Bloque 7. La precisión en este apartado vendrá dada por las propias imágenes. Tanto la parte de claves como la melódico-armónica habrán de ceñirse, no tanto a la notación convencional, con posibles ligeros desajustes, como a la estructura visual.

- Bloque 8. De nuevo, aprovechando el descanso anterior, ahora ejecutan los xilófonos y pequeños apuntes del equipo "B".

- Bloque 9. La aparición de todos realizando efectos sobre la mesa (y el añadido del telón con las flautas de émbolo) sirve para enfatizar la labor de equipo que se ha realizado. 
Como indicamos, la generación de los cuatro grupos respondía a criterios de operatividad (que los alumnos tuvieran tiempo suficiente para organizar, en vivo, todo el proceso). Otra posibilidad es la que estructura esos equipos en función del tipo de sonidos que cada uno de ellos incluye en el discurso general. Salvando las obvias distancias, guarda una estrecha relación con la manera en que Beltrán Moner presenta un ejemplo de sonorización en la que se distingue sonido original, locución y traducción, música y efectos ${ }^{556}$ :

\begin{tabular}{|c|c|c|c|c|}
\hline \multicolumn{2}{|l|}{ "Pueblos del Mundo" } & NDIA & (ROLLO 1) & $26^{\prime} 30$ \\
\hline IMAGEN & $\begin{array}{l}\text { BANDA I } \\
\text { SON. ORIGINAL }\end{array}$ & $\begin{array}{l}\text { BANDA II } \\
\text { LOC. Y } \\
\text { TRADUCCIÓN }\end{array}$ & $\begin{array}{l}\text { BANDA III } \\
\text { MÚSICA }\end{array}$ & $\begin{array}{l}\text { BANDA IV } \\
\text { EFECTOS }\end{array}$ \\
\hline SEC.CABECERA & & & & \\
\hline PL. SANTÓN CONGE & AMB. POZO & & & \\
\hline LADO & SANTÓN CANTA & & & \\
\hline & CRIQUET & & & \\
\hline & RAPADO & & & \\
\hline & MARAHA CIUDAD & & & \\
\hline & HILANDERA, & & & \\
\hline & FABRICA Y & & & \\
\hline & SANTÓN & & & \\
\hline & & & & \\
\hline SEC. CARAS CON & & LOCUTOR & M 1 PINTURA & \\
\hline PINTURAS & & & & \\
\hline & & $\downarrow$ & $\downarrow$ & \\
\hline \multicolumn{5}{|l|}{ SEC. POBREZA } \\
\hline & & & & \\
\hline ENTREVISTA LUIS & ENT. OR. & TRAD. & & \\
\hline PL. CUBREN ENT. & & & & ARROZAL \\
\hline & $\gamma$ & $\downarrow$ & & $\checkmark$ GENTE CALLE \\
\hline SEC. DIOSES & MÚSICA ORIG. & LOC. & & \\
\hline MARIONETAS & & & & \\
\hline & $\downarrow$ & $\gamma$ & & \\
\hline SEC. RIO GANGES & & LOC. & M 2 GANGES & CHORRITO \\
\hline & & & ABRE & $\searrow \quad$ AGUA \\
\hline ENTRADILLA LUIS & SON. ORIG. & 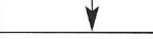 & & \\
\hline EN BARCA & $\downarrow$ & & & \\
\hline ... & & & & \\
\hline SEC. PIRA FUNERARIA & & LOC. & & EFEC. BUITRES \\
\hline & & & & \\
\hline & & & & CREPITAR FUEGO \\
\hline & & & & BUITRES \\
\hline & & & & FUEGO \\
\hline & EFEC. ALETEO & $\forall$ & & LADRIDOS \\
\hline & BUITRES & & & LADRIDOS \\
\hline SEC. NIÑOS MUERT. & $\downarrow$ & LOC. & & \\
\hline POR EL RÍO & & $\downarrow$ & $\downarrow$ & \\
\hline SEC. BODA EN GANGES & MÚSICA ORIG. & LOC. & FUNDE & \\
\hline & $\eta$ & $\downarrow$ & & \\
\hline LAVAN EN GANGES & FUNDE & LOC. & M3 & AMB. LAVANDO \\
\hline & & $\downarrow$ & $\downarrow$ & EN GANGES \\
\hline TEMPLO DE ORO & & & & \\
\hline
\end{tabular}


Por su parte, extrapolar técnicas derivadas de la audición activa para elaborar un esquema propio de actuación, en función del audiovisual concreto, también puede ser acertado. Así, podemos servirnos para estructurar fragmentos visuales a partir de consideraciones como los temas musicales, la duración o tiempo aproximado de su aparición, los compases que abarcan, el número de compases que representan dentro de la obra y la práctica procedimental a llevar a cabo sobre ello ${ }^{557}$.

En cualquier caso, también es posible el camino inverso: realizar un discurso sonoro "estándar" que pueda sugerir determinadas situaciones y buscarle acomodo en imágenes. Aunque el procedimiento plantee dificultades evidentes de aplicación su pertinencia, dentro del marco en que estamos trabajando, queda fuera de duda. Esta es la estrategia seguida por Molas y Herrera ${ }^{558}$ en su composición para el aula "Sintonía", cuyo desarrollo puede ser llevado a cabo por medio de una sonorización similar a la expuesta en las líneas precedentes. En contra de la especificidad de las sintonías que habrían de adecuarse a un producto determinado ${ }^{559}$, las pretensiones de la misma quedan expuestas claramente por los autores:

"es una pieza de corta duración en la que se ha buscado crear un ambiente musical que bien podría servir como cabecera de cualquier programa de radio o televisión"

En el inicio de la obra, se aprecian ya algunas de las características elementales de su desarrollo, tales como el uso de instrumental específico por parte del alumnado (básicamente flautas, xilófonos y pequeña percusión de altura indeterminada), la formulación rítmica adecuada a niveles a partir del tercer ciclo de educación primaria

\footnotetext{
${ }^{557}$ Esa es la estructura utilizada en la audición activa para posterior aplicación de ejercicios de movimiento realizada por BLASER, A., FROSETH, J. D. y WEIKART, P. (2001): Música y movimiento. Actividades rítmicas en el aula. Barcelona: Graó, pp. 59-83. Como puede comprobarse, el ejemplo descrito con detenimiento anteriormente bebe en cierto modo de la unión de fuentes cinematográficastelevisivas como la mostrada por Beltrán Moner y pedagógico-musicales como ésta.

${ }^{558}$ MOLAS, S. y HERRERA, Ll. M. (2000): Música de hoy para la escuela de hoy. Repertorio instrumental con propuestas didácticas. Barcelona: Graó.

${ }^{559}$ La sintonía presentada por estos autores tiene un fin pedagógico que le desvía, obviamente, de los elementos comerciales descritos, por ejemplo, por BELTRÁN MONER, R. (2005): Op. cit., p. 47. Por ello, no es excesivamente relevante, como sí lo sería desde las pretensiones de Beltrán Moner, que esta composición fuera trasladable de unas imágenes a otras, ya que su finalidad es completamente distinta.

${ }^{560}$ MOLAS, S. y HERRERA, Ll. M. (2000): Op. cit., p. 61.
} 
incluyendo el tramo de educación secundaria (tal vez más adecuado, con corcheas con puntillo, grupos de semicorcheas y contratiempos a base de silencios y corcheas) o una estructura formal simple (repetición de una forma binaria con una pequeña introducción). En todo caso, la complejidad, como puede observarse en la imagen que remite a la parte final de la misma, es mayor que la de los procedimientos anteriormente descritos, especialmente por la inclusión de instrumentos como el sintetizador ${ }^{561}$ :

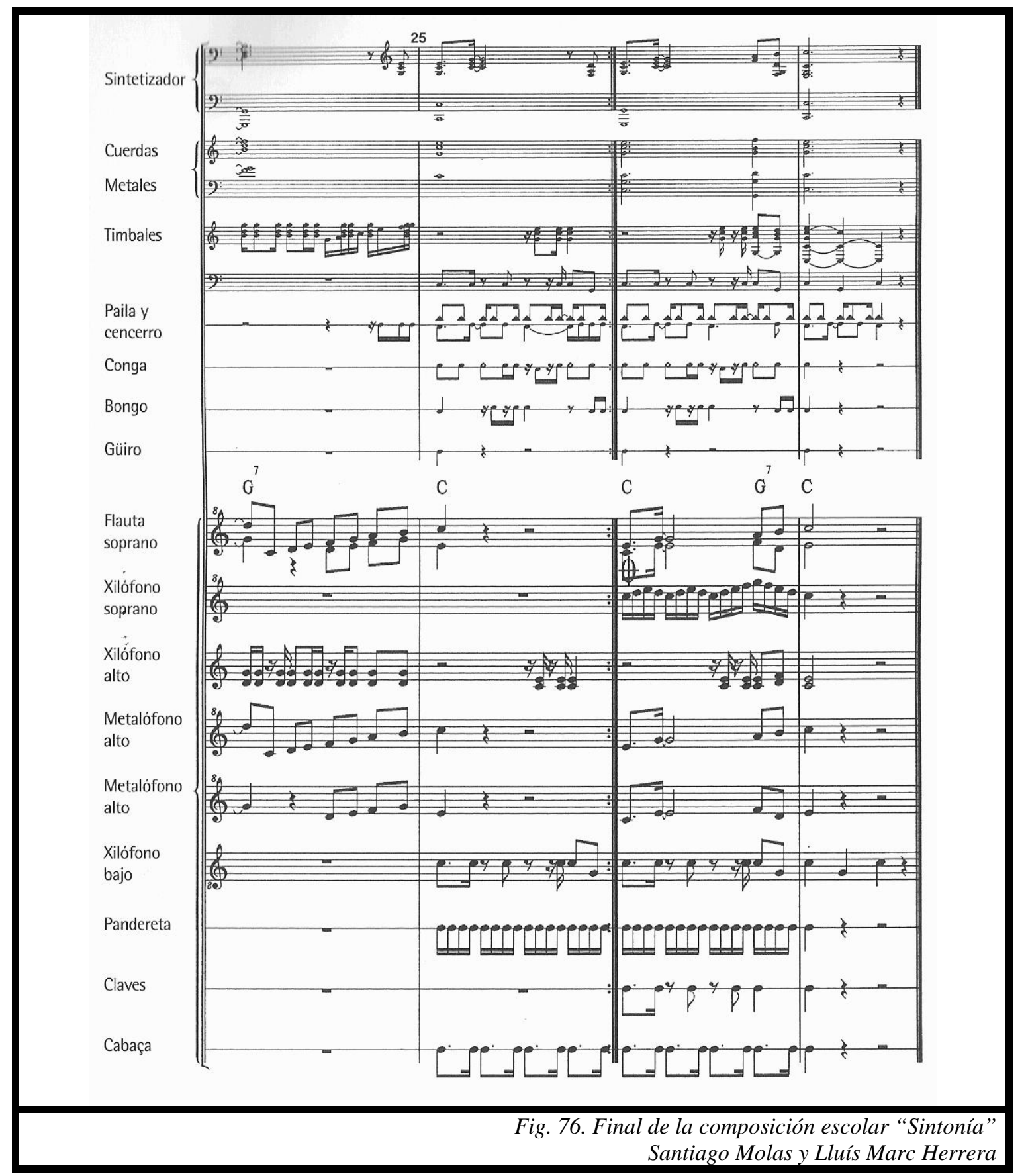

${ }^{561}$ Ibíd., p. 69. Composición completa pp. 61-69. 
Otra posibilidad muy atractiva para el conjunto del alumnado es extrapolar dicha sintonía de un fragmento audiovisual preexistente. En una práctica de aula, se experimentó sobre una melodía que aparece en repetidos episodios de la serie Los Simpson cuando los protagonistas de la serie ven en la propia televisión las peripecias del reportero local, Kent Brockman en su programa "Eye on Springfield". La reutilización de dicha melodía puede ser altamente efectiva para implementarla sobre cualquier otro discurso visual, debido a que todo resulta mucho más sugestivo para los discentes, al acercarnos una vez más a sus códigos de relación con el entorno ${ }^{562}$.

Por otro lado, para completar la visión en torno a la sonorización "en vivo" pasamos a abordar la otra variante apuntada al principio del apartado, la aplicación de diversos sonidos sin necesidad de omitir el discurso auditivo ya inserto en el audiovisual. Se trata pues, de una sobreexposición sonora que completa aquello que ya en sí es un producto acabado en sus planos visual y musical. Salvando las distancias obvias, podría decirse que este modo de proceder se asemejaría al que, en el ámbito de la composición para el audiovisual, describe Joan Padrol acerca de la tarea del arreglista, el cual sería:

\footnotetext{
"un músico que pone música a una música ya establecida, es decir un compositor que compone adornos, melodías nuevas de carácter secundario a una melodía central ya asentada" ${ }^{, 563}$.
}

La adición de sonidos a los ya establecidos, la inserción de "adornos" o "melodías secundarias", puede servir en el plano didáctico para llegar a un nivel de comprensión suplementario al que habitualmente se consigue acceder, en tanto en cuanto, ya no sólo

\footnotetext{
562 Aunque la calidad no es muy buena, sí se recoge el fragmento exacto del corte audiovisual al que nos referimos en <http://www.youtube.com/watch?v=df-y17bX4Xc $>$ [Consulta 9-II-10]. En nuestro caso, para los fines que proponemos, recomendamos la versión exclusivamente sonora: <http://www.youtube.com/watch?v=ERz7gupbAH0 > [Consulta 9-II-10].

563 PADROL, J. (2005): "Los arreglistas musicales como futuros compositores de bandas sonoras". OLARTE MARTÍNEZ, M. (Ed.) La música en los medios audiovisuales. Salamanca: Plaza Universitaria Ediciones, p. 384.
} 
es necesario adecuarse al discurso visual, sino que se ha de estar en concordancia con el sonoro ya existente.

Al margen de esas particularidades, el resto de características y procedimientos para la sonorización son los compartidos y explicados en los ejemplos anteriores, los cuales serán presentados a modo de síntesis en breve. Por ello, nos limitamos a constatar algún caso publicado en el cual la sonorización se haya producido por estos medios y a elaborar otro que pueda servir, por sus diferentes características y posibilidades, como acicate a la evolución de estos materiales aún, hoy día y en nuestro contexto, bastante limitados en cuanto a número.

El primero de los ejemplos nos conduce a un anuncio expuesto en varias temporadas en televisión ${ }^{564}$, el cual recoge un fragmento de la obertura de La Gazza Ladra de G. Rossini para, a partir de esos sonidos, elaborar un espectacular montaje de colores con la explosión de grandes cantidades de pintura sobre un edificio en ruinas en Glasgow. No ahondaremos en la cuestión del encendido de la mecha del resorte significativo ya expuesto con profusión en el capítulo anterior, pero sí hacemos referencia a que es en este tipo de producciones cuando mejor se puede encauzar al alumnado a conocimientos, a menudo complejos como pueda el mundo de la opera, de modo que se establezcan puntos de conexión atractivos y sugerentes.

Al decidir analizar este anuncio nos hallamos ante un producto al que Beltrán Moner acuñaría como realizado sobre "música sola", elemento propio de la televisión. Para él, en estos casos:

"La música debe ser sugerente, interesante de principio a fin puesto que estará en primer plano acompañando a la imagen. El sentido descriptivo es apropiado" 565 .

Al tratarse de una producción que acompasa los estallidos de la pintura con la música rossiniana, el trabajo sonorizador consistirá, esencialmente, en reforzar con

\footnotetext{
564 "Sony Bravia", Dir. Jonathan Glazer, 2005. Disponible en $<$ http://www.youtube.com/watch?v=pGL0gdEPCtU $>$ [Consulta 9-II-10].

${ }^{565}$ BELTRÁN MONER, R. (2005): Op. cit., p. 56.
} 
diferentes tímbricas el discurso ya forjado, haciendo que además éste tenga en la medida de lo posible una mayor profundidad. Para este ejemplo, se prevé la utilización del instrumental del aula de manera bastante prototípica, por lo que ese elemento no habría de suponer ninguna dificultad adicional. Una vez fraccionada la melodía en cuestión y repartidos los roles de manera similar a la expuesta para los casos previos, el resultado propuesto es el que sigue ${ }^{566}$ :

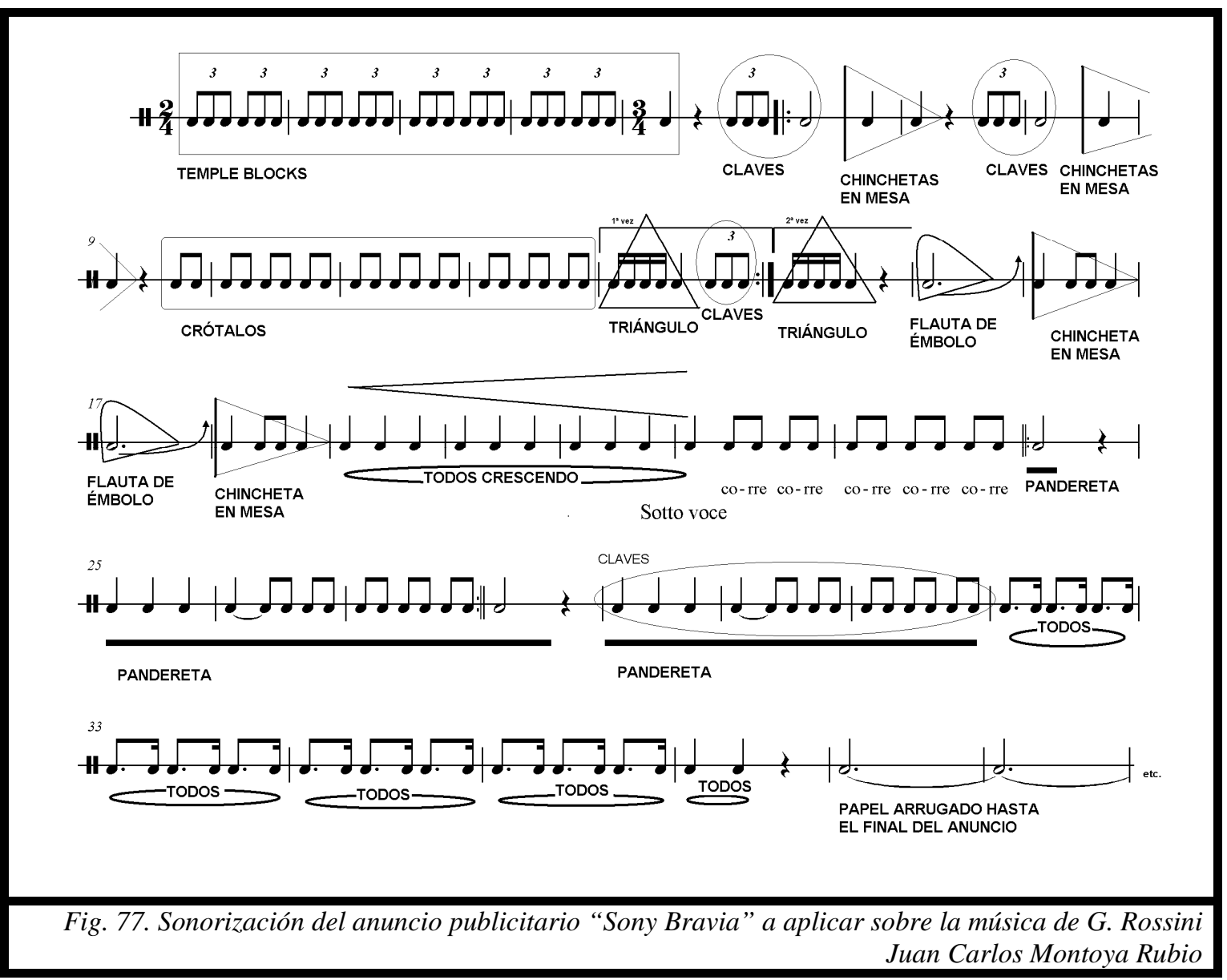

Como se observa, de acuerdo con el criterio de acomodo a cada una de las realizaciones, en este caso se prefiere el uso de una notación convencional con la inclusión de símbolos no convencionales, lo cual refuerza de manera visual el momento en que cada alumno, en función de la misión que se le encomiende, ha de intervenir. En otras ocasiones, es posible omitir cualquier tipo de notación y dejar que los alumnos, guiados por las propias imágenes y con algunas claves de funcionamiento elementales, desarrollen el proceso sonorizador. Esto será posible cuando el material seleccionado invite a ello. En el caso que se muestra a continuación, es mucho más rentable en

${ }^{566}$ MONTOYA RUBIO, J. C. (2008a): Op. cit., p. 65. 
términos de consecución de objetivos didácticos dejar que las imágenes conduzcan a la práctica en cuestión, ya que se busca que los alumnos toquen unos instrumentos determinados adaptándose al discurso visual, silenciado en el siguiente ejemplo ${ }^{567}$ :

567 “The cog”. Publicidad para el Honda Accord (Dir. Antoine Bardou-Jacquet, 2003). Disponible en <http://www.youtube.com/watch?v=FGngcQb_0qg> [Consulta 9-II-10] 


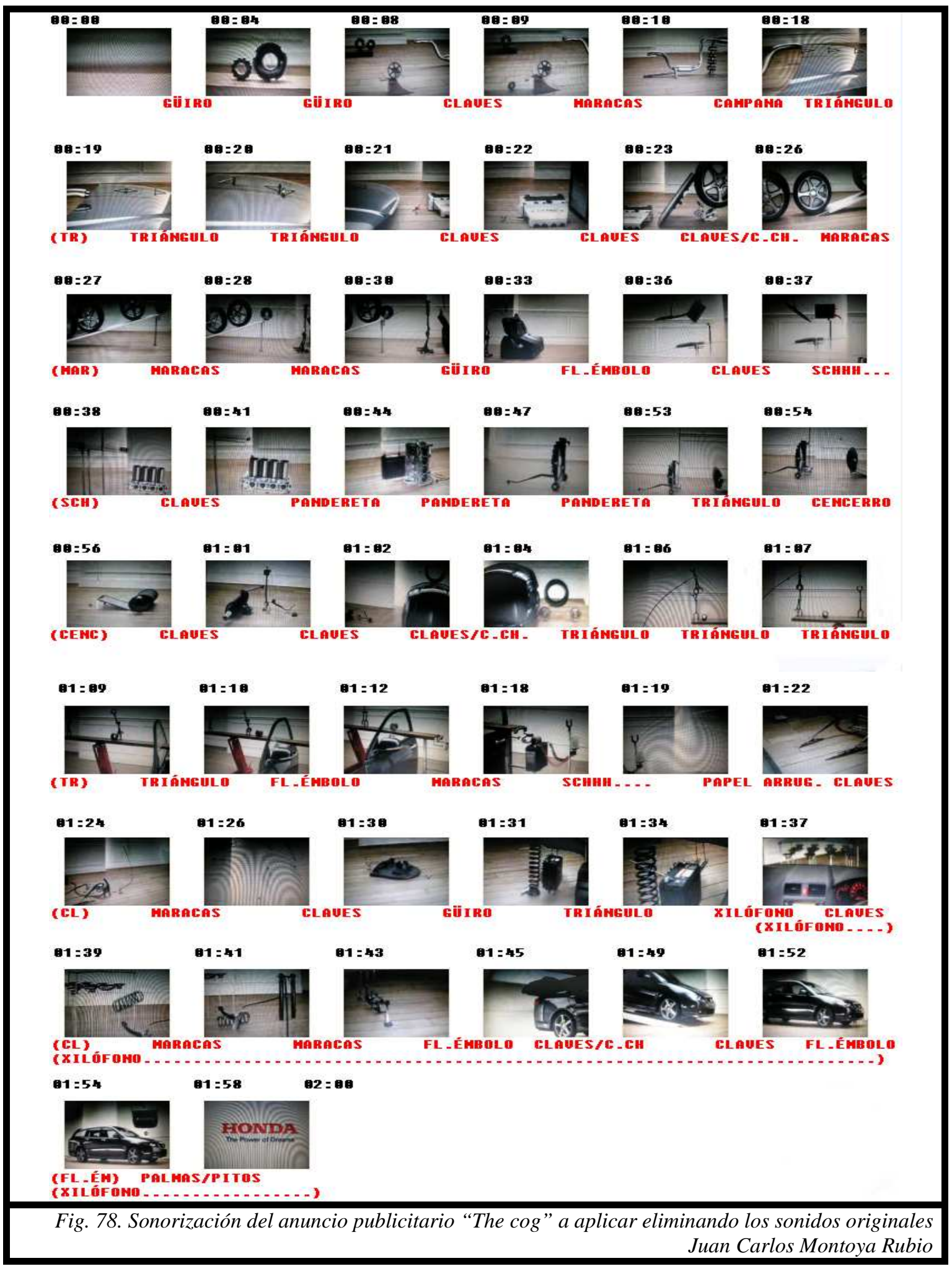


Como puede apreciarse, tratan de buscarse relaciones entre los sonidos que podrían reproducirse por los movimientos y caídas de las piezas del coche con sonoridades producidas por el instrumental típico del aula. La secuencia organológica comienza con el rasgado del güiro, identificándose con las muescas metálicas de la rueda dentada sobre la superficie, para continuar con las claves, ideales para los golpes más secos, o las maracas, que ayudan a describir el movimiento circular del tubo de escape en su girar. El relevo es tomado por campanas o triángulos (ambos por su sonoridad metálica al discurrir el recorrido de los tornillos sobre el capó) y, al margen de la reiteración de instrumentos anteriores, destaca el uso de flautas de émbolo para los vuelos de determinadas piezas o panderetas para describir el aleteo sobre el ventilador, así como susurros o cencerros para sonoridades muy concretas. Con la intención de hacer más completa la sonorización del anuncio en cuestión, cabe la posibilidad de acotar algunas de las partes que en el original aparecen no como sonidos "reales", es decir, que se identifican con el movimiento de alguna de las piezas del coche en cuestión, sino como otros artefactos que producen música, como el $c d$ del propio vehículo. Para este momento se reserva la participación del xilófono que improvisaría al tiempo que sigue el discurso de otros instrumentos aquello que supuestamente se escucha por el audio del automóvil.

De los postulados teóricos y las derivaciones de los ejemplos prácticos, se desprenden una serie de elementos sustancialmente importantes para considerar el éxito o fracaso de las sonorizaciones directas, bien sea sobre imágenes mudas bien sea sobre imágenes sonorizadas. Entre ellas destacamos cinco aspectos importantes:

A) La funcionalidad del uso de la notación. Es preciso resaltar que el propio discurso visual podrá dictar cuál es el momento más indicado para proponer uno u otro tipo de notación (convencional o no), pero que siempre será la inteligibilidad del alumno en el desarrollo del proceso lo que habrá de primar, independientemente de que también sea preceptivo, de cualquier modo, el aprendizaje de los signos convencionales de escritura musical. Así, los procedimientos de adición musical suponen una serie de intenciones (efectivas o productivas y ficcionales) ${ }^{568}$ que pueden ser alcanzadas por

${ }^{568}$ GÉRTRUDIX BARRIO, M. (2003): Op. cit, pp. 187-188. 
diferentes métodos, por lo que ceñirse a un solo tipo de representación gráfica podría significar una traba, por ejemplo, a la hora de querer representar momentos improvisados o de difícil encaje dentro de las cuadradas estructuras del lenguaje musical. Por ello, enfatizamos la necesidad de flexibilizar los diseños gráficos de aquello que se pretenda sonorizar. Así, los posibles desajustes, derivados de cambios en el tempo o de falta de rigor al plasmar lo que se pretende quedan supeditados a la lógica que imprimen las imágenes, que son el origen de la práctica y que habrán de dictar su devenir en cada momento. Por tanto, la comprensión por parte del alumno hará crecer las virtudes del producto sonorizado.

B) La delimitación de los cortes a sonorizar por medio de representaciones icónicas de la estructura facilitará enormemente su aprehensión. Al igual que sucedería con el caso de la notación, es muy adecuado trasladar las potencialidades de los musicogramas de seguimiento auditivo ${ }^{569}$ al audiovisual, relacionándolos con el montaje de las imágenes con sonido. Desde la teoría cinematográfica:

"La combinación de sonido e imágenes complica el montaje debido a la necesidad de resolver un problema de composición nuevo. Este problema consiste en hallar una clave de congruencia entre una secuencia musical y una secuencia de imágenes; un tipo de congruencia que nos permita combinar 'verticalmente', es decir, simultáneamente, la progresión de cada frase de música en paralelo con la progresión de las unidades gráficas de representación, los planos; y esto tiene que hacerse en condiciones que se observen tan estrictamente como las que combinan imágenes 'horizontalmente', es decir, secuencialmente, plano a plano en el montaje mudo o frase a frase en el desarrollo de un tema musical" ${ }^{, 570}$.

Con ello, vincularemos las realidades pedagógicas más cercanas de nuestros alumnos a aquellas que pretendemos que consigan hacer propias, de modo que se logra

\footnotetext{
569 WUYTACK, J. y BOAL-PALHEIROS, G. M. (2009): “Audición musical activa con el musicograma". Eufonía 47, pp. 43-55.

${ }^{570}$ EISENSTEIN, S. M. (2001): Op. cit., v. II. p. 168.
} 
a través de la conexión de aprendizajes comenzar a hacer familiar este tipo de procedimientos didácticos. En todo caso esta vía de actuación se desarrollará con mayor detenimiento en el siguiente apartado de la investigación.

C) La utilización de materiales para producir los sonidos. Teniendo como máxima la idea de Small según la cual "la mejor manera de musicar es la de quienes lo hacen lo mejor que pueden con los medios que tienen" ${ }^{\text {"571, }}$, el uso instrumental no ha de ceñirse sólo a instrumentos escolares de altura determinada o indeterminada, sino que entre estos tienen cabida "cotidiáfonos" ${ }^{, 572}$ y otro tipo de instrumentos muy útiles pero escasamente utilizados en los últimos tiempos, tales como las flautas de émbolo. En este sentido, es reseñable que todo el material de aula utilizado con normalidad puede ser valedero pero además, cobra especial relevancia el uso de instrumental construido por el propio alumnado, porque en ocasiones, la sonoridad específica que pretendamos o el efecto al que queramos aludir será más logrado si éste deriva de un "cotidiáfono". Con estos recursos se multiplican las posibilidades sonorizadoras para golpes de efecto $^{573} \mathrm{y}$ otros momentos que precisan una notoriedad específica. Siguiendo a Alsina:

"La fabricación de estos instrumentos no debe enfocarse hacia conseguir formas que superen instrumentos musicales en su sentido más ortodoxo sino hacia buscar sonoridades y timbres deseados"

De acuerdo con ello, engarzamos directamente la tradición de construcción de instrumentos musicales con materiales de uso cotidiano con la aplicación audiovisual. Desde esta última rama, apreciaríamos los elementos rudimentarios con los que se han

\footnotetext{
${ }^{571}$ SMALL, C. (2006): "Siete aforismos y seis comentarios". Quodlibet 35, p. 140.

572 AKOSCHKY, J. (1988): Op. cit. Otras aproximaciones pedagógicas centradas en el uso de instrumentos construidos a partir de materiales con otro origen son: ARGUEDAS QUESADA, C. (2006a): Op. cit.; GORDILLO, J. (2003): "Los materiales pobres enriquecen la música". Revista Eufonía 27, pp. 45-53; PALACIOS, F y RIVEIRO, L. (1990): Artilugios e instrumentos para hacer música. Madrid: Ópera Tres; BENSAYA, P. (1986): Instrumentos de papel: construcción y consejos para la ejecución y aplicación en el aula. Buenos Aires: Ricordi.

${ }_{573}^{5}$ LUMET, S. (1999): Así se hacen las películas. Madrid: Rialp, p. 181.

${ }^{574}$ ALSINA, P. (1997): Op. cit., p. 114. En todo caso, aún refiriéndose a ellos, la terminología de "cotidiáfono" no es empleada en este ejemplo concreto por el autor.
} 
pretendido sonorizar determinadas producciones. Algunos ejemplos derivados de la sonorización audiovisual aprovechables en el aula de educación musical $\operatorname{son}^{575}$ :

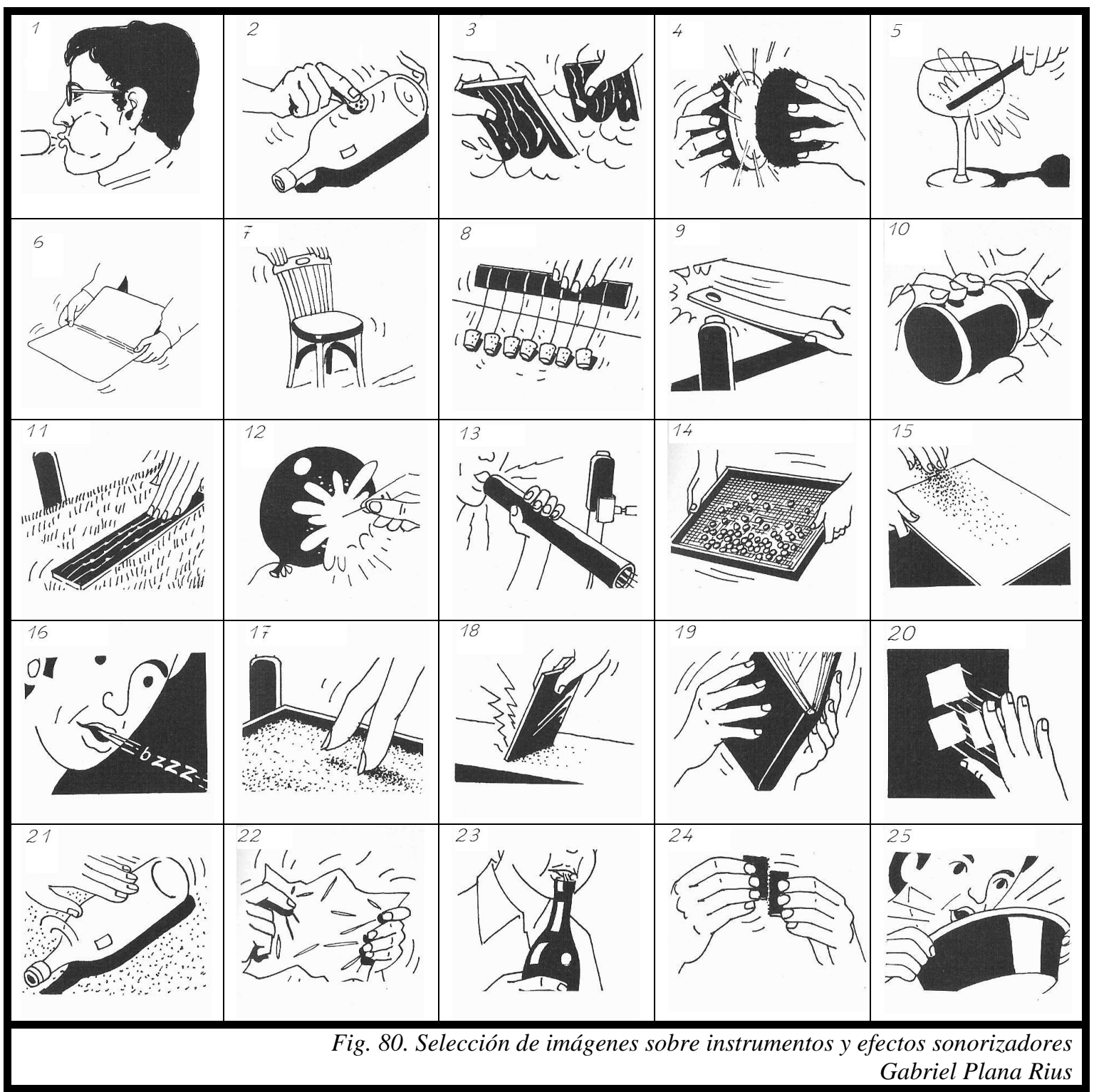

La identificación de cada imagen con la analogía de su sonido correspondiente es, siguiendo de manera resumida al autor ${ }^{576}$ :

\footnotetext{
${ }^{575}$ Imágenes extraídas de PLANA RIUS, G. (1982): Cine-Sonorización. Barcelona: Instituto Parramón Ediciones, pp. 81-96. Se incluye una rotulación con números para identificar los diferentes dibujos. Es preciso reseñar que se ha realizado una selección, ya que los procedimientos de sonorización descritos por el autor, en ocasiones, precisaban de medios materiales poco apropiados para las aulas o algo más aparatosos de lo recomendable, por lo que se ha optado por presentar los veinticinco modelos más accesibles.
} 
1. Cohete de verbena. Soplar y aspirar un tubo de cartón. Reproducir a mitad de velocidad y jugar sobre los agudos.

2. Aves. Cortar un tapón de corcho en bisel, mojarlo con agua o alcohol y frotar luego con él una botella de vidrio.

3. Bote de remos. Introducir dos tablillas de madera en el agua y efectuar ritmo de remos.

4. Caballos. Golpear rítmicamente una contra otra dos mitades de coco vacío. Si se envuelven con un trapo parecerá que los caballos trotan por un bosque o pradera; sobre mármol se imita el cabalgar en pavimento.

5. Campanadas. Golpear un lápiz contra una copa de champán. Golpear un plato grande de cobre o el de una balanza con el mazo o la cabeza de un martillo.

6. Aleteo de pájaros. Batir entre sí dos de los ángulos de una carpeta de cartón.

7. Crujidos de madera. Usar una silla vieja, preferentemente de las de tijera y madera. Este sonido sirve para completar el sonido de embarcaciones.

8. Desfile militar. Enfilar varios corchos en los extremos de siete u ocho pedazos de cordel; fijar éstos en lo alto de una tablilla de unos $20 \mathrm{~cm}$. de ancho y agitarla para que los cordeles con sus corchos de en la madera a ritmo militar.

9. Disparo. Descargar un golpe seco con una regla de dibujo sobre una mesa de madera.

10. Eco. Hablar por un tarro de cristal de boca ancho o en una lata de galletas vacía metálica.

11. Esquiar. Hacer deslizar una tablilla de madera sobre la alfombra o una manta peluda.

12. Explosión. Reventar un globo de goma.

13. León. Ronronear en la extremidad de un tubo largo de cartón.

14. Lluvia. Agitar suavemente una caja de cartón o un cedazo que contenga guisantes, avellanas o conchas vacías de caracol.

${ }^{576}$ Ibid. 
15. Mar. Hacer deslizar arena de un extremo a otro de una larga bandeja de madera.

16. Mosca. Ensayar el característico "bzzz” con los labios.

17. Pasos. En el bosque: estrujar ovillos de cintas magnetofónicas viejas o tiras de celofán al ritmo de los pasos. En la nieve: utilizar bolsitas de harina o de plástico expandido. En la arena: poner una capa de tierra en una cajita y con los dedos, imitar los pasos.

18. Puerta con chirrido. Una chapa arrastrada verticalmente sobre hormigón.

19. Puerta de coche cerrándose. Cerrar bruscamente un libro.

20. Rotura de vidrios. Arrojar cinco o seis plaquitas de metal contra la pared.

21. Ruedas de un vehículo lento. Sobre una capa de arena se hace rodar lentamente una botella vacía de vidrio colocada horizontalmente.

22. Sierra. Moviendo papel de celofán cogido con ambas manos de uno a otro lado.

23. Sirena de barco. Soplar dentro de una botella medio vacía.

24. Tren de vapor. Frotar con movimiento de vaivén dos plaquitas de madera recubiertas con papel de lija, esmeril o papel secante.

25. Voz por teléfono. Hablar dentro de un vaso de plástico o un recipiente de arcilla.

La gran diferencia en la utilización de estos recursos dentro de las aulas de música radica en la concepción y el uso final del artilugio musical. Así, la concepción del propio instrumento ya no iría determinada tanto por una hipotética analogía con el instrumento original como por su uso o función dentro del entramado audiovisual al que se vaya a insertar. A este primer paso, del cual se nutre la elaboración de instrumentos caseros, seguirían otros comunes en la construcción de dichos "cotidiáfonos": la búsqueda de materiales a través de la exploración de los sonidos del entorno, el trabajo plástico de transformación sobre el instrumento para variar su funcionalidad y la familiarización con dicho nuevo agente sonoro, aprendiendo su manejo a través de la 
manipulación. Por fin, la puesta en práctica deriva en un nuevo uso, como decimos, el de integrarse según necesidades en el compendio audiovisual.

D) Un cuarto aspecto a tener en cuenta es el de la pertinencia de unas u otras aplicaciones sonorizadoras en función del corte seleccionado. Así, si la resultante de una sonorización es una de tantas posibilidades pedagógicas que pueden arrojar las prácticas que utilizan los materiales propios de la educación musical ${ }^{577}$, la elección de la mejor opción pasa, generalmente, por el estudio previo que confiera una lógica al método y procedimientos a utilizar, ya que de ahí se derivará si es más conveniente una u otra representación icónica, qué instrumentos utilizar, improvisar en mayor o menor medida, etc.

E) En estrecha vinculación con la idea precedente, la fragmentación u omisión de elementos del audiovisual si esto simplifica la tarea del alumno. En ocasiones, sonorizar unos pocos segundos de un anuncio publicitario puede resultar una tarea compleja. Por ello, es posible y conveniente tratar de seleccionar elementos sonorizables, a veces insertos en discursos mayores. Si en el proceso de elección de una entidad perteneciente a un discurso audiovisual mayor conseguimos que el seleccionado tenga entidad propia y autonomía, el éxito será mayor. Por otro lado, el trabajo de simplificación pasa, igualmente, por seccionar el corte elegido, haciendo de él episodios menores, en ocasiones minúsculos, que sirvan para la práctica fragmentada y reiterativa.

\footnotetext{
${ }^{577}$ Como atestigua Hartmann, al referirse a los planteamientos de Orff: HARTMANN, W. (2005): "El pensamiento pedagógico de Orff y su influencia en la enseñanza instrumental”. Quodlibet 33, p. 47.
} 


\subsection{FILMACIÓN Y REPRESENTACIÓN VISUAL DE LA MÚSICA}

\section{Delimitación metodológica}

Si al abordar la sonorización partíamos, genéricamente, de unas imágenes sobre las que implementar sonidos de cualquier tipología, hemos de atender a la existencia del fenómeno contrario, la aparición de discursos audibles que pueden beneficiarse de la adición de elementos visuales que guíen y estimulen el conocimiento musical, esto es, aplicación de imágenes a sonidos preexistentes. Sin embargo, no será este nuestro primer centro de interés dentro del apartado sino otro modo más común de aproximar los medios audiovisuales al conjunto del alumnado, la filmación. Así, entre las posibles técnicas a utilizar en el aula de música desde el concurso de los medios audiovisuales, no podemos dejar de lado este procedimiento, entendido de manera reduccionista como registro de cualquier tipo de evento en el contexto escolar. Como veremos, el abanico de actuaciones a partir de esta estrategia puede ser mayor ${ }^{578}$.

De este modo, dentro de las filmaciones se erige como principal eje pedagógico el uso del vídeo, el cual enfocado como punto de partida de aprendizajes ha tenido cierto desarrollo, aunque su vertiente más generalizada peca de nuevo de no inmiscuirse en el discurso audiovisual sino que intenta extraer el potencial de su propia trama argumental:

"Por tanto, lo relevante del vídeo como medio didáctico no son sus posibilidades instrumentales: pausa, visionado con rebobinado..., sino sus sistemas simbólicos, cómo ellos interaccionan con determinadas habilidades cognitivas de los alumnos y su inserción dentro de un plan curricular que determinará su diseño y estrategia de utilización"

\footnotetext{
${ }^{578}$ Así como el nivel de complejidad y elaboración, que vendrá determinado por la capacidad del docente para acercarse al mundo de las grabaciones y ediciones. Un ejemplo muy accesible para no iniciados es GÓMEZ VARAS, P. (2009b): "Software libre para la edición multimedia". OLARTE MARTÍNEZ, M. (Ed.) Reflexiones en torno a la música y la imagen desde la musicología española. Salamanca: Plaza Universitaria Ediciones, pp. 277-284. En dicho artículo el autor explica determinadas características videográficas y muestra diversos modos de aprovechamiento de los recursos de edición de imágenes y sonido.

579 CABERO ALMENARA, J. (1989): “Tecnología educativa: diseño y evaluación del medio vídeo”. Enseñanza: Anuario Interuniversitario de Didáctica 7, pp. 17-40.
} 
Así, se suele tener en consideración la relevancia de la información y la estructura y presentación del mismo para considerar su grado de adecuación didáctica ${ }^{580}$ aunque en todo caso siempre se haya atisbado el potencial abierto del mismo, que exigiría

"un proceso de reflexión por parte del profesorado, que permita encontrar posibles usos o funciones de vídeo en el trabajo escolar, [...] por lo tanto es el propio profesor el que debe probar 'en su propio terreno' los usos didácticos del vídeo en su acción docente" ${ }^{, 581}$.

Fuera del campo musical, sus utilidades se extienden a ámbitos tan dispares como el registro y análisis de la evaluación hasta la estimulación de elementos socioculturales varios $^{582}$. Sea cual fuere el método elegido, la efectividad del mismo va a ser directamente proporcional al nivel de participación del alumnado en el proceso. Así, no bastará sólo con hacer que el grupo "lea la imagen y los sonidos", sino que el verdadero reto es el de implicar al alumnado en la realización de producciones audiovisuales de uno u otro modo ${ }^{583}$. Con ello, los procedimientos por medio de los cuales se aplica música a elementos visuales pueden responder a diferentes tipologías. En consecuencia con todo lo perfilado de manera preliminar, el esquema básico en torno al que gravita este sintético apartado es el siguiente:

\footnotetext{
${ }^{580}$ CAMPUZANO RUIZ, A. (1992): Op. cit., pp. 115-126.

${ }^{581}$ DE PABLOS PONS, J. (1995): Op. cit., pp. 242-243.

582 MAURICE, M. et als. (1983): El vídeo en la enseñanza. Barcelona: Planeta.

${ }^{583}$ Son varios los intentos por hacer énfasis en la faceta de la integración de lenguajes en el vídeo didáctico. Entre ellos destacamos los de Deó, quien reitera comúnmente dichos postulados en varias publicaciones, entre las cuales seleccionamos: DEÓ, F. J. (1997): "La Educación Audiovisual en la Educación Secundaria Obligatoria”. Comunicar 9, pp. 171-174.
} 


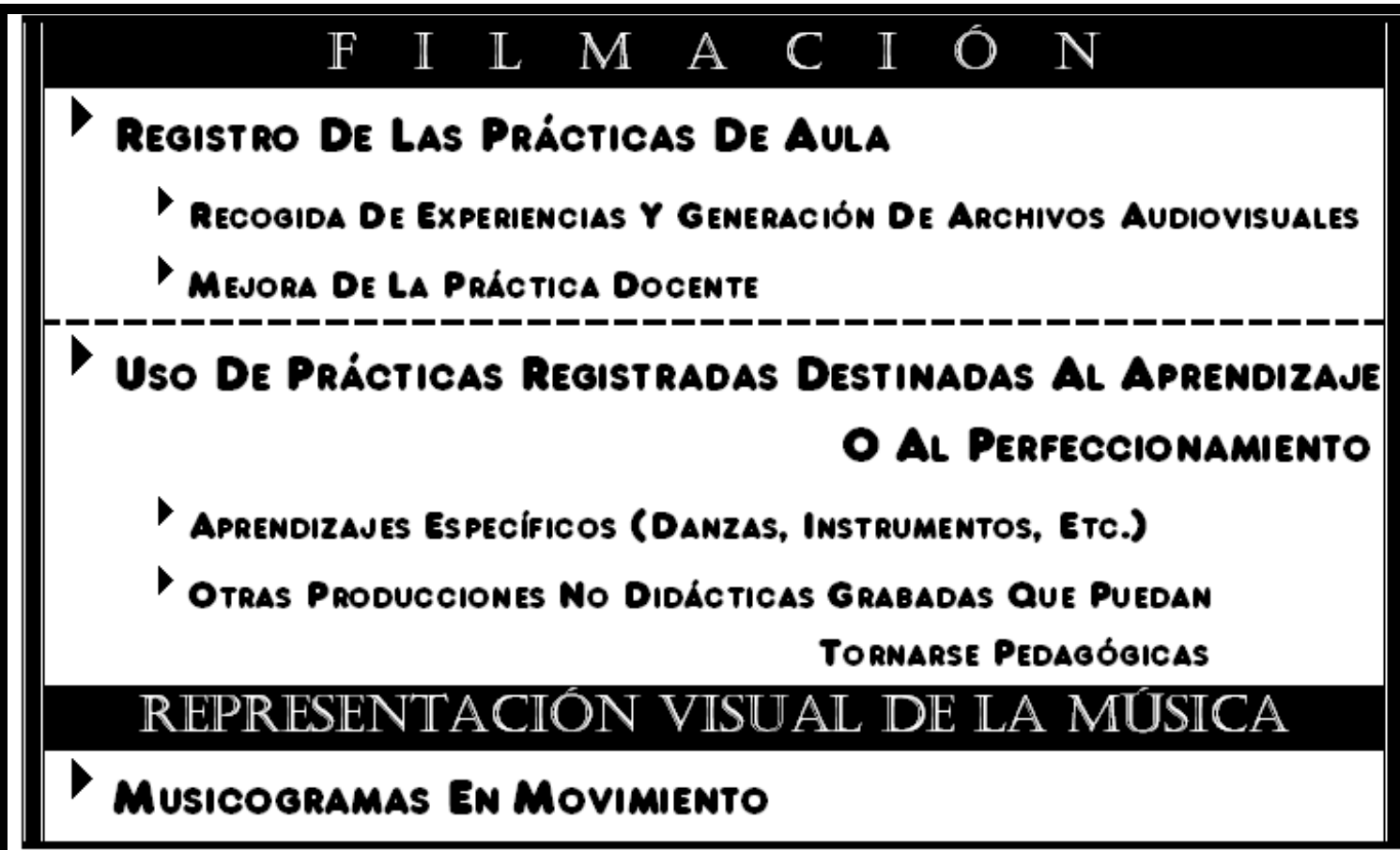

Fig. 80. Filmación y representación visual de la música. Principales posibilidades. Juan Carlos Montoya Rubio

Registro de las prácticas de aula

La filmación, entendida como registro de situaciones, puede tomar la forma de distintas variantes, desde la producida por los alumnos ${ }^{584}$ hasta la propiciada sobre ellos como objeto de estudio. En todo caso, nos centramos primeramente en aquellas prácticas en las que se filma al grupo de alumnos sobre los que se está llevando a cabo la labor de enseñanza-aprendizaje. En estos supuestos las peculiaridades de los registros han de superar, por supuesto de manera preceptiva, los filtros que impiden tomar imágenes de los alumnos e hipotéticamente utilizarlas para cualquier fin. Téngase en cuenta pues, que las prácticas a que se hacen referencia han de tener los permisos necesarios para su realización.

Algunos paralelismos venidos de la teoría de la música de cine referidos a la filmación como contraposición a la sonorización pueden extraerse de obras de referencia clásicas:

\footnotetext{
${ }^{584}$ Determinados autores consideran que desde el cuarto nivel de primaria los alumnos pueden llevar a cabo experiencias de filmación de una escena: SOLÁ ARGUIMBAU, A. y SELVA MASOLIVER, M. (1996): Op cit., p. 51.
} 
“...el régimen sincronizador se produce a la inversa cuando la partitura ha sido compuesta a priori. Nos hallamos ante el supuesto de la música "viva" determinante de la acción. El proceso es el siguiente: se compone primero, luego se graba la composición y finalmente, mediante la utilización del play-back, se filma la escena" ${ }^{585}$.

Teniendo presente que la composición musical puede ser sustituida por una grabación preexistente, en la práctica didáctica este uso es muy adecuado a las coreografías típicas de las clases de música. En esos casos nos vincularíamos directamente con los cuentos narrados y la bibliografía didáctica existente al respecto y comentada para el apartado de sonorización ${ }^{586}$. Extrapolando las ideas de los citados autores

"este procedimiento se emplea cuando se trata de secuencias cantadas o bailadas por los actores en la pantalla o en situaciones que exigen una coreografía que se monta y organiza en función de las inflexiones o incidencias de la partitura, la cual, por otra parte, ha sido pensada, desarrollada y, en definitiva, compuesta siguiendo las indicaciones del director de la película" ${ }^{\text {"587. }}$.

Llegados a este punto, hemos de incidir en que los planteamientos que describimos en este texto se fundamentan en el desarrollo de habilidades derivadas de la educación musical, y no tanto de una hipotética formación audiovisual, por lo que los tratamientos de los sonidos y posibles mezclas quedan bajo el ámbito de la comunicación audiovisual y no son fácilmente aplicables con total profundidad, de manera realista, en nuestros contextos educativos. Ello, no obstante, no implica que se puedan llevar a cabo procesos con diferente grado de complejidad, en función de las contingencias de cada situación y grupo de alumnos. En este sentido, podrían ser de utilidad criterios como los apuntados por Squires ${ }^{588}$, quien remite a la utilización de efectos sonoros que aparecen en escena, la colocación de micrófonos cerca de la fuente

\footnotetext{
${ }^{585}$ VALLS GORINA, M. y PADROL, J. (1990): Op. cit., p. 57.

${ }^{586}$ Especialmente ESCUDERO, M. P. (1988): Op. cit.

${ }^{587}$ VALLS GORINA, M. y PADROL, J. (1990): Op. cit., p. 57.

${ }^{588}$ SQUIRES, M. (1993): Filmar con la cámara de vídeo. Barcelona: Blume.
} 
de sonido para evitar confusiones sonoras o la implementación musical por separado de las imágenes (adición de música incidental).

De este modo, entre las estrategias más usuales de aplicación audiovisual en las aulas encontramos la generación de vídeos, realizados desde diferentes prismas, siendo recurrente el formato de videoclip. Entendido como conjunción equilibrada de artes ${ }^{589}$, puede ser un recurso a explotar de manera didáctica. De hecho es en este campo donde encontramos un buen número de aplicaciones didácticas reseñables que muestran como las experiencias de este tipo pueden resultar exitosas. En este sentido, éste es uno de los campos donde con mayor entusiasmo, los docentes de todas las etapas educativas han empleado su tiempo, en el empeño de dotar de contenido didáctico aquello que, en origen, carecería del mismo. Tal vez, la necesidad de trabajar con elementos autónomos $\mathrm{y}$, en cierto modo cerrados, facilita el abordaje de este tipo de producciones claramente delimitadas. Ello se ve favorecido, sin duda, porque los ámbitos de su desarrollo conectan casi intuitivamente con muchos de los postulados básicos de la educación musical. Para Fandos Igado ${ }^{590}$, el principal sería el movimiento, ilustrado por múltiples aspectos, tales como la fragmentación de planos a través del montaje, la alternancia de contenidos o escenarios, los movimientos de los personajes, los escenarios móviles, los desplazamientos de la cámara o su diferentes planos, la fragmentación de la pantalla en diferentes campos de visión o la alternancia de colores y formas.

De manera práctica, el uso didáctico de la elaboración de videoclip en el modo al que nos estamos refiriendo ha sido desarrollado con cierta profusión en los últimos años aunque, de cualquier modo, suele ser bastante común que las propuestas que encontramos al respecto no sean lo suficientemente profundas como para invitar a su realización. Este hecho, que no se muestra de este modo en propuestas específicas desarrolladas en artículos especializados, es por otro lado casi paradigmático y endémico en determinados libros de texto, en cuyas páginas finales se atisba la posibilidad de hacer un videoclip sin detenerse en exceso en las muchas particularidades que encierra su realización final. Señalamos, porque muestra gran parte de las claves

\footnotetext{
${ }^{589}$ En tanto en cuanto se acerca al ideal de obra de arte total oteado por Wagner: RADIGALES, J. (2005b): "El videoclip com a obra d'art total. Sobre "Africa Shox" (Leftfield) de Chris Cunningham". Trípodos 17, pp. 191-200.

${ }^{590}$ FANDOS IGADO, M. (1993): "El video-clip musical. Una asignatura pendiente". Comunicar 1, pp. 95-96.
} 
que estamos abordando, la propuesta de trabajo para la elaboración de un videoclip escolar ideada por Del Álamo y Gil ${ }^{591}$, partiendo de siete pasos sucesivos:

- Grabar algunos videoclips comerciales.

- Verlos en grupo, fijándose en las principales técnicas que emplean.

- Escoger una canción.

- Pensar qué técnica visual utilizaremos para la grabación.

- Grabación.

- Montaje.

- Proyección del resultado.

Los materiales necesarios para esta propuesta de trabajo son:

- Un monitor de televisión con vídeo.

- Cámara videograbadora.

- Un magnetófono.

- Videoclips grabados.

- Canciones grabadas.

La ausencia de un desarrollo mayor de propuestas como estas hace que, en la práctica, queden como islotes procedimentales que rara vez llegan a ser ejecutados por la ausencia de tiempo y las dificultades técnicas.

Por último, hemos de señalar que entre las potencialidades del registro está la publicación de la información audiovisual (obteniendo si cabe aún más permisos paternos necesarios) para su análisis en otros contextos colaborativos. En referencia al uso de internet para la muestra de tareas de corte musical, Frega indica que el medio puede considerarse como un estímulo para el discente, en tanto en cuanto su labor va a poderse consultar abiertamente y ello, en consecuencia, redundará en un aumento del cuidado en la elaboración ${ }^{592}$.

Volvemos por tanto a la significación del aprendizaje para constatar que este bloque puede ser, al igual que el resto tratado previamente, un modo acertado de aproximación a los intereses de los discentes.

El acercamiento alternativo que reseñábamos al inicio del apartado en torno a la filmación hacía referencia a la mejora de la práctica docente. En este ámbito, el uso de

${ }^{591}$ DEL ÁLAMO, L. y GIL, V. (1999): Música. Secundaria 3. Madrid: Ediciones SM.

${ }^{592}$ FREGA, A. L. (1996): Op. cit. 
sistemas de registro, como pueda ser el vídeo, se postula como un buen medio de mejora de dicha práctica docente, ya que, por medio de su estudio detenido, permite perfilar mejor las situaciones del aula, en este caso de educación musical. Procedimientos de este tipo han sido utilizados en diversa forma para el trabajo de la audición desde el registro exclusivo del plano sonoro, con independencia de imágenes ${ }^{593}$. En un caso práctico expuesto por Cecilia Portela ${ }^{594}$, la grabación que tiene como objeto aquello que acontece en el aula de educación musical no debe ceñirse en exclusiva al momento en que se producen interacciones en ella, sino que ha de partir del contexto (el recinto), el interior del centro (instalaciones) y por fin el aula, desde donde se registra la entrada de los alumnos y los episodios y tareas que se llevan a cabo hasta su salida. A modo de ejemplo, las conclusiones que podría arrojar una aproximación así, basada exclusivamente en la mejora de los procedimientos susceptibles de serlo son: ${ }^{595}$

- Muchas tareas en un corto espacio de tiempo, algunas inconclusas.

- Gran interacción de todos los protagonistas, profesora y alumnos.

- Aunque existen contenidos de todo tipo, destacan los procedimientos sobre los demás.

- Se trabajan todos los bloques de contenido.

- En todas las tareas existe consigna y cierre.

Como se puede observar, las intenciones de este tipo de aproximaciones son, claramente, la mejora de la práctica docente a través de la búsqueda de un perfil más ajustado a la hora de llevar a cabo las clases con grupos concretos de alumnos. En otros casos el uso del vídeo, orientado a tal finalidad, se complementa con otro tipo de técnicas que ajusten el perfil de la investigación que en cada caso se realice ${ }^{596}$.

\footnotetext{
${ }^{593}$ Por ejemplo CHILDS, J. (2005): Op. cit. pp. 54ss, aporta claves para trabajar en el aula de música con micrófonos, grabaciones, magnetófonos, etc.

${ }^{594}$ PORTELA LÓPEZ, C. (2000): "El análisis de tareas en las clases de educación musical: un caso práctico". Revista de la Lista Europea de Música en la Educación 5. Disponible en $<$ http://musica.rediris.es/leeme/revista/portela00.pdf> [Consulta 9-II-10].

595 Ibíd., p. 8.

596 A este respecto, las observaciones y grabaciones de aula pueden complementarse con entrevistas, lecturas, etc.: VILADOT VALLVERDÚ, L. y MALAGARRIGA ROVIRA, T. (2008): "Inferencia de finalidades de un proyecto de innovación didáctica en educación musical”. ÁLAMO, A. y LUCEÑO, M. Actas del I Congreso de Investigación y Educación Musical. Madrid: Enclave Creativa Ediciones, p. 41.
} 


\section{Uso de prácticas registradas destinadas al aprendizaje o al perfeccionamiento}

A diferencia de las modalidades expuestas hasta ahora, nos centramos en este momento en los registros en los cuales la grabación se muestra a los alumnos en cuestión, sin necesidad de que sean ellos los protagonistas de la misma, ya que la principal finalidad es la de provocar una mejora a partir del propio visionado más que de su análisis exhaustivo. Se produce por tanto cuando una filmación se aplica al aula. Dentro de las posibilidades que quedan en este planteamiento, existen ejemplos centrados en lo musical en los cuales el propio docente graba cómo debería ser la praxis correcta, de modo que el alumno pueda aprender por repetición del modelo filmado. Para el caso del aprendizaje de un instrumento, Bautista Vizcaíno ${ }^{597}$ enuncia las ventajas de la creación de un método audiovisual del siguiente modo:

“1. La posibilidad de que el alumno maneje un material didáctico interactivo, con las ventajas que ello supone.

2. La posibilidad de que el alumno tenga acceso a ese material en casa y en clase.

3. La posibilidad de que el alumno tenga grabado en audio, como modelo, todos los ejercicios y canciones que él deberá interpretar. Y además, guías rítmicas, verbales y otros instrumentos que le acompañen.

4. La posibilidad de un uso rico de elementos simbólicos visuales móviles que ayuden a comprender mejor el conocimiento que se desea trasvasar, usando formas, colores, lenguajes...

5. La posibilidad de que el alumno aprenda a estructurar una sesión de estudio. Que aprenda los rudimentos de una metodología.

6. La posibilidad de que el alumno realice un autoaprendizaje efectivo mediante el manejo de las herramientas dispuestas para ello.

7. El aumento de motivación que conlleva la combinación de medios para la transmisión de un conocimiento."

\footnotetext{
597 BAUTISTA VIZCAÍNO, F. (2000): "La metodología audiovisual como alternativa a la enseñanza instrumental tradicional". Revista de la Lista Europea de Música en la Educación 5. Disponible en <http://musica.rediris.es/leeme/revista/bautista00.pdf > [Consulta 9-II-10], p. 2.
} 
Según el autor, de proceder correctamente los cambios metodológicos, ellos revierten de inmediato en beneficios ${ }^{598}$ :

"La labor fiscalizadora del profesor, muy evidente en la metodología tradicional [...] se transforma en labor de "acompañamiento" del proceso de aprendizaje que el alumno realiza directamente sobre el material audiovisual. [...] La clase se convierte en un momento más de la tarea de autoaprendizaje emprendida por el alumno, sólo que con un consejero experimentado cerca"

Existen ejemplos que enlazan el visionado de prácticas concretas con las realizaciones que los alumnos habrán de conseguir, o que servirían para ilustrar explicaciones anexas al nudo estructural de una unidad didáctica ${ }^{599}$.

En todo caso, la vertiente audiovisual más centrada en el objeto de estudio de esta investigación es aquella en la que los alumnos, a partir de imágenes tomadas por ellos mismos, implementan sonidos previamente seleccionados, buscando un aprendizaje que ha sido orientado por el docente. Esta vía conecta directamente con la representación visual de la música a partir de musicogramas en movimiento.

\section{Representación visual de la música: Musicogramas en movimiento}

Dentro de la gestación de materiales para su orientación didáctica hemos de apuntar la generación de todo el audiovisual, no sólo ya la implementación de unas imágenes a un audio o viceversa. El hecho de no tratar con extremado detenimiento este tipo de realizaciones estriba en la dificultad para llevarlas a cabo de manera efectiva en los términos que queda establecida la educación musical obligatoria actual, por lo cual, siguiendo la pauta de efectividad práctica que nos hemos marcado, simplemente dejaremos constancia de su existencia. En etapas educativas posteriores su desarrollo puede ser una buena manera de ejercitar prácticas audiovisuales que, bien canalizadas, sean el embrión de aplicaciones concretas. En este sentido, es posible encontrar

\footnotetext{
${ }^{598}$ Ibíd., p. 3.

599 Malagarriga y Valls muestran un ejemplo aislado de este tipo de aplicación en referencia a un fragmento de la reiteradamente utilizada en clave didáctica Suite Cascanueces Op. 71 de Tchaikovsky. Aunque referidas a la etapa de Educación Infantil, los postulados de este núcleo de actividades pueden ser fácilmente trasladables al primer ciclo de primaria: MALAGARRIGA, T. y VALLS, A. (2003): La audición musical en la Educación Infantil. Propuestas didácticas. Barcelona: Ediciones Ceac, p. 218.
} 
productos que, teniendo muy presentes los rasgos musicales en conjunción con los visuales y generados desde las aulas universitarias, pretendan adentrarse en elementos transversales tratables en los currícula de las enseñanzas obligatorias:

"Su interés era llevar un mensaje a los niños [acerca de la salud bucodental] así que planteó un corto que fuera breve, y a que utilizara una única música, sencilla, fácil de escuchar, alegre. Así llegó a la elección de 'Das Klinget so herrlich, das Kinget so schön' de La Flauta Mágica de Mozart. De hecho la obra, que es una danza cantada, comienza diciendo 'Qué armonía más maravillosa, qué armonía tan delicada' y su clara textura, homofónica y regular, corre a cargo de un coro a tres voces, las cuerdas y el instrumento estrella, el xilófono, que aporta un timbre alegre y divertido que acerca la obra a los niños, aportando el carácter buscado para el vídeo. La conjunción con la imagen aparece desde la elección de su puesta en escena: personajes de plastilina, con gran luminosidad y colorido, planos detalle o primeros planos, miradas frontales y sin angulación, etc. Además la música será la articuladora protagonista del audiovisual"600.

En todo caso, en la práctica educativa actual, tal vez sea más recurrente la evolución de materiales de uso cotidiano, tradicionalmente impresos, para trabajar los bloques de contenido musical más habituales. Así, antes de la emergente llegada de los medios audiovisuales, era común encontrar realizaciones orientadas a desarrollar la audición musical en la educación formal ${ }^{601}$. Especialmente, en el trabajo sobre el perfil auditivo del alumno, es común entender que

“el oyente óptimo sería aquel capaz de hacer una audición inteligente o activa; un oyente capacitado para percibir todos los elementos que componen una obra [por lo que] la formación hará de la apreciación musical algo asequible y fluido, atractivo, al poder materializar en el lenguaje musical las abstracciones que el

\footnotetext{
${ }^{600}$ AGUIRRE RINCÓN, S. (2009): “'Música e imagen’. Reflexiones pedagógicas en torno a una asignatura”. OLARTE MARTÍNEZ, M. (Ed.) Reflexiones en torno a la música y la imagen desde la musicología española. Salamanca: Plaza Universitaria Ediciones, pp. 758-759.

${ }^{601}$ GIMÉNEZ MORELL, M. T. (1984): La música en la escuela. Barcelona: Paidós.
} 
medio sonoro impone; sin ella, la audición se vuelve oscura e imprecisa, sobreviniendo el cansancio y pronto el abandono de la escucha",602.

En este apartado, los medios audiovisuales que permiten el seguimiento sonoro pueden implementar todo un arsenal de significatividad difícilmente alcanzable desde otros postulados. Es necesario recordar que dentro del plano didáctico la interpretación o reproducción exacta de una notación o representación musical no tiene por qué ser el fin a conseguir. La función más obvia de la notación es la conservación, pero no la única $^{603}$, por lo que en el ámbito pedagógico no hemos de caer en la tentación de perseguir el rigor exacto en la representación de los sonidos. Además, es preciso enaltecer en este apartado, por encima de otros criterios, el de operatividad. De un modo similar al que aconteció en el desarrollo de las notaciones convencionales:

"Los artistas adoptarán un tipo de representación gráfica de acuerdo a una estética y objetivo determinado en cada una de sus obras. Cada una de estas representaciones corresponderán, por tanto, a criterios individuales" ${ }^{\prime 604}$.

Existen algunas aportaciones que tratan de mostrar, por ejemplo, equivalencias entre planos visuales y elementos sonoros. En el siguiente ejemplo se muestra cómo ha sido abordada en determinadas investigaciones este fenómeno aplicado a un vídeo musical $^{605}$ :

\footnotetext{
${ }^{602}$ SAMPER RODRÍGUEZ, R. (2003): "La apreciación musical y la formación del oyente". Revista de la Lista Europea de Música en la Educación 11, p. 3. Disponible en $<$ http://musica.rediris.es/leeme/revista/samper03.pdf > [Consulta 9-II-10]. ${ }^{603}$ COOK, N. (2001): Op. cit., p. 82.

${ }^{604}$ ARIZA, J. (2003): Las imágenes del sonido. Cuenca: Servicio de Publicaciones de la Universidad de Castilla - La Mancha, p. 105.

${ }^{605}$ Ejemplo modelo utilizado como patrón aplicado a varios casos por Ana $\mathrm{M}^{\mathrm{a}}$ Sedeño Valdellós en su tesis doctoral Realización audiovisual y creación de sentido en la música: El caso del videoclip musical de Nuevo Flamenco. Málaga: Universidad de Málaga, 2003, p. 201.
} 


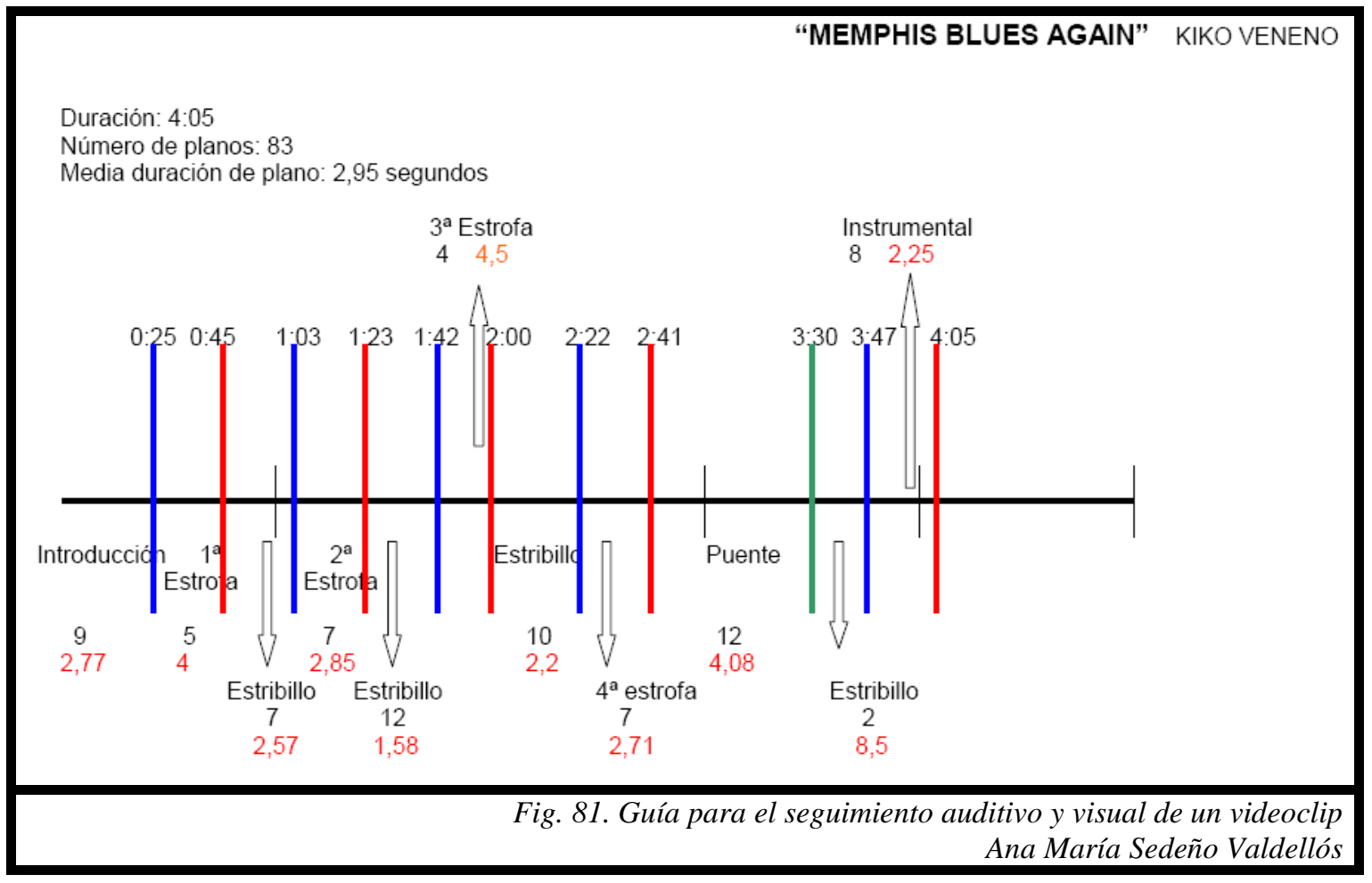

Desde la música cinematográfica, tomamos ejemplos extremadamente familiares para los docentes de educación musical, que rápidamente encuentran paralelismos entre lo que es una representación detallada de unas secuencias con el tradicional seguimiento de las audiciones. Nos estamos refiriendo a la ya clásica teoría del montaje vertical de Eisenstein y su famoso ejemplo "desplegable", que vendría a ilustrar la primera de las fases en el desarrollo secuencial, esto es, la descripción, la cual a continuación pasa a ser elaborada para acabar cobrando un significado específico ${ }^{606}$ :

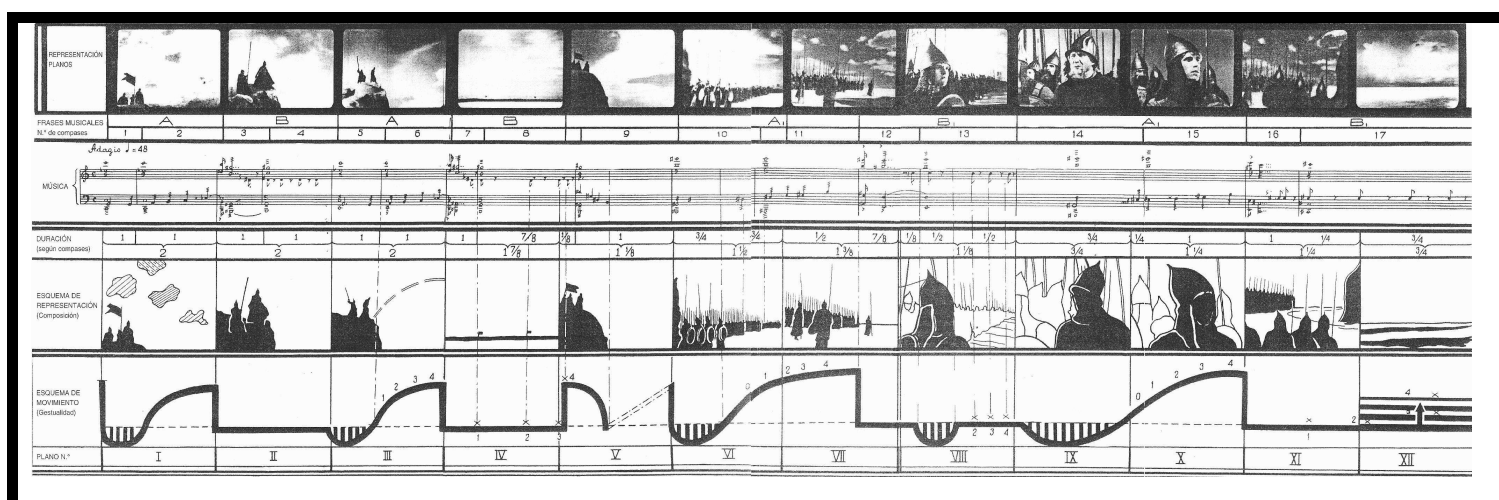

Fig. 82. Teoría cinematográfica del montaje vertical S. M. Eisenstein

${ }^{606}$ EISENSTEIN, S. M. (2001): Op. cit. v. II, pp. 168ss. 
Pretendemos hacer converger este origen mítico que se trata de apuntar desde la teoría musical audiovisual con los criterios de seguimiento sonoro propios de la metodología desarrollada por el belga Jos Wuytack ${ }^{607}$, con gran éxito en nuestro país ${ }^{608}$. Así, no es peregrino observar relaciones entre la plasmación de Eisenstein, en la cual se permite una panorámica intuitiva y completa a la vez del modo en que, verticalmente, coinciden elementos visuales y sonoros, con los musicogramas al uso, entendidos como un complemento al lenguaje musical tradicional que tienen como rasgo distintivo una representación lineal del discurso sonoro. A medio camino entre lo uno y lo otro, surgen una retahíla de vídeos con finalidad pedagógica musical que, linderos con la informática, ofrecen al docente (a pesar de que pudiera ser neófito en esos ardides) un extenso campo de recursos ya creados, aprovechables de manera muy simple. Por este hecho, la usabilidad de recursos ya generados y disponibles en la red y sus grandes potencialidades como vídeos al uso, incluimos esta categoría en la investigación, conscientes de que si penetráramos en la confección de los mismos invadiríamos el terreno de la vertiente informática de las Tecnologías de la Información y la Comunicación, lo cual no deja de ser interesante pero escapa en cierto modo a los intereses de la investigación doctoral. En palabras de García-Valcárcel Muñoz-Repiso:

"Se denominan materiales audiovisuales aquellos que integran los códigos visuales (imagen fija, imagen en movimiento) y los auditivos (lenguaje oral, música, efectos sonoros...). Los materiales de estas características más empleados en el ámbito educativo son los diaporamas, conocidos también como montajes audiovisuales (conjunto de imágenes fijas proyectadas -elaboradas manualmente o captadas mediante cámara fotográfica-, sincronizadas con una banda sonora casete en la que se ha grabado el audio-) y los vídeos (videogramas). También

\footnotetext{
${ }^{607}$ WUYTACK, J. (1998): Op. cit. Las últimas evoluciones de los musicogramas desde los postulados de este autor se encuentran en WUYTACK, J. y BOAL-PALHEIROS, G. M. (2009): Op. cit.

${ }^{608}$ Algunos ejemplos: MONTERO GARCÍA, J. (1994): "Comentario didáctico con musicograma de la obertura 1812, op. 49 de Tchaikovsky”. Música y Educación 20, pp. 59-66; HERNÁNDEZ FREIXINOS, J. (1996): "La otra partitura". Eufonía 3, pp. 121-130; GORDILLO, J. J. (2003): "Musicograma: actividad musical que aproxima a los pequeños al desarrollo personal y creativo". Eufonía 29, pp. 108115; LÓPEZ GARCÍA, N. J. (2006): "Recursos y materiales didácticos. Musicograma Mussete en Re M. del álbum de Ana Magdalena Bach (J. S. Bach)”. Música y Educación 68, pp. 181-184; HERNÁNDEZ BRAVO, J. R. (2006): "Don Quijote y su universo a través de los musicogramas escolares. Una experiencia didáctico-musical en el C. P. 'Alcázar Serrano' de Caudete (Albacete)”. CANO VELA, Á. G. y PASTOR COMÍN, J. J. (Coord.) Don Quijote en el aula. La aventura pedagógica. Ciudad Real: Servicio de Publicaciones de la Universidad de Castilla - La Mancha, pp. 211-219.
} 
podríamos introducir en esta categoría los multimedias que incorporan de forma conjunta audio y vídeo, pero por tratarse de un soporte digital, pueden ser considerados como material informático"609.

Por tanto, la búsqueda modelos que compendien y expliquen secuencias sonoras a través de lo visual ha sido tratada desde hace años ${ }^{610}$. Así, podríamos argumentar que los recursos que se presentarán a continuación beben, en cierto modo, de otros como fueron los diaporamas (secuencia de diapositivas acompañadas por sonidos), cuya estrategia de composición puede ser trasladada sin problema alguno a otros medios más trabajados hoy en día, esto es: planificación, redacción del guión, selección de diapositivas, preparación del sonido, registro, sincronización y evaluación ${ }^{611}$.

Por consiguiente, queda patencia de la importancia de la representación visual como resorte del proceso cognitivo de comprensión global de parámetros musicales. Determinados estudios basados en estos supuestos así lo corroboran ${ }^{612}$. Ahora bien, los medios audiovisuales pueden servir como una evolución de los métodos ya tradicionales de seguimiento musical minimizando sus limitaciones y potenciando sus muchos aspectos positivos ${ }^{613}$. En este sentido, es común utilizar en los centros docentes cartulinas u otros elementos que lleven impresos elementos gráficos para determinar la forma musical o cualquier otro aspecto relevante de determinadas audiciones. Esto, en ocasiones, puede acarrear dificultades derivadas de la propia realización de los ejercicios y reclama cierta precisión en la presentación del material:

\footnotetext{
${ }^{609}$ GARCÍA-VALCÁRCEL MUÑOZ-REPISO, A. (2003): Op. cit., p. 232.

${ }^{610}$ En el ámbito musical, algunos de los intentos más llamativos por vincular el aprendizaje sonoro a partir de imágenes (sin movimiento) son las aplicaciones de "música visual": DÍAZ, S. (2002): "Las nuevas músicas en la educación". Música y educación 51, p. 35. También resultan interesantes acercamientos de aspecto algo más rudimentario pero igualmente efectivos como las evoluciones de musicogramas de Teresa Carvajal, quien precisa sobre ellos fórmulas rítmicas y alturas de sonido: CARVAJAL BAÑOS, T. (1993): "Comentario didáctico a través de la dramatización y el musicograma de la Danza Macabra de Saint Saens ". Música y educación 13, pp. 41-48.; Más llamativa es la propuesta "Colormúsica": CIDONCHA, P. (2007): "Recursos y materiales didácticos. Colormúsica: nuevo método de escritura musical con números y colores". Música y educación 70, pp. 77-82.

${ }^{611}$ Tal como lo enuncian ALONSO, C. M. y GALLEGO, D. J. (1993): Op. cit., p. 74.

${ }^{612}$ TEMPESTI, L. (2008): "Nuove tecnologie ed apprendimento musicale: esperienze e estretegie di ricerca". Revista de la Lista Europea de Música en la Educación 21. Disponible en $\langle$ http://musica.rediris.es/leeme/revista/tempesti08.pdf > [Consulta 9-II-10]

${ }_{613}$ Con animaciones digitales como las presentadas por ORTEGA CARRILLO, J. A. (1998): Comunicación visual y tecnología educativa. Perspectivas curriculares y organizativas de las nuevas tecnologías aplicadas a la educación. Granada: Grupo Editorial Universitario.
} 
"la rapidez con la que se colocan las fichas facilita la percepción completa del motivo y la representación grafía será lo que tiene que ser: una imagen de una fórmula rítmica o giro melódico característicos y no una serie de signos aislados sin relación entre sî’614.

El uso de "audiográficos",615 o "musicomovigramas"616, término tal vez más acertado por la referencia más evidente a su génesis, mantiene la comprensión global de la obra al tiempo que facilita la labor de presentación de materiales. Estos recursos podrían emparentarse pues con los diaporamas, siendo una evidente variante actualizada de los mismos. Así, los musicomovigramas son un medio novedoso de seguir desarrollando aspectos curriculares tradicionales a la vez que necesarios, y quedan definidos como

"musicogramas con movimiento para el acercamiento intuitivo a la música y para el desarrollo de la apreciación musical activa de diferentes fragmentos de música",617,

El resumen de la aportación de Ramón Honorato bien podría sintetizarse en varias afirmaciones de este tipo:

"Cuando en clase de música nos limitábamos a poner a los niños una música para que la oigan pasivamente pensando que así van a descubrir su sentido, su estructura y el gusto por ella... estábamos en un error",618.

De manera tan radical como acertada, el autor somete a crítica constructiva a algunos de los planteamientos pedagógicos actuales más utilizados, como son las

\footnotetext{
${ }^{614}$ SZEKELY, K. (2006): "La enseñanza del lenguaje musical". Quodlibet 35, p. 105. La autora dedica su artículo a mostrar objetivos y procedimientos de aplicación didáctica para la enseñanza del lenguaje musical. En los métodos que describe, se percibe la importancia de las representaciones gráficas melódicas y formales, por lo que resulta de gran utilidad comparar esas con las que se pueden obtener, con otros medios, gracias al concurso del audiovisual.

${ }^{615}$ MÜLLER GÓMEZ, Á. y MORENO HEREDIA, L. V. (2000): "Enseñanza musical e Internet. Descripción de un proyecto en marcha". Revista de la Lista Europea de Música en la Educación 5, p. 4. Disponible en 〈http://musica.rediris.es/leeme/revista/mulleretal00.pdf> [Consulta 9-II-10].

${ }^{616}$ HONORATO, R. (2001): Op. cit.

${ }^{617}$ Ibíd., p. 1.

${ }^{618}$ Ibíd., p. 1.
} 
estructuras metodológicas de Wuytack, ideador de los musicogramas, para evolucionarlos. Por ello, los objetivos que plantea con este tipo de praxis son trasladables a los musicogramas con la implementación del sesgo interactivo, en aras de una mayor significatividad $^{619}$ :

- "Favorecer en los niños y las niñas el gusto por la música. Sensibilización musical en una palabra.

- Desarrollar las posibilidades que ofrece la música como fuente de formación y enriquecimiento personal tanto en el ámbito individual como social.

- Crear alternativas que apoyen el trabajo del aula en el área de música, enmarcadas dentro de la programación general.

- Desarrollo de la expresividad de manera integral y global, interactuando a la vez con la música y la plástica.

- Desarrollar una serie de actividades globalizadoras de plástica con música, animación, etc... en el camino hacia una expresión de medios múltiples."

Otro aspecto muy revelador de la importancia de este tipo de recursos es la fácil conexión con otros aspectos de la práctica musical, no sólo ya el mero seguimiento. Así, entre los ejemplos que plantea amalgama la filmación de alumnos realizando los pasos de una danza con su estructura formal, de manera que las potencialidades del resultado son mayores:

"En el caso de unos niños/as de $6^{\circ}$ crearon una coreografía sobre esa danza que ha sido el centro del musicograma para comprender la cuadratura de la obra. Grabamos en vídeo a los niños y alrededor de esta pista de vídeo montamos otra con dibujos en cuadrado según iba sonando la melodía. La finalidad era clara: ver la cuadratura rítmica y formal de las danzas populares sencillas"620.

${ }^{619}$ Ibíd., p. 2.

${ }^{620}$ Ibíd., p. 5. 
Con el ánimo de apuntalar esta vía de actuación que quedó en suspenso ${ }^{621}$, una reciente publicación conjunta pretende dar a conocer cuáles han sido las derivaciones existentes de los musicomovigramas y las posibilidades de futuro ${ }^{622}$. En resumen, estas son las posibilidades más importantes de los musicogramas en movimiento que se pueden encontrar en internet, como principal fuente de información:

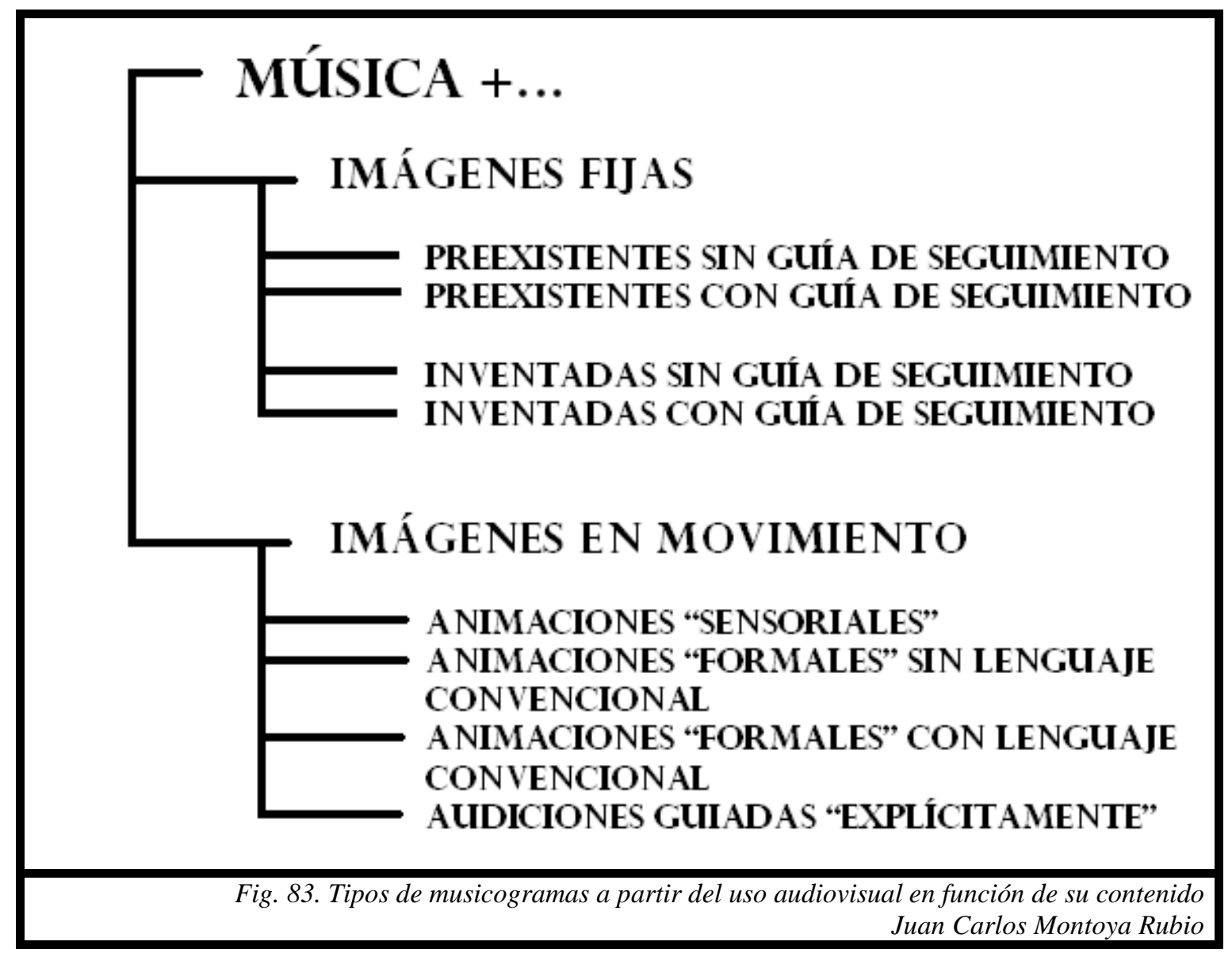

A modo de último ejemplo, aportamos un caso que trata de mostrar la evolución de los musicogramas al uso con aquellos que tienen como referente el movimiento. La generación de esquemas visuales que establezcan relaciones con el discurso auditivo es

\footnotetext{
621 Lamentablemente, la brillante idea de generar discursos audiovisuales a partir de los estáticos musicogramas no tuvo una continuidad lineal en el autor, quien nos comentaba que estos procedimientos derivaron en otro tipo de aplicaciones que, a pesar de resultar de gran atractivo para la docencia en general, se escapan un tanto de las pretensiones de nuestra investigación.

${ }^{622}$ Publicación realizada por profesores especialistas en educación musical que imparten esta materia en diferentes niveles, desde las etapas obligatorias de primaria y secundaria hasta la docencia universitaria: MONTOYA RUBIO, J.C., MONTOYA RUBIO, V. M. y FRANCÉS ARIÑO, J. M.: op. cit.
} 
una manera muy acertada de trasladar las diferentes partes formales de una audición, en tanto en cuanto la misma, para ser rentable en términos pedagógicos, precisa de un alto nivel de consciencia por parte del alumno ${ }^{623}$. No obstante, el entendimiento de la estructura auditiva a partir del movimiento guiado genera en el discente un nivel de comprensión mayor y más duradero que la escucha con un apoyo visual menos logrado. Así por ejemplo, la interiorización de las peripecias del Don Quixote de Strauss queda más patente para el alumnado si las apariciones de cada uno de los personajes que van entrando en el devenir sonoro tienen un reflejo a tiempo real en imágenes. El resultado de cómo quedarían las conocidísimas variaciones de la batalla contra los molinos de viento y la lucha contra el ejército de ovejas bien podrían asemejarse a las que siguen ${ }^{624}$ :
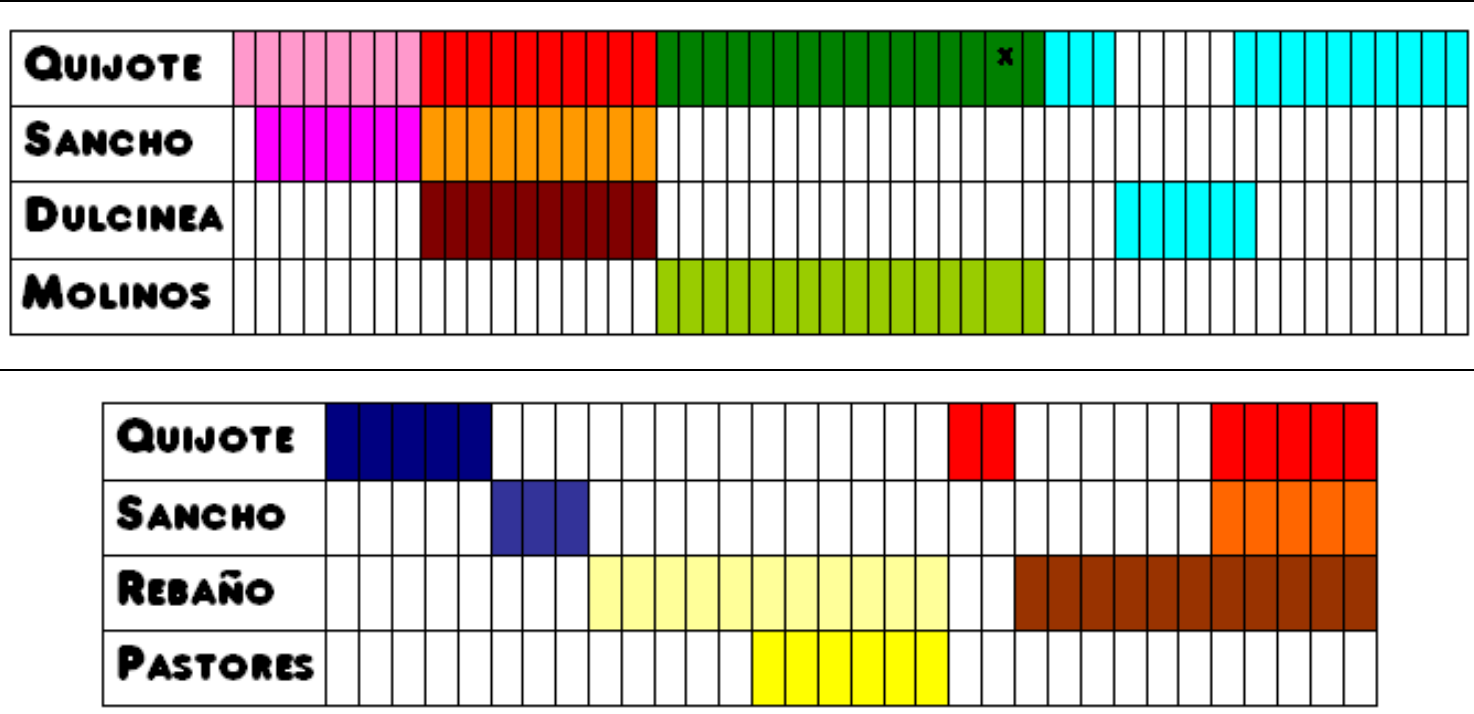

Fig. 84. Resultado final de musicogramas con movimiento a partir del poema sinfónico "Don Quixote"

${ }^{623}$ WILLEMS, E. (1963): Las bases psicológicas de la educación musical. Buenos Aires: Eudeba.

${ }^{624}$ Se muestran las entradas de los temas por compases con diferentes indicaciones de colores para facilitar al alumnado su seguimiento. Una explicación mucho más detallada de los esquemas gráficos puede encontrarse en MONTOYA RUBIO, J. C. (2006b): “Al ritmo de Rocinante: Propuesta pedagógica para el poema sinfónico Don Quixote de Richard Strauss”. CANO VELA, A. G. y PASTOR COMÍN, J. J. Don Quijote en el aula. La aventura pedagógica. Ciudad Real: Universidad de Castilla-La Mancha, pp. 221-230. En gran medida, se trata de una aplicación didáctica basada en el análisis formal de GARCÍA LABORDA, J. M. (2000): La música del siglo XX. Primera parte (1890-1914). Modernidad y emancipación. Madrid: Alpuerto. 
Las apariciones acompasadas de cada una de las circunstancias que acontecen generan en el alumnado una comprensión mayor que la escucha abstracta o guiada por medios menos rigurosos. 
MÚSICA Y MEDIOS AUDIOVISUALES.

PLANTEAMIENTOS DIDÁCTICOS EN EL MARCO DE LA EDUCACIÓN MUSICAL. Juan Carlos Montoya Rubio 


\title{
CAPÍTULO 4
}

\author{
LA APREHENSIÓN DE \\ CONTENIDOS INTERCULTURALES \\ A TRAVÉS DEL AUDIOVISUAL. \\ ENFOQUES TEÓRICOS Y \\ PROPUESTAS PRÁCTICAS.
}


MÚSICA Y MEDIOS AUDIOVISUALES.

PLANTEAMIENTOS DIDÁCTICOS EN EL MARCO DE LA EDUCACIÓN MUSICAL. Juan Carlos Montoya Rubio 


\subsection{INTRODUCIENDO CONCEPTOS BÁSICOS: \\ INTERCULTURALIDAD E INCLUSIÓN COMO MARCO \\ EDUCATIVO PARA LOS MEDIOS AUDIOVISUALES}

\section{Escuela inclusiva: hacia la vivencia de la interculturalidad.}

El presente capítulo pretende ser una reflexión que, como todo lo expuesto hasta el momento, articule la teoría con la práctica para mostrar marcos de actuación válidos dentro de una enseñanza musical real. Por ello, la primera de las consideraciones que enunciamos al acotar este bloque es la de instaurar las propuestas dentro de los paradigmas educativos que se están mostrando con mayor vigor en los últimos tiempos en nuestro país, la interculturalidad, eje vertebrador de un buen número de propuestas en todas las áreas de conocimiento, y la inclusión, la cual, vinculada directamente con la anterior, pretende abrigar las bondades de ella y entender el centro docente como un contexto global de múltiples relaciones que han de ser tenidas en cuenta. En nuestro intento por aproximar las estrategias educativas al mundo audiovisual, la siguiente reflexión guía la filosofía de esta parte de la investigación:

"La importancia que la escuela tiene en la formación de los alumnos en los medios de comunicación, viene no sólo porque generen actividades específicas formativas, sino también por el modelo social, cultural y curricular en el que se desarrolle la escuela. Así, la forma en que la escuela socializa a los estudiantes y los métodos y estrategias docentes que utiliza en su formación, parecen también determinar el tipo de interacción que posteriormente 
establecerán con los medios. Una escuela donde el método de enseñanza es autoritario y se socializa al alumno para obedecer las normas, tiende a formar alumnos que consumen de manera no crítica la información que les llega a través de los medios de comunicación" 625 .

En sintonía con lo expuesto, consideramos oportuno incluir, tras la determinación de los métodos y técnicas para la inclusión del audiovisual, el tratamiento de contenidos no musicales a partir, paradójicamente, de la música del audiovisual. Si hasta ahora la principal pretensión fue la de abordar el desarrollo auditivo desde los propios parámetros que podían desprenderse del arte musical en conjunción con el resto de lenguajes que forman el audiovisual, en este momento entendemos como crucial hacer patente que, por medio de la música, también se puede acceder a la observación de la educación en valores, piedra angular del proceso de enseñanza-aprendizaje en los días que corren. Por tanto, exploraremos el modo en que la música de los medios audiovisuales puede ser orientada hacia el tratamiento transversal, ocupándose de aspectos como el trato igualitario con la alteridad o la compensación educativa que puede darse en un sistema como el nuestro, el cual atiende a un colectivo de alumnos muy heterogéneo.

En consecuencia, en las líneas siguientes abordaremos la definición tanto de la interculturalidad como de la inclusión para adecuarlas a nuestras finalidades didácticas. Por este último motivo, no ahondaremos en las muchas interioridades de ambos conceptos (no procedería en el caso que estamos trabajando), sino que apuntaremos las cualidades de uno y otro término para atender al modo en que esas virtudes pueden ser descubiertas y fomentadas dentro del formato audiovisual y, más concretamente, a través de su banda de sonido. De este modo, la interculturalidad nos interesará en tanto en cuanto será un marco de comprensión global del mundo por medio de la praxis educativa, mientras que el trabajo inclusivo será enfocado como aquel que nos invite a compensar desigualdades derivadas de factores culturales dentro del aula. No es novedoso el entendimiento de la música como una esfera que ha de ser tratada desde una óptica social, sino que la imbricación del hecho sonoro con el resto de los dominios

${ }^{625}$ CABERO ALMENARA, J (1994): “Nuevas tecnologías, comunicación y educación”. Comunicar 3, pp. 14-25. 
culturales es una práctica conocida en educación musical ${ }^{626}$. Todo ello, por tanto, involucrando tácitamente a la educación musical en el proceso de socialización del que participa $^{627}$, desde el valor que se otorga a las convenciones musicales y en función de la carga de significados simbólicos que pueden subyacer de su interpretación.

El primero de los ámbitos, el plano intercultural, será planteado con mayor intensidad, ya que las prácticas que se llevan a cabo bajo su amparo son más numerosas y dejan entrever más características para la discusión. En ese caso nuestro interés fundamental será el de rastrear el ideario concreto que una aplicación musical determinada puede apoyar dentro del discurso audiovisual, de modo que la música de cine (esencialmente pero no de manera exclusiva) connote más allá del cumplimiento de sus tópicas funciones estructurales o evocadoras, haciendo por medio de una música esperada y accesible que el espectador sea cómplice de la situación que se está narrando.

La inclusión será abordada desde el prisma de la acción compensatoria, realidad emergente desde algunas administraciones educativas que pretende la abolición, en la medida de lo posible, de las trabas que limitan las posibilidades de ciertos alumnos por su origen foráneo o dificultades sociales varias. Como ámbito en el que aún se está experimentando, nuestra aproximación será mucho menos profunda que la anterior, ya que por tratarse de un aspecto en periodo de definición y formación nos limitaremos a colaborar en esa configuración, aportando ideas desde el plano de la música del audiovisual. En esencia, a partir de las aplicaciones concretas que llevaremos a cabo, se tratará de paliar la inclinación que hace que los alumnos que no responden a las características estándar suelan pasar a formar parte de algún grupo con el que manejarnos y, por consiguiente, manejarlos en nuestras mentes. Generalmente, quedan definidos por la etiqueta de aquellos que no pueden hacer algunas cosas y precisan de otras atenciones porque sus habilidades cognitivas son inferiores, desconocen la lengua, tienen problemas de estructuración familiar u otro tipo de factores (con toda la carga peyorativa que puede acarrear tal encasillamiento). Conviene recordar que en la mayoría

\footnotetext{
${ }^{626}$ Notorio en las obras como la de REGELSKI, T. A. (1980): Principios y problemas de la Educación Musical. México: Diana.

${ }^{627}$ VILAR i MONMANY, M. (2004): "Acerca de la educación musical”. Revista de la Lista Europea de Música en la Educación 13. Disponible en <http://musica.rediris.es/leeme/revista/vilar04.pdf > [Consulta 9-II-10]
} 
de las ocasiones, estas categorizaciones se unen a otro tipo de percepciones estereotipadas que pueden tener su base fuera de las aulas (especialmente aunque no únicamente gracias a los medios de comunicación), y acaban filtrándose de manera inconsciente al resto de alumnos ayudando a perpetuar las imágenes que van a acarrear los primeros.

Las soluciones que aportan los profesionales de la educación parten, en muchas ocasiones, de la buena voluntad y el espíritu de ayuda para quien lo necesita. Contrariamente a lo que se pretende, se puede llegar a acentuar la diferencia en lugar de tratarla con naturalidad. Parece claro que la interculturalidad ha de erigirse como uno de los principios básicos de la enseñanza, pero entre sus virtudes encontramos su principal problema: estamos ante aplicaciones sujetas en una realidad polimórfica que, utilizada desde planteamientos equivocados, puede desvirtuarse. Para nuestros intereses, es evidente que la mejor definición de interculturalidad será aquella que coincida mayoritariamente con diálogo intenso, esto es, de igual a igual, dando la voz y reconociendo con la misma importancia el contenido del discurso ajeno que el propio, en condiciones de efectiva paridad. Desde estos parámetros, no es tan importante el razonamiento en las aulas acerca del contenido de la interculturalidad como la propia vivencia del hecho intercultural a través, en primer lugar, de actividades adaptadas a los diferentes niveles de aprendizaje $\mathrm{y}$, posteriormente, haciendo de los valores interculturales su propia manera de entender la cotidianeidad.

\section{¿Qué interculturalidad?: Visualizando la alteridad.}

Como venimos exponiendo, nuestra prioridad será la de subrayar los aspectos multiculturales presentes en manifestaciones audiovisuales que rapten la capacidad expresiva de la alteridad y elaboren discursos desde nuestros parámetros para retroalimentar la posición de los "Unos" frente a los "Otros". Dedicaremos estas reflexiones preliminares a ubicar aquellas características interculturales que, con posterioridad, serán objeto de análisis en clave pedagógica.

Hace años que la interculturalidad o interculturalismo se han convertido en una seña de identidad de aquellas prácticas que pretenden ser interesantes o contemplar con rigor cualquier planteamiento didáctico. En este sentido, se suele asumir que la calidad 
y potencial de los procedimientos pedagógicos aumenta en el mismo grado en que se encuentran visos de actividad intercultural. No obstante, el término no es entendido del mismo modo en todas las circunstancias, ni tiene correspondencia exacta desde el imaginario de un docente al de otro. Esto es debido, fundamentalmente, al constante cruce de informaciones y delimitaciones terminológicas que acaban desvirtuando el verdadero significado de multiculturalismo e interculturalidad, ambas nociones inscritas en la sociedad pluricultural pero una, la primera, aludida para la mera constatación de la diferencia (por supuesto, dejando al margen muchos matices de un término visto en perspectiva histórica ${ }^{628}$ ) y otra, por el contrario, fomentando el trasvase y el contacto ${ }^{629}$, lo cual ofrece a los docentes un tratamiento potencial más fructífero ${ }^{630}$.

De este modo, la interculturalidad que pretendemos alcanzar parte del análisis y la interpretación de las situaciones reales para la elaboración de soluciones concretas en una sociedad específica, que vive cambios significativos. Para ello, quizás se precise el concurso de científicos sociales en el organigrama que articula el engranaje educativo aunque, entretanto, la figura que más se asemeja por sus condiciones laborales sea la del profesor $^{631}$. Por todo ello, no es baladí otorgar la importancia justa a la formación docente referida a estas manifestaciones sociales, ya que tal vez sea el mejor posicionado de aquellos agentes que intervienen en el proceso de enseñanzaaprendizaje para realizar juicios certeros sobre la situación real de las relaciones que se establecen entre las paredes de sus aulas, con el agravante de ser el único capaz de desarrollar un trabajo de campo prolongado esgrimiendo la observación participante como fundamental arma de modificación y orientación de conducta. Se trata de "estar

\footnotetext{
${ }^{628}$ Llegando por ejemplo a la lucha por el cambio en contextos deprimidos: TURNER, T. (1993): “Anthropology and Multiculturalism”. Cultural Anthropology 8, p. 412.

${ }^{629}$ En la literatura en castellano, son recurrentes estos posicionamientos en las trabajos como: BARTOLOMÉ PINA, M. (2002): Identidad y ciudadanía. Un reto a la educación intercultural. Madrid: Narcea; JULIANO, D. (1993): Educación intercultural. Escuela y minorías étnicas. Madrid: Eudema.

${ }^{630}$ El trasvase entre los términos multicultural e intercultural muestra hasta qué punto han podido entenderse como términos no tanto limítrofes sino incluso concomitantes. Por ejemplo, Simmons se remonta a los orígenes del multiculturalismo y lo aborda desde una perspectiva más reivindicativa que la que hemos señalado: SIMMONS III [sic], R. (2007): "La educación multicultural". Actas de las ponencias del I Congreso Mundial de Educación de la Infancia para la Paz. Albacete: Asociación Mundial de Educadores Infantiles, pp. 81-86. Por ello, es importante remarcar que ante la imposibilidad de una definición unívoca tendamos a utilizar ambos términos de la manera que, desde nuestro punto de vista, resulta más funcional: tomando la multiculturalidad como una situación "de hecho" y la interculturalidad como un campo de influencias mutuas. Un breve repaso histórico centrado en la educación musical revela dichas incursiones en una y otra terminología: GIRÁLDEZ, A. (1997): "Educación musical desde una perspectiva multicultural: Diversas aproximaciones". Trans Iberia 1. Disponible en <http://www.sibetrans.com/trans/transiberia/giraldez.htm> [Consulta 9-II-10]

${ }^{631}$ Ya hicimos referencia a esta situación en el Capítulo 2.
} 
ahí" en el sentido más antropológico del término ${ }^{632}$, analizando, interpretando, valorando la capacidad de una u otra estrategia y, en su caso, actuando con unos u otros medios.

En cierta manera, puede entenderse que la realidad social contemporánea, con una movilidad de personas e información desconocida hasta el momento, remita inevitablemente al tratamiento de la diversidad cultural, ya que trabajar dentro de esta maraña de conexiones exige, de manera más o menos voluntariosa, involucrarse en la sociedad multicultural $^{633}$. Además, los medios audiovisuales forman parte, como el resto de manifestaciones actuales, de la red que urde estrategias de conocimiento de la alteridad y nutre y retroalimenta percepciones preconcebidas desde infinidad de planos. Haciendo converger la interconexión del mundo y el consecuente (supuesto) conocimiento global que otorga, con el tratamiento de la diversidad en las aulas (mediatizado en ocasiones con las controversias que crea la inmigración así como las relaciones sociales ${ }^{634}$ ) surge la práctica concreta que el docente lleva a cabo la cual, desafortunadamente, no siempre puede tildarse como intercultural.

En concordancia con las reflexiones anteriores, los recursos que se presentan al alumno han de plantear un análisis de la experiencia personal para, a partir de él, enfatizar aquellos elementos perceptivos que no tomamos en consideración porque, ante ellos, solemos poner en marcha los típicos mecanismos de defensa que evitan el trato igualitario con el Otro. El proceso que adoptamos parte de determinados postulados que pretenden "educar la mirada" "635: es aquel que surge de la percepción de un hecho audiovisual para descubrir qué trasluce tras de sí, qué nos invita a pensar y sentir y de qué modo esas ideas llevan consigo valoraciones. Se tienen en cuenta pues las circunstancias generales que hacen que dichas valoraciones respondan a un perfil determinado y si ello ha acarreado actos específicos en nuestras vidas cotidianas. La reconstrucción de este esquema habría de potenciar actitudes tolerantes derivadas del

\footnotetext{
${ }^{632}$ GEERTZ, C. (1989): El antropólogo como autor. Barcelona - Buenos Aires - Madrid: Paidós, p. 14.

${ }^{633}$ Como manifiesta Ulf Hannerz en su segundo capítulo "Lo local y lo global: continuidad y cambio": HANNERZ, U. (1998): Conexiones transnacionales. Cultura, gente, lugares. Madrid: Cátedra, pp. 3354.

${ }^{634}$ Octavio Vázquez Aguado resalta que, ante una hipotética falta de contacto intercultural, la construcción de la alteridad suele llevarse a cabo por las imágenes transmitidas mediáticamente. Cfr. VÁZQUEZ AGUADO, O. (1999): "Negro sobre blanco: inmigrantes, estereotipos y medios de comunicación". Comunicar 12, pp. 55-60.

${ }^{635}$ GARCÍA-RINCÓN DE CASTRO, C. (2006): Educar la mirada: Arquitectura de una mente solidaria. Madrid: Narcea, p. 22.
} 
reconocimiento de la alteridad, asumiendo como propias reflexiones centradas en los cauces por los que transita la información que llega a docentes y alumnos:

"Un modelo educativo fundamentado en un diagnóstico de la realidad actual y en constante renovación debería encontrar cauces para la interacción multicultural en las aulas. El problema no está en la diversidad cultural sino en el proyecto educativo que la asume y la utiliza como rasgo distintivo de la formación integral del alumnado en un mundo cada vez más global”636.

En función del enfoque plasmado en las líneas precedentes, las principales pretensiones que nos proponemos para un trabajo didáctico que pretenda fomentar prácticas de corte intercultural observarán, al menos, los siguientes postulados ${ }^{637}$ :

- El estímulo de la capacidad de empatía por parte del alumnado, ya que será sumamente difícil aceptar la convivencia y la figura del Otro sin ser capaz de ubicarse en su posición ${ }^{638}$. La empatía, por tanto, luchando frontalmente contra la infravaloración.

- El reconocimiento de la capacidad expresiva y dialéctica de la alteridad, de modo que se asimile que la posición del interlocutor puede enriquecer la relación entre ambos. Desde esta perspectiva, el Otro no sólo existe sino que además vive e incide en una misma realidad que forja en la interacción con el resto.

- El fomento del aprendizaje dialógico ${ }^{639}$, entendido como un intercambio de experiencias toda vez se han abolido asimetrías y avanzado en la reproducción

\footnotetext{
${ }^{636}$ PADRÓN FRAGOSO, J., PLATA SUÁREZ, J. R., MARTÍN TEIXÉ, G., QUINTERO RODRÍGUEZ, S. y GÜEMES ARTILES, R. M. (2009): "Análisis descriptivo de la interacción cultural en centros de Educación Primaria”. ROIG VILA, R. (Dir.) Investigar desde un contexto educativo innovador. Alicante: Marfil, p. 323.

${ }^{637}$ MONTOYA RUBIO, J. C. (2007b): “¡Qué viene el lobo! Interculturalidad para caperucitas feroces y lobos buenos a través de la música”. Actas de las comunicaciones del I Congreso Mundial de Educación de la Infancia para la Paz. Albacete: Asociación Mundial de Educadores Infantiles, pp. 239-250.

638 JORDÁN SIERRA, J. A. (2003): "Educar para la convivencia intercultural en sociedades multiculturales". Revista de Educación (núm. extraordinario de 2003), pp. 213-239.

${ }^{639}$ Teorizado esencialmente, para comunidades de aprendizaje, por FLECHA GARCÍA, J. R. (2005): "Calidad para todos y todas: transformación de centros educativos en comunidades de aprendizaje". Actas del III Congreso de Atención a la Diversidad. Elche: Cefire d'Elx, pp. 79-84. Entre las últimas aportaciones: AUBERT, A., FLECHA, A., GARCÍA, C., FLECHA, R. y RACIONERO, S. (2008): Aprendizaje dialógico en la sociedad de la información. Barcelona: Hipatia.
} 
sistemática de patrones gracias a la "conciencia práctica"640, fuente de superación de parámetros asumidos sin reflexión previa.

- La aceptación de un proyecto social compartido. Este aspecto, altamente complicado en determinados $\operatorname{casos}^{641}$, puede esgrimirse como la mayor de las dificultades a superar, ya que pone en liza la incoherencia entre algunos valores a transmitir en el ámbito docente y otros recibidos a través de la educación no formal. Así, aunque la tolerancia o la solidaridad están sólidamente instaurados en los libros de texto de educación musical ${ }^{642}$, es preciso establecer puentes que lleguen más allá de las paredes del centro escolar.

- La supresión de prejuicios que hagan portador al Otro de valores que pudieran resultar conflictivos con los axiomas vitales de la sociedad de acogida ${ }^{643}$ y que, generalmente, no son sino entelequias que evocan a una irrealidad construida y promueven juicios apriorísticos ${ }^{644}$.

- La generación de marcos de aprendizaje que anclen sus fundamentos en la vivencia y la interactividad, ya que la contemplación y el estatismo huyen por definición del contacto directo e imposibilitan el derruir las fronteras erigidas durante años en sólidas disposiciones mentales.

\section{Prácticas musicales e interculturales: querer y poder.}

Desde los fundamentos apuntados, la interculturalidad en el marco de la escuela inclusiva no se enseña, se vive y no se aprende, se aprehende, por lo que no es tanto un ejercicio de ardua elaboración cognitiva como de asimilación. Con todo ello, y aunque

${ }^{640}$ GIDDENS, A. (1998): "El estructuralismo, el post-estructuralismo y la producción de la cultura". GIDDENS, A., TURNER, J. et al. La teoría social hoy. Madrid: Alianza Universidad, p. 279.

${ }^{641}$ BARTOLOMÉ PINA, M. y CABRERA RODRÍGUEZ, F. (2003): "Sociedad multicultural y ciudadanía: hacia una sociedad y ciudadanía interculturales". Revista de Educación (núm. extraordinario de 2003), pp. 33-56.

${ }^{642}$ Como expone en un estudio para la educación primaria VICENTE NICOLÁS, G. (2007): "Música y valores: diálogo, tolerancia y solidaridad en las canciones infantiles". Música y educación 71, pp. 17-44.

${ }^{643}$ JABARDO VELASCO, M. (2000): "Migración, multiculturalismo y minorías étnicas en España". Anales del Museo Nacional de Antropología VII, pp. 139-164.

${ }^{644} \mathrm{De}$ hecho, una de las principales rémoras de las aplicaciones que persiguen la interculturalidad como axioma de actuación es el modo de superar las contradicciones a que el fenómeno migratorio provoca, en tanto en cuanto se teoriza sobre aspectos que son palpables y con los que se conviven. Estas contradicciones son puestas sobre el tapete en: GARCÍA MARTÍNEZ, A. y COBACHO INGLÉS, M. L. (2005): "El fenómeno migratorio y las respuestas que provoca. La perspectiva intercultural". Educatio Siglo XXI 23, pp. 105-124. 
existen corrientes metodológicas más sólidas fuera del contexto español ${ }^{645}$, el trabajo sobre músicas procedentes de otras culturas en nuestro entorno más inmediato es un hecho que, aunque minoritario, puede ser encontrado en determinadas publicaciones ${ }^{646}$, algunas de las cuales han acuñado curiosos términos al respecto, como "educación intermusical"647. Más aún, propuestas específicas muestran que integrar la interculturalidad, entendida como diálogo, a través de la música es factible ${ }^{648}$, buscar que esa integración curricular se haga a partir de experiencias de desarrolladas sobre el campo, en colegios de enseñanza obligatoria es también posible ${ }^{649}$, y hacerlo fomentando el uso de las Tecnologías de la Información y la Comunicación, no sólo sigue siéndolo sino que existen ejemplos didácticos que lo constatan ${ }^{650}$.

No obstante, en el simple hecho de que se trate de una práctica "posible" -que no fiscalizadamente obligatoria o preceptiva- encontramos una dificultad añadida, ya que las claves que identifican el trabajo del profesorado en este contexto inclusivo parten con mayor frecuencia de una actitud voluntariosa, una exigencia ética y personal ante una situación a la que tiene que dar respuesta, que no de un protocolo sistemático en todos los casos. Esta traba supone que el tratamiento inclusivo e intercultural pueda entenderse como aquella estrategia que responde a las necesidades de un momento puntual (de manera que se suele asumir "a medias" el discurso del relativismo cultural),

\footnotetext{
${ }^{645}$ Desde una formación de corte antropológico, destacan los trabajos de P. S. Campbell, cuyas líneas centrales publicaciones más destacadas son descritas por IBARRETXE, G. (2007a): "Patricia Shehan Campbell". DÍAZ, M. y GIRÁLDEZ, A. (coord.) Aportaciones teóricas y metodológicas a la educación musical. Barcelona: Graó, pp. 133-140.

${ }^{646}$ Entre las más recientes, cfr. VALLS i CASANOVAS, A. y BATTLE i PANADÈS, A. (2008): "Las músicas del mundo en el aula". ÁLAMO, A. y LUCEÑO, M. Actas del I Congreso de Investigación y Educación Musical. Madrid: Enclave Creativa Ediciones, pp. 89-99. Las autoras señalan especialmente dos tipos de aportaciones al trabajar con "músicas del mundo", incluyendo en éstas las occidentales, por un lado elementos sociales como la educación por la diversidad y la apertura al mundo y, por otro, musicales como la oferta de nuevos contenidos que acarreen nuevas líneas de trabajo. Con algo más de antigüedad pero igualmente atractiva es la propuesta de LAUCIRICA, A. (2000): "Limitaciones perceptivas que obstaculizan la introducción de mensajes sonoros de otras culturas en el currículo musical". Eufonía 18, pp. 90-97.

${ }^{647}$ ORTIZ MOLINA, M. A. y OCAÑA FERNÁNDEZ, A. (2004): “¿Música intercultural o interculturalidad?". Música y educación 58, pp. 51-66.

${ }^{648}$ MORALES, L. (2005): “Música para la integración y el mestizaje”. Eufonía nº 33, pp. 84-92.

${ }^{649}$ Como propone NADAL FERRERO, N. (2007): Músicas del mundo. Una propuesta intercultural de educación musical. Barcelona: Horsori; Asimismo, entre las últimas experiencias musicales publicadas que tratan de extraer el sustrato intercultural a partir de la vivencia destacamos: LLOPIS, E. (2009): “Fills de Kassim' un musical para educar en la convivencia cultural”. Eufonía 47, pp. 104-116; GONZÁLEZ MEDIEL, O. (2010): "Una experiencia de currículum musical intercultural". Música y educación 81, pp. 18-33.

${ }^{650}$ SÁNCHEZ BARRASA, R. y ARGUÍS REY, R. (2003): "La educación intercultural en el área de música: un proyecto de innovación e investigación educativa”. Música y Educación 54, pp. 57-72.
} 
y no tanto a la constatación de una filosofía de enseñanza global, que filtre las necesidades del mundo exterior por las paredes de los centros docentes.

El hecho de amalgamar los sonidos procedentes de los medios audiovisuales con la propia docencia de la educación musical implica enfocar de manera novedosa la práctica educativa, en tanto en cuanto suele ser habitual entender que las prácticas interculturales en esta materia han de fundamentarse en la utilización de escalas, ritmos o canciones procedentes de latitudes cuanto más lejanas mejor. No obstante, la raíz verdaderamente intercultural de este tipo de procedimientos no estriba tanto en la praxis que realicen los propios alumnos sobre esas melodías (instrumentaciones, prosodias, danzas...) como en el trabajo de rastreo de información y vivencia del hecho sonoro a partir del conocimiento razonado. En este sentido, conviene no etiquetar bajo el amparo de la interculturalidad aquellas actividades que simplemente se dediquen a constatar la existencia multicultural de manera redundante sino que, para que ese calificativo sea aplicado con corrección, habrá que centrarse en las que alienten los vínculos comunicativos entre iguales, entendidos como una necesidad de formación integral de la persona. Liora Bresler identifica perfectamente ese problema:

"La inclusión de músicas y temas multiculturales refleja su tratamiento en la sociedad: a menudo una exposición superficial, más que interpretativa o experiencial, a músicas de otras culturas. Tanto la enseñanza en el aula como las actuaciones para festividades incluyen canciones presentadas de forma descontextualizada, o con un 'leve' contexto factual (en vez de experiencial). Esta visión estrecha de la multiculturalidad refleja una obligada postura "cosmética", más que una actitud curiosa de reconocimiento de la complejidad que se basa en las experiencias personales de los alumnos" ${ }^{\prime 651}$.

En concordancia con lo anterior y de manera metafórica, se puede argumentar que no es un concierto didáctico aquel al que asisten niños, sino el que está pensado, preparado y orientado para esos mismos niños que sacan un provecho de él. En este mismo sentido, no todas las prácticas escolares que reciben la catalogación de "cultural"

${ }^{651}$ BRESLER, L. (2004): Op. cit., p. 16. 
remiten inexcusablemente a diálogo cultural, esto es, a interculturalidad. Ya apuntamos que este último término ha de articularse como una estrategia de aprendizaje global, inclusiva si se quiere, que no frene sus aspiraciones en reconocer la relevancia de la matriz cultural de una u otra sociedad, sino que interactúe con la misma y forme, desde ese punto de contacto, una nueva relación recíproca y simétrica. Las prácticas que, desde el aula de música, inciden el conocimiento de otras culturas musicales, sus instrumentos y modos de expresión y comunicación ${ }^{652}$, han de completarse con un importante apartado de interacción, para sobrepasar la evidencia del multiculturalismo e introducirse en la necesidad de la interculturalidad:

"La música contribuye a la definición de significados ideológicoculturales y sentidos autoidentitarios dentro de la comunidad o grupo social. Además, para que la educación musical tenga un verdadero carácter humanista, debe adentrarse en el estudio y las prácticas musicales de culturas y estilos diversos que provoquen la ampliación de miras y el autoanálisis" ${ }^{\circ 53}$.

Ello provocará, además, la superación de la falacia según la cual las sociedades (indistintamente idealizadas como más o menos avanzadas) siguen un curso unidireccional, y suponen departamentos cerrados e impermeables al exterior, de manera que se desdibuje el significado de la propia cultura como ente maleable y difícilmente identificable en un poseedor, sino que se trata de un concepto que vive y tiene sentido en las situaciones de relación, formando entonces su propia silueta.

Con todo ello el papel de los medios audiovisuales puede y debe ser destacado. Con frecuencia, muchas de las reticencias que dichos medios han experimentado a la hora de ser insertados en el discurso educativo provienen de la manipulación interesada a que pueden ser llevados y a la inabarcable tipología de actitudes susceptibles de

\footnotetext{
${ }^{652}$ Elementos sugeridos por REAL VALCÁRCEL, J. L. (2000): "La música y la solidaridad con los pueblos". Revista de la Lista Europea de Música en la Educación 5. Disponible en $<$ http://musica.rediris.es/leeme/revista/real00.pdf > [Consulta 9-II-10]

${ }^{653}$ Líneas que describen algunas de las aportaciones de Elliot al respecto de la didáctica de la música: IBARRETXE, G. (2007b): “David J. Elliot”. DÍAZ, M. y GIRÁLDEZ, A. (coord.) Aportaciones teóricas y metodológicas a la educación musical. Barcelona: Graó, p. 143.
} 
propagación ${ }^{654}$. De todos estos aspectos se pueden extraer conclusiones pedagógicas valederas, ya que tanto la observación de los criterios relativistas como la catarsis que supone desmontar las estratagemas que acallan al Otro pueden ser, mediada una correcta orientación, resortes de aprendizaje en valores. Además, como es defendido a lo largo de toda la investigación, siempre será una buena idea aproximarnos a los códigos utilizados por los propios alumnos, mostrando cómo a menudo los propios medios de conocimiento esconden intenciones más o menos aviesas. De este modo, un trabajo intercultural ejemplar será aquel que sea capaz de decodificar, desde el sentido común y el análisis razonado, los contenidos que implican la activación de fobias, porque ahora todos somos multiculturales ${ }^{655} \mathrm{y}$, dentro de la obviedad que representa la cohabitación se hace necesaria un posicionamiento crítico dentro del engranaje social. A modo de ejemplo, sirvan prestadas las ideas de Juana M. Casado ${ }^{656}$ quien, hablando de los cambios que se debieran perpetrar en las programaciones televisivas con el ánimo de dotarlas de un matiz más adecuado al alumnado que atendemos, titula "La televisión que queremos..., si realmente queremos lo que decimos", apostillando la necesidad de la superación hipócrita de aspectos aceptados por cómodos o no reflexionados.

En este sentido, y dentro de la amplia gama de posibilidades, la parcela intercultural que nos interesa en un trabajo de este tipo es aquella que consiga, sin tapujos, dar la voz al Otro, ofreciendo y aceptando instrumentos de entendimiento que no se conciban como laxas aproximaciones a la coexistencia multicultural sino que se abran a las necesidades propias y de la alteridad. Todo ello, sin duda, supone impulsar un giro copernicano a elementos, con frecuencia, aceptados a regañadientes en determinados sectores de la sociedad, ya que tan dañino resulta ceñir la faceta intercultural a atestiguar positivistamente la presencia de "equis" sociedades culturales

\footnotetext{
${ }^{654}$ Entre las escasas referencias a la manipulación de los lenguajes que integran el audiovisual destacamos la referencia que, centrada en los dibujos animados, realiza ARÓSTEGUI PLAZA, J. L. (2009): "La banda sonora en los dibujos animados". OLARTE MARTÍNEZ, M. (Ed.) Reflexiones en torno a la música y la imagen desde la musicología española. Salamanca: Plaza Universitaria Ediciones, p. 561. El propio autor constata la escasez de estudios que se centren en el significado que transmiten los distintos códigos audiovisuales, citando como excepción también para los dibujos animados el análisis de Austen, sobre la manipulación en torno al lenguaje verbal, las imágenes y la banda de sonido: AUSTEN, J. (2002): "Hidey Hidey Hidey Ho... Boop-Boop-A Doop! The Fleischer Studio and Jazz Cartoons". GOLDMARK, D. y TAYLOR, Y. (Eds.) The Cartoon Music Book. Chicago: A Capella, pp. 61-66.

${ }^{655}$ Sentencia lacónica de Glazer que compendia perfectamente su argumentario y, trasladado a nuestro plano didáctico, conserva todo su potencial. Cfr. GLAZER, N. (1997): We Are All Multiculturalists Now. Cambridge: Harvard University Press.

${ }^{656}$ CASADO SALINAS, J. M. (2005): "La televisión que queremos... si realmente queremos lo que decimos". Comunicar 25, pp. 71-77.
} 
diferenciadas en un contexto educativo, como limitarla a la ayuda al escolar inmigrante en aras de su integración y rápida asimilación. Será preciso pues aprovechar que la música del audiovisual ofrezca marcos de actuación que, como expondremos ejemplificadamente, reivindiquen el análisis de la generación de los discursos como principio de la igualdad, en tanto en cuanto faciliten la empatía en el alumnado y, de manera consecuente, muestren nuevos matices significativos que hagan que valga la pena interpretar la realidad desde un prisma alternativo al que la ausencia de reflexión nos remite. Por este motivo el potencial del audiovisual es tan grande, porque da acceso desde el mundo de las representaciones y las convenciones al mundo real.

En todo caso, constatamos que es creciente el interés por desarrollar planificaciones educativas que persigan el aprendizaje de igual a igual, tal vez auspiciadas por el galopante crecimiento de realizaciones audiovisuales que, desde el contexto español, abordan el tema del contacto cultural ${ }^{657}$ :

"Cada vez son más las iniciativas y productos audiovisuales que procuran un mundo en diálogo, que presentan alternativas y reflexiones para lograr el encuentro intercultural. La productora 'Tus ojos', se fundó con el objetivo de crear un marco de referencia en el mundo audiovisual, capaz de conjugar el lenguaje del cine con la sensibilización sobre problemas actuales de la infancia. Ha apostado por la tecnología digital, para la filmación y para la distribución, realizada en centros educativos y culturales, con el fin de que el film y las situaciones que lo hacen posible, se analicen y procuren la reflexión y la concienciación"

\footnotetext{
${ }^{657}$ Aspecto puesto de manifiesto, por ejemplo, en publicaciones como GORDILLO, I. (2007): "El diálogo intercultural en el cine español contemporáneo: entre el estereotipo y el etnocentrismo". Frame 1. Disponible en $<$ http://fama2.us.es/fco/frame/new_portal/textos/El\%20di\%E1logo\%20intercultural\%20en\%20el\%20cine \%20espa\%F1ol\%20contempor\%E1neo\%20editado.pdf> [Consulta 9-II-10]; VILLAR HERNÁNDEZ, P. (2002): "El Otro: conflictos de identidad en el cine español contemporáneo". Graduate Romanic Association 6. Disponible en <http://ccat.sas.upenn.edu/romance/gra/WPs2002/paz 1.htm> [Consulta 9II-10].

${ }^{658}$ MARTÍNEZ-SALANOVA SÁNCHEZ, E. (2009): "Medios de comunicación y encuentro de culturas: propuesta para la convivencia”. Comunicar 32, p. 228.
} 
No obstante, al igual que se ha hecho a lo largo de toda la investigación, es conveniente reflexionar del mismo modo acerca de los modelos de aplicación pedagógica $\mathrm{y}$, admitiendo que existen procedimientos basados en los desarrollos argumentales, indagar también en torno a otros medios de acercamiento al compendio audiovisual, en cuyo entramado también podemos encontrar herramientas de tratamiento intercultural. La música encontrará ahí un gran campo de propagación, en tanto en cuanto la interacción entre imagen y sonido denota indefectiblemente un núcleo de significados añadidos ${ }^{659}$.

En resumen, en el bloque del apartado que sigue a continuación trataremos de resaltar de qué modo dentro de la escuela inclusiva, con todos los matices interculturales que se quieran pincelar, puede triunfar un sesgo dialogante, focalizando el papel de la música que sirve de apoyo visual hacia los momentos en que la alteridad queda estereotipada, de modo que la inversión y redimensión del proceso redunde en la construcción de aprendizajes significativos que avancen en el posicionamiento crítico. Además, en la parte dedicada a la acción compensatoria el papel encomendando a la música del audiovisual será el de mediador entre sociedades diversas, con el fin de elaborar aprendizajes no sólo deconstruyendo conceptos sino también elaborando nuevos procedimientos.

\footnotetext{
659 Aquello que Alejandro Román nomina como "lenguaje musivisual”. Cfr. ROMÁN, A. (2008): El lenguaje musivisual, semiótica y estética de la música cinematográfica. Madrid: Visión Libros; ROMÁN, A. (2009): "Estética de la música cinematográfica: Aspectos diferenciadores". OLARTE MARTÍNEZ, Matilde (Ed.) Reflexiones en torno a la música y la imagen desde la musicología española. Salamanca: Plaza Universitaria Ediciones, pp. 105-118.
} 


\subsection{LA MÚSICA DEL AUDIOVISUAL COMO ELEMENTO DE ANÁLISIS DISCURSIVO EN LAS AULAS}

\section{Consideraciones previas}

Las reflexiones anteriores generan una estructura de aplicación pedagógica sumamente motivadora, ya que la amplia variedad de objetivos a desarrollar y la profundidad de los mismos han de ser valorados muy positivamente. Teniendo en cuenta que el escenario en que nos movemos es global y mediático, con una desproporcionada profusión informativa de diversa procedencia y orientación ideológica, el esfuerzo que se plantea es el de abordar procedimientos didácticos que fomenten el diálogo entre iguales y evite, en la medida de lo posible, la mera constatación del hecho cultural.

Como exponemos, para todo ello, es relativamente frecuente dirigir la atención de los alumnos hacia los medios audiovisuales, ya que se suponía que su poder como amplificadores de la realidad social con capacidad para esculpir conductas podría canalizar aquellas actitudes dialogantes insertas en los diferentes currícula. En este sentido, en la enseñanza general la práctica más habitual ha sido la que se ha servido de documentales o filmes que dejaran patente un mensaje intercultural nítido, a partir del cual estructurar pautas pedagógicas coherentes con el discurso que fue visto:

“...si el cine posibilita el camino para que la cultura y los sujetos inicien juntos la andadura, también promociona formas de conocer y enfocar la realidad social para que el conocimiento permita la reproducción del orden cultural y la reconstrucción reflexiva y crítica" ${ }^{\circ 60}$.

No es objeto de este estudio adentrarnos en la pertenencia o limitaciones de esos procedimientos, ya que, como exponemos, suelen desarrollarse fuera del ámbito de la

${ }^{660}$ PEREIRA DOMÍNGUEZ, C. (2005b): Op cit., p. 217. 
educación musical, pero sí es interesante observar cómo este tipo de actividades no dejan hueco al uso del propio discurso audiovisual como un lenguaje ya montado, de modo que se omite la capacidad del alumno para inmiscuirse entre los márgenes de dicho compendio de lenguajes para extraer, desde ese punto, conclusiones personales derivadas del aprendizaje, generalmente por descubrimiento. Este hecho se hace especialmente interesante al definir como objetivo esencial de estudio la construcción de la alteridad:

“...la introducción del otro dentro de un filme cuya acción se desarrolla en una sociedad diferente a la suya es una evidente muestra de comunicación intercultural en el seno de la diégesis presentada"661.

Intensificar la mirada sobre los sonidos diegéticos o incidentales de realizaciones audiovisuales de todo tipo (anuncios televisivos, reportajes o documentales, sintonías, cortometrajes o largometrajes...) puede ser de gran utilidad para entender de qué modo se construyen percepciones ilusorias sobre la alteridad, llegando a generarnos expectativas igualmente construidas en torno a ese Otro con el que nos relacionamos generalmente asimétricamente. Plantear procedimientos pedagógicos como estos, incidiendo en la manera en que otras culturas son representadas, alienta el verdadero espíritu intercultural que propugnamos desde las líneas introductorias.

En cualquier caso, aunque son minoría, existen prácticas educativas que tienden a hacer partícipes y protagonistas a los medios audiovisuales de la comprensión de las sociedades contemporáneas ${ }^{662}$. De hecho, puede argumentarse en clave metafórica que aproximarse a estos códigos en el aula de música puede servir para acercarse, del mismo modo, a las diferencias que a veces perfila la sociedad multicultural, de modo que se superen barreras a través del conocimiento. Ana Lucía Frega enuncia este proceso de amalgama entre tecnologías y educación musical del siguiente modo:

${ }^{661}$ GORDILLO, I. (2007): Op. cit., pp. 1-2.

${ }^{662}$ GUTIÉRREZ SAN MIGUEL, B. (1999): Op. cit. 
“...todo en esta época postmoderna que busca, en la flexibilidad y en la comprensión de las diferencias y sus valores intrínsecos, un reservorio multicultural para la educación de las generaciones jóvenes. Se trata de eliminar el rechazo por la ignorancia o por el miedo a lo desconocido" ${ }^{\circ 63}$.

La clave del éxito de estas realizaciones radicará en la capacidad de todos los implicados en el proceso de enseñanza en escuchar detenidamente lo que antes fue simplemente oído y presentado bajo el trasluz e influjo de la imagen. Es aceptado que el filtro de selección de matices acomoda al espectador enfatizando lo importante y omitiendo o minimizando lo que se entiende por trivial ${ }^{664}$. Según Willis ${ }^{665}$, la ideología “convierte las resoluciones y resultados culturales inciertos y frágiles en un naturalismo omnipresente", por ello, en la penetración subliminal de significados cobra especial relevancia el estudio detenido sobre la banda de sonido del audiovisual, la cual desempeña un papel determinante y no siempre reconocido, al contrario que el otro lado de la moneda, el visual, mucho más aceptado como filtrador de estándares que pasan a convertirse en reglas ortodoxas ${ }^{666}$.

En consecuencia, es admisible la idea de que cualquier realización audiovisual, sea del tipo que sea (científica, pedagógica, divulgativa...) entraña ciertas falacias ${ }^{667}$, debido a que las intenciones productivas acarrean una serie de connotaciones que, especialmente en el caso de la audición, no implican arbitrariedad en su aplicación sino que responden a unas necesidades evidentes. Atender a este procedimiento puede estimular un buen número de aprendizajes en el ámbito educativo ${ }^{668}$.

En cualquier caso, a pesar de que los razonamientos teóricos puedan servir para justificar el abordaje de temas interculturales a través de los medios audiovisuales, el

\footnotetext{
${ }^{663}$ FREGA, A. L. (1996): Op. cit., p. 7.

${ }^{664}$ RAMOS, C. (1995): "Los medios de comunicación, agentes constructores de lo real”. Comunicar 5, pp. 108-112.

665 WILLIS, P. (1988): Aprendiendo a trabajar. Madrid: Akal. p. 187.

${ }^{666}$ CORREA GARCÍA, R. I. (1999): "Del razonamiento argumental a la retórica de las imágenes". Comunicar 12, p. 196.

667 ALVAR, J. (1992): "Reflexiones en torno al cine etnológico". Gazeta de Antropología 9, Texto 0903. Disponible en <http://www.ugr.es/ pwlac/G09_03Julio_Alvar.html> [Consulta 9-II-10]

668 ROCA VIDAL, F. (2004): "Creatividad y comunicación musical desde las nuevas tecnologías". Comunicar 23, pp. 31-36.
} 
paso previo para hacer relevante el producto que ha de tornarse pedagógico es razonar ante el propio alumnado la pertinencia de llevar a cabo análisis de este tipo:

“...se trata de sistematizar mínimamente la necesaria reflexión sobre un fenómeno comunicativo cuya implantación resulta tan fuerte y sigilosa que no nos parece extraña, sino normal, hasta el punto de constituir sorpresa el hecho de que alguien, plantee la conveniencia de analizarla"669.

Este aspecto que citamos no es en absoluto accesorio. Es frecuente entender que a raíz de una película o cualquier otro producto audiovisual se puede acceder a conocimientos específicos de manera exclusiva, en el caso de que se trate de una producción que aborde temas históricos o divulgativos, pero no suele ser común apreciar que desde el lenguaje audiovisual se puedan llevar a cabo aprendizajes ${ }^{670}$. Como indica Feld:

“...Esto subyace en dos de nuestros fuertes mitos culturales, que la película es entretenimiento, y que la película es un espectáculo y cuenta cosas que tienen un significado intrínseco. A través de toda mi experiencia en escuelas, las películas se enseñaban cuando los maestros estaban enfermos, fuera de clase, o como "regalo" después de un examen. No creo que mi experiencia sea la única; aún es más, era algo predecible tanto en los centros de enseñanza para graduados como en los anteriores. Además, no recuerdo nunca una discusión sobre una película que tratara de algo más que del contenido, asumiendo que es real, ni recuerdo

\footnotetext{
${ }^{669}$ ALONSO, M. y MATILLA, L. (1989): Op. cit., p. 56. En la misma dirección, Montes del Castillo evidencia que el retrato social desde un posicionamiento específico es una de las tareas primordiales de las filmaciones: MONTES DEL CASTILLO, Á. (2001): "Films etnográficos. La construcción audiovisual de las 'otras culturas'". Comunicar 16, p. 85.

${ }^{670}$ Entre los ejemplos que, utilizando elementos audiovisuales, sí vinculan áreas de conocimiento para, de este modo, relacionar las competencias que los alumnos habrán de desarrollar destacamos el trabajo de tesis doctoral que actualmente está completando Almudena Mosquera en la Universidad de Salamanca bajo la dirección de la profesora Matilde Olarte: "Aplicaciones didácticas en la E.S.O.: Análisis musical en obras adaptadas al cine de Emilia Pardo Bazán y J. K. Rowling que contribuyen al desarrollo en competencias."
} 
nunca que me hayan pedido que leyese o que me preparase de otro modo para ver una película",671.

Consecuentemente, salvados los problemas de focalización ante el elemento audiovisual, el esfuerzo del profesorado habrá de centrarse en propiciar que el aprendizaje sea, de hecho, resultado de un proceso de construcción personal que implique a su propio mundo interior, posicionándose críticamente ante el entorno y que sirvan para cuestionarse, hasta cierto punto, las convenciones de los discursos que, generalmente, asumimos sin más. De este modo, se instará a los alumnos a analizar el modo en que la música de cine, por ejemplo, en principio libre de ataduras discursivas, puede ser portadora de connotaciones de todo tipo. Con ello, si logramos alcanzar el gran objetivo que se plantea, fomentar en los alumnos el compromiso con la sociedad e integrarlos netamente en ella, estaremos contribuyendo de manera real a la filosofía más enraizada de la interculturalidad.

\section{Definición de otras culturas a través de la música. Función expresiva del audiovisual.}

Es sumamente interesante atender al modo en que determinadas manifestaciones generadas en una sociedad nos pueden acercar a realidades culturales concretas, de manera que se pueda acceder a aquello que muestran u ocultan ${ }^{672}$, o aquello que refuerzan, reflejan o contradicen con respecto a otros dominios culturales ${ }^{673}$. De ahí que no resulte peregrino tratar de aplicar elementos derivados del análisis discursivo de corte antropológico a la música de cine, porque como cualquier otra realización

\footnotetext{
${ }^{671}$ FELD, S. (1976): "Ethnomusicology and Visual Communication”. Ethnomusicology 20, p. 299: "It is underlied by two of our particulary strong cultural myths -that film is entertainment, and that film is a show and tell item that bears some intrinsic meaning. Throughout muy entire experience in schools, films were shown when teachers were sick, out of town at meetings, or used on the last day of classes, or as a 'treat' for the class right after an examination. I do not think that my experience is unique; what is more, it was as predictable in graduate school as it was in grade school. Furthermore, I do not ever remember a discussion of a film that dealt with any more than the content, assuming it to be real, nor can I recall ever being asked to read or otherwise prepare for seeing a film." [traducción propia del inglés]

${ }^{672}$ ROSSI, I. y O'HIGGINS, E. (1981): Teorías de la cultura y métodos antropológicos. Barcelona: Anagrama, p. 23.

${ }^{673}$ NETTL, B. (2003): Op. cit.
} 
producida en el seno de una sociedad específica puede ayudarnos a desenmarañar, en última instancia, la naturaleza humana ${ }^{674}$.

De este modo, desde los referentes ineludibles en cuanto a la construcción de significados y la idea de Otredad se puede estructurar un razonamiento que nos lleve por la senda del modo en que Occidente ha estudiado, imaginado y mostrado la imagen de otras entidades socioculturales (África, Oriente...) y en qué medida las relaciones que se han establecido con esta alteridad han sido construidas a través de dicho reflejo y no tanto de situaciones objetivamente fundadas, con lo que será esa imagen la que llegue a dictar, en última instancia, lo que es efectivo de pensar ${ }^{675}$. Por consiguiente, partiremos de un posicionamiento de análisis discursivo mediante el cual penetraremos en el modo en que el proceso de generación y transmisión de información se asume y nos crea una realidad con la que nos relacionamos de manera más o menos consciente ${ }^{676}$. En este sentido, no sólo fijaremos nuestras miras en el poder autorregulado desde Occidente para hablar por la alteridad, sino que atenderemos al modo en que la gramática icónica y sonora desarrollada sobre la Otredad ha construido esta interacción y acaba por condicionar las interpretaciones de los hechos que generalmente se ofrecen. La música inserta en el audiovisual, como veremos, forma parte de esta elaboración interesada de manera muy elocuente, especialmente al sobrepasar los mecanismos del propio código musical para, en su conjunción con lo visual, incidir en el poder evocador de mundos ${ }^{677}$. Por tanto, siguiendo las ideas de Tagg en sus planteamientos sobre la manipulación sonora ${ }^{678}$, la decodificación de los códigos musicales insertos en el audiovisual pueden llevar a un entendimiento visceral de aquello que se percibe, el cual es susceptible de generar una sensación común en el conjunto de los sujetos que se relacionan con el producto acerca de lo que transmite.

\footnotetext{
${ }^{674}$ FINNEGAN, R. (1998): “¿Por qué estudiar la música? Reflexiones de una antropóloga desde el campo". Revista de Antropología 15-16, p. 30.

675 Así por ejemplo, Marcello Giacomantonio, en el primer capítulo de su obra sobre aplicaciones metodológicas audiovisuales ya alertaba sobre el halo de objetividad con que pueden ser enmascarados los mensajes de este tipo: GIACOMANTONIO, M. (1979): La enseñanza audiovisual. Metodología didáctica. Barcelona: Ed. Gustavo Gili.

${ }^{676}$ Para Claudia Gorbman uno de los aspectos determinantes es la abstracción que supone el visionado, que permite la penetración "imperceptible" por el sentido del oído y hace partícipe de todo el proceso a quien observa, si bien inconscientemente: GORBMAN, C. (1987): Op. cit.

${ }^{677}$ CRUCES, F. (1998): "Niveles de coherencia musical. La aportación de la música a la construcción de mundos". Revista de Antropología 15-16, p. 50.

${ }^{678}$ TAGG, P. (1995): "Studing Music in the Audio-Visual Media -An Epistemological Mess-“. Glasgow: IASPM Conference. Disponible en <http://www.tagg.org/articles/glasg95.html> [Consulta 9-II-10]
} 
Ahondando en este rapto expresivo será altamente significativo explorar cuáles son las ideas en torno a los modos de entender la vida por parte de "ellos", los retratados y objetivados visual y musicalmente en los discursos audiovisuales, ya que ello servirá igualmente para percibir cómo "nosotros", la sociedad de donde ha partido el discurso, nos posicionamos ante una realidad basada en convenciones. Este proceso, prolongado en el tiempo, ha sido posible debido al hecho de asumir como extraños, desde una visión propia, otras formas lejanas de aproximarse a la cotidianeidad e, igualmente, a causa de la acumulación de pretensiones e imágenes sobre estos otros lugares y personas. Se trataría pues de reflejar la legitimidad que desde los contextos que forjan las historias se ostenta para estigmatizar ideas y asociarlas a realidades únicas y verdaderas fundamentadas sólidamente a través de la distribución del conocimiento ${ }^{679}$, de modo que personajes y músicas puedan plasmar a toda una sociedad con breves pinceladas ancladas en el bagaje mental preexistente en las conciencias eurocéntricas.

Como venimos exponiendo, dentro de nuestro campo de acción pedagógica, el cine es uno de los máximos exponentes de la estandarización a la que estamos aludiendo. Las últimas tendencias del estudio de la teoría musical cinematográfica destacan la faceta decisiva de lo sonoro en la construcción identitaria a partir de la sensación que se provoca en la audiencia y en función de los códigos culturales que ésta maneja ${ }^{680}$. El hecho de que estemos frente a una manifestación cultural que precisa de la aplicación musical en asociación con otros lenguajes puede hacer que el análisis antropológico-discursivo de la propia banda de sonido nos aproxime, irremisiblemente, a la producción y apoyo ideológicos, tanto en la conjunción de los elementos audiovisuales como en la observación del rol que de manera autónoma pueda desarrollar la dimensión sonora. Con ello, el audiovisual se tornará revelador para nuestros fines cuando seamos capaces de abstraernos de la adormecedora narración general y podamos atender a los estereotipos que propician que la música se despoje de su papel ambientador para adentrarse y adherirse en la producción y construcción de significados.

En el sentido en que las planteamos, las producciones audiovisuales se entienden desde el mismo prisma de asimilación que otros discursos, los cuales parten de la

\footnotetext{
${ }^{679}$ FOUCAULT, M. (1999): Op. cit., p. 19.

${ }^{680}$ KASSABIAN, A. (2001): Hearing Film. Tracking Identifications in Contemporary Hollywood Film Music. New York \& London: Routledge.
} 
necesidad de transmisión ideológica de su propio creador, con lo que en aquellas cintas en las que se aborde el contacto cultural podamos inferir cuáles son las expectativas y el tratamiento que se tiene acerca de la alteridad, y el modo en que esto puede servir a intereses tanto comerciales como ideológicos. Así, la aprehensión musical de la identidad del Otro nos hace patente un mundo sonoro tan real (en tanto que existe) como virtual (en tanto que vive de la evocación), alejado de la realidad etnográfica pero altamente rentable, en términos de efectiva captación estereotípica. Todo ello redunda en afianzar connotaciones ligadas a la Otredad, ya que incide en sonidos inteligibles para un espectador que es capaz de ubicarlos sin problema alguno en un campo significativo preexistente. El paso de esa asimilación musical a la elaboración de conceptos específicos es casi imperceptible.

En esencia, si el audiovisual en general y el cine en particular sirve para transmitir mensajes y la música que los acompaña los acaba de redondear puede resultar muy motivador para un alumnado ávido de desarrollar su espíritu crítico atender al modo en que dichos conceptos son vehiculados, ya que de esta comprensión depende gran parte de la capacidad de discernimiento y distanciamiento de las manifestaciones actuales, objetos de estudio inscritos en un panorama global y mediático. Con ello, la tarea que proponemos no es otra que la de establecer categorías analíticas que, a través de la banda sonora, desvelen cómo es entendido el contacto cultural en cada producción fílmica. Los materiales para el desarrollo de este tipo de procedimientos no han de ser difícilmente accesibles, ya que es cierto que, en los últimos tiempos, el cine se ha mostrado como uno de los más evidentes ejemplos de constatación multicultural, siendo muchas las películas centradas en las consecuencias de los procesos migratorios contemporáneos.

Llegados a este punto, conviene reflexionar brevemente acerca del modo en que se produce la transmisión de emociones a través de la música del audiovisual, de forma que, a partir de esa penetración en lo subjetivo, podamos enlazar con la construcción discursiva que se esconde tras la música étnica. En primera instancia, es particularmente relevante recordar la incidencia de lo sonoro sobre el compendio audiovisual como parte de un recorrido que cataliza la verosimilitud de lo que se presenta: 
"El sonido se convierte en legitimador de la verdad visual porque apoya las imágenes, y es verdaderamente la dimensión sonora la que aporta el grado simbólico que determina la credibilidad de la información que transmiten”,681.

De este modo, cuando Sklovski ${ }^{682}$ afirmaba que el lenguaje cinematográfico no es compresible pero sí fácilmente aceptado por todos nos está otorgando claves acerca de aquello que queremos investigar. Así, la música de cine cumple una serie de funciones asumidas de manera más o menos general. Entre ellas destacan las de estructurar la película (facilitando la ligazón entre las secuencias), orientar su interpretación (especialmente cuando no se es totalmente consciente de su presencia), conseguir una convincente atmósfera de ubicación espacio-temporal y reforzar el sentido de las escenas aumentando sus posibilidades emocionales, de forma que se subrayen o creen elementos psicológicos allá donde los diálogos o las situaciones no puedan penetrar, y se dirija, de este modo, la percepción de los espectadores ${ }^{683}$. Esta última misión, es tal vez la que adquiere mayor relevancia desde que se superó la visión según la cual la música de cine era tolerada como una intrusa imprescindible ${ }^{684}$. Con todo ello, se asume que, esencialmente, "la música de cine tiene como fin reforzar nuestras reacciones emocionales ante las escenas filmadas" ${ }^{\prime 65}$.

Por todo ello, las funciones de la música que se inserta en los discursos audiovisuales tienen una serie de condicionantes que hacen que sus pretensiones, en origen meramente operativas, queden abiertas al plano de la comprensión en clave de interpretación guiada. De este modo, estamos ante un tipo de música -en principioestrictamente funcional que se hace comprensible en su asociación con las imágenes para consensuar con el espectador una determinada perspectiva sobre la ficticia realidad que se ilustra, dimensiones éstas, lo ficticio y lo real en el audiovisual, que pueden ser

\footnotetext{
${ }^{681}$ RADIGALES, J. y FRAILE PRIETO, T. (2006): Op. cit., p. 100.

${ }^{682}$ SKLOVSKI, V. (1971): Cine y lenguaje. Barcelona: Anagrama, p. 124.

${ }^{683}$ PRENDERGAST, R. M. (1977): A Neglected Art: A Critical Study of Music in Films. New York: New York University Press.

${ }^{684}$ Apuntada por Adorno y Eisler ya en 1947 en una obra reimpresa con cierta asiduidad: ADORNO, Th. W. y EISLER, H. (2003): El cine y la música. Madrid: Fundamentos, p. 24.

${ }^{685}$ LACK, R. (1999): La música en el cine. Madrid: Cátedra, p. 96.
} 
llevadas a razonamientos más profundos ${ }^{686}$. Como ha sido apuntado en determinados escritos,

\begin{abstract}
"la ambigüedad de la música en cuanto elementos subjetivos que contribuye a la consistencia objetiva de las imágenes nos hizo ver que ella misma no rellena subjetivamente el film, sino que apela directamente a la subjetividad del espectador que es el que, implicándose, concede coherencia y realidad. Esto se extendía a cualquier otra función que la música pueda desempeñar en el cine, ella misma no completa ninguna insuficiencia, no sacia ninguna necesidad, invoca al espectador para que clausure el proceso. Su función básica es más la de instigar a una dimensión de la subjetividad humana, que aportar ella misma a una dimensión propia. Si la concepción de la música de cine, y de la música en general, ha asumido una serie de dimensiones como propias es debido a una cierta personificación, humanización, que nos acerca racionalmente un elemento indefinible en una torpe prosopopeya" 687 .
\end{abstract}

Desde un plano más radical, y enfatizando en la capacidad demarcativa musical $^{688}$, las funciones del cine pueden penetrar, según autores, con mayor o menor firmeza en el ámbito de la generación del conocimiento. Es aceptado sin grandes diferencias que "contribuye a la formación de mitos, estrellas y estandariza estereotipos" 689 , y la propia historia del cine atestigua cómo éste "esconde con más o menos evidencia ciertas intenciones que hemos determinado en resumir en dos grandes bloques: las mercantiles y las ideológicas" y que, igualmente, "fue consolidando en torno a sí una economía exitosa y un sistema de comunicación que genera, controla y

\footnotetext{
${ }^{686}$ OBRADORS, M. (2005): “Abrazar la existencia. Territorios de 'realidad' y territorios de 'ficción' en la creación cinematográfica". Formats. Revista de Comunicació Audiovisual 4. Disponible en $<$ http://www.upf.edu/materials/depeca/formats/impresion/pdf_espanol/mobradors2_esp.pdf $>$ [Consulta 9-II-10]

${ }^{687}$ COLÓN PERALES, C., INFANTE DEL ROSAL, F. y LOMBARDO ORTEGA, M. (1997): Historia y Teoría de la Música en el Cine. Presencias afectivas. Sevilla: Alfar, p. 235.

${ }^{688}$ En cuyos términos Gómez Sánchez ilustra lo que para él es la función más ostentosa de la música del audiovisual: GÓMEZ SÁNCHEZ, J. P. (1983): El análisis fílmico. Semiología textual. Murcia: Caja de Ahorros de Alicante y Murcia.

${ }^{689}$ ABAD TEJERINA, M. J. (2001): “¿Para qué sirve el cine comercial en la aldea global? La India un caso singular". Arte, Individuo y Sociedad 11, pp. 159-170.
} 
transforma las ideologías" ${ }^{\natural 90}$. Hoy día puede entenderse que este aspecto se extiende a todo tipo de filmaciones, incluso aquellas que no lo parecieran a simple vista. En este sentido,

\begin{abstract}
"los filmes comerciales pueden constituir, entonces, documentos acerca de cómo se percibe cierta situación social o cómo se conceptualiza la alteridad bajo determinadas circunstancias; pero también los productos autoconsiderados documentales lo hacen"691
\end{abstract}

y, más aún, hemos de tener presente que si superamos la visión superficial de las grabaciones documentales se atestigua que

"la observación de la realidad en el cine etnográfico está sujeta a procedimientos empleados en el género de ficción" ${ }^{\circ 92}$.

Por todo ello es tan susceptible de análisis de discurso una monografía como pudiera serlo un film $^{693}$. Entender pues los mecanismos de la inclusión del lenguaje musical en el todo de la narración audiovisual la hace partícipe de un plan general de actuación. De este modo,

"la narración audiovisual permite dar una interpretación de la realidad, pudiendo
modificar la percepción de dicha realidad a través de un sentido más categórico
y más elemental que el caos representado por las cosas del ámbito real. El
estructurar la narración audiovisual en torno a unas leyes de funcionamiento
resulta un trabajo absurdo, banal y reiterativo si no se llega a captar el fin que el

${ }^{690}$ AMAR RODRÍGUEZ, V. M. (2003): Op. cit., pp. 73 y 75.

${ }^{691}$ GRAU REBOLLO, J. (2005): "Antropología, cine y refracción. Los textos fílmicos como documentos etnográficos". Gazeta de Antropología 21, $<$ http://www.ugr.es/ pwlac/G21 03Jorge Grau_Rebollo.html> [Consulta 9-II-10]

${ }^{692}$ VEGA SOLÍS, C. (2000): "Miradas sobre la otra mujer en el cine etnográfico". Gazeta de Antropología 16, <http://www.ugr.es/ pwlac/G16_07Cristina_Vega_Solis.html> [Consulta 9-II-10]

${ }^{693}$ MONTES DEL CASTILLO, Á. (2001): Op. cit., p. 83. 
creativo ha perseguido con su obra, aprehender los objetivos que ha planteado aleccionar, convencer e influir-. El análisis desde una perspectiva meramente estética, sin la valoración de su mensaje, no llega a englobar todas las sugerencias que una película puede aportar, ${ }^{\circ 94}$.

Existen pues evidentes mecanismos de elaboración y definición de pareceres a través de los medios audiovisuales, siendo estos más evidentes en determinados casos. Para algunos autores, esta faceta puede hacerse palpable en cintas que buscan un determinado adoctrinamiento político e ideológico ${ }^{695}$, pero el sesgo que resulta más atractivo para nuestros intereses es aquel que no se manifiesta de manera tan abierta, sino que se sirve de la conjunción de lenguajes audiovisuales de manera, si se quiere, relativamente oculta. Arnheim ${ }^{696}$ nos aproxima a la complicidad del espectador ante las historias narradas que, en todo caso, son rodeadas de un halo de objetividad aceptado de manera general ${ }^{697}$. Las estrategias para contar con la complicidad del espectador, especialmente en el caso de los sonidos, nos hacen fijar las miras en la relación que se establece entre escucha, sentido y significado a través de la mediación cultural. Así, Gorbman ${ }^{698}$ postula que la adecuación de los sonidos invita a dejarse llevar, de modo que existen convenciones culturales que son comprensibles desde esa aplicación sonora. De manera paralela, el citado Lack ${ }^{699}$ habla del modo en que esos códigos entendibles afectan, además, a la sensibilidad emocional. Por todo ello el círculo que hace comprender de pleno la situación se cierra cuando, a partir de todos los criterios anteriores, se insta al espectador a completar con su propia participación aquello a que ha sido canalizado. Desde este punto de vista, la música de cine "apela directamente a la subjetividad del espectador que es el que, implicándose, concede coherencia y realidad"700 y ratifica un discurso que resulta accesible y esperado. Este aspecto cobra capital importancia cuando el asunto que se trata aborda la coexistencia cultural.

\footnotetext{
${ }^{694}$ GUTIÉRREZ SAN MIGUEL, B. (1999): Op. cit., p. 210.

${ }^{695}$ HUESO, A. L. (1998): Op. cit.

${ }^{696}$ ARNHEIM, R. (1996): El cine como arte. Paidós: Barcelona, p. 31.

${ }^{697}$ VIRILIO, P. (1998): La máquina de visión. Madrid: Cátedra, p. 69.

${ }^{698}$ GORBMAN, C. (1987): Op. cit.

${ }^{699}$ LACK, R. (1999): Op. cit.

700 COLÓN PERALES, C., INFANTE DEL ROSAL, F. y LOMBARDO ORTEGA, M. (1997): Op. cit., p. 235
} 


\section{Música no occidental en el audiovisual: de la emoción a la evocación sesgada.}

En este marco de múltiples relaciones e intereses surge la música del audiovisual la cual, por tanto y en palabras de Salmi ${ }^{701}$, no puede sonar demasiado poco familiar. En ocasiones, las propias funciones aludidas con anterioridad propician que, el simple desarrollo de la trama, haga cuestionarse sobre la idoneidad o no de incluir música de raíz étnica. Como muestran recientes estudios, su uso, durante años, ha servido para incidir en la diferencia, ahondando en aquello que representa al Otro, de modo que esa representación llegue hasta nuestras sociedades actuales, siendo posible acceder a los cambios que se han producido en su ámbito de aplicación ${ }^{702}$. Según Mark Neyrinck $^{703}$, la primera precisión que hemos de realizar a la hora de abordar este tipo de aplicación es la distinción entre el uso de elementos étnicos, como fuente de inspiración, o de música étnica, adquiriendo en este caso un punto mayor de rigor en cualquier caso nunca conseguido por completo. Siguiendo a este autor, las funciones de la música aplicada a las películas de este estilo varían sensiblemente de las expuestas con anterioridad. Son estas:

- Fuente de ideas para el compositor. Es el plano en el que tendría menor relevancia la inclusión de aspectos étnicos, en tanto en cuanto se seguiría componiendo en el típico estilo hollywoodiense del resto de la filmografía del compositor en cuestión.

- Establecimiento de la localización geográfica y temporal. Del mismo modo que ocurre cuando, para ubicar una escena en cualquier ciudad del mundo, se comienza por mostrar una imagen fija de un monumento representativo de dicho lugar, esta ubicación a través del sonido ha sido usada desde los primeros tiempos de la utilización musical en el cine. Sin duda, lo más significativo de esta función será atender a cuándo y cómo se transgrede la simple fijación

\footnotetext{
${ }^{701}$ SALMI, H. (1998): "Composing the Past: Music and the Sense of History in Hollywood Epics of the 1950s and Early 1960s". Screening the Past 5. Disponible en <http://www.latrobe.edu.au/screeningthepast/firstrelease/fir1298/HSfr5d.html> [Consulta 9-II-10]

${ }^{702}$ D'AMICO, L. (2007): "People and Sounds: Filming African Music Between Visual Anthropology and Television Documentary". Trans 11. Disponible en <http://www.sibetrans.com/trans/trans11/art06.htm> [Consulta 9-II-10]

${ }^{703}$ NEYRINCK, M. (2001): "Ethplotiation: The Use of Ethnic Film Music". $<$ http://www.filmscoremonthly.com/articles/2001/29_Nov---

Ethploitation_The_Use_of_Ethnic_Film_Music.asp> [Consulta 9-II-10]
} 
espacial y temporal y la música consigue cristalizar en el mundo de lo subjetivo, dando paso a la siguiente función.

- Establecimiento del llamado "orientalismo" o distancia conceptual entre lo próximo y lo ajeno. Es curioso atestiguar como en esta tercera funcionalidad, a todas luces la más importante en tanto en cuanto está aunque no lo aparente, es acuñada bajo el término citado, "orientalismo", traslación de aquello que Edward W. Said ${ }^{704}$ utilizó para describir los procesos de construcción de la realidad -también musical ${ }^{705}$ - desde la perspectiva occidental, la cual durante siglos habría generado un gran número de imágenes y expectativas sesgadas en torno a "lo oriental". A partir del desarrollo de este pensamiento asumido para la música del cine, Santaolalla precisa (desde una perspectiva heredera de los estudios de Foucault) que los montajes cinematográficos son un terreno abonado en el cual "las sociedades occidentales contemporáneas comercializan "la diferencia" y "lo étnico", o más bien, "una versión manipulada, empaquetada y etiquetada de esa Otredad para su propio beneficio" ${ }^{, 706}$. Todo ello nos induce a preguntarnos hasta qué punto la música de este tipo de cine habla de los Otros y en qué momento se rebasa la frontera en la que, en realidad, se deja de hablar de ellos para hacerlo por ellos.

A partir de estas nuevas funcionalidades, se dan otra serie de características aplicadas a la música étnica del discurso cinematográfico. Entre ellas, destacamos la importancia de la idea de evocación de mundos irreales pero inteligibles al espectador, con los cuales relacionarnos. De hecho, para muchos el cine es el arte supremo de la evocación ${ }^{707}$. Esta virtualidad es infinitamente más rentable para los realizadores de la película que un mundo sonoro "etnográficamente real". En ocasiones, se ha pretendido cierto grado de exactitud histórica a partir del acercamiento, curioso o idealizado, al referente que se trata de plasmar:

\footnotetext{
${ }^{704}$ SAID, E. W. (1990): Orientalismo. Madrid: Libertarias.

${ }^{705}$ VALERO SERRA, C. (2006): "Interpretación, memoria y contexto: una introducción a la obra sobre música de Edward W. Said". La Torre de Virrey: Revista de Estudios Culturales 1, pp. 24-28.

706 SANTAOLALLA, I. (2005): Los “Otros". Etnicidad y “raza” en el cine español contemporáneo. Zaragoza: Prensas Universitarias de Zaragoza y Ocho y Medio, p. 146.

${ }^{707}$ VILLEGAS LÓPEZ, M. (1992): El cine en la sociedad de masas. Madrid: JC.
} 
"Me escuché toda la música étnica que había editada en España hasta encontrar exactamente el tipo de canto que yo quería y que reflejase además la vida cotidiana del sitio de donde proceden estos personajes que nunca se ve ni se sabe dónde es. Quería conectar a aquel hombre con su origen y me encontré con el canto de unas chicas de Burundi [...]. Se me ocurrió inventar una parte de orquesta ajena a la música africana y combinarla con ella. El resultado resulta muy emocionante y su lectura indica que los seres humanos somos por dentro todos iguales y que lo que cambia son pequeños matices de color",708.

"Peter cogió ritmos de Turquía, Grecia, Armenia, norte de África y Senegal, y los mezcló para hacer que la música fuera lo más primaria posible [...] Para mí, los ritmos que usa reflejan lo primitivo, y su voz refleja lo sublime: es como si el espíritu y la carne coincidieran en el mismo sitio [...] Utilizó percusionistas egipcios y cantantes pakistaníes, y un violinista hindú, Shankar, que fusionaba el violín con la viola imitando el sonido de la voz humana, hasta el punto de que se podría jurar que se trataba de alguien cantando. Fue un trabajo realmente grandioso",709.

En todo caso, hemos de entender que la pretendida aproximación al tiempo y lugar establecido para la narración, el inadecuado uso de material organológico basado en la utilización puntual de instrumentos musicales tradicionales de esa u otra región, en ocasiones, no hace sino mostrar más exotismo que trasfondo cultural:

“más obvio es que la música étnica [...] acentúa la idea de Otredad u orientalismo. Este hecho potencia el realismo, pero también acentúa el

\footnotetext{
708 Palabras del compositor José Nieto en referencia a Bwana (Dir. Imanol Uribe, 1996): PADROL, J. (2006): Conversaciones con músicos de cine. Badajoz: Diputación Provincial. Servicio de Publicaciones, pp. 384-385.

${ }^{709}$ Reflexiones de Martin Scorsese sobre su película La última tentación de Cristo (1988) con música de Peter Gabriel: THOMPSON, D. y CHRISTIE, I. (Eds.) (1999): Martin Scorsese por Martin Scorsese. Barcelona: Alba Editorial, pp. 196-197.
} 
escapismo, convenciendo al público de que no están viendo una película, e incluso intentando distanciarle de su propia sociedad y época" ${ }^{\text {}}{ }^{\circ}$.

En suma, la efectividad de este tipo de aplicaciones musicales en el plano de la evocación evita que nos adentremos, en muchas ocasiones, en el fondo de la cuestión, que no es otro que su utilización como parte de un plan general de actuación en el cual prima la transmisión de ideales y perspectivas respecto a la alteridad.

Se asume pues que, con un mayor o menor grado de conciencia, existe una tendencia a componer "sobre el estereotipo" cuando se pretende ilustrar la personalidad o la identidad colectiva del "Otro", sin olvidar que ello ha de conjugarse con el cumplimiento de otro tipo de pretensiones dramáticas. Con ello, activando velozmente el mecanismo habitual en este tipo de aplicaciones ${ }^{711}$, la falta de neutralidad del uso estereotípico sirve para defender la posición en la sociedad de una persona o grupo respecto a otro colectivo ${ }^{712}$.

Sin duda, la tendencia hacia la estandarización musical y los clichés ${ }^{713}$ es un hecho constatable y presente en la cinematografía como manifestación con origen occidental. En cualquier caso, lo verdaderamente significativo para nuestros intereses es incidir en el modo que todo ello facilita la creación de entidades de significado accesibles, cercanas e inteligibles en tanto que reconocibles, a pesar de que puedan resultar tan ficticias como la propia ilusión que supone la superposición de lenguajes en el cine. Así pues, el imaginario global que implica la película-cuyas reminiscencias pueden mostrarse en aspectos extramusicales ${ }^{714}$ - se ve acrecentado por la participación de la música en su elaboración y recreación significativa, de tal modo que se incide en la percepción y la interpretación, es decir, se inocula el germen de la idea a expresar y

\footnotetext{
${ }^{710}$ NEYRINCK, M. (2001): Op. cit., s.p.: "Most obviously, ethnic music, [...] emphasizes the idea of "otherness," or orientalism. This goes toward heightening realism, but also toward heightening escapism, persuading audiences that they are not watching a film, and trying even to distance them from their own society and time" [traducción propia del inglés]

${ }^{711}$ LEPORE, L. y BROWN, R. (2000): “Category and Stereotype Activation: Is Prejudice Inevitable?". STANGOR, Ch. (Ed.) Stereotypes and Prejudice. Philadelphia: Psychology Press, pp. 119-137.

${ }_{712}$ HUICI, C. (1999): "Estereotipos". MORALES, F. (coord.) Psicología Social. Madrid: McGraw-Hill, pp. $73-84$.

${ }^{713}$ DE ARCOS, M. (2006): Experimentalismo en la música cinematográfica. Madrid: Fondo de Cultura Económica, pp. 70-74.

${ }^{714}$ DI GIOVANNI, E. (2003): "Cultural Otherness and Global Communication in Walt Disney Films at the Turn of the Century". The Translator 9, pp. 207-233.
} 
se facilita, por medio de una música tan esperada como posible, que el espectador complete la interpretación de la escena y la haga suya, pasando a formar parte de un bagaje almacenado de representaciones similares en torno al "Otro". Es preciso tener en cuenta que

\begin{abstract}
"las personas decimos que 'entendemos' lo que oímos sólo si podemos organizarlo bajo una pauta que le dé sentido, que haga inteligibles los estímulos respecto a un patrón coherente y, a su vez, la música contiene, evoca y construye todos esos mundos de experiencia, a través de la relación íntima que se establece entre patrones sociales y patrones sonoros" ${ }^{\text {, }}$.
\end{abstract}

Por ello, la entrada del sonido en el receptor de un compendio de lenguajes como es el cine, transmite (a través de códigos accesibles al espectador) una percepción que propicia "sensaciones y conceptos" que se pueden interpretar en tanto en cuanto nos resultan familiares. De ahí que el triunfo de un determinado modo de insertar música al audiovisual se fortalezca en tanto en cuanto los cifrados empleados para su realización impliquen un estrecho vínculo con lo que es esperado. Este modo de proceder no es exclusivo de la música cinematográfica, sino que ya el propio Alan Merriam, referente de la moderna antropología de la música, atestiguaba cómo se nutría la conducta de elaboración musical al aseverar que

\footnotetext{
"cuando el sonido musical que se produce agrada al que lo ejecuta y a su auditorio, la inspiración particular a que debe su existencia se revigoriza; cuando no agrada a nadie, el artista se ve obligado a dirigir su inspiración por otros cauces, lo que redunda en un cambio de conducta y, en última instancia, en un cambio del producto artístico",716.
}

\footnotetext{
${ }^{715}$ CRUCES, F. (1998): Op. cit., pp. 35-36.

716 MERRIAM, A. P. (1964): "Las artes y la antropología". TAX, S. (Ed.) Antropología, una nueva visión. Cali: Norma, pp. 270-271.
} 
Por todo ello, en la pretensión de dar sentido a aquello a que nos enfrentamos para hacerlo inteligible echamos mano de nuestro campo de significado disponible, obteniendo de este modo un valor extra-simbólico- que nos ratifica en nuestras propias convicciones en función de aquellos aspectos que ya hemos asimilado ${ }^{717}$. Volvemos pues a la producción y reproducción de significados como parte de la red que hilvana al sujeto en su sociedad. En consecuencia, estos hábitos y acciones encuentran fácil acomodo y pasan a ser normalizadas e identificadas como propios del grupo de pertenencia y a integrarse dentro de la propia persona ${ }^{718}$.

En resumen, se trata de explorar las diatribas a que se ve sometido el compositor de música para el audiovisual cuando no sólo tiene que cumplir con una serie de cuestiones de tipo "mecánico", la observación de ciertas reglas para transmitir las funciones emotivas que pretende el discurso general, sino que además traza las líneas básicas de determinados personajes, haciéndoles acercarse o alejarse del estereotipo. Entre otros autores, en esta definición de la alteridad en el contexto del audiovisual, hemos de volver a la postura de la citada Isabel Santaolalla ${ }^{719}$, quien muestra el modo en que la industria hollywoodiense se ha encargado, sistemáticamente, de otorgar una imagen construida de la Otredad, de acuerdo con los axiomas básicos de una sociedad, la occidental, que defiende una posición hegemónica no sólo en este mercado sino también en el mundo. De sus escritos se destaca el interés por rescatar cómo los momentos de encuentro con el Otro representan más que una necesidad cinematográfica una objetivación que evoca rasgos tan estereotípicos como ficticios ("representando" y no tanto "presentando" al Otro), de modo que el uso de la imagen elaborada sirva a unos fines concretos desde la propia producción (mercantiles, ideológicos o de cualquier índole). En el siguiente apartado desgranaremos cómo pueden ser aprovechadas estas incursiones representativas que nos conducen a la aprehensión mental de la alteridad, ya que si de algo informan es de cómo son y funcionan las sociedades productoras del audiovisual y no tanto de aquello que se plasma en imágenes y sonidos. Edgar Morin, lo asevera del siguiente modo:

\footnotetext{
${ }^{717}$ MANDLY ROBLES, A. (1996): Op. cit.

${ }^{718}$ BOURDIEU, P. (1994): Razones prácticas. Sobre la teoría de la acción. Barcelona: Anagrama.

${ }^{719}$ SANTAOLALLA, I. (1998): "East is East, and West is West? Otherness in Capra's The Bitter Tea of General Yen". Literature Film Quarterly 26, pp. 67-75.
} 
"Debido a que es espejo antropológico, el cine refleja necesariamente las realidades prácticas e imaginarias, es decir, también las necesidades, las comunicaciones y los problemas de la individualidad humana de su siglo. [...] La antropología de lo imaginario nos lleva, pues, al corazón de los problemas contemporáneos" 720 .

\section{Traslación didáctica de los planteamientos teóricos. Ejemplos prácticos.}

De acuerdo con los criterios planteados con anterioridad, queda patente que uno de los principales aspectos que pueden ser desarrollados con el fin de lograr una interiorización intercultural de los contenidos es la sensibilización del alumno hacia el reconocimiento de la alteridad, así como la orientación de la mirada propia en aras de despojarse de los prejuicios e ideas preconcebidas que han podido ser asumidas de manera directa o indirecta. En este último sentido, cobra especial relevancia la reflexión sobre la propia perspectiva que se tiene del Otro y del mundo, tanto como la posición personal como generadores de discursos asumidos y rara vez cuestionados. Así, el hecho de acercar a los alumnos al compendio audiovisual desde este prisma puede servir, según objetivos trazados previamente, a desvelar las intencionalidades que, con mayor o menor subterraneidad, se traslucen tras lo que parece mostrarse en realidad.

A pesar de focalizar nuestro objeto de estudio en una manifestación actual netamente occidental en su origen, el interés que instiga esta reflexión se vincula directamente con la perspectiva antropológica que históricamente ha movido al estudio de la música, desde las sociedades más alejadas a las más cercanas. Así, una aproximación como la que sigue, que vincula música e imagen, trata de servir para cumplimentar los mismos fines que un estudio musical en cualquier grupo humano, esto es, dar acceso a la comprensión global de la sociedad generadora de la manifestación cultural en cuestión. De ahí que, principalmente, se busque poner al descubierto aquello que queda oculto aunque debería ser evidente sin una profunda reflexión: las pretensiones de quienes elaboran un discurso cinematográfico concreto. En palabras de Aguaded Gómez

${ }^{720}$ MORIN, E. (2001): Op. cit., p. 188. 
“...el reto de la sociedad audiovisual no es otro que integrar los medios de comunicación en los procesos educativos para reflexionar sobre ellos, sus lenguajes, sus maneras de informar sobre el mundo y sus poderosas armas para recrearlo y 'construirlo', 721 .

Teniendo presente la existencia de un espacio común en las prácticas audiovisuales, optamos por ver la manifestación no sólo en su producto, sino también (especialmente) "desde fuera", atendiendo al trabajo en la elaboración fílmica. En esta reflexión trataremos de mostrar de qué modo las películas que se desenvuelven en el contexto de un marco urbano y multicultural denotan tras su propia trama, más que una postura objetiva sobre las relaciones sociales, una perspectiva condicionada por la dirección de dichas cintas cinematográficas. Tratamos pues de atender a cómo esto, que pudiera parecer más o menos obvio, queda de manifiesto a través de la música que se adhiere al discurso y lo hace más comprensible. Con ello, el rastreo de los mecanismos musicales de forja del proceso general será el que oriente el grueso de las praxis, cuyo axioma fundamental será entender que la imagen cinematográfica va acompañada de sonidos los cuales nunca son neutros. Así pues, el descifrado de la significación de la banda sonora informa, tanto sobre la carga emocional que se pretende aplicar a la cinta como de otros aspectos soterrados bajo un mayor o menor nivel de intencionalidad.

Con ello, el trabajo irá encaminado a reconocer cómo películas, documentales, anuncios o series van acompañados de elementos sonoros que sirven para designar e implantar ideas preconcebidas y sesgadas en torno a la alteridad, de modo que su concurso haga más elocuente la penetración del núcleo de connotaciones que sirven para relacionarnos con otras sociedades. De este modo, más allá de que la música inserta en los anuncios publicitarios lleve como finalidad última la venta de productos o determinadas sintonías sirvan para enmarcar situaciones concretas que se quieran transmitir al televidente, en ellas se pueden observar otro tipo de elementos que se muestran diáfanos con un trabajo de mediación que focalice la atención hacia esos aspectos. Cuando abordamos un fragmento audiovisual de mayor entidad (especialmente un largometraje) y éste se posiciona en torno a situaciones derivadas del

${ }^{721}$ AGUADED GÓMEZ, J. I. (2005): Op. cit., p. 27. 
contacto cultural es factible buscar una intencionalidad tras ello, ya que es sumamente sencillo que se pretenda connotar y articular discursos más allá de aquello que se muestra con palabras o imágenes. Metodológicamente, nos hallaremos cerca del análisis crítico y creativo de mensajes audiovisuales propuesto por Aguaded (en su caso centrado exclusivamente en la televisión) como una de las facetas para explotar didácticamente estos recursos:

"El entorno de la clase, el trabajo en pequeños grupos, los visionados repetidos, las estrategias de observación, juicio crítico y 'recreación' y amplia, variada y enriquecida batería de actividades pueden ser recursos excepcionales para que entiendan mejor los mensajes televisivos y, al mismo tiempo, sepan responder mejor y más conscientemente a sus estímulos" ${ }^{, 722}$.

Teniendo en mente todos estos elementos y los apuntados en los párrafos previos, otro de los factores a considerar (como hemos visto no sólo en este apartado sino también en los precedentes), será la selección del material a trabajar. Este paso preliminar de reflexión por parte del docente es inexcusable para lograr el máximo de aprovechamiento de las actividades. Por supuesto, en este momento se precisa de una formulación de objetivos clara y una orientación de los contenidos de aprendizaje, sin descuidar todos los planteamientos de ludicidad, duración o accesibilidad al material ya comentados con profusión. Del análisis previo y la dedicación docente en este primer estadio dependerá, en gran medida, el éxito o fracaso de la experiencia.

Por tanto, valorando que no todos los materiales que aborden el choque o contacto cultural pueden ser usados de la misma manera y que su utilidad y reporte de beneficios puede variar ampliamente, ejemplificaremos con tres casos en los que se trate de buscar la capacidad de empatía por parte del alumnado. En ellos, plantearemos diferentes modos de actuación, desde el acercamiento a la alteridad por medio de la situación que se plantea en imágenes y palabras, hasta la transmisión de contingencias interculturales a través de la ligazón entre la propia música y el argumento.

722 AGUADED GÓMEZ, J. I. (1997): "La televisión en el nuevo diseño curricular español”. Comunicar 8, p. 99. 
En primer lugar, optamos por presentar un ejemplo tan sencillo como efectivo. Así, la práctica inicial con que pretendemos ubicar en la realidad nuestros razonamientos teóricos es, tal vez, la más simple, ya que claramente trata de buscar la efectividad de los axiomas interculturales a través del posicionamiento directo al otro lado, sirviéndonos de la realidad migratoria contemporánea. Teniendo presente que la gama de posibilidades es muy heterogénea, mostramos como paradigma de este cúmulo de actividades una práctica concreta basada en el uso audiovisual como metáfora de aquello que se pretende transmitir:

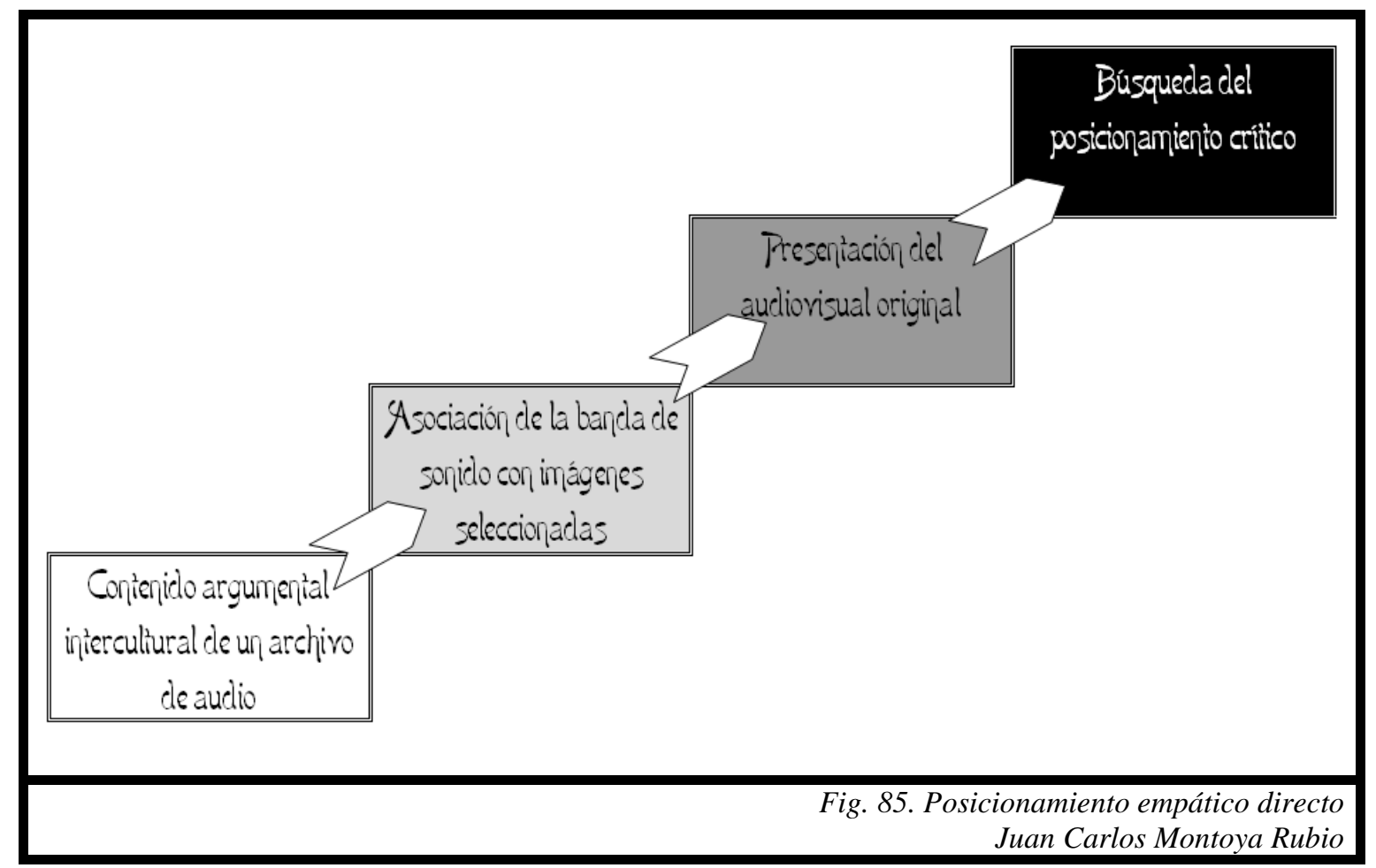

Se presentó el archivo sonoro de un diálogo en el que una mujer explica a un niño el valor de los emigrantes, el porqué de la marcha que están llevando a cabo y la justicia de su empresa del siguiente modo ${ }^{723}$ :

\footnotetext{
${ }^{723}$ Marco. De los Apeninos a los Andes, Cap. 20 "Noche de tormenta", Dir. Isao Takahata (1976). El diseño de la actividad está inspirado con cierta libertad del postulado por Domingo Castillo y Rafael Prieto (2003): $O p$. cit., quienes en un ejercicio para alumnos de segundo nivel de educación secundaria partían de comentarios en torno a imágenes fijas y, a través de la presentación de archivos independientes de audio o vídeo, llegaban a mostrar las imágenes ya montadas con su sonido para aplicar actividades de extrapolación.
} 
- Pera nasatras samas más afartunadas que las que desembarcaran en Río, a las que vienen a la Argentina sin tener casa ni trabaja y ni siquiera saben dónde van a ir ¿No piensas la misma que ya?

- ¿Qué dice?, ¿de verdad hay gente en este barca que na tiene a dónde i几?

- Sí, me tema que la mayaría de las pasajeras

- ¿La mayaría? Entances, jpar qué quieren ir a la Argentina?

- Una vez allí procurarán encantrar trabaja cama sea, al menas esa es la esperanza que abrigan. Algunas se quedarán en la ciudad, atras trabajarán en haciendas, en grandes plantaciones, y muchas de ellas tendrán que irse hacia el interiar, pera siempre será mejar que en Italia dande no hay trabaja

- Ya entienda

- Deben estar muy angustiadas, sobre todo las que han enfermado durante el viaje a llevan niñas cansiga. Par esa cuanda ayeran que había trabaja en las plantaciones de café del Brasil muchas abandanaran el barca y se quedaran en Ría. Parque la que todas están deseanda es encontrar trabaja sea dande sea.

- Pera toda esa debe ser muy dura jverdad?

Fig. 86. Diálogo extraído de la serie "Marco, de los Apeninos a los Andes" Cap. 20 "Noche de tormenta", Dir. Isao Takahata (1976).

Con posterioridad a ese fragmento de audio se le asociaron a unas imágenes en las cuales se veía arribar de manera clandestina a una mujer y un niño de origen desconocido a una costa (supuestamente) española. Tras un tiempo para la reflexión y el diálogo en clase, se desvela que el sonido y la imagen habían sido tomadas por separado y se repite el experimento, en esta ocasión, vinculando el mismo archivo sonoro con otras imágenes, en las cuales se ve igualmente a una señora (en este caso con rasgos fenotípicos sudamericanos) aleccionando a un niño en un barco a bordo del cual, enmascarado de un viaje turístico, accederían a un país europeo dejando atrás su lugar de origen. El tiempo dedicado a la puesta en común de ideas se repitió, tras el cual se opta por enseñar el verdadero origen de aquello con lo que se está trabajando, es decir, el vídeo que incluye sonido e imagen original. La sorpresa es mayúscula cuando ven que, por apariencia, la mujer que razona en torno a la inmigración, acerca de sus 
contingencias y consecuencias, puede ser cualquiera de sus madres mientras que el niño que recibe las explicaciones a bordo de un barco -el barco de los emigrantes- no es otro que Marco, el entrañable personaje de dibujos animados con el que varias generaciones han sufrido (incluso experimentado empáticamente) el efecto de las migraciones y con el cual han anhelado una serie de deseos universales.

Lo realmente significativo de la práctica concreta es la asimilación de elementos transversales, ya que con su desarrollo se consigue la comprensión de situaciones no siempre razonadas. El hecho de verse reflejados en un personaje al cual se han podido llegar a sentir vinculados y entender que las dificultades siguen existiendo en otros contextos provoca el sentimiento de identificación con la alteridad que es el germen de la interculturalidad. Además, la cuestión que pretendemos desentrañar para voltear su significado en contextos didácticos, no es exclusivo del cine o las series televisivas, sino que en arte musical ha servido para categorizar a grupos sociales en repetidas ocasiones. Tal vez, ejemplificar con el contexto español en relación al resto de Europa, pueda servir para complementar las explicaciones al respecto ${ }^{724}$.

Como puede intuirse, el trabajo puede ser llevado hasta el punto que se estime oportuno ya que el aprovechamiento que se esconde tras este tipo de actividades puede llegar a articular prácticas que involucren incluso a toda la comunidad educativa.

Una vez mostrado el ejemplo del posicionamiento empático “directo", nos centraremos en otros casos más complejos, en tanto en cuanto precisan de una reflexión en torno a lo que supone el compendio audiovisual y la superposición de lenguajes que alberga. Así, nos adentraremos en el aprovechamiento que los discentes pueden llegar a extraer de la suma auditiva y visual, en primer lugar en un fragmento de pequeñas dimensiones y, para rematar la explicación con una mayor carga teórica-referencial, a través de la comparación entre dos largometrajes que intentan retratar la coexistencia cultural.

\footnotetext{
${ }^{724}$ Durante décadas, las concepciones en torno a lo que representaba una imaginada "España" fue objetivado desde la antropología centroeuropea, lo cual se vio reflejado en posicionamientos concretos en torno a lo que podía ser encontrado en nuestro país. Un acercamiento desde una óptica discursiva-musical en MONTOYA RUBIO, J. C. (2006c): "Mozart en España. Imaginación y construcción de la alteridad a través de la ópera". Gazeto Internacia de Antropologio 1: 46-60. <http://antropologia.umh.es/GIA/Index_revista/Volumen_1/Vol_01-artículos/Montoya-castellano.PDF> [Consulta: 9-II-10]
} 
De acuerdo con ello, presentamos el segundo de los ejemplos, para el cual nos decantamos por mostrar las interioridades de un cortometraje de dibujos animados, Mickey's Man Friday ${ }^{725}$. Entendemos que éste puede representar un buen campo de experimentos para acceder, por un lado, a la representación estereotípica del Otro a través de la música y, por otro, al modo en que todo ello es asumido sin reflexión alguna. En este sentido, suele argumentarse que:

"la interculturalidad de la música de cine está sometida a los mismos principios de dominación que el resto de las manifestaciones culturales, y los valores dominantes de la sociedad posmoderna son también los que presiden el mundo implícito en sus bandas sonoras que aparecen asociados a sus ideologías. La elección estilística de una música así como sus factores de diversidad, representados por la música popular de la banda sonora, describen lo que la película no se atreve a decir con palabras ni con imágenes pero representa el aura ideológica" 726 .

No obstante, es necesario precisar y subrayar ante posicionamientos como el anterior que la música, en sí misma, no provoca el sesgo ideológico que se busca, sino que es la suma de los componentes audiovisuales la que cataliza todo su potencial simbólico y en ese plano sí juega un papel preponderante la adición sonora. Como refleja acertadamente Radigales:

“...el componente anempático de la música (que atañe a su inherente inexpresividad e incluso a su asemanticidad) puede ser utilizado en el cine desde la vertiente puramente ideológica. Con esto no queremos decir que la música sea ideológica, porque en sí misma ni expresa ni significa nada, pero el uso que se puede hacer de ella, atendiéndonos a aspectos sociológicos o de valor añadido,

\footnotetext{
${ }^{725}$ Dir. Walt Disney, 1935.

${ }^{726}$ PORTA NAVARRO, A. (2007): Op. cit., p. 40.
} 
puede remitir a la ideología que un director o realizador quieren dar al discurso audiovisual en toda su complejidad e integridad"727.

A pesar de la brevedad del corte audiovisual seleccionado, de apenas ocho minutos de duración, los aspectos a indagar pueden fundamentar toda una unidad pedagógica. Las referencias para conseguir acceder al meollo de las connotaciones a través de lo que simplemente parece denotarse nos las aportan obras como las de Lacroix $^{728}$, que vinculan este tipo concreto de animación fílmica con la manipulación discursiva o las de Kaye ${ }^{729}$, quien destapa claves interpretativas sobre el modo en que la industria cinematográfica ha dado forma a ideas como "lo africano" por medio, fundamentalmente, de elementos sonoros y musicales. Para este último autor, la estigmatización de los habitantes de este continente arroja un ramillete de características adheridas a ellos y fundamentadas especialmente a su primitivismo, conectando directamente con aspectos de índole colonialista. Gracias al muestreo que realiza Kaye, entre otros reveladores aspectos, queda al descubierto cómo las cintas documentales de los años treinta y cuarenta incluyen en su nudo argumental (aderezado con fuertes vínculos no sólo visuales sino también sonoros) aspectos que refrendan dicha categorización, tales como un escenario de difícil acceso, inexplorado y relativamente perdido, la simplicidad de los personajes (asumiendo como rasgo característico de todo el continente la negritud) que viven dentro de una elemental estructura piramidal de poder en la que tienen cierta importancia arquetípicos chamanes que efectúan sacrificios y jefes con poder absoluto y, además, un buen número de animales si no extraños al menos diferentes a los que acostumbran a aparecer en las producciones ambientadas en contextos occidentales. Todo ello solía ir acompañado de la referencia eurocéntrica de un cazador blanco vestido con un prototípico atuendo colonizador que, no obstante, aparecería como un explorador.

En consecuencia, los efectos sonoros incidentales utilizados en estas producciones habrían de perseguir un ambiente "salvaje", el llamado "estilo jungla o caníbal". A

${ }^{727}$ RADIGALES, J. (2005a): Op. cit., pp. 20-21.

${ }^{728}$ LACROIX, C. (2004): "Images of Animated Others: The Orientalization of Disney's Cartoon Heroines From The Little Mermaid to The Hunchback of Notre Dame". Popular Communication 2, pp. 213-229.

${ }^{729}$ KAYE, A. L. (2007): "The Film Score and the African Musical Experience: Some Comments on a Work in Progress". Trans 11. Disponible en <http://www.sibetrans.com/trans/trans11/art09.htm> [Consulta 9-II-10] 
pesar de ello, entre las paradojas que encierran estas realizaciones destaca sobremanera el uso organológico occidental aunque, en ocasiones, de una forma poco usual (con el fin de destacar la extrañeza del lugar representado), esto es, tañendo de manera diferente a la convencional el instrumento o abusando de tímbricas como puedan ser las trompetas con sordina o los clarinetes en registro extremo. Otro elemento revelador sería el uso de acordes de quinta vacía, escalas menores, pentatónicas y de tonos enteros, acentuando disonancias para subrayar auditivamente lo arcaico y a la vez ajeno de la situación. Un último aspecto, representativo de estos lugares aprehendidos es tal vez el más extendido: el uso diegético casi generalizado de los instrumentos de percusión por parte de los nativos con que los protagonistas occidentales se topan a lo largo de sus andanzas. Es sumamente interesante atender a cómo esta construcción ideológica crea verdad, utilizando de nuevo la terminología foucaltiana, ya que desde los primeros testimonios etnográficos hasta las obras de referencia clásicas basadas en trabajos de campo o compilaciones posteriores se hace especial énfasis en que, de manera complementaría a la fuerza rítmica de la música del continente africano, la riqueza organológica del mismo rebasa las fronteras de los instrumentos percutidos:

"Una de las características del África negra es la enorme variedad de instrumentos musicales. Lejos de ser exclusivamente una tierra de tambores, según se la retrataba en algunas obras antiguas, es una zona en la cual hay una gran variedad de instrumentos"

Realizamos pues un análisis del ejemplo apuntado según el marco conceptual descrito. Es preciso hacer notar que el alumnado ha de evitar centrar su interés en los efectos musicales sincrónicos típicos de la época, que tratan de imitar los movimientos de la animación, el famoso mickeymousing ${ }^{731}$, para buscar implicaciones escondidas tras

\footnotetext{
${ }^{730}$ NETTL, B. (1985): Música folklórica y tradicional de los continentes occidentales. Madrid: Alianza, p. 159.

${ }^{731}$ CHION, M. (1993): Op. cit., p. 117.
} 
los sonidos que, de manera diegética o incidental, vinculen la realidad de producción del cortometraje con el resultado ${ }^{732}$, el cual podría ser similar al que ofrecemos:

\begin{tabular}{|c|c|c|}
\hline IMÁGENES & Tiempo & AsPEGTOS MUSIGALES \\
\hline - Presentación y créditos de comienzo. & $\begin{array}{l}0: 00 \\
0: 26\end{array}$ & $\begin{array}{l}\text { - Sonidos de inicio y anticipo de la melodia que } \\
\text { aparecerá con posterioridad. }\end{array}$ \\
\hline - Navegación a la deriva de Mickey. & $\begin{array}{l}0: 27 \\
0: 47\end{array}$ & $\begin{array}{l}\text { - La sensación sonora es de total calma, en } \\
\text { contraposición con lo endeble de la embarcación del } \\
\text { protagonista. }\end{array}$ \\
\hline $\begin{array}{l}\text { - Mickey se percata de las extrafias huellas que hay } \\
\text { en el suelo. } \\
\text { - Inquietud general que culmina con el descubrimiento } \\
\text { de la tribu en pleno ritual canibal. Rasgos de } \\
\text { estratificación social (coronas al estilo occidental en } \\
\text { algunos de los habitantes de la jungla). } \\
\text { - Entrada en acción del protagonista que consigue, en } \\
\text { primera instancia, que todos huyan despavoridos. }\end{array}$ & $\begin{array}{l}0: 48 \\
1: 34\end{array}$ & $\begin{array}{l}\text { - Toques de percusión ante el descubrimiento. } \\
\text { - La orquestación indica revuelo y se mezcla con voces } \\
\text { sin orden ni concierto. } \\
\text { - Aparición de clarinetes en registro grave. Efectos } \\
\text { con glissandi. } \\
\text { - La banda sonora refleja que no importa la } \\
\text { individualidad de los nativos sino que son un grupo } \\
\text { homogéneo. }\end{array}$ \\
\hline $\begin{array}{l}\text { - Mickey nomina a aquel a quien ha salvado. Friday, le } \\
\text { reverencia como si fuera un dios. } \\
\text { - Rasgos de primitivismo desde el plano visual (Friday } \\
\text { corta arboles con los pies) } \\
\text { - Ambos preparan la más que posible vuelta de los } \\
\text { canibales en la busca de los dos. }\end{array}$ & $\begin{array}{l}1: 35 \\
3: 50\end{array}$ & $\begin{array}{l}\text { - Continúa la instrumentación y el estilo occidental. } \\
\text { - Se baja la intensidad para dar acceso al diälogo, que } \\
\text { minoriza al nativo (es nominado por Mickey, al modo } \\
\text { que se le otorga nombre a una posesión) } \\
\text { - El dominio de Mickey sobre lo natural: melodia } \\
\text { sinuosa "oriental" para amaestrar a la serpiente. }\end{array}$ \\
\hline $\begin{array}{l}\text { - El desembarco de los canibales comienza una } \\
\text { auténtica batalla campal que acaba con el triunfo } \\
\text { del dúo Mickey - Friday, quienes logran huir sanos y } \\
\text { salvos. }\end{array}$ & $\begin{array}{l}3: 51 \\
7: 59\end{array}$ & $\begin{array}{l}\text { - Vuelta de la tensión con sonidos más sombrios. } \\
\text { - Aparición de sonidos diegéticos (toques de bocina) } \\
\text { que se combinan con otros incidentales para } \\
\text { alimentar la tensión. } \\
\text { - Progresiones asociadas a los nativos. } \\
\text { - Sonidos atipicos (frullatti en las trompetas) } \\
\text { - Finalmente se tranquiliza la acción con la melodia } \\
\text { triunfal de despedida. }\end{array}$ \\
\hline
\end{tabular}

Una vez se ha llevado a cabo el visionado y se han convenido aquellos aspectos musicales que refuerzan la posición de quien realiza la cinta, los alumnos empiezan a vislumbrar el proceso de homogeneización, en este caso de la negritud africana (aunque bien podría tratarse de cualquier otra zona caribeña a la que el protagonista llega desde la deriva de su frágil barcaza), y queda abierta la posibilidad de actividades de todo tipo relacionadas con los capítulos anteriores del presente escrito, con especial atención a la sonorización alternativa con los mecanismos ya ilustrados, de modo que se reedifique un nuevo sentido general a través de lo sonoro para aquello que estaba plagado de

\footnotetext{
${ }^{732}$ Es importante conectar el peso de la descripción musical con la visual en cada uno de los fragmentos en que se divida el corte. Un ejemplo en el que la estructuración musical y visual se explican mutuamente lo encontramos en RADIGALES, J. (2008): Op. cit., p. 42.
} 
estereotipos aunque, para salvar definitivamente las trabas a que conduce una sonorización orientada a la designación de la alteridad desde su concepción, tal vez sea más rentable el uso de otras técnicas, como la creación de una historia alternativa con imágenes seleccionadas ex profeso y su consiguiente adición musical.

En tercer lugar, nos centramos en uno de los ejemplos que por su complejidad práctica y por la cantidad de referencias teóricas que ha generado merece una mayor atención $^{733}$. Hablamos pues de la representación cinematográfica de la entelequia "Oriente" y su aplicación pedagógica en el aula de educación musical. Ciertamente, uno de los contextos más recurrentes es el de la representación de la ilusión orientalista, dicho el término con toda la carga implícita desde la visión del citado Edward W. Said $^{734}$. Es sabido pues, que en función de las expectativas de los realizadores de los documentos audiovisuales a que nos remitamos las opciones o medios de inserción musical se tornan en estratagemas de actuación que sirven para acotar un amplio abanico de posibilidades, desde la negación del diálogo intercultural hasta la total hibridación entre sociedades. En ambos extremos, la música que describe el contacto cultural es instrumentalizada en favor de una idea concreta que, de manera más o menos vehemente, ilustre la capacidad o incapacidad de un individuo o sociedad para acercarse a los discursos ajenos. Así, la generación ilusoria de un discurso audiovisual, apoyado en su música, puede llevarnos a entender a la alteridad como un ente arcaico o moderno, enclaustrado o abierto, en definitiva condicionado por su credo o libre para decidir su destino. En todo ello el tratamiento sonoro tiene una importancia sin igual, incidiendo en la negación de espacios interactivos o sirviendo de puente sobre el que hacer emerger nuevos escenarios mediados por la relación entre iguales.

\footnotetext{
${ }^{733}$ Parte de las ideas que se exponen formaron el corpus teórico de la comunicación "La música de la ciudad multicultural en el cine" presentada en el Congreso de la Sociedad Iberoamericana de Etnomusicología en marzo de 2008 en Salamanca. La referencia al recurso digital de las actas: MONTOYA RUBIO, J. C. (2008c): "La música de la ciudad multicultural en el cine”. GÓMEZ MUNS, R. y LÓPEZ CANO, R. (Eds.) Música, ciudades, redes. Creación musical e interacción social. Salamanca: SIbE. Se implementa ahora a esos postulados un carácter pedagógico ausente entonces.

${ }^{734}$ Reiteramos que no nos resulta tan motivador para nuestros fines didáctico-musicales llevar al extremo el trasluz imperialista que se desprende en última instancia de algunos postulados de Said, pero sí nos parece sumamente estimulante y atractivo extrapolar sus pensamientos, que por otro lado han calado hondo en una u otra dirección de la producción científica posterior a él, para analizar y abordar la generación de audiovisuales enfocando dicha elaboración al hecho musical.
} 
Por tanto, ha sido enunciado el argumento según el cual la aplicación musical dentro de los discursos audiovisuales que abordan la coexistencia cultural entre los mundos occidentales y orientales está plagada de contradicciones y mensajes que se retroalimentan desde su propia puesta en escena. Es inevitable que el cine, como parte fundamental del mundo audiovisual, se aproxime con profusión a las situaciones de relación entre culturas que se acentúan en los últimos tiempos, ya que los procesos migratorios han perfilado una nueva realidad social a la que plasmar, con mayor o menor acierto, y a la que dirigirse. Por todo ello, es común hallar ejemplos en los que estas cuestiones son abordadas, bien como elemento central bien como aspectos puntuales a lo largo del desarrollo argumental. Ante todo, es preciso tener presente que estas relaciones sociales precisan de una reflexión intensa y previa desde el ámbito de la geografía humana, de modo que los intereses cinematográficos no siempre van a converger con las prioridades que la producción y análisis de los científicos sociales, y todo ello puede acabar redundando en repetidos procesos de estereotipación. La clave para enfrentarnos desde el análisis pedagógico a estas producciones será la de entender que estamos ante realizaciones que, entre sus finalidades comerciales, trasladan necesidades de expresión y posicionamiento en torno a una situación "de hecho", de modo que habremos de buscar el mensaje que pretende el director o realizador del montaje audiovisual.

En suma, las esferas contrapuestas en las que suele ser tratada la idealización oriental, no sólo ya en el ámbito fílmico sino también en otros ámbitos artísticos o no, basculan entre al sensualidad idílica y mágica y la violencia intransigente e irracional. El elemento a detectar, con el fin de hacer de los visionados audiovisuales productos con intención pedagógica, será el posicionamiento de los realizadores de dichos discursos, prestando especial atención al modo en que la aplicación sonora redunda en afianzar un mensaje de diálogo cultural o sirve para establecer férreas diferencias entre los distintos grupos sociales. Así, no es difícil encontrar ejemplos en los que sonidos arquetípicos definan los aspectos más simplistas de una cultura, aunque es igualmente cierto que también existen casos en los que se busque deliberadamente desmontar mitos concretos que acarrean estigmas que han servido para nominar e idealizar ilusoriamente a sociedades altamente cargadas de prejuicios, de modo que esta nueva perspectiva sirva 
para aproximarse con una mirada más constructiva a ella a partir de la catarsis que supone dicha observación diferenciada ${ }^{735}$.

La gama de posibilidades en esta elaboración de discursos en torno a la alteridad en el caso de Oriente puede ser tan dispar que no cabe sino una aproximación que deje al descubierto algunas de las posibilidades de actuación didáctica desde filmes paradigmáticos. Por ello en nuestra propuesta de análisis y abordaje pedagógico nos centraremos en dos largometrajes que, a nuestro entender, pueden ejemplificar en muchos casos los extremos de la horquilla que van de la negación entre culturas hasta el diálogo total intercultural ${ }^{736}$. En el primero de los casos, tomaremos como referencia

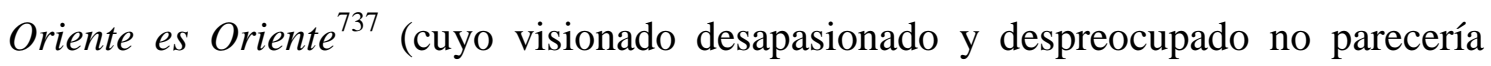
esconder ningún tipo de pretensión oculta) y, en el segundo, El próximo Oriente ${ }^{738}$ (en donde las ideas de hermanamiento y reciprocidad son tal vez mostradas con excesiva vehemencia). La principal tarea sería la de rastrear si en las aplicaciones musicales de Deborah Mollison y Juan Bardem, respectivamente, el alumno puede encontrar pistas acerca de planteamientos no declarados, esto es, atender al modo en que entienden la cultura, bien como un conjunto de departamentos estancos o si a partir de lo musical se aconseja o permite el intercambio cultural ${ }^{739}$. Asimismo, es posible que las situaciones narradas, en las cuales toman vigor las generaciones de inmigrantes, reflejen alguna de las realidades cercanas a un buen número de alumnos. Así, basándonos en algunos de los postulados propuestos en apartados anteriores acerca del cinefórum y la reflexión guiada de los discursos audiovisuales, podemos establecer diferentes niveles de análisis sonoro en los alumnos que se enfrenten a la comparación entre ambas películas. Un ejemplo quedaría tal como se presenta a partir del siguiente esquema.

\footnotetext{
${ }^{735}$ EGEA FERNÁNDEZ - MONTESINOS, A. (2003): Tópicos andaluces en el cine contemporáneo: de la españolada al poscostumbrismo. Sevilla: Fundación Centro de Estudios Andaluces.

${ }^{736}$ Dicho ello con las pertinentes reservas, ya que los fines comerciales enmascaran en muchos casos pretensiones de otro tipo.

${ }^{737}$ Dir. Damien O’Donnell, 1999.

${ }^{738}$ Dir. Fernando Colomo, 2005.

${ }^{739}$ A pesar de que, ante las escenas a veces crudas de Oriente es Oriente, el guionista Ayub Kan Din se esforzaba por hacer ver que no generaliza sino que narra su propia historia vital: OLDEN, M. (1999): "A Quick Chat with Ayub Khan-Din”. <http://www.kamera.co.uk/interviews/ayubkhandin.html> [Consulta 9-II-10].
} 


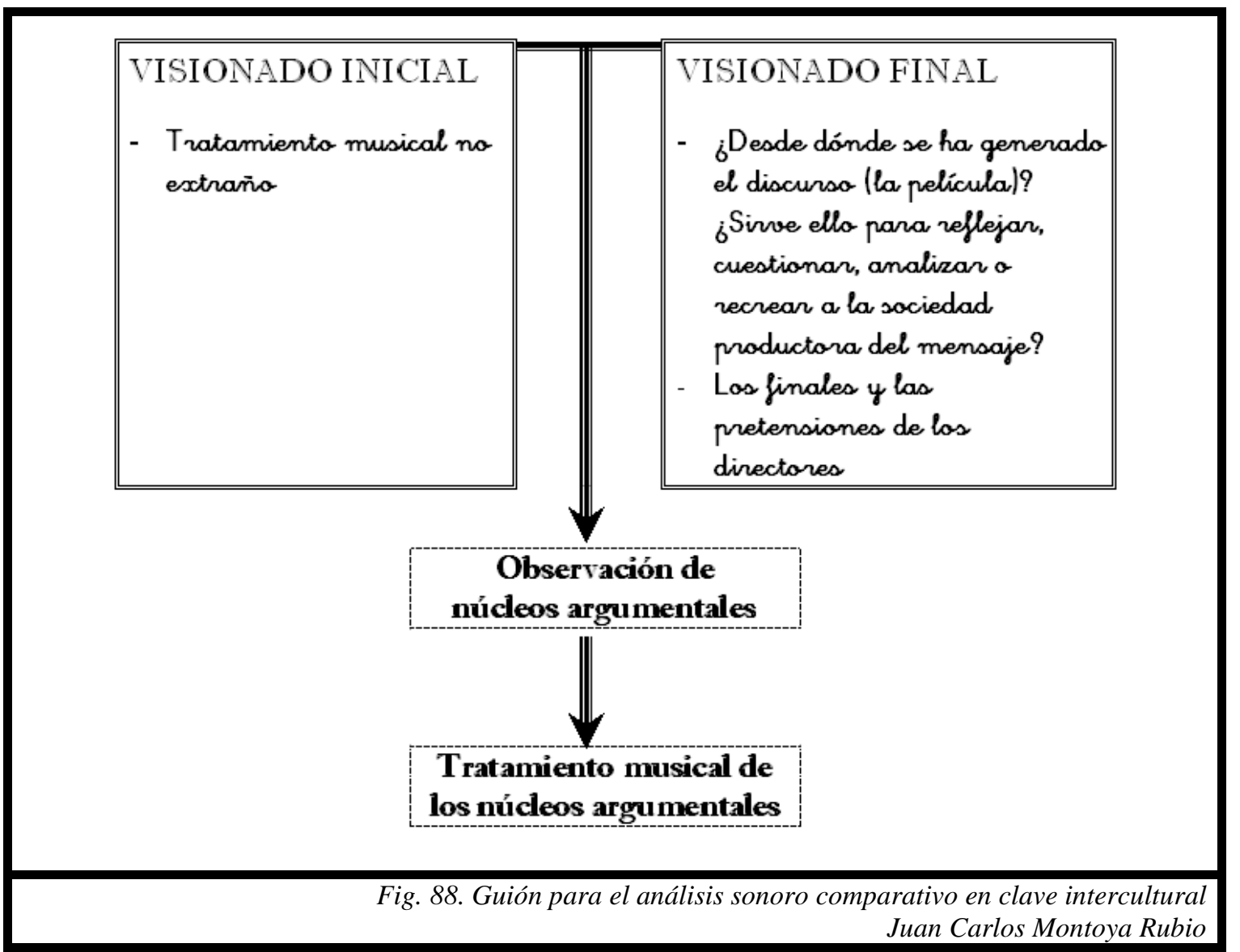

De acuerdo con el diagrama, se podría partir de un visionado "informal” sin mayores pretensiones que la de constatar que, a simple vista, el tratamiento musical que se lleva a cabo en las películas seleccionadas no parece presentar ningún rasgo extraño o que parezca condicionar particularmente el filme más allá de las obvias funciones que la música de cine cumpliría.

De este primer visionado se empezarían a extraer conclusiones acerca del nudo argumentar, focalizándose por parte del docente aquellos núcleos que puedan ser potencialmente atractivos para su tratamiento en clave intercultural. En el caso que nos ocupa, y con el ánimo de ir avanzando en la explicación a través de ejemplos, estos niveles argumentales se corresponderían a tres esferas que nos informan sobre la globalidad de los largometrajes: el entorno que muestran, el tratamiento de la hibridación y la convivencia y el modo de abordar las religiones, aspecto capital por la gran carga simbólica que acarrea su interpretación. Tanto éste como el siguiente nivel de análisis, dedicado a lo musical, pueden servirse de visionados parciales dirigidos. 


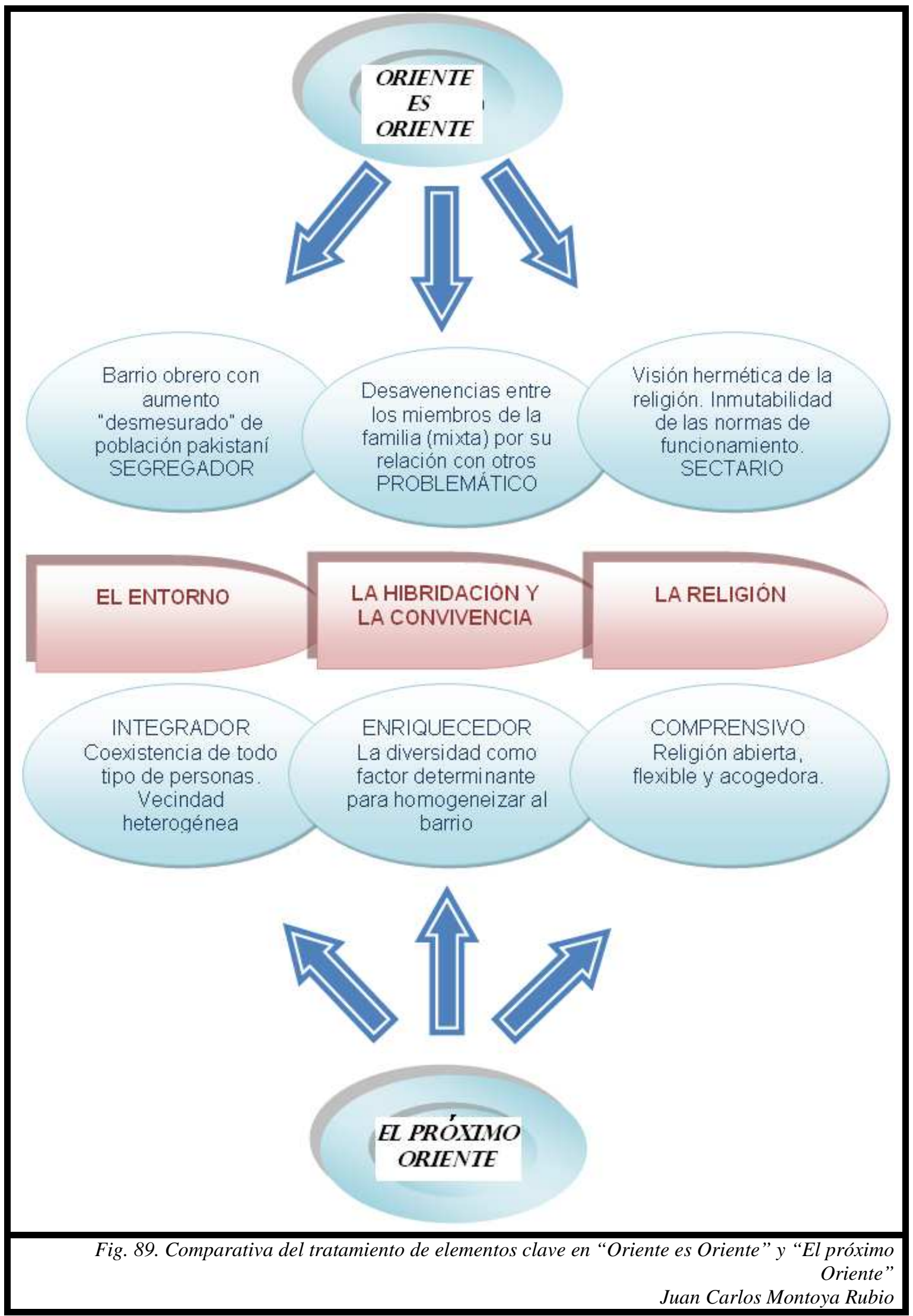


Tras este plano de análisis se empiezan a constatar sensibles diferencias en lo que respecta al tratamiento de la diversidad. Llegamos pues al momento de ver hasta qué punto estas presunciones son ratificadas o desmentidas por la música que alberga cada uno de los discursos, la cual según los compositores, trata de penetrar sin mostrar de manera aparente todo su potencial ${ }^{740}$. Así, dentro del tratamiento musical de los nudos argumentales una metodología como la que se presenta habrá de direccionar al alumno hacia los aspectos más relevantes que, como veremos en los casos concretos que estamos considerando, serán muchos y muy productivos. De todos ellos, tratando únicamente de mostrar posibilidades de actuación, focalizamos primeramente en la aplicación musical que se da en torno a las figuras paternas, reservas culturales musulmanas y fuente de conflictos e intrigas en ambas películas, pero con un tratamiento abiertamente desigual en cada una de ellas. La utilización de unos u otros sonidos imprime connotaciones muy específicas que, en última instancia, conducen a interpretar cómo son los mundos que se nos muestran y hasta qué punto pueden ser opuestos o cercanos:

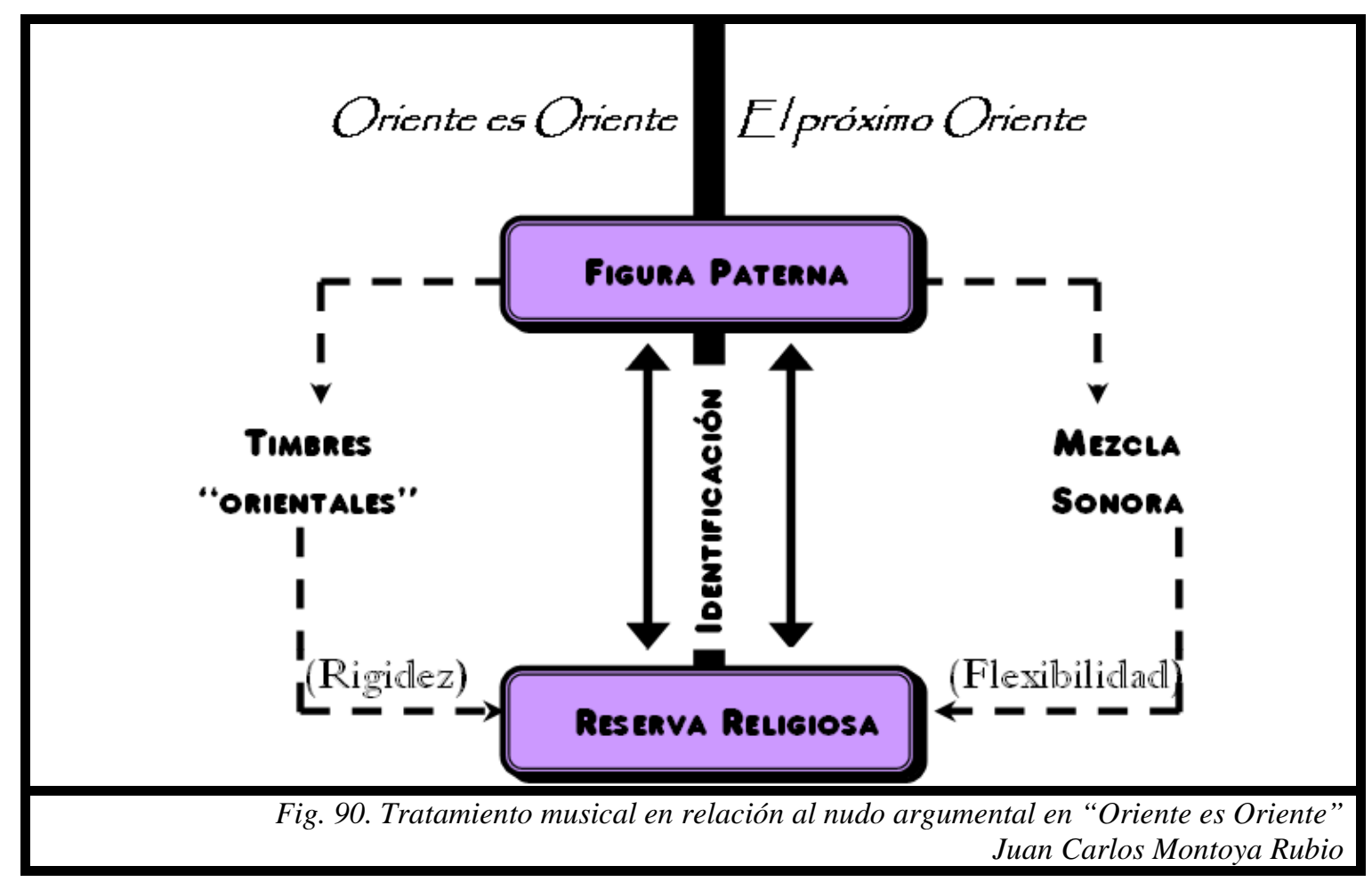

\footnotetext{
${ }^{740}$ Tanto la música de Deborah Mollison como la de Juan Bardem comparten esta característica, que es refrendada por este último en la entrevista que puede ser encontrada en ORDÓÑEZ, M. Á. (2007): "Entrevista a Juan Bardem" <http://www.scoremagacine.com/Entrevistas_det.php?Codigo=37> [Consulta 9-II-10]
} 
Otros ámbitos que pueden dar pie al análisis y posterior discusión son, por ejemplo, frente a la negación en una historia, el modo en que se negocian situaciones de profundo calado musical en otra ${ }^{741}$, con música de Mozart trasladada a un ambiente híbrido o con sonidos orientales interpretados en conjunción por unos y otros protagonistas, así como los momentos paralelos que se muestran en ambos largometrajes, especialmente la pintoresca boda en El próximo Oriente y su contrapunto en la asfixiante ceremonia nupcial de Oriente es Oriente. La intransigencia sonora de este último referente fílmico (sonidos sueltos, inconexos y, a todas luces, extraños al oído occidental) choca frontalmente con el acomodo musical que se da, diegéticamente, en la otra película, en la cual la ambientación musical puede llevarse a cabo, incluso en un momento tan trascendente como es una boda de este tipo, por músicos callejeros peruanos con su instrumental a cuestas.

En resumen, puede considerarse que el alumno logrará entrar en el núcleo de la cuestión intercultural tal como se plantea si es capaz de entender que estamos ante discursos elaborados con pretensiones concretas que, por lo tanto, dejan entrever en su propio método de producción visual y sonora retazos de su orientación ideológica. El visionado final que se propone bebe de dichos postulados, preguntando acerca de la generación del producto audiovisual y sus consecuencias ${ }^{742}$.

\footnotetext{
${ }^{741}$ El modo en que se niega la coexistencia en Oriente es Oriente tiene un particular reflejo en las ideas de SHARMA, S. (2006): Multicultural Encounters. Basingstoke: Palgrave Macmillan. El autor, hace especial énfasis en el modo en que la cultura musulmana puede ser presentada desde la maleabilidad y no tanto desde la rigidez, lo cual da pábulo a reflejar sociedades estancadas en el tiempo, incapaces de progresar y amoldarse a los nuevos tiempos. Para él, estamos ante una dialéctica entre lo arcaico (donde se supone se instala "lor oriental" a partir de estas construcciones) y lo moderno (vetado por sus ancestrales anclajes).

${ }^{742}$ Utilizando para ello ideas de BARRENETXEA MARAÑÓN, I. (2006): "Pensar la historia desde el cine". Entelequia 1, p. 101.
} 


\subsection{MÚSICA, INCLUSIÓN Y COMPENSACIÓN EDUCATIVA.}

\section{El marco de la acción compensatoria}

Es evidente que el trabajo desde la atención a la diversidad se fundamenta como uno de los principales parámetros de actuación dentro de estos nuevos marcos de referencia educativa, para lo cual las administraciones educativas están tratando de reglar determinadas pautas de actuación. Por otro lado, en función de su procedencia, la configuración de las aulas de los centros educativos actuales está impregnada de una variedad de alumnado que no había sido conocida en nuestro entorno con anterioridad.

En este contexto, la acción compensatoria, dedicada a favorecer el desarrollo armonioso de las capacidades de aquellos alumnos que ven peligrar dicha evolución por causas diversas (origen extranjero con o sin desconocimiento de la lengua, pertenencia a grupos socialmente desfavorecidos, etc.), está tomando vigor en los últimos tiempos ${ }^{743}$. Bajo el amparo de las premisas inclusivas, el acoplamiento de estos alumnos en el engranaje educativo a partir de la legislación generada y de la propia atención cotidiana está derivando en la conformación de estructuras teóricas (con evidentes reflejos en la práctica) muy atractivas, en torno a las cuales pretendemos apuntar nuevas estrategias

\footnotetext{
${ }^{743}$ Debido a las diferentes tipologías puestas en funcionamiento por Comunidades Autónomas en el conjunto de España, optamos por inscribir los ejemplos que servirán como clave metodológica dentro del desarrollo planteado en la Región de Murcia, marco en el que han sido testadas sobre la práctica las experiencias que describiremos y que, además, está desarrollando con vigor aspectos curriculares de esta índole. En este sentido, las principales referencias tenidas en cuenta en el marco de la compensación educativa han sido: Decreto 359/2009, de 30 de octubre (BORM de 3 de noviembre), por el que se establece y regula la respuesta educativa a la diversidad del alumnado en la Comunidad Autónoma de la Región de Murcia (en cuyo capítulo IV se trata de dar respuesta educativa a las desigualdades generadas en el ámbito educativo); Resolución de 13 de septiembre de 2001 de la Dirección General de Enseñanzas de Régimen Especial y Atención a la Diversidad, por la que se dictan las medidas para la organización de las actuaciones de compensación educativa en la etapa de Educación Secundaria Obligatoria en los centros docentes sostenidos con fondos públicos de la Comunidad Autónoma de Murcia (la cual, a pesar de quedar tras la importancia normativa del Decreto anteriormente citado, otorga claves para definir la compensación educativa y sus derivaciones pedagógicas); Orden de 18 de Octubre de 2007 (BORM del 6 de Noviembre), de la Consejería de Educación, Ciencia e Investigación por la que se regula la impartición del programa específico de Español para Extranjeros y se proponen orientaciones curriculares (asignatura específica dentro de la cual tienen cabida algunos de los planteamientos que nos ocuparán); Orden de 16 de diciembre de 2005 (BORM de 31 de diciembre), de la Consejería de Educación y Cultura, por la que se establecen y regulan las aulas de acogida en centros docentes sostenidos con fondos públicos de la Región de Murcia (para cuyas estructuras se puede mostrar igualmente valedera una interacción entre materiales musicales y compensadores).
} 
de actuación ${ }^{744}$. El mayor inconveniente que extraemos desde nuestra docencia directa en los ámbitos musicales y compensadores es el de que, en ocasiones, no existe una combinación lo suficientemente fluida entre ambas realidades, de modo que no funcionan como eslabones de una misma cadena sino como entidades autónomas (lo cual por supuesto no es exclusivo de la educación musical, sino que puede ser extrapolado al resto de áreas de conocimiento). Así, suele ser común encontrar prácticas dicotómicas como la que presentamos:

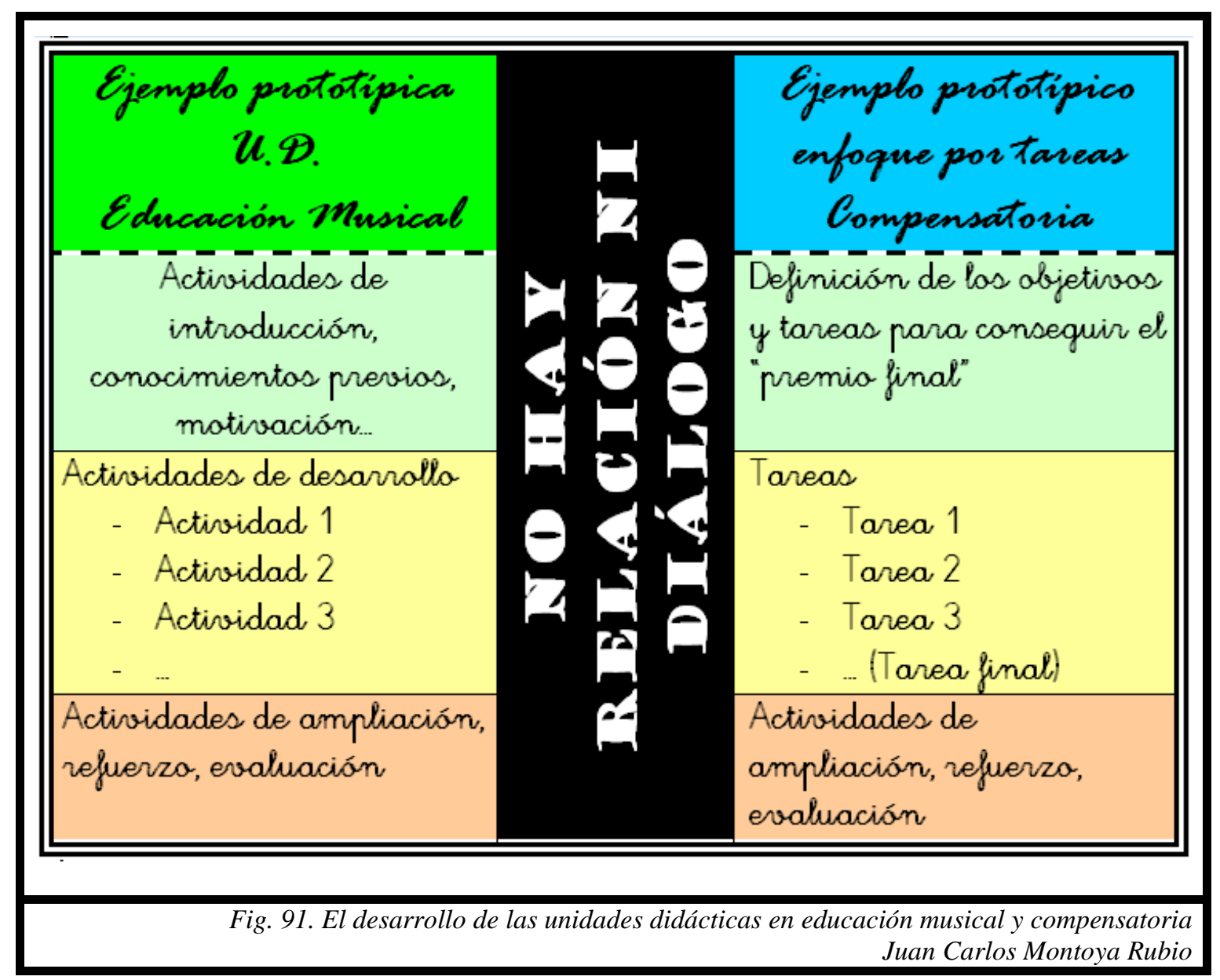

Paliar este tipo de incomunicaciones es perentorio ${ }^{745}$, pero no suponen la única desavenencia que se encuentra en la gestación de estos contenidos. Resumimos pues, a

\footnotetext{
${ }^{744}$ Entre las referencias teóricas manejadas con mayor profusión en este ámbito, el cual como señalamos comienza a ser inabarcable, destacamos: ARNÁIZ SÁNCHEZ, P. (2003): Educación inclusiva: una escuela para todos. Málaga: Aljibe.

${ }^{745}$ Especialmente desde la aceptación de que el contenido curricular implica no sólo el compendio de conceptos albergados en el currículo, sino también todo aquello que tiene su reflejo en el proceso de
} 
partir de dos referencias seleccionadas, algunas de las problemáticas más acuciantes de los enfoques que pretenden el trabajo centrado en esta vertiente de la diversidad cultural:

“...los maestros reciben de la sociedad una presión más o menos tácita para que amortigüen o neutralicen las distintas manifestaciones culturales, que en muchas ocasiones se entienden de manera negativa y son difíciles de aceptar,"746.

“...[el entorno de enseñanza ha de dar] verdadera respuesta a los problemas actuales y especialmente de futuro consolidándose como la institución más comprometida con la formación en una interacción didáctica en colaboración"747.

La primera de las citas nos conduce a una realidad que, en ocasiones, traba hasta tal punto la labor a desarrollar que, de llevarla a cabo en plenitud, acaba por convertirla en un trabajo de obcecación por parte del docente. Es cierto que, indistintamente de la procedencia, estimular el desarrollo de la diversidad implica luchar contra la uniformidad lo cual, en ocasiones, supone enfrentarse a presunciones venidas desde fuera de los muros de los centros educativos. La segunda de las referencias apunta soluciones a las dificultades señaladas, las cuales pasan fundamentalmente por abordar sin gambeteos los problemas reales del presente como base para preparar el futuro, entender el centro educativo como un cúmulo de relaciones basadas en el compromiso y el desarrollo de estrategias de enseñanza cooperativas. El hecho de que la acción compensatoria se conciba como un medio para conseguir que los alumnos con problemáticas derivadas del desconocimiento del idioma o desventaja social no pierdan

enseñanza-aprendizaje dentro del contexto del centro educativo. Este hecho es señalado por MARTÍNEZ VALCÁRCEL, N. et cols. (2003): Didáctica general pedagogía. Murcia: Diego Marín Librero-Editor, p. 209.

${ }^{746}$ HERNÁNDEZ BRAVO, J. A., HERNÁNDEZ BRAVO, J. R. y MILÁN ARELLANO, M. A. (2006): "La interculturalidad en la escuela actual. Una aproximación a las competencias interculturales del alumnado de educación primaria". Ensayos 21, p. 257.

${ }_{747}$ MEDINA, A. (2002): "La intervención didáctica en el aula: el clima socio-comunicativo". MEDINA, A., RODRÍGUEZ, J. L. y SEVILLANO, M ${ }^{a}$ L. (Coords.) Diseño, desarrollo e innovación del currículum en las instituciones educativas (II). Madrid: Universitas, p. 603. 
la posibilidad de llevar a cabo aprendizajes conjuntos con su grupo de referencia abre vías de exploración pedagógicas hasta ahora tratadas con cierta timidez.

Por tanto, los procedimientos metodológicos que apuntaremos tendrán como fuente directa de inspiración tres ejes vertebradores, tales como la acción compensatoria, la educación musical y la vertiente audiovisual de las Tecnologías de la Información y la Comunicación. La conjunción de todos estos elementos continúa asumiendo como propios los criterios de conexión con el alumnado ya descritos con profusión. Por ello, si entendemos que el especialista de educación musical ha de ser capaz, de manera general, de aproximarse a los intereses de sus alumnos, en este plano, la reelaboración imaginativa de materiales audiovisuales ha de ser de nuevo el emblema a enarbolar. Además, hemos de resaltar que abordando la dimensión compensatoria de la educación nos hallamos ante una realidad emergente, la cual afortunadamente cuenta con mayores recursos y salidas, y es en la interacción con la educación musical (cuya fortaleza queda en entredicho a la luz de su infravaloración dentro del sistema educativo general), donde podremos hallar estrategias para robustecer didácticas que tengan en cuenta el universo sonoro del discente. Por otro lado, abundamos en que la añadidura que supone el uso audiovisual sirve para aumentar el interés general de las propuestas metodológicas que compendien los ámbitos referidos.

\section{Los parámetros inclusivos por medio del audiovisual y la educación musical. Propuesta metodológica globalizadora.}

En concordancia con la filosofía que hemos diseñado para este apartado, la metodología que planteamos continuará incidiendo en postulados inequívocamente interculturales. Las referencias básicas serán ${ }^{748}$ :

- Propiciar elaboraciones pedagógicas que reflejen el espíritu inclusivo a partir de la conexión entre las aulas ordinarias (donde incluimos la de educación musical) y los lugares de aprendizaje específico, como pueda ser el aula de

\footnotetext{
${ }^{748}$ Similares a las que propiciaron la experiencia práctica desarrollada en MONTOYA RUBIO, J. C. (2008d): "Música e imágenes para una educación inclusiva. Aplicaciones didácticas audiovisuales para los programas de acción compensatoria". HURTADO MONTESINOS, M. D., y SOTOS PÉREZ, F. J. (coord.) La igualdad de oportunidades en el mundo digital. Actas Tecnoneet 2008. Cartagena: Universidad de Cartagena, pp. 793-801.
} 
compensatoria. Así, se enfatiza la importancia de que tanto alumnos como contenidos didácticos quedan enmarcados bajo una misma realidad educativa que responde a una lógica global y lucha contra la inconexión entre agentes implicados en el proceso.

- Consecuentemente, engrosar los recursos y materiales para los nuevos marcos de actuación pedagógica que abre esta vertiente de la atención a la diversidad, la cual suele ser entendida mayoritariamente como la superación de la dificultad derivada de la discapacidad. En todo caso, no sólo ése es el escenario de desarrollo de la diversidad ${ }^{749}$, sino que a partir de este gran cajón de sastre pretendemos que las necesidades educativas abriguen también la diversidad cultural $^{750}$.

- Alentar modelos cooperativos entre docentes y áreas que estimulen un trabajo similar entre los alumnos. Está comprobado que los centros en los cuales rigen actitudes cooperativas el rendimiento a todos los niveles puede ser superior, llegando a implicarse, por el propio devenir de las situaciones, agentes que en principio no parecerían dispuestos a participar de situaciones colaborativas ${ }^{751}$.

- Estimular que los intercambios (lingüísticos o de cualquier otro ámbito) se lleven a cabo no sólo entre alumnos inmigrantes sino que aquellos que son receptores lo sean también del bagaje que traen consigo sus compañeros. La difícil articulación de la igualdad desde la diferencia como núcleo de actuación $^{752}$.

- Amparar todo el proceso bajo la asociación de las áreas curriculares con los contenidos audiovisuales. La atención a la diversidad ha sido un campo de

\footnotetext{
${ }^{749}$ Para lo cual suelen hallarse un mayor número de realizaciones didácticas desde la educación musical. Sirva como ejemplo: AMUSATEGUI, C. (1996): "Educación musical en educación especial". Eufonía 4, pp. 85-96.

${ }^{750}$ En todo caso es justo constatar que desde la educación musical, a pesar de no ser su principal foco de atención, sí podemos empezar a encontrar ejemplos en esta dirección: MUÑOZ MUÑOZ, J. R. (2006): "La educación musical en niñas y niños con necesidades educativas especiales derivadas de factores sociales, económicos, geográficos, culturales y étnicos" en Eufonía 37, pp. 80-94.

${ }^{751}$ GÜEMES ARTILES, R. M. y PADRÓN FRAGOSO, J. (2005): "Estudio sobre los procesos del aula en contextos escolares democráticos". Revista Interuniversitaria de Formación de Profesorado 19, pp. $175-194$.

${ }^{752}$ DÍAZ PEREA, M. P. (2007): “Atención a las dificultades en la alfabetización de la población inmigrante en el primer ciclo de educación primaria”. Docencia e Investigación 17, p. 66.
} 
experimentación propicio para la inserción de las tecnologías actuales ${ }^{753} \mathrm{y}$, en propuestas como las que pretendemos sistematizar, se antojan primordiales.

Al cobijo de dichas intenciones, describiremos dos modelos para la inserción de los materiales audiovisuales como nexo entre las realidades compensadoras y musicales. En ambos diseños, partiremos de un elemento audiovisual que actúe como resorte significativo $^{754}$. Igualmente, esa mecha encendida tendrá que ser debidamente alimentada por medio de lo que denominamos en el siguiente esquema "intensificación" o "refuerzo significativo", que se entiende como un paso más en la canalización de los aprendizajes hacia nuestros fines como docentes. Los medios en que esa intensificación será llevada a cabo se expondrán detalladamente en cada uno de los ejemplos.

En el diseño metodológico primero, hemos partido de un elemento musical conocido por todos, el cual ha sido mostrado en formato audiovisual para estimular el resto del proceso. La particularidad de este procedimiento es que, de manera aislada, se trabajan elementos específicos con los alumnos de compensatoria para proceder a su inserción en el gran grupo en, supuestamente, igualdad de condiciones con el resto de los compañeros. Por su parte, el segundo de los diseños que planteamos nace en un fragmento audiovisual que cada cual puede haber visto en su lugar de origen con la particularidad de que, al conjunto de los compañeros, se presentará en diferentes idiomas. El avance que se pretende es el de hacer del proceso de enseñanza un recorrido de ida y vuelta, que se inmiscuya en una y otra lengua, una y otra cultura, para modelar la realidad del aula a través de los ojos del alumnado. Pasamos a detallar por medio de ejemplos concretos cada una de las aplicaciones metodológicas trazadas sobre estas líneas y esquematizadas bajo ellas.

\footnotetext{
${ }^{753}$ Hace años que esas posibilidades se atisban en trabajos como ALBA, C. y NAFRÍA, E. (1993): "Utilización didáctica de las nuevas tecnologías en educación especial. Análisis desde los modelos teóricos". COMES, G. y GISBERT, M.: La necesidad de una educación para la diversidad. Tarragona: El Mèdol, pp. 61-69.

${ }^{754} \mathrm{La}$ importancia que otorgamos a esta fase queda puesta de manifiesto en el Capítulo 2, dentro del diseño de unidades didácticas prototípicas que dependen del modo en que se despierta el interés por el contenido a enseñar.
} 


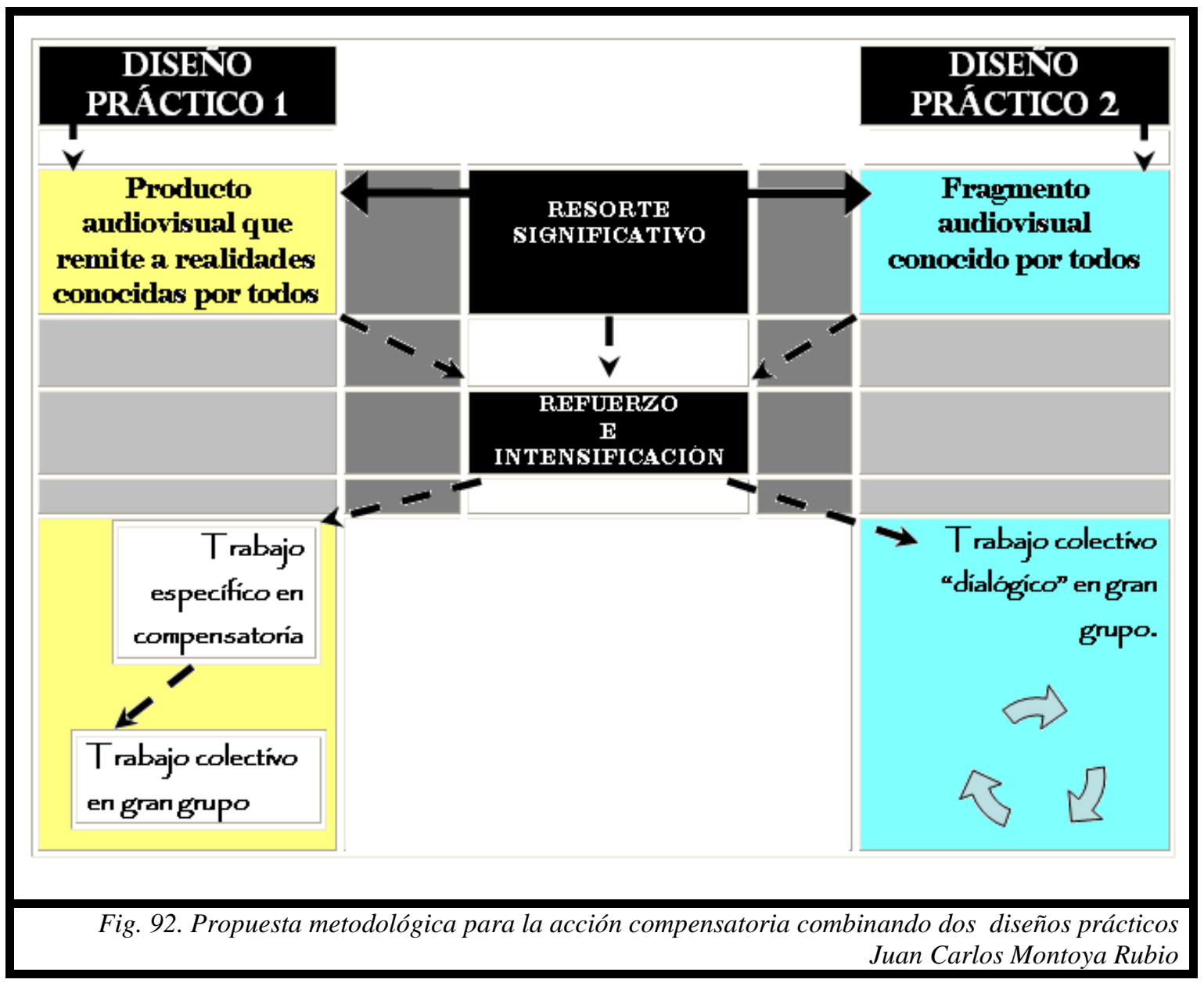

\section{Diseño práctico 1}

El primero de los diseños metodológicos propuestos busca su origen en situaciones concretas dentro del aula ordinaria (en este caso de educación musical) que continúe con un trabajo específico para los alumnos del plan de acción compensatoria, conducente a paliar las dificultades que el tratamiento directo de contenidos en gran grupo pudiera ocasionar en ellos. Como principal pretensión, por tanto, surge la de propiciar que los alumnos de origen extranjero participen con totales garantías de éxito en los procedimientos habituales para el grupo de referencia.

Imaginemos una unidad didáctica cuya culminación, dentro de las actividades de desarrollo, nos lleva a que todo el alumnado se integre en un ejercicio en el que la ejecución instrumental fuera el principal baluarte. $\mathrm{Si}$, en ese caso hipotético pero fundamentado en supuestos muy posibles, se pretende que los alumnos exploren todos 
los registros de la flauta dulce y sean capaces de mantener la constancia rítmica al asociarle obstinatos, bien podríamos proponer una actividad como la que se muestra:

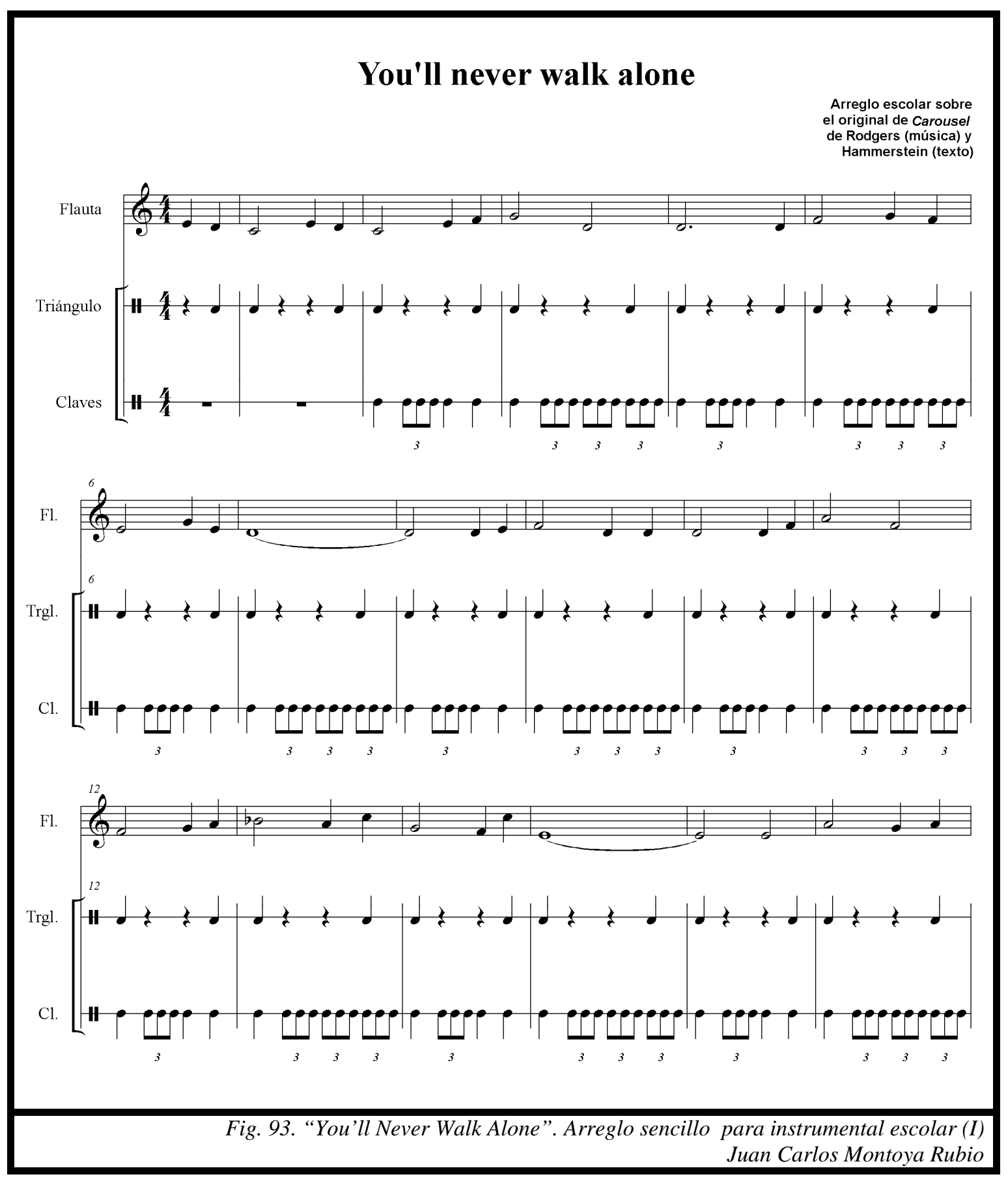




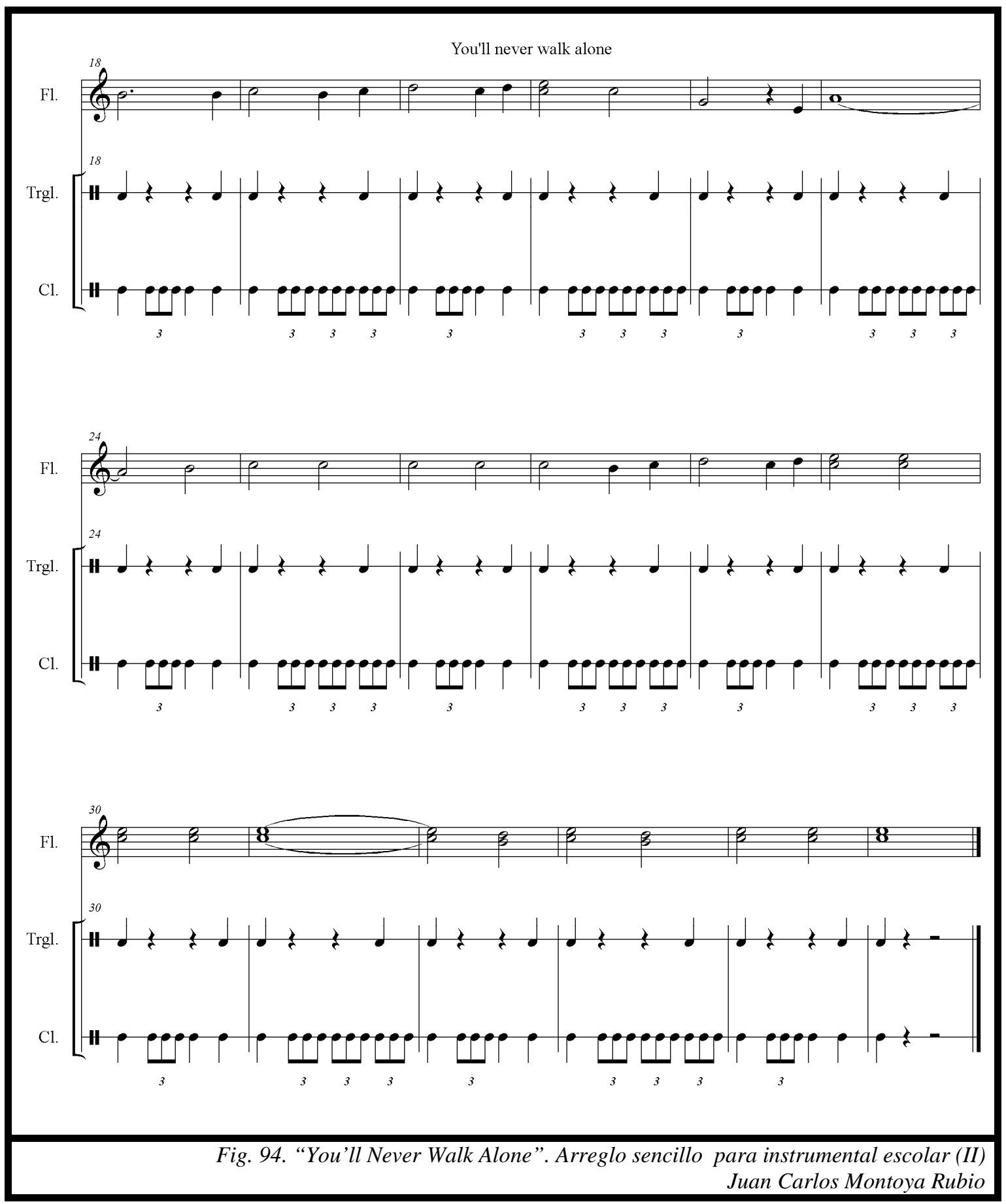

El resorte significativo del cual partimos para desarrollar el ejemplo es, como quedó definido con anterioridad, el hecho sonoro que el docente elige por su cercanía al alumnado, provenga éste del medio que provenga. Para el caso ideal que tratamos (especialmente centrado en alumnos a partir del tercer ciclo de primaria e inicio de la 
secundaria) nos centraremos en la melodía "You'll never walk alone"755, reconocida sin grandes dificultades por los estudiantes si es presentada como la música que define a un conocido club inglés de fútbol. Para que su efectividad sea la esperada, la presentación del material tendrá la forma de vídeo que muestre cómo la hinchada del equipo en cuestión, Liverpool F. C., entona desde las gradas del estadio de Anfield dicha melodía.

Con este elemento musical conseguimos hacer que el trabajo se focalice a través de un aspecto ampliamente conocido por alumnos de todas las latitudes. En todo caso, hasta el momento la labor se ha centrado en promover sorpresa e interés en los alumnos, tanto en los inmigrantes como en el resto de la configuración del aula. Llega pues el momento de implementar información relevante e intensificadora a estos pasos preliminares del proceso. Para ello, ante todo, clarificamos aquello que se está cantando (por ejemplo a través de un vídeo que muestre con mayor nitidez el contenido ${ }^{756}$ ), damos a conocer el origen de la melodía que está siendo trabajada (del musical Carousel $^{757}$ ) a través de uno de los innumerables ejemplos que circulan por internet, para además, comenzar un trabajo específicamente musical (por ejemplo a partir de karaokes o realizaciones similares, también disponibles en la red para su desarrollo audiovisual). Además, en este segundo paso de intensificación, es sumamente importante hacer ver a los alumnos que esta melodía ha sido reutilizada hasta la saciedad. Para ello podemos optar por remitirles a otros elementos audiovisuales donde dicha canción haya dado lugar a productos concretos. Entre las muchas posibilidades, por su distancia con los otros dos vídeos presentados, optamos por dar a conocer su uso en algún anuncio televisivo, como es el caso de "Puleva Peques 2"758.

El guión didáctico a desarrollar ya ha sido puesto en funcionamiento. A partir de él, en una realización pedagógica prototípica, se seguiría incidiendo en todos y cada uno de los pasos establecidos por la secuencia didáctica al uso pero, en este caso, siguiendo el plan propuesto, se abre el camino hacia el trabajo específico de los alumnos de compensatoria. A partir de él se espera que todo aquello que vayan a tener que realizar con el resto de los compañeros en sucesivas sesiones de educación musical sea

\footnotetext{
${ }^{755}$ El desarrollo de la propuesta que se muestra tiene como referente MONTOYA RUBIO, J. C. (2008d): Op. cit.

${ }^{756}$ Un ejemplo entre la creciente lista de ellos: <http://www.youtube.com/watch?v=ma3Nax8yyOE > [Consulta 9-II-10]

${ }_{757}^{75}$ Música de R. Rodgers y texto de O. Hammerstein II, 1945.

${ }^{758}$ Agencia ArnoldFuel. <http://www.youtube.com/watch?v=41v8omm0XIU> [Consulta 9-II-10]
} 
"entrenado" o "mediado" con anterioridad para que, desde ese conocimiento previo, puedan insertarse sin problema alguno en el gran grupo. En todo caso, no se pretende que estos alumnos dejen de lado en su formación compensatoria aquellos aspectos que vienen desarrollando de manera habitual. Por ese motivo, se buscará una conexión firme entre el trabajo que vendrían a desarrollar para su adquisición de habilidades comunicativas y lingüísticas con estas otras cuestiones musicales. Es preciso pues recordar que, cuando son tratados de manera aislada del resto del grupo, para los alumnos que precisan de una formación concreta en el plano oral, se suelen programar sesiones en forma de pequeñas células de aprendizaje, esto es, el conocido como "enfoque por tareas"759. Este tratamiento de la diversidad ansía que la acción, el desarrollo de determinados ejercicios particulares, sirva de mecanismo para ir rubricando avances en la comunicación general ${ }^{760}$. En nuestro caso estas tareas irán enfocadas a la consecución de aspectos propios de la enseñanza en el plan compensador y, a su vez, a preparar al alumno para habilidades que tendrá que poner en práctica con posterioridad. Ejemplos de estas tareas de mediación o posibilitadotas son ejercicios de canto en idioma original y su traducción al castellano, actividades que sirvan para aprender vocabulario básico referido al nombre de los dedos y el modo de colocarlos en la flauta, desarrollo de secuencias melódicas sobre la canción en cuestión (realizando explicaciones sobre el sonido que se ejecuta antes, después, etc.) u observaciones que vinculen los campos semánticos que aparecen en la melodía trabajada con los registros grave - medio - agudo, de modo que el significado global se adquiera también a través de lo musical. La tarea final, también necesaria en enfoques de este tipo, irá de nuevo encaminada a buscar la simbiosis entre la compensación y la educación musical, para lo cual se ha previsto la realización de un musicograma por parte del alumnado explorando

\footnotetext{
${ }^{759}$ Este enfoque tiene un nivel de aceptación grande para la enseñanza del español como segunda lengua. Por ello, existe una gran cantidad de bibliografía que no es objeto de análisis por parte de esta investigación. No obstante, entre las más recientes publicaciones destacamos para su definición, planteamiento metodológico y estrategias en el desarrollo de tareas la siguiente referencia: ESTAIRE, S. (2009): El aprendizaje de lenguas mediante tareas: De la programación al aula. Madrid: Edinumen.

${ }^{760}$ Otros autores delatan que esta perspectiva accional ha de tender a una "co-accional", que enfatice la dimensión colectiva de las acciones enmarcada en un plan estratégico social: PUREN, C. (2004): "Del enfoque por tareas a la perspectiva co-accional". Porta Linguarum: Revista internacional de didáctica de las lenguas extranjeras 1, pp. 31-36.
} 
imágenes que evocan significados $\operatorname{concretos}^{761}$, con lo cual las aportaciones en ambas dimensiones quedan fuera de duda:

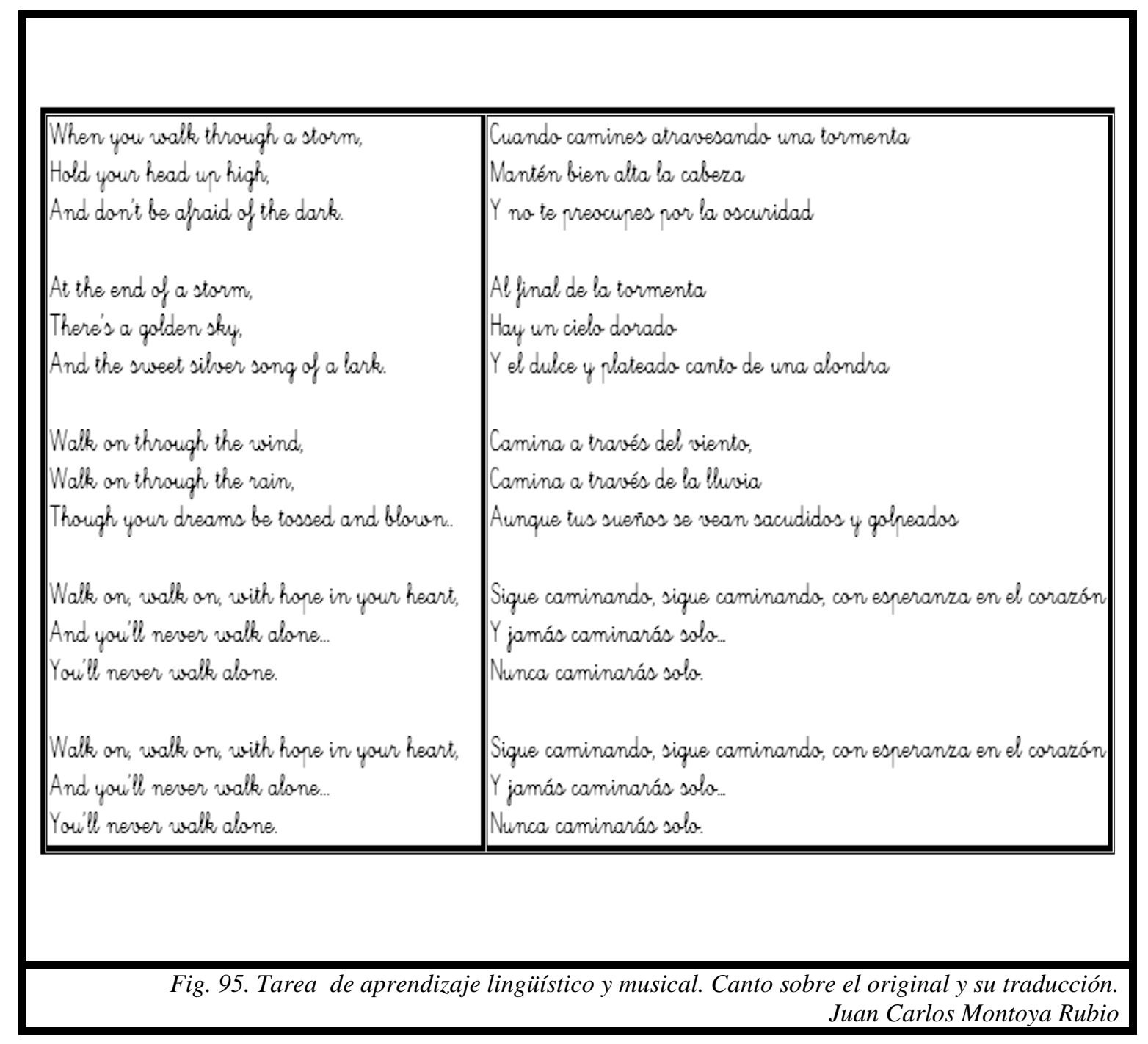

${ }^{761}$ En el ejemplo que se mostrará se utiliza el archivo de pictogramas "Aumentativa", recurso muy extendido para extraer y editar imágenes con finalidad didáctica, adquirido por algunas administraciones: http://www.aumentativa.net/ [Consulta 9-II-10] 


\section{Colocamos los dedos y practicamos.}

Explica como se teca cada una de las siguientes notas musicales. Fijate en el ejemplo.

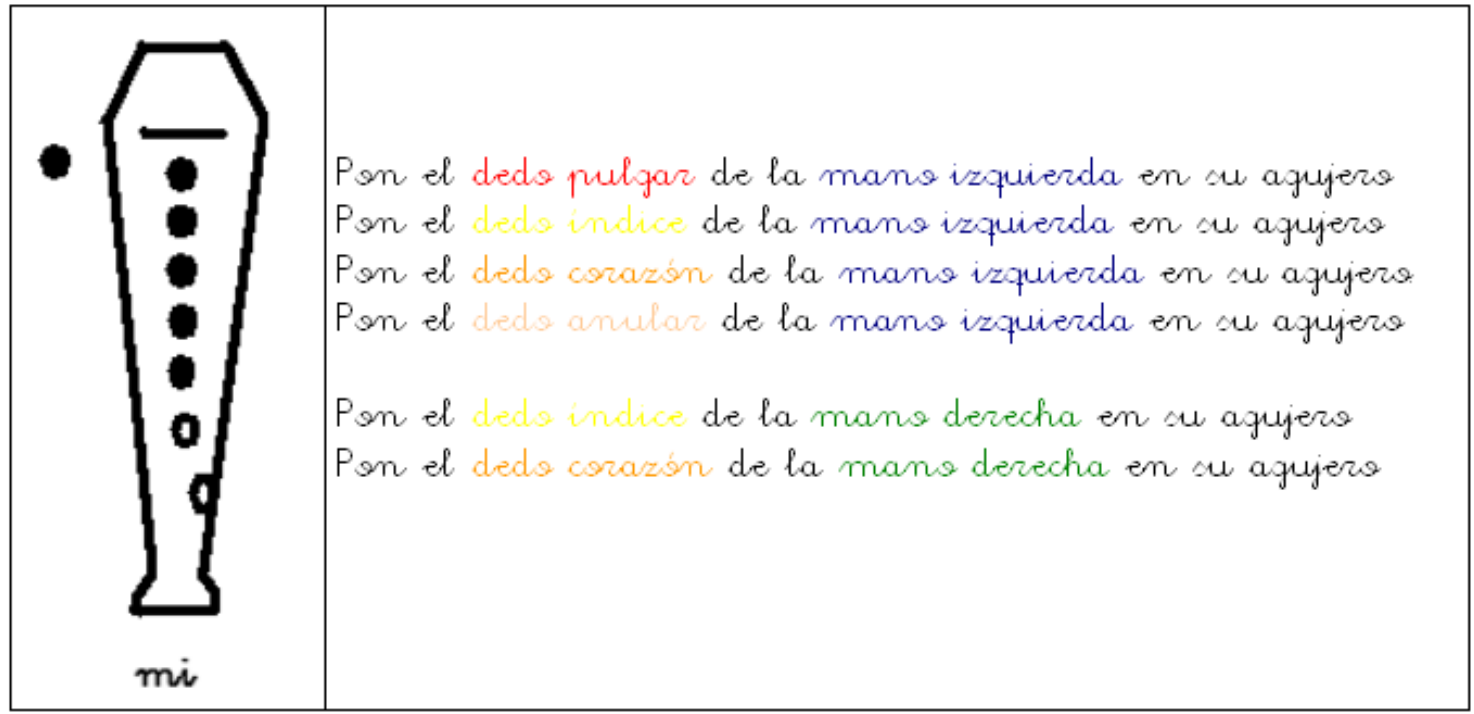

Fig. 97. Tarea de aprendizaje lingüístico y musical. Secuencias melódicas de You'll Never Walk Alone Juan Carlos Montoya Rubio 


\section{Trabajo sobre campos semanticos}

Storm $\rightarrow$ Tormenta

Dark $\rightarrow$ Oscuridad

Golden shy $\rightarrow$ Cielo dorado
Silver Song $\rightarrow$ Canción plateada

Wind $\rightarrow$ Viento
Rain $\rightarrow$ Lhuia

Hope $\rightarrow$ Esperamza
Heart $\rightarrow$ Corazón
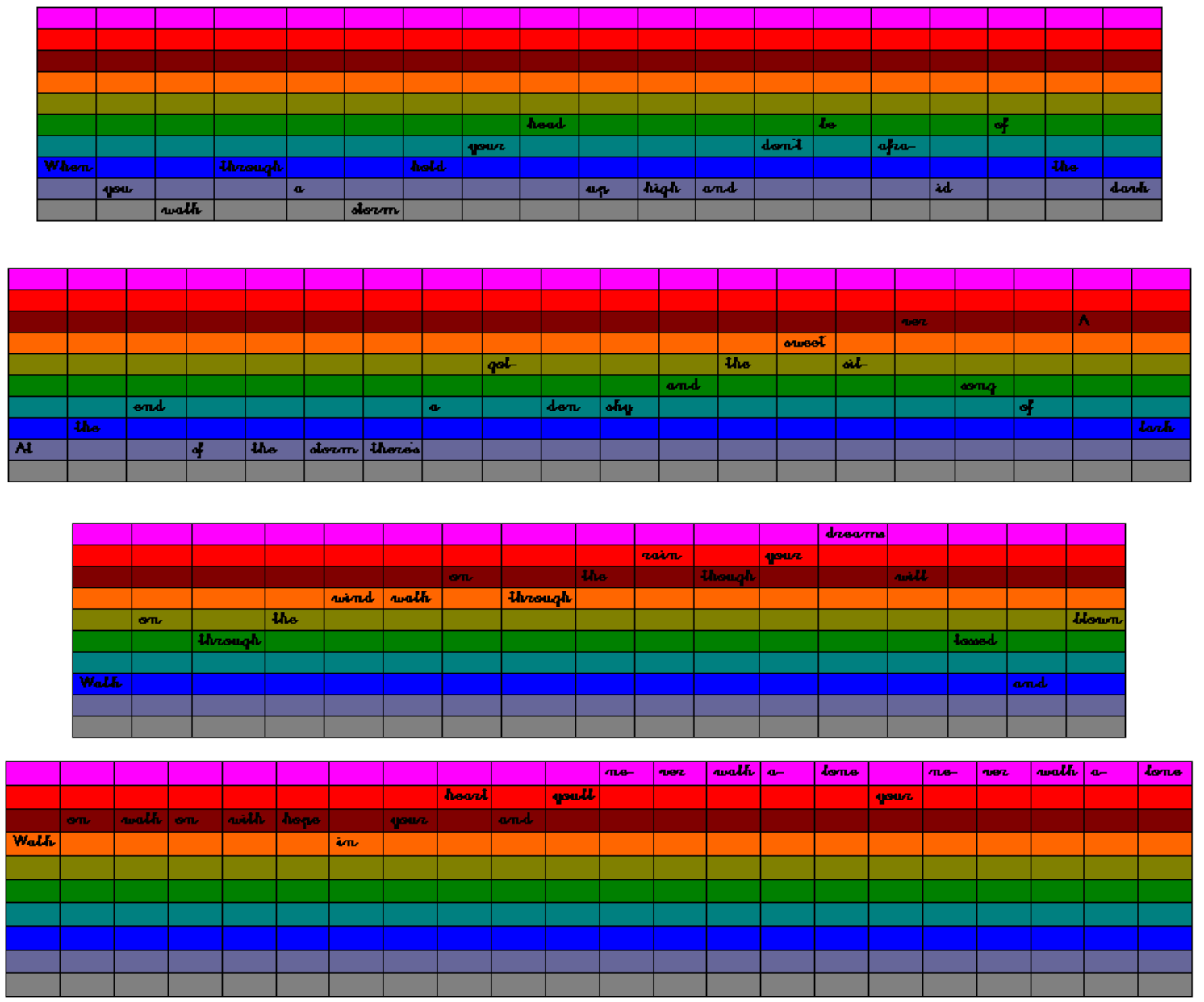


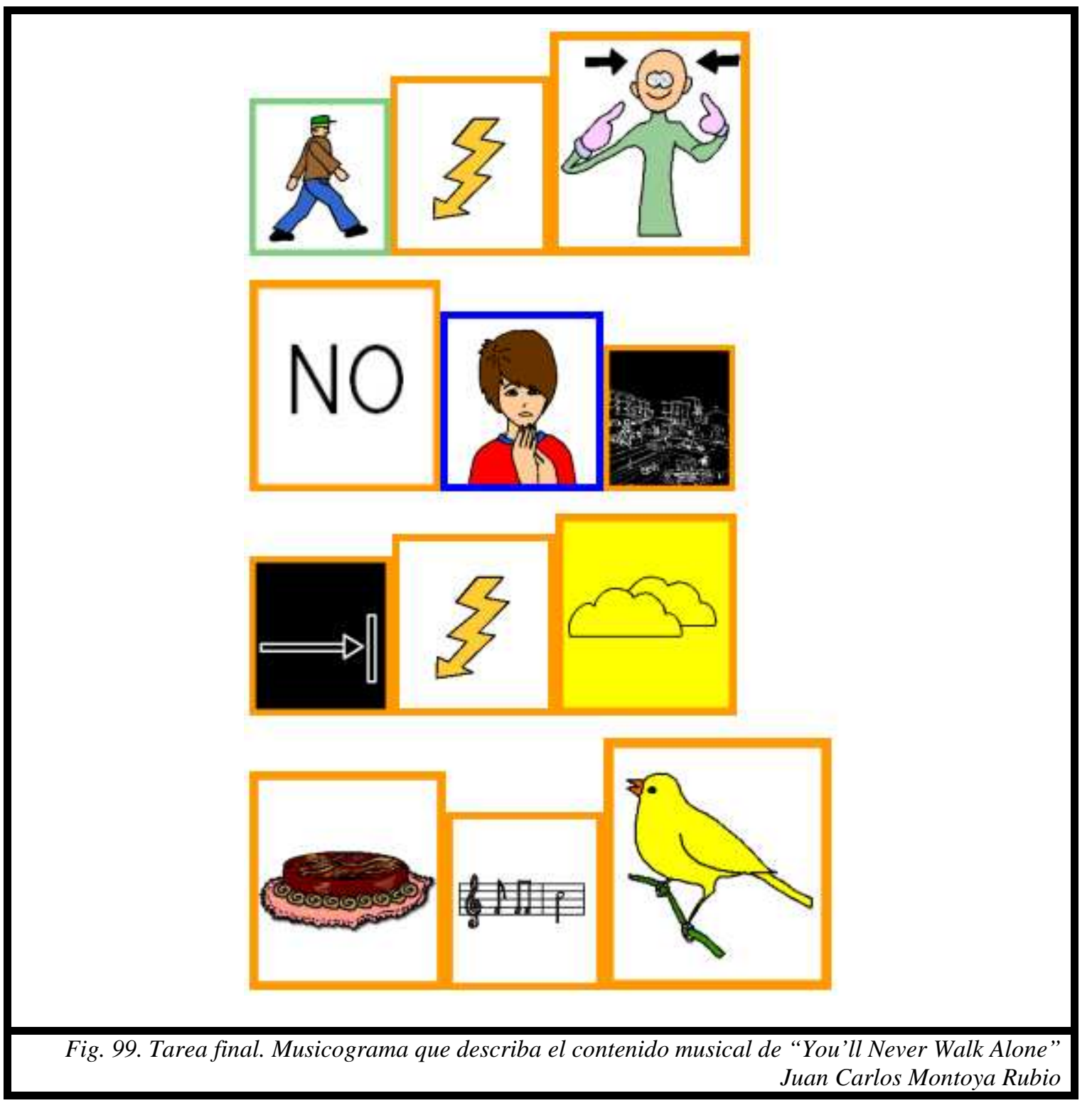

Una vez abordado el tratamiento específico del alumnado que asiste a las clases propias de la compensación educativa es de esperar que la realización didáctica planteada al principio (la melodía para flauta con su acompañamiento de percusión de altura indeterminada) no suponga una traba mayor para el niño foráneo que para el que no lo es. La superación de las dificultades puede llevar a la aplicación de dicha melodía a alguno de los audiovisuales propuestos, llevando a cabo ejercicios de sonorización como los descritos en el capítulo anterior. Además, parte del trabajo realizado por el primero en su labor al margen del gran grupo puede servir de ayuda al resto, con lo cual, 
a partir de estas aportaciones, se multiplican las posibilidades de consecución de objetivos. El resumen de este primer enfoque queda como sigue ${ }^{762}$ :

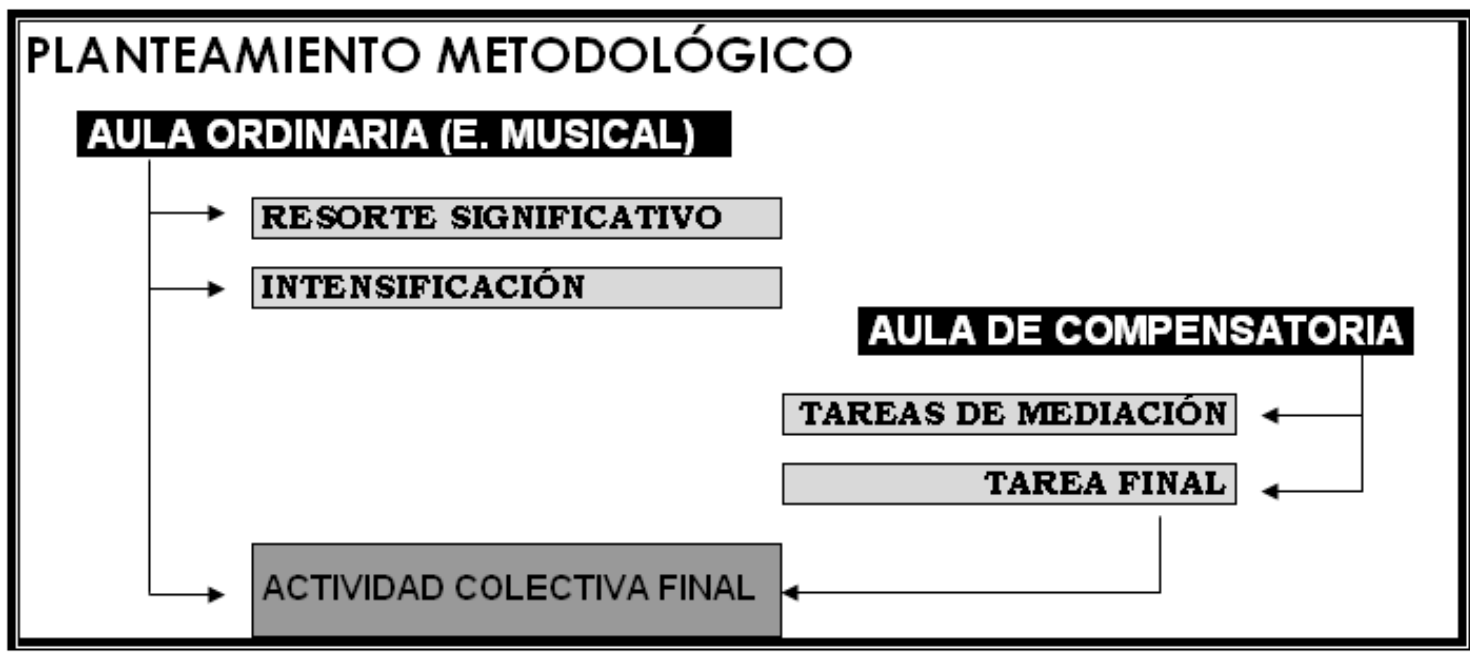

Fig. 100. Planteamiento metodológico del diseño I (Música y Compensatoria) Juan Carlos Montoya Rubio

\section{EJEMPLO PROCEDIMENTAL \\ AULA ORDINARIA (E. MUSICAL)}

Fragmento audiovisual:

"You'11 never walls alone"

Original: Musical Carousel

$\rightarrow$ Derivación: Anuncio Publicitario

\section{AULA DE COMPENSATORIA}

Creación de obstinatos

Actividades de práctica instrumental

Cambio textual...

Musicograma de seguimiento

NUEVA VERSIÓN SONORIZADA

Fig. 101. Ejemplo procedimental para del diseño I (Música y Compensatoria) Juan Carlos Montoya Rubio

${ }^{762}$ MONTOYA RUBIO, J. C. (2008d): Op. cit., p. 799. 


\section{Diseño práctico 2.}

La propuesta metodológica que sigue se orienta, fundamentalmente, hacia favorecer los procesos de enseñanza de todos los alumnos, con especial énfasis en aquellos que tienen problemas derivados del desconocimiento linguiístico. En el proceso, se pretende que una correcta interacción guiada promueva que los unos aprendan de los otros y viceversa y, por consiguiente, desarrollen al máximo sus pontencialidades dentro de un ambiente colaborador. A este respecto, y al tratarse de un planteamiento abierto, pueden resultar muy fructíferos postulados que nos aproximen al acuñado como aprendizaje por cooperación o cooperativo ${ }^{763}$.

Al igual que en el desarrollo procedimental anterior, será esencial encontrar un resorte significativo que sea intensificado debidamente, con la salvedad de que en esta ocasión dicho resorte ya proviene de un audiovisual conocido por los discentes ${ }^{764}$. Del mismo modo, a diferencia del diseño anterior, el que ejemplificamos a continuación no registra en ningún momento el trabajo aislado de los alumnos del programa de compensatoria (lo cual desde determinadas posturas rompería con los criterios de inclusión), sino que se fundamenta en que toda la labor que se propone es desarrollada en común por la globalidad del grupo de alumnos.

Con ello, la primera y principal preocupación habría de ser la de seleccionar un fragmento audiovisual que haya podido ser encontrado no sólo en nuestro ámbito más inmediato sino también en los lugares de origen de los alumnos que trabajarán con él. A

\footnotetext{
${ }^{763}$ A partir de nuestra experiencia docente, consideramos que entre las propuestas más atractivas por su posibilidad de integrarse en el aula son las de Pere Pujolàs y José Ramón Lago, expuestas en varios foros (en los que se muestran las líneas maestras de su proyecto PAC: Programa didáctico inclusivo para atender en el aula al alumnado con necesidades educativas diversas. Una investigación evaluativa) y plasmadas en publicaciones como PUJOLÀS MASES, P. y LAGO MARTÍNEZ, J. R. (2007): "La organización cooperativa de la actividad educativa". BONALS PICAS, J. y SÁNCHEZ CANO, M. (coords.) Manual de asesoramiento psicopedagógico. Barcelona: Graó, pp. 349-392. Sus trabajos en esta dirección tienden a dotar de importancia a la estructura de la actividad cooperativa a partir de la comprensión de un nuevo estilo docente, en el cual el profesor incita a que los estudiantes formen pequeños equipos de trabajo que se ayudan y resuelven cuestiones propias de su aprendizaje de manera casi autónoma, por lo que cobra especial relevancia la contribución de los compañeros entendida como una interdependencia de finalidades positiva. A diferencia de lo que sucedería en un aprendizaje individualista o competitivo, su intención es la de optimizar todos los elementos que inciden en la enseñanza, incluido el tiempo, atendiendo a que las interacciones que se propicien sean estimulantes.

${ }^{764}$ Recordamos que en el caso anterior el audiovisual que se presenta en primera instancia no tiene por qué haber sido visionado antes, sino que remite a un elemento musical que sí es reconocido en cualquier otro contexto.
} 
partir de un ejemplo ensayado en las aulas de primaria $^{765}$, se seleccionó un corte audiovisual que entendíamos podía ser significativo en su aplicación en varios idiomas, para que el quehacer de los alumnos fuera enriquecedor desde el punto de vista de la interacción y que, además, presentara similares facilidades y dificultades para todos ellos. Tras un pequeño muestreo a los alumnos se convino el trabajo sobre la melodía "Escalas y Arpegios"766, de la película de dibujos animados Los Aristogatos ${ }^{767}$.

El primer paso para definir esta metodología consistiría en mostrar el documento audiovisual en castellano y, preferentemente, en las lenguas de aquellos que están presentes en el aula, aunque es igualmente posible focalizar los esfuerzos hacia algún idioma concreto que se desee trabajar. Afortunadamente, hoy en día cortes fílmicos de este tipo (conocidos y generalizados por todo el mundo) son fácilmente accesibles. Un rápido repaso nos acercaría a tantas nacionalidades con sus consiguientes lenguas como tuviéramos necesidad $^{768}$. Entendiendo que con ello se cumple con las fases de resorte significativo e intensificación, al presentar los fragmentos en diferentes versiones, pasamos a las tareas o actividades específicas, las cuales, como novedad, se desarrollan siempre en conjunto. Algunos ejemplos con origen en el elemento audiovisual ya conocido por los alumnos son:

- A partir del canto, actividades de expresión oral y vocabulario específico. De corte similar a los ejercicios propuestos en el ejemplo anterior.

\footnotetext{
765 Presentado de manera práctica en el X Congreso Internacional "Cultura Europea" (Universitat Internacional de Catalunya, octubre de 2009) bajo el título "La música del audiovisual como resorte educativo intercultural en el contexto europeo" (actas en prensa).

${ }^{766}$ Richard M. Sherman y Robert B. Sherman.

${ }^{767}$ Dir. Wolfgang Reitherman, 1970. En el capítulo anterior, se referenció la obra en cuestión al presentar una aplicación didáctica concreta: BRAVO MARÍN, R. y DE MOYA MARTÍNEZ, M. (2006): Op cit.

${ }^{768}$ Algunas direcciones de internet en las que se encuentran estos ejemplos en diversos idiomas son:

Castellano <http://www.youtube.com/watch?v=D5fw iUckiI > [Consulta 9-II-10].

Árabe <http://www.youtube.com/watch?v=pTlHH6sDRcs $>$ [Consulta 9-II-10].

Francés <http://www.youtube.com/watch?v=uHp1b-c4oVE $>$ [Consulta 9-II-10].

Alemán <http://www.youtube.com/watch?v=HH3uqvMPWXs $>$ [Consulta 9-II-10].

Húngaro $\langle$ http://www.youtube.com/watch?v=iyU9Ae481-M $>$ [Consulta 9-II-10].

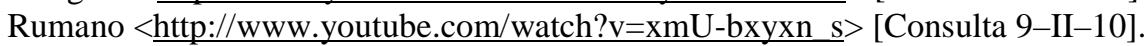

Italiano $\langle$ http://www.youtube.com/watch?v=9p42Dkr7zTw $>$ [Consulta 9-II-10].

Islandés <http://www.youtube.com/watch?v=OC_wdig7AZU > [Consulta 9-II-10].

Polaco <http://www.youtube.com/watch?v=H-t5aaYTtlg $>$ [Consulta 9-II-10].

Danés <http://www.youtube.com/watch?v=pTlHH6sDRcs $>$ [Consulta 9-II-10].

Noruego $<$ http://www.youtube.com/watch?v=PAugxuRAbvg $>$ [Consulta 9-II-10].

Finlandés <http://www.youtube.com/watch?v=VSXcjiWQHO4> [Consulta 9-II-10].

Ruso <http://www.youtube.com/watch?v=D04RpYzIE8Y> [Consulta 9-II-10].

Portugués <http://www.youtube.com/watch?v=lVMPAjKwURQ> [Consulta 9-II-10].
} 
- Análisis del doblaje de la canción. Comparativa entre el fragmento en castellano y otra versión que ataña algún alumno de los que pertenecen al grupo. Es más que posible que del diálogo acerca de lo que significan unas y otras frases se encuentren divergencias significativas que llamen la atención del alumnado. El ejemplo de la versión original cotejada con la castellana así lo muestra:

\begin{tabular}{|c|c|}
\hline Do. Mi Sol Do. Do. Sol Mi Do & Do. Mi So. Do. Do. So. Mi Do. \\
\hline El solfea es necesario en musica & $\begin{array}{l}\text { Ev'uy trully cultured } \\
\text { music student knores }\end{array}$ \\
\hline Practicar escalas y arpegias & $\begin{array}{l}\text { You must learn your scales } \\
\text { And your arpeggios }\end{array}$ \\
\hline Y se canta desde el pecho. & Bring the music ringing \\
\hline Y no par la "nariuz" & $\begin{array}{l}\text { From your chest } \\
\text { And not your nase }\end{array}$ \\
\hline Al cantar escalas y arpegias & $\begin{array}{l}\text { While you sing your scales } \\
\text { And your arpeggios }\end{array}$ \\
\hline Ya verás que con el diario practicar & $\begin{array}{l}\text { If youre faithful } \\
\text { To your daily practicing }\end{array}$ \\
\hline $\begin{array}{l}\text { Bien se puede en paco tiempo. } \\
\text { progresar }\end{array}$ & $\begin{array}{l}\text { You will find your progress } \\
\text { Is encouraging }\end{array}$ \\
\hline$D_{\alpha}-M_{i} S_{o} l M_{i} D_{\alpha}-M_{i} S_{o} l M_{i} F_{a}, L_{a}$ Do $L_{a}$ Do & Do-Mi $S_{0}-M_{i} D_{0}-M_{i} S_{0}-M_{i} F_{a}$ La, So- it qoes \\
\hline Canta tus escalas y arpegias & $\begin{array}{l}\text { While you sing your scales } \\
\text { And your arpeggios }\end{array}$ \\
\hline Do- Mi Sol Do- & Do-MiSo-Do- \\
\hline Do-Mi Sol Do-Do-Sol Mi Do & $D_{\alpha}-M_{i} S_{\alpha}-D_{\alpha}-D_{\alpha}-S_{\alpha}-M_{i} D_{\alpha}$ \\
\hline Do-Mi Sol Do-Do-Sol Mi Do & $D_{\alpha}-M_{i} S_{-}-D_{\alpha}-D_{\alpha}-S_{0}-M_{i} D_{\alpha}$ \\
\hline Aunque fácil no lo sea al comenzar & $\begin{array}{l}\text { Though at first it seems } \\
\text { As though it doesnt showe }\end{array}$ \\
\hline Practicando se consigue dominar & $\begin{array}{l}\text { Like a tree, ability will } \\
\text { Bloom and growe }\end{array}$ \\
\hline Si gran música deseas ser un día tú & $\begin{array}{l}\text { If youre smart } \\
\text { Youll learn by heart }\end{array}$ \\
\hline & What evruy artist knowes: \\
\hline Canta escalas y también arpegios & $\begin{array}{l}\text { While you sing your scales } \\
\text { And your arpeggios }\end{array}$ \\
\hline
\end{tabular}

Fig. 102. Tarea de mediación. Trabajo sobre melodía y traducción de una canción Juan Carlos Montoya Rubio

- Juegos vocales en diferentes lenguas. Una variante del ejercicio anterior podría consistir en aplicar diversos idiomas con o sin subtítulos, los cuales 
pueden ayudar a un alumno de procedencia extranjera a entender lo que se está cantando. Proponemos como ejemplos, insistimos fácilmente accesibles y disponibles en la red, para alumnos de habla germana la primera de las imágenes (alemán con subtítulos en alemán) y la segunda como versión bilingüe (francesa con subtítulos en francés e inglés) ${ }^{769}$ :
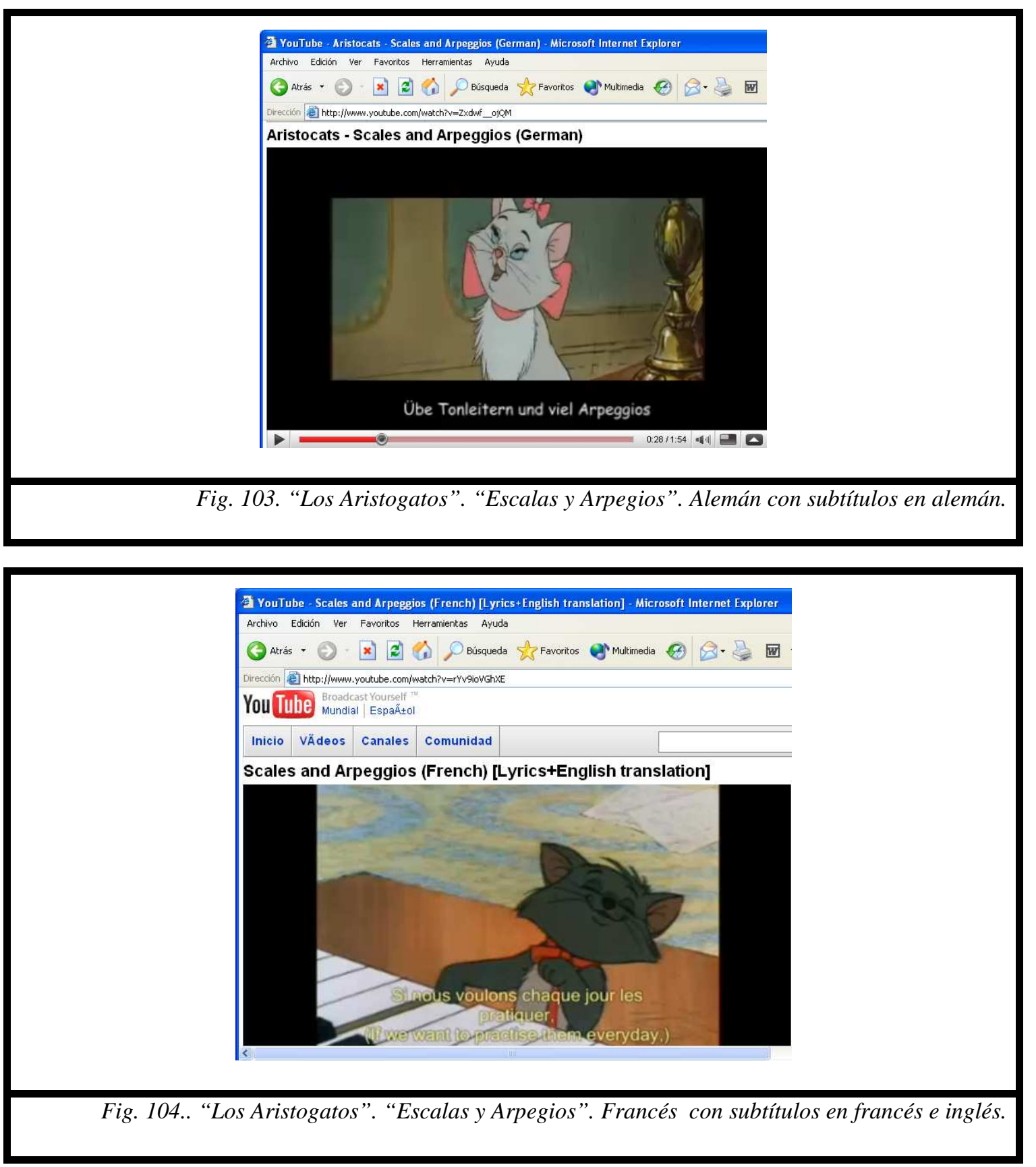
${ }^{769}<$ http://www.youtube.com/watch?v=Zxdwf_ojQM $>$ [Consulta 9-II-10]
$<$ http://www.youtube.com/watch?v=rYv9ioVGhXE $>$ [Consulta 9-II-10] 
- Actividades de canto y danza. Las versiones exclusivamente instrumentales pueden ser también un buen apoyo para el canto. Así, son factibles tanto procedimientos que partan del karaoke como otros que acarreen movimiento o danzas, teniendo en cuenta que se pueden encontrar, igualmente, versiones más o menos rápidas ${ }^{770}$ :
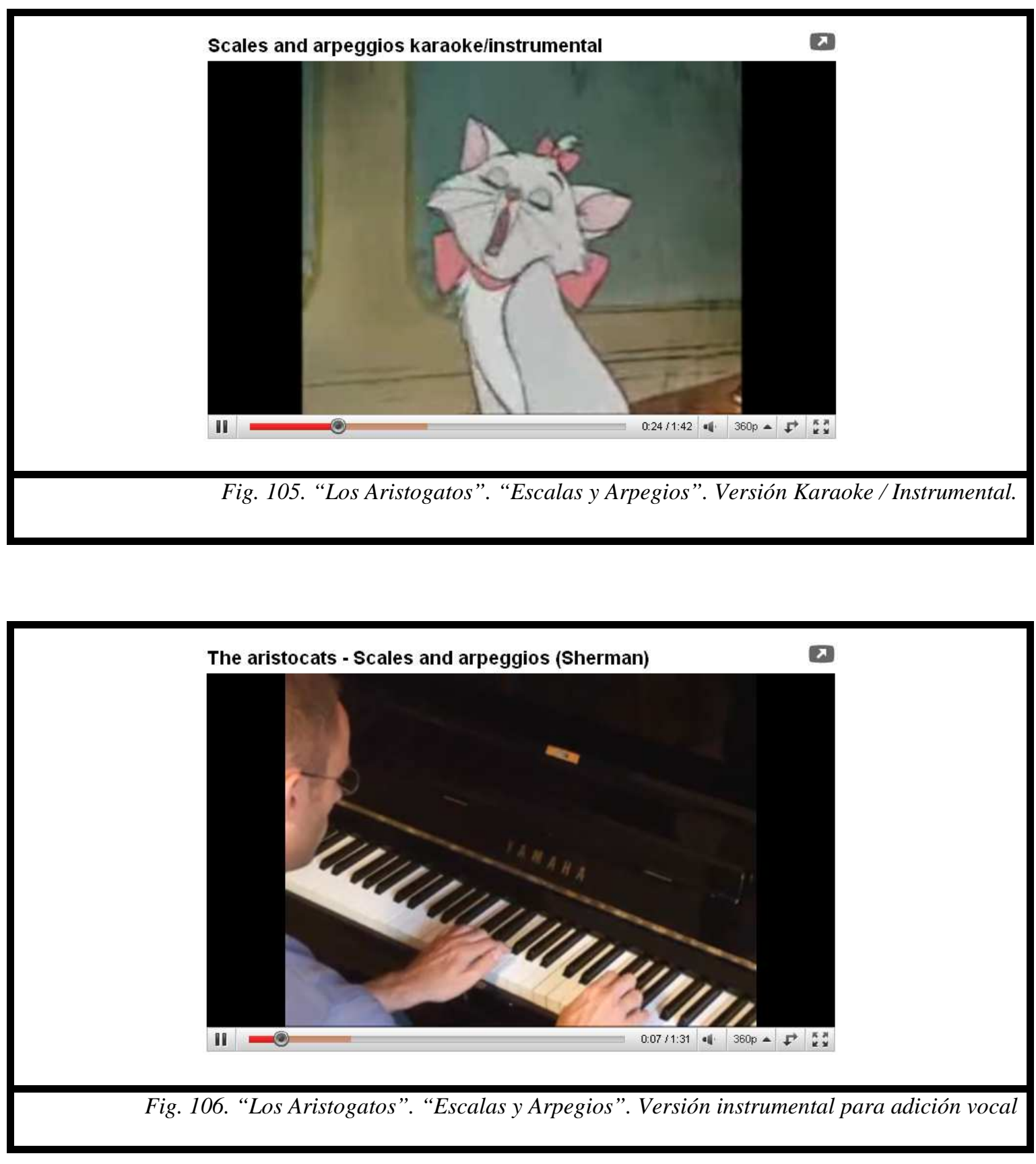

\footnotetext{
${ }^{770}<$ http://www.youtube.com/watch?v=pb24Yj05Cnw> [Consulta 9-II-10] $<$ http://www.youtube.com/watch?v=jx7vFSyboZk> [Consulta 9-II-10]
} 
- Actividades de ejecución instrumental. La simplicidad de algunos de los pasajes puede dar pie a su interpretación con instrumental del aula, especialmente a través de las láminas, que podrán acompañar imágenes mudas. Del mismo modo, los serpenteos melódicos puede ser ejecutados con flauta (ajustando y variando, por supuesto, aquellos sonidos que con dicho instrumento no se pueden digitar).

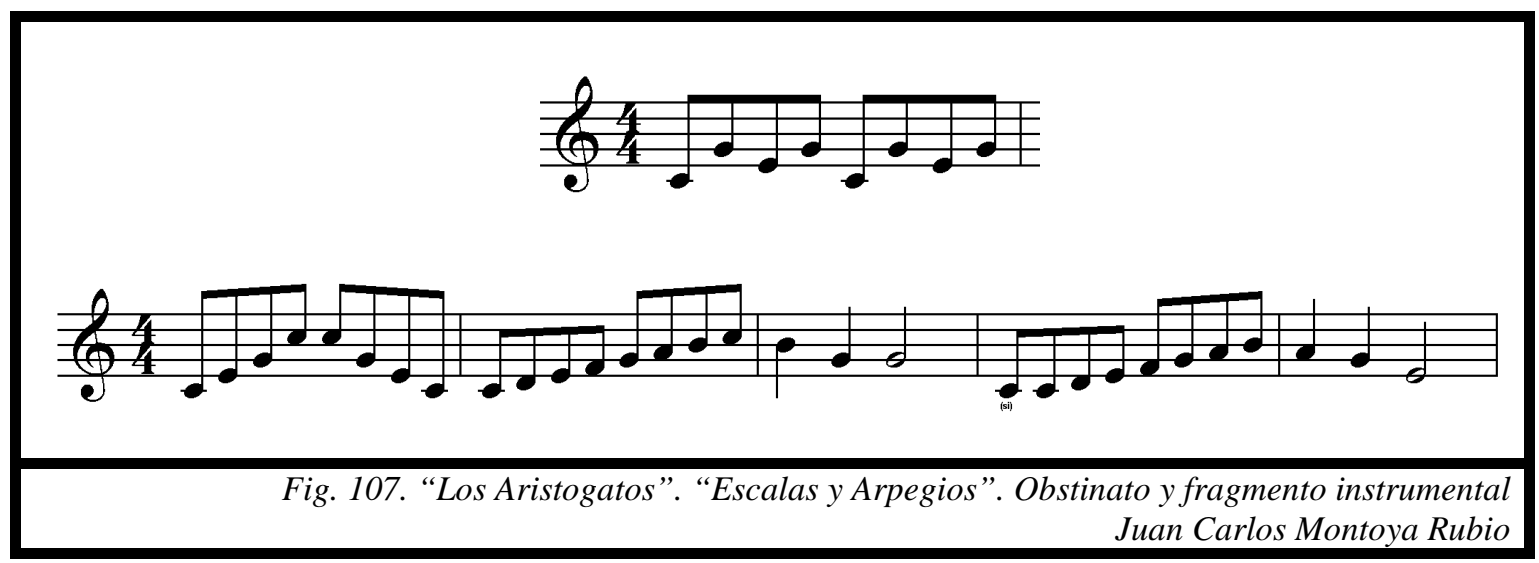

- Versión multilingüe que compendie todas las propuestas anteriores ${ }^{771}$. A modo de resumen y con talante evaluador, se propone una actividad que suponga un "collage sonoro" sobre todo lo trabajado. Es posible encontrar en ejemplos ya elaborados que muestran cuál puede llegar a ser el resultado, aunque las pretensiones del docente no tienen por qué ser tan ambiciosas y han de servir siempre a las necesidades del grupo.

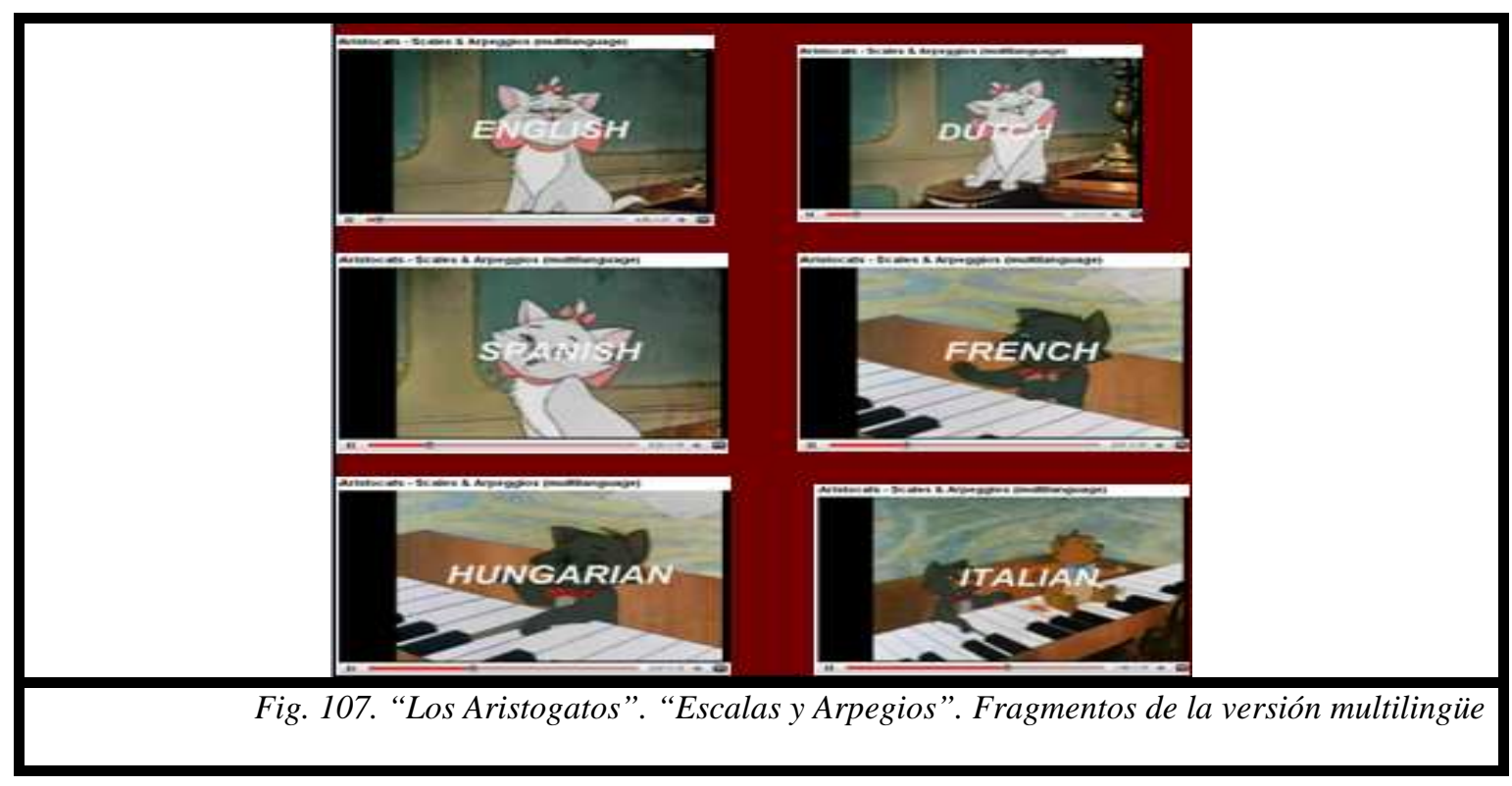

${ }^{771}<$ http://www.youtube.com/watch?v=1tBLaBR3L4g> [Consulta 9-II-10] 
MÚSICA Y MEDIOS AUDIOVISUALES.

PLANTEAMIENTOS DIDÁCTICOS EN EL MARCO DE LA EDUCACIÓN MUSICAL. Juan Carlos Montoya Rubio 


\title{
CAPÍTULO 5
}

\author{
ESTUDIO EMPÍRICO. \\ USOS Y POSIBILIDADES DE LOS \\ RECURSOS AUDIOVISUALES EN \\ LAS AULAS DE EDUCACIÓN MUSICAL
}


MÚSICA Y MEDIOS AUDIOVISUALES.

PLANTEAMIENTOS DIDÁCTICOS EN EL MARCO DE LA EDUCACIÓN MUSICAL. Juan Carlos Montoya Rubio 


\section{ESTUDIO EMPÍRICO. USO Y POSIBILIDADES DE LOS RECURSOS AUDIOVISUALES EN LAS AULAS DE EDUCACIÓN MUSICAL}

\subsection{ENFOQUE, OBJETIVOS Y DISEÑO METODOLÓGICO}

\section{Enfoque de la investigación: otra vez la "mirada pedagógica"}

Consideramos importante que, antes de abordar los entresijos que definen el estudio que a continuación se presenta, realicemos una sucinta introducción en torno a la filosofía que lo mueve. En este sentido, al igual que se intentó conseguir desde el inicio de la investigación, postulamos la necesidad de acercarnos hasta el punto que nos sea posible a la interpretación comprensiva de los hechos sobre los que indagar. Por ello, tomando prestados algunos planteamientos teóricos desde el campo de la antropología - disciplina desde la que tal vez se muestra con mayor vehemencia que una investigación no tiene sentido sin la aplicación de un prisma comprensivo- apuntalamos la creencia de que todo lo expuesto hasta ahora, más próximo a prácticas testadas "en vivo", y todo aquello que se presentará a partir de este momento, concerniente a una esfera que podría considerarse como más "neutral", obtiene su sentido científico no tanto desde la elaboración taxonómica o de la enumeración de respuestas a unos ítems cuidadosamente seleccionados, sino en su especial acercamiento al complejo del proceso investigador, el cual tiene unas motivaciones y unos intereses prefijados. Beattie lo exponía del siguiente modo:

"Toda investigación argumentada se propone comprender su objeto de estudio, y el tipo de comprensión adecuado a cada caso particular dependerá 
tanto de lo que interesa al investigador como del tipo de material que investigue" ${ }^{, 772}$.

Por tanto, es preciso dejar constancia de que el investigador acumula una experiencia docente, especialmente en tramos de las etapas obligatorias, desde la cual se han vivido en primera persona las dificultades y las esperanzas de una materia que puede ser mejorada pero que, per se, posee unos matices pedagógicos que le hacen tener un enorme potencial. El hecho de hacer patente nuestra orientación no hace sino aceptar los condicionantes que ello implica, conviniendo igualmente en la dificultad de desembarazarse de dichos condicionantes en la búsqueda de una postura supuestamente aséptica. Entre los científicos sociales son muchos los que se han preocupado por estas diatribas, siendo a nuestro modo de ver una postura acertada la de Teresa San Román:

"Cada vez que nos planteamos un nuevo tema de estudio realizamos de alguna forma una elección de los aspectos que vamos a tomar en consideración. Los fenómenos y las explicaciones que construimos para dar cuenta de ellos dependen de nuestra visión disciplinaria y de otros aspectos de nuestra visión del mundo, como contexto sobre el cual ubicamos teóricamente ambas cosas: los fenómenos se sitúan en uno u otro conjunto de variables y se les atribuye uno u otro conjunto de factores (disciplinarios y, en su interior, teóricos); las explicaciones se orientan a través de la atribución de existencia de relaciones, de una u otra naturaleza entre esos componentes de la situación que hemos seleccionado" ${ }^{, 773}$.

De acuerdo con las premisas descritas, la investigación se lleva a cabo con profesionales de la educación con los que, desde nuestra posición, es sumamente sencillo acercarse al tantas veces aludido desde el campo antropológico "rapport" -si

\footnotetext{
${ }^{772}$ BEATTIE, J. H. M. (1975): “Comprensión y explicación en antropología social”. LLOBERA, J. R. La antropología como ciencia. Barcelona: Anagrama, pp. 293-309.

${ }^{773}$ SAN ROMÁN, T. (1996): "Interdisciplinariedad, interprofesionalidad e intervención social". PRAT, J. y MARTínEZ, Á. (Eds.) Ensayos de antropología cultural. Homenaje a Claudio Esteva-Fabregat. Barcelona: Ariel, p. 411.
} 
bien es cierto que para el trabajo de campo-, cuyo establecimiento, en palabras de Taylor y Bogdan implica una serie de aspectos como ganarse la aceptación del informante, evitar las defensas que se generan cuando alguien pregunta acerca de las atribuciones propias, conseguir la apertura del otro para lograr respuestas sinceras, poder ser visto como alguien inobjetable, desmoronar la imagen que cada uno construye a su alrededor para acceder a cuestiones relevantes o, lo más significativo desde el enfoque dado a nuestra investigación, “compartir el mundo simbólico de los informantes, su lenguaje y sus perspectivas" ${ }^{\text {774 }}$.

Somos conscientes de que valernos de criterios propios de la investigación cualitativa en un entorno que nos remite a elementos puramente cuantitativos hace que cuidemos especialmente la perspectiva integradora de la cual no hemos de quedar desprovistos. Compartimos con determinados autores que, si lo que se persigue es la interpretación cultural, lo cualitativo y lo cuantitativo no tienen por qué presentarse en forma de términos excluyentes sino complementarios ${ }^{775}$.

La esencia pues de una investigación de este tipo viene dada, no tanto por el diseño y los instrumentos que se aplican, como por la guía y la orientación que se les imprime, por la aludida en capítulos anteriores "mirada pedagógica", que pretendemos recabe las bondades de la "mirada antropológica" en nuestro contexto de actuación:

"El reconocimiento de que la especificidad e, incluso, la calidad de un proceso de investigación dependen ante todo de la 'mirada' no es más que la confirmación de que el principal instrumento de investigación, al menos en ciencias sociales, es -como rememora Hymes- el propio investigador y, desde su óptica, su formación académica y/o práctica (su puesta a punto) adquieren una gran importancia. Pero ¿en qué estriba, en definitiva, esa 'mirada' antropológica? Tomando prestada la expresión de Bourdieu para describir el habitus, yo diría que está compuesta por un conjunto de principios de percepción, sentimiento y

\footnotetext{
774 TAYLOR, S. J. y BOGDAN, R. (1994): Introducción a los métodos cualitativos de investigación. Barcelona: Paidós.

${ }^{775}$ JOCILES RUBIO, M. I. (1999): "Las técnicas de investigación en antropología. Mirada antropológica y proceso etnográfico". Gazeta de Antropología 15. Texto 15-01, s. p. Disponible en <http://www.ugr.es/ pwlac/G15_01MariaIsabel_Jociles_Rubio.html> [Consulta 9-II-10]
} 
actuación que, encarnados en el sujeto de la investigación, termina por guiar explícita o implícitamente sus indagaciones" ${ }^{\text {776 }}$.

Hechas pues las pertinentes declaraciones de intenciones, pasamos a desgranar las líneas básicas de este estudio.

\section{Elementos a investigar: objetivos}

Hemos reiterado que nuestro marco teórico nos aboca a la enseñanza musical actual. En este sentido, existen una serie de premisas insoslayables que contextualizan toda aproximación al fenómeno educativo y que inspiran la formulación de los objetivos que trazamos.

Entre estas características, es preciso señalar que la legislación educativa actual tiende, en perspectiva histórica, a potenciar el uso de las Tecnologías de la Información y la Comunicación en todas las áreas de conocimiento, por lo que puede resultar interesante aproximarnos al modo en que este hecho se está refrendando o no dentro de las prácticas habituales de aula en el contexto de la educación musical.

Por otro lado, los recursos, humanos y materiales, son crecientes en comparación con situaciones pretéritas. A pesar de ello, no hay un espacio horario suficiente que permita desarrollar con totales garantías los postulados musicales, por lo que no siempre es sencillo articular secuencias procedimentales que lleguen a su fin cumpliendo todos y cada uno de sus objetivos iniciales. Es preciso estimar el encaje del audiovisual en estas circunstancias.

Junto con ello, existe un conjunto de metodologías que gozan de una mayor propensión a ser utilizadas dentro del plano musical. La herencia metodológica del siglo pasado, en todo caso, suele desarrollarse desde la relación entre los postulados de unos y otros autores, de modo que el acomodo de formatos audiovisuales puede sumarse a esta tendencia si viene acompañada de la dotación material adecuada.

En consonancia con lo anteriormente mencionado, la hipótesis que mueve el estudio y la consecuente elaboración metodológica que la desarrolla será la de que se

${ }^{776}$ JOCILES RUBIO, M. I. (1999): Ibíd., s. p. 
intuye que hay recursos materiales para el desarrollo musical desde el audiovisual, se entiende que este tipo de procedimientos son significativos para conectar con el alumnado, pero el uso efectivo es marginal.

Por tanto, como objetivo central de la investigación que se desarrolla en este capítulo destacamos el siguiente:

- En función de algunas de las categorías empleadas para identificar los tipos de contenidos audiovisuales útiles dentro del aula de educación musical, determinar el grado de conocimiento, uso efectivo y prospección entre docentes de educación primaria.

A este objetivo básico se añaden otros más específicos que lo desarrollan. Entre ellos destacamos:

- Aproximarnos al conocimiento que los docentes de educación musical tienen de los posibles planteamientos pedagógicos que aprovechan la vertiente audiovisual de las Tecnologías de la Información y la Comunicación.

- Determinar la disposición del profesorado de educación musical para trabajar procedimientos que tienen como elemento fundamental el uso del audiovisual.

- Realizar un acercamiento al uso efectivo de materiales audiovisuales en el aula de música.

- Establecer relaciones entre el nivel de uso y la disposición de los docentes de educación musical.

- Conocer la importancia que el profesorado otorga a los recursos derivados del audiovisual dentro de las metodologías utilizadas habitualmente.

- Atender a la percepción del profesorado según la cual estamos ante prácticas susceptibles de formar parte normalizada de los currícula de educación musical o si, por el contrario, su función respondería a una inclusión anecdótica y casi pintoresca dentro de los mismos. 


\section{Diseño metodológico}

La necesidad de encontrar un instrumento funcional para la recogida de información ha sido otro de los elementos a considerar con detenimiento, ya que estimábamos como fundamental que se propiciase una herramienta que fuera realmente operativa y sirviera a nuestras pretensiones de manera fiable y eficaz. Con ello, el instrumento a utilizar vino determinado por el conjunto de circunstancias que envuelve tanto la investigación presente, entendida desde la filosofía de sus líneas introductorias, como la materia, la educación musical. Así, era necesario articular un mecanismo que reuniera, al menos, las siguientes características: concreción de los materiales a evaluar, simplificación de las preguntas a realizar a los docentes y universo de la muestra diverso y a la vez homogéneo e inscrito en la realidad educativa actual:

- Principalmente, para recabar información acerca de la inserción de los medios audiovisuales en las aulas de educación musical, habría que mostrar ejemplos acerca de lo que pretendíamos obtener respuestas. Cuestionar al profesorado acerca de qué les sugería, por ejemplo, un proceso de sonorización en sus clases de música podría pecar de ingenuidad, ya que ello sobreentendería que todos ellos están al tanto de qué tipo de praxis es la referida. Por tanto, era necesario hacer llegar al profesorado una selección de actividades para recibir información acerca de esos procedimientos concretos, representativos de cada modelo de enseñanza, y no tanto de la generalidad que supone saber opiniones sobre, por ejemplo, extrapolación o musicomovigramas.

- Del mismo modo, desde el conocimiento práctico que nos ha dado la docencia directa en primaria y secundaria, no pretendíamos involucrar a los profesores en un tedioso trabajo de revisión y evaluación, sino que el instrumento habría de ser capaz de simplificar las cuestiones que se les planteaban y que, al tiempo, éstas fueran lo suficientemente potentes como para arrojar resultados fructíferos para nuestra investigación. Si los materiales que se presentaban podían ser útiles durante un largo tiempo a los docentes, la formulación de las preguntas y su correspondiente respuesta no habría de llevar más de cinco o diez minutos. 
- Otra cuestión relevante era la de responder al criterio de acercamiento a la realidad, axioma elemental del conjunto de la investigación. Por ello, habría que contar con un nutrido grupo de docentes en activo, los cuales, conocedores de su propia problemática y potencialidades, especialmente en lo referido a recursos, evaluasen sobre un campo real los materiales propuestos. Además, el profesorado al que se pidiera colaboración habría de formar un colectivo heterogéneo, en lo referente a la ubicación de los centros donde trabajase, y homogéneo, en lo concerniente a su filiación institucional. Lo primero garantizaría una perspectiva amplia acerca de la implantación audiovisual, ya que lograríamos penetrar en barrios más y menos deprimidos y contextos sumamente dispares. En cuanto al segundo criterio, el de homogeneidad, consideramos que la descentralización estatal en torno a la educación precisaba de una muestra con cierta unidad, circunscrita a una provincia o Comunidad Autónoma específica, que sirviera de referencia y amparase bajo un mismo marco normativo a todos los centros docentes.

Tras comprobar las necesidades aplicables al instrumento, convinimos en que la respuesta más adecuada a los planteamientos anteriores era la generación de un espacio en el cual se contuvieran tanto los ejemplos didácticos que pretendíamos fueran testados $^{777}$ como un cuestionario que aludiera directamente a ellos ${ }^{778}$, para que el docente encontrara de manera intuitiva la vinculación entre lo uno y lo otro.

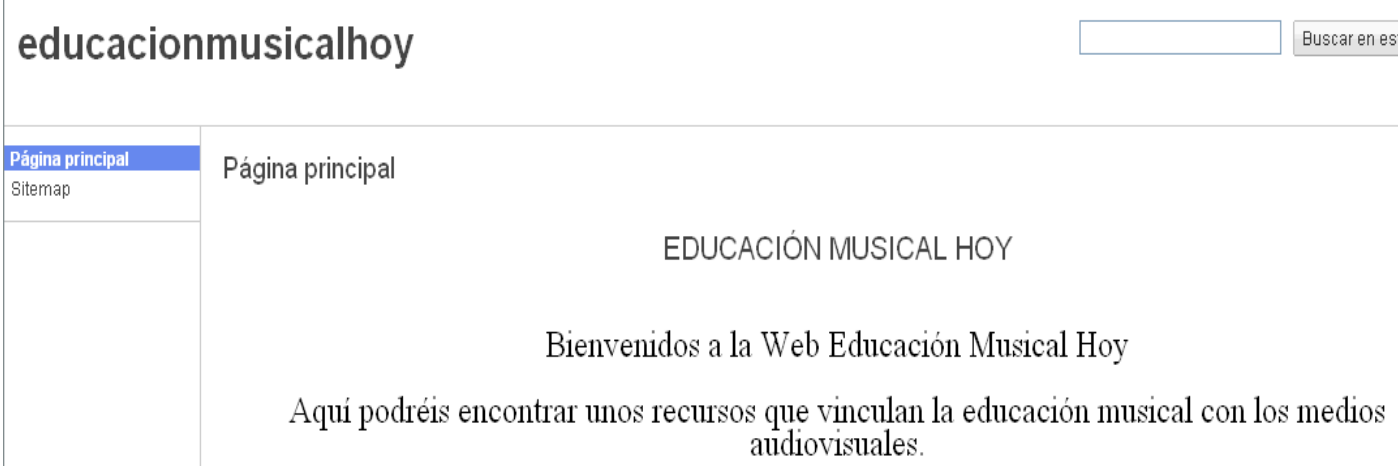

Fig. 109. Materiales alojados en la página web. Presentación Juan Carlos Montoya Rubio

\footnotetext{
$777<$ http://sites.google.com/site/educacionmusicalhoy/home> [Consulta 24-III-10]

$778<$ http://www.makesurvey.net/cgi-bin/survey.dll/21C45B5910DA4BBDB014FBBFE7A8048B>

[Consulta 24-III-10]
} 


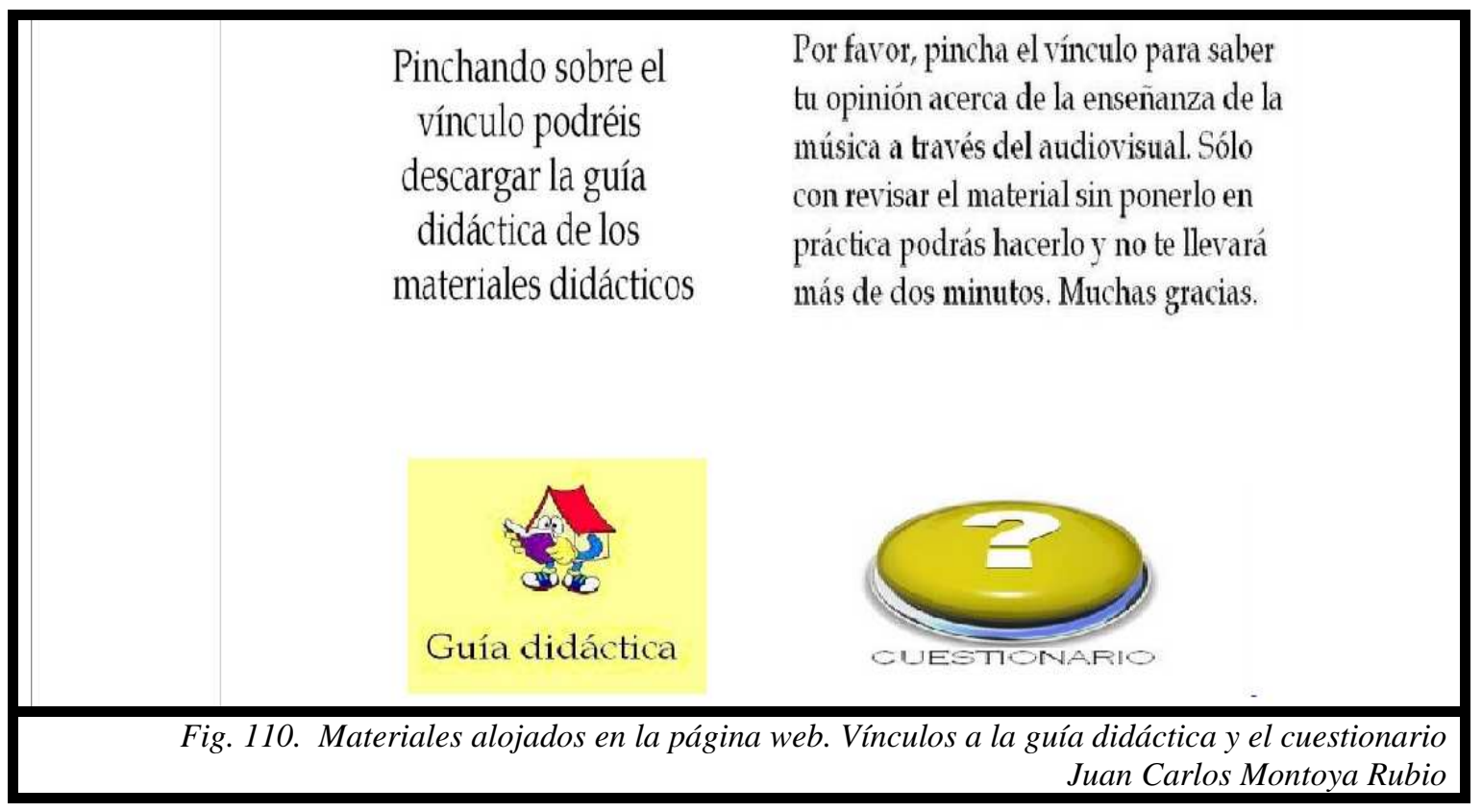

La respuesta que se dio a los elementos que servían como líneas maestras de actuación fue la que mostramos a continuación:

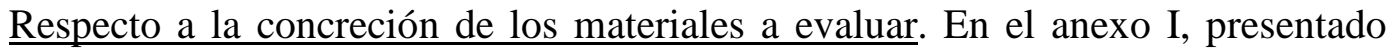
tras los resultados de este estudio, se muestra el contenido de una guía didáctica elaborada específicamente para el profesorado a quien se dirigía la investigación. Por su parte, el anexo II mostrará fichas didácticas concretas que aluden a esa guía didáctica y que sirven para que, en el hipotético caso de que así lo estimasen, los docentes pudieran hacer un uso directo con sus alumnos de dichos materiales. La totalidad de los materiales, tanto la guía como las fichas didácticas y, además, los vídeos y archivos de audio para desarrollar correctamente los ejercicios, quedaron a disposición de estos profesores a partir de las cuatro categorías establecidas a tal efecto: sonorización, extrapolación, musicogramas y movimiento y conocimiento musical a través del audiovisual. 
Para acceder a cada una de las secciones, pincha sobre ellas. Sólo has de seguir las recomendaciones de la guía didáctica.

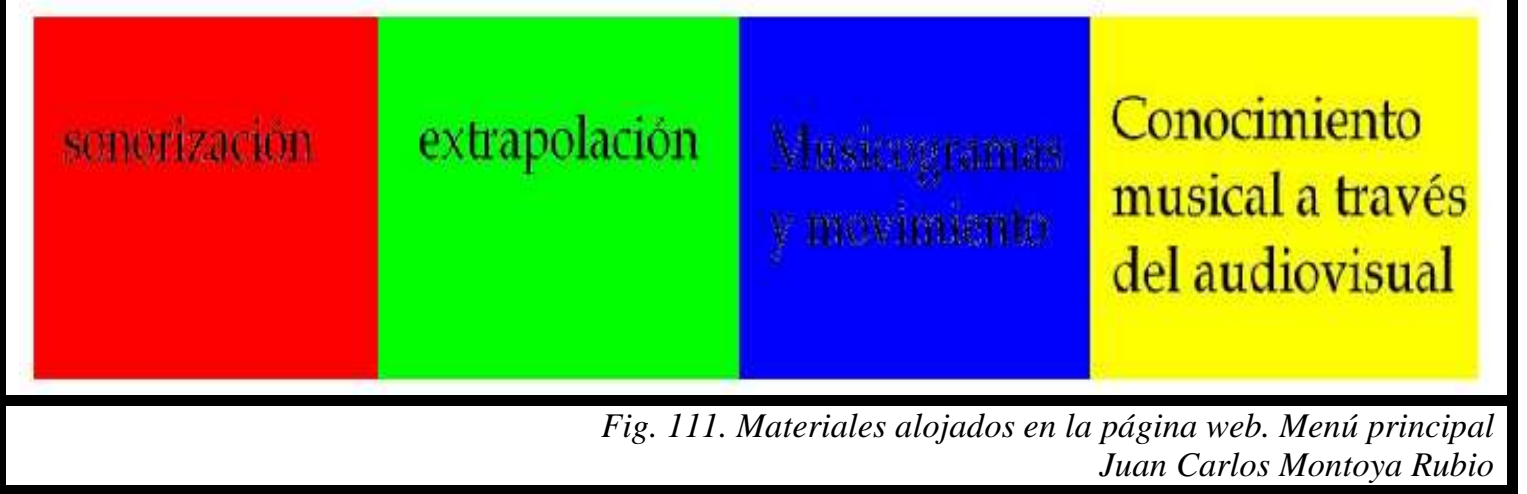

Cada uno de los bloques propuestos remitía a una serie de actividades modelo, las cuales informaban de manera práctica acerca de lo que significaba cada uno de los contenidos $^{779}$.

El apartado de sonorización, identificado con el color rojo en su vínculo para estructurarse claramente al entrar en su sitio web, albergaba tres casos prácticos que pretendían ser paradigmáticos en lo referente los procesos sonorizadores dentro de las aulas de música. El primer núcleo de actividades se centraba en sonorizaciones que eliminaban el audio original y mostraban ejemplos de implementación sonora realizada por alumnos. Por tanto, se mostraban dos vídeos de corta duración en formato original y su traslación a partir de la sonorización llevada a cabo en el aula, para ilustrar cómo podía ser realizada por el docente que accediera al grupo de documentos.

\footnotetext{
${ }^{779}$ De manera práctica, se vinculó a cada uno de los bloques con otra dirección web en la que alojar los contenidos específicos de cada uno de ellos:

Sonorización: 〈http://sites.google.com/site/sonorizacionjcmr/>

Extrapolación: <http://sites.google.com/site/extrapolacionjcmr/>

Musicogramas y Movimiento: 〈http://sites.google.com/site/musicogramasymovimientojemr/>

Conocimiento Musical a través del Audiovisual: <http://sites.google.com/site/conocimientomusicaljcmr/> [Consulta en todos los casos 24-III-10] Por otro lado, aunque los vídeos y demás actividades insertas en la propuesta didáctica pueden ser encontrados en estos vínculos, las direcciones específicas de cada uno de los vídeos alojados en Youtube quedan especificadas en la Guía Didáctica, dentro del anexo I.
} 
MÚSICA Y MEDIOS AUDIOVISUALES.

PLANTEAMIENTOS DIDÁCTICOS EN EL MARCO DE LA EDUCACIÓN MUSICAL. Juan Carlos Montoya Rubio

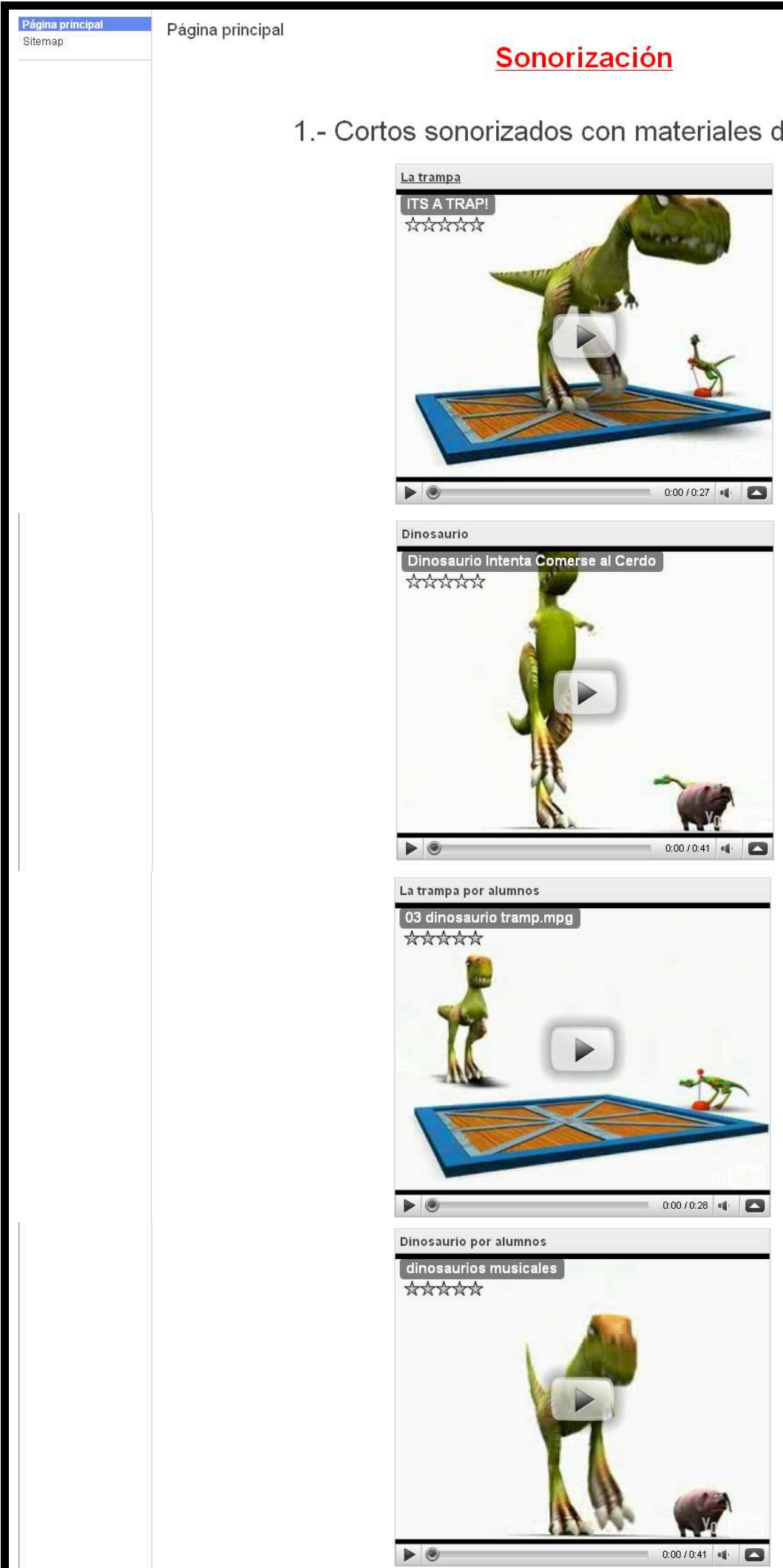

Fig. 112. Materiales alojados en la página web. Sonorización (I). Vídeos Juan Carlos Montoya Rubio 
El segundo de los paquetes de actividades hacía referencia a una actividad ya mostrada a lo largo de la investigación como paradigma de sonorización de un anuncio televisivo, y en este caso, al vídeo original y su derivación realizada por alumnos se adjuntaba una ficha didáctica que sirviera de guía para superponer sonidos a los ya preexistentes.

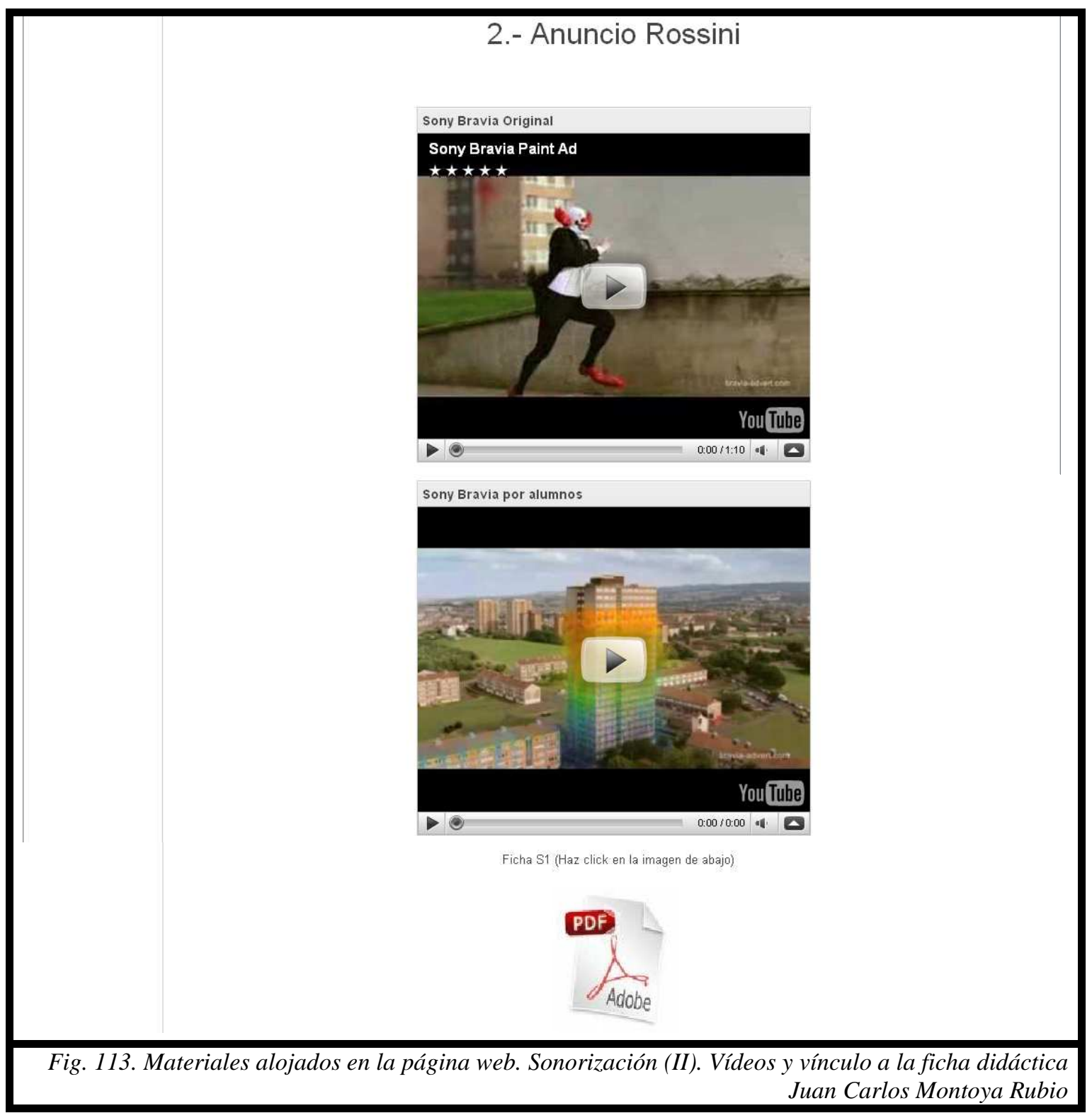


En tercer lugar, siguiendo con materiales utilizados para el desarrollo de la presente investigación, se adjuntaba otro vídeo que pudiera compendiar y clarificar las ideas expuestas. La vista de estos elementos en la página de sonorización es la que se muestra en la siguiente imagen:

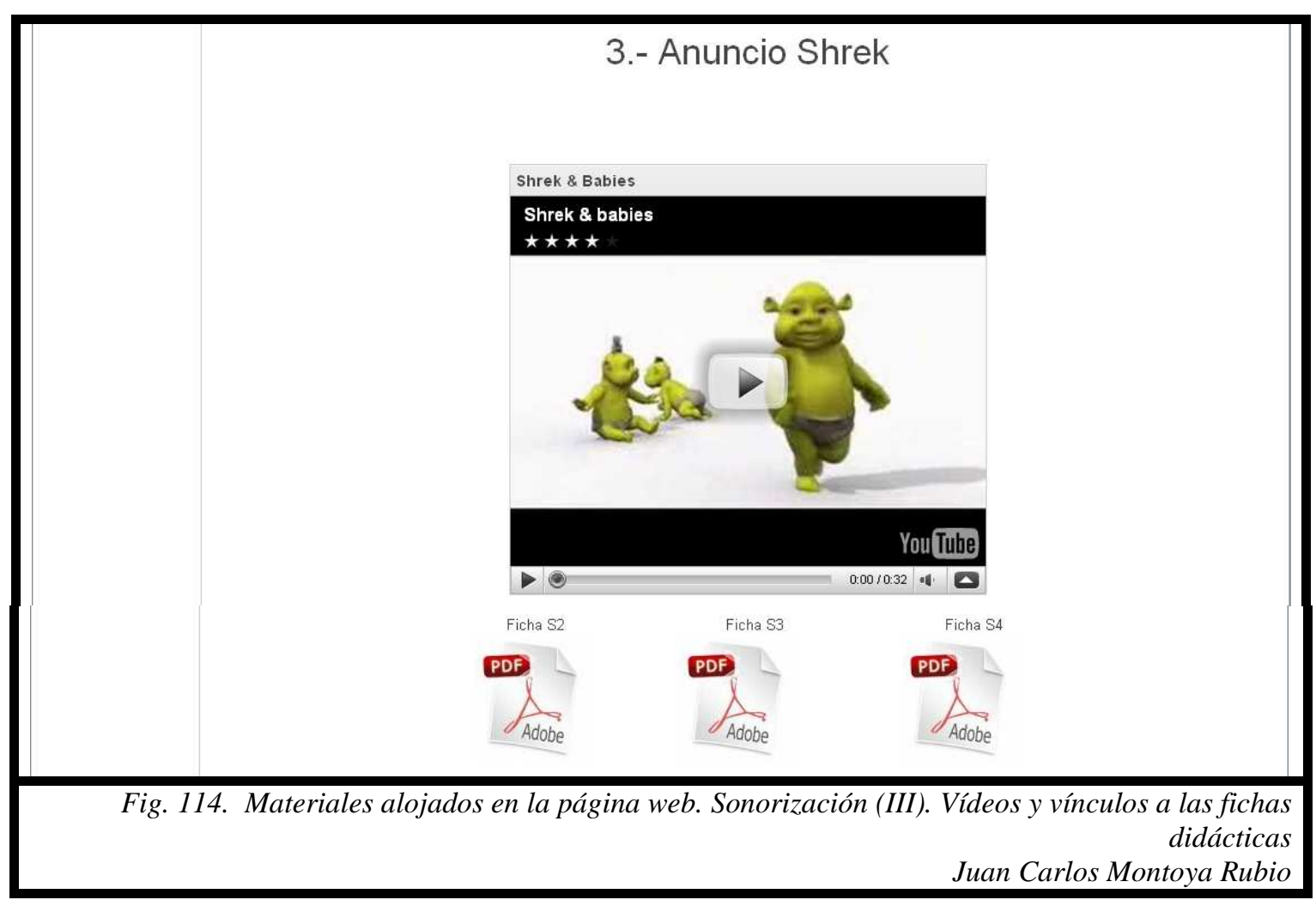

Una vez identificado el bloque de contenidos sonorizadores nos centramos en el segundo de los núcleos temáticos, identificado con el color verde y referido a la extrapolación de contenidos procedentes del audiovisual. Debido a lo detalladamente que fue trabajada la melodía del Hedwig Theme ${ }^{780}$, abogamos por indagar por medio de ella en la percepción del profesorado. Para ello, al archivo de audio se adjuntaron las fichas didácticas que pretendían mostrar cómo trabajar varios ámbitos de esta melodía de acuerdo con los criterios que expusimos en el tercero de los capítulos de esta

\footnotetext{
${ }^{780}$ Paradigma de extrapolación musical, como expusimos, no sólo en nuestros trabajos sino en otros ya citados como los de Almudena Mosquera.
} 
investigación. El aspecto hacia los vínculos (que recordamos se mostrarán en el anexo

II) es el siguiente:

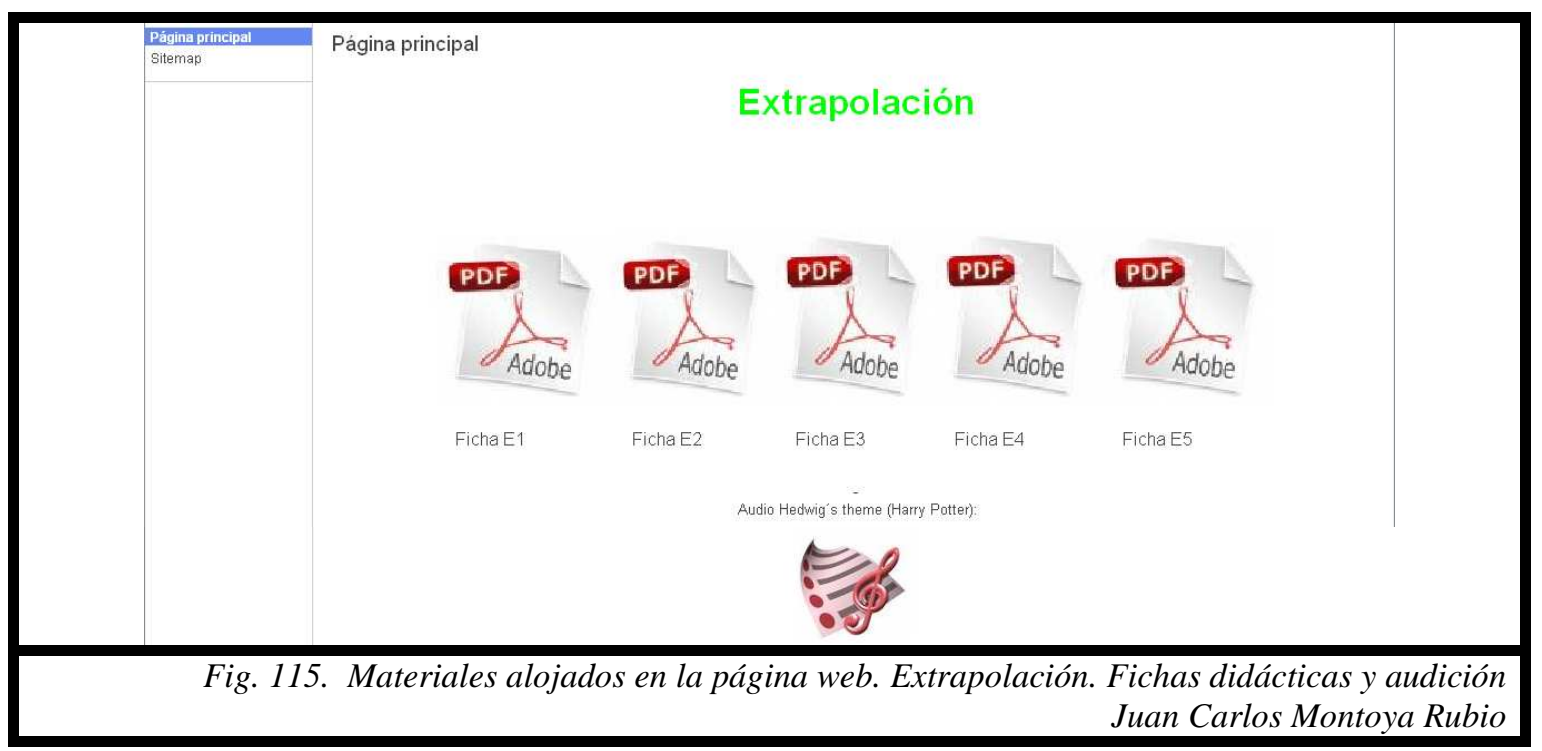

El tercero de los bloques que propusimos fue la observación de los musicogramas con diferente tipo de animación (tal como quedó reflejado en la última parte del tercer capítulo, desde la imagen fija hasta los musicomovigramas con mayor grado de dificultad). Optamos por hacer referencia a este conglomerado de actividades y no insertar elementos que refirieran a la filmación porque entendíamos que ello contravendría con el principio de simplicidad e inmediatez en la puesta en práctica de los procedimientos. Por ello, los procesos de filmación, que como quedó descrito pueden ser muy heterogéneos, no se incluyen en el presente apartado. De este modo, la selección de vídeos nos llevó a presentar, de entre las grandes posibilidades y casos que pueden encontrarse en la red, seis muestras significativas: la primera de ellas a través de un musicograma de imagen fija, la segunda con un musicomovigrama acuñado por Ramón Honorato $^{781}$ (como expusimos, caracterizado por su aproximación sensorial al hecho sonoro), la tercera con un caso que acota más cada una de las partes del discurso sonoro a partir de las imágenes, la cuarta con una descripción formal más rigurosa del archivo de audio, la quinta con una realización que, tomando las ventajas del vídeo anterior, hiciera más ameno su desarrollo con la inclusión de imágenes animadas y, por último, la sexta con una aproximación más exacta al desarrollo textural de una obra concreta. El modo en que los docentes podían observar esta gradación de contenidos quedó como se expone:

${ }^{781}$ HONORATO, R. (2001): Op. cit. 


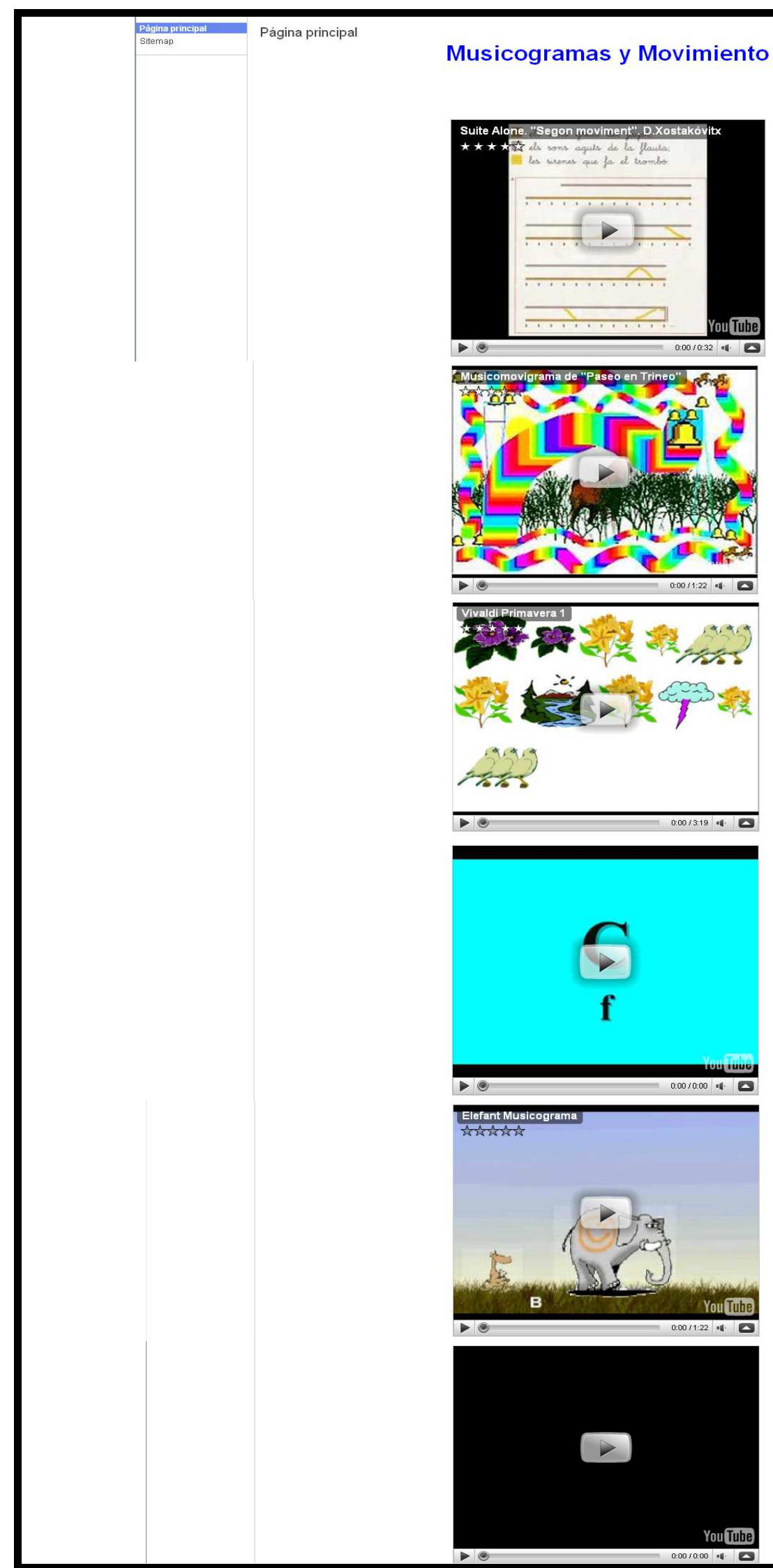

Fig. 116. Materiales alojados en la página web. Musicogramas y movimiento. Selección de vídeos Juan Carlos Montoya Rubio 
Por último, la cuarta estrategia a abordar fue el conocimiento musical a través del audiovisual, con identificador amarillo. Para su desarrollo, tomamos como nudo argumental extractos muy breves de la serie Los Simpson, ya utilizada en el capítulo tercero, en el cual nos extendimos acerca de la imagen de figuras musicales como Mozart y Beethoven. Esa excusa fue la que articuló el trabajo de conocimiento musical presentado a evaluación de los docentes. Las dimensiones que se propusieron fueron tres, a partir de otros tantos epígrafes: "Bart Simpson es Mozart", "Nelson es Beethoven" y "Pequeña Serenata Nocturna". En la primera, al fragmento audiovisual en el que el protagonista de la serie en cuestión toma posesión de la imagen de Mozart, se añadió una ficha con el diálogo del audiovisual y comentarios para la discusión en grupos de clase. Además, como complemento, se prepararon actividades de extrapolación anejas a la anterior para aprovechar mejor, si así lo estimaba el docente, la melodía que se ejecutaba al piano. Todo ello se reforzaba con un vídeo que publicitaba un coche por medio de sonidos producidos por la percusión de una varilla en botellas de cristal que resultaban ser la misma melodía mozartiana.

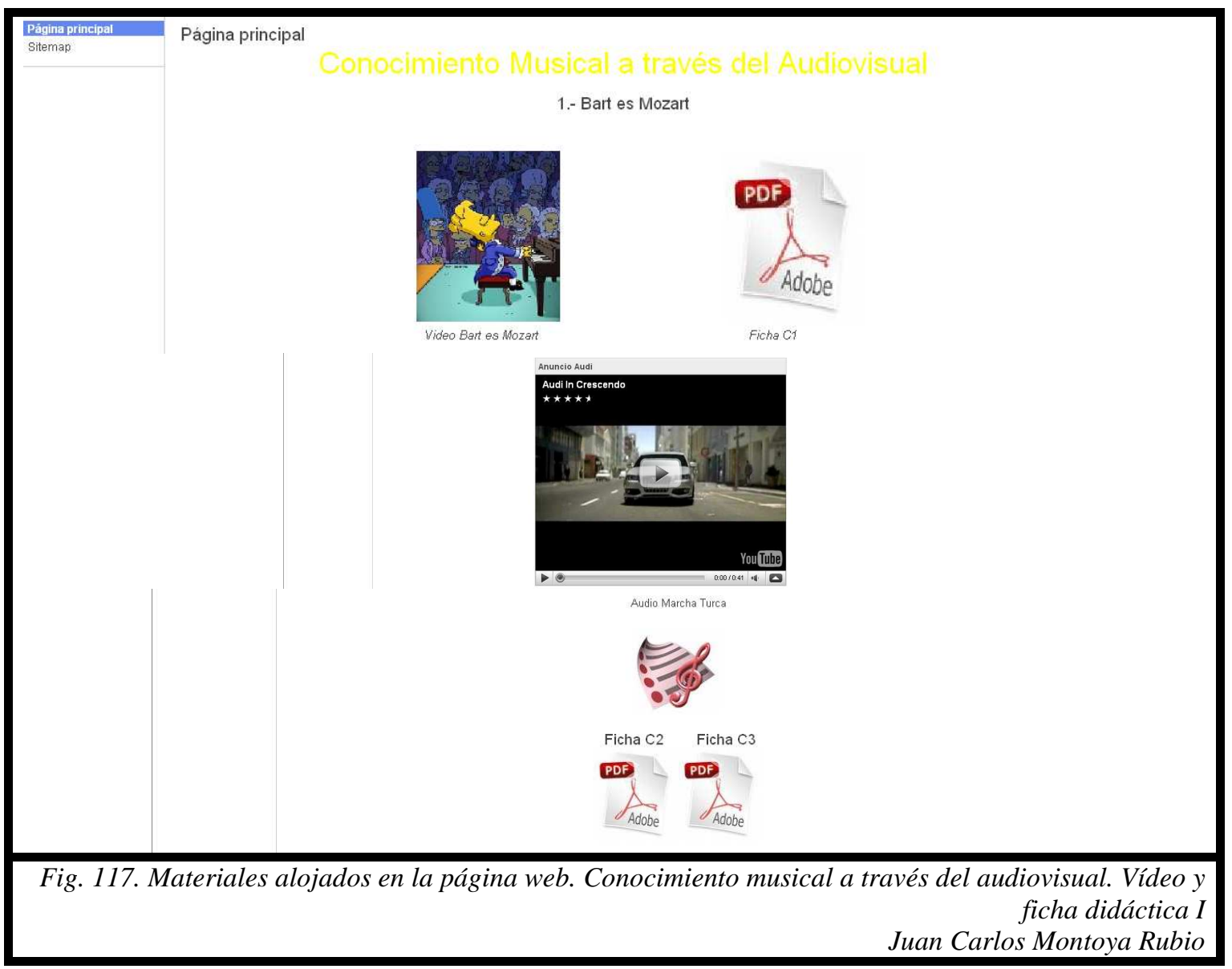


La segunda de las dimensiones, que hacía referencia a la imagen de Beethoven, es identificada, al igual que en el caso anterior, a través de dos breves vídeos que dan paso a una ficha con la cual se puede llegar a indagar sobre la veracidad o falsedad de las presunciones que se hacen en estos cortes audiovisuales. Además de esos dos vídeos, un tercero muestra un curioso "diálogo-disputa" musical entre una pareja que se sirve de los acordes más famosos de la Quinta Sinfonía beethoveniana para estructurar su discusión:

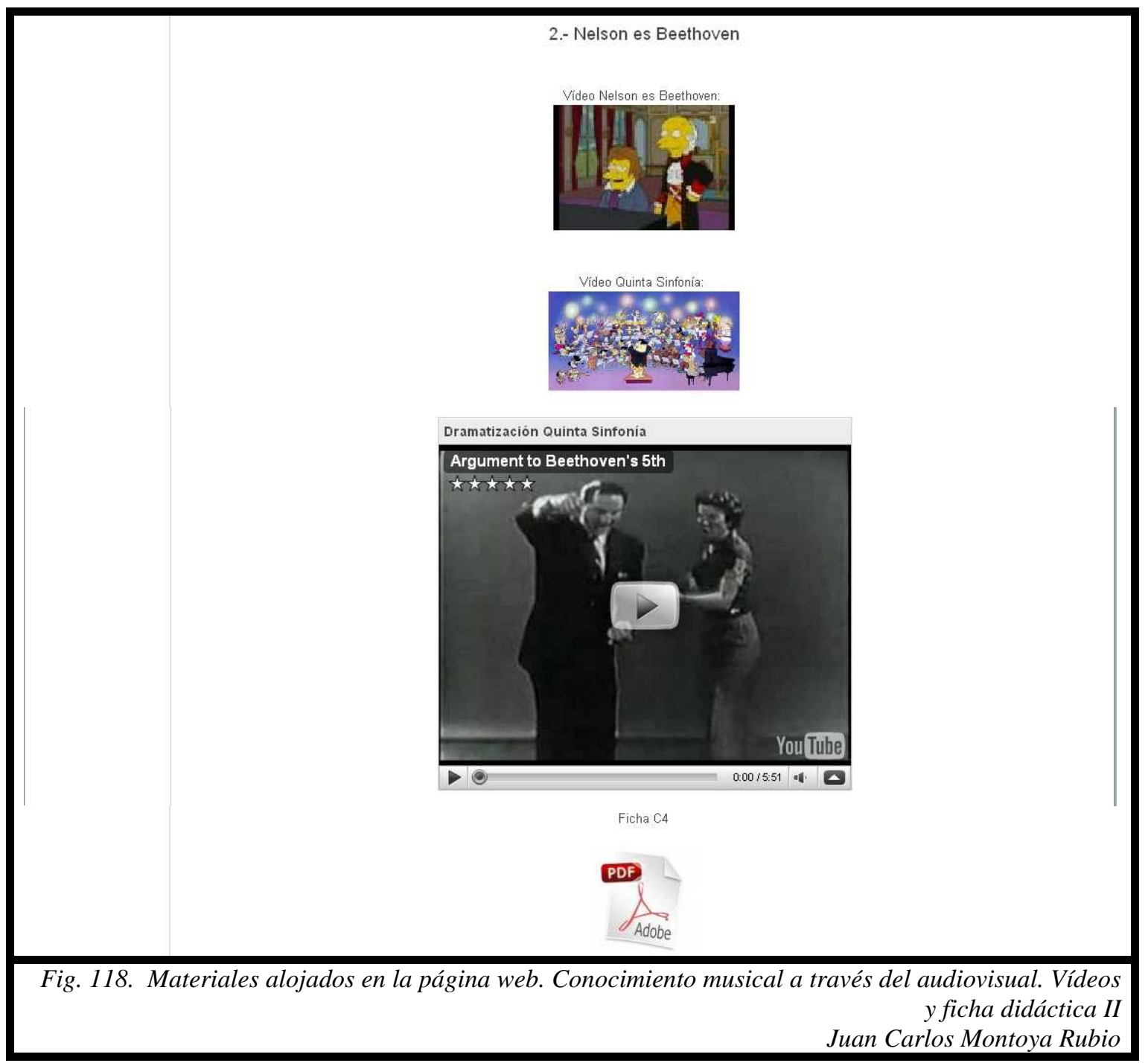


A continuación, la tercera dimensión a la que hacíamos referencia se nutre del mismo resorte significativo pero, en este caso, para realizar actividades en torno a la Pequeña Serenata Nocturna de Mozart. El uso de "cotidiáfonos" para su ejecución, en el segundo de los vídeos presentado como ejemplo, guía el desarrollo de las actividades de extrapolación y del musicograma con movimiento, de nuestra propia factura, adjuntado junto a ellas.

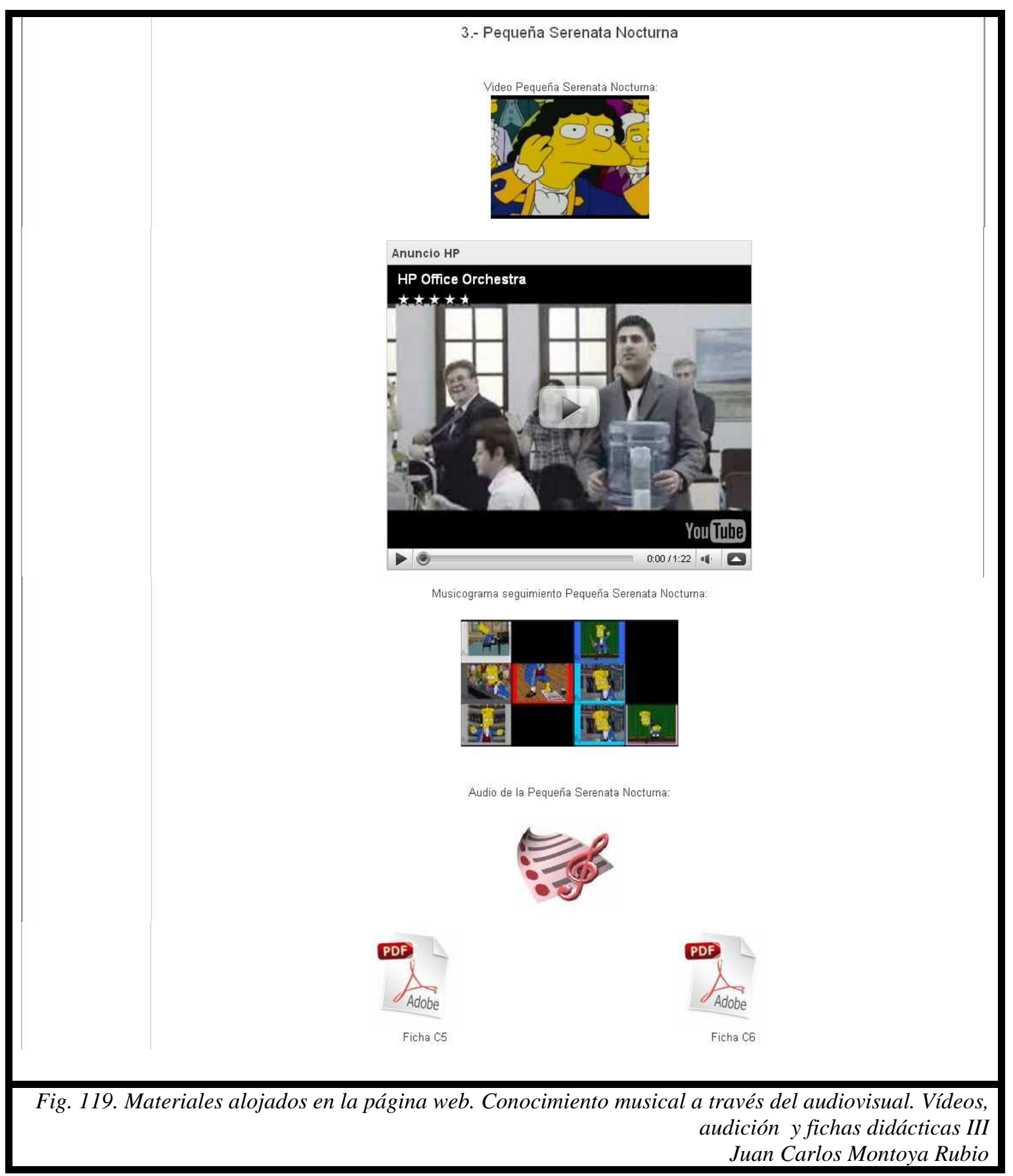


Con todo ello, la concreción de los materiales que los docentes habrían de evaluar queda especificada, de manera que los profesores pudieran volver a ellas siempre que lo desearan o tuvieran dudas sobre qué era y representaba cada uno de los bloques de contenidos.

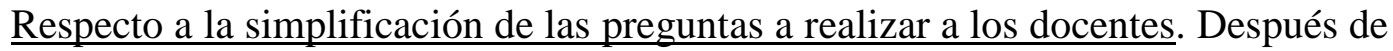
estimar cuáles eran los parámetros más adecuados a medir, y teniendo en cuenta que una revisión detallada de los materiales podría llevar un tiempo precioso para los profesores que colaborasen con nosotros, entendimos que lo más adecuado era llevar a cabo la evaluación de los mismos a través de un cuestionario que, a partir de un máximo de veinte ítems de respuesta entre opciones cerradas, nos arrojara la suficiente información como para cruzar datos en todos los sentidos. Así pues, el criterio básico tanto en la elaboración global del cuestionario como en la de los ítems sería la operatividad para los docentes y para nuestros intereses. En este sentido, después de adecuar las dimensiones que se estimaron como más convenientes para estudiar, se presentaron cinco cuestiones para cada uno de los ámbitos planteados (sonorización, extrapolación, musicogramas y movimiento y conocimiento musical a través del audiovisual). Estas cuestiones serían idénticas para cada uno de los bloques y, en ellos, se haría referencia a:

a) La aplicabilidad de los materiales en su propio contexto didáctico.

b) La significatividad que consideran aportan los materiales a su alumnado.

c) La posibilidad o imposibilidad de generar unidades didácticas a partir de materiales como los presentados.

d) La posibilidad o imposibilidad de globalizar, a partir de esos materiales, los conocimientos musicales con otras áreas de conocimiento.

e) El uso que, hasta el momento, han dado a materiales similares en su práctica docente.

Por tanto, el resultado es el de veinte ítems que se vinculan en las cuatro dimensiones, lo cual nos permite cruzar resultados entre ellas. Las opciones que se dan 
al docente a la hora de responder son cuatro, gradadas de mayor aceptación o rasgos positivos a menor aceptación o rasgos negativos. Con ello, se evita un hipotético refugio en valores centrales. La planilla con cuestiones planteadas y sus posibles contestaciones quedó como sigue:

\section{SONORIZACIÓN}

1. Este material es aplicable al aula de educación musical
a. Fácilmente aplicable
b. Aplicable con ligeros retoques
c. Aplicable con grandes retoques
d. No aplicable

2. Este material es significativo para el alumnado
a. Altamente significativo
b. Es significativo
c. Poco significativo
d. Nada significativo

3. A partir de estos materiales se puede estructurar una Unidad Didáctica

a. Se configura una Unidad Didáctica sin problemas

b. Se configura una Unidad Didáctica con ligeros cambios

c. No, lo utilizaría como actividad complementaria a otra Unidad Didáctica

d. No encajaría en ninguna Unidad Didáctica

4. Este material se puede globalizar con otras áreas

a. Fácilmente

b. Con ligeros retoques

c. Con grandes retoques

d. No se puede globalizar con otras áreas

5. Con anterioridad he utilizado recursos de sonorización similares a los presentados en los materiales
a. A menudo, en cada Unidad Didáctica
b. De manera puntual en cada trimestre
c. Esporádicamente
d. No, nunca

\section{CONOCIMIENTO MUSICAL A TRAVÉS DEL AUDIOVISUAL}

6. Este material es aplicable al aula de educación musical
a. Fácilmente aplicable
b. Aplicable con ligeros retoques
c. Aplicable con grandes retoques
d. No aplicable

7. Este material es significativo para el alumnado
a. Altamente significativo
b. Es significativo
c. Poco significativo
d. Nada significativo

8. A partir de estos materiales se puede estructurar una Unidad Didáctica

a. Se configura una Unidad Didáctica sin problemas 
b. Se configura una Unidad Didáctica con ligeros cambios

c. No, lo utilizaría como actividad complementaria a otra Unidad

Didáctica

d. No encajaría en ninguna Unidad Didáctica

9. Este material se puede globalizar con otras áreas

a. Fácilmente

b. Con ligeros retoques

c. Con grandes retoques

d. No se puede globalizar con otras áreas

10. Con anterioridad he utilizado recursos de conocimiento musical a través del audiovisual similares a los presentados en los materiales

a. A menudo, en cada Unidad Didáctica

b. De manera puntual en cada trimestre

c. Esporádicamente

d. No, nunca

\section{MUSICOGRAMAS Y MOVIMIENTO}

11. Este material es aplicable al aula de educación musical
a. Fácilmente aplicable
b. Aplicable con ligeros retoques
c. Aplicable con grandes retoques
d. No aplicable

12. Este material es significativo para el alumnado

a. Altamente significativo

b. Es significativo

c. Poco significativo

d. Nada significativo

13. A partir de estos materiales se puede estructurar una Unidad Didáctica

a. Se configura una Unidad Didáctica sin problemas

b. Se configura una Unidad Didáctica con ligeros cambios

c. No, lo utilizaría como actividad complementaria a otra Unidad

Didáctica

d. No encajaría en ninguna Unidad Didáctica

14. Este material se puede globalizar con otras áreas

a. Fácilmente

b. Con ligeros retoques

c. Con grandes retoques

d. No se puede globalizar con otras áreas

15. Con anterioridad he utilizado recursos de musicogramas y movimiento similares a los presentados en los materiales
a. A menudo, en cada Unidad Didáctica
b. De manera puntual en cada trimestre
c. Esporádicamente
d. No, nunca

\section{EXTRAPOLACIÓN}

16. Este material es aplicable al aula de educación musical

a. Fácilmente aplicable

b. Aplicable con ligeros retoques 

c. Aplicable con grandes retoques
d. No aplicable

17. Este material es significativo para el alumnado
a. Altamente significativo
b. Es significativo
c. Poco significativo
d. Nada significativo

18. A partir de estos materiales se puede estructurar una Unidad Didáctica

a. Se configura una Unidad Didáctica sin problemas

b. Se configura una Unidad Didáctica con ligeros cambios

c. No, lo utilizaría como actividad complementaria a otra Unidad Didáctica

d. No encajaría en ninguna Unidad Didáctica

19. Este material se puede globalizar con otras áreas
a. Fácilmente
b. Con ligeros retoques
c. Con grandes retoques
d. No se puede globalizar con otras áreas

20. Con anterioridad he utilizado recursos de extrapolación similares a los presentados en los materiales
a. A menudo, en cada Unidad Didáctica
b. De manera puntual en cada trimestre
c. Esporádicamente
d. No, nunca

A continuación se refleja, en vista real, el modo en que los cuestionarios fueron delimitados:

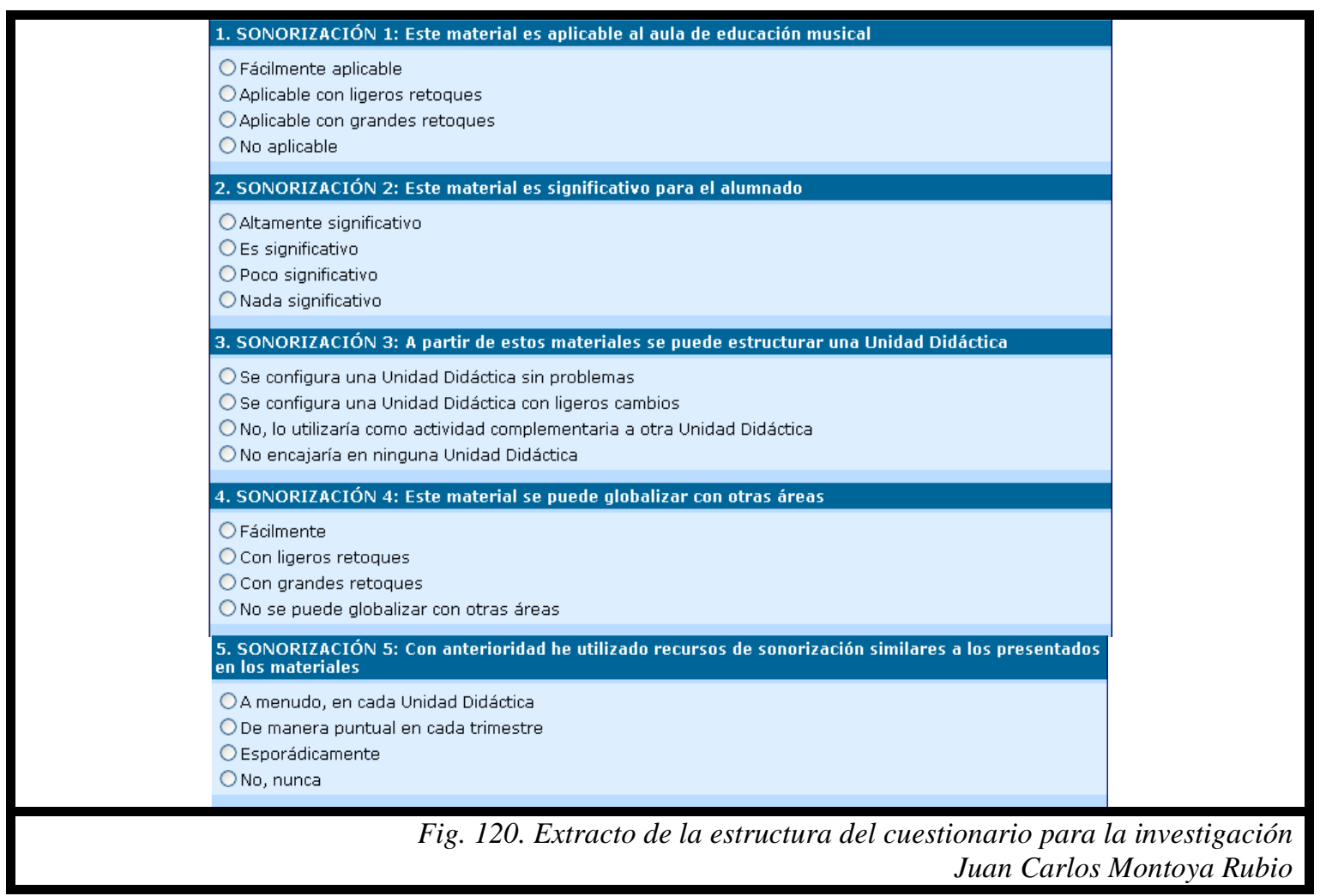


$\underline{\text { Respecto a la diversidad y homogeneidad del universo de la muestra y su }}$ pertenencia a la realidad educativa actual. Como indicamos al inicio del capítulo, la adecuación del colectivo a quien dirigir los esfuerzos investigadores hará virar más o menos levemente los resultados de los mismos. Por ello, en el planteamiento inicial subyacía la necesidad de conseguir penetrar en diferentes tipos de contextos escolares y, a su vez, llevar a cabo el muestreo bajo el amparo de un mismo marco legal, debido a que la mayor o menor incidencia de recursos tecnológicos u otros elementos de orden legislativo podría hacer variar los resultados de una a otra Comunidad Autónoma. En la convergencia de los criterios anteriores se estimó como muy adecuado realizar el estudio en todos los centros de educación general que imparten la etapa de primaria dentro de la Región de Murcia. De acuerdo con las premisas anteriores, se puso en conocimiento de todos los especialistas de educación musical el contenido del estudio y la disponibilidad de los materiales a los cuales se les asociaba el cuestionario ${ }^{782}$.

\footnotetext{
${ }^{782}$ En este sentido, se entregaron un total de 175 sobres con todo el material a otros tantos docentes de música o representantes de los centros educativos, bien en su propia ubicación bien a través de un reparto masivo en el marco del "Seminario estrategias de apoyo en la compensación educativa y atención al alumnado de integración tardía en el sistema educativo" para lo cual se obtuvo permiso de la Dirección General de Promoción, Ordenación e Innovación Educativa de la Consejería de Educación, Formación y Empleo de la Región de Murcia. Otros 188 centros fueron atendidos vía postal y el resto de aquellos a los que se dirigiría el estudio, 121, recibieron vía $e$-mail, noticia del contenido de la web a su disposición y el cuestionario. Una vez recabada la información se sumaron 164 aportaciones, de las cuales se tomaron en consideración las de 152 centros en los que se impartía educación primaria, descartándose las 12 restantes por imposibilidad de ratificar la procedencia o cumplimentación parcial.
} 


\subsection{RESULTADOS OBTENIDOS}

\section{Aspectos introductorios}

"Las teorías, entonces, son algo más que resúmenes de datos, ya no solamente nos dicen lo que sucede, sino también porque sucede asî,783.

Como fue apuntado al inicio del capítulo, la elaboración del cuestionario tuvo como referencia principal buscar el cruce de informaciones entre los diferentes ítems de modo que pudiéramos llevar a cabo el pretendido paso comprensivo una vez recabados los datos. Con el ánimo de presentar de manera gráfica los resultados, distinguiremos los diferentes ámbitos en que se estructuraron las distintas preguntas para abordar su interpretación.

Los cinco primeros ámbitos tratan de describir, a la luz de las respuestas obtenidas, cuál es el uso y las posibilidades de cada uno de los procedimientos presentados como paradigmáticos en los materiales. En primera instancia, se hace un recorrido por las respuestas que, de manera cuantitativa, se han recogido (ámbitos 1, 2, 3 y 4). Por su parte, en el quinto de los ámbitos se comparará la importancia que se otorga a cada dimensión (obtenida por la suma de los resultados positivos de los cuatro procedimientos didácticos, esto es, las dos primeras posibles respuestas) con el nivel de uso que los docentes declaran hacer de ellos en sus aulas (ítems 5, 10, 15 y 20 ponderados al número de respuestas que se manejan en la comparación). A partir del ámbito sexto nos centramos en establecer nexos entre las prácticas de sonorización, conocimiento musical, musicogramas y movimiento y extrapolación, para explorar las últimas consecuencias acerca del conocimiento que se tiene y la relevancia que se les concede a cada una de ellas.

\footnotetext{
${ }^{783}$ KAPLAN, D. y MANNERS, R. A. (1998): “Antropología: métodos y problemas en la formulación de teorías”. VELASCO, H. (comp.) Lecturas de antropología social y cultural. Madrid: UNED, p. 27.
} 


\section{Ámbito 1. Los procedimientos de sonorización. Usos y posibilidades.}

\section{Ítems de referencia: $1-2-3-4-5$}

En líneas generales, los procesos de sonorización que se han mostrado describen una tendencia positiva hacia su hipotética aplicabilidad dentro de las aulas, significatividad para el alumnado, posibilidad de integración en unidades didácticas diseñadas a tal efecto y globalización con otras áreas, lo cual no implica que su nivel de uso actual sea destacado. Como veremos, se trata de una tendencia similar en todos los planteamientos estudiados.

Nos centramos pues en la descripción de los resultados partiendo del nivel de aplicabilidad que los docentes estimaban para estos procedimientos. De manera abrumadora, se considera que estamos ante materiales aplicables, si bien en la mayoría de los casos se piensa que se precisa de una adaptación "ligera" para encauzar correctamente los contenidos en un escenario educativo propio. La estimación de necesidad de cambios mayores es contemplada por un número mínimo de docentes.

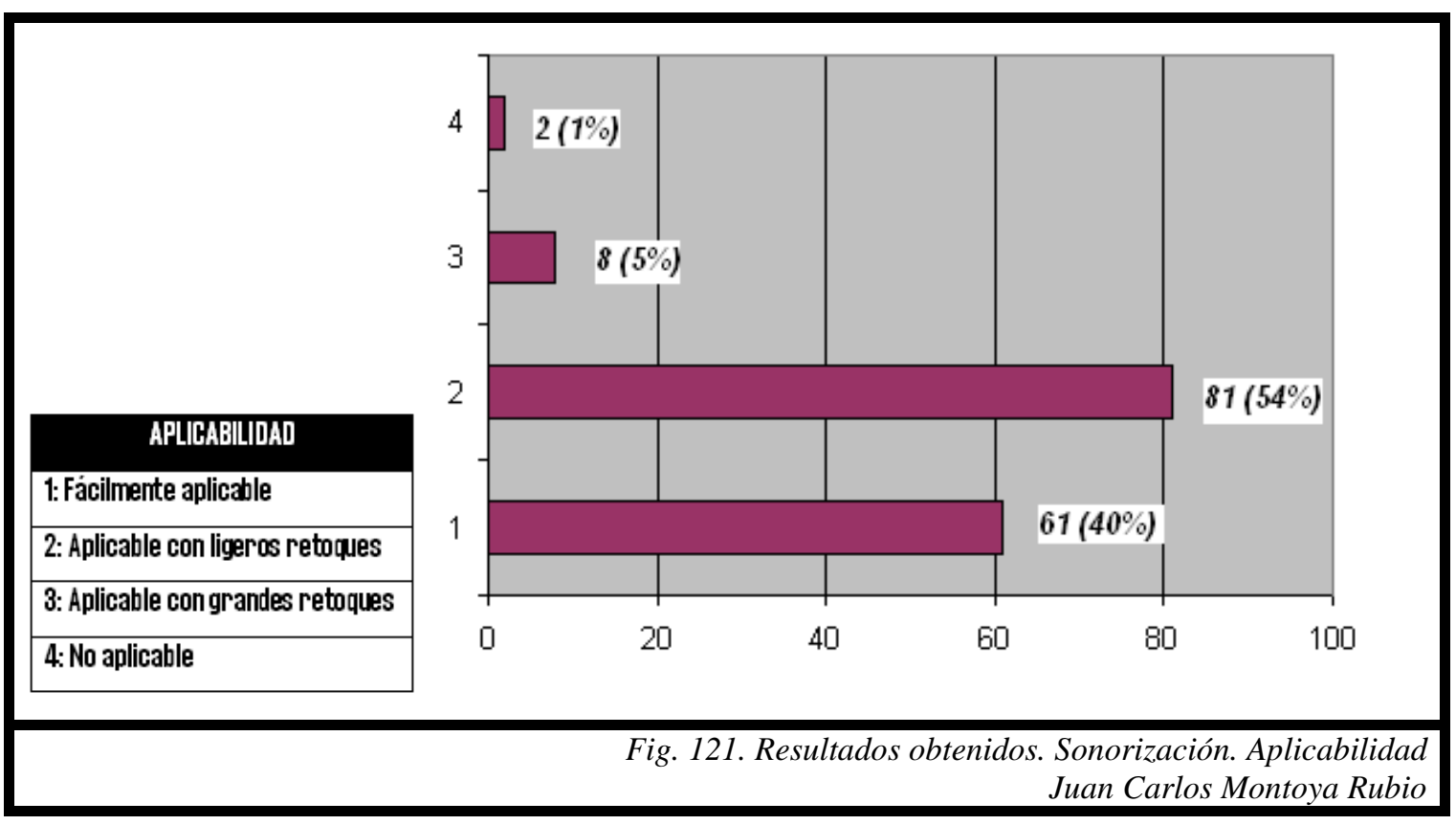

Es en el campo de la significatividad donde hallamos un mayor consenso dentro de los procesos de sonorización. Éste es el apartado en que se conviene en interpretar 
que a partir de estos procedimientos los alumnos pueden involucrarse completamente en los diseños pedagógicos. Si tenemos en cuenta que no existen prácticamente divergencias al respecto, urge la necesidad de actuar direccionando los enunciados prácticos hacia elementos de este tipo, especialmente a tenor del incremento tecnológico, citado en capítulos anteriores, que permite desarrollar las clases de música a partir de la conexión a un proyector de imagen en movimiento.

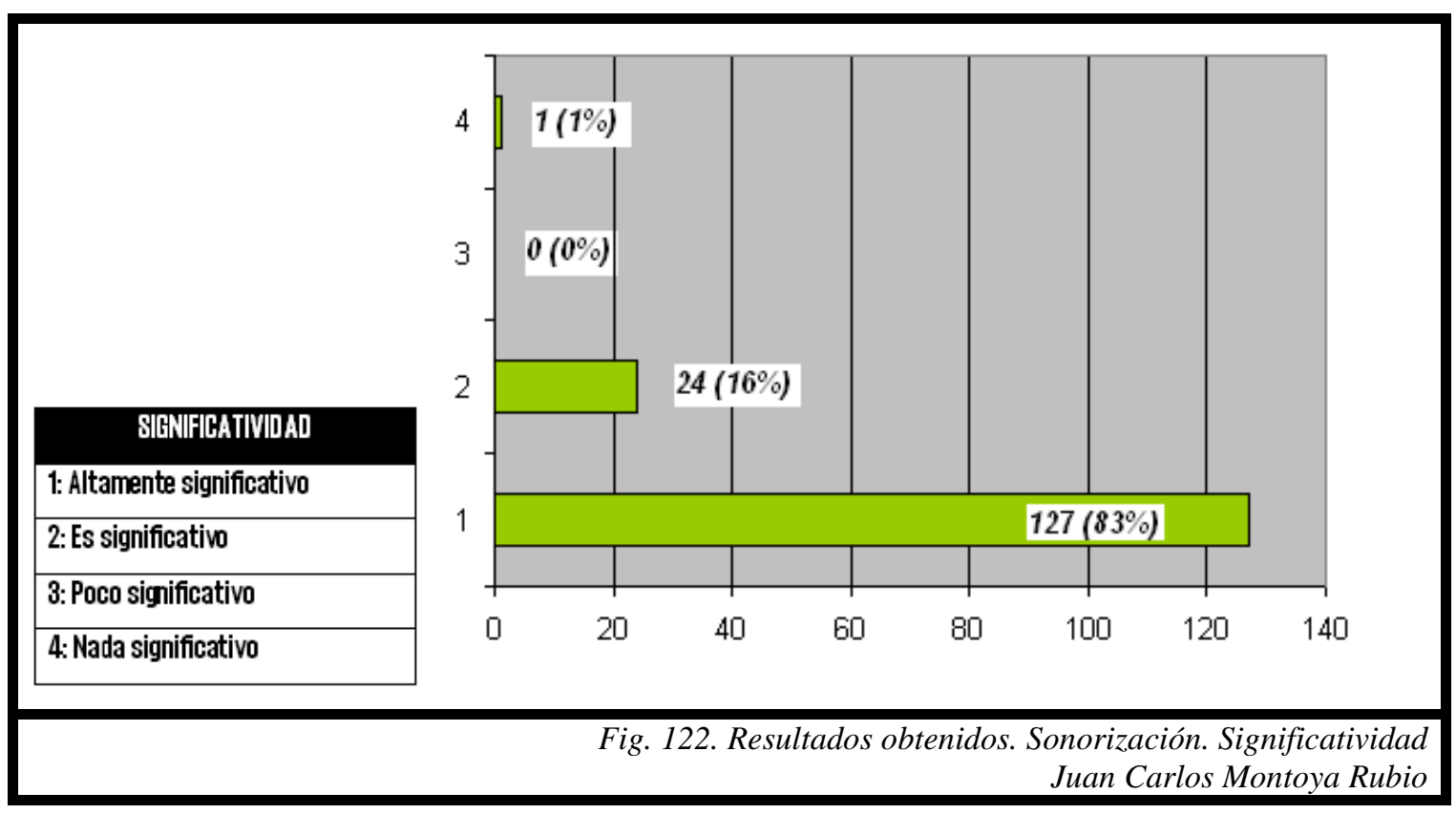

El porcentaje que hace referencia a la significatividad baja levemente al abordar la cuestión de la inclusión real y efectiva en contextos específicos de la aplicación en el marco de unidades didácticas. A pesar de que la percepción de que, a partir de pequeños cambios, no habría inconveniente en insertarlos, son tantos los que opinan que este proceso serviría para articular, per se, una unidad didáctica de manera directa como los que encuentran más recomendable su uso de manera puntual, en alguna unidad didáctica. Muy posiblemente, la ausencia de una utilización sistemática de estos procesos hace que haya quien sienta que entre sus capacidades no esté la de manejar abiertamente elementos derivados de la sonorización, aunque sí pequeñas pinceladas de ellos. En todo caso es preciso recordar que la mayor proporción (más del doble de las respuestas obtenidas) considera que, con simples matizaciones, una unidad didáctica vertebrada bajo estos principios es tan adecuada como probable. 


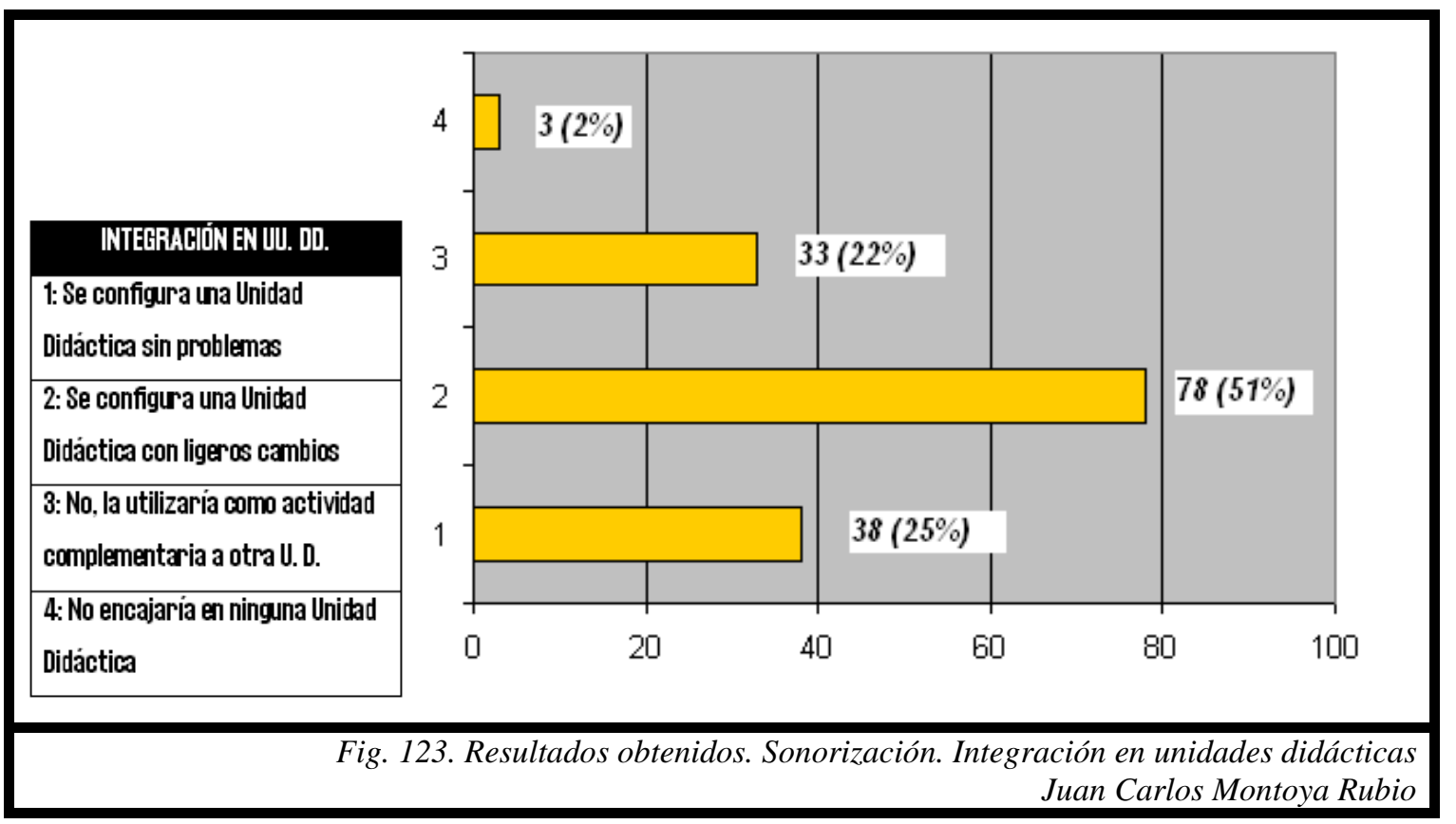

Dentro de la tendencia general, se comprueba que existe una sensación homogénea que remite a la facilidad para globalizar estos contenidos con el resto de las áreas propias de la enseñanza, si bien es cierto que en la mayoría de los casos se estima como pertinente un proceso de mediación leve que adecue lo que, en realidad, son procedimentos muy concretos que no muestran una vinculación evidente por una u otra materia a globalizar. En todo caso, la predisposición general es la de entender que, con el interés necesario, no parece difícil llevar a cabo dicha globalización.

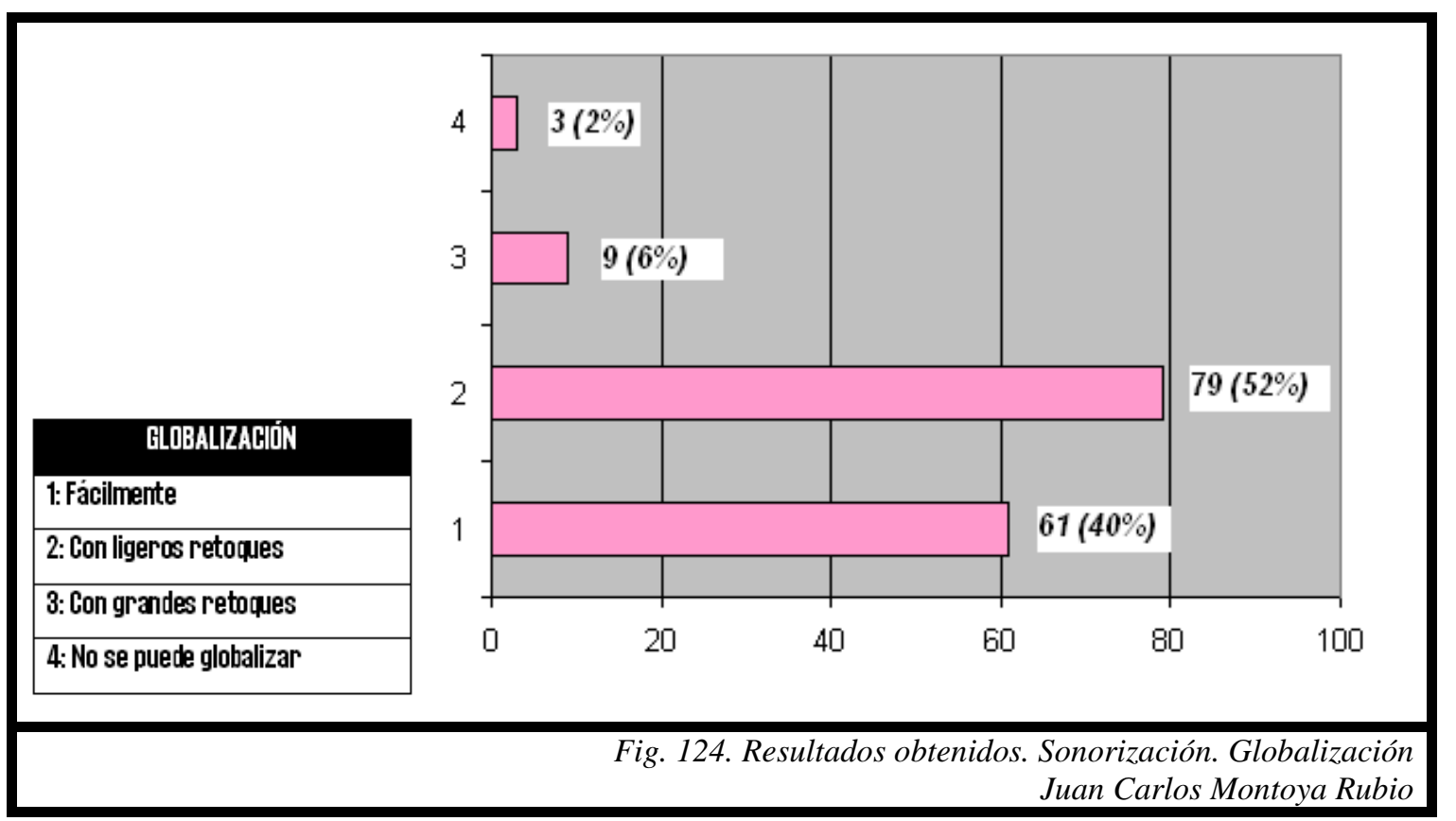


La interpretación de los datos anteriores abre la puerta a la comprensión del último de los gráficos expuestos sobre estos párrafos, todos ellos referidos a la sonorización. Así, se constata que el uso efectivo, es decir, la utilización previa es, si no residual, sí al menos muy minoritaria. Casi la mitad de los cuestionarios muestran una omisión total de procedimientos de este formato en sus clases, mientras que el resto se debate entre una mayoría que acude a ellos como meras pinceladas y una minoría que tiene conciencia clara de su utilización y opta por ella. La desproporción entre uso efectivo y su supuesta importancia como resorte de aprendizaje vivencial y significativo se abordará en breve.

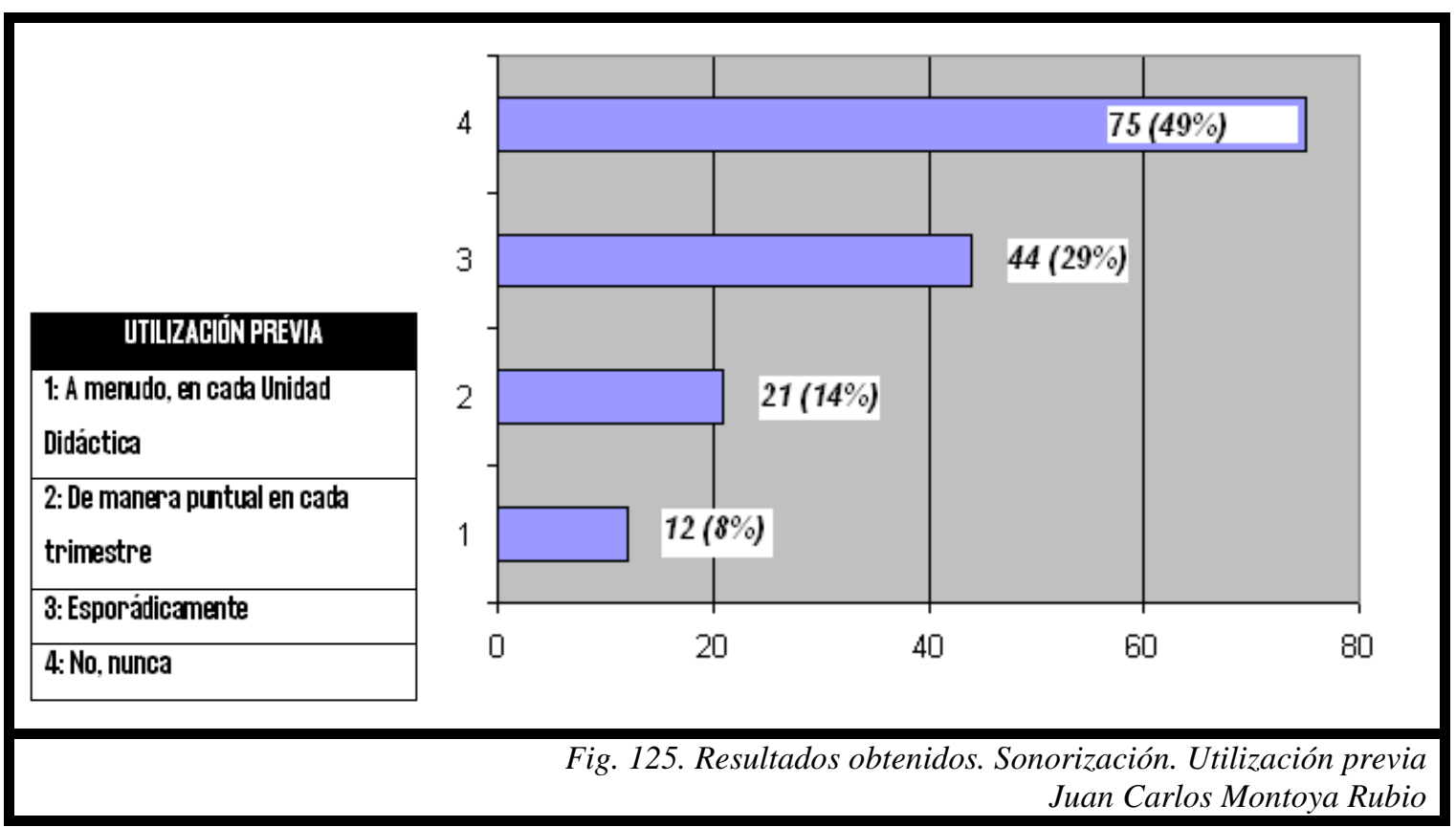

Ámbito 2. Los procedimientos de conocimiento musical a través del audiovisual. Usos y posibilidades.

Ítems de referencia: $6-7-8-9-10$

La tendencia a considerar que las actividades propuestas para este tipo de procedimiento son aplicables es una evidencia palpable. La única discrepancia parece ser el hecho de poder insertarlas sin más dentro de los procesos pedagógicos que se estaban llevando a cabo o realizar pequeños retoques que perfilen las mismas a un alumnado concreto. Ciertamente, la aplicabilidad viene dada del hecho de presentar 
cortes audiovisuales con un trasfondo musical tan evidente que se antoja complicado no intuir tras ellos elementos pedagógicos.

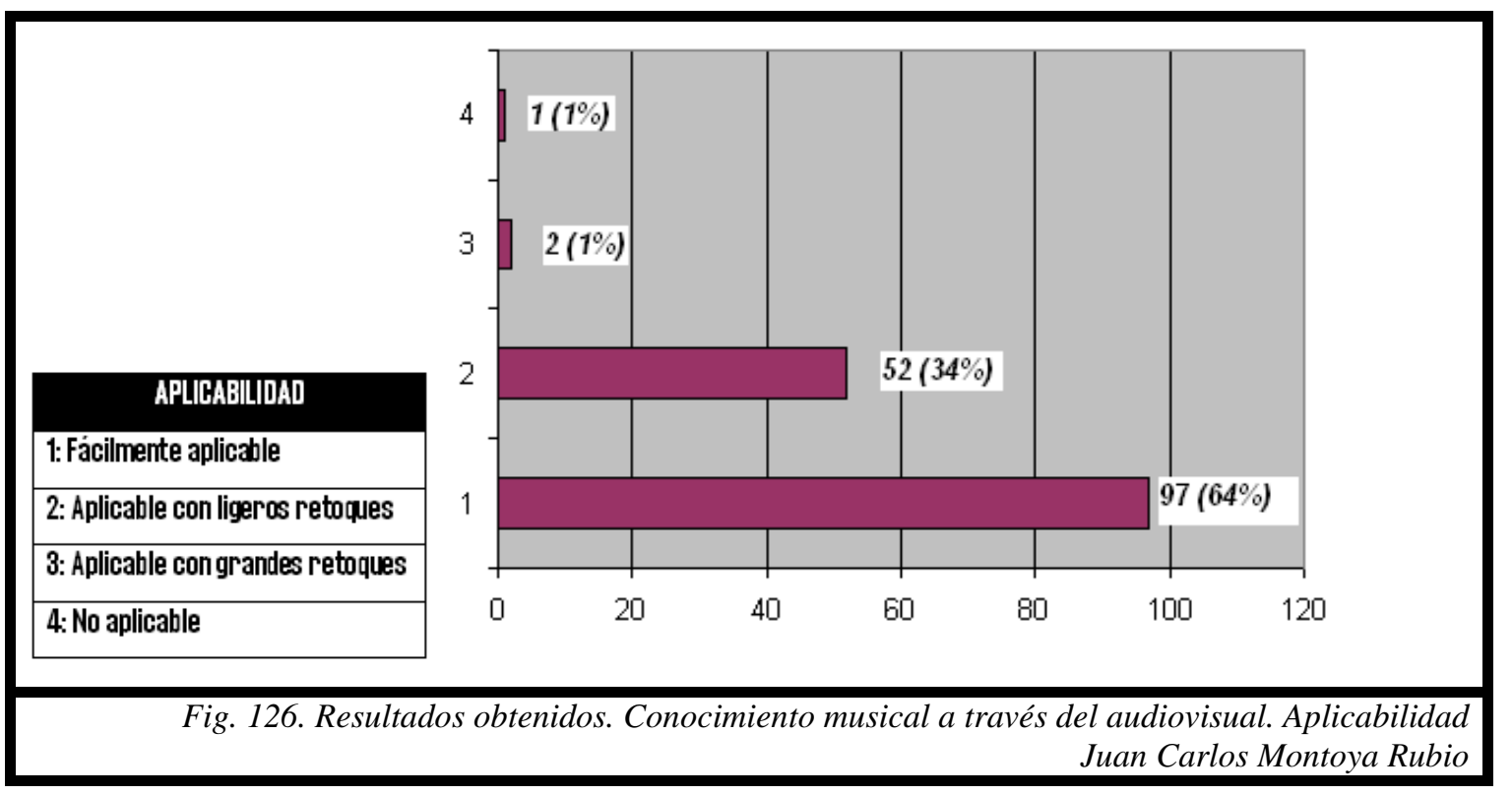

De manera muy similar se apuntan los resultados en el plano de la significatividad. El hecho de que se estime, por parte del profesorado, que el material no sólo es aplicable al aula sino que también es significativo hace intuir un futuro prometedor al aprendizaje de conceptos musicales desde el audiovisual, siempre que éste encuentre el espacio de fomento adecuado. Reseñamos que la inmensa mayoría estima que estamos ante desarrollos procedimentales "altamente significativos", lo cual es un reto para la generación de materiales que continúen vinculando la realidad de los alumnos con las prácticas pedagógico-musicales.

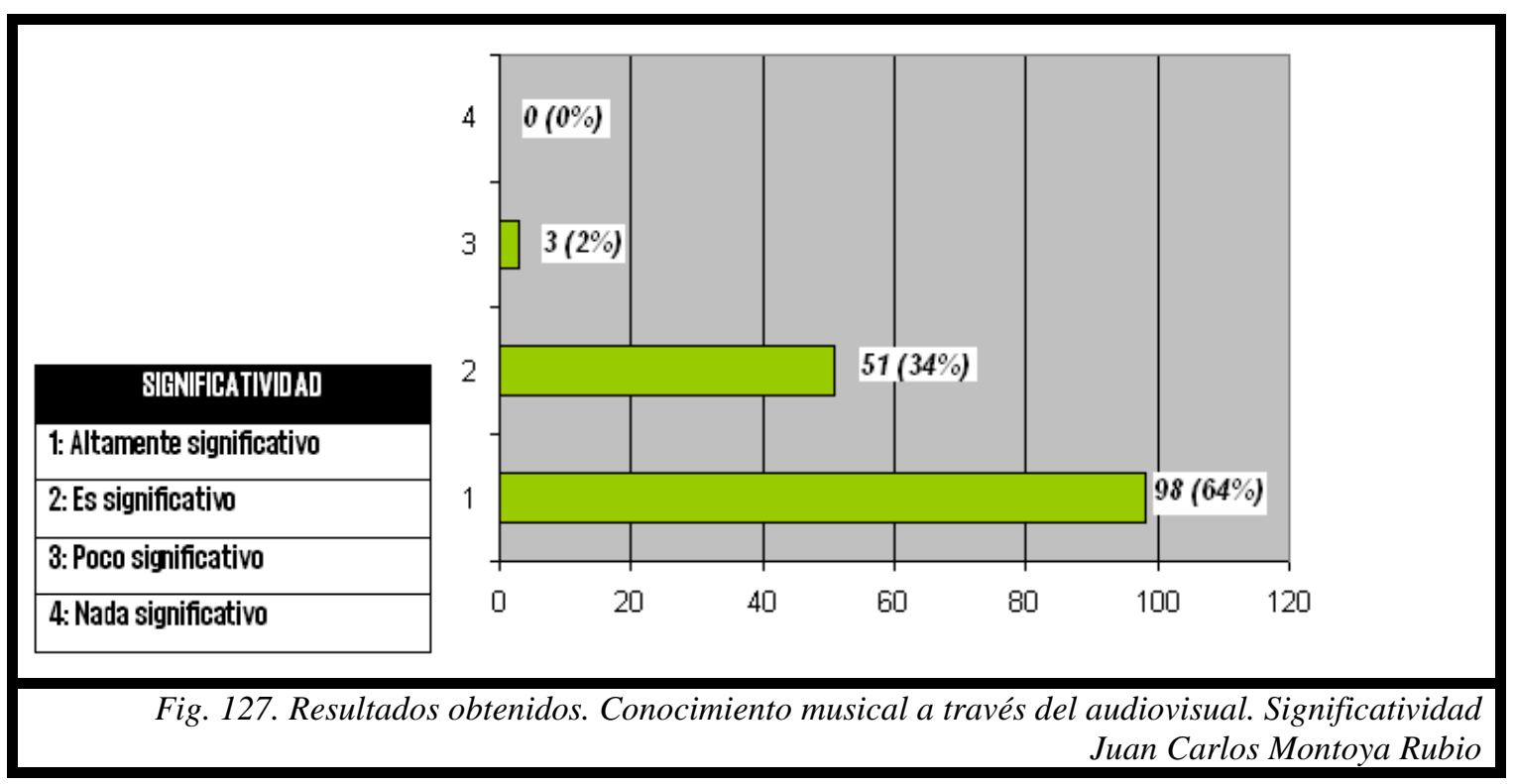


Aunque la tendencia sigue siendo similar, se observa cierta falta de adecuación entre los datos recabados en la aplicación y los que a continuación se presentan, referidos a la posibilidad de integrar dentro de unidades didácticas concretas los materiales. Es cierto que en torno al $85 \%$ de los docentes estiman que la configuración de la unidad didáctica no causaría ningún problema, pero también es cierto que el resto, el porcentaje menor, crece con respecto a los que no encontraban traba alguna de aplicabilidad. Muy posiblemente esto sea debido a la dificultad que siempre entraña plasmar de manera efectiva una secuencia didáctica coherente, y la relativa simplicidad de hacerlo de manera aislada, incluyendo actividades puntuales.

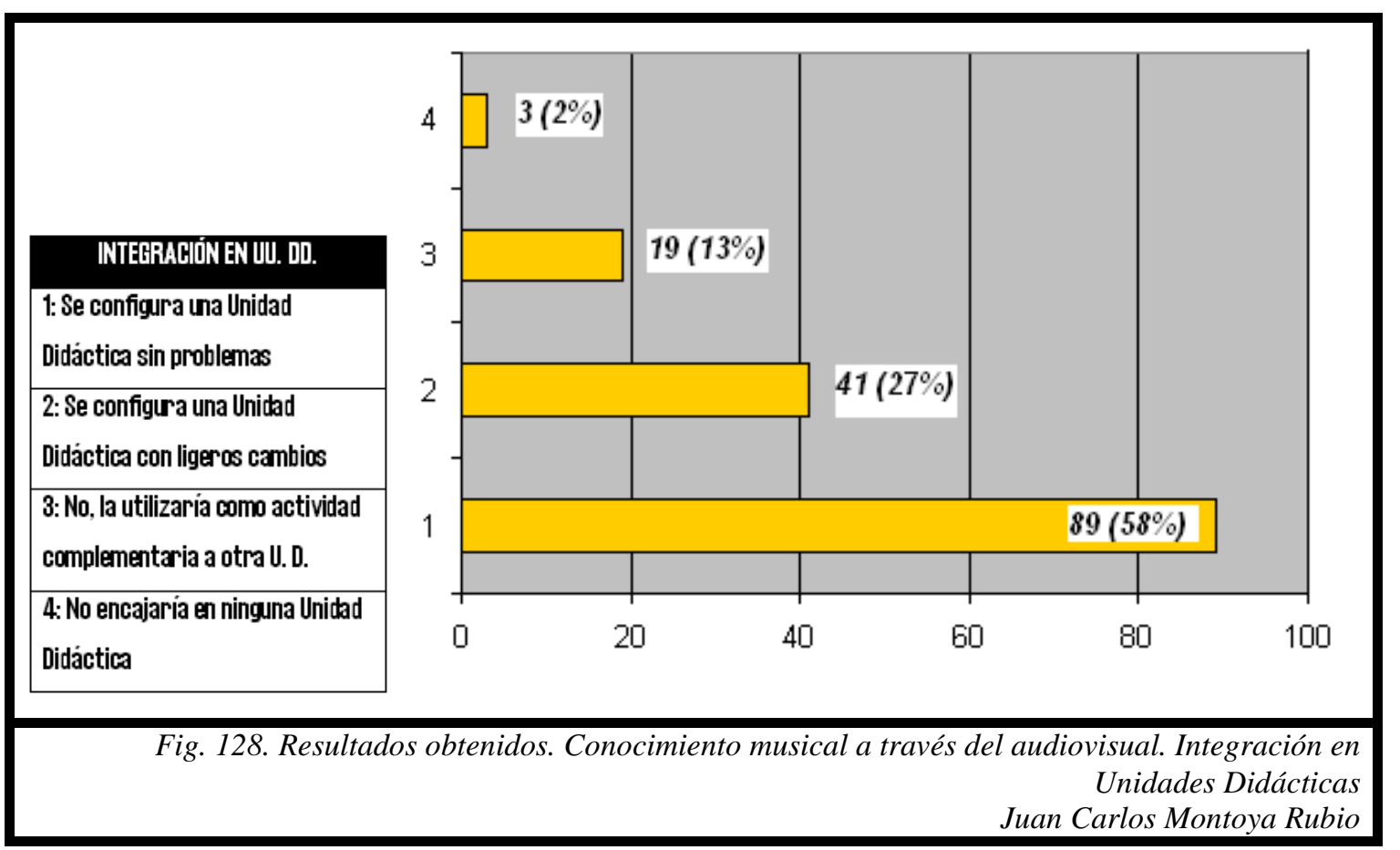

El proceso de globalización a partir de los contenidos descritos no parece tampoco entrañar grandes dificultades. Los casos típicos de globalización con la música, que suelen partir del resto de contenidos artísticos como la plástica, son ahora vistos desde una perspectiva más amplia, ya que se observa cómo hay ligazones inequívocas en los materiales presentados con áreas curriculares, como por ejemplo las que se ocupan de los conocimientos históricos. 


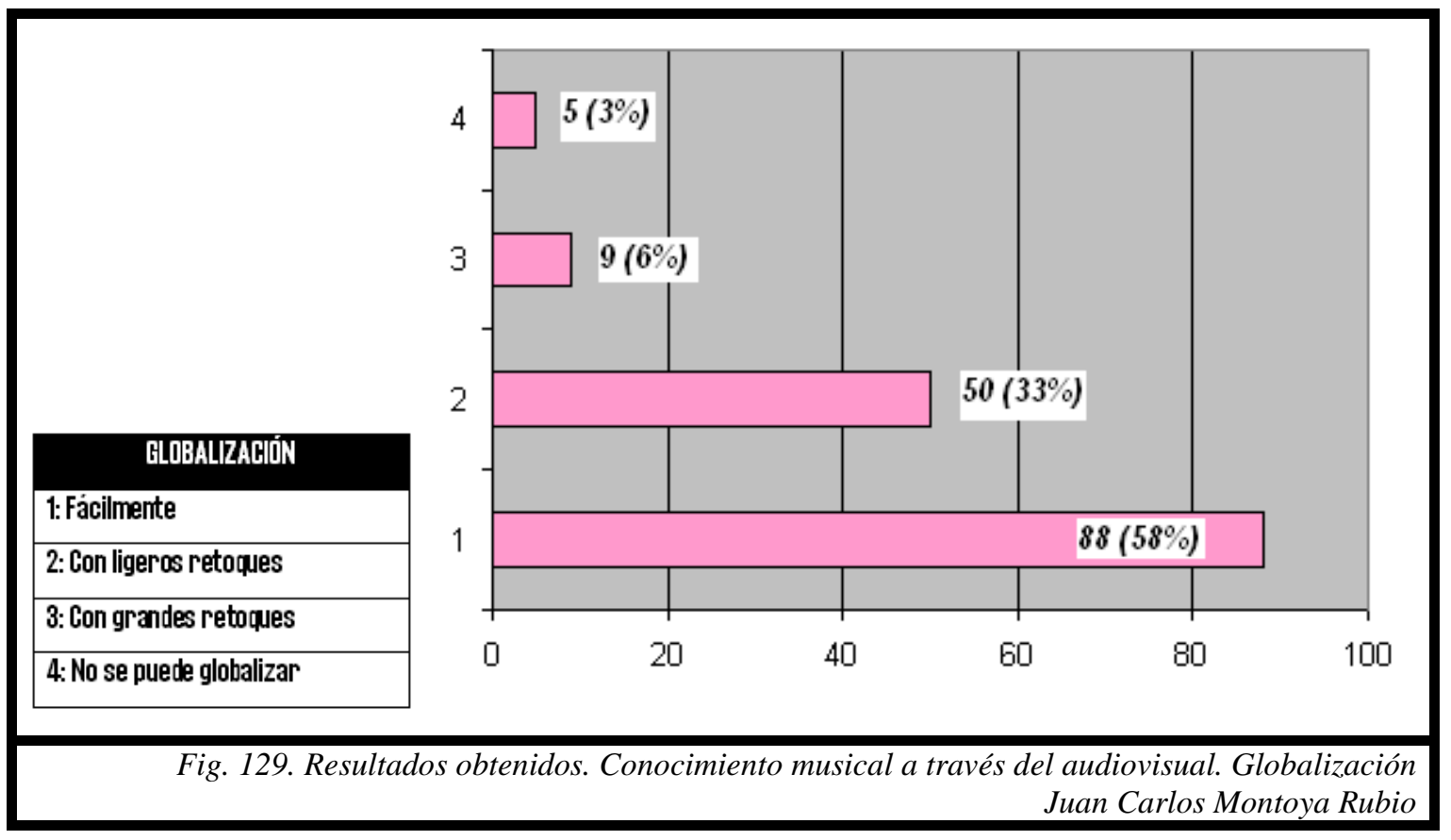

De todos los datos manejados, este es uno de los que más heterogeneidad ha hallado en las respuestas. Así, aunque lo veremos con más nitidez en la comparativa de utilizaciones previas, el procedimiento no suele ser desarrollado con profusión, pero sí de manera esporádica durante el curso o puntual durante el trimestre. Es necesario pues enfatizar la importancia de rescatar estas prácticas que aparecen ocasionalmente en más de la mitad del profesorado pero que han sido testadas y aceptadas como muy adecuadas.

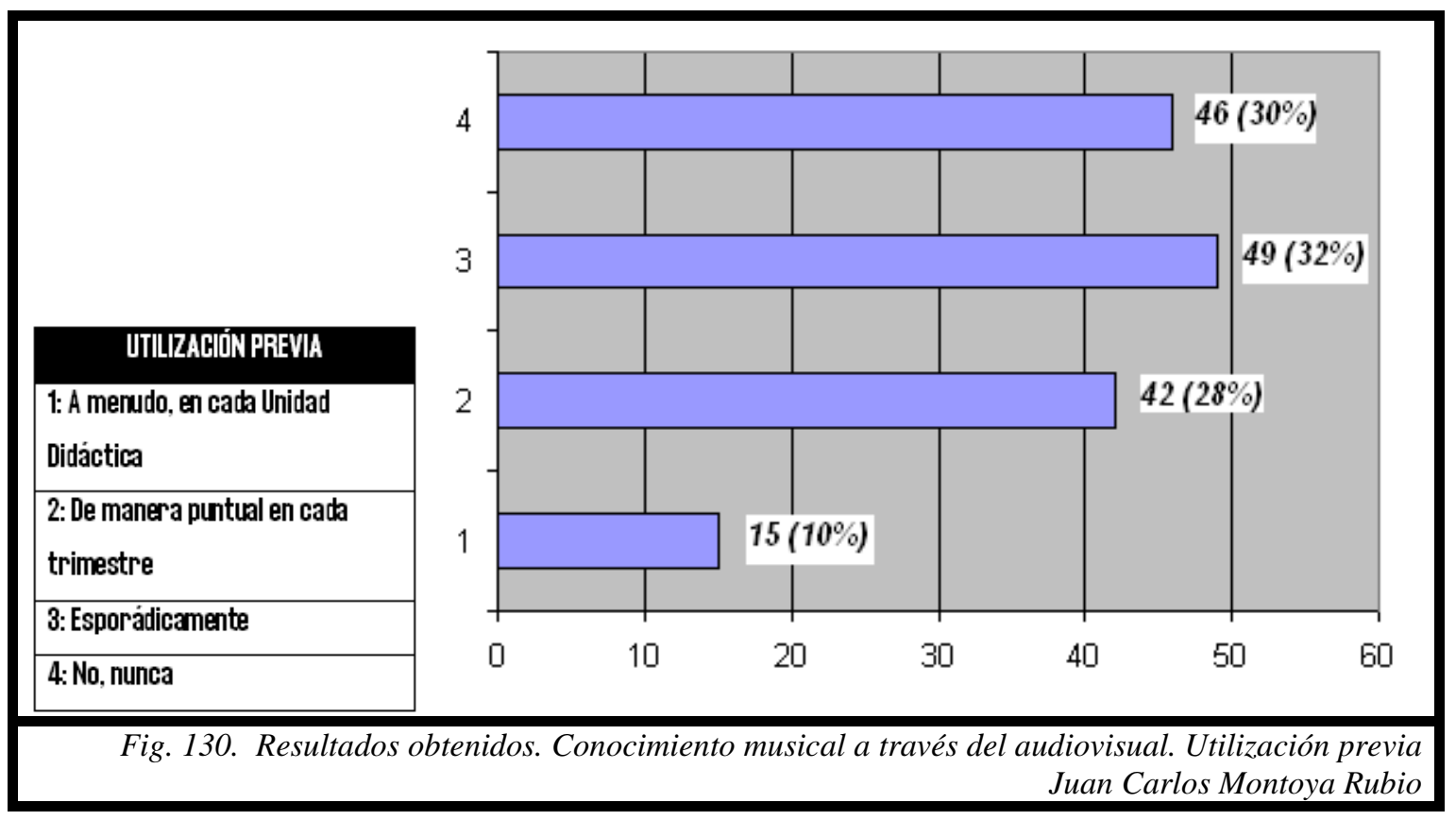




\section{Ámbito 3. Los procedimientos de musicogramas y movimiento. Usos y posibilidades.}

Ítems de referencia: $11-12-13-14-15$

La variada gama de posibilidades que arroja la tipología de musicogramas con mayor o menor movimiento producido en vídeos hace que éste sea uno de los recursos que cuente con mejor consideración de aplicabilidad por parte de los docentes. Afortunadamente, a partir de procesos didácticos que alberguen el uso de musicogramas tradicionales no parece muy complicado llegar a otros evolucionados a partir del desarrollo tecnológico, por lo que éste puede ser un campo de desarrollo inmediato dentro de las esferas del audiovisual.

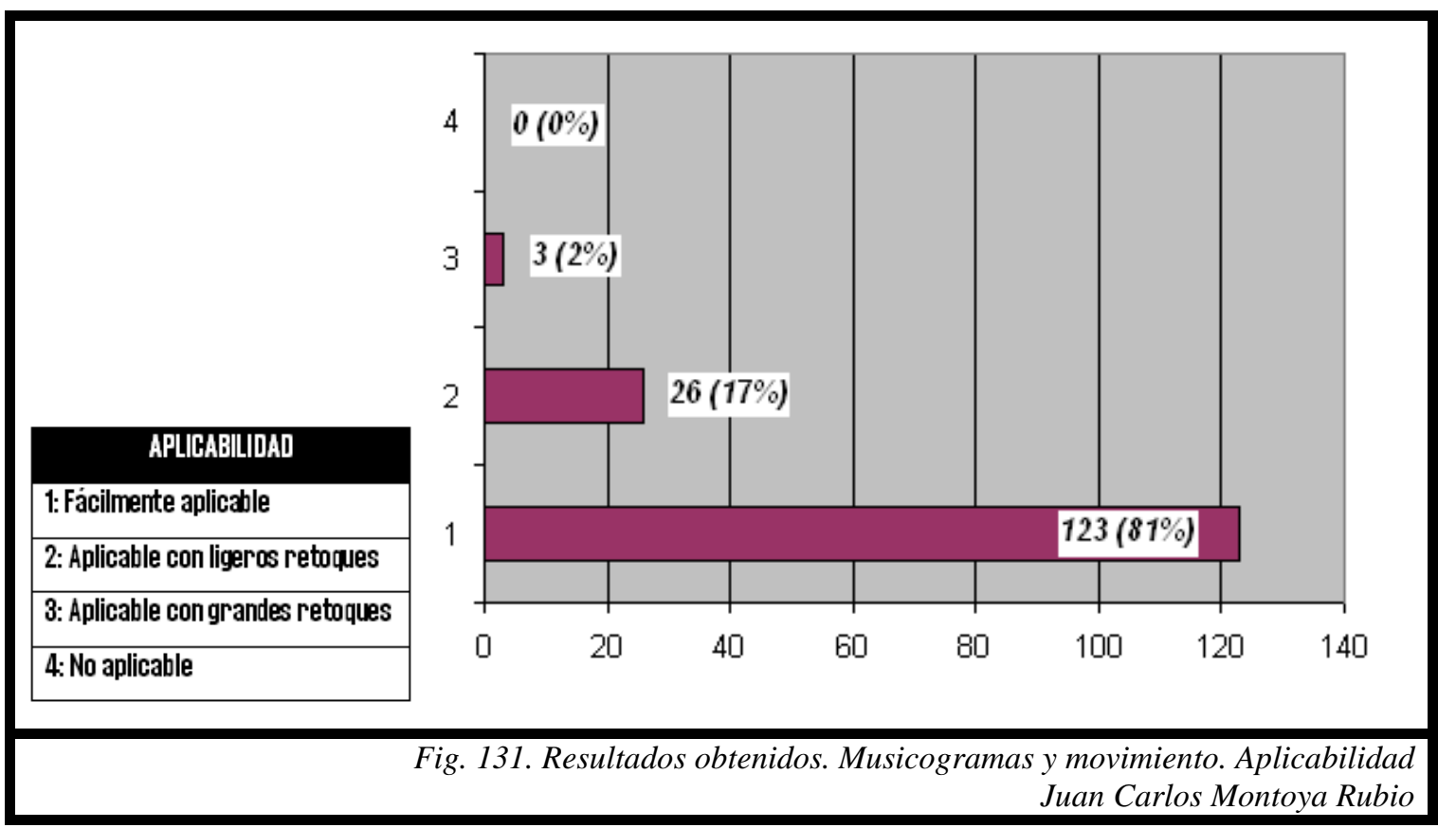

Por otro lado, a la consideración de ser aplicable se une la de ser significativo. Prácticamente se mantienen los porcentajes anteriores en el abordaje del ítem que se estructura en torno a la significatividad. En la unión de ambos aspectos se ratifica el advenimiento de una evolución pronta de estos recursos. 


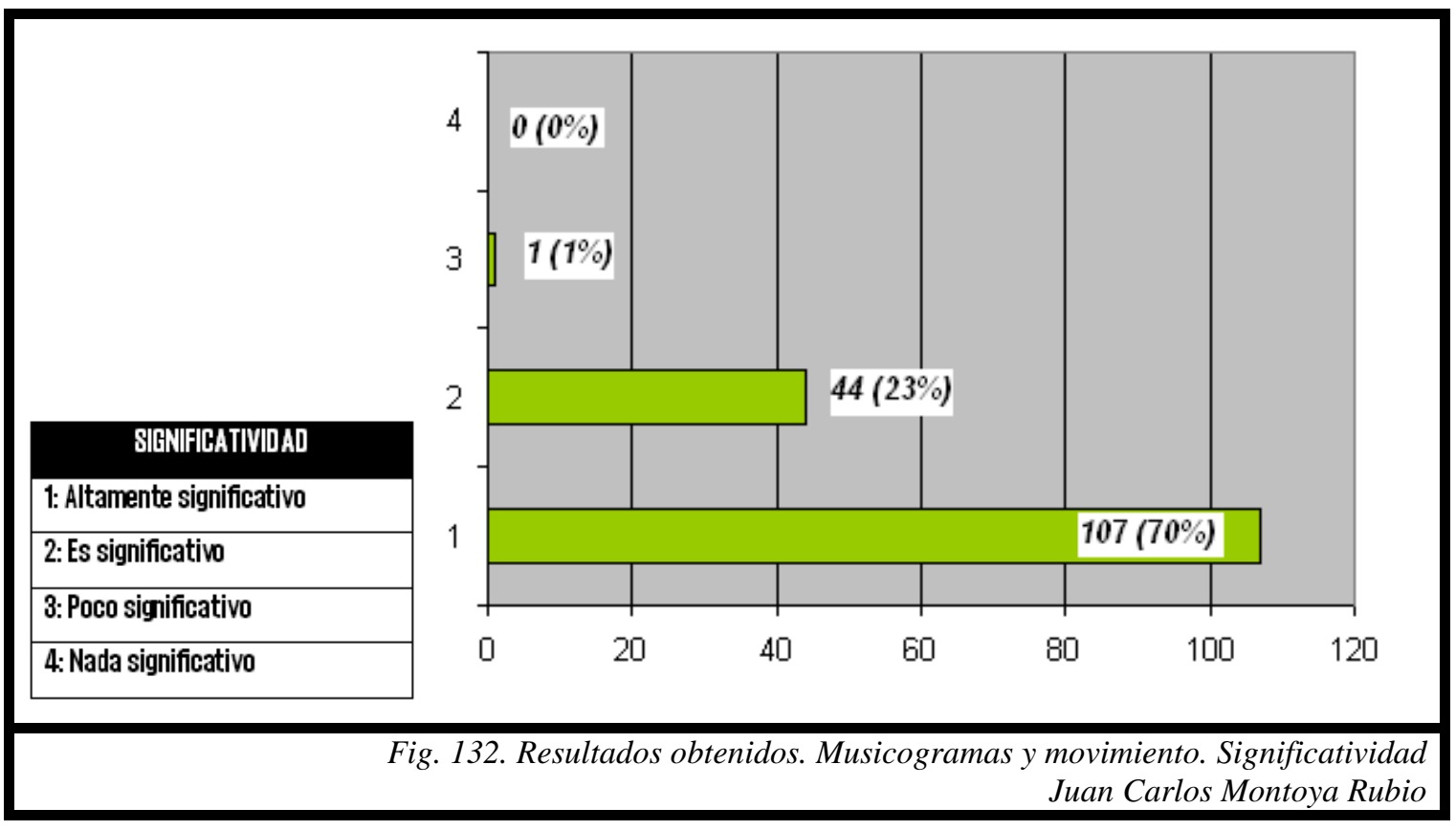

Suele ser común que las cotas alcanzadas en la aplicabilidad bajen un poco al plasmar de manera concreta los procedimientos a pie de aula. Aunque este hecho se constata también en el análisis de los datos para los musicogramas y movimiento, la moderación de dicha tendencia es suficiente para entender que no se precisan grandes cambios para insertar directamente el abanico de recursos presentados.

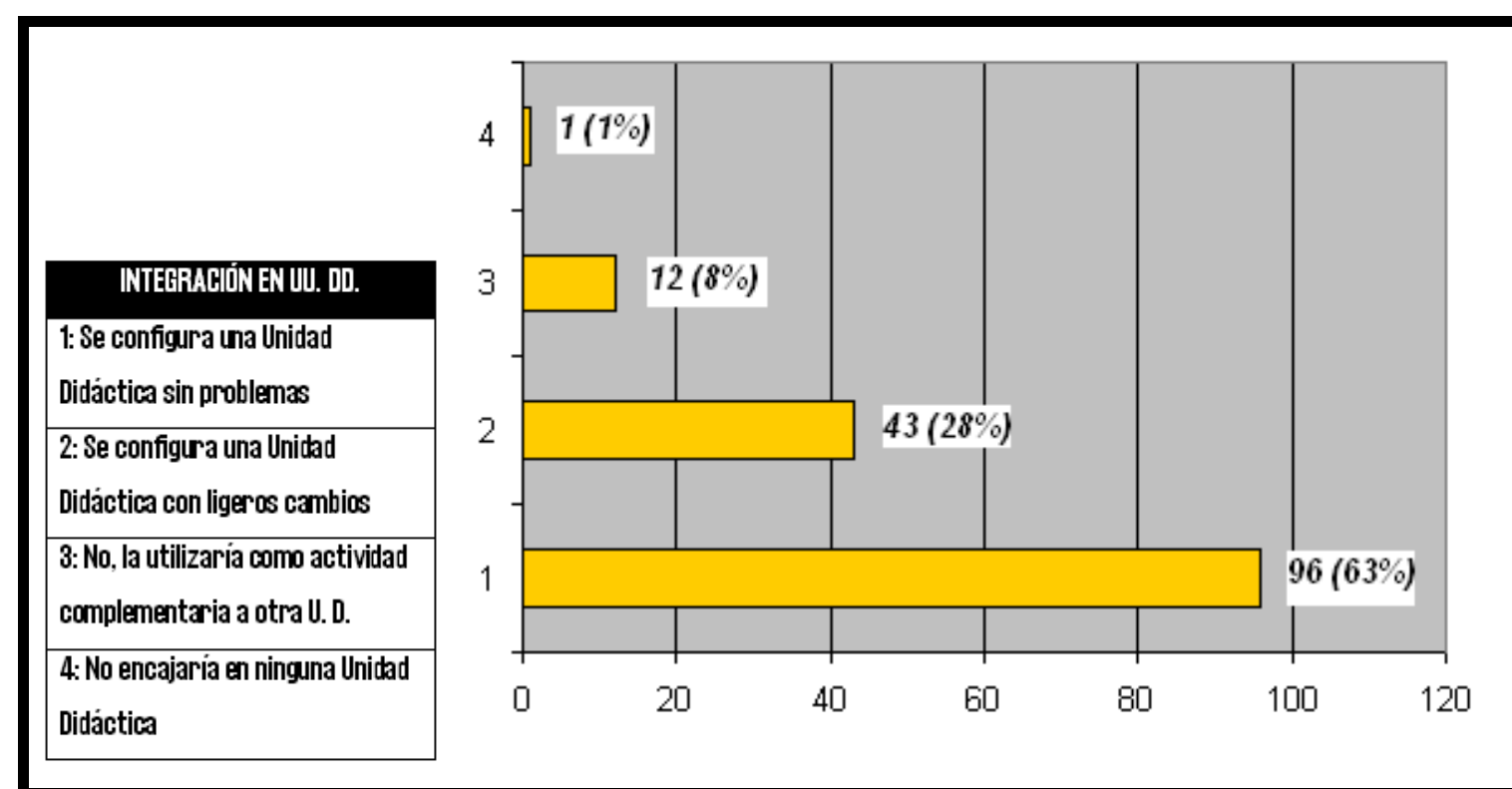

Fig. 133 Resultados obtenidos. Musicogramas y movimiento. Integración en unidades didácticas Juan Carlos Montoya Rubio 
Por otro lado, la mayor carencia que los docentes observan en el análisis de los musicogramas y movimiento (al igual que en los musicogramas al uso) es cierta dificultad en los procesos de globalización con otras áreas. Partimos, por supuesto, de la observación según la cual la mayoría de los profesores estiman que sí es un material globalizable, pero para buscar matices significativos hemos de atender al hecho de que hay un pequeño grupo del colectivo que muestra dificultades en ese proceso. Consideramos que éste es un material tan globalizable como el resto, pero que han de urdirse las estrategias adecuadas para que, dentro de unidades didácticas concretas, se llegue a dicha globalización.

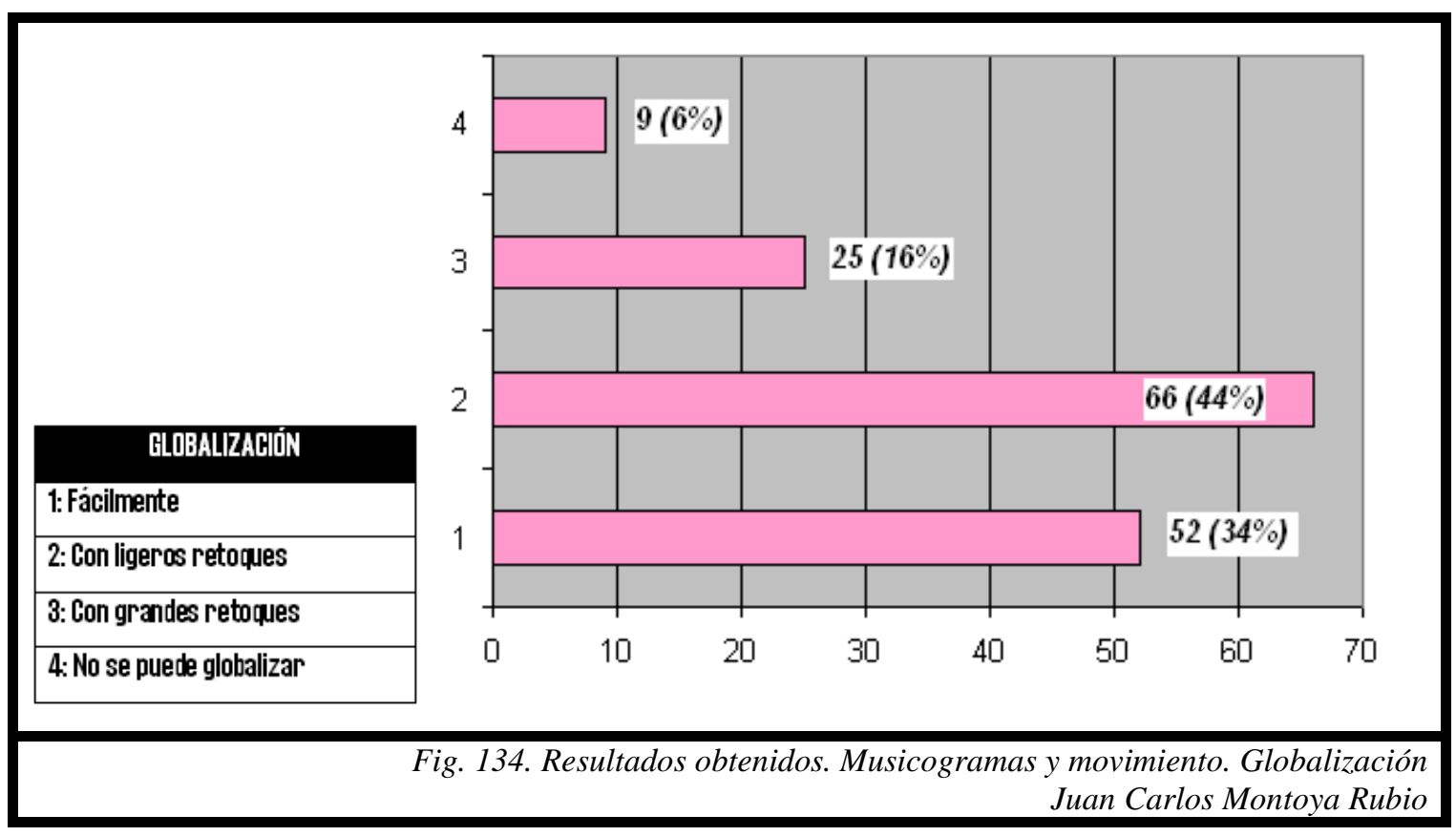

El grueso de docentes consultados declara utilizar puntualmente en cada trimestre alguno de los modelos presentados o similares. Siendo un porcentaje alto, se estima que su inclusión y uso puede ser todavía mayor, llegándose a eliminar los porcentajes residuales que contemplan práctica inexistencia o nulo desarrollo procedimental de unos recursos los cuales, como fue apuntado, tienen un gran potencial significativo. 


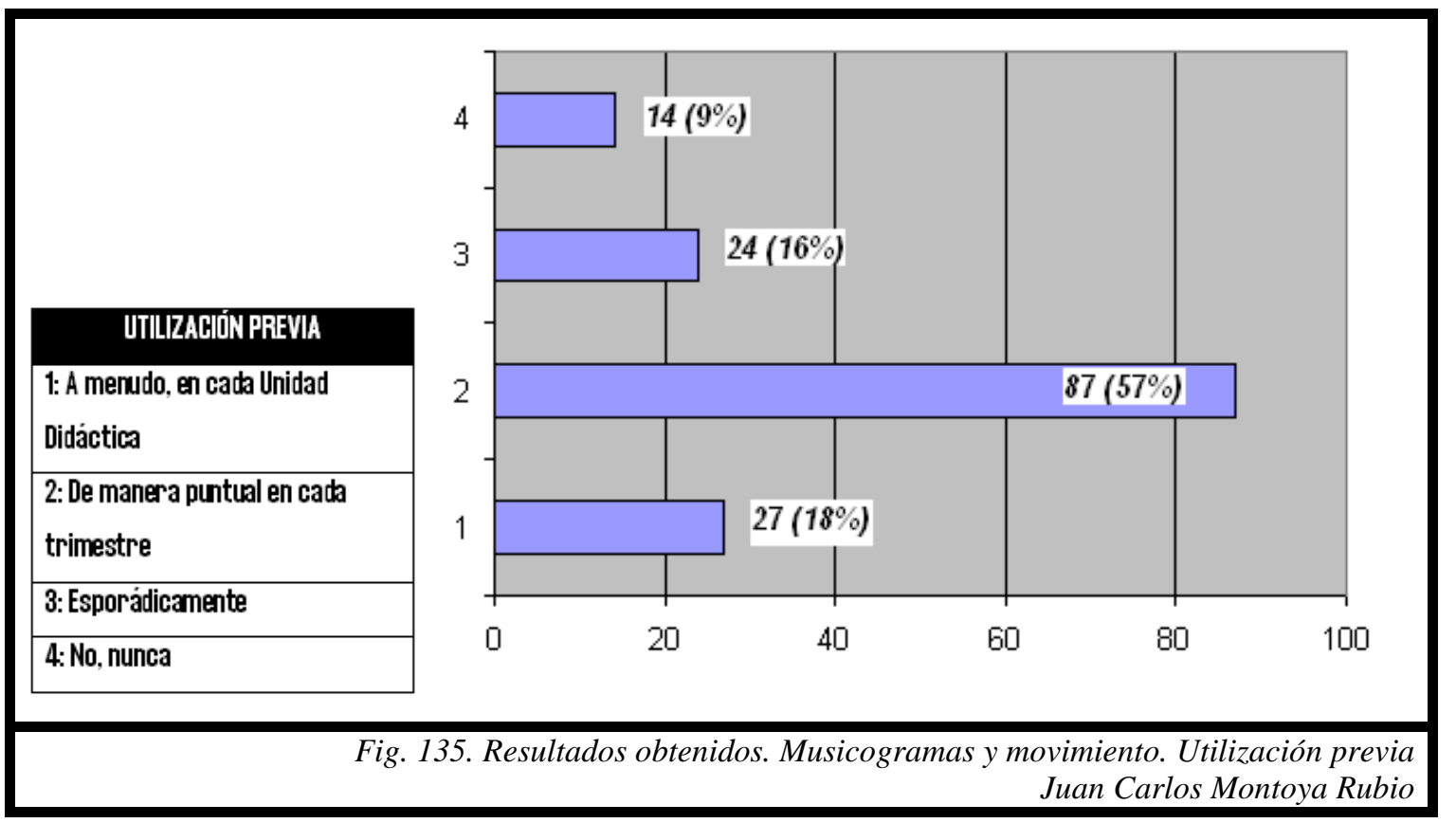

\section{Ámbito 4. Los procedimientos de extrapolación. Usos y posibilidades.}

Ítems de referencia: $16-17-18-19-20$

La extrapolación de melodías contenidas en un audiovisual conocido por los alumnos es un procedimiento relativamente extendido, dentro de los escasos márgenes tantas veces apuntados. Por ello, encontrar entre los materiales a analizar algunos que remitan a ello suele entenderse como apropiado. Además, entre las características de la extrapolación destacaba la conexión con las metodologías preexistentes, de modo que lo que los profesores han evaluado ha sido la aplicabilidad de unos procedimientos de origen audiovisual pero íntimamente ligados a lo que su labor diaria les invita a realizar. Por todo ello, es tan abrumadora la mayoría de docentes que, desde la familiaridad, encuentra el conjunto de recursos como fácilmente aplicables en contextos reales. 


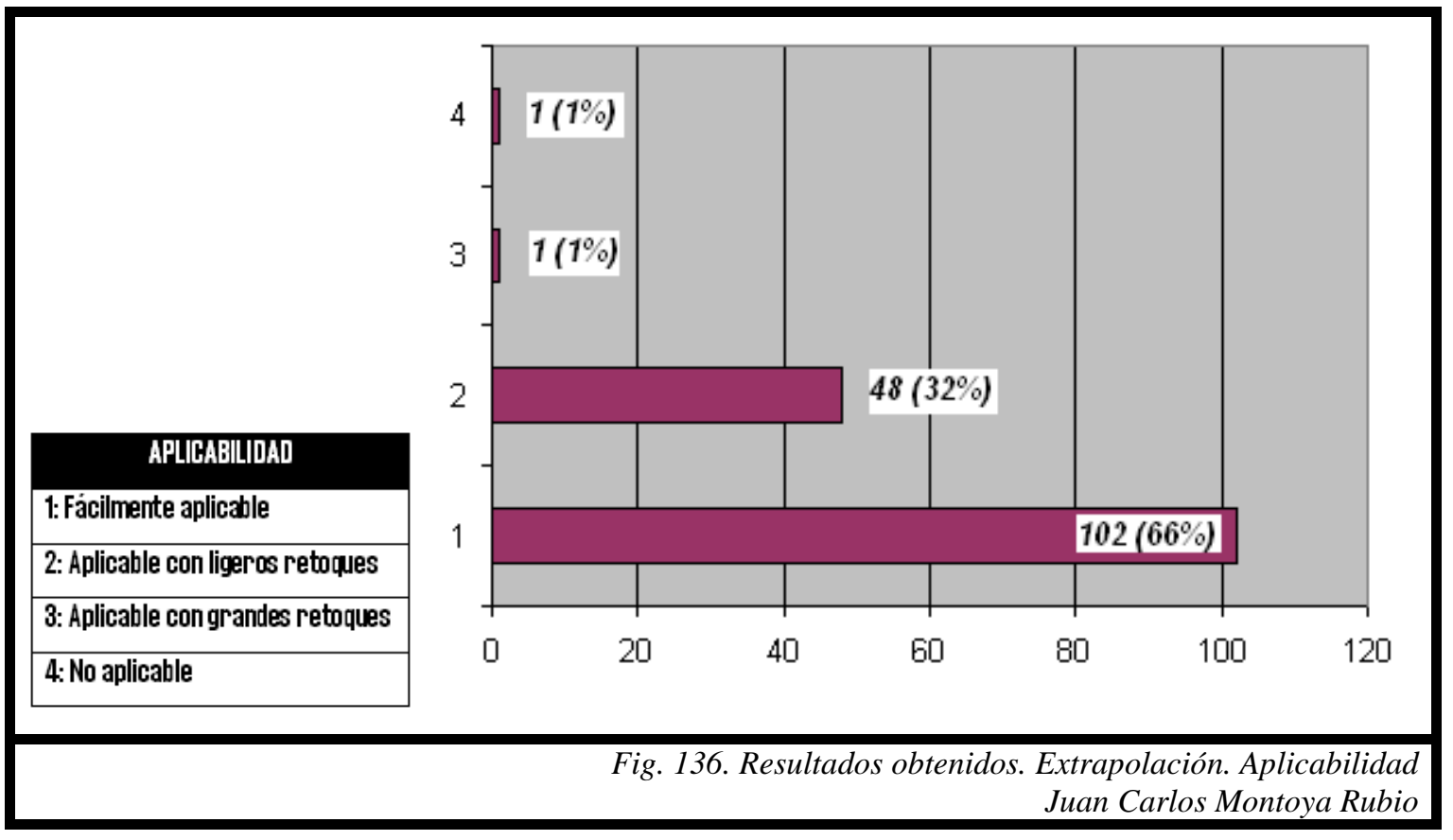

Igualmente, con pequeñas diferencias, se considera que estamos ante un conjunto de actividades significativas. Tal vez, el hecho de poder ser más o menos significativas (altamente o simplemente significativas, como indicaban los ítems) viene dado no tanto por el continente, el método de extrapolación, como por el contenido, los ejemplos concretos que se le presentaron al profesorado, por lo que no hemos de entender como determinante para el ámbito de la significatividad en este apartado que los docentes se decanten por una u otra postura dentro de las que indican valoración positiva.

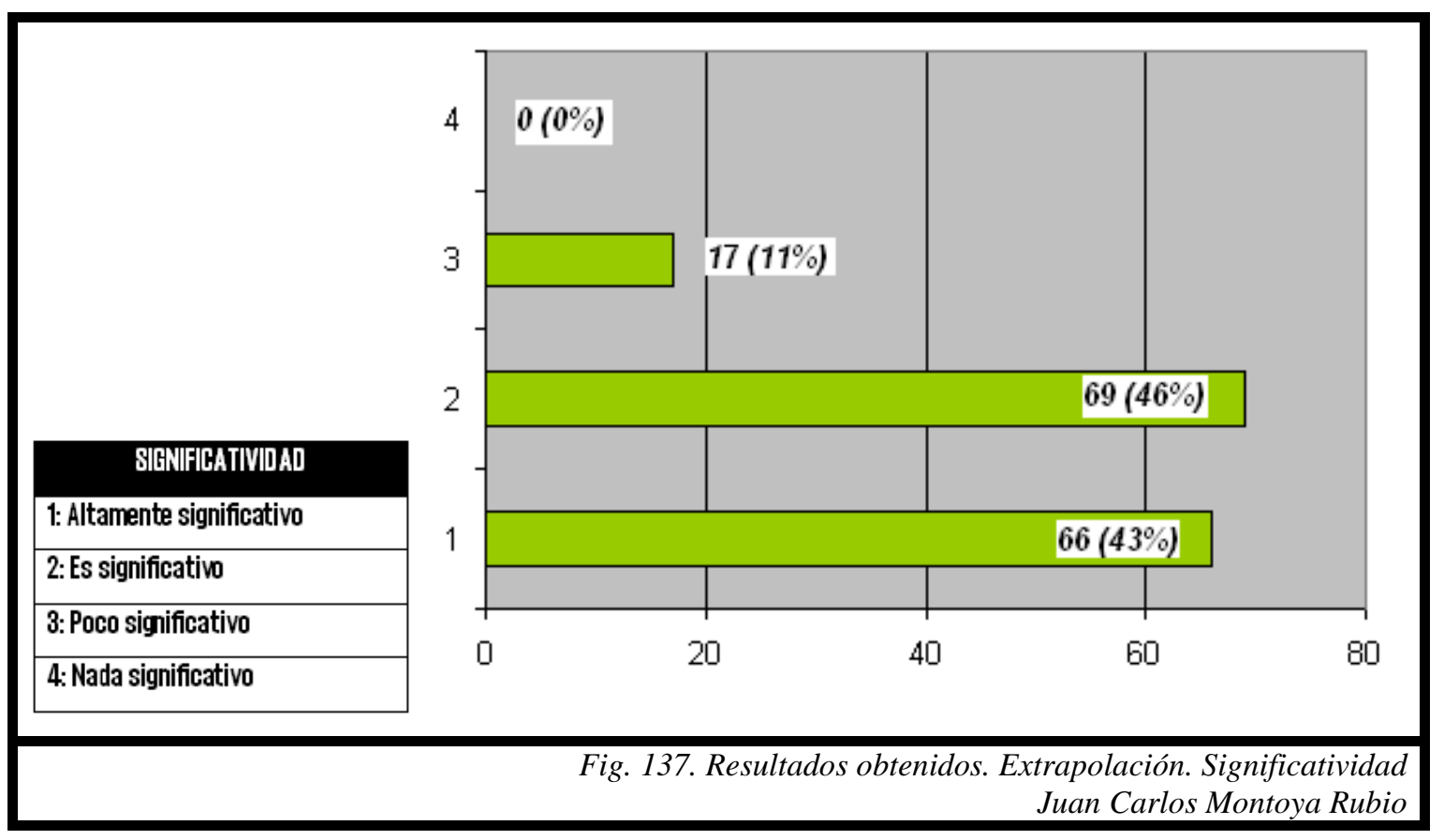


Con estrechos paralelismos con respecto al apartado de aplicabilidad, la integración en unidades didácticas de los materiales de extrapolación no parece ser dificultosa. La configuración de la unidad didáctica a partir de ellos, intención primordial de la cuestión formulada, es ratificada por más del $90 \%$ de los participantes, lo cual evidencia su disposición para formar parte de las secuencias didácticas.

INTEERABIION ENUU. DD.

1: Se configura una Unidad

Didáctica sin problemas

2: Se configura una Unichad

Didáctica con ligeros cambios

3: No, la utilizaría como actividad

complementaria a otra U. D.

4: No encajaria en ninguna Unidad

Didáctica

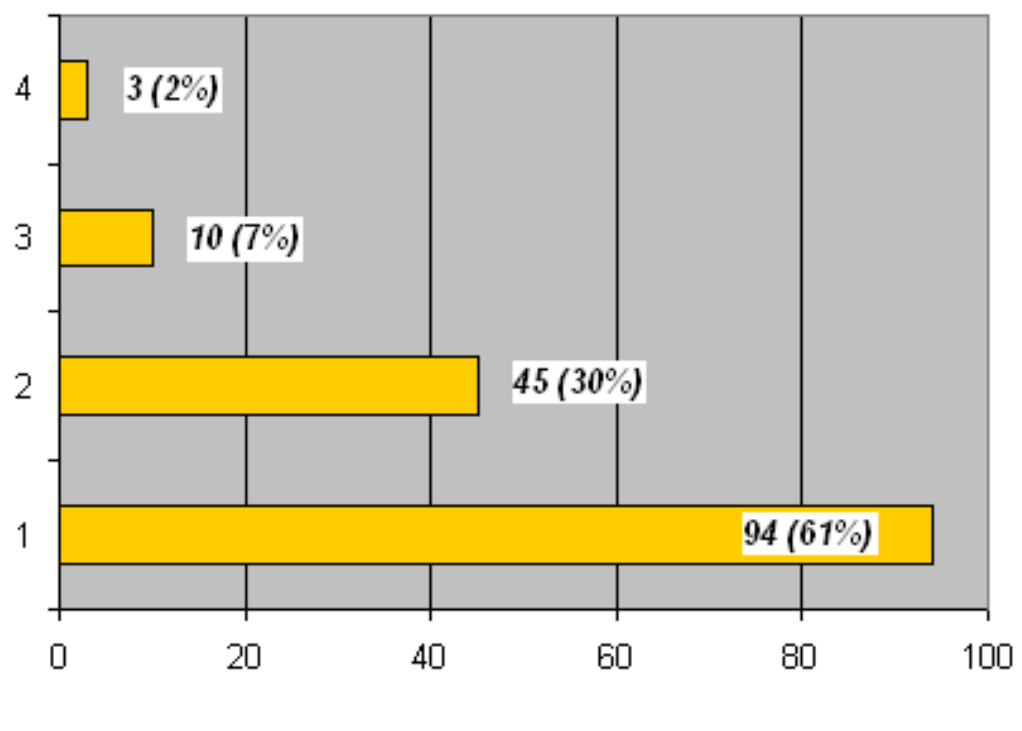

Fig. 138. Resultados obtenidos. Extrapolación. Integración en unidades didácticas Juan Carlos Montoya Rubio

Dentro de la sensación general que obliga a pensar que estamos ante elementos con alto potencial de globalización, es cierto que un porcentaje que representa el cuarto de las reacciones recabadas indica que es preciso elaborar estrategias que muestren el modo en que pueden ser llevados a cabo estos procesos. Para tres cuartas partes, en todo caso, es evidente que sí podemos establecer vínculos con otras áreas de conocimiento con o sin un leve trabajo de mediación, lo cual es sumamente importante para garantizar la pervivencia de estos desarrollos didácticos. 


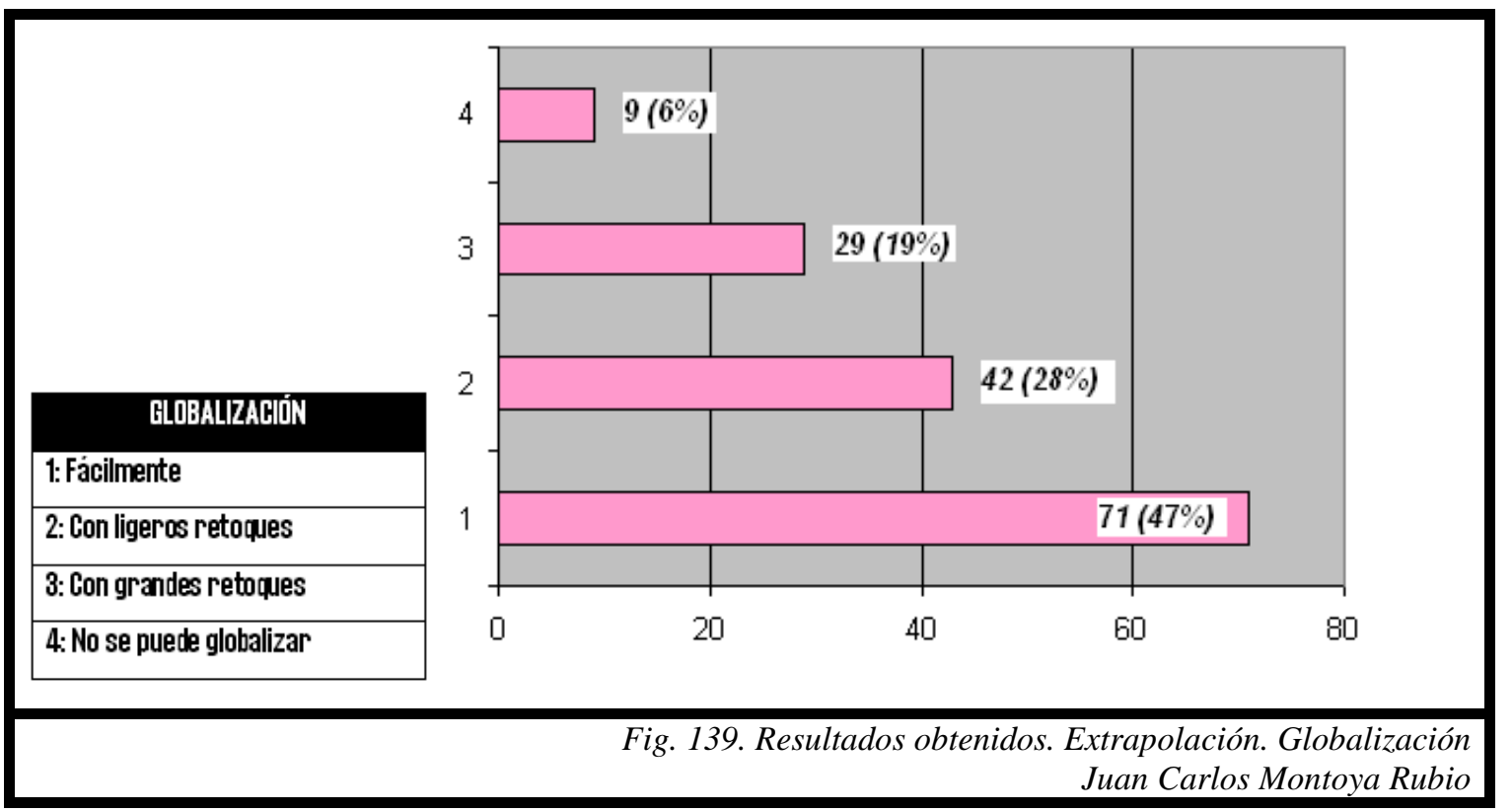

Por otro lado, teniendo en cuenta la facilidad con la que se pueden elaborar este tipo de propuestas, los porcentajes de utilización previa son altos pero mejorables. En este sentido, la mitad del profesorado indica no sólo su disposición sino también su compromiso diario con ellos, pero la otra mitad no parece implicarse en exceso en su activación, tal vez debido a que no sientan la necesidad de hacerlo al llevar a cabo otros procesos didácticos similares en cuanto a estructura pero no al contenido. Entender que el aumento de la casuística en torno a actividades audiovisuales beneficiaría todo el proceso dentro de las unidades didácticas es el reto que haría que estos resultados fueran incrementados.

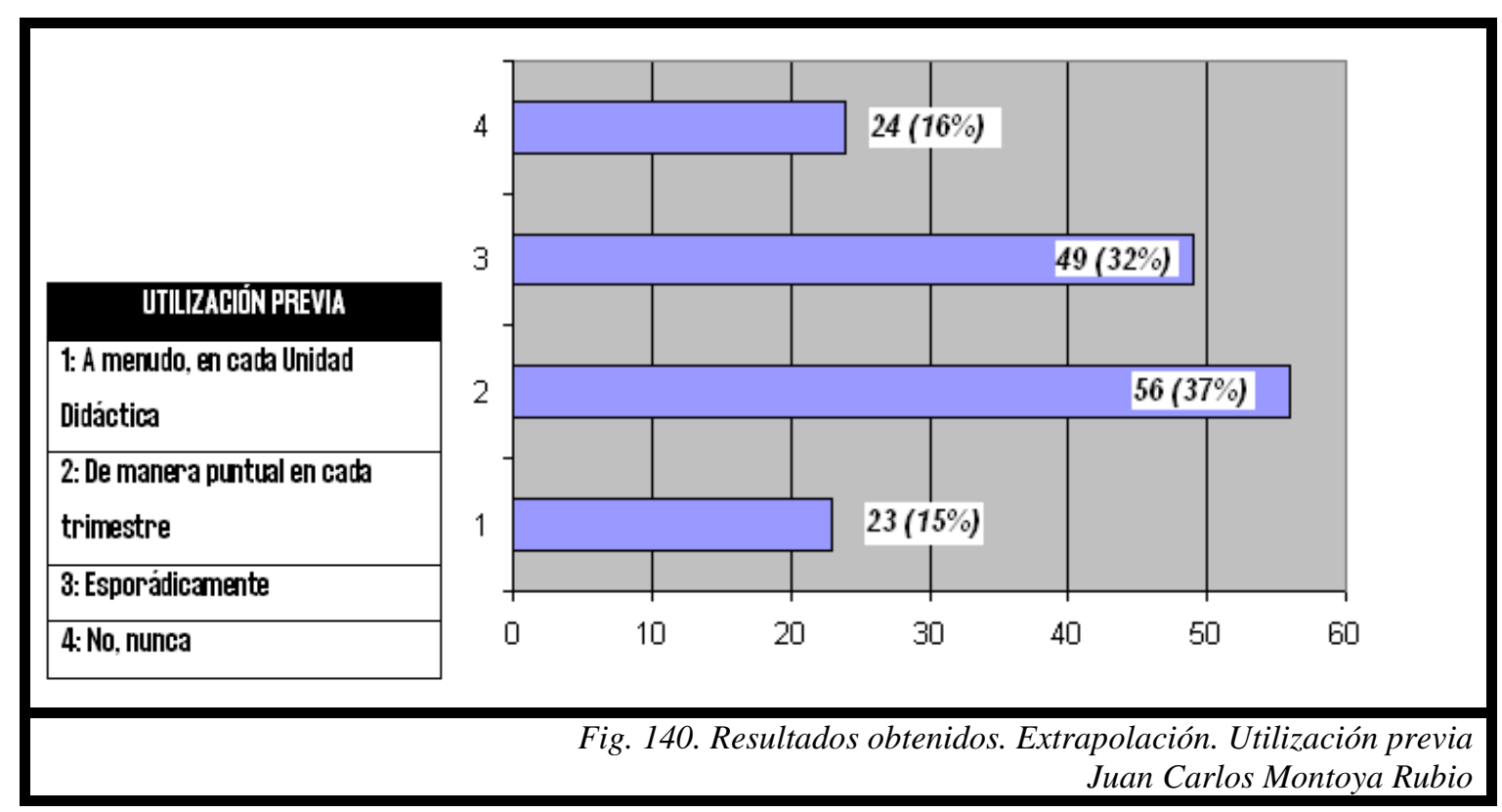




\section{Ámbito 5. Vinculación entre el uso declarado y las potencialidades observadas en los distintos procedimientos.}

Ítems de referencia: Todos

Por medio de este apartado vinculamos el uso que los docentes dicen tener de los procedimientos audiovisuales y la importancia que les conceden a cada uno de ellos, a partir de sus consideraciones sobre viabilidad, significatividad, globalización o inserción en la realidad. En el gráfico que se muestra a continuación, se realiza una estimación porcentual de ambas dimensiones resultante, por un lado, de la suma de respuestas positivas (dos primeras opciones) de cada uno de los ítems (sonorización 1 $2-3-4$, conocimiento musical a través del audiovisual $6-7-8-9$, musicogramas y movimiento $11-12$ - 13 - 14 y extrapolación 16 - 17 - 18 - 19) y, por otro, la ponderación para tal número de respuestas de los ítems que estiman la utilización declarada por parte de los docentes (sonorización 5, conocimiento musical a través del audiovisual 10, musicogramas y movimiento 15 y extrapolación 20). Un desarrollo coherente sería, por tanto, el que en cada una de las dimensiones mostrara equilibrio entre el nivel de utilización y el grado de importancia que se le otorga a cada uno de los procedimientos.

Sin embargo, por lo general dicha proporción no existe, de lo cual se infiere que en los casos en que se otorga una valoración positiva (alta o media-alta) de los usos potenciales de sonorización, ésta no va unida a un desarrollo efectivo, sino que a pesar de estimarse que los procedimientos didácticos son muy valederos, de manera cotidiana, se opta por desarrollar otro tipo de realizaciones pedagógico-musicales. Esta circunstancia es especialmente notoria en el caso de la sonorización, que parece resultar muy atractiva al profesorado pero que, sin embargo, tal vez debido a la falta de herramientas conceptuales para su desarrollo, no forma parte de las praxis cotidianas, a tenor de los resultados obtenidos.

En el extremo opuesto, siempre dentro de la tendencia general por la cual se ve con benevolencia el uso de los materiales pero no se ejercitan con soltura de forma práctica, situamos los procesos derivados de los musicogramas y movimiento. Como decimos, este conglomerado de actividades es el que muestra un mayor equilibrio entre 
la aceptación (recordemos que el ámbito tercero delataba que ésta era muy grande) y el uso declarado por parte de los docentes. Muy posiblemente, esto es debido a que entre los procedimientos presentados a modo de ejemplo había casos extremadamente cercanos a los musicogramas al uso (los cuales son ineludiblemente utilizados en el día a día por todos los profesores) y ello implica que, de uno u otro modo, en el proceso imaginativo de búsqueda de nuevos materiales, en algún momento, los docentes se hayan topado con este tipo de evoluciones en los recursos con origen en los musicogramas.

Entre los resultados registrados para el caso sonorizador y los musicogramas en sus diversas versiones, encontramos ubicados los procesos de extrapolación y conocimiento musical a través del audiovisual. No es extraño que la extrapolación sea la siguiente de las dimensiones en nivel de uso, eso sí, todavía relativo. Hemos de recordar que fue puesto de manifiesto que, de utilizarse (especialmente a partir de libros de texto) algún recurso vinculante entre la música y cine y la educación musical éstos respondían a los criterios de extrapolación de melodías de su contexto original para realizar, a partir de ellas, ejercicios de todo tipo, especialmente de ejecución instrumental con flauta dulce. Sin embargo, es preciso notar que ya en este ámbito se empieza a apuntar fehacientemente la desproporción entre el valor que se otorga al procedimiento (alto) y el uso que de él se hace (con tendencia a la baja), el cual impregnará con mayor fuerza los procesos de conocimiento musical a través del audiovisual.

Así, la dimensión apuntada con anterioridad, se ubica tras la sonorización como segundo ámbito de escasa repercusión efectiva en relación con su gran potencial observado por los docentes. El razonamiento más evidente nos induce a pensar que, al tratarse de un conjunto de actividades relativamente novedosas, es posible todavía hoy un cierto desconocimiento que no niega, en todo caso, su gran valor cuando se examina un material concreto como fue el caso. 


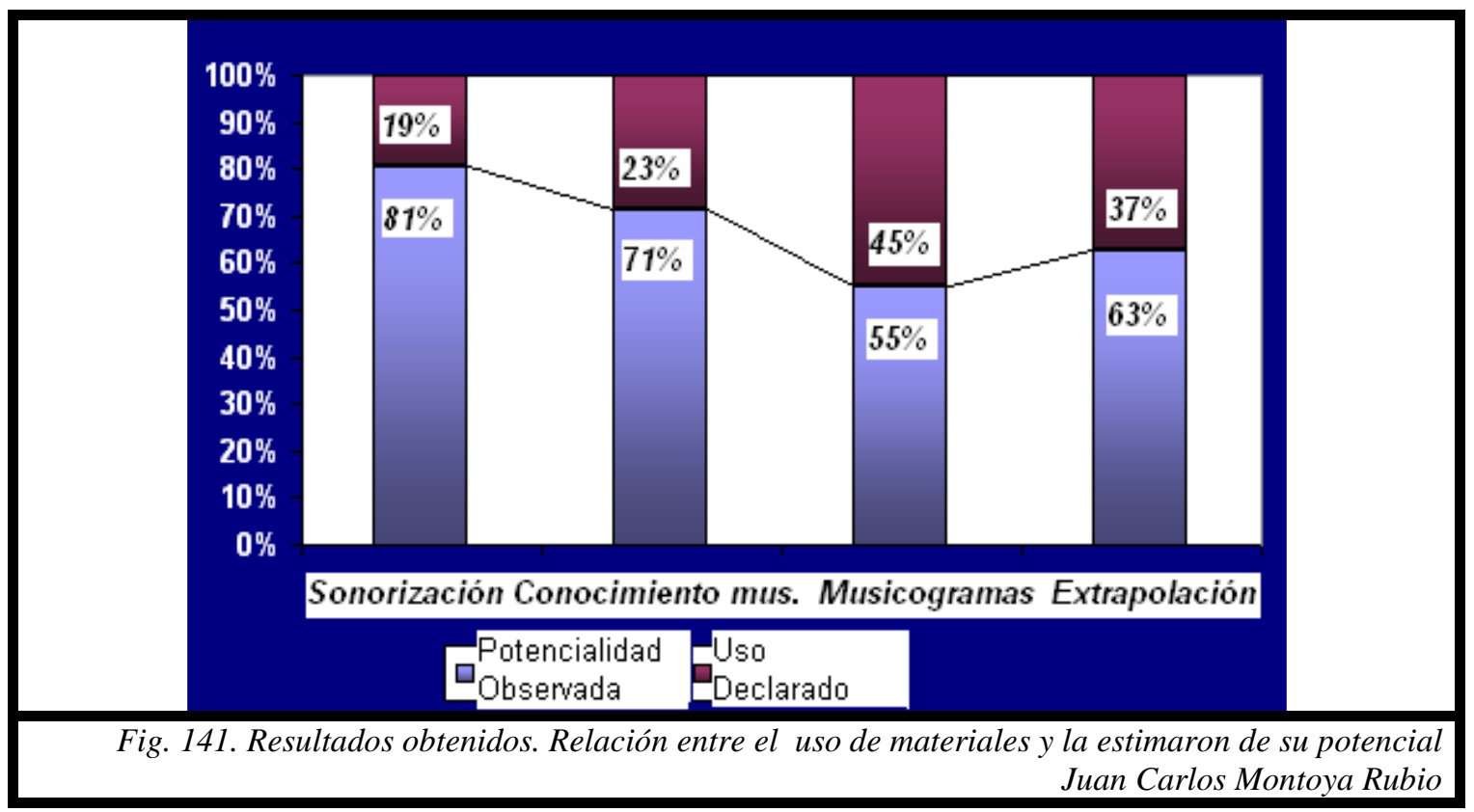

Ámbito 6. Nivel de aplicación que se estima de los diversos tipos de procedimientos audiovisuales.

Ítems de referencia: $1-6-11-16$

De acuerdo con el plan trazado, comenzamos con la comparativa entre las dimensiones de aplicabilidad en las aulas, significatividad de materiales, acoplamiento en secuencias didácticas, posibilidades de globalización y grado de utilización real. Tomando como referencia las respuestas obtenidas para el primero de los parámetros, el nivel de aplicación que los docentes estiman para cada procedimiento concreto, hemos de corroborar que los planteamientos de musicogramas y movimiento gozan del mayor beneplácito de los participantes en la muestra. Así, de manera destacada, se entiende que es en estos ámbitos donde con mayor facilidad se puede conectar con el alumnado, pero no es menos cierto que en estas sensaciones juega un papel muy importante el grado de conocimiento y uso que se tiene de estos materiales en su versión tradicional. El hecho de encontrar la evolución de manera tan intuitiva es visto como una ventaja sin igual. Por otro lado, tanto la extrapolación como el conocimiento musical a través del audiovisual son planteamientos que se consideran fácilmente aplicables, especialmente si se tienen los recursos necesarios, pero es igualmente veraz que en ellos es preciso un desarrollo específico de creatividad por parte del docente, lo cual frena en cierta manera 
el hecho de poder ser aplicados sin retoque alguno. En este sentido, la sonorización se ve mermada por esa necesidad mediadora, ya que los docentes entienden que, a pesar de su gran potencial de inserción real en sus aulas, es tanto más importante llevar a cabo cambios, si bien leves, para acceder a su aplicación.

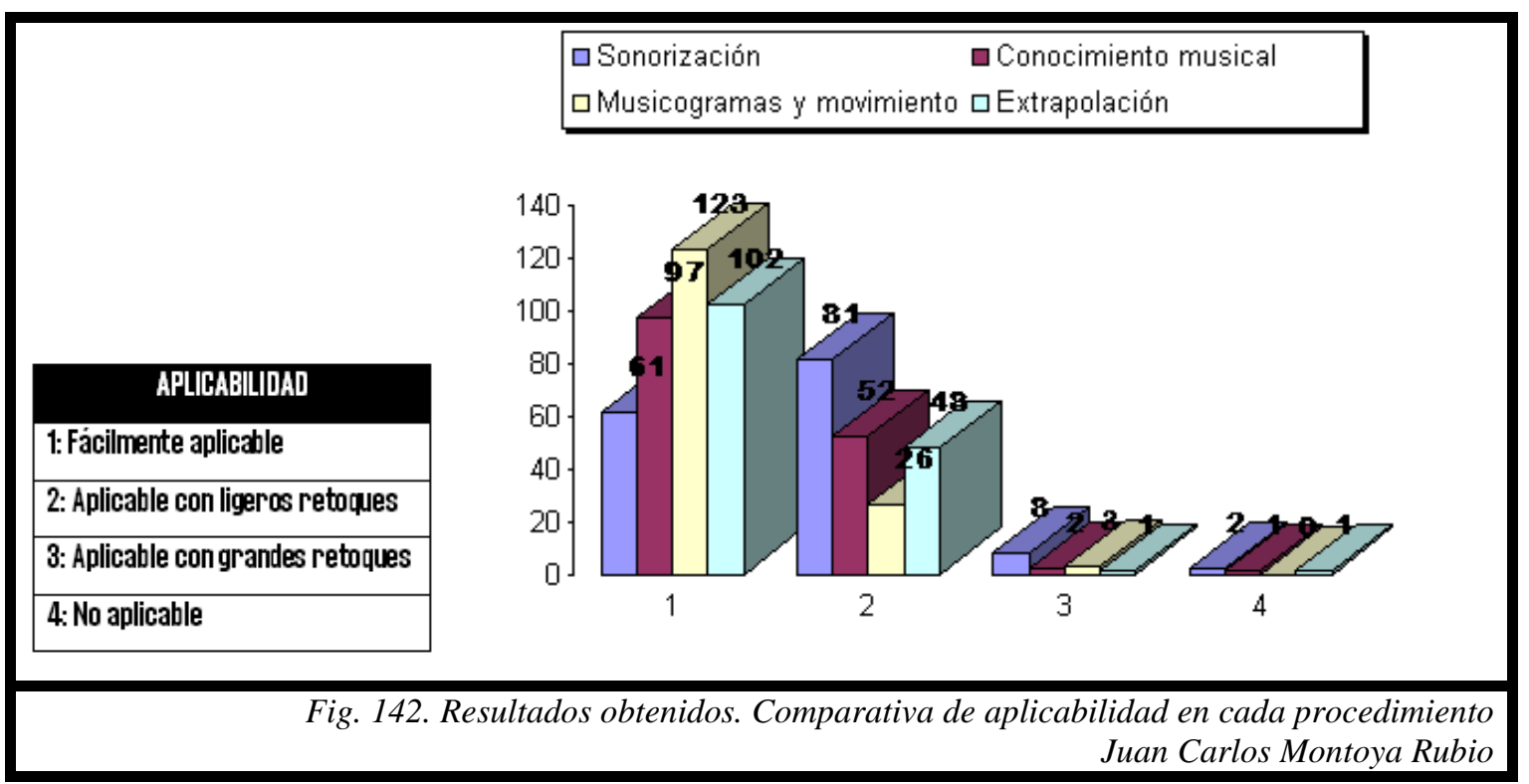

\section{Ámbito 7. Grado de significatividad observada en los diversos tipos de procedimientos audiovisuales.}

Ítems de referencia: $2-7-12-17$

En la anterior reflexión, derivada del análisis de la aplicabilidad, finalizábamos haciendo referencia a la inserción de la sonorización y a sus condicionantes. En este momento, al abordar la significatividad, observamos con esperanza que para el conjunto de los docentes merecería la pena focalizar sus esfuerzos hacia el desarrollo de los procesos sonorizadores en el aula de música, ya que de las cuatro dimensiones es la mejor considerada en este plano. La aceptación de su alta significatividad es casi unánime, lo cual no va en detrimento de la que se estima para las otras tres praxis. En este sentido, tanto los musicogramas y movimiento como el conocimiento musical a través del audiovisual son vistos como resortes significativos de gran potencial para enlazar con las vivencias y saberes de los alumnos, si bien la diferencia con respecto a la sonorización estriba en que ésta es considerada incluso más atractiva, muy 
posiblemente por la novedad que implica su uso. Respecto a la extrapolación de contenidos audiovisuales para su traslación didáctica hemos de apuntar que la tendencia, con respecto a las otras dos dimensiones, es a la baja, pero aún así son escasísimas las aportaciones que la consideran poco significativa. En este último caso, el catalizador sorpresivo que aludíamos para la sonorización no causa el mismo efecto, en tanto en cuanto -reiteramos- estamos ante rudimentos procedimentales ya conocidos a los que se les ha añadido el sesgo audiovisual.

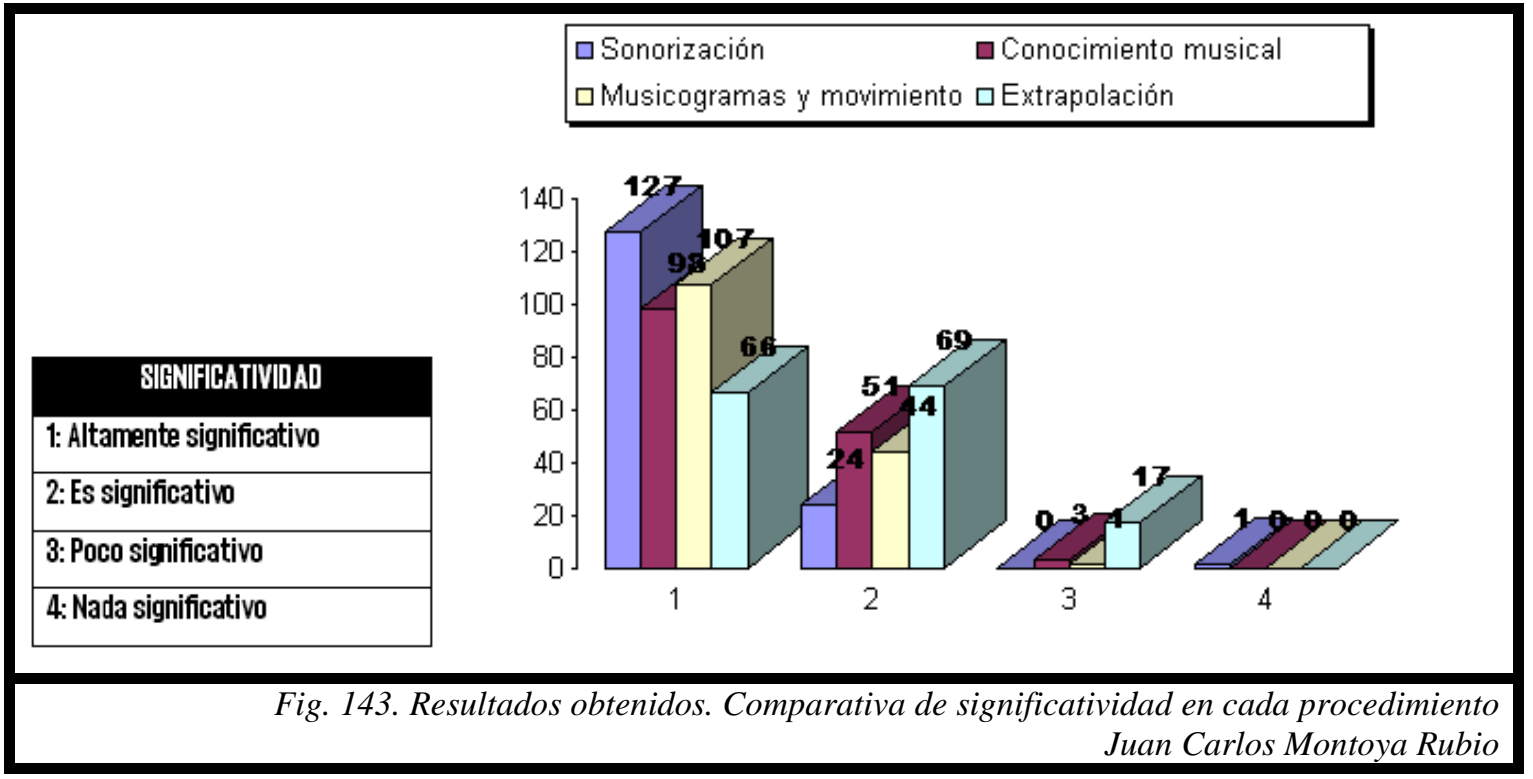

\section{Ámbito 8. Validez de los tipos de procedimientos audiovisuales como parte integral de unidades didácticas.}

Ítems de referencia: $3-8-13-18$

Ya fue analizada la integración de las dimensiones dentro de la práctica docente entendida de manera general. Aterrizando sobre un campo más específico, como es la generación de unidades didácticas, observamos como los registros se mueven paralelamente en tres de las cuatro praxis: conocimiento musical a través del audiovisual, musicogramas y movimiento y extrapolación. Con escasas diferencias al respecto, estos tres ámbitos se muestran, según las impresiones del profesorado, como muy indicados para generar unidades didácticas completas que se nutran básicamente de sus propios postulados. Como fue descrito en apartados anteriores, cada una de ellas tiene una especificidad tal que, desde sus propios parámetros, facilitan enormemente el 
trabajo a su alrededor. Por su parte, la sonorización, que ya mostraba dificultades en una primera aproximación, constata dichas trabas tras estos resultados (téngase en cuenta que estamos refiriéndonos a la sonorización en relación con el resto de dimensiones ya que aisladamente los resultados que ofrece no son desalentadores sino todo lo contrario). Con ello, todas las dimensiones, bien canalizadas y cada una desde sus patrones de desarrollo, pueden generar secuencias didácticas coherentes de manera autónoma y con la participación de elementos añadidos derivados de la práctica didáctico-musical habitual.

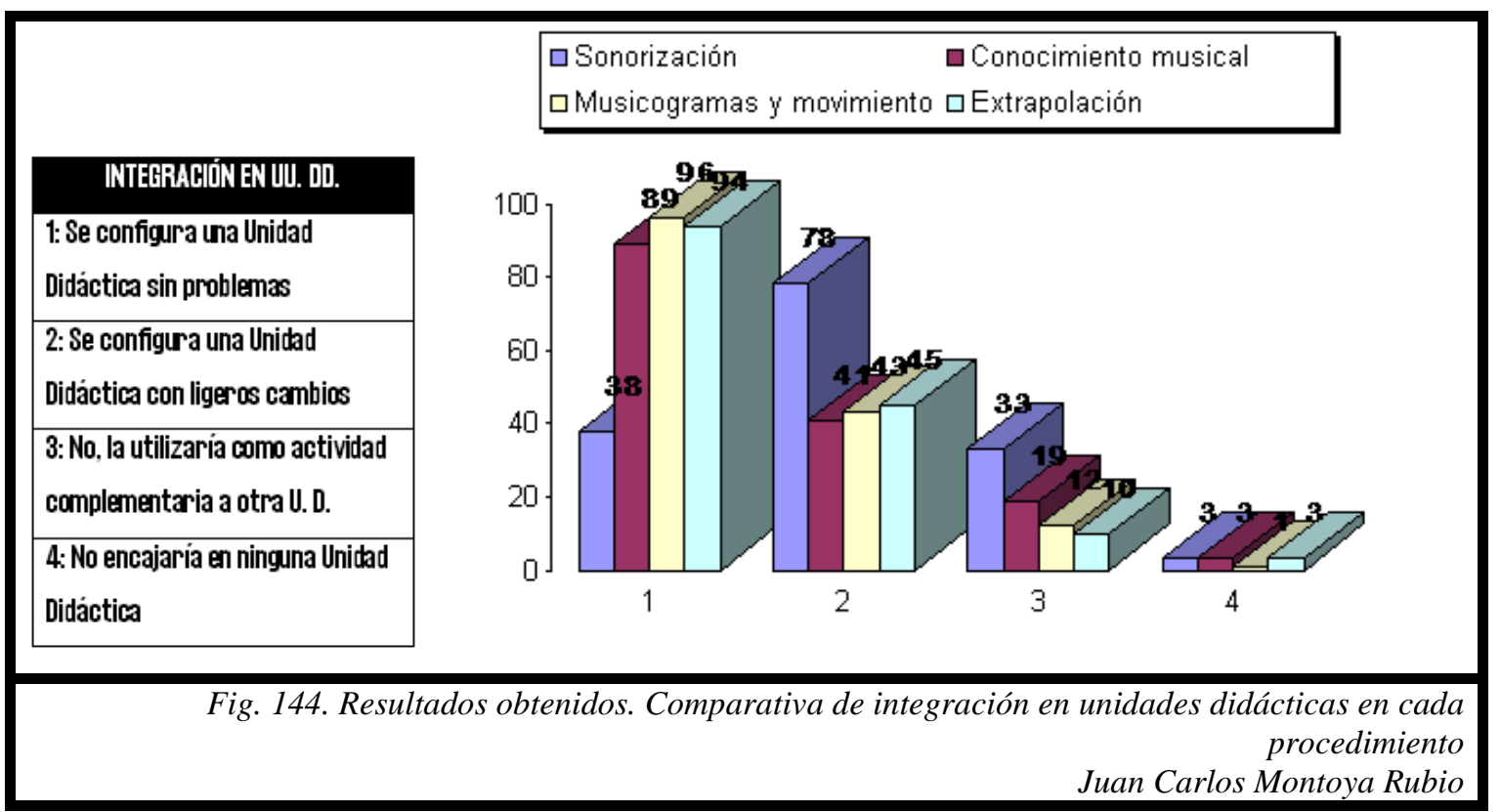

Ámbito 9. Posibilidades de globalización de los procedimientos audiovisuales con otras áreas diferentes a la educación musical.

Ítems de referencia: $4-9-14-19$

Cuando razonábamos el porqué de las distintas cuestiones planteadas decíamos que nos interesaba mucho conocer la posibilidad de globalizar estos materiales con otros procedentes de otras áreas de conocimiento. En una educación basada en el desarrollo competencial la capacidad de los recursos para ejercer un recorrido transversal es sumamente importante. Por ello, es preciso constatar la satisfactoria imagen que 
traslucen los resultados de este apartado, que también corroboran la importancia de todas y cada una de las dimensiones, si bien con ligeros matices. Además, hemos de añadir aludiendo de nuevo a nuestra propia práctica docente que, por un lado, estos resultados reflejan la sensación del profesor acerca de la posibilidad de globalizar el material pero, por otro, entendemos que esa sensación puede ser modificada a raíz de la intervención directa con estos procedimientos y que, a medida que se familiarizan con ellos, se encuentra una mayor flexibilidad en ellos para llegar a áreas de conocimiento antes supuestamente inaccesibles.

Con ello, sonorización y conocimiento musical a través del audiovisual, especialmente este último ámbito, son los que suscitan una mejor capacidad de globalización. Algunas dudas más provienen de las otras dos dimensiones a las cuales, además de reconocerles mayoritariamente esta potencialidad, se añade un grupo relativamente numeroso de docentes que entiende que para llevar a cabo la globalización con otras áreas se precisa de un esfuerzo más intenso.

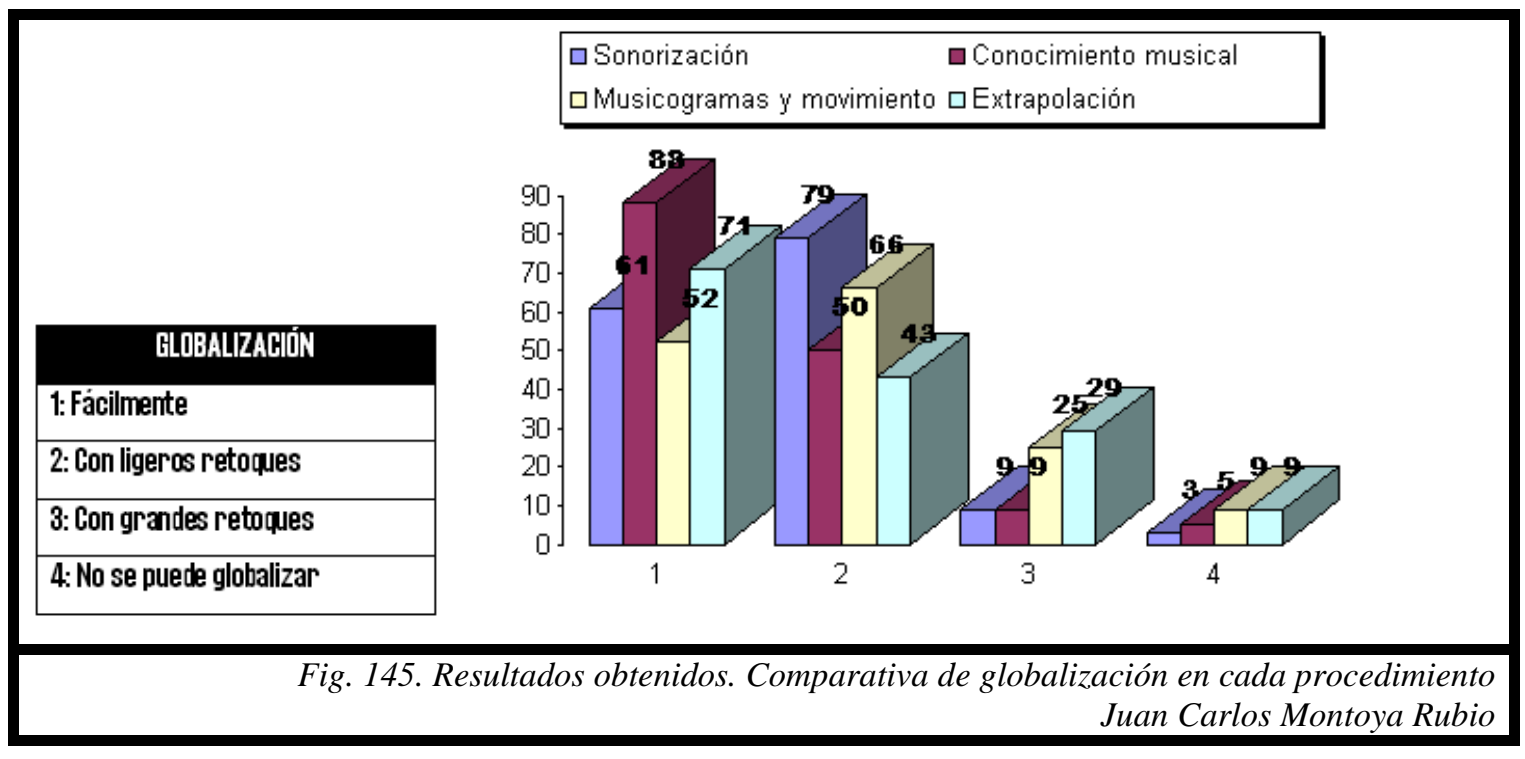




\section{Ámbito 10. Nivel de utilización real de los procedimientos audiovisuales.}

$$
\text { Ítems de referencia: } 5-10-15-20
$$

El último de los ámbitos ha sido discutido en relación con el resto en apartados precedentes. Hacemos constancia de esta comparativa a efectos recopilatorios. En general, ha sido apuntado que el nivel de utilización efectiva de los procedimientos audiovisuales descritos es precario. Asimismo, se enfatizó que no existe, exceptuando el caso de los musicogramas y movimiento, una correlación directa entre la percepción de la importancia y significatividad del procedimiento (habitualmente alta o muy alta) con su aplicación real (de menor incidencia).

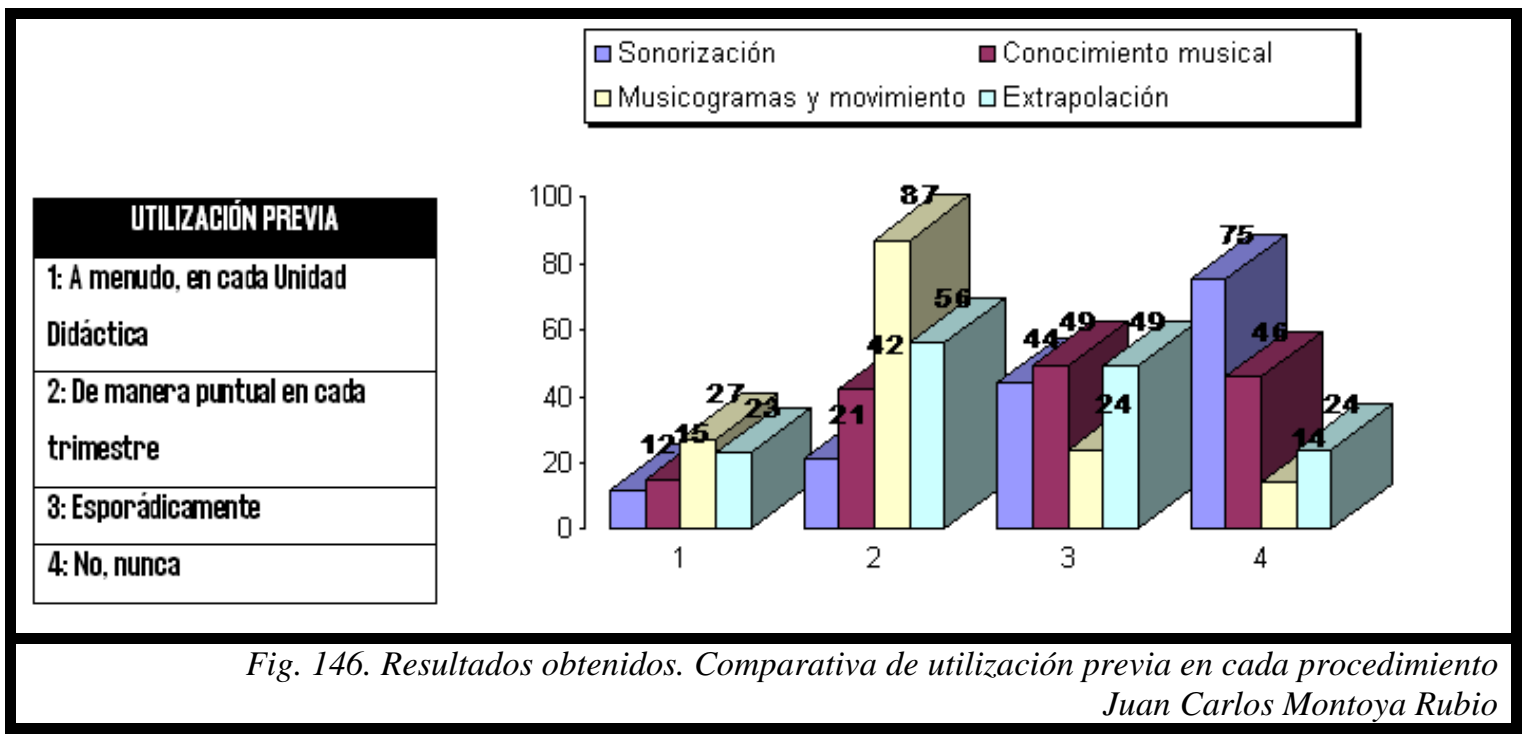

Aprovechamos estas líneas para destacar sucintamente varios aspectos:

- En primer lugar, la aceptación de los recursos es muy amplía, y el reconocimiento de sus posibilidades de inserción y globalización, en función de su alta significatividad, también lo es.

- Por otro lado, las evoluciones de los procesos didácticos más habituales, como es el caso de los musicogramas con sus diferentes grados de animación, suponen un estímulo mayor para el docente, ya que encuentran 
ligazones más vehementes con su propia labor cotidiana, y ello anima a mostrarlos como más adecuados que otros desarrollos.

- Además, hay un uso al menos esporádico de todos los procesos prototípicos de las cuatro dimensiones, lo cual invita a pensar que su falta de inserción efectiva en las aulas no depende tanto de dificultades estructurales como de ausencia de conocimiento del funcionamiento interno o de una formación específica al respecto. El hecho de que una minoría de docentes diga desarrollar las cuatro dimensiones con cierta naturalidad y frecuencia ratifica la existencia de estas prácticas y puede servir de estímulo para continuar focalizando esfuerzos hacia esa vertiente.

- Finalmente, se constata una ausencia de aplicación, si no total sí sumamente significativa, de elementos que se han mostrado como efectivos y motivadores. El caso de la sonorización es especial, ya que precisa de estrategias para su promoción. 


\section{ANEXO I. GUÍA DIDÁCTICA}

Guía didáctica para el aprovechamiento de los archivos adjuntos:

- De manera general, no hay señalados los niveles o etapas en los que aplicar cada una de las propuestas. Cada uno de los docentes, en función del contexto en el que os mováis, decidiréis a qué grupo ha de ir dirigida cada actividad.

- Al desviarse del sentido de la propuesta, tampoco se han descrito secuencias concretas de actuación. En este sentido, no encontraréis unidades didácticas al uso, sino núcleos de actividades que tal vez puedan completarse a modo de unidad didáctica.

- Encontraréis cuatro carpetas: Sonorización, Conocimiento Musical a través del Audiovisual, Extrapolación y Musicogramas y movimiento. La explicación detallada se muestra a continuación. 


\section{SONORIZACIÓN}

* La sonorización en clave pedagógica la entendemos como la inclusión de música a un discurso visual, mudo o sonoro. Proponemos ejemplos variados pero extremadamente sencillos.

\section{Carpeta 1. Cortos sonorizados con materiales del aula.}

- Se adjuntan dos archivos en formato vídeo.

- En ambos se ha suprimido el sonido original y se ha ejecutado sobre lo que se ve con diferentes instrumentos del aula (desde claves o cajas chinas hasta golpes sobre la mesa o efectos con la boca, sin olvidar la flauta de émbolo, la cual es tan útil como barata).Originales:

http://www.youtube.com/watch?v=Je93RCV7vDM http://www.youtube.com/watch?v=XxXL9DTa9IU

- Mostrar a los alumnos el contenido de los mismos y elaborar propuestas alternativas. Ejecutar sobre los dos cortos otras posibilidades explorando timbres, sin necesidad de utilizar notación alguna.

- Por supuesto, tampoco es preciso registrarlo. La esencia del ejercicio está en su ejecución directa. El trabajo puede ser improvisado o dirigido del modo que el docente estime oportuno.

- Para indagar más acerca de la propuesta pedagógica consultar: Montoya Rubio, J. C. (2009): "La sonorización del audiovisual como fuente de aprendizajes musicales" en Olarte Martínez, Matilde (Ed.): Reflexiones en torno a la música y la imagen desde la musicología española, Plaza Universitaria: Salamanca, 2009, pp. $705-746$.

\section{* Carpeta 2. Anuncio Rossini.}

- Se adjuntan 2 archivos en formato vídeo y 1 en formato texto.

- El primero de los vídeos se corresponde con un anuncio de televisión que ha sido repuesto en varias ocasiones por su espectacularidad:

http://www.youtube.com/watch?v=GURvHJNmGrc En él, sobre la obertura de "La Gazza Ladra" de G. Rossini, se muestra la explosión de grandes cantidades de pintura sobre un edificio en ruinas en la ciudad escocesa de Glasgow. La realización de Jonathan Glazer sirve para anunciar televisores. Proponemos una sonorización sobre la música preexistente, potenciándola.

- El segundo de los vídeos muestra cómo puede llevarse a cabo la experiencia, sobreponiendo sonidos del aula al anuncio en cuestión. No es más que un ejemplo que puede ser mostrado a los alumnos. Como veréis (escucharéis) está menos logrado que 
el anterior ejemplo. No es lo realmente importante: lo relevante es el medio y no el fin.

- El archivo escrito añade una propuesta para aplicar sonido al primero de los vídeos. Mezcla notación convencional y no convencional para resultar más intuitiva y a la vez ser rigurosa. Recordad que lo interesante es utilizar ese u otro modelo de sonorización que estiméis oportuno para el grupo con que estéis trabajando.

- Para indagar más acerca de la propuesta pedagógica consultar: Montoya Rubio, J. C. (2008): "Viejas y nuevas claves para la formación del profesorado en educación musical. Aprendizaje significativo a través de los medios audiovisuales" en Actas del I Congreso de Educación e Investigación Musical. Madrid, pp. 5567. Disponible volumen entero en

http://sem-ee.creando.net/pdfs/Actas\%20CEIMUS.pdf

\section{* Carpeta 3. Anuncio Shrek.}

- Tratando de buscar lazos significativos con los alumnos presentamos un vídeo que publicitaba la tercera entrega de Shrek. En este caso hay un archivo de vídeo y tres más para trabajar la sonorización.

- El archivo en vídeo muestra el anuncio sobre el que trabajar. En este caso, al abordar la sonorización, habrá que silenciar el reproductor de vídeo. http://www.youtube.com/watch?v=zYi7xr2YPXs

- El primer archivo escrito muestra a través de un diagrama los movimientos de cada uno de los pequeños ogros. El que se sitúa en primer término realiza tres movimientos, que quedan reflejados en la franja superior de la imagen. El que se sitúa en segundo término realiza dos, repitiendo el primero en la parte final. El tercero gatea de derecha a izquierda de la imagen sin descanso: ello también queda reflejado. Nótese que hay constancia de los segundos exactos en los que ocurre cada cosa y que, los créditos iniciales y finales quedan "vacíos" por el momento.

- La segunda de las fichas muestra cómo podría sonorizarse el anuncio. Elegimos para el ogro que muestra mayor movimiento el xilófono. Tal vez resulte demasiado complicada su tarea: es importante recordar que puede ser modificada al gusto o interés del docente. El ogro representado en la franja central palmea, en tiempo fuerte o débil según el momento, y silba en la parte central (blanca). El tercero de los ogros, que sólo gateaba, marca el pulso a cada uno de sus movimientos. Es curiosa la sincronía que se muestra en los dos últimos casos. 
- La tercera ficha es una guía para el docente que informa de cómo podría resultar el efecto final. Para indagar más acerca de la propuesta pedagógica consultar: Montoya Rubio, J. C. (2008): "La vertiente audiovisual de las TIC en educación musical. Usos metafóricos y efectivos de la Web 2.0". Congreso Ticemur. III Jornadas Nacionales TIC y Educación. 


\section{CONOCIMIENTO MUSICAL A TRAVÉS DEL AUDIOVISUAL}

* La música del cine o la televisión puede servir para estimular otro tipo de conocimientos musicales de muy diverso tipo. Proponemos el estudio de las figuras de Mozart y Beethoven a través, fundamentalmente, de la serie Los Simpson. A partir de determinados ejemplos enfocaremos cómo a Mozart se le asocia siempre con elementos jocosos y a Beethoven con aspectos rudos y toscos, aunque a ambos se les reconozca un talento inmenso.

* Para indagar más acerca de la propuesta pedagógica consultar: Montoya Rubio, J. C. (2008): "Música de cine: Imágenes ilusorias del binomio Mozart - Beethoven" en Actas del I Congreso Internacional Imagen $y$ Apariencia, Murcia. Disponible en http://congresos.um.es/imagenyapariencia/11$\underline{08 / p a p e r / v i e w F i l e / 2501 / 2451}$

\section{* Carpeta 1. Bart Simpson es Mozart}

- Se incluyen tres carpetas más.

- Carpeta 01. Bart Simpson es Mozart. Tratamos de aproximar a través de un corte muy pequeño a un gran número de elementos que pudieran ser el inicio de conocimientos musicales. Para ello presentamos el vídeo del episodio Margical History Tour (http://www.youtube.com/watch?v=HjuL -XT1ll) y comentamos algunos de sus elementos a partir de la ficha $\mathrm{C} 1$.

- Carpeta 02. Si se quiere profundizar sobre la música que Bart Simpson ejecuta en el fragmento inicial, se puede utilizar como curiosidad el vídeo de un anuncio televisivo e, igualmente, las fichas en formato texto que se incluyen en esta carpeta. Se trata de un pequeño ejercicio para acompañar la melodía de la Marcha Turca (estructura y musicograma de seguimiento en la ficha C2, explicación del modo de aplicación en la ficha C3). Para indagar más acerca de la propuesta pedagógica consultar: Montoya Rubio, J. C. (2006): "Mozart en casa de Bach: Elaboración pedagógica para el tránsito del barroco al clasicismo musical”, en Ensayos $n^{\circ}$ 21, pp. 141-155, disponible volumen entero en http://www.uclm.es/AB/magisterio/ensayos/pdf/revista21.pdf

\section{* Carpeta 2. Nelson es Beethoven}

- Encontramos tres fragmentos de vídeo y un texto para la discusión.

- Vídeo 01. procede del mismo episodio Margical History Tour. Se trata de observar el modo en que pasa la novedad de Mozart con 
Beethoven y el carácter que se le asocia al último (agrio, rudo, etc.) en su vinculación con el "niño malo" de la serie, Nelson.

- Ficha C4. Se incluyen tres textos que tratan de acotar lo que se espera de Mozart y de Beethoven a través de las imágenes que nos han llegado de ellos. Es de esperar que, sin preguntas a contestar por escrito, lo cual haría perder espontaneidad al razonamiento, los alumnos pudieran atender a 1) las ideas previas acerca de ambos compositores 2) el modo en que se supone componían y 3) lo irreflexivo de dichas construcciones.

- Vídeo 02. Del episodio El soplón vive arriba se extrae un fragmento en el que se toma el inicio de la Quinta Sinfonía de Beethoven para continuar hablando sobre la tendencia al reduccionismo en torno a estas figuras de la música clásica.

- Vídeo 03. Ejemplo de dramatización a partir del carácter testarudo y machacón de la Quinta Sinfonía de Beethoven. http://www.youtube.com/watch?v=EEhF-7suDsM

\section{* Carpeta 3. Pequeña Serenata Nocturna.}

- Hay 2 vídeos y 1 carpeta con actividades de extrapolación.

- Vídeo 01. Pequeña serenata nocturna. Tercer fragmento de Margical History Tour. Los elementos que pueden ser trabajados son muchos, desde los paralelismos con Amadeus hasta la contrafacta textual que se aplica a la música de Mozart. Optamos por desarrollar un trabajo de extrapolación sobre la Pequeña Serenata Nocturna.

- Vídeo 02. Anuncio HP.

http://www.youtube.com/watch?v=x9SutyL uDI Sirva como ampliación y reclamo a la atención del alumnado (hemos de decir que las posibilidades rastreando un poco internet son inmensas)

- Carpeta de actividades de extrapolación

- Vídeo musicograma de seguimiento. Se muestra la forma musical de la exposición de la Pequeña Serenata Nocturna, la cual tiene estructura de sonata prototípica.

- Ficha C5. Sirve para introducir al alumno en lo que es una sonata, la estructura general de la forma sonata en la obra de Mozart, y el fragmento concreto en que nos hemos centrado

- Ficha C6. Se trata de una aplicación para pequeña percusión y materiales básicos sobre la audición que se muestra en el vídeo. Lleva inserto el lenguaje musical en cada parte para facilitar el seguimiento por parte del docente. Para indagar más acerca de la propuesta 
pedagógica consultar: Montoya Rubio, J. C. (2006): "Mozart en casa de Bach: Elaboración pedagógica para el tránsito del barroco al clasicismo musical", en Ensayos $n^{\circ}$ 21, pp. 141-155, disponible volumen entero en http://www.uclm.es/AB/magisterio/ensayos/pdf/revista21.pd $\underline{f}$ 


\section{EXTRAPOLACIÓN}

* Las actividades de extrapolación consisten en utilizar una música conocida por un buen número de alumnos y "extrapolarla" de su contexto original para utilizarla en el aula. La aportación que trabajamos parte del Hedwig's Theme perteneciente a la saga de películas de Harry Potter.

* Para indagar más acerca de la propuesta pedagógica consultar: Montoya Rubio, J. C. (2007):"La música de cine como estrategia educativa" en Ensayos no 22, pp. 99-124, disponible volumen entero en http://www.uclm.es/AB/magisterio/ensayos/pdf/revista22.pdf

- Este es el tema de la lechuza Hedwig que toma protagonismo en determinados momentos de la película (archivo audio). Como extrapolación proponemos actividades muy básicas:

- Ficha 1. Seguimiento auditivo. Actividades relacionadas:

$\rightarrow$ Seguir la audición por medio de los símbolos no convencionales. Las figuras con lenguaje convencional sólo sirven para hipotéticas explicaciones del docente.

$\rightarrow \mathrm{Si}$ se quiere, señalar la importancia de la tónica y la dominante, resaltadas en el esquema.

$\rightarrow$ Dependiendo de las posibilidades técnicas, se puede proyectar la imagen de la ficha para realizar un seguimiento conjunto

- Ficha 2. Danza. Actividades relacionadas:

$\rightarrow$ Se presentan algunos movimientos muy básicos que podrían ser modificados en función de las necesidades del grupo.

$\rightarrow$ La idea general es la de aprehender la estructura fraseológica a través del movimiento

- Ficha 3. Canto. Actividades relacionadas:

$\rightarrow$ Se propone un texto inventado para superponerse a la melodía o cantarlo de manera autónoma, sin música de fondo. Se han suprimido ciertas dificultades.

$\rightarrow$ Es interesante desarrollar esta técnica, la de la contrafacta, haciendo que los propios niños inventen nuevos textos relacionados con Harry Potter o con cualquier otro aspecto

- Ficha 4. Flauta. Actividades relacionadas:

$\rightarrow$ Se adapta la melodía a la práctica con flauta dulce.

- Ficha 5. Instrumentación simple. Actividades relacionadas:

$\rightarrow$ Sobre la melodía anterior, para flauta o láminas, se aplican unos obstinatos para diferentes instrumentos PAI.

$\rightarrow$ Es un ejemplo que puede ser variado como se estime oportuno. 


\section{MUSICOGRAMAS Y MOVIMIENTO}

* Adjuntamos algunos ejemplos que tienen como origen la técnica del musicograma, ideada y desarrollada durante años por Jos Wuytack. Son ejemplos extraídos de la red, en la que se muestran diferentes niveles de complejidad. Sería de gran interés saber el valor que se le concede a cada uno de los vídeos, que van desde una simplicidad muy elemental a un nivel de complejidad mayor.

* Vídeo 1. http://www.youtube.com/watch?v=lj0yuc809qQ 20 Movimiento de la "Suite Alone", de Dimitri Shostakovich.

* Vídeo 2. http://www.youtube.com/watch?v=uzhOhgUNOjU. "Paseo en trineo", de Leopold Mozart. Para indagar más acerca de la propuesta pedagógica consultar: Honorato, R. (2001): "Trabajando con musicomovigramas", en Revista de la Lista Europea de Música en la $\begin{array}{lllll}\text { Educación } & n^{\circ} & 8, & \text { Disponible }\end{array}$ http://musica.rediris.es/leeme/revista/honorato01.pdf

* Vídeo 3. http://www.youtube.com/watch?v=PFcM4zuUm3w "Rondó de la Suite $\mathrm{n}$-1", de Jean Joseph Mouret

* Vídeo 4. http://www.youtube.com/watch?v=608XRFwSO8U "La primavera", de Las cuatro estaciones de Antonio Vivaldi.

* Vídeo 5. http://www.youtube.com/watch?v=fr7F9PgyipY "El elefante", de El carnaval de los animales de Camile Saint-Saëns.

Vídeo 6. http://www.youtube.com/watch?v=YUTIp0ODS7s "Fugue for Friday", de Stephen Malinowski 


\section{ANEXO II. FICHAS DIDÁCTICAS}
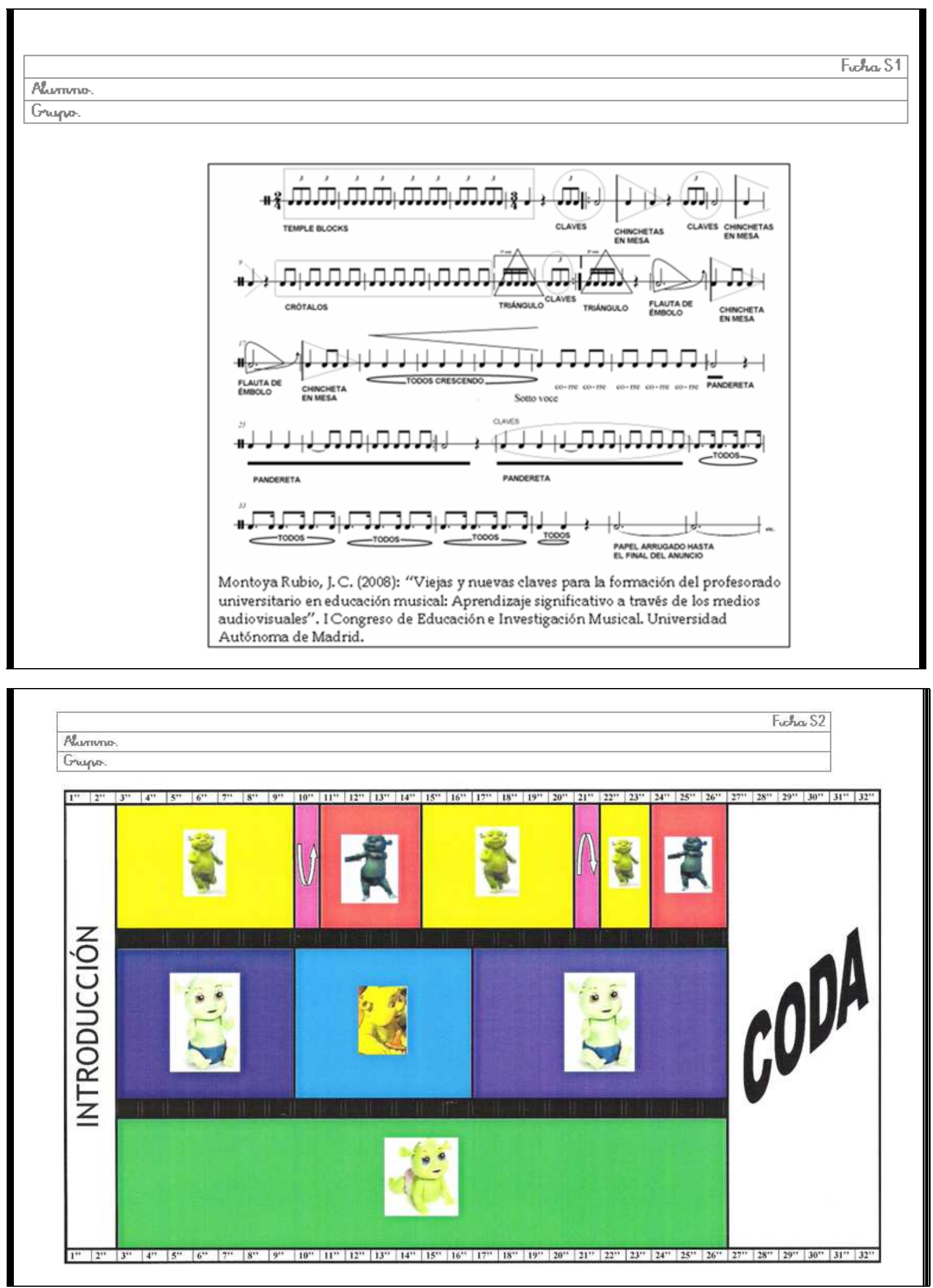


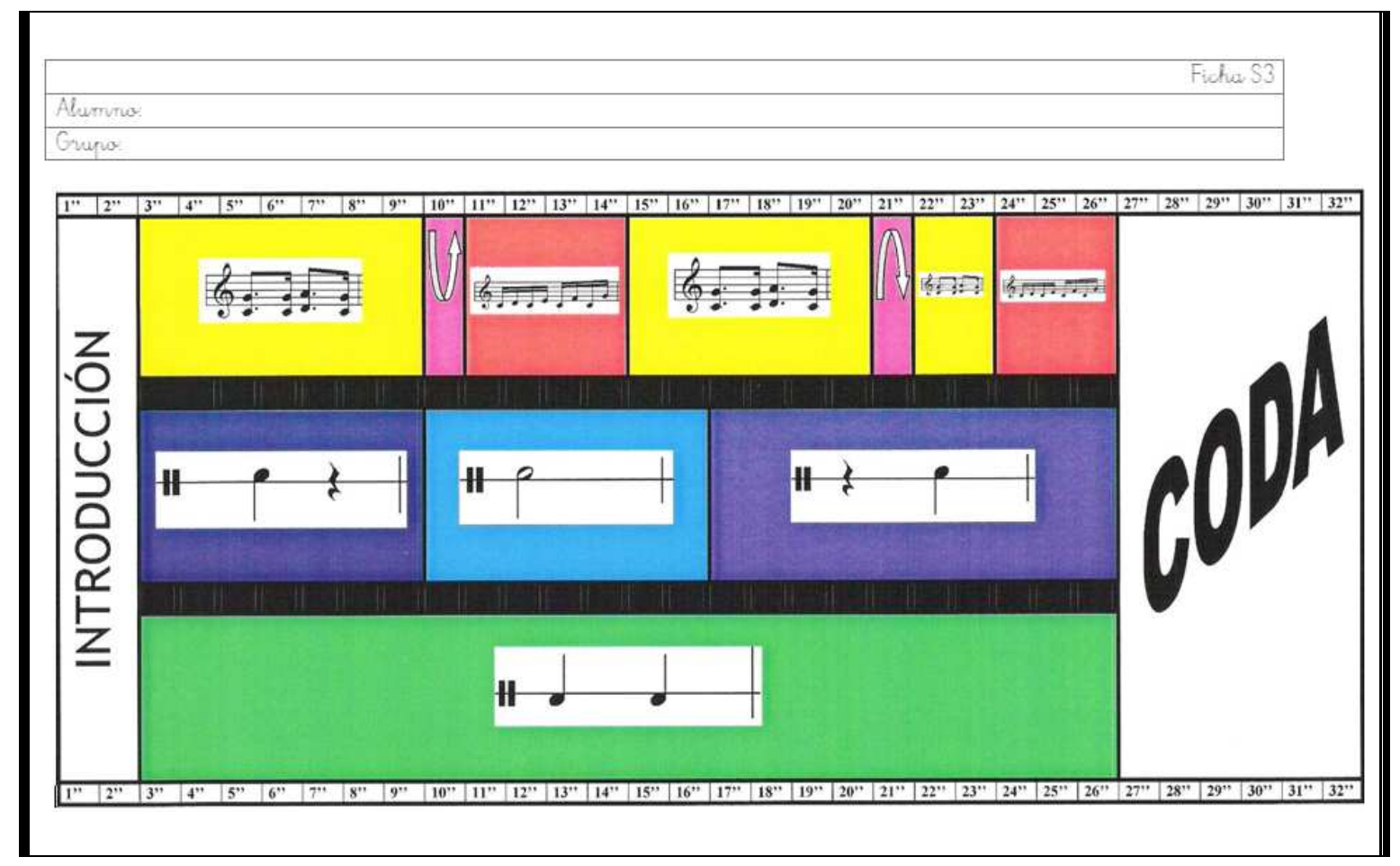

Ahumino:

Guspra.

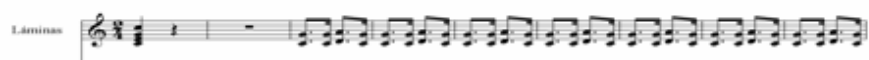

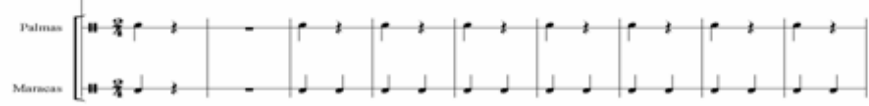

का

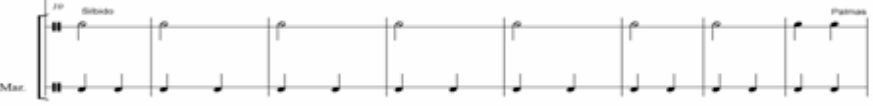

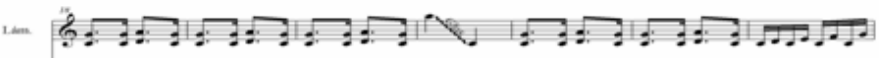

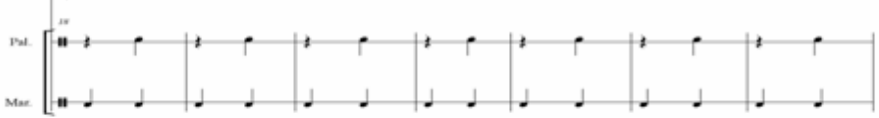

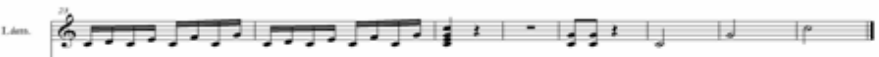

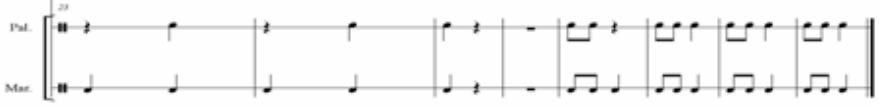



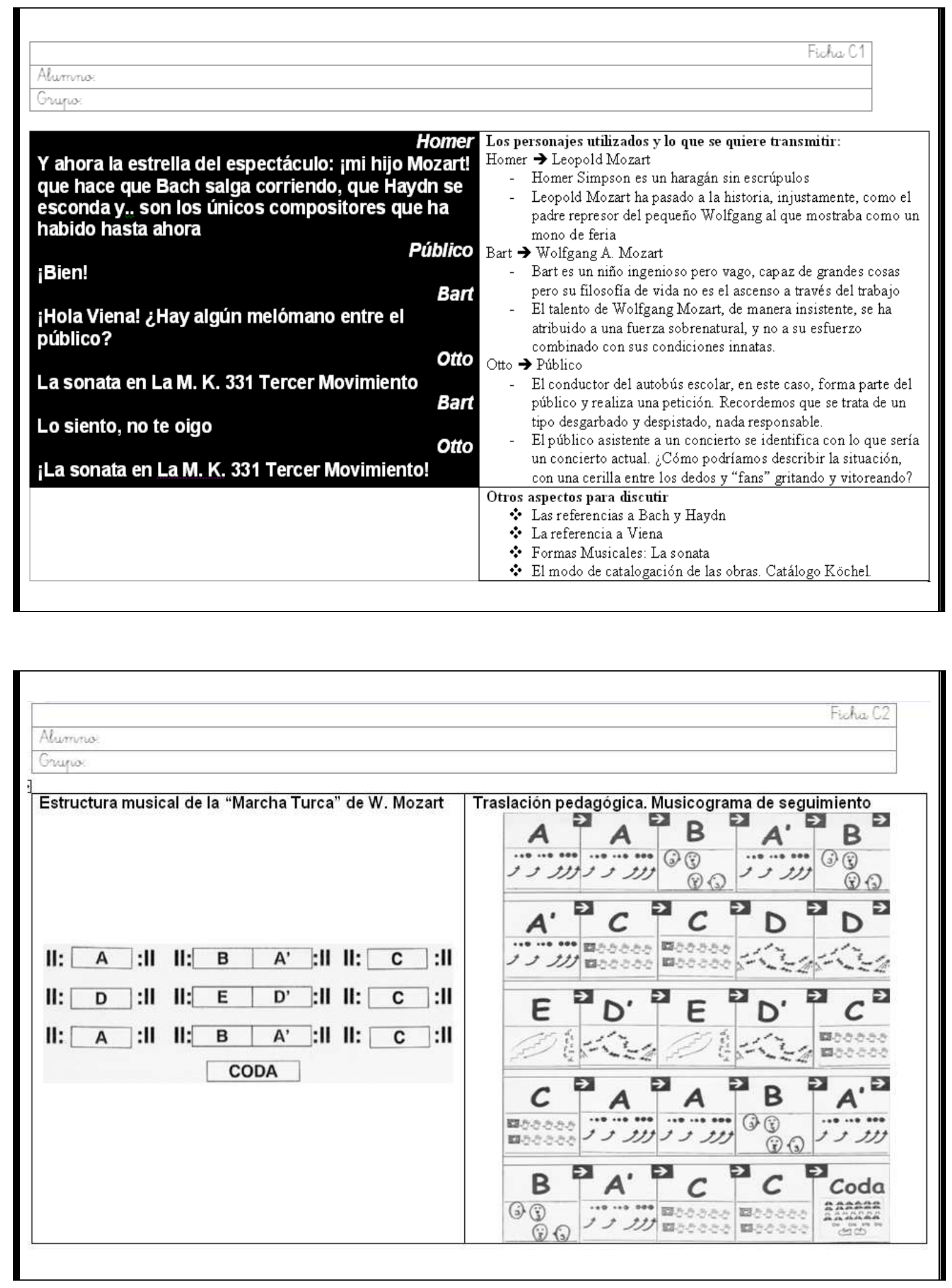


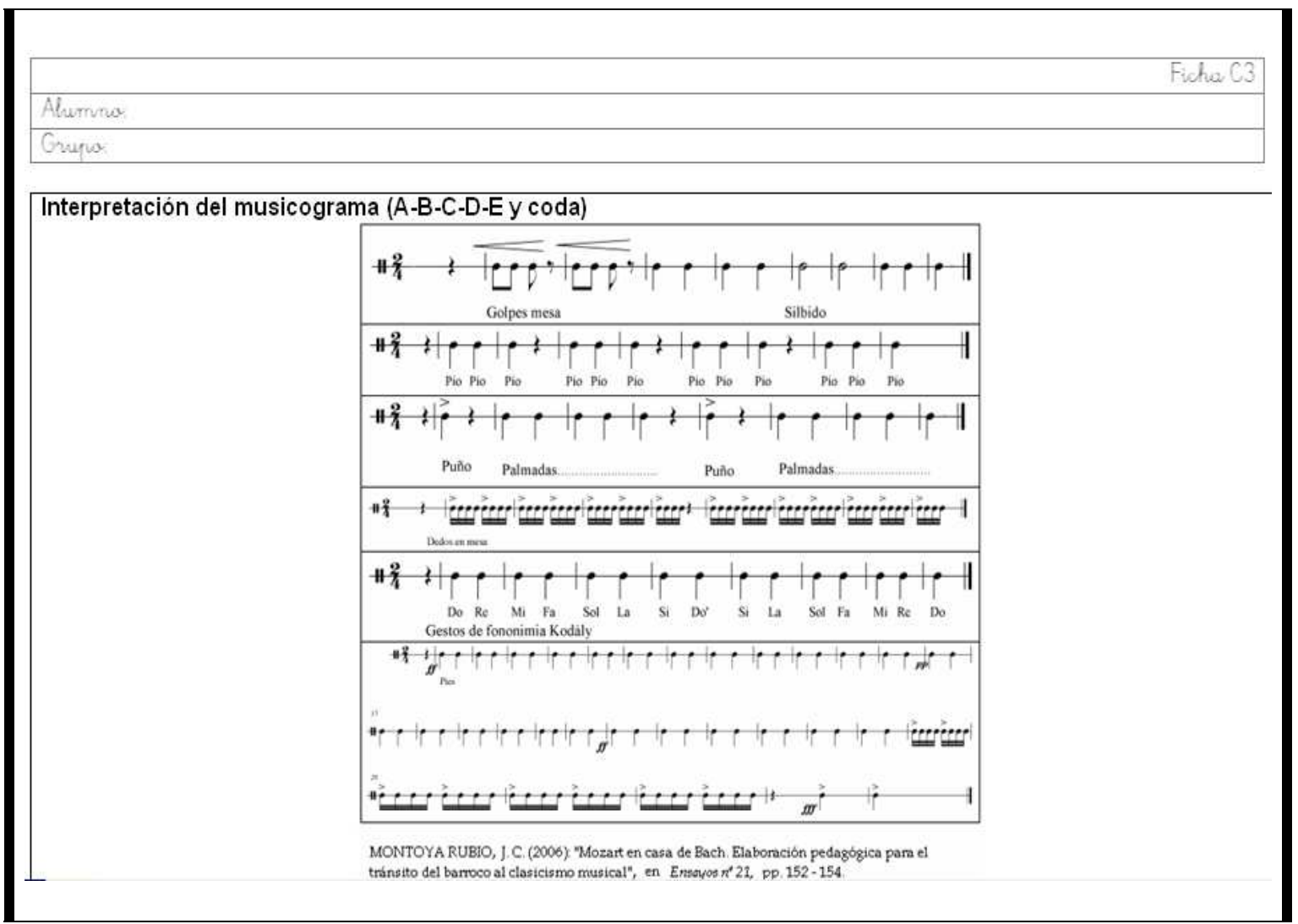

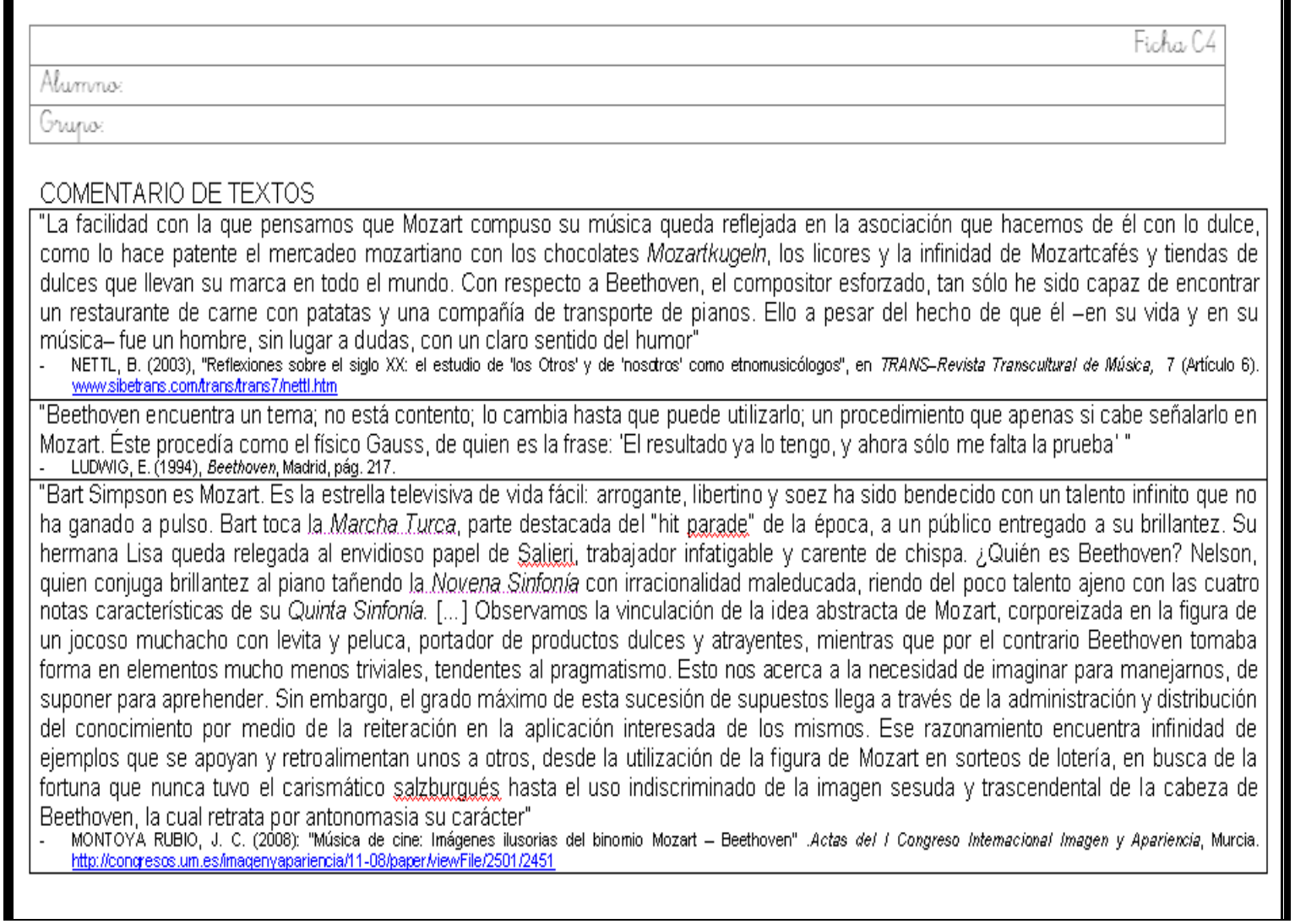



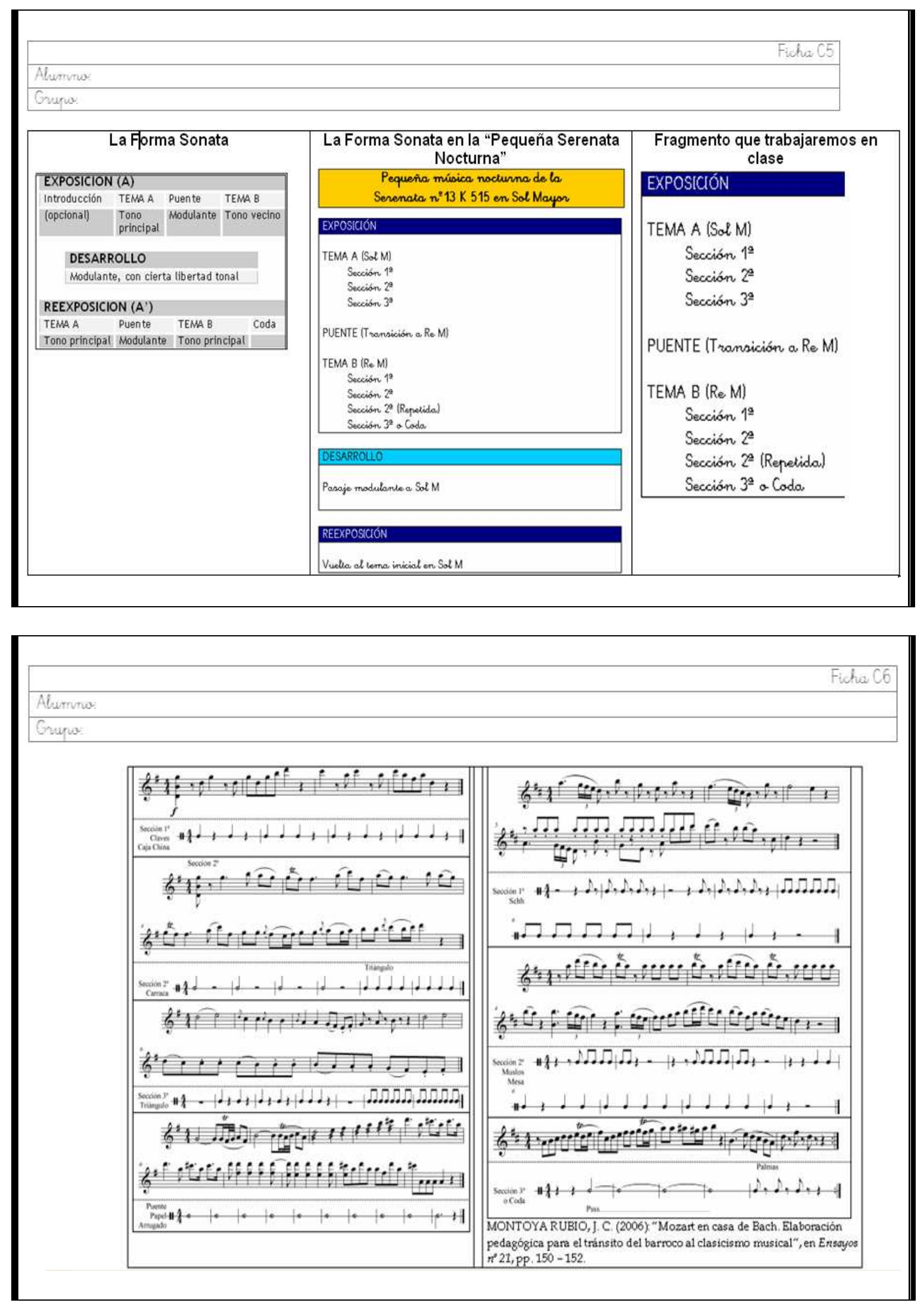

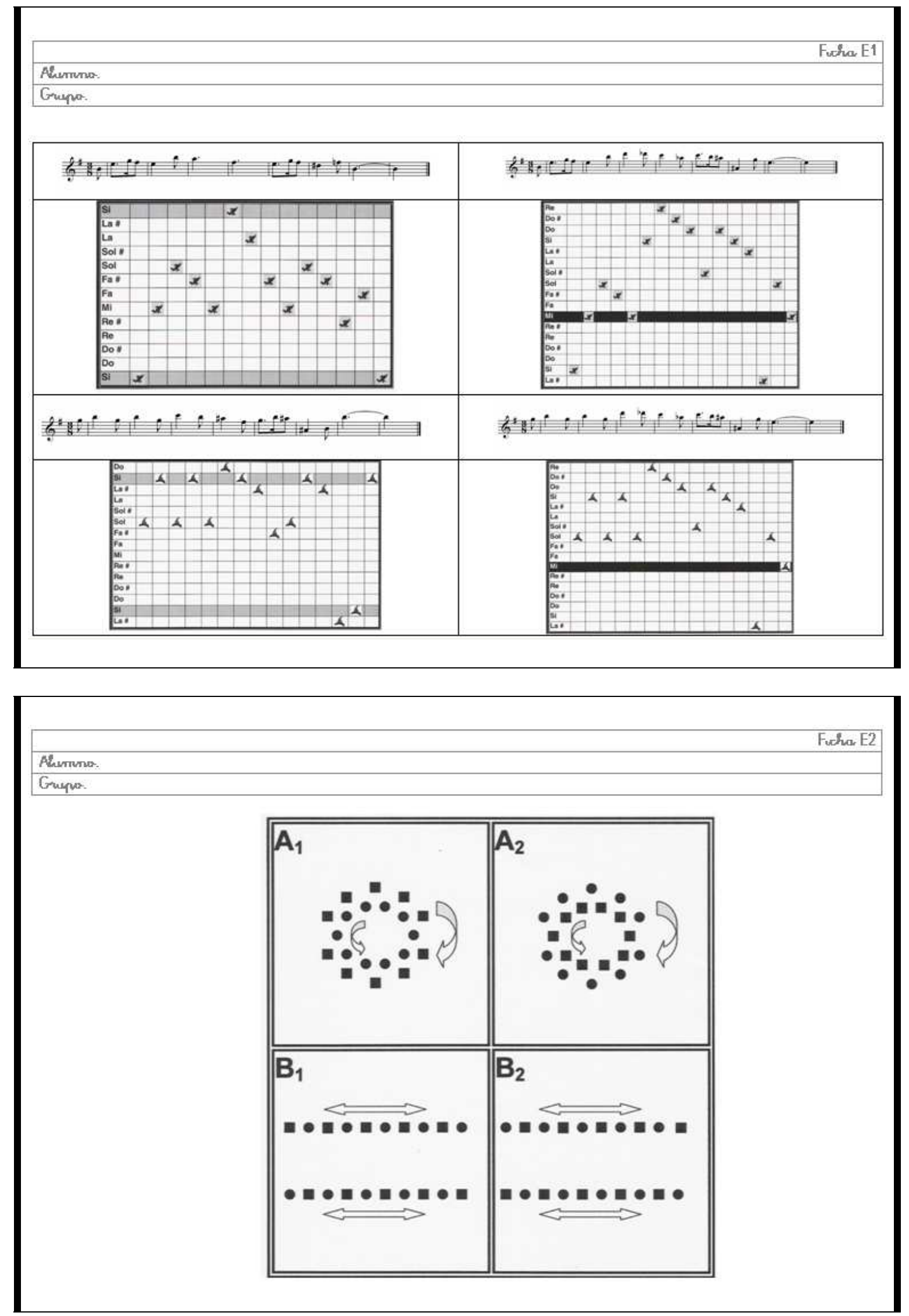
Alhuminat.

Goupra-

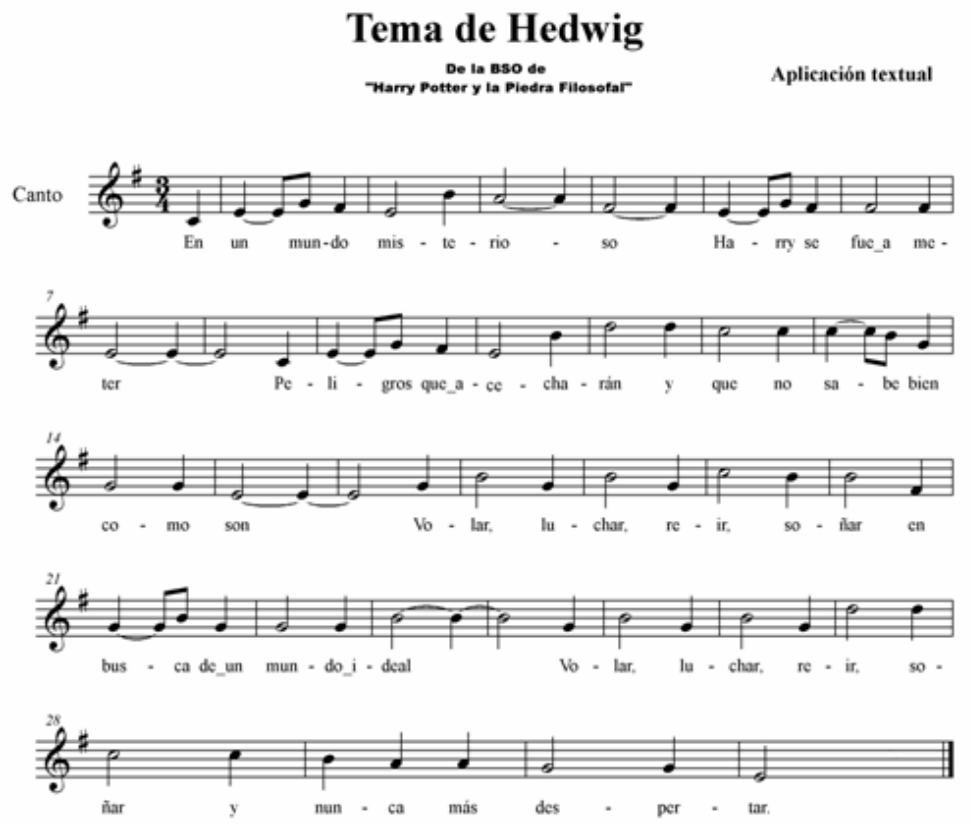

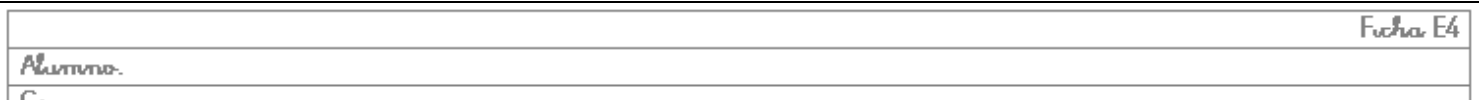

Gupva.

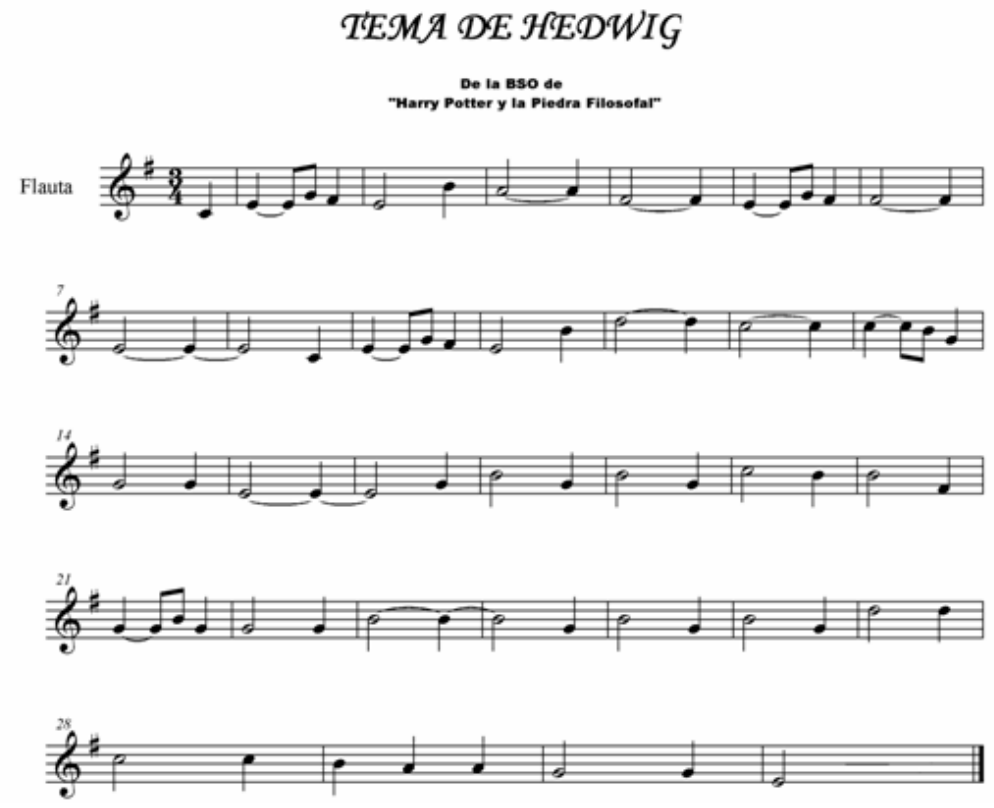




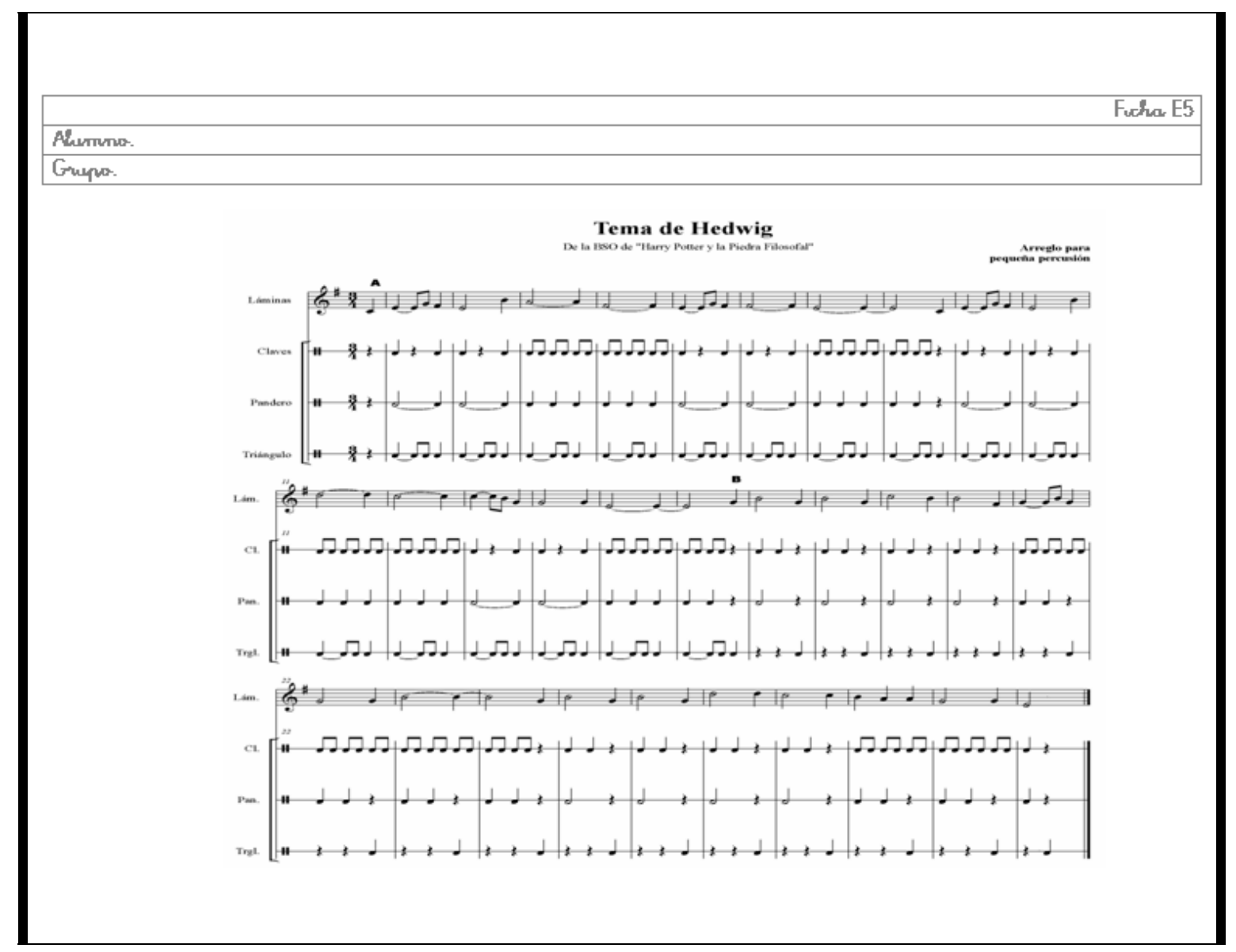


MÚSICA Y MEDIOS AUDIOVISUALES.

PLANTEAMIENTOS DIDÁCTICOS EN EL MARCO DE LA EDUCACIÓN MUSICAL. Juan Carlos Montoya Rubio 
MÚSICA Y MEDIOS AUDIOVISUALES.

PLANTEAMIENTOS DIDÁCTICOS EN EL MARCO DE LA EDUCACIÓN MUSICAL. Juan Carlos Montoya Rubio 


\section{CONCLUSIONES}

La aportación del audiovisual a la investigación en educación musical. Dentro del contexto español, las investigaciones dedicadas a la educación musical ponen de manifiesto la existencia de un buen número de dificultades que lastran la propia configuración del objeto de estudio. Entendiendo la tendencia al alza de otros ámbitos que se están desarrollando e investigando, tales como las Tecnologías de la Información y la Comunicación, se concluye que desde la interdisciplinariedad se puede robustecer y actualizar el grueso de las investigaciones en educación musical.

Legislación. Las principales referencias legislativas tanto a nivel estatal como dentro del estudio específico realizado para la Región de Murcia muestran cómo, desde la inserción de los estudios musicales con cierta seriedad, a raíz de la implantación y desarrollo de la LOGSE, la tendencia general es la de estimar como muy convenientes las aproximaciones didácticas que integran los códigos audiovisuales. Sin embargo, no todos los docentes siguen estas orientaciones por lo que la utilización audiovisual es apreciada pero no siempre practicada. En suma, la legislación no sólo no discute una educación musical bajo las premisas audiovisuales, es más, la alienta, pero en los niveles prácticos no se halla un reflejo a tal predisposición.

Contexto de cambio. El momento actual se caracteriza por el advenimiento de nuevas estructuras educativas, si bien en los estratos universitarios. Como en todo contexto de cambio, en el modo en que se lleve a cabo la implantación y en la plasmación efectiva en los niveles obligatorios se hallan oportunidades para regenerar las estructuras pedagógico-musicales. Sólo el paso de los años determinará si la 
educación musical ha evolucionado hacia la vinculación con los elementos tecnológicos o, por el contrario, ha variado sus organigramas permaneciendo sus contenidos, hasta cierto punto, intactos.

La realidad de la educación musical. A pesar de los sucesivos cambios legislativos, la educación musical no acaba de encontrar un espacio lo suficientemente firme para poder desarrollarse en plenitud y con solvencia en el marco de la educación obligatoria. Se precisa marcar un punto de inflexión al alza para lo cual es necesario observar actuaciones, al menos, respecto a tres planos: los alumnos, el profesorado y los recursos materiales. En lo que atañe a los alumnos, la premisa básica pasa por seguir incidiendo en su motivación para extraer consecuencias que guíen el conjunto de los procesos pedagógicos. En referencia al profesorado, urge dotar al colectivo de herramientas conceptuales elementales para desarrollar el potencial de los nuevos medios de aprendizaje, así como el estímulo necesario para llevarlos a buen puerto. Por su parte, los recursos materiales habrán de responder a los lenguajes que la sociedad actual demanda y dentro de los cuales nos movemos fuera de la enseñanza formal.

Teoría - Práctica. Enunciada en forma de distancia entre centros de educación obligatoria e investigaciones desde la universidad, se intuye la necesidad de vinculación entre ambas dimensiones, pero tanto las aportaciones de unos como los testimonios de otros delatan que ello no siempre se consigue. En el caso de la reorientación metodológica que planteamos, la articulación de modelos teóricos nutridos de referencias prácticas y viceversa se antoja como el camino más adecuado a la actualización de la materia.

Música, medios audiovisuales y aprendizaje significativo. Se constata que, en torno a la educación musical, seguimos inmersos en el paradigma de la significatividad. La convergencia entre las vivencias sonoras del alumnado y los objetivos pedagógicomusicales a desarrollar son considerados como puntales básicos del proceso de enseñanza-aprendizaje musical. Tanto el desarrollo de procedimientos concretos como nuestra experiencia y la señalada por los docentes en ejercicio a través de las consultas 
realizadas indican que todos los procesos apuntados como prototípicos en el tercero de los capítulos son recursos que gozan de un gran potencial significativo. Su puesta en funcionamiento ayuda a ratificar dicha sensación. En suma, la implementación de contenidos audiovisuales a partir de los cuales estructurar secuencias pedagógicas en el aula de educación musical constata un aumento de la significatividad en el proceso general.

Disponibilidad de materiales. Desde los inicios de la aplicación de las pedagogías activas del pasado siglo en nuestras aulas el docente de música se ha identificado con un agente "hacedor". En función del tipo de conocimiento a impartir y las particularidades del alumnado, la generación de materiales basados en criterios metodológicos de autores de renombre ha sido una constante. Ya advertimos como el propio Willems señalaba la necesidad de elaborar materiales y apuntaba estrategias para ello. Para nuestro apartado de conclusiones hemos de resaltar que se constata la existencia de muchos materiales audiovisuales a disposición de todos, especialmente a partir de las herramientas de publicación de información alojadas en internet. Sin embargo, el nivel de aprovechamiento de los mismos no es el adecuado, en tanto en cuanto el primero de los elementos a desarrollar-desvelar tras ellos matices susceptibles de integrarse dentro de las secuencias didácticas que ocupan las sesiones de educación musical- no suele llevarse a cabo. En general, se trata de recursos accesibles a los cuales basta con aplicar una nueva perspectiva: la mirada pedagógica.

Mirada pedagógica. Salvando las distancias, al estilo de la relacional y holista mirada antropológica, la mirada pedagógica en el plano musical ha sido aludida en varias ocasiones a lo largo del texto como esa intuición que, naciendo del docente, sirve para conectar con los intereses y perspectivas del alumnado, sus gustos y necesidades, para plasmarse en el proceso de generación de materiales pedagógicos a partir de elementos que no parecieran, en principio, tener esa misión. Desde el contexto audiovisual, la importancia de esta mirada pedagógica es vital, ya que gran parte de los contenidos presentados pierden totalmente su validez si carecen del nexo que cohesiona los objetivos pedagógicos de unos con la decisión de aprender de otros. 
La musicología como fuente de elaboración de materiales curriculares. Se asume pues que la sutura a la brecha establecida entre teoría y práctica puede favorecer marcos de aprendizaje significativo musical. A la luz de los planteamientos que hemos propuesto, observamos que la producción musicológica ha de ser, igualmente, un punto de referencia para aprovechar aspectos teorizados que, a través de un trabajo de mediación educativo, puede revertir en procedimientos concretos de actuación dentro de los diseños pedagógicos para la educación musical. La inoperante separación taxativa entre áreas de conocimiento musical conduce a un desaprovechamiento global de todas ellas, y no favorece en modo alguno el desarrollo integral de los campos que la integran. Del mismo modo que la música del audiovisual va ganando enteros dentro del engranaje de la musicología entendida como más ortodoxa, la didáctica derivada de los estudios de música y audiovisual ha de ser capaz de encontrar un hueco que permita su desarrollo.

Valor y uso de los medios audiovisuales. A día de hoy, la utilización de los medios audiovisuales en las aulas de educación musical es escasa. En función del conocimiento que se tiene del procedimiento concreto (extrapolación, filmación, conocimiento musical...), este grado de uso oscila levemente (se comprobó, por ejemplo, que los procedimientos de sonorización a pesar de su gran aceptación no eran desarrollados siquiera de manera puntual) pero siempre es mayor el reconocimiento de su validez que su práctica real. A tenor de las informaciones recabadas, es gratificante encontrar que estamos ante elementos con un potencial didáctico muy grande, pero es igualmente necesario un trabajo de difusión que haga patentes estos procedimientos didácticos, ya que el camino a la aceptación pasa por su identificación.

Aplicabilidad global y secuencial de los medios audiovisuales. Conocidos los recursos específicos de aplicación audiovisual en educación musical, la muestra de docentes empleada estimaba que todos estos materiales son fácilmente integrables en el transcurso de sus clases, de manera general. No obstante, al tratar de concretar su aplicación en secuencias didácticas específicas, la aceptación musical de los recursos 
disminuyó, si no notablemente al menos sí lo suficiente como para constatar que las mayores dificultades estribaban en dar formato "tradicional" a elaboraciones pedagógicas novedosas. Salvar estos problemas entendiendo que estamos ante procesos capaces de plasmarse igualmente sobre las unidades didácticas y formar parte de la Programación General de Aula ayudará a normalizar este tipo de recursos materiales.

Prospectiva. La determinación del tema de la tesis doctoral acotó la misma en torno a la educación musical dentro de las etapas obligatorias, proponiéndose explorar los métodos y técnicas posibles en un entorno educativo como el que vivimos hoy día. Sin duda, gran parte de las aportaciones que se derivan de la taxonomía elaborada para el capítulo tercero podrían buscar acomodo, con variaciones más o menos severas, fuera de los límites de estos periodos educativos establecidos. Así, nos mostramos convencidos de que tanto la educación infantil como la ubicada tras los tramos de primaria y secundaria (incluyendo bachillerato y enseñanza universitaria), pueden de uno u otro modo abordar exitosamente procedimientos de aprendizaje basados en postulados como los descritos. De hecho, desde la óptica personal de quien escribe, constatamos que el esfuerzo por llevar a cabo aprendizajes de este tipo en etapas tan dispares es posible con una adecuada trama de objetivos y planteamientos metodológicos que guíen los contenidos a desarrollar.

Por otro lado, señalamos como crucial para realizar una prospectiva de la investigación atender al modo en que el contexto de cambio actual vaya afianzándose en estructuras musicales firmes. Es evidente que los estudios de educación musical, como el resto de las especialidades propias del magisterio, se ubican en una situación de encrucijada a la que se está dando respuesta en estos momentos, dentro de la adaptación al contexto europeo de educación. La ubicación efectiva del docente de música en los nichos laborales y el tipo (y cantidad) de docencia que a ello se le asocie hará que, en cierto modo, se facilite o no la experimentación sobre nuevos caminos para la educación musical. En este sentido, dependerá de la concienciación y determinación de los propios docentes para poder llegar a un desarrollo real de nuevas dimensiones educativas como las propuestas en torno a lo musical. 
MÚSICA Y MEDIOS AUDIOVISUALES.

PLANTEAMIENTOS DIDÁCTICOS EN EL MARCO DE LA EDUCACIÓN MUSICAL. Juan Carlos Montoya Rubio 


\section{BIBLIOGRAFÍA}


MÚSICA Y MEDIOS AUDIOVISUALES.

PLANTEAMIENTOS DIDÁCTICOS EN EL MARCO DE LA EDUCACIÓN MUSICAL. Juan Carlos Montoya Rubio 


\section{BIBLIOGRAFÍA}

\section{INTRODUCCIÓN}

Dentro de las posibilidades para la plasmación de las referencias bibliográficas, optamos por presentar todos los textos que han sido reseñados en algún momento de la investigación agrupados por centros de interés. Al desarrollar un estudio como el que ahora concluye, que implica abrigar teorías y procedimientos concretos venidos de diversos campos de conocimiento, consideramos más gráfico este método de exposición de las referencias bibliográficas por encima de otros como la enumeración sistemática (lo cual haría perder en cierto modo la lógica de nuestra argumentación) o la generación de una bibliografía específica por capítulos (debido a que la repetición de algunos textos podría acarrear una lectura reiterativa y, en consecuencia, poco fluida). Los ámbitos que tomamos como más significativos para organizar las referencias bibliográficas son tres: referencias en el ámbito de la musicología y la música del audiovisual, referencias relativas a la educación musical y, por último, las referencias sobre aspectos educativos, sociales y medios audiovisuales. Ante la posibilidad de encontrar referencias que podrían insertarse en uno u otro apartado, expondremos brevemente el porqué de este tipo de agrupamiento encabezando cada grupo temático.

Por otro lado, hemos de reseñar que, aunque en el texto se haya respetado la firma de cada autor consignando solamente el primer apellido allá donde éste figurara como único, en la mayoría de los casos se ha optado por citar con ambos apellidos a los autores españoles para evitar confusiones que pudieran tener origen en la aparición de un mismo referenciado de diferente manera. En autores de habla hispana que habitualmente consignan el primero de los apellidos (especialmente sudamericanos) se ha optado por mantener esa forma de reseñar. 
Por último, como ha sido expuesto a lo largo de toda la tesis doctoral, hacemos constar que la importancia de las referencias que ahora se adjuntan ha sido capital, ya que ante la ausencia de textos específicos a los que poder acudir para afianzar los planteamientos propios, las lecturas realizadas desde diferentes campos de conocimiento y sus aportaciones, a veces dirigidas hacia otros contextos, han enriquecido grandemente la línea argumental en torno a la que se ha llevado a cabo la investigación. 


\section{REFERENCIAS EN EL MARCO DE LA MUSICOLOGÍA Y LA MÚSICA DEL AUDIOVISUAL}

Las reseñas en el plano de la musicología incluyen toda la producción bibliográfica musicológica ajena al mundo audiovisual pero citada en el transcurso del texto por su importancia para la elaboración de la argumentación. Asimismo, se insertan las referencias que aluden directamente a la música del audiovisual fuera de los márgenes de lo educativo.

Para la globalidad del estudio que se presenta, la relevancia de ambos ámbitos, íntimamente relacionados, ha sido muy grande. Aunque es cierto que entre los textos que aluden directamente a la música del audiovisual encontramos un mayor número de ellos que se dedican a la observación de la banda de sonido inserta en el cine, es relativamente importante la referencia a otros ámbitos del audiovisual. De este tipo de obras ha sido común, entendiendo la distancia de diferentes órdenes que se establece con el presente estudio, la extracción de reflexiones, por ejemplo, sobre el montaje o la inclusión de materiales musicales. Por estos motivos, de la lectura de estos manuales se rescatan principios metodológicos esenciales en campos como la sonorización didáctica, tanto en el proceso de inserción musical en sí como en lo que atañe a la elección de material sonoro aplicable a fragmentos visuales. Además, es frecuente también encontrar diversos sistemas de análisis que guarden estrechas relaciones con otros procesos descritos como la extrapolación o el conocimiento musical.

Por otro lado, en algunos de los artículos referenciados encontramos estrategias para aproximarnos a la realidad sonora del alumnado, ya que se ofrecen elementos sonoros asociados a visuales que, bajo determinadas circunstancias, pueden ser explotados pedagógicamente mediada una elaboración de materiales específicos. En este sentido, es destacable que, a pesar de que la didáctica no sea la pretensión de partida, las estructuraciones marcadamente esquemáticas que se pueden encontrar así como el establecimiento de categorías analíticas concretas son rescatables con fines pedagógicos. 
Las referencias reseñadas en el transcurso del texto son:

- ADORNO, Th. W. y EISLER, H. (2003): El cine y la música. Madrid: Fundamentos.

- AGUIRRE RINCÓN, S. (2009): “'Música e imagen'. Reflexiones pedagógicas en torno a una asignatura". OLARTE MARTÍNEZ, M. (Ed.) Reflexiones en torno a la música y la imagen desde la musicología española. Salamanca: Plaza Universitaria Ediciones, pp. 758-759.

- ALCALDE DE LA ISLA, J. (2007): "Pautas para el estudio de los orígenes de la música cinematográfica”. Aula Abierta 16, pp. 105-132.

- ARIZA POMARETA, J. (2003): Las imágenes del sonido. Cuenca: Servicio de Publicaciones de la Universidad de Castilla - La Mancha.

- ARÓstegui PlaZA, J. L. (2009): "La banda sonora en los dibujos animados". OLARTE MARTÍNEZ, M. (Ed.) Reflexiones en torno a la música y la imagen desde la musicología española. Salamanca: Plaza Universitaria Ediciones, pp. 553563.

- ARÓStegui PlAZA, J. L. (2005a): "La música en el cine español contemporáneo". OLARTE MARTÍNEZ, M. (Ed.) La música en los medios audiovisuales. Salamanca: Plaza Universitaria Ediciones, pp. 333-342.

- AUSTEN, J. (2002): "Hidey Hidey Hidey Ho... Boop-Boop-A Doop! The Fleischer Studio and Jazz Cartoons". GOLDMARK, D.; TAYLOR, Y. (Eds.) The Cartoon Music Book. Chicago: A Capella, pp. 61-66.

- AZZAM GÓMEZ, M. (2009): "La música como factor estructural y dramático en el cine de Ingmar Bergman". OLARTE MARTÍNEZ, M. (Ed.) Reflexiones en torno a la música y la imagen desde la musicología española. Salamanca: Plaza Universitaria Ediciones, pp. 817-857.

- BELTRÁN MONER, R. (2005): La ambientación musical en radio y televisión. Selección, montaje y sonorización. Madrid: Instituto Oficial de Radio y Televisión.

- BENÍTEZ, J. M. y CARMONA, L. M. (1996): Nombres de la banda sonora. Diccionario de compositores cinematográficos. Madrid: Stripper.

- BERMÚDEZ CUBAS, Y. (2009): "El tango en el cine: Carlos Gardel en la cinematografía de los años noventa”. OLARTE MARTÍNEZ, M. (Ed.) Reflexiones en torno a la música y la imagen desde la musicología española. Salamanca: Plaza Universitaria Ediciones, pp. 967-988.

- BURROWS, D. J.; HUME, R. D. (1991): "George I, the Haymarket Opera Company and Handel's Water Music". Early Music 19, pp. 323-341. 
- CHION, M. (1993): La audiovisión. Introducción a un análisis conjunto de la imagen y el sonido. Barcelona: Paidós.

- CHION, M. (1997): La música en el cine. Barcelona: Paidós.

- COLÓN PERALES, C. (1993): Introducción a la historia de la música en el cine. La imagen visitada por la música. Sevilla: Facultad de Ciencias de la Información.

- COLÓN PERALES, C., INFANTE DEL ROSAL, F. y LOMBARDO ORTEGA, M. (1997): Historia y Teoría de la Música en el Cine. Presencias afectivas. Sevilla: Alfar.

- COOK, N. (1988): Analyzing Musical Multimedia. New York: Oxford University Press.

- COOK, N. (2001): De Madonna al Canto Gregoriano. Una breve introducción a la música. Madrid: Alianza.

- CRUCES VILLALOBOS, F. (1998): "Niveles de coherencia musical. La aportación de la música a la construcción de mundos". Revista de Antropología 15-16, pp. 3357.

- CUETO LlERA, R. (1996): Cien bandas sonoras en la historia del cine. Madrid: Nuer.

- D’AMICO, L. (2007): "People and Sounds: Filming African Music Between Visual Anthropology and Television Documentary". Trans 11. Disponible en <http://www.sibetrans.com/trans/trans11/art06.htm $>$ [Consulta 9-II-10]

- DE ANDRÉS BAYLÓN, S. (2009): “¡Glorioso Technicolor!, ¡Impactante Cinemascope!, ¡Sonido estereofónico!: Cole Porter y el cine”. OLARTE MARTÍNEZ, M. (Ed.) Reflexiones en torno a la música y la imagen desde la musicología española. Salamanca: Plaza Universitaria Ediciones, pp. 475-494.

- DE ARCOS RUS, M. (2006): Experimentalismo en la música cinematográfica. Madrid: Fondo de Cultura Económica.

- DUARTE, M. A. (2009): "Un análisis retórico del proceso de creación de la banda sonora en un programa televisivo infantil (Río de Janeiro, Brasil)". OLARTE MARTÍNEZ, M. (Ed.) Reflexiones en torno a la música y la imagen desde la musicología española. Salamanca: Plaza Universitaria Ediciones, pp. 787-806.

- DUARTE, M. A. (2006): "Músicas y modas. La creación a través de la teoría de las representaciones sociales". Comunicar 27, pp. 69-77.

- EISENSTEIN, S. M. (2001): Hacia una teoría del montaje, v. I. Barcelona: Paidós.

- ENCABO FERNÁNDEZ, E. (2009): "Nuevas películas, viejas canciones: La cuestión del repertorio en el cine folklórico español de los noventa". OLARTE 
MARTÍNEZ, M. (Ed.) Reflexiones en torno a la música y la imagen desde la musicología española. Salamanca: Plaza Universitaria Ediciones, pp. 439-459.

- FELD, S. (1982): Sound and sentiment. Birds, Weeping, Poetics, and Song in Kaluli Expression. Philadelphia: University of Pennsylvania Press.

- FELD, S. (1976): "Ethnomusicology and Visual Communication". Ethnomusicology 20, p. 293-325.

- FERNÁNDEZ DE LA CUESTA, I. (1999): "Contrafactum". Diccionario de la música española e iberoamericana, v. III. Madrid: SGAE, pp. 921-922.

- FRAILE PRIETO, T. (2009a): La creación musical en el cine español contemporáneo (Tesis Doctoral). Salamanca: Servicio de Publicaciones de la Universidad de Salamanca. Colección Vítor.

- FRAILE PRIETO, T. (2009b): "De nuevo el dedo en la llaga. Algunas reflexiones metodológicas sobre el estudio de la música cinematográfica". OLARTE MARTÍNEZ, M. (Ed.) Reflexiones en torno a la música y la imagen desde la musicología española. Salamanca: Plaza Universitaria Ediciones, pp. 83-103.

- FRAILE PRIETO, T. (2005): “Aproximación a los mecanismos temporales de la música de cine”. OLARTE MARTÍNEZ, M. (Ed.) La música en los medios audiovisuales. Salamanca: Plaza Universitaria Ediciones, pp. 213-224.

- GALBIS LÓPEZ, V. (2009a): "La música preexistente en la comedia americana de los años ochenta: Trading Places (1983)". OLARTE MARTÍNEZ, M. (Ed.) Reflexiones en torno a la música y la imagen desde la musicología española. Salamanca: Plaza Universitaria Ediciones, pp. 217-223.

- GALBIS LÓPEZ, V. (2009b): "La música de concierto en el cine español posterior a 1975". OLARTE MARTÍNEZ, M. (Ed.) Reflexiones en torno a la música y la imagen desde la musicología española. Salamanca: Plaza Universitaria Ediciones, pp. 225-244.

- GARBAYO MONTABES, F. J. (2005): “Amadeus (1984) e Inmortal [sic] Beloved (1994); El papel de la banda sonora en la creación de una ficción cinematográfica". OLARTE MARTÍNEZ, M. (Ed.) La música en los medios audiovisuales. Salamanca: Plaza Universitaria Ediciones, pp. 45-58.

- GARCÍA LABORDA, J. M. (2005): "Músicos en el cine (biografías cinematográficas de músicos)". OLARTE MARTÍNEZ, M. (Ed.) La música en los medios audiovisuales. Salamanca: Plaza Universitaria Ediciones, pp. 375-382.

- GARCÍA LABORDA, J. M. (2000): La música del siglo XX. Primera parte (18901914). Modernidad y emancipación. Madrid: Alpuerto.

- GARCÍA MARTÍN, J. H. (2009): “What a Wonderful World” o la construcción de mundos simbólicos”. OLARTE MARTÍNEZ, M. (Ed.) Reflexiones en torno a la 
música y la imagen desde la musicología española. Salamanca: Plaza Universitaria Ediciones, pp. 903-919.

- GÈRTRUDIX BARRIO, M. (2003): Música y narración en los medios audiovisuales. Madrid: Laberinto.

- GIL SEARA, M. A. (2009): "El legado de Shirley Walker". OLARTE MARTÍNEZ, M. (Ed.) Reflexiones en torno a la música y la imagen desde la musicología española. Salamanca: Plaza Universitaria Ediciones, pp. 613-632.

- GÓMEZ RODRÍGUEZ, J. A. (2005): “ 'Lo que no venda, cántelo’. Algunas reflexiones sobre el papel de la música en la publicidad: de los viejos pregones a los spots de televisión”. OLARTE MARTÍNEZ, M. (Ed.) La música en los medios audiovisuales. Salamanca: Plaza Universitaria Ediciones, pp. 225-265.

- GÓMEZ VARAS, P. (2009a): "Recursos compositivos para una secuencia de cine". OLARTE MARTÍNEZ, M. (Ed.) Reflexiones en torno a la música y la imagen desde la musicología española. Salamanca: Plaza Universitaria Ediciones, pp. 3944.

- GÓMEZ VARAS, P. (2009b): "Software libre para la edición multimedia". OLARTE MARTÍNEZ, M. (Ed.) Reflexiones en torno a la música y la imagen desde la musicología española. Salamanca: Plaza Universitaria Ediciones, pp. 277284.

- GORBMAN, C. (1987): Unheard Melodies. Narrative Film Music. Bloomington: Indiana University Press.

- KASSABIAN, A. (2001): Hearing Film. Tracking Identifications in Contemporary Hollywood Film Music. New York \& London: Routledge.

- KAYE, A. L. (2007): "The Film Score and the African Musical Experience: Some Comments on a Work in Progress". Trans 11. Disponible en $<$ http://www.sibetrans.com/trans/trans 11/art09.htm > [Consulta 9-II-10]

- KUNZE, S. (1990): Las óperas de Mozart. Madrid: Alianza.

- LACK, R. (1999): La música en el cine. Madrid: Cátedra.

- LLUÍS i FALCÓ, J. (2009): "Contra una historia monumental de la música en el audiovisual. Más allá del cine y las estrellas”. OLARTE MARTÍNEZ, M. (Ed.) Reflexiones en torno a la música y la imagen desde la musicología española. Salamanca: Plaza Universitaria Ediciones, pp. 45-81.

- LLUÍS i FALCÓ, J. (2005): “Análisis musical vs. análisis audiovisual: el dedo en la llaga”. OLARTE MARTÍNEZ, M. (Ed.) La música en los medios audiovisuales. Salamanca: Ediciones Plaza Universitaria, pp. 143-153.

- LLUÍS i FALCÓ, J. (1995): "Paràmetres per a una anàlisi de la banda sonora musical cinematogràfica”. D’Art 21, pp. 169-186. 
- LONDON, K. (1936): Film Music. London: Faber and Faber.

- LUDWIG, E. (1994): Beethoven. Madrid: Anaya \& Mario Muchnik.

- MALETÁ COCIÑA, J. (2009): "La banda sonora en los dibujos animados: del tópico a la brevedad". OLARTE MARTÍNEZ, M. (Ed.) Reflexiones en torno a la música y la imagen desde la musicología española. Salamanca: Plaza Universitaria Ediciones, pp. 565-583.

- MARTÍN FÉLEZ, D. (2009a): "Experiencia innovadora de música de cine en la escuela: proyecto de innovación 'La influencia de la comunicación audiovisual en el alumnado de educación primaria' ". OLARTE MARTÍNEZ, M. (Ed.) Reflexiones en torno a la música y la imagen desde la musicología española. Salamanca: Plaza Universitaria Ediciones, pp. 761-779.

- MARTÍN FELEZ, D. (2009b): "La banda sonora de Nobleza Baturra: monumento a la figura del baturro y los estilos de jota". OLARTE MARTÍNEZ, M. (Ed.) Reflexiones en torno a la música y la imagen desde la musicología española. Salamanca: Plaza Universitaria Ediciones, pp. 357-374.

- MARTÍN SÁNCHEZ, D. (2005): “Aspectos analíticos del sinfonismo de John Williams". OLARTE MARTÍNEZ, M. (Ed.) La música en los medios audiovisuales. Salamanca: Plaza Universitaria Ediciones, pp. 443-458.

- MONTERO RODRÍGUEZ, J. (2009): "Pautas compositivas en los videojuegos del siglo XXI". OLARTE MARTÍNEZ, M. (Ed.) Reflexiones en torno a la música y la imagen desde la musicología española. Salamanca: Plaza Universitaria Ediciones, pp. 585-598.

- MONTOYA RUBIO, J. C. (2009b): "Didáctica de la música de cine: la música preexistente como pretexto pedagógico". OLARTE MARTÍNEZ, M. (Ed.) Reflexiones en torno a la música y la imagen desde la musicología española. Salamanca: Plaza Universitaria Ediciones, pp. 669-704.

- MONTOYA RUBIO, J. C. (2009c): "La investigación en el ámbito de la didáctica de la música de cine. Experiencias y posibilidades". Póster presentado en el VII Congreso de la Sociedad Española de Musicología (en prensa).

- MONTOYA RUBIO, J. C. (2009d): "La sonorización del audiovisual como fuente de aprendizajes musicales". OLARTE MARTÍNEZ, M. (Ed.) Reflexiones en torno a la música y la imagen desde la musicología española. Salamanca: Plaza Universitaria Ediciones, pp. 705-746.

- MONTOYA RUBiO, J. C. (2009e): "Música de cine: imágenes ilusorias del binomio Mozart - Beethoven". DE LA PEÑA, C., PÉREZ, M., ALBERO, M. M., MARÍN, M. T. y GONZÁLEZ, J. M. Actas del Congreso Internacional Imagen y Apariencia. Murcia: Editum, Servicio de Publicaciones de la Universidad de Murcia, Recurso digital. 
- MONTOYA RUBIO, J. C. (2008c): "La música de la ciudad multicultural en el cine”. GÓMEZ MUNS, R. y LÓPEZ CANO, R. (Eds.) Música, ciudades, redes. Creación musical e interacción social. Salamanca: SIbE.

- MONTOYA RUBIO, J. C. (2006c): "Mozart en España. Imaginación y construcción de la alteridad a través de la ópera". Gazeto Internacia de Antropologio 1 : 46-60. Disponible en <http://antropologia.umh.es/GIA/Index_revista/Volumen_1/Vol_01artículos/Montoya-castellano.PDF> [Consulta: 9-II-10]

- MOSQUERA FERNÁNDEZ, A. (2009): "Música incidental para momentos mágicos". OLARTE MARTÍNEZ, M. (Ed.) Reflexiones en torno a la música y la imagen desde la musicología española. Salamanca: Plaza Universitaria Ediciones, pp. 633-667.

- MOSQUERA FERnÁndEZ, A. (2005): "Emilia Pardo Bazán y su aportación al cine". OLARTE MARTÍNEZ, M. (Ed.) La música en los medios audiovisuales. Salamanca: Plaza Universitaria Ediciones, pp. 517-521.

- MOZART, W. A. (1997): Cartas. Barcelona: Siruela.

- NAVARRO ARRIOLA, H. y NAVARRO ARRIOLA, S. (2003): Música de cine: historia y coleccionismo de bandas sonoras. Madrid: Ediciones Internacionales Universitarias.

- NETTL, B. (2003): "Reflexiones sobre el siglo XX: el estudio de 'los Otros' y de 'nosotros' como etnomusicólogos". TRANS-Revista Transcultural de Música 7, Artículo 6. Disponible en <www.sibetrans.com/trans/trans7/nettl.htm $>$ [Consulta 9II-10]

- NETTL, B. (1989): "Mozart and the Ethnomusicological Study of Western Culture (An Essay in Four Movements)". Yearbook for Traditional Music 21, pp. 1-16.

- NEUMEYER, D.; BUHLER, J. (2001): “Analytical and Interpretative Approaches to Film Music: Analysing the Music". DONNELLY, K. L. (Ed.) Film Music. Critical Approaches. New York: Continuum International, pp. 16-38.

- NEYRINCK, M. (2001): "Ethplotiation: The Use of Ethnic Film Music". Filmscore. Disponible en <http://www.filmscoremonthly.com/articles/2001/29_Nov--Ethploitation_The_Use_of_Ethnic_Film_Music.asp $>$ [Consulta 9-II-10]

- NIETO GONZÁlEZ, J. (1996): La música para la imagen. La influencia secreta. Madrid: S.G.A.E.

- OlARTE MARTíneZ, M. (2009) (Ed.): Reflexiones en torno a la música y la imagen desde la musicología española. Salamanca: Plaza Universitaria Ediciones.

- OlARTE MARTÍNEZ, M. (2009a): “La inserción del número musical como elemento recurrente en las películas: ¿Una nueva tipología Nowadays Musical?”. 
Reflexiones en torno a la música y la imagen desde la musicología española. Salamanca: Plaza Universitaria Ediciones, pp. 495-520.

- OLARTE MARTÍNEZ, M. (2009b): "Música de cine compuesta por mujeres. La utopía del universo femenino". Reflexiones en torno a la música y la imagen desde la musicología española. Salamanca: Plaza Universitaria Ediciones, pp. 601-612.

- OlARTE MARTíneZ, M. (2005) (Ed.): La música en los medios audiovisuales. Salamanca: Plaza Universitaria Ediciones.

- OLARTE MARTíNEZ, M. (2005a): “Aportación femenina a la creación musical cinematográfica". La música en los medios audiovisuales. Salamanca: Plaza Universitaria Ediciones, pp. 367-374.

- OLARTE MARTÍNEZ, M. (2005b): "El género del musical y la utilización de sus melodías con fines expresivos". La música en los medios audiovisuales. Salamanca: Plaza Universitaria Ediciones, pp. 101-118.

- OLARTE MARTíNEZ, M. (2002): "La música incidental en el cine y el teatro". BANÚS, E. (Ed.) El legado musical del siglo XX. Pamplona: EUNSA, pp. 151-179.

- OLARTE MARTÍNEZ, M. (2001): “¿Existe una frontera en la música aplicada a la imagen como elemento expresivo y estructural?". LOLO, B. (Ed.) Campos interdisciplinares de la musicología, vol. 1. Madrid: Sociedad Española de Musicología, pp. 745-759.

- ORDÓÑEZ, M. Á. (2007): "Entrevista a Juan Bardem" $<$ http://www.scoremagacine.com/Entrevistas_det.php?Codigo=37> [Consulta 9-II10]

- ORTEGA, F. (2006): "Mozart, amado de Dios". Revista Teología 90, pp. 343-358.

- PACHÓN RAMÍREZ, A. (1992): La música en el cine contemporáneo. Badajoz: Diputación Provincial de Badajoz [revisión de 1998].

- PADROL i ESCOLIES, J. (2007): Diccionario de Bandas sonoras. Barcelona: Pujol \& Amado S.L.L.

- PADROL i ESCOLIES, J. (2006): Conversaciones con músicos de cine. Badajoz: Diputación Provincial. Servicio de Publicaciones.

- PADROL i ESCOLIES, J. (2005): "Los arreglistas musicales como futuros compositores de bandas sonoras". OLARTE MARTÍNEZ, M. (Ed.) La música en los medios audiovisuales. Salamanca: Plaza Universitaria Ediciones, pp. 383-402.

- PADROL i ESCOLIES, J. y VALLS GORINA, M. (1990): Música y cine. Barcelona: Ultramar.

- PARDAVILA NEIRA, M. (2009): "Las primeras creaciones musicales para publicidad en radio y televisión en España: El jingle (1950-1960)". OLARTE 
MARTÍNEZ, M. (Ed.) Reflexiones en torno a la música y la imagen desde la musicología española. Salamanca: Plaza Universitaria Ediciones, pp. 997-1007.

- PlANA RIUS, G. (1982): Cine-Sonorización. Barcelona: Instituto Parramón Ediciones.

- PORTA NAVARRO, A. (2009): "La banda sonora del cine y la televisión infantil. Nuevos textos para nuevos paradigmas". OLARTE MARTínEZ, M. (Ed.) Reflexiones en torno a la música y la imagen desde la musicología española. Salamanca: Plaza Universitaria Ediciones, pp. 781-786.

- PORTA NAVARRO, A. (2007): Músicas públicas, escuchas privadas: hacia una lectura de la música popular contemporánea. Valencia: Universitat de Valencia; Castellón: Universitat Jaume I; Bellaterra: Universitat Autónoma de Barcelona; Barcelona: Universitat Pompeu Fabra.

- PRICE, C., MILHOUS, J. y HUME, R. D. (1995): Italian Opera in Late EighteenthCentury London. The King's Theatre, Haymarket 1778-1791. Oxford: Clarendon Press.

- RADIGALES i BABÍ, J. (2009a): "Mozart en el cine: del biopic a la ópera filmada". OLARTE MARTÍNEZ, M. (Ed.) Reflexiones en torno a la música y la imagen desde la musicología española. Salamanca: Plaza Universitaria Ediciones, pp. 167196.

- RADIGALES i BABÍ, J. (2009b): "Lo cinematográfico en Puccini. Lo pucciniano en el cine". OLARTE MARTÍNEZ, M. (Ed.) Reflexiones en torno a la música y la imagen desde la musicología, pp. 197-215

- RADIGALES i BABÍ, J. (2008): La música en el cine. Barcelona: Editorial UOC.

- RADIGALES i BABÍ, J. (2005a): "Usos y abusos de la música "clásica" en el cine. Estudio de casos". OLARTE MARTÍNEZ, M. (Ed.) La música en los medios audiovisuales. Salamanca: Plaza Universitaria Ediciones, pp. 13-32.

- RADIGALES i BABÍ, J. (2005b): "El videoclip com a obra d'art total. Sobre "Africa Shox" (Leftfield) de Chris Cunningham". Trípodos 17, pp. 191-200.

- RADIGALES i BABÍ, J. (2002): Sobre la música. Reflexions a l'entor de la música i l'audiovisual. Barcelona: Facultat de Ciéncies de la Comunicació Blanquerna. Universitat Ramon Llull.

- RADIGALES i BABÍ, J. (2001): “Creació i muntatge musical en el dibuix animat clàssic”. Trípodos 11, pp. 107-122.

- RADIGALES i BABÍ, J. (2000): Llenguatge musical: una aplicació audiovisual. Barcelona: Facultat de Ciéncies de la Comunicació Blanquerna. Universitat Ramon Llull. 
- RADIGALES i BABÍ, J. y FRAILE PRIETO, T. (2006): "La música en los estudios de comunicación audiovisual. Prospecciones y estado de la cuestión”. Trípodos 19, pp. $98-112$.

- ROBBINS LANDON, H. C. (1990): Mozart. Los años dorados 1781-1791. Barcelona: Destino.

- ROMAGUERA i RAMIÓ, J. (2002): El jazz y sus espejos. Madrid: Ediciones de la Torre.

- ROMÁN, A. (2009): "Estética de la música cinematográfica: Aspectos diferenciadores". OLARTE MARTÍNEZ, M. (Ed.) Reflexiones en torno a la música y la imagen desde la musicología española. Salamanca: Plaza Universitaria Ediciones, pp. 105-118.

- ROMÁN, A. (2008): El lenguaje musivisual, semiótica y estética de la música cinematográfica. Madrid: Visión Libros.

- RUSSEL, M y YOUNG, J. (2002): Bandas sonoras. Madrid: Océano.

- SALMI, H. (1998): "Composing the Past: Music and the Sense of History in Hollywood Epics of the 1950s and Early 1960s". Screening the Past 5. Disponible en <http://www.latrobe.edu.au/screeningthepast/firstrelease/fir1298/HSfr5d.html> [Consulta 9-II-10]

- SEDEÑO VALDELlÓS, A. M. (2004b): "La música contemporánea en el cine". Revista Historia y Comunicación Social 9, pp. 155-162.

- SEDEÑO VALDELLÓS, A. M. (2003): Realización audiovisual y creación de sentido en la música: El caso del videoclip musical de Nuevo Flamenco. Tesis doctoral. Málaga: Universidad de Málaga.

- SEDEÑO VALDELlós, A. M. (2002): "Música e imagen. Aproximación a la historia del video musical". Área Abierta 3. Disponible en $<$ http://revistasucm.es/inf/1578393/articulos/ARAB002230002A.PDF $>$ [Consulta 9-II-10]

- SOlANAS DÍAZ, V. (2009): "Teorema, de Pier Paolo Pasolini: Estudio de la banda sonora musical". OLARTE MARTÍNEZ, M. (Ed.) Reflexiones en torno a la música y la imagen desde la musicología española. Salamanca: Plaza Universitaria Ediciones, pp. 859-874.

- SOLANAS, V. (2005): "Significados añadidos a través de la música en las películas The Exorcist, Black Angels de G. Crumb y The Devils of Loudun de K. Penderecki". OLARTE MARTÍNEZ, M. (Ed.) La música en los medios audiovisuales. Salamanca: Plaza Universitaria Ediciones, pp. 459-466.

- STILWELL, R. J. (2002): "Music in Films: A Critical Review of Literature, 19801996". The Journal of Film Music I, pp. 19-61. 
- STILWELL, R. J. (2000): "Sense \& Sensibility. Form, Genre and Function in the Film Score”. Acta Musicológica 72, pp. 219-240.

- TAGG, P. (1995): "Studying Music in the Audio-Visual Media -An Epistemological Mess-“. Glasgow: IASPM Conference. Disponible en <http://www.tagg.org/articles/glasg95.html > [Consulta 9-II-10]

- VEGA-TOSCANO, A. (2001): "Música y creación audiovisual”. LOLO, B. (Ed.) Campos interdisciplinares de la Musicología, v. 1, Madrid: Sociedad Española de Musicología, pp. 699-709.

- VIÑUELA SUÁREZ, E. (2009): "La inter-acción de la música de cine. Relación multimedia en Azul de Kieskowski". OLARTE MARTÍNEZ, M. (Ed.) Reflexiones en torno a la música y la imagen desde la musicología española. Salamanca: Plaza Universitaria Ediciones, pp. 875-886.

- VIÑUELA SUÁREZ, E. (2008): “Convergencias y divergencias en el estudio de la música en los fenómenos audiovisuales". AYATS, J. y GINESI, G. (Eds.) Quaderns de l'arxiu del so $i$ de la imatge 5. Experiència musical, cultura global. Mallorca: Consell de Mallorca. Departament de Cultura i Patrimoni, pp. 355-362.

- XALABARDER, C. (2006): Música de cine: una ilusión óptica. LibrosEnRed.

- XALABARDER, C. (1997): Enciclopedia de las bandas sonoras. Barcelona: Ediciones B.

- XAlABARDER, C. (2005): "Principios informadores de la música de cine". OLARTE MARTÍNEZ, M. (Ed.) La música en los medios audiovisuales. Salamanca: Plaza Universitaria Ediciones, pp. 155-204.

- ZUNZUNEGUI DÍEZ, S. (1995): Pensar la imagen. Madrid: Cátedra. 


\section{REFERENCIAS EN EL ÁMBITO DE LA INVESTIGACIÓN Y PRÁCTICAS EDUCATIVAS MUSICALES}

Las referencias relativas a la educación musical tratan de reflejar los elementos que se derivan de la investigación en educación musical y sus desarrollos prácticos. Hemos de mencionar como parte integral de este grupo de referencias aquellas que se dedican a trazar las líneas básicas de lo que implica investigar en educación musical, así como de sus métodos y desarrollos procedimentales básicos. Por otro lado, algunas de las referencias que a continuación se enumeran son planteamientos genéricos sobre las metodologías de enseñanza musical, a partir de las cuales reedificamos nuestros postulados de renovación pedagógica. Otras reseñas, especialmente a partir de artículos en revistas especializadas de educación musical, se aproximan más directamente a prácticas concretas, con mayor o menor cercanía al hecho audiovisual pero con innegable valor a la hora de enmarcar nuestro objeto de estudio en la realidad actual.

Quedan apuntadas a continuación:

- ABEL-STRUTH, S. (1985): Grundriss der Musikpädagogik. Mainz: Schott Music.

- AKOSCHKY, J. (1988): Cotidiáfonos: instrumentos sonoros realizados con objetos cotidianos, confección y sugerencias didácticas. Buenos Aires: Ricordi.

- ALONSO MARÍN, M. J. (2004): "Perfil musical y rendimiento académico en los alumnos de música de magisterio". Música y Educación 57, pp. 77-102.

- ALSINA MASMITJÀ, P. (2007): "Métodos de enseñanza musical. Algunos puntos de contacto". DÍAZ GÓMEZ, M. y GIRÁLDEZ HAYES, A. (coord.): Aportaciones teóricas y metodológicas a la educación musical. Barcelona: Graó, pp. 15-21.

- ALSINA MASMiTJÀ, P. (1997): El área de educación musical. Propuestas para aplicar en el aula. Barcelona: Graó.

- ALSINA MASMITJÀ, P. y SESÉ, F. (1994): La música y su evolución: historia de la música con propuestas didácticas y 49 audiciones. Barcelona: Graó. 
- ÁllVAREZ-NÓVOA SÁNCHEZ, C. (1995): Dramatización. El teatro en el aula. Barcelona: Octaedro.

- AMUSATEGUI, C. (1996): "Educación musical en educación especial”. Eufonía 4, pp. 85-96.

- ANGUlO LÓPEZ-CASERO, M. (1999): "La educación musical: nuevas alternativas". Música y educación 37, pp. 197-209.

- ARAMBERRI BALBOA, M. J. (2007): “Susan Hallam”. DÍAZ GÓMEZ, M. y GIRÁLDEZ HAYES, A. (coord.): Aportaciones teóricas y metodológicas a la educación musical. Barcelona: Graó, pp. 189-201.

- ARGUEDAS QUESADA, C. (2006a): "Vivencias de la expresión musical: áreas y estrategias metodológicas". Actualidades Investigativas en Educación 6. Disponible en <http://revista.inie.ucr.ac.cr/articulos/3-2006/vivencias.php > [Consulta 9-II-10]

- ARGUEDAS QUESADA, C. (2006b): “Cuentos musicales para los más pequeños”. Revista Actualidades Investigativas en Educación 6. Disponible en <http://revista.inie.ucr.ac.cr/articulos/1-2006/cuentos.php> [Consulta 9-II-10]

- ARÓSTEGUi PLAZA, J. L. (2006): “La formación del profesorado en educación musical ante la convergencia europea en enseñanzas universitarias". Revista de Educación 341, pp. 829-844.

- ARÓSTEGUi PlAZA, J. L. (2005b): "Las Tecnologías de la Información y la Comunicación en el Aula de Música". Musiker, Cuadernos de Música 14, pp. 173189.

- ARRIAGA SANZ, C. (2006): "Importancia de los condicionantes contextuales en la educación musical”. Música y educación 68, pp. 131-140.

- AUSUBEL, D. P., NOVAK, J. D. y HANESIAN, H. (1983): Psicología Educativa. Un punto de vista cognoscitivo. México: Trillas.

- BAUTISTA VIZCAÍNO, F. (2008): "La investigación entra en los conservatorios: El caso canario". ÁlAMO ORELLANA, A. y LUCEÑO RAMOS, M. Actas del I Congreso de Investigación y Educación Musical. Madrid: Enclave Creativa Ediciones, pp. 340-366.

- BAUTISTA VIZCAÍNO, F. (2000): "La metodología audiovisual como alternativa a la enseñanza instrumental tradicional". Revista de la Lista Europea de Música en la Educación $\quad 5 . \quad$ Disponible en <http://musica.rediris.es/leeme/revista/bautista00.pdf $>$ [Consulta 9-II-10]

- BARNIOL i TERRICABRAS, E. (2000): “Reflexiones en torno a la innovación y la investigación en la enseñanza de música en Cataluña”. Revista de la Lista Europea de Música en la Educación 5. Disponible en <http://musica.rediris.es/leeme/revista/barniol00.pdf $>$ [Consulta 9-II-10] 
BENSAYA, P. (1986): Instrumentos de papel: construcción y consejos para la ejecución y aplicación en el aula. Buenos Aires: Ricordi.

- BERG, M. (2008): "La improvisación como recurso para el desarrollo de la ejecución instrumental en el segundo ciclo de educación primaria”. ÁLAMO ORELLANA, A. y LUCEÑO RAMOS, M. Actas del I Congreso de Investigación y Educación Musical. Madrid: Enclave Creativa Ediciones, pp. 322-328.

- BLANCO GARCÍA, C. (1999): "Cuentos, juegos y canciones tradicionales en educación infantil”. Música y Educación 39, pp. 35-55.

- BLASER, A., FROSETH, J. D. y WEIKART, P. (2001): Música y movimiento. Actividades rítmicas en el aula. Barcelona: Graó, pp. 59-83.

- BRAVO MARÍN, R. y DE MOYA MARTÍNEZ, M. V. (2006): "Multiculturalidad musical para las aulas del siglo XXI”. Ensayos 21, pp. 131-139.

- BRESLER, L. (2004): "Metodología de investigación cualitativa: prestando atención a la música escolar como género en sus macro y micro contextos". Revista Electrónica Complutense de Investigación en Educación Musical 1. Disponible en <http://www.ucm.es/info/reciem/v1n5.pdf > [Consulta 9-II-10].

- CAMPOS CALVO-SOTELO, J. (2002): "Sistemas prácticos para la realización de ensayos en el aula de secundaria". Música y educación 52, pp. 75-98.

- CARBAJO MARTÍNEZ, C. (2008): “Autopercepción de competencias musicales del docente de música en primaria”. ÁLAMO, A. y LUCEÑO, M. Actas del I Congreso de Investigación y Educación Musical. Madrid: Enclave Creativa Ediciones, pp. 143-151.

- CARVAJAL BAÑOS, T. (1993): "Comentario didáctico a través de la dramatización y el musicograma de la Danza Macabra de Saint Saens ". Música y educación 13, pp. 41-48.

- CASALS IBÁÑEZ, A. y VILAR i MONTMANY, M. (2008): “De la investigación universitaria a la aplicación escolar: Introducción de la canción improvisada en una escuela primaria". ÁLAMO ORELLANA, A. y LUCEÑO RAMOS, M. Actas del I Congreso de Investigación y Educación Musical. Madrid: Enclave Creativa Ediciones, pp. 106-114.

- CAStillo Álvarez, D. y PRIETO AlBerola, R. (2003): "Medios audiovisuales: una estrategia para mejorar la motivación”. Música y Educación 56, pp. 83-94.

- CASTILlo FERREIRA, M., MORALES VIllaR, M. C. y COMINO CRESPO, F. J. (2008): "La educación musical del alumnado universitario en la titulación de maestro en educación musical: problemas, retos y soluciones". ÁLAMO ORELLANA, A. y LUCEÑO RAMOS, M. Actas del I Congreso de Investigación y Educación Musical. Madrid: Enclave Creativa Ediciones, pp. 68-75. 
- CERVERA BORRÁS, J. (1996): La dramatización en la escuela. Madrid: Bruño.

- CERVERA BORRÁS, J. (1986): Cómo practicar la dramatización con niños de 4 a 14 años. Madrid: Cincel-Kapelusz.

- CHAPUIS, J. (1995): "El papel de la música en la vida del niño". Música y educación 22, pp. 87-91.

- CHÁVEZ CANCINO, F. (2009): "Las tecnologías de la información y la comunicación en el aula, un desafío con premura para la educación musical”. Ecos, revista de música 2 , pp. 45-54.

- CHILDS, J (2005): Haciendo especial la música. Formas prácticas de hacer música. Madrid: Akal.

- CIDONCHA TABUENCA, P. (2007): "Recursos y materiales didácticos. Colormúsica: nuevo método de escritura musical con números y colores". Música y educación 70, pp. 77-82.

- CORBAlÁN ABELlÁN, M. (2008): "Música y representación cognitiva: un enfoque psicopedagógico". ÁLAMO ORELLANA, A. y LUCEÑO RAMOS, M. Actas del I Congreso de Investigación y Educación Musical. Madrid: Enclave Creativa Ediciones, pp. 10-24.

- COX, G. (2006): “Transforming Research in Music Education History". COLWELL, R. (Ed.) MENC Handbook of Research Methodologies. New York: Oxford University Press, pp. 73-94.

- CREMADES ANDREU, R. y LORENZO QUILES, O. (2007): "Familia, música y educación informal". Música y educación 72, p. 40.

- DAVIDSON, L.; SCRIPP, L. (1997): "Educación y desarrollo musicales desde el punto de vista cognitivo". HARGREAVES, D. J. (Ed.) Infancia y educación artística. Madrid: Morata, pp. 80-111.

- DE MOYA MARTÍNEZ, M. V., BRAVO MARÍN, R. y GARCÍA LÓPEZ, F. J. (2008): "Análisis de los estilos de aprendizaje de los estudiantes de magisterio (educación musical)". ÁLAMO ORELLANA, A. y LUCEÑO RAMOS, M. Actas del I Congreso de Investigación y Educación Musical. Madrid: Enclave Creativa Ediciones, pp. 76-88.

- DEL Álamo CABAllero, L. y GIL ARRATE, V. (1999): Música. Secundaria 3. Madrid: Ediciones SM.

- DÍAZ GÓMEZ, M. (2005): “La educación musical en la escuela y el espacio europeo de educación superior". Revista Interuniversitaria de Formación de Profesorado 19, pp. 23-37.

- DÍAZ GÓMEZ, M., y FREGA DE CORONEL, A. L. (1998): La creatividad como transversalidad al proceso de educación musical. Vitoria: AgrupArte. 
- DÍAZ GÓMEZ, M. y GIRÁLDEZ HAYES, A. (2007) (coord.): Aportaciones teóricas y metodológicas a la educación musical. Barcelona: Graó.

- DÍAZ IGLESIAS, S. y DÍAZ GUERRA, R. (2000): “El papel del maestro en la investigación en educación musical". Revista de la Lista Europea de Música en la Educación 5. Disponible en 〈http://musica.rediris.es/leeme/revista/diazetal00.pdf> [Consulta 9-II-10].

- DÍAZ LARA, G. (1996): "Música y ordenador en la educación primaria". Eufonía 4, pp. 105-116.

- DÍAZ MOHEDO, M. T. (2009): "La educación musical en la universidad española: claves de futuro". Ecos, revista de música 2, pp. 12-20.

- DÍAZ MOHEDO, M. T. (2006): "La educación musical en la Europa del futuro". Música y educación 68, pp. 33-48.

- DÍAZ RODRÍGUEZ, S. (2002): “Las nuevas músicas en la educación”. Música y educación 51, pp. 29-42.

- DUSIL DIÉGUEZ, R. (2007): “Amadeus. Una visión del genio a través del cine”. Música y Educación 70, pp. 47-58.

- EPELDE LARRAÑAGA, A. (2007): "Creatividad musical en educación primaria". Música y educación 69, pp. 55-70.

- ESCUDERO GARCÍA, M. P. (1988): Cuentos Musicales. Madrid: Real Musical.

- ESPEJO AUBERO, A. y ESPEJO AUBERO, A. (2000): Juegos musicales en la escuela. Madrid: CCS.

- ESPINOSA, S. (2007): “Creación y pedagogía: los compositores van al aula”. DÍAZ GÓMEZ, M. y GIRÁLDEZ HAYES, A. (coord.): Aportaciones teóricas y metodológicas a la educación musical. Barcelona: Graó, pp. 95-112.

- ESTEVE FAUBEL, J. M., MOLINA VALERO, M. A. y ESPINOSA ZARAGOZA, J. A. (2008): "Los materiales de autoaprendizaje musical en el ámbito del EEES en la Universidad de Alicante". ÁLAMO, A. y LUCEÑO, M. Actas del I Congreso de Investigación y Educación Musical. Madrid: Enclave Creativa Ediciones, pp. 45-54.

- eSteVe faubel, J. M., MOLina VAlero, M. Á. y LÓPEZ DE REGO, C. (2007): "El futuro de los estudios de maestro especialista en música". Música y educación 72, pp. 21-34.

- ESTÉVEZ VILA, J. (2002): "Del Plan 66 al Plan LOGSE: aspectos positivos y problemáticos". Música y educación 49, pp. 45-60.

- FERNÁNDEZ DE SEVILLA VELlÓN, M. Á. (2002): “Informática musical al servicio de la formación de profesionales". Música y educación 49, pp. 69-81. 
- FREGA DE CORONEL, A. L. (1998): "La investigación en las enseñanzas musicales". Revista de la Lista Europea de Música en la Educación 1. Disponible en 〈http://musica.rediris.es/leeme/revista/frega98.pdf> [Consulta 9-II-10]

- FREGA DE CORONEL, A. L. (1996): "Nuevas tecnologías en la educación musical”. Eufonía 4, pp. 7-20.

- FUENTES HERNÁNDEZ, P. y CERVERA BORRÁS, J. (1989): Pedagogía y didáctica para músicos. Valencia: Piles.

- FUERTES ROYO, C. (1998): "La telemática en la educación musical". Comunicación y pedagogía 151, pp. 75-78.

- FUERTES ROYO, C. (1996): "Las tecnologías en el aula de música”. Eufonía 4, pp. 21-31.

- GALÁN BUENO, C. (2007): "La sonorización del silencio. La improvisación en el cine mudo". Música y Educación 69, pp. 19-47.

- GAlERA NÚÑ̃EZ, M. M. y PÉREZ CEBALlOS, J. (2008): "La investigación en educación musical en la base de datos ERIC". Revista de la Lista Europea de Música en la Educación 22. Disponible en <http://musica.rediris.es/leeme/revista/galeraetal08.pdf $>$ [Consulta 9-II-10]

- GIMÉNEZ MORELL, M. T. (1984): La música en la escuela. Barcelona: Paidós.

- GIRÁLDEZ HAYES, A. (2005): Internet y educación musical. Barcelona: Graó.

- GIRÁldDEZ HAYES, A. (1997): "Educación musical desde una perspectiva multicultural: Diversas aproximaciones". Trans Iberia 1. Disponible en <http://www.sibetrans.com/trans/transiberia/giraldez.htm> [Consulta 9-II-10]

- GOLDBERG DE BERNASCONI, S. A. (1992): "La computadora en la educación musical". Música y educación 12, pp. 19-22.

- GONZÁlEZ MEDIEL, O. (2010): "Una experiencia de currículum musical intercultural”. Música y educación 81, pp. 18-33.

- GORDILLO, J. (2003): "Los materiales pobres enriquecen la música”. Eufonía 27, pp. 45-53.

- GORDILlO, J. J. (2003): "Musicograma: actividad musical que aproxima a los pequeños al desarrollo personal y creativo". Eufonía 29, pp. 108-115.

- GREEN, L. (1988): Music on Deaf Ears. Musical Meaning, Ideology and Education. Manchester, New York: Manchester University Press.

- GUSTEMS CARNICER, J. (2005): "Escuchar los anuncios: una aproximación al uso de la música y del sonido en la publicidad televisiva”. Eufonía 34, pp. 91-100. 
- GUTIÉRREZ BARRENECHEA, M. (2008): "Desafíos y oportunidades para la investigación musical en el horizonte del proceso de Bolonia”. ÁLAMO, A. y LUCEÑO, M. Actas del I Congreso de Investigación y Educación Musical. Madrid: Enclave Creativa Ediciones, pp. 367-374.

- HARGREAVES, D. J. (1997) (Ed.): Infancia y educación artística. Madrid: Morata.

- HARGREAVES, D. J.; NORTH, A. C. (2001) (Eds.): Musical Development and Learning. The International Perspective. London, New York: Ed. Continuum.

- HARTMANN, W. (2005): "El pensamiento pedagógico de Orff y su influencia en la enseñanza instrumental". Quodlibet 33, pp. 38-47.

- HEGYI, E. (1999): Método Kodály de Solfeo (vols I y II). Madrid: Pirámide.

- HEMSY DE GAINZA, V. (2002): Pedagogía musical. Dos décadas de pensamiento y acción educativa. Buenos Aires - México: Lumen.

- HEMSY DE GAINZA, V. (1990): Nuevas perspectivas de la educación musical. Buenos Aires: Guadalupe.

- HEMSY DE GAINZA, V. (1989): "La iniciación musical del niño y desarrollo del oído”. Música y educación 4, pp. 403-413 ${ }^{784}$.

- HERNÁNDEZ BRAVO, J. R. (2006): "Don Quijote y su universo a través de los musicogramas escolares. Una experiencia didáctico-musical en el C. P. 'Alcázar Serrano' de Caudete (Albacete)". CANO VELA, Á. G. y PASTOR COMÍN, J. J. (coord.): Don Quijote en el aula. La aventura pedagógica. Ciudad Real: Servicio de Publicaciones de la Universidad de Castilla - La Mancha, pp. 211-219.

- HERnÁNDEZ BRAVO, J. R. y HERNÁNDEZ BRAVO, J. A. (2008): "La didáctica de la expresión musical en la Escuela Universitaria de Magisterio siguiendo el modelo de los créditos europeos ECTS. Un reto formativo para los profesores de música". ÁLAMO ORELLANA, A. y LUCEÑO RAMOS, M. Actas del I Congreso de Investigación y Educación Musical. Madrid: Enclave Creativa Ediciones, pp. 115-121.

- HERNÁNDEZ FREIXINOS, J. (1996): “La otra partitura”. Eufonía 3, pp. 121-130.

- HONORATO MARTÍN, R. (2001): "Trabajando con musicomovigramas". Revista de la Lista Europea de Música en la Educación 8. Disponible en <http://musica.rediris.es/leeme/revista/honorato01.pdf > [Consulta 9-II-10].

- HUERTA RAMÓN, R. (1999): “Imágenes que nos suenan. Aprender a conocer los sonidos del cine y la televisión”. Eufonía 16, pp. 65-71.

\footnotetext{
${ }^{784}$ Las primeras ediciones de la revista Música y educación aparecen listados con indicación de año y volumen, y no de número. La asignación del número es posterior a la publicación y aparece reseñada en su web <www.musicalis.es> [Consulta 9-II-10]. Por tanto, la indicación del número 4 de la revista viene determinada por esa fuente, siendo la orientación original Año II, v. 2.
} 
- IBARRETXE TXAKARTEGI, G. (2007a): "Patricia Shehan Campbell". DÍAZ GÓMEZ, M. y GIRÁLDEZ HAYES, A. (coord.): Aportaciones teóricas y metodológicas a la educación musical. Barcelona: Graó, pp. 133-140.

- IBARRETXE TXAKARTEGI, G. (2007b): “David J. Elliot”. DÍAZ GÓMEZ, M. y GIRÁLDEZ HAYES, A. (coord.): Aportaciones teóricas y metodológicas a la educación musical. Barcelona: Graó, pp. 141-148.

- JORQUERA JARAMILLO, M. C. (2004): "Métodos históricos o activos en educación musical". Revista de la Lista Europea de Música en la Educación 14, p. 24. Disponible en <http://musica.rediris.es/leeme/revista/jorquera.pdf $>$ [Consulta 9II-10]

- LACÁRCEL MORENO, J. (1995): Psicología de la música y educación musical. Madrid: Visor.

- LAUCIRICA LARRINAGA, A. (2000): "Limitaciones perceptivas que obstaculizan la introducción de mensajes sonoros de otras culturas en el currículo musical". Eufonía 18, pp. 90-97.

- LINES, D. K. (2009) (comp.): La educación musical para el nuevo milenio: El futuro de la teoría y la práctica de la enseñanza y del aprendizaje de la música. Madrid: Morata.

- LLOPIS BUENO, E. (2009): “'Fills de Kassim' un musical para educar en la convivencia cultural". Eufonía 47, pp. 104-116.

- LÓPEZ GARCÍA, N. J. (2006): "Recursos y materiales didácticos. Musicograma Mussete en Re M. del álbum de Ana Magdalena Bach (J. S. Bach)". Música y Educación 68, pp. 181-184.

- LÓPEZ IBOR, S. (2007): “Carl Orff”. DÍAZ GÓMEZ, M. y GIRÁLDEZ HAYES, A. (coord.): Aportaciones teóricas y metodológicas a la educación musical. Barcelona: Graó.

- LORENZO YANES, A. I. y RACIONERO LLORENTE, D. E. (2000): "El aula de música". Revista de la Lista Europea de Música en la Educación 5. Disponible en <http://musica.rediris.es/leeme/revista/lorenzoetal00.pdf > [Consulta 9-II-10]

- LORENZO YANES, A. I. y RACIONERO LLORENTE, D. E. (1999): "Las condiciones de la docencia musical en primaria: el aula de música". Eufonía 14, pp. 81-90.

- MAINÉ, M. C. (1987): Escenificar un cuento. Barcelona: Hogar del Libro.

- MALAGARRIGA i ROVIRA, T. (2000): “Audición musical, producciones sonoras y aproximación a la lectura en los niños de 5 años". Revista de la Lista Europea de Música en la Educación 5. Disponible en <http://musica.rediris.es/leeme/revista/malagarriga00.pdf $>$ [Consulta 9-II-10] 
- MALAGARRIGA i ROVIRA, T. y VALLS CASANOVAS, A. (2003): La audición musical en la Educación Infantil. Propuestas didácticas. Barcelona: Ediciones Ceac.

- MALBRÁN, S. (2007): “Teorías, modelos y métodos en investigación musical. Hacia la recuperación de sus figuras prominentes”. DÍAZ GÓMEZ, M. y GIRÁLDEZ HAYES, A. (coord.): Aportaciones teóricas y metodológicas a la educación musical. Barcelona: Graó.

- MALBRÁN, S. (1996): "Los atributos de la audición musical. Notas para su descripción”. Eufonía 2, pp. 55-68.

- MALBRÁN, S., FURNÓ, S. y ESPINOSA, S. (1990): "La música en la enseñanza secundaria”. Música y educación 6, pp. 371-379 ${ }^{785}$.

- MANEVEAU, G. (1993): Música y educación. Madrid: Rialp.

- MARGARIT DALMAU, J. (2000): “Aplicación de la investigación en teoría de la música a la educación musical: la globalidad como contenido básico". Revista de la Lista Europea de Música en la Educación 5. Disponible en $<$ http://musica.rediris.es/leeme/revista/margarit00.pdf> [Consulta 9-II-10]

- MARTÍNEZ, J. M. (1996): "Nuevas herramientas para la educación musical: MIDI y nuevas tecnologías”. Eufonía 4, pp. 33-45.

- MARTÍNEZ VALCÁRCEL, N. y CUADRADO CAPARRÓS, M. D. (2003): "La construcción del conocimiento musical en alumnos de $2^{\circ}$ de la E.S.O. en contextos no escolares: un estudio realizado en dos aulas de marcos socio - económicos culturales diferentes". TOHARIA CORTÉS, M. Actas del Congreso La Ciencia es cultura: II Congreso sobre Comunicación Social de la Ciencia (2001). Disponible en

$<$ http://www.um.es/docencia/nicolas/menu/publicaciones/propias/docs/valencia/MU

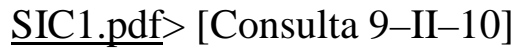

- MOLAS, S. y HERRERA, Ll. M. (2000): Música de hoy para la escuela de hoy. Repertorio instrumental con propuestas didácticas. Barcelona: Graó.

- MONTERO GARCÍA, J. (1994): "Comentario didáctico con musicograma de la obertura 1812, op. 49 de Tchaikovsky”. Música y Educación 20, pp. 59-66.

- MONTOYA RUBIO, J. C. (2009a): "Kodály, Orff y Willems van al cine. Metodologías de enseñanza musical desde los medios audiovisuales". ROIG VILA, R. (Dir.): Investigar desde un contexto educativo innovador. Alicante: Marfil, pp. 283-294.

- MONTOYA RUBIO, J. C. (2008a): "Viejas y nuevas claves para la formación del profesorado universitario en educación musical: aprendizaje significativo a través de

${ }^{785}$ De acuerdo con las indicaciones anteriores, Año III, v. 2 
los medios audiovisuales". ÁLAMO, A. y LUCEÑO, M. Actas del I Congreso de Investigación y Educación Musical. Madrid: Enclave Creativa Ediciones, pp. 55-67.

- MONTOYA RUBIO, J. C. (2008b): “El romanticismo de 'Don Giovanni' desde los medios audiovisuales hasta el aula de educación musical”. Ensayos 23, pp. 103-123.

- MONTOYA RUBIO, J. C. (2008d): "Música e imágenes para una educación inclusiva. Aplicaciones didácticas audiovisuales para los programas de acción compensatoria". HURTADO MONTESINOS, M. D., y SOTOS PÉREZ, F. J. (coord.): La igualdad de oportunidades en el mundo digital. Actas Tecnoneet 2008. Cartagena: Universidad de Cartagena, pp. 793-801.

- MONTOYA RUBIO, J. C. (2007a): "La música de cine como estrategia educativa". Ensayos 22, pp. 99-124.

- MONTOYA RUBIO, J. C. (2007b): “¿Qué viene el lobo! Interculturalidad para caperucitas feroces y lobos buenos a través de la música". Actas de las comunicaciones del I Congreso Mundial de Educación de la Infancia para la Paz. Albacete: Asociación Mundial de Educadores Infantiles, pp. 239-250.

- MONTOYA RUBIO, J. C. (2006a): "Mozart en casa de Bach. Elaboración pedagógica para el tránsito del barroco al clasicismo musical". Ensayos 21, pp. 141155.

- MONTOYA RUBIO, J. C. (2006b): "Al ritmo de Rocinante: Propuesta pedagógica para el poema sinfónico Don Quixote de Richard Strauss". CANO VELA, A. G. y PASTOR COMÍN, J. J. Don Quijote en el aula. La aventura pedagógica. Ciudad Real: Universidad de Castilla-La Mancha, pp. 221-230.

- MONTOYA RUBiO, J. C., MONTOYA RUBiO, V. M. y FRANCÉS ARIÑO, J. M.: "Musicogramas con movimiento, un paso más en la audición activa". Ensayos 24 (en prensa).

- MORALES FERNÁNDEZ, Á. (2008): “La formación musical en los maestros para la etapa de educación primaria en la LOGSE y la LOE”. ÁLAMO ORELLANA, A. y LUCEÑO RAMOS, M. Actas del I Congreso de Investigación y Educación Musical. Madrid: Enclave Creativa Ediciones, pp. 25-38.

- MORALES GÓMEZ, L. (2005): "Música para la integración y el mestizaje”. Eufonía 33, pp. 84-92.

- MÜLlER GÓMEZ, Á. y MORENO HEREDIA, L. V. (2000): "Enseñanza musical e Internet. Descripción de un proyecto en marcha". Revista de la Lista Europea de Música en la Educación 5. Disponible en <http://musica.rediris.es/leeme/revista/mulleretal00.pdf> [Consulta 9-II-10].

- MUÑOZ MUÑOZ, J. R. (2006): "La educación musical en niñas y niños con necesidades educativas especiales derivadas de factores sociales, económicos, geográficos, culturales y étnicos”. Eufonía 37, pp. 80-94. 
- MURRAY SCHAFER, R. (1986): El compositor en el aula. Buenos Aires: Ricordi.

- MURRAY SCHAFER, R. (1969a): El nuevo paisaje sonoro. Buenos Aires: Ricordi

- MURRAY SCHAFER, R. (1969b): Limpieza de oídos. Buenos Aires: Ricordi.

- NADAL FERRERO, N. (2007): Músicas del mundo. Una propuesta intercultural de educación musical. Barcelona: Horsori.

- NOVILLO FERTRELL-VÁZQUEZ, M. (2000): "El taller de construcción de instrumentos en el aula de secundaria". Música y educación 44, pp. 61-82.

- ÖRDÖG, L. (2000): La educación musical según el sistema Kodály. Valencia: Rivera Editores.

- ORIOL DE ALARCÓN, N. (2009): "La investigación musical en España: tesis doctorales y temática en la última década". Eufonía 45, pp. 59-87.

- ORIOL DE ALARCÓN, N. (2007): "Enseñanza musical en España". DÍAZ GÓMEZ, M. y GIRÁLDEZ HAYES, A. (coord.): Aportaciones teóricas y metodológicas a la educación musical. Barcelona: Graó, pp. 87-93.

- ORIOL DE ALARCÓN, N. (2005): "La música en las enseñanzas de régimen general en España y su evolución en el siglo XX y comienzos del XXI". Revista de la Lista Europea de Música en la Educación 5. Disponible en <http://musica.rediris.es/leeme/revista/oriol2.pdf > [Consulta 9-II-10].

- ORIOL DE ALARCÓN, N. y PARRA, J. M. (1979): La expresión musical en la educación básica. Madrid: Alpuerto.

- ORTIZ MOLINA, M. A. y OCAÑA FERNÁNDEZ, A. (2004): “¿Música intercultural o interculturalidad?". Música y educación 58, pp. 51-66.

- PALACIOS JORGE, F. (1997): Escuchar. 20 reflexiones sobre música y educación musical. Las Palmas de Gran Canaria: Fundación Orquesta Filarmónica de Gran Canaria.

- PAlACIOS JORGE, F y RIVEIRO HOLGADO, L. (1990): Artilugios e instrumentos para hacer música. Madrid: Ópera Tres.

- PASCUAL MEJÍA, P. (2004): La batuta mágica 1. Madrid: Alambra Pearson.

- PASCUAl MEJÍA, P. (2002): Didáctica de la música. Madrid: Prentice Hall.

- PASTOR COMÍN, J. J. (2008): "Didáctica de la música: Oportunidades para una investigación coordinada”. ÁLAMO ORELLANA, A. y LUCEÑO RAMOS, M. Actas del I Congreso de Investigación y Educación Musical. Madrid: Enclave Creativa Ediciones, pp. 464-473.

- PASTOR i GORDERO, P. (2004): "Las marías.www.marchitopensil.boe.es". Revista de la Lista Europea de Música en la Educación 14. Disponible en 
$<$ http://musica.rediris.es/leeme/revista/pastor04.pdf > [Consulta 9-II-10]. Publicado anteriormente en Eufonía 14 (1999), pp. 91-98.

- PASTOR i GORDERO, P. (2002): "La investigación educativa musical". Eufonía 26, pp. 84-88.

- PAYNTER, J. (1999): Sonido y estructura. Madrid: Akal.

- PEÑA NEGUERUELA, M. J. (2006): Flauta fácil 2. Madrid: Pearson Alambra.

- PÉREZ GUTIÉRREZ, M. (1994): "Breve reseña histórica sobre la educación musical en España y comparación con otros países". Música y educación 17, pp. $19-28$.

- PORTA NAVARRO, A. (1999): "Pedagogía musical y cambio de contexto sonoro en educación infantil”. Eufonía 14, pp. 59-81.

- PORTA NAVARRO, A. (1998): "Cine, música y aprendizaje significativo". Comunicar 11, pp. 107-108.

- PORTELA LÓPEZ, C. (2000): "El análisis de tareas en las clases de educación musical: un caso práctico". Revista de la Lista Europea de Música en la Educación 5. Disponible en <http://musica.rediris.es/leeme/revista/portela00.pdf $>$ [Consulta 9II-10].

- PRIETO AlBEROLA, R. (2008): What a Wonderful World. Alicante: Editorial Club Universitario.

- PRIETO ALBEROLA, R. (2001): "El perfil del maestro de primaria especialista en educación musical”. Revista Interuniversitaria de Formación de Profesorado 40, pp. 175-186.

- RAMÍREZ HURTADO, C. (1996): “Apuntes sobre la sonorización del cuento infantil”. Música y Educación 27, pp. 57-68.

- REAL VALCÁRCEL, J. L. (2000): "La música y la solidaridad con los pueblos". Revista de la Lista Europea de Música en la Educación 5. Disponible en <http://musica.rediris.es/leeme/revista/real00.pdf> [Consulta 9-II-10]

- REgElSKI, T. A. (1980): Principios y problemas de la Educación Musical. México: Diana.

- ROCA VIDAL, F. (1998): "La informática musical en el aula de música". Eufonía 13, pp. 37-48.

- RODRÍGUEZ QUILES y GARCÍA, J. A. (2003): “(Sub)culturas musicales juveniles y la formación del profesorado de música". VV. AA. Participación, convivencia y ciudadanía. Granada: Ediciones Osuna, pp. 361-367. 
- RODRÍGUEZ QUILES y GARCÍA, J. A. (2000): "Investigación cualitativa en educación musical: un nuevo reto en el contexto educativo español". Revista de la Lista Europea de Música en la Educación 5. Disponible en $<$ http://musica.rediris.es/leeme/revista/rodriguezja00.pdf > [Consulta 9-II-10].

- ROMERO CARMONA, J. B. (2005): "La música en la escuela y su tratamiento histórico". Música y Educación 62, pp. 43-58.

- ROMERO CARMONA, J. B. (2004): "Las nuevas tecnologías y la expresión musical, otros lenguajes en la educación”. Comunicar 23, pp. 25-30.

- RUSINEK, G. (2004): “Aprendizaje musical significativo". Revista Electrónica Complutense de Investigación en Educación Musical 5. Disponible en <http://www.ucm.es/info/reciem/v1n5.pdf> [Consulta 9-II-10]

- SAMPER RODRÍGUEZ, R. (2003): "La apreciación musical y la formación del oyente". Revista de la Lista Europea de Música en la Educación 11, p. 3. Disponible en <http://musica.rediris.es/leeme/revista/samper03.pdf $>$ [Consulta 9II-10]

- SÁNCHEZ BARRASA, R. y ARGUÍS REY, R. (2003): "La educación intercultural en el área de música: un proyecto de innovación e investigación educativa". Música y Educación 54, pp. 57-72.

- SANUY SIMÓN, M. (1999): "La música como elemento integral en la educación escolar”. Música y educación 37, pp. 41-48.

- SANUY SIMÓN, M. y GONZALEZ SARMIENTO, L. (1969): Orff-Schulwerk. Música para niños. Madrid: Unión Musical Española.

- SARFSON GLEIZER, S. (2002): "Internet y editores de partituras en la didáctica de la música en la ESO”. Música y educación 50, pp. 85-92.

- SEDEÑO VALDELLÓS, A. M. (2004a): "Recorrido histórico por las relaciones entre música e imagen: el videoclip musical". Música y Educación 58, pp. 67-84.

- SUBIRATS BAYEGO, M. Á. (2007): “Zoltán Kodály”. DÍAZ, M. y GIRÁLDEZ, A. (coord.): Aportaciones teóricas y metodológicas a la educación musical. Barcelona: Graó, pp. 63-70.

- SUBIRATS BAYEGO, M. Á. (2000): "La investigación en educación musical: perspectivas desde el Departamento de Didáctica de la Expresión Musical y Corporal de la Facultad de Formación de Profesorado en la Universidad de Barcelona". Revista de la Lista Europea de Música en la Educación 5. Disponible en $\langle$ http://musica.rediris.es/leeme/revista/subirats00.pdf $>$ [Consulta 9-II-10]

- SUSTAETA LlOMBART, I. y DOMÍNGUEZ-ALCAHUD MONGE, M. P. (2004): "Aplicaciones didácticas de la informática musical". Revista Electrónica Complutense de Investigación en Educación Musical 4. Disponible en <http://www.ucm.es/info/reciem/v1n4.pdf> [Consulta 9-II-10] 
- SWANWICK, K. (2000): "Research and the Music Curriculum". Revista de la Lista Europea de Música en la Educación 5. Disponible en <http://musica.rediris.es/leeme/revista/swanwick00.pdf> [Consulta 9-II-10]

- SWANWICK, K. (1999): Teaching Music Musically. London: Routledge.

- SZEKELY, K. (2006): “La enseñanza del lenguaje musical”. Quodlibet 35, pp. 100129.

- TAFURI, J. (2006): ¿Se nace musical? Cómo promover las aptitudes musicales de los niños. Barcelona: Graó.

- TEJADA GIMÉNEZ, J. (2004): "Música y mediación de la tecnología en sus procesos de aprendizaje". Educación XXI 7. Disponible en <http://www.uned.es/educacionXX1/pdfs/07-01.pdf > [Consulta 9-II-10]

- TEJADA GIMÉNEZ, J. (2001a): "El adiestramiento auditivo y la teoría de la música en los programas informáticos". Música y Educación 47, pp. 101-107.

- TEJADA GIMÉNEZ, J. (2001b): MIDI para el Conservatorio, la Escuela y el Instituto: Encore, Finale, Band in a Box. Valencia: Piles.

- TEJADA GIMÉNEZ, J. y ANGULO SÁNCHEZ-PRIETO, C. (1993a): "El ordenador y las nuevas tecnologías en la enseñanza de la música". Música y educación 13, pp. 49-53.

- TEJADA GIMÉNEZ, J. y ANGULO SÁNCHEZ-PRIETO, C. (1993b): "El ordenador y las nuevas tecnologías en la enseñanza de la música (II). La comunicación de los instrumentos musicales electrónicos entre sí y con el ordenador. MIDI y dispositivos”. Música y educación 14, pp. 33-47.

- TEJADA GIMÉNEZ, J. y ANGUlO SÁNCHEZ-PRIETO, C. (1993c): “El ordenador y las nuevas tecnologías en la enseñanza de la música (III). Ordenadores y sus aplicaciones musicales". Música y educación 15, pp. 49-74.

- TEJADA GIMÉNEZ, J. y ANGUlO SÁNCHEZ-PRIETO, C. (1993d): "El ordenador y las nuevas tecnologías en la enseñanza de la música (y IV). Aplicaciones en la educación musical”. Música y educación 16, pp. 41-50.

- TÉLlEZ, E. (1996): "La composición musical al servicio de la imagen cinematográfica”. Eufonía 4, pp. 47-58.

- TEMPESTI, L. (2008): "Nuove tecnologie ed apprendimento musicale: esperienze e estretegie di ricerca". Revista de la Lista Europea de Música en la Educación 21. Disponible en <http://musica.rediris.es/leeme/revista/tempesti08.pdf > [Consulta 9II-10]

- TOMASI, E. y VANMAELE, J. (sin año): "Doctoral Studies in the field of music current status and latest developments". Erasmus TNP Polifonia. Disponible en: 
<http://tuning.unideusto.org/tuningeu/index.php?option=content\&task=view\&id=21 9\&Itemid=243> [Consulta 9-II-10]

- TORRES OTERO, L. (2006): "Consideraciones sobre historia de la música en primaria: una propuesta sobre audiciones musicales activas". Eufonía 37, pp. 119125.

- VALLS i CASANOVAS, A. (2000): "La enseñanza de la didáctica de la música". Revista de la Lista Europea de Música en la Educación 5. Disponible en $<$ http://musica.rediris.es/leeme/revista/valls.htm> [Consulta 9-II-10]

- VAllS i CASANOVAS, A. y BATTLE i PANADÈS, A. (2008): "Las músicas del mundo en el aula". ÁlAMO, A. y LUCEÑO, M. Actas del I Congreso de Investigación y Educación Musical. Madrid: Enclave Creativa Ediciones, pp. 89-99.

- VALLS PÉREZ, M. R. (2009): "La importància de les actitudes en la docència. L'actitud del mestre". ROIG VILA, R. (Dir.): Investigar desde un contexto educativo innovador. Alicante: Marfil, pp. 453-459.

- VICENTE NICOLÁS, G. (2007): "Música y valores: diálogo, tolerancia y solidaridad en las canciones infantiles". Música y educación 71, pp. 17-44.

- Viladot VALlVERdú, L. y MALAGARRIGA ROVIRA, T. (2008): "Inferencia de finalidades de un proyecto de innovación didáctica en educación musical”. ÁLAMO, A. y LUCEÑO, M. Actas del I Congreso de Investigación y Educación Musical. Madrid: Enclave Creativa Ediciones, pp. 39-44.

- VILAR i MONMANY, M. (2003): "El maestro de música en primaria: enfoques y perspectivas". Música y educación 54, pp. 33-56.

- VILAR i MONMANY, M. (2004): “Acerca de la educación musical”. Revista de la Lista Europea de Música en la Educación 13. Disponible en <http://musica.rediris.es/leeme/revista/vilar04.pdf > [Consulta 9-II-10]

- VÍlCHEZ FERNÁNDEZ, N. (2000): "Nuevas tecnologías: la didáctica del siglo XXI". Música y educación 44, pp. 109-120.

- VIÑAO FRAGO, A. (2000): "Una educación musical para todos". VV.AA.: Actas de las I Jornadas sobre la Música y la Juventud. Nuevos horizontes en Educación Musical. Murcia: Universidad de Murcia, pp. 7-25.

- VV.AA. (2005): Música. $6^{\circ}$ Primaria. Madrid: Santillana Educación.

- VV.AA. (2002): Música 6. Barcelona: Edebé.

- WEBSTER, P. (2002): "Computer-based technology and music teaching and learning". COLWELL, R.; RICHARDSON, C. (Eds.) The New Handbook of Research on Music Teaching and Learning. New York: Oxford University Press, pp. 416-439. 
- WILLEMS, E. (1963): Las bases psicológicas de la educación musical. Buenos Aires: Eudeba.

- WILlEMS, E. (1994): El valor humano de la educación musical. Barcelona: Paidós.

- WILlEMS, E. (2001): El oído musical. La preparación auditiva del niño. Barcelona: Paidós.

- WILlEMS, E. y CHAPUIS, J. (1993): “Los ejercicios de audición”. Música y educación 16, pp. 17-32.

- WILLEMS, E. y CHAPUIS, J. (1989): “Características del método Willems de educación musical. principios válidos tanto para la iniciación de los niños pequeños como para la preparación al solfeo, instrumento y creación musical". Música y educación 4, pp. 383-390 ${ }^{786}$.

- WUYTACK, J. (1992): “Puesta al día de las ideas educativas de Carl Orff?”. Música y educación 12, pp. 11-22.

- WUYTACK, J. (1998): Audición Musical Activa. Oporto: Associaçao Wuytack de Pedagogía Musical.

- WUYTACK, J. y BOAL-PALHEIROS, G. M. (2009): "Audición musical activa con el musicograma". Eufonía 47, pp. 43-55.

- ZARAGOZÀ MUÑOZ, J. L. (2009): Didáctica de la música en la educación secundaria. Competencias docentes y aprendizaje. Barcelona: Graó.

- ZARAGOZÀ MUÑOZ, J. L. (2000): "La competencia afectiva del docente de música es un arma cargada de futuro". Eufonía 18, pp. 63-70.

${ }^{786}$ Siguiendo de nuevo esta nomenclatura, Año II, v. 2. 


\section{REFERENCIAS SOBRE ASPECTOS EDUCATIVOS, SOCIALES Y MEDIOS AUDIOVISUALES}

Las referencias sobre aspectos educativos, sociales y medios audiovisuales suponen un esfuerzo por compendiar, bajo un mismo epígrafe, reseñas educativas no específicamente musicales, mayoritariamente aunque no exclusivamente ligadas al audiovisual, y los textos que han servido para anclar nuestro discurso en la sociedad actual.

Así, dentro de este conjunto de publicaciones agrupamos, por un lado, textos que se refieren a aspectos como la generación de ambientes cooperativos o creativos en torno a la docencia, y que desde la observación de criterios generales de actuación facilitan la comprensión de unos procesos pedagógicos como los que hemos descrito, basados en elementos de innegable matiz dialógico. Del mismo modo, los escritos de corte sociológico o antropológico han contribuido a implementar un plus de acercamiento a la realidad a veces presentada veladamente en los audiovisuales, especialmente en los apartados centrados en el reconocimiento de la capacidad dialéctica de la alteridad. Por último, tienen cabida los planteamientos en torno al audiovisual en su relación, no tanto con la música como con la educación en general. De dichos desarrollos pedagógicos se han extraído valiosas consecuencias para trasladarlas al ámbito de la docencia musical, al tiempo que se han utilizado para forjar las teorías en torno a la música del audiovisual.

Las referencias, que acaban por completar todas las obras citadas en el transcurso de la tesis doctoral son las que siguen:

- ABAD TEJERINA, M. J. (2001): “¿Para qué sirve el cine comercial en la aldea global? La India un caso singular”. Arte, Individuo y Sociedad 11, pp. 159-170.

- AGUADED GÓMEZ, J. I. (2005): "Estrategias de edu-comunicación en la sociedad audiovisual". Comunicar 24, pp. 25-34. 
- AGUADED GÓMEZ, J. I. (1997): "La televisión en el nuevo diseño curricular español”. Comunicar 8, pp. 97-109.

- ALBA AMBRÓS, R. (2007): Cine y educación. En cine en el aula de primaria y secundaria Barcelona: Graó.

- ALBA PASTOR, C. y NAFRÍA LÓPEZ, E. (1993): "Utilización didáctica de las nuevas tecnologías en educación especial. Análisis desde los modelos teóricos". COMES, G. y GISBERT, M.: La necesidad de una educación para la diversidad. Tarragona: El Mèdol, pp. 61-69.

- ALBARRÁN DEZA, F. J., MARTÍNEZ GIMENO, M., MENÉNDEZ GARCÍA, M. V.; VICENTE MARTÍN, F. (2007): "Aplicaciones didácticas del cine en la enseñanza de las lenguas". Idea La Mancha 4, pp. 202-205.

- ALBERO ANDRÉ, M. (1987): La televisión didáctica. Barcelona: Mitre.

- ALFONSO ESCUDER, P. (1998): “Nos gusta tanto hacer pedazos el cine!”. Comunicar 11, pp. 21-25

- AlmACEllas BeRNARDÓ, M. A. (2004): Educar en el cine. 22 películas. Madrid: Ediciones Internacionales Universitarias.

- ALONSO TAPIA, J. (1998): Motivación y aprendizaje en el aula. Cómo enseñar a pensar. Madrid: Santillana.

- ALONSO GARCÍA, C. M. y GALLEGO GIL, D. J. (1993): Medios audiovisuales y recursos didácticos en el nuevo enfoque de la educación. Madrid: C.E.C.E-I.T.E.

- ALONSO ERAUSQUIN, M. y MATILLA, L. (1989): Imágenes en acción. Análisis y práctica de la expresión audiovisual en la escuela activa. Madrid: Akal.

- ALVAR LÓPEZ, J. (1992): "Reflexiones en torno al cine etnológico". Gazeta de Antropología 9, Texto 09-03. Disponible en <http://www.ugr.es/ pwlac/G09_03Julio_Alvar.html> [Consulta 9-II-10]

- ÁllVAREZ, I. y KILBOURN, B. (2005): "La integración de las tecnologías de la información y la comunicación en la formación del profesorado: desafíos para la enseñanza y el aprendizaje constructivista”. Revista Iberoamericana de Educación 36. Disponible en 〈http://www.rieoei.org/deloslectores/1206Alvarez.PDF> [Consulta 9-II-10].

- AMAR RODRÍGUEZ, V. M. (2009): "Web 2.0: nueva sintaxis y semántica para la educación". ROIG VILA, R. (Dir.): Investigar desde un contexto educativo innovador. Alicante: Marfil, pp. 15-24.

- AMAR RODRÍGUEZ, V. M. (2003): Comprender y disfrutar el cine. La gran pantalla como recurso educativo. Huelva: Grupo Comunicar Ediciones. 
- AMEIJEIRAS, S., PEREIRA, C., SUEIRO, E. y VILLAR, P. (2000): “Cine y salud. Aproximación a un programa de acción socio-educativa y cultura en los ámbitos formal y no formal". CARIDE, J. A. (coord.): Educación social y políticas culturales. Santiago de Compostela: Servicio de Publicaciones, pp. 593-607.

- AMEIJEIRAS, S., PEREIRA, C.; VILLAR, P. (2001): "Evaluación y análisis de una propuesta de intervención pedagógica en educación y valores. El Programa Cine y Salud". NÚÑEZ CUBERO et als. (eds.): Evaluación de políticas educativas. Huelva: Servicio de Publicaciones de la Universidad de Huelva.

- ANCÍZAR MUNEVAR MOLINA, R. y QUINTERO CORZO, J. (2000): "Investigación pedagógica y formación del profesorado". Revista Iberoamericana de Educación Sin número, sección digital. Disponible en <http://www.rieoei.org/deloslectores/054Ancizar.PDF> [Consulta 9-II-10].

- ARNÁIZ SÁNCHEZ, P. (2003): Educación inclusiva: una escuela para todos. Málaga: Aljibe.

- ARNHEIM, R. (1996): El cine como arte. Paidós: Barcelona.

- ARREDONDO PÉREZ, H. y GARCÍA GALLARDO, F. J. (1998): “Los sonidos del cine". Comunicar 11, pp. 101-105.

- ARROYO ALMARAZ, I. (2003): "Entretenimiento inteligente o consumo infantil en los programas contenedor". Revista de Tecnologías de la Información y Comunicación Educativas 4.4 Disponible <http://reddigital.cnice.mecd.es/4/firmas/isidoro_ind.html > [Consulta 9-II-10].

- AUBERT, A., FleCHA, A., GARCÍA, C., FLECHA, R. y RACIONERO, S. (2008): Aprendizaje dialógico en la sociedad de la información. Barcelona: Hipatia.

- AUSUBEL, D. (1968): Educational Psychology: A Cognitive View. New York: Holt, Rinehart \& Winston.

- AUSUBEL, D. (1963): The Psychology of Meaningful Verbal Learning. New York: Grune \& Stratton.

- BALleStA PAGÁN, J. (coord.): (2004): El consumo de medios en los jóvenes de secundaria. Madrid: CCS.

- BARRENETXEA MARAÑÓN, I. (2006): "Pensar la historia desde el cine". Entelequia 1, pp. 99-107.

- BARRIO MARTÍN, M. y PÉREZ HERRERO, P. (1997): "Desmitificar la publicidad: lectura crítica de los medios en el aula”. Comunicar 9, pp. 130-133.

- BARTHES, R. (1980): Mitologías. México: Siglo Veintiuno Editores.

- BARTOLOMÉ PINA, M. (2002): Identidad y ciudadanía. Un reto a la educación intercultural. Madrid: Narcea. 
- BARTOLOMÉ PINA, M. y CABRERA RODRÍGUEZ, F. (2003): "Sociedad multicultural y ciudadanía: hacia una sociedad y ciudadanía interculturales". Revista de Educación (núm. extraordinario de 2003), pp. 33-56.

- BEATTIE, J. H. M. (1975): “Comprensión y explicación en antropología social”. LLOBERA, J. R. La antropología como ciencia. Barcelona: Anagrama, pp. 293309.

- BELLIDO LÓPEZ, A. (1998): “El aprendizaje del cine”. Comunicar 11, pp. 17-18.

- BERNARDO CARRASCO, J. (1991): Técnicas y recursos para el desarrollo de las clases. Madrid: Rialp.

- BOURDIEU, P. (1994): Razones prácticas. Sobre la teoría de la acción. Barcelona: Anagrama.

- BOZA, L. (2005): "Proyecto educativo, herramientas de educación audiovisual". Comunicar 25, pp. 177-180.

- BURCH, N. (1998): Praxis de cine. Madrid: Fundamentos.

- CABERO ALMENARA, J. (1998): “Usos e integración de los medios audiovisuales y las nuevas tecnologías”. PÉREZ, R. (comp.) Educación y tecnologías de la comunicación. Oviedo: Servicio de Publicaciones, pp. 47-67.

- CABERO ALMENARA, J. (1997): "Más allá de la planificación en la 'Educación en Medios de Comunicación' ”. Comunicar 8, pp. 39-48.

- CABERO ALMENARA, J. (1994): "Nuevas tecnologías, comunicación y educación”. Comunicar 3, pp. 14-25.

- CABERO ALMENARA, J. (1989): “Tecnología educativa: diseño y evaluación del medio vídeo". Enseñanza: Anuario Interuniversitario de Didáctica 7, pp. 17-40.

- CABERO ALMENARA, J. et als. (2003): "Las nuevas tecnologías en la actividad universitaria". Píxel-Bit: Revista de Medios y educación 20, pp. 81-100. Disponible en <http://www.sav.us.es/pixelbit/articulos/n20/n20art/art2008.htm> [Consulta 9II-10]

- CABERO AlMENARA, J. y LOSCERTAlES ABRIL, F. (Eds.) (1998): ¿Cómo nos ven los demás? La imagen del profesor y la enseñanza en los medios de comunicación social. Sevilla: Secretariado de Publicaciones de la Universidad.

- CABERO ALMENARA, J.; LlORENTE CEJUdO, M. C. y ROMÁN GRAVÁN, P (2007): "La tecnología cambió los escenarios: el efecto Pigmalión se hizo realidad". Comunicar 28, pp. 167-173.

- CAMPO-REDONDO, M. S. (2006): "El cine como recurso tecnológico en la creación de conocimiento: estudio de caso en la enseñanza de la orientación de la violencia familiar". Enl@ce: Revista Venezolana de Información, Tecnología y 
Conocimiento, $\quad$ v. $3, \quad$ pp. 11-31. Disponible en <http://redalyc.uaemex.mx/redalyc/src/inicio/ArtPdfRed.jsp?;Cve=82330302 > [Consulta 9-II-10]

- CAMPUZANO RUIZ, A. (1992): Tecnologías audiovisuales y educación. Una visión desde la práctica. Madrid: Akal.

- CANDEL, J. M. (2005): Arte y técnica de los dibujos animados. Murcia: Consejería de Educación y Cultura.

- CARRITHERS, M. (1992): ¿Por qué los humanos tenemos culturas? Madrid: Alianza.

- CASADO SALINAS, J. M. (2005): "La televisión que queremos... si realmente queremos lo que decimos". Comunicar 25, pp. 71-77.

- CASADO, J. M. (1996): "Canal Sur y el desarrollo de la televisión educativa andaluza". Comunicar 6, pp. 57-62.

- COPPEN, H. (1976): Utilización didáctica de los medios audiovisuales. Salamanca: Anaya.

- CORRAl, J., DE CAStro, D. y PAREJO, C. (sin año): “Con Harry Potter lee y experimenta". Disponible en 〈http://www.profes.net/varios/feria/fichas/secundaria/harrypotter/harrypotter.pdf > [Consulta 9-II-10].

- CORREA GARCÍA, R. I. (1999): "Del razonamiento argumental a la retórica de las imágenes". Comunicar 12, pp. 191-197.

- DE LA TORRE, S. (coord.) (1996): Cine formativo. Una estrategia innovadora para los docentes. Barcelona: Octaedro.

- DE LA TORRE, S. (1996a): "Películas formativas. Un apunte para su utilización". Cine formativo. Barcelona: Octaedro, pp. 55-86.

- DE MOYA MARTíNEZ, M. V. (2005): "Creatividad y docencia. Aprender a ser creativos para enseñar a ser creativos". GERVILLA CASTILLO, E. (coord.): Creatividad: aspectos psicológicos, educativos y sociales. Málaga: Dykinson, pp. 281-296.

- DE PABLOS PONS, J. (2008): "Nuevas formas de trabajo en las aulas universitarias con el soporte de las Tecnologías de la Información y la Comunicación”. DEL MORAL PÉREZ, M. E. y RODRÍGUEZ GONZÁLEZ, R. (coord.): Experiencias docentes y TIC. Barcelona: Octaedro, pp. 43-58.

- DE PABLOS PONS, J. (2003): “La enseñanza del cine”. BLÁZQUEZ, F. (coord.): Las nuevas tecnologías en los centros educativos, Mérida: Consejería de Educación, Ciencia y Tecnología de la Junta de Extremadura, pp. 197-227. 
- DE PABLOS PONS, J. (1996): Tecnología y educación. Una aproximación sociocultural. Barcelona: Cedecs.

- DE PABLOS PONS, J. (1995): "El vídeo: Usos didácticos fundamentales". RODRÍGUEZ DIÉGUEZ, J. L. y SÁENZ BARRIO, Ó. (dir.) Tecnología Educativa. Nuevas tecnologías aplicadas a la educación. Alcoy: Marfil.

- DE PABLOS PONS, J. (1989): "La diegésis cinematográfica y sus implicaciones didácticas”. Enseñanza: Anuario interuniversitario de didáctica 7, pp. 9-15.

- DE PABLOS PONS, J. (1986): Cine y enseñanza. Madrid: MEC, Centro Nacional de Investigación y Documentación Educativa.

- DE PABlos PONS, J. (1980): Cine didáctico. Posibilidades y metodología. Madrid: Narcea.

- DE PABLOS PONS, J. y CABERO ALMENARA, J. (1990): “El vídeo en el aula I. El vídeo como mediador del aprendizaje". Revista de Educación 291, pp. 351-370.

- DEL MORAL, A. M. (1997): “Aproximación al análisis de películas en las aulas de Ética”. Comunicar 9, pp. 149-152.

- DELGADO, P. E. (2000): El cine de animación. Madrid: Ediciones JC, Colección imágenes 28.

- DEÓ RAVENTÓS, F. J. (1997): "La Educación Audiovisual en la Educación Secundaria Obligatoria". Comunicar 9, pp. 171-174.

- DI GIOVANNI, E. (2003): "Cultural Otherness and Global Communication in Walt Disney Films at the Turn of the Century". The Translator 9, pp. 207-233.

- DÍAZ PEREA, M. P. (2007): “Atención a las dificultades en la alfabetización de la población inmigrante en el primer ciclo de educación primaria". Docencia $e$ Investigación 17, pp. 39-69.

- DIEUZEIDE, H. (1965): Les techniques audiovisuelles dans l'ensegnement. París: Presses Universitaires de France.

- EGEA FERNÁNDEZ - MONTESINOS, A. (2003): Tópicos andaluces en el cine contemporáneo: de la españolada al poscostumbrismo. Sevilla: Fundación Centro de Estudios Andaluces.

- ESPINO BARAHONA, E. A. (2006): “ 'Cuando la cámara habla...': propuesta didáctica para la lectura del film”. Educación y Educadores 9. Vol. II, pp. 47-59.

- ESTAIRE, S. (2009): El aprendizaje de lenguas mediante tareas: De la programación al aula. Madrid: Edinumen.

- FANDOS IGADO, M. (1993): "El video-clip musical. Una asignatura pendiente". Comunicar 1, pp. 94-97. 
- FERNÁNDEZ IBÁÑEZ, J. J. y DASO, M. S. (1982): El cine en el aula. Madrid: Narcea.

- FERRÉS i PRATS, J. (2003): "El estilo comunicativo en la televisión educativa". Red Digital 4.4 Disponible en <http://reddigital.cnice.mecd.es/4/firmas/ferres_ind.html > [Consulta 9- II-10]

- FERRÉS i PRATS, J. (1992): Vídeo y educación. Barcelona: Paidós.

- FERRÉS i PRATS, J. (1988): Cómo integrar el vídeo en la escuela. Barcelona: CEAC.

- FINNEGAN, R. (1998): “¿Por qué estudiar la música? Reflexiones de una antropóloga desde el campo". Revista de Antropología 15-16, pp. 9-31.

- FLECHA GARCÍA, J. R. (2005): “Calidad para todos y todas: transformación de centros educativos en comunidades de aprendizaje". Actas del III Congreso de Atención a la Diversidad. Elche: Cefire d'Elx, pp. 79-84.

- FlORES AUÑÓN, J. C. (1982): El cine, otro medio didáctico. Madrid: Editorial Escuela Española.

- FOMBONA CADAVIECO, J. (1999): "Análisis de documentos audiovisuales para el aula". Comunicar 13, pp. 225-230.

- FONOLL i SALVADOR, J. (2008): "Explorando los límites para superar limitaciones". HURTADO MONTESINOS, M. D. y SOTO PÉREZ, F. J. (coords.) La igualdad de oportunidades en el mundo digital. Cartagena: Servicio de Publicaciones de la Universidad Politécnica.

- FOUCAULT, M. (1999): El orden del discurso. Barcelona: Tusquets.

- FOUCAULT, M. (1979): Microfísica del poder. Madrid: La Piqueta.

- FUNES, V. (2005): "Espectadores, los alumnos del siglo XXI". Comunicar 24, pp.105-112.

- GABELAS BARROSO, J. A. (2007): "Una perspectiva de la educación en medios para la comunicación en España”. Comunicar 28, pp. 69-73.

- GARCÍA CAlVO, A. (1989): Hablando de lo que se habla. Estudios de lenguaje. Madrid. Lucina.

- GARCÍA DOMENE, J. C. (2004): El cine de Ken Loach. Murcia: Foro Ignacio Ellacuría.

- GARCÍA JIMÉNEZ, J. (1993): Narrativa audiovisual. Madrid: Cátedra.

- GARCÍA MARTínEZ, A. y COBACHO INGLÉS, M. L. (2005): “El fenómeno migratorio y las respuestas que provoca. La perspectiva intercultural". Educatio Siglo XXI 23, pp. 105-124. 
- GARCÍA MARTÍNEZ, J. (2009): "Profesionalidad docente y gestión del cambio en contextos complejos". ROIG VILA, R. (Dir.): Investigar desde un contexto educativo innovador. Alicante: Marfil, pp. 183-200.

- GARCÍA, M. D. y BENÍTEZ, M. V. (1998): "Formación de profesores en alfabetización audiovisual". Comunicar 11, pp. 202-207.

- GARCÍA-RINCÓN DE CASTRO, C. (2006): Educar la mirada: Arquitectura de una mente solidaria. Madrid: Narcea.

- GARCÍA-VARCÁRCEL MUÑOZ-REPISO, A. (2003): Tecnología educativa. Implicaciones educativas del desarrollo tecnológico. Madrid: La Muralla.

- GEERTZ, C. (1989): El antropólogo como autor. Barcelona - Buenos Aires Madrid: Paidós.

- GEERTZ, C. (1987): La interpretación de las culturas. Barcelona: Gedisa.

- GiACOMANTONIO, M. (1979): La enseñanza audiovisual. Metodología didáctica. Barcelona: Ed. Gustavo Gili.

- GIDDENS, A. (1998): "El estructuralismo, el post-estructuralismo y la producción de la cultura". GIDDENS, A., TURNER, J. et al. La teoría social hoy. Madrid: Alianza Universidad, pp. 250-289.

- GLAZER, N. (1997): We Are All Multiculturalists Now. Cambridge: Harvard University Press.

- GÓMEZ SÁNCHEZ, J. P. (1983): El análisis fílmico. Semiología textual. Murcia: Caja de Ahorros de Alicante y Murcia.

- GONZÁLEZ, F. M. y NOVAK, J. D. (1996): Aprendizaje significativo. Técnicas y aplicaciones. Madrid: Ediciones Pedagógicas.

- GORDILLO, I. (2007): "El diálogo intercultural en el cine español contemporáneo: entre el estereotipo y el etnocentrismo". Frame 1. Disponible en <http://fama2.us.es/fco/frame/new_portal/textos/E1\%20di\%E1logo\%20intercultural $\% 20 \mathrm{en} \% 20 \mathrm{el} \% 20 \mathrm{cine} \% 20 \mathrm{espa} \% \mathrm{~F} 1 \mathrm{ol} \% 20 \mathrm{contempor} \% \mathrm{E} 1$ neo\%20editado.pdf $>$ [Consulta 9-II-10]

- GRAU REBOLLO, J. (2005): “Antropología, cine y refracción. Los textos fílmicos como documentos etnográficos". Gazeta de Antropología 21. <http://www.ugr.es/ pwlac/G21_03Jorge_Grau_Rebollo.html > [Consulta 9-II-10]

- GRIZYK, A. (1984): Le rôle du sons dans le récit cinématographique. París: Minard.

- GROS SAlVAT, B. (1987): Aprender mediante el ordenador. Posibilidades pedagógicas de la informática en la escuela. Barcelona: Promociones y Publicaciones Universitarias. 
- GÜEMES ARTILES, R. M. y PADRÓN FRAGOSO, J. (2005): "Estudio sobre los procesos del aula en contextos escolares democráticos". Revista Interuniversitaria de Formación de Profesorado 19, pp. 175-194.

- GUERRERO SERRANO, P. y MOYANO CONDE, M. A. (1994): "Unidad didáctica: la publicidad". Comunicar 3, pp. 118-128.

- GUTIÉRREZ, D. J. (1980): Cine-forum. Teoría y funcionamiento. Madrid: Claret Films.

- GUTIÉRREZ SAN MIGUEL, B. (1999): "La investigación cinematográfica desde la interdisciplinaridad". Comunicar 13, pp. 209-219.

- HANNERZ, U. (1998): Conexiones transnacionales. Cultura, gente, lugares. Madrid: Cátedra, pp. 33-54.

- HEILMAN, E. E. (2003) (Ed.): Harry Potter's World: Multidisciplinary Critical Perspectives. New York: Routledge Falmer.

- HERNÁNDEZ BRAVO, J. A., HERNÁNDEZ BRAVO, J. R. y MILÁN ARELLANO, M. A. (2006): "La interculturalidad en la escuela actual. Una aproximación a las competencias interculturales del alumnado de educación primaria". Ensayos 21, pp. 255-265.

- HUESO MONTÓN, A. L. (1998): El cine y el siglo XX. Barcelona: Ariel Historia.

- HUICI CASAL, C. (1999): "Estereotipos". MORALES, F. (coord.): Psicología Social. Madrid: McGraw-Hill, pp. 73-84.

- IGLESIAS FORNEIRO, M. L. y RAPOSO RIVAS, M. (1998): "El papel del profesorado ante la influencia de la televisión”. Comunicar 11, pp. 142-148.

- JABARDO VELASCO, M. (2000): "Migración, multiculturalismo y minorías étnicas en España”. Anales del Museo Nacional de Antropología VII, pp. 139-164.

- JACQUINOT, G. (1977): Image et pédagogie. París: Presses Universitaires de France.

- JIMÉNEZ PULIDO, J. (1999) (coord.) El cine como medio educativo. Madrid: Laberinto.

- JOCILES RUBIO, M. I. (1999): "Las técnicas de investigación en antropología. Mirada antropológica y proceso etnográfico". Gazeta de Antropología 15. Texto $15-01$. Disponible

en <http://www.ugr.es/ pwlac/G15_01MariaIsabel_Jociles_Rubio.html $>$ [Consulta 9II-10]

- JÓDAR, F. (2007): Alteraciones pedagógicas. Educación y políticas de la experiencia. Barcelona: Laertes. 
- JORDÁN SIERRA, J. A. (2003): "Educar para la convivencia intercultural en sociedades multiculturales". Revista de Educación (núm. extraordinario de 2003), pp. 213-239.

- JUEZ VICENTE, J. (1951): "El cine y su utilización en los centros de enseñanza". Revista Española de Pedagogía 34, pp. 205-224.

- JULIANO CORREGIDO, D. (1993): Educación intercultural. Escuela y minorías étnicas. Madrid: Eudema.

- KAPLAN, D. y MANNERS, R. A. (1998): “Antropología: métodos y problemas en la formulación de teorías". VELASCO, H. (comp.) Lecturas de antropología social y cultural. Madrid: UNED, pp. 15-50.

- LACHANCE, A., WAGNER, M. M. y HAMMOND, B. (2004): "Mathematical Adventures with Harry Potter". Teaching Children Mathematics, Vol. 10, pp. 274 277.

- LACROIX, C. (2004): "Images of Animated Others: The Orientalization of Disney's Cartoon Heroines From The Little Mermaid to The Hunchback of Notre Dame". Popular Communication 2, pp. 213-229.

- LATORRE BELTRÁN, A. (2003): La investigación - acción. Conocer y cambiar la práctica educativa. Barcelona: Graó.

- LEEDS SALMERÓN, A. (2003): “¡Harry Potter habla inglés!”. Cuadernos de Pedagogía 324, pp. 18-19.

- LEPORE, L. y BROWN, R. (2000): "Category and Stereotype Activation: Is Prejudice Inevitable?". STANGOR, Ch. (Ed.): Stereotypes and Prejudice. Philadelphia: Psychology Press, pp. 119-137.

- LÓPEZ HERNÁNDEZ, Á. (2003): "El análisis cronológico-secuencial del documento fílmico". Documentación de las Ciencias de la Información 26, pp. 261294.

- LOSCERTALES ABRIL, F. (1999): "Mitos, estereotipos y arquetipos de la educación en los medios". Comunicar 12, pp. 15-18.

- LUMET, S. (1999): Así se hacen las películas. Madrid: Rialp.

- LUNA, M. R. (2009): "La enseñanza del lenguaje audiovisual: Una propuesta didáctica de evaluación". BAUTISTA GARCÍA-VERA, A. y ATRIO CEREZO, S. (Eds.) Actas del I Congreso Internacional sobre Antropología Audiovisual e Investigación en Tecnología Educativa. Madrid: RUTE Universidad Complutense. Recurso Digital.

- MacCANNELL, D. (1973): "Staged Authenticity: Arrangements of Social Space in Tourist Settings". American Journal of Sociology 79 (3), pp. 589-603. 
- MANDLY ROBLES, A. (1996): "El cante contra el discurso". 'Echar un revezo'. Cultura: razón común en Andalucía. Málaga: Servicio de Publicaciones de la Diputación Provincial de Málaga, pp. 201-212.

- MARCOS RECIO, J. C. (2000): "Europa quiere preservar su identidad lingüística y social. Cine y televisión educativa: mito o realidad". Cuadernos de documentación multimedia 11. Disponible en <http://www.ucm.es/nfo/multidoc/revista/num11/paginas/atei/jmarcos.pdf $>$ [Consulta 9-II-10]

- MARQUÉS GRAELLS, P. (2007): "La Web 2.0 y sus aplicaciones didácticas". <http://peremarques.blogspot.com/search/label/WEB2> [Consulta 9-II-10].

- MARTí SALA, E. (1993): Aprender con ordenadores en la escuela. Barcelona: Horsori.

- MARTÍNEZ SÁNCHEZ, E. (1994): "La publicidad y su integración en las aulas. No es tan fiero el león como lo pintan". Comunicar 3, pp. 65-73.

- MARTÍNEZ SÁNCHEZ, F. (1992): "Producción de vídeo y televisión con fines educativos y culturales". DE PABLOS, J. y GORTARI, C. (Eds.): Las nuevas tecnologías de la información y la comunicación. Sevilla: Alfar, pp. 77-99.

- MARTÍNEZ VALCÁRCEL, N., MIRALlES MARTÍNEZ, P. y NAVARRO MEDINA, E. (2009): "Análisis de cómo los docentes plantean el inicio de las clases desde la perspectiva del alumnado". Revista de educación 349, pp. 413-433.

- MARTÍNEZ VALCÁRCEL, N. et cols. (2003): Didáctica general pedagogía. Murcia: Diego Marín Librero-Editor.

- MARTÍNEZ VALCÁRCEL, N. (1994): Los grupos de trabajo de C.E.P. y el perfeccionamiento del profesorado: un estudio evaluativo. Murcia: Centro de Profesores de Murcia.

- MARTÍNEZ-SALANOVA SÁNCHEZ, E. (2009): "Medios de comunicación y encuentro de culturas: propuesta para la convivencia". Comunicar 32, pp. 223-230.

- MARTÍNEZ-SALANOVA SÁNCHEZ, E. (2002): Aprender de cine, aprender de película. Una visión didáctica para aprender e investigar con el cine. Huelva: Grupo Comunicar Ediciones.

- MARTÍNEZ-SALANOVA SÁNCHEZ, E. (1997): "El valor de la imagen en movimiento". Comunicar 9, pp. 23-35.

- MASTERMAN, L. (1993): La enseñanza de los medios de comunicación. Madrid: Ediciones de la Torre.

- MAURICE, M. et als. (1983): El vídeo en la enseñanza. Barcelona: Planeta. 
- MEDINA RIVILLA, A. (2002): "La intervención didáctica en el aula: el clima socio-comunicativo”. MEDINA RIVILLA, A., RODRÍGUEZ DIÉGUEZ, J. L. y GARCÍA SEVILLANO, $\mathrm{M}^{\mathrm{a}}$ L. (Coords.) Diseño, desarrollo e innovación del currículum en las instituciones educativas (II). Madrid: Universitas, pp. 595-635.

- MENA MERCHÁN, B., MARCOS PORRAS, M. y MENA MARCOS, J. J. (1995): Didáctica y nuevas tecnologías en educación. Madrid: Escuela Española.

- MERRIAM, A. P. (1964): "Las artes y la antropología”. TAX, S. (Ed.): Antropología, una nueva visión. Cali: Norma, pp. 265-279.

- MiLleRSON, G. (1983): Técnicas de realización y producción en televisión. Madrid: Instituto Oficial de Radio y Televisión.

- MITRY, J. (1978): Estética y psicología del cine. Madrid: Siglo XXI.

- MONTES DEL CASTILlO, Á. (2001): "Films etnográficos. La construcción audiovisual de las 'otras culturas' ". Comunicar 16, pp. 79-87.

- MONTOYA VILAR, N. (2005): Comunicación audiovisual en la educación. Madrid: Laberinto.

- MONTOYA VILAR, N. (2007): La influencia de la publicidad audiovisual en los niños: Estudios y métodos de investigación. Barcelona: Ed. Bosch.

- MORIN, E. (2001): El cine o el hombre imaginario. Barcelona: Paidós Comunicación.

- MORO RODRÍGUEZ, M. M. (2007): "Educación en valores a través de la publicidad en televisión”. Comunicar 28, pp. 183-190.

- NOVAK, J. D. (1998): Conocimiento y aprendizaje. Madrid: Alianza.

- OBRADORS BARBA, M. (2005): “Abrazar la existencia. Territorios de 'realidad' y territorios de 'ficción' en la creación cinematográfica". Formats. Revista de Comunicació Audiovisual 4.4 Disponible en <http://www.upf.edu/materials/depeca/formats/impresion/pdf_espanol/mobradors2_ esp.pdf $>$ [Consulta 9-II-10]

- OLDEN, M. (1999): “A Quick Chat with Ayub Khan-Din”. <http://www.kamera.co.uk/interviews/ayubkhandin.html> [Consulta 9-II-10]

- ORTEGA CARRILlO, J. A. (1998): Comunicación visual y tecnología educativa. Perspectivas curriculares y organizativas de las nuevas tecnologías aplicadas a la educación. Granada: Grupo Editorial Universitario.

- ORTIGOSA LÓPEZ, S. (2002): "La educación en valores a través del cine y las artes". Revista Iberoamericana de Educación 29. Disponible en $<$ http://www.rieoei.org/rie29a07.htm $>$ [Consulta 9-II-10] 
- PEREIRA DOMÍNGUEZ, C. (2003): "El cine nuevo escenario de la educación". ROMAÑÁ BLAY, M. T. y MARTÍNEZ MARTÍN, M. (Eds.) Otros lenguajes en educación. Barcelona: Universitat de Barcelona, pp. 101-105.

- PADRÓN FRAGOSO, J., PLATA SUÁREZ, J. R., MARTíN TEIXÉ, G., QUINTERO RODRÍGUEZ, S. y GÜEMES ARTILES, R. M. (2009): “Análisis descriptivo de la interacción cultural en centros de Educación Primaria". ROIG VILA, R. (Dir.): Investigar desde un contexto educativo innovador. Alicante: Marfil, p. 323.

- PEIRÓ i GREGÒRI, S. (2009): “Teoría, investigación y práctica en educación”. ROIG VILA, R. (Dir.): Investigar desde un contexto educativo innovador. Alicante: Marfil, pp. 329-358.

- PEÑAfiEL MARTÍNEZ, F. y TORRES GONZÁLEZ, J. A. (1996): "El lenguaje audiovisual y la formación del profesorado". Comunicar 7, pp. 146-153.

- PEREIRA DOMÍNGUEZ, C. (2005a): Los valores del cine de animación. Propuestas pedagógicas para padres y educadores. Barcelona: PPU.

- PEREIRA DOMÍNGUEZ, C. (2005b): "Cine y educación social”. Revista de Educación 338, pp. 205-228.

- PEREIRA DOMÍNGUEZ, C. y URPÍ GUERCIA, C. (2005): "Cine y juventud: una propuesta educativa integral”. Revista Juventud 68, pp. 73-89.

- PÉREZ PÉREZ, C. (1990): Creatividad, ordenador y escuela. Propuestas para el desarrollo de la creatividad. Murcia: Secretariado de Publicaciones de la Universidad.

- PÉREZ MORENO, H. M. (1997): "Nivel de uso pedagógico de los medios de comunicación en Educación Primaria”. Comunicar 9, pp. 183-190.

- PERTIERra ÁlvareZ, T. (1999): Pasión de cine. Barcelona: Alba Editorial.

- PLA VALL, E. y TORRENT FUERTES, K. (2003): Taller de cine. Una propuesta didáctica para apoyar el uso del cine en las aulas. Huesca: Gobierno de Aragón.

- PORTER i MOIX, M. (1996): "El cine: una cultura del siglo XX". DE LA TORRE, S. (coord.): Cine formativo. Barcelona: Octaedro, pp. 41-45.

- PRATS MARTÍNEZ, L. (2005): Cine para educar. Guía de más de 200 películas con valores. Barcelona: Belacqva.

- PRENDERGAST, R. M. (1977): A Neglected Art: A Critical Study of Music in Films. New York: New York University Press.

- PRIETO VELASCO, D. (1997): "El aprendizaje de la televisión en escuelas de Mendoza en Argentina". Comunicar 8, pp. 129-138. 
- PUJOLÀS MASES, P. y LAGO MARTÍNEZ, J. R. (2007): "La organización cooperativa de la actividad educativa". BONALS PICAS, J. y SÁNCHEZ CANO, M. (coords.) Manual de asesoramiento psicopedagógico. Barcelona: Graó, pp. 349392.

- PUREN, C. (2004): "Del enfoque por tareas a la perspectiva co-accional". Porta Linguarum: Revista internacional de didáctica de las lenguas extranjeras 1, pp. 3136.

- QUIROZ VELASCO, M. T. (1997): "Propuestas para la educación y la comunicación”. Comunicar 8, pp. 31-37.

- REDONDO BELLÓN, I. (2000): Marketing en el cine. Madrid: Pirámide.

- REIA-BAPTISTA, V. (2005): “O valor pedagógico do cinema: Os casos Edison e Lenin”. Ámbitos 13-14, pp. 213-229.

- REYZABAL RODRÍGUEZ, M. V. (2002): Didáctica de los discursos persuasivos: la publicidad y la propaganda. Madrid: La Muralla.

- RIVAYA GARCÍA, B. y DE CIMA, P. (2004): Derecho y cine en 100 películas. Una guía básica. Valencia: Tirant Lo Blanch.

- ROCA VIDAL, F. (2004): “Creatividad y comunicación musical desde las nuevas tecnologías”. Comunicar 23, pp. 31-36.

- RODLEY, C. (Ed.) (1998): David Lynch por David Lynch. Madrid: Alba Editorial.

- ROIG VILA, R. (Dir.): Investigar desde un contexto educativo innovador. Alicante: Marfil.

- ROLDÁN CASTRO, I. y CÁRDENAS SÁNCHEZ, T. (1994): “Teoría y práctica en la producción de un vídeo educativo". Comunicar 3, pp. 43-49.

- ROMAGUERA i RAMIÓ, J. (1991): El lenguaje cinematográfico. Gramática, géneros, estilos y materiales. Madrid: Ediciones de la Torre.

- ROMAGUERA i RAMIÓ, J.; RIMBAU i MÖLLER, E.; LORENTE COSTA, J.; SOLÀ ARGUIMBAU, A. (1989): El cine en la escuela: Elementos para una didáctica. Barcelona: Ed. Gustavo Gili.

- ROSSI, I. y O’HIGGINS, E. (1981): Teorías de la cultura y métodos antropológicos. Barcelona: Anagrama.

- RUIZ RUBIO, F. (1998): "Preliminares para una didáctica del cine: la detección de ideas previas". Comunicar 11, pp. 37-42.

- RUIZ RUBIO, F. (1994): “Cine y enseñanza”. Comunicar 3, pp. 74-80.

- SABIDÓ DASANOVA, S. (1996): "Cadena perpetua”. DE LA TORRE, S. (coord.): Cine formativo. Barcelona: Octaedro, pp. 167-171. 
- SAID, E. W. (1990): Orientalismo. Madrid: Libertarias.

- SAN MARTÍN ALONSO, A. (1994): "El método y las decisiones sobre los medios didácticos". SANCHO GIL, J. M. (coord.): Para una tecnología educativa. Barcelona: Horsori, pp. 61-85.

- SAN ROMÁN ESPINOSA, T. (1996): "Interdisciplinariedad, interprofesionalidad e intervención social”. PRAT, J. y MARTÍNEZ, Á. (Eds.) Ensayos de antropología cultural. Homenaje a Claudio Esteva-Fabregat Barcelona: Ariel, pp. 407-416.

- SÁNCHEZ ALARCÓN, I. (1999): "El cine, instrumento para el estudio y la enseñanza de la historia". Comunicar 13, pp. 159-164.

- SÁNCHEZ GONZÁLEZ, S. y SÁNCHEZ SANZ, B. (2006): La melancolía de la revolución. Panorama del cine europeo moderno. Madrid: Fragua.

- SANTAOlalla RAMÓN, I. (2005): Los "Otros". Etnicidad y "raza" en el cine español contemporáneo. Zaragoza: Prensas Universitarias de Zaragoza y Ocho y Medio.

- SANTAOLALla RAMÓN, I. (1998): "East is East, and West is West? Otherness in Capra's The Bitter Tea of General Yen". Literature Film Quarterly 26, pp. 67-75.

- SERnA AlONSO, J. (2001): “QQué nos enseña Harry Potter?”. Cuadernos de Pedagogía 302, pp. 80-82

- SEVILlANO GARCÍA, M. L. (1997): "La aventura del saber: Análisis del programa educativo de televisión española”. Enseñanza 15, pp. 193-208.

- SHARMA, S. (2006): Multicultural Encounters. Basingstoke: Palgrave Macmillan.

- SIMMONS III [sic], R. (2007): "La educación multicultural". Actas de las ponencias del I Congreso Mundial de Educación de la Infancia para la Paz. Albacete: Asociación Mundial de Educadores Infantiles, pp. 81-86.

- SKLOVSKI, V. (1971): Cine y lenguaje. Barcelona: Anagrama.

- SMALL, C. (2006): "Siete aforismos y seis comentarios". Quodlibet 35, pp. 130141.

- SMALL, C. (1989): Música, sociedad, educación. Madrid: Alianza.

- SOlÁ ARGUimbAU, A. y SElVA MASOliVER, M. (1996): "El cine: imagen y conocimiento". DE LA TORRE, S. (coord.): Cine formativo. Barcelona: Octaedro, pp. 47-54.

- SQUIRES, M. (1993): Filmar con la cámara de vídeo. Barcelona: Blume.

- STAIGER, J. (1995): "El modo de producción en Hollywood durante la transición del mudo al sonoro". VV.AA., Historia general el cine,v. VI. Madrid: Cátedra. Signo e Imagen, pp. 109-145. 
- TAYLOR, R. P. (Ed.) (1980): The Computer in the School: Tutor, Tool, Tutee. New York: Teachers College Press.

- TAYLOR, S. J. y BOGDAN, R. (1994): Introducción a los métodos cualitativos de investigación. Barcelona: Paidós.

- THOMPSON, D. y CHRISTIE, I. (Eds.) (1999): Martin Scorsese por Martin Scorsese. Barcelona: Alba Editorial.

- TITONE, R. (1981): Metodología didáctica. Madrid: Rialp.

- TRÁPAGA MARISCAL, F. (1997): “¡Escuela e imagen, hoy!”. Comunicar 8, pp. 49-55.

- TRUFFAUT, F. (1998): El cine según Hitchcock. Madrid: Alianza.

- TUCHO FERNÁNDEZ, F. (2006): "La educación en comunicación como eje de una educación para la ciudadanía”. Comunicar 26, pp. 83-88.

- TURNER, T. (1993): “Anthropology and Multiculturalism”. Cultural Anthropology 8, pp. 411-429.

- VALERO MARTÍNEZ, T. (2005): "Cine e historia: una propuesta didáctica". Making of 35, pp. 21-27.

- VALERO SERRA, C. (2006): "Interpretación, memoria y contexto: una introducción a la obra sobre música de Edward W. Said". La Torre de Virrey: Revista de Estudios Culturales 1, pp. 24-28.

- VÁZQUEZ AGUADO, O. (1999): "Negro sobre blanco: inmigrantes, estereotipos y medios de comunicación". Comunicar 12, pp. 55-60.

- VEGA SOLÍS, C. (2000): "Miradas sobre la otra mujer en el cine etnográfico". Gazeta de Antropología $16 . \quad$ Disponible en <http://www.ugr.es/ pwlac/G16_07Cristina_Vega_Solis.html> [Consulta 9-II-10]

- VILAR i TORRENS, J. M. (1997): "La utilización de las músicas del entorno del alumnado en el aula y algunos parámetros de etnomusicología”. Eufonía 6, pp. 101109.

- VILLAR HERNÁNDEZ, P. (2002): "El Otro: conflictos de identidad en el cine español contemporáneo". Graduate Romanic Association 6. Disponible en <http://ccat.sas.upenn.edu/romance/gra/WPs2002/paz_1.htm> [Consulta 9-II-10].

- VILLEGAS LÓPEZ, M. (1992): El cine en la sociedad de masas. Madrid: JC.

- VIRILIO, P. (1998): La máquina de visión. Madrid: Cátedra.

- WILLIS, P. (1988): Aprendiendo a trabajar. Madrid: Akal. 
- WORTH, S. (1974): "The Uses of Film in Education and Communication". OLSON, D. (Ed.) Media and Symbols: The Forms of Expression, Communication and Education. Chicago: Chicago University Press, pp. 271-301. 